Systematic

Mineralogy

Of Uranium

And Thorium

GEOLOGICAL SURVEY BULLETIN 1064

This report concerns work done on behalf of the U.S. Atomic Energy Commission and is published with the permission of the Commission

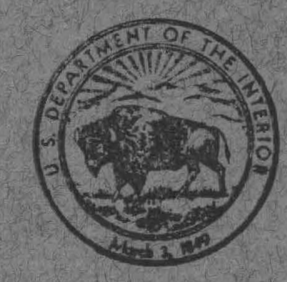




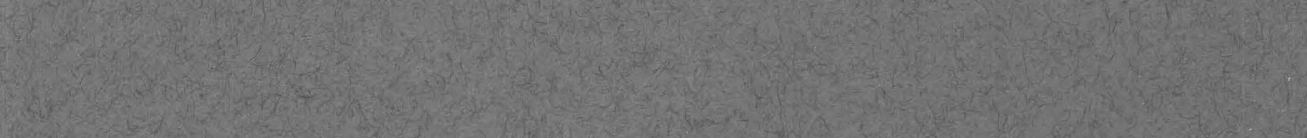

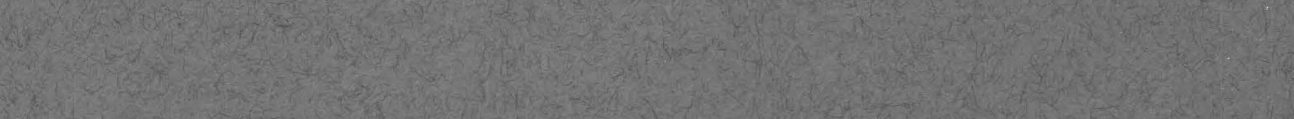

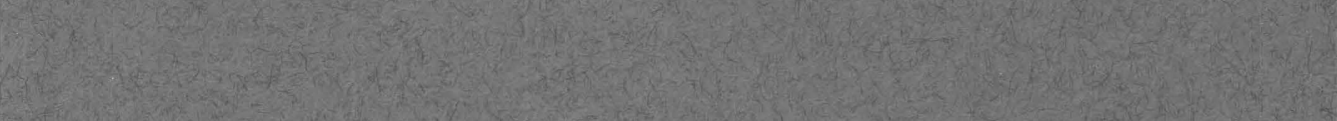

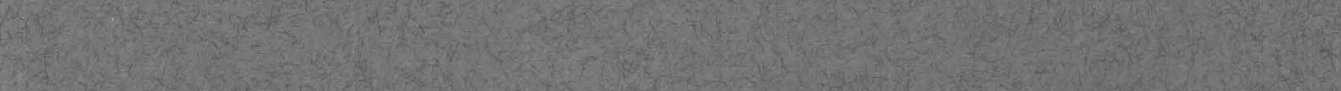
M.

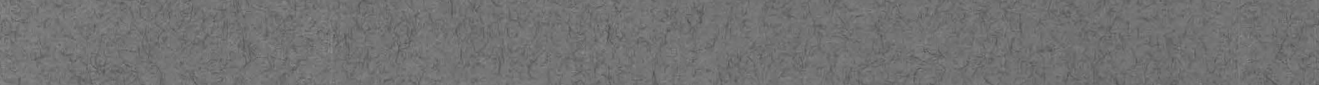
T. 1.5.

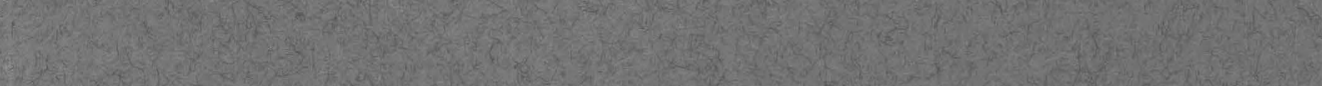
(5) (3)

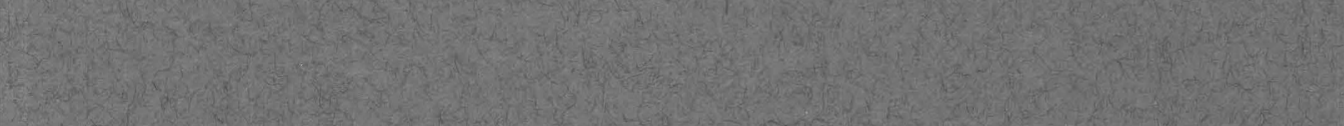

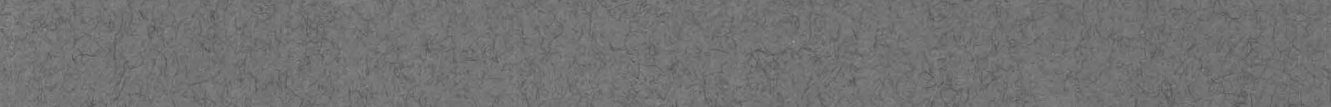

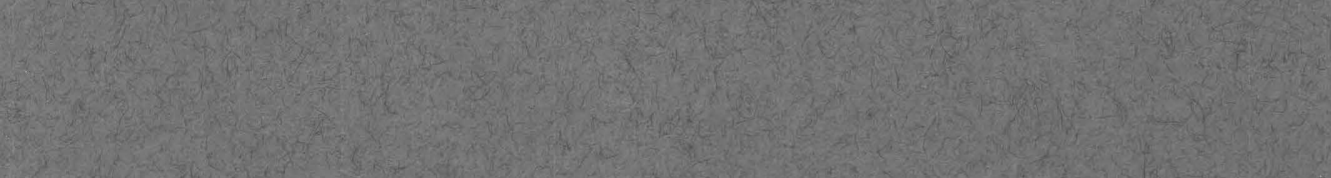

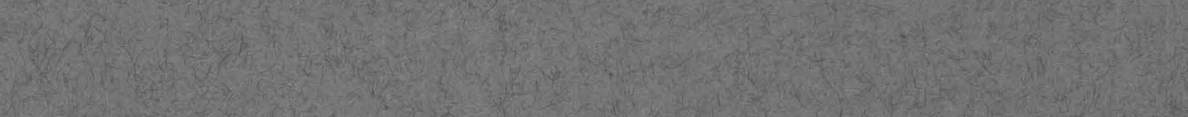

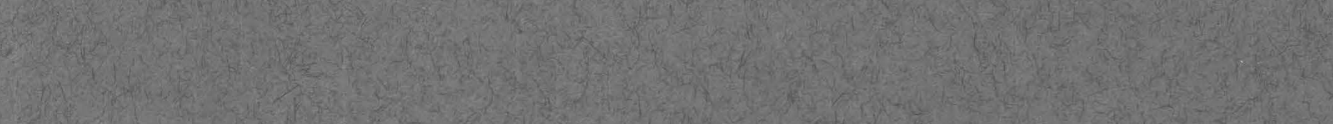

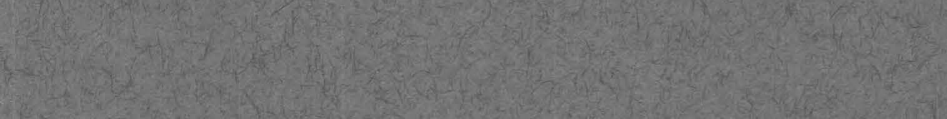

(1)

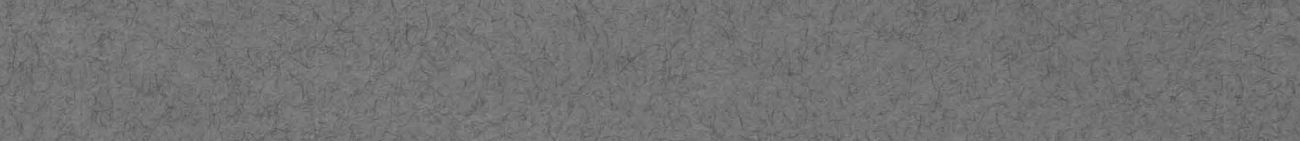

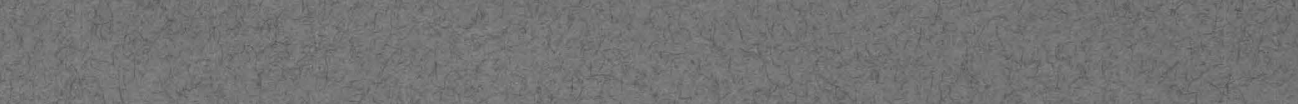
He 


\section{Systematic}

Mineralogy

Of Uranium

And Thorium

By CLIFFORD FRONDEL

GEOLOGICAL SURVEY BULLETIN 1064

This report concerns work done on behalf of the U.S. Atomic Energy Commission and is published with the permission of the Commission

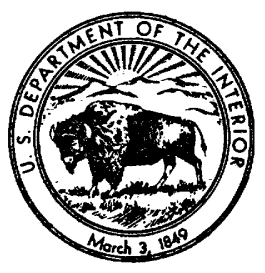




\section{UNITED STATES DEPARTMENT OF THE INTERIOR}

FRED A. SEATON, Secretary

\section{GEOLOGICAL SURVEY}

Thomas B. Nolan, Director

Frondel, Clifford, 1907-

Systematic mineralogy of uranium and thorium. Washington, U. S. Govt. Print. Off., 1958.

viii, 400 p. illus., plate, tables. $29 \mathrm{~cm}$. (U. S. Geological Survey. Bulletin 1064)

"This report concerns work done on behalf of the U. S. Atomic Energy Commission and is published with the permission of the Commission."

Bibliography: p. 361-396.

1. Uranium ores. 2. Thorium. 3. Uranium ores-Bibl. 4. Thorium-Bibl. I. Title. II. Title: Mineralogy of uranium and thorium. (Series)

QE75.B9 no. 1064

549.74

G S 58-254 Copy 2. QE391.U67F7 


\section{FOREWORD}

Since 1948 the U. S. Geological Survey has been making a broad and intensive study of the mineralogy of uranium and thorium as part of its program of investigation of the geology of fissionable materials on behalf of the Division of Raw Materials of the U. S. Atomic Energy Commission.

The first work undertaken in this study was the compilation of a list of specimens and X-ray powder-diffraction spindles and patterns of uranium and thorium minerals in the collections of the U. S. National Museum and Harvard University. The list, and instructions concerning the availability of the material to interested workers, was prepared as U. S. Geological Survey TEI-129 (Trace Elements Investigations Report 129) "A catalog of study material of radioactive minerals," by T. W. Stern, and issued in 1951 by the Technical Information Service, U. S. Atomic Energy Commission.

During this time, to bring some system into the nomenclature of these minerals, a glossary was prepared by Judith Weiss Frondel and Michael Fleischer entitled "Glossary of uranium- and thorium-bearing minerals." The first edition of this work was published as U. S. Geological Survey Circular 74 in 1950. A revised edition was issued as Circular 194 in 1952. Both of these editions were reprinted a number of times and a third edition (revised) was issued as U. S. Geological Survey Bulletin 1009-F in 1955.

As a result of intensive work on the mineralogy of the uranium deposits of the Colorado Plateau, which was also started during this period, a report was prepared entitled "Identification and occurrence of uranium and vanadium minerals from the Colorado Plateaus," by A. D. Weeks and M. E. Thompson, and issued as Survey Bulletin 1009-B in 1954. This work has been reprinted several times.

Early in the program, plans were made to prepare a comprehensive volume on the mineralogy of uranium and thorium. This work has progressed as a cooperative endeavor of the Geological Survey, the Department of Mineralogy and Petrography, Harvard University, and the Division of Mineralogy and Petrology, U. S. National Museum, Smithsonian Institution. Preparation of the volume was placed in the hands of Professor Clifford Frondel of Harvard University who had joined the Geological Survey as a part-time member of the staff. George Switzer, Acting Curator, 
Division of Mineralogy and Petrology, U. S. National Museum, has aided the work significantly. The work of many others is acknowledged in the text.

As the manuscript neared completion a wide demand became evident among scientific workers in this field for the tables of $\mathrm{X}$-ray powder-diffraction $d$-spacings that had been prepared for the present volume. These have therefore been published separately, in essentially the same form as presented here, as Survey Bulletin 1036-G, "X-ray powder data for uranium and thorium minerals," by Clifford Frondel, Daphne Riska, and Judith Weiss Frondel, 1956. A summary account of the mineralogy of thorium and a comparison of the mineralogy of thorium, uranium, cerium, and zirconium, together with a description of the geochemistry and occurrence of thorium, has also been prepared by Professor Frondel. This account has been published as "The mineralogy of thorium" in Survey Professional Paper 300, "Contributions to the geology of uranium and thorium by the United States Geological Survey and Atomic Energy Commission for the United Nations International Conference on Peaceful Uses of Atomic Energy, Geneva, Switzerland, 1955," p. 567-579, 1956.

Extremely rapid progress is being made in the study of the mineralogy of uranium and thorium in the Geological Survey and elsewhere. The volume presented here, it is hoped, will serve as a useful basic reference work in this active field.

JOHN C. RABBITT

Chief, Trace Elements Section, 1948-1953 


\section{CONTENTS}

Foreword

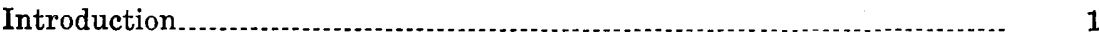

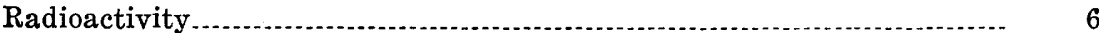

Age determination............................................................... 7

Autoradiography.................................................................. 8

Radiation damage in crystals........................................... 8

Index and classification of species.............................................. 10

Descriptive mineralogy............................................................... 11

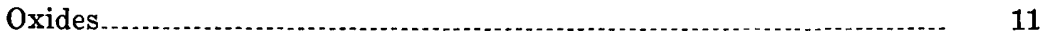

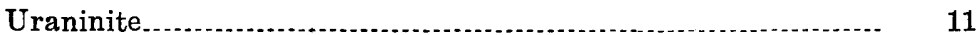

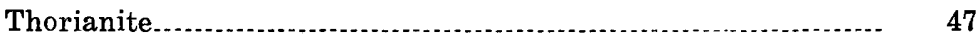

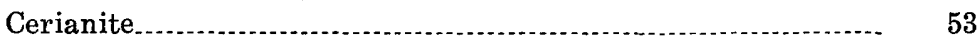

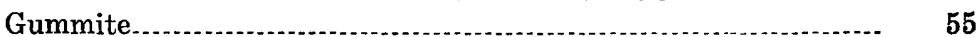

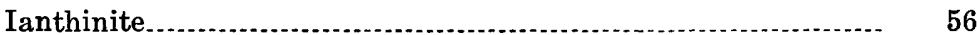

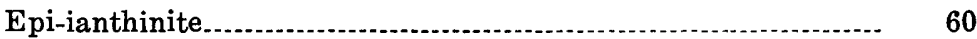

Unnamed mineral related to ianthinite........................... 62

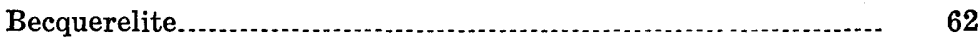

Billietite................................................................................... 68

Schoepite_.......................................................................... 72

Masuyite........................................................................... 78

Vandendriesscheite............................................................. 81

Fourmarierite............................................................. 87

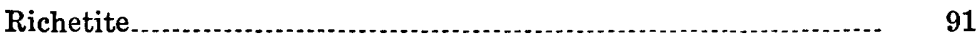

Curite

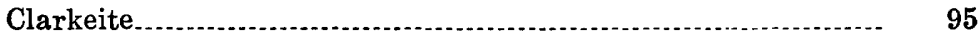

Uranospherite.................................................................. 98

Vandenbrandeite......................................................... 100

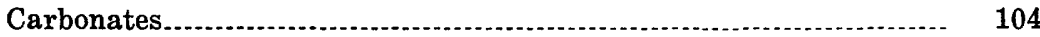

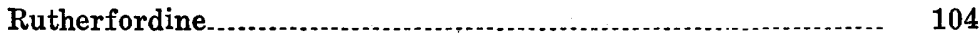

Sharpite........................................................................... 106

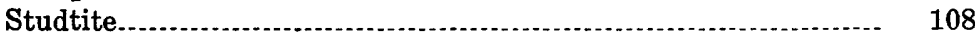

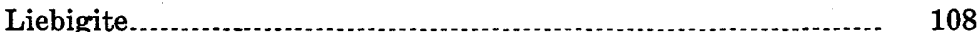

Bayleyite .......................................................................... 112

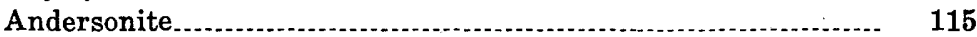

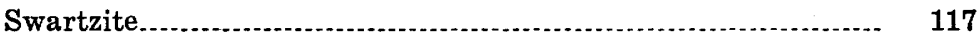

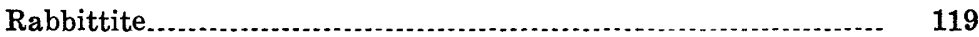

Schroeckingerite............................................................... 121

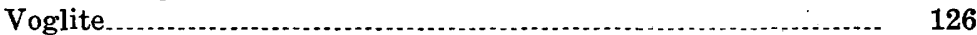

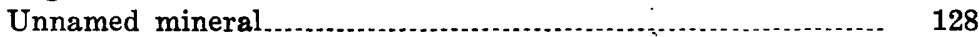

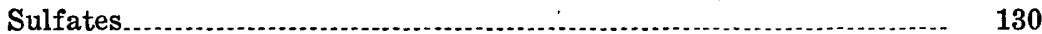

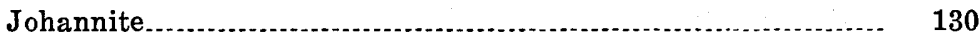

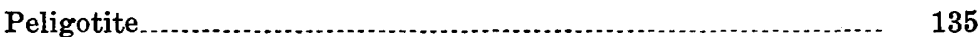

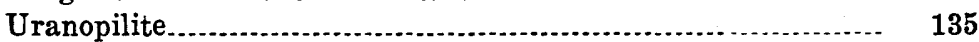

Meta-uranopilite............................................................. 140 
Descriptive mineralogy-Continued

Sulfates-Continued

Zippeite and zippeite-like minerals

Molybdates

Umohoite

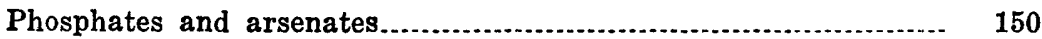

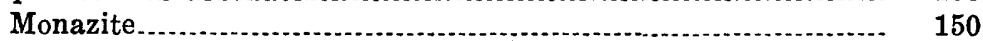

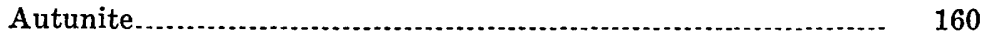

Torbernite.......................................................................... 170

Uranocircite..................................................................... 177

Saléeite-novacekite series............................................... 177

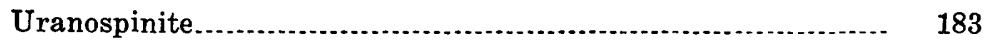

Troegerite................................................................. 187

Hörnbergite................................................................. 191

Zeunerite........................................................................... 191

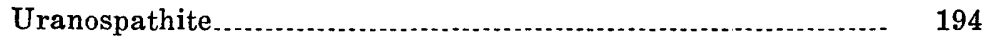

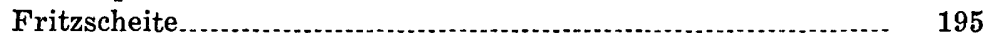

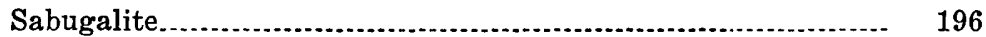

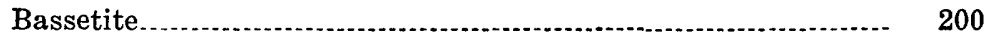

Minerals related to bassetite.............................................. 204

Kahlerite.................................................................... 204

Meta-autunite.................................................................... 205

Metatorbernite............................................................. 208

Meta-uranocircite............................................................... 211

Metazeunerite................................................................. 215

Abernathyite................................................................ 220

Phosphuranylite................................................................ 222

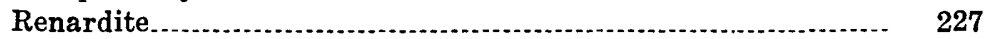

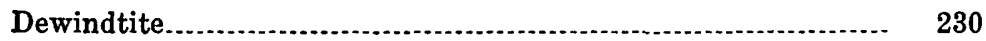

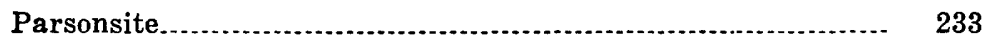

Dumontite.................................................................... 236

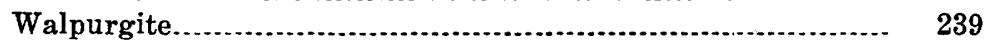

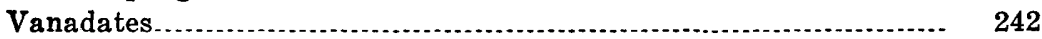

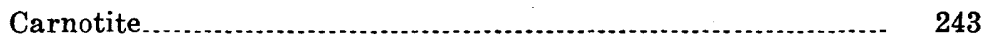

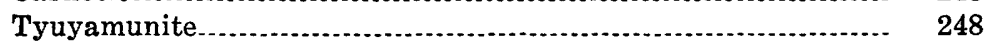

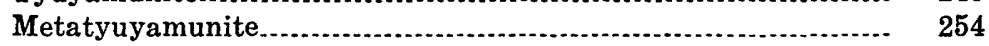

Unnamed mineral of Chirvinsky...................................... 257

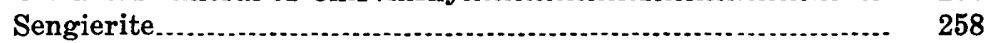

Unnamed mineral of Chernik

Ferghanite............................................................. 260

Uvanite .......................................................................... 261

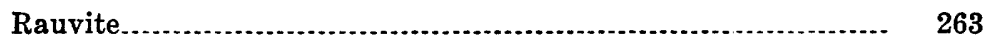

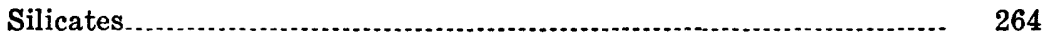

Thorite .................................................................... 265

Auerlite................................................................. 276

Calciothorite........................................................... 277

Freyalite.................................................................... 278

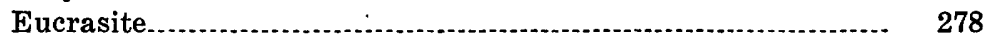

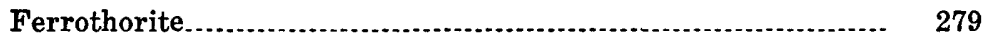

Enalite.......................................................................... 279

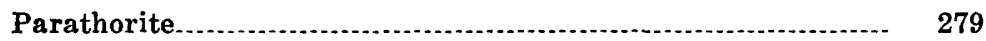


Descriptive mineralogy-Continued

Silicates-Continued

Thorogummite

Coffinite

Huttonite

285

Cheralite

Pilbarite.

292

Uranophane.

294

Sklodowskite

294

Cuprosklodowskite

300

Beta-uranophane.

304

Gastunite

307

Soddyite

311

Kasolite

312

315

Multiple oxides

320

Betafite

320

Pyrochlore-microlite

326

Pisekite

333

Brannerite

333

Davidite

337

Delorenzite.

341

344

Uranium and thorium minerals arranged according to $\mathrm{X}$-ray powder-diffraction interplanar spacings.

Uranium and thorium minerals arranged according to chemical composition

Uranium and thorium minerals arranged according to optical properties

Uranium and thorium minerals arranged according to color............

Uranium and thorium minerals arranged according to specific gravity

Uranium and thorium minerals arranged according to fluorescence. References

Index

\section{ILLUSTRATIONS}

Plate 1. Autoradiograph of dendritic aggregate of uraninite crystals

Frgure 1. Uraninite. $A$. Cube, $a\{100\}$. B. Cubo-octahedron, $a\{100\}$ and $o\{111\}$

2. Thorianite. $A$. Forms : $a\{100\}$ and $m\{113\}$. B. Interpenetration twin on (111)

3. Billietite

4. Masuyite. A. Optical orientation. B. A twin crystal ....

5. Vandendriesscheite. $A, B$. Plane projection on (010) ....

6. Richetite. A. A twinned crystal. B. A repeated twin ....

7. Schroeckingerite

8. Uranopilite 
FIgURE 9. Monazite. A, B. Typical habit. C. New York. D. Tavetsch, Switzerland

10. Autunite

11. Torbernite. A. Forms: $c\{001\}, m\{110\}, e\{011\}, o\{013\}$. $B$. Forms : $c\{001\}, p\{111\}, e\{011\}$. C. Forms: $c\{001\}$, $e\{011\}, o\{013\}$

12. Saléeite

13. Bassetite. $A$. Drawing shows the observed habit and its relation to the tetragonal interpretation of the morphology. $B$. Idealized monoclinic habit, showing the optical orientation

14. Renardite

15. Parsonsite

16. Dumontite

17. Walpurgite

18. Carnotite. $A, B$. Typical habit

19. Tyuyamunite

20. Thorite. A. Pyramidal habit. B. Prismatic habit.

21. Beta-uranophane

22. Soddyite. $A$. Form: $p\{111\}$. B. Forms : $p\{111\}, c\{001\} \ldots$

23. Betafite

24. Microlite. A. Forms: $d\{011\}, 0\{111\}$. B. Forms: $0\{111\}$, $m\{113\}$

\section{TABLES}

TABLE 1. Uranium and thorium minerals arranged according to $\mathrm{X}$-ray powder-diffraction interplanar spacings

2. Known uranium and thorium minerals listed by principal cation or cations (in addition to uranium)

3. Known uranium and thorium minerals listed by principal anion or anions present

4. Indices of refraction of uranium and thorium minerals ....

5. Uranium and thorium minerals arranged by color ...............

6. Specific gravity of uranium and thorium minerals ..............

7. Fluorescence of uranium and thorium minerals listed alphabetically

8. Fluorescence of uranium and thorium minerals listed by color and intensity of fluorescence 


\title{
SYSTEMATIC MINERALOGY OF URANIUM AND THORIUM
}

\author{
By ClifFord FrONDEL
}

\begin{abstract}
Uranium and thorium minerals, together with a few rare-earth minerals containing uranium and thorium as nonessential constituents, are systematically and comprehensively described in this volume. The classification of the minerals included here is chemical. It is based on the nature of the anion, giving rise to the following broad categories: oxides, carbonates, sulfates, molybdates, phosphates and arsenates, vanadates, silicates, and the niobatecantalate-titanates or, more properly, multiple oxides. The phosphates and arsenates are described together because in general they are isostructural and form partial or complete solid-solution series. Within each category, minerals of analogous chemical composition and crystal structure are grouped together, such as the torbernite group of minerals within the phosphates in general. No formal distinction is made in the classification between anhydrous species and those containing water or hydroxyl. Almost all of the minerals described are hydrated.

Each mineral species is described according to its synonymy, composition, crystallography and crystal habit, physical properties, optical properties, synthesis, identification, natural formation, and occurrence. The descriptive mineralogy is followed by determinative tables in which the mineral species are arranged according to their $\mathrm{X}$-ray powder-diffraction interplanar spacings, chemical composition, optical properties, color, specific gravity, and fluorescence.

The work is documented by more than 800 references to the world literature of the past 200 years.
\end{abstract}

\section{INTRODUCTION}

The element uranium was discovered in 1789 by the German chemist and mineralogist M. H. Klaproth (1743-1817). Klaproth, the first professor of chemistry in the University of Berlin, was the leading chemical analyst of his time. He prepared a yellow oxide $\left(\mathrm{UO}_{3}\right)$ from pitchblende from the Georg Wagsfort mine at Johanngeorgenstadt in the Erzgebirge of Saxony. Pitchblende had been earlier recognized from this place and from the nearby locality of Joachimsthal as a separate mineral entity, pechblend, but its composition, variously thought to include zinc, iron, and tungsten, was unknown. Klaproth heated his yellow oxide with carbon and thought that he had reduced it to the element when he obtained a dark, somewhat metallic-looking powder. This powder he called uranium, and the name uranite was applied to the natural ore. Klaproth's product was assumed to be the element for about 50 years, until it was shown by the French chemist 
E. Péligot in 1841 to be in fact the oxide, $\mathrm{UO}_{2}$. Péligot then prepared the first elemental uranium by reducing $\mathrm{UCl}_{4}$ with potassium.

The radioactivity of uranium was discovered by Henri Becquerel in 1896, and the element radium was isolated by P. Curie, M. Curie, and G. Bémont in 1898 from pitchblende from Joachimsthal. Until the discovery of atomic fission, uranium ores were mined for radium and for various small-scale technical and industrial applications. These included the use of uranium or its compounds in the ceramic and textile industries, as an alloy constituent in steel, in the preparation of fluorescent materials, as a catalyst in ammonia synthesis, in photography, and as incandescent filaments and X-ray anticathodes. In chemical analysis, uranyl nitrate has been used as a reagent for the determination of phosphoric acid. The uranium ores used for these purposes were originally obtained from uraninite deposits in Saxony, Bohemia, and Cornwall. They were later supplemented by the carnotite deposits of the Colorado Plateau, discovered in 1898, and to a certain extent by the tyuyamunite ores of Ferghana and the autunite deposits of Portugal. The carnotite mines of the Colorado Plateau became almost wholly inactive in the 1920's following the discovery and subsequent development of the rich uranium ores of the Katanga district in the Belgian Congo. The uraninite ores of Great Bear Lake, Canada, discovered in 1930, became a further and major source of supply. The discovery of atomic fission in 1937 by Hahn and Strassmann was followed by a great program of work on the uses of uranium and the transuranium elements both as sources of power and as military weapons. This work brought a large and immediate demand for uranium ores and gave a great impetus to the study of the geology and mineralogy of uranium.

The element thorium was discovered in 1828 by the Swedish chemist J. J. Berzelius (1779-1848). The element was isolated from a silicate mineral, $\mathrm{ThSiO}_{4}$, to which the name thorite was applied, found in a pegmatite on an island in the Langesund Fiord, southern Norway. The radioactivity of thorium was discovered independently by Madame Curie and C. G. Schmidt in 1898. The element and its compounds have not yet found largescale applications, although they formerly were used extensively in the manufacture of incandescent gas mantles. Thorium is of potential importance in the field of atomic energy because the natural isotope of thorium, $\mathrm{Th}^{232}$, can be converted by neutron bombardment to the thorium isotope, $\mathrm{Th}^{233}$, which yields an isotope of uranium, $\mathrm{U}^{233}$, that is fissionable. Minerals in which 
thorium is an essential constituent are few. The element occurs, however, in solid solution in variable and usually small amounts in many rare-earth, zirconium, and uranium minerals, notably zircon, uraninite, and monazite. The presence of thorium in monazite was discovered in 1839. Most of the world's supply of thorium comes from detrital deposits of monazite in Brazil, Ceylon, and Travancore, India.

Approximately 70 different mineral species are known that contain uranium as an essential constituent, and there are 6 minerals containing thorium as an essential constituent. These minerals are described in the present volume. There are also many minerals some specimens of which contain uranium or thorium in variable and usually small amounts as nonessential constituents. A few of these minerals, such as monazite, brannerite, davidite, and pyrochlore-microlite, are included in this work. Descriptions of the others are in standard mineralogic reference books, and a glossary of all minerals that have been found to contain uranium and thorium both as essential and as vicarious constituents has been published by J. W. Frondel and Fleischer (1955).

Advances in the descriptive mineralogy of uranium have been sporadic and reflect the discovery of new deposits or of new uses for this element. Two species were known prior to 1800 , uraninite and torbernite (other members of the torbernite family being confused therewith), and only five additional species, autunite, johannite, zippeite, thorite, and liebigite, were recognized up to 1850. In the whole period to 1910 only about one-third of the total number of species now known had been recognized. These were described mostly from localities in middle Europe by German and Austrian mineralogists, chief among whom were A. Weisbach, A. Schrauf, and J. F. Vogl. In the 20 years following the discovery, in 1915, of the mineralogically diverse ores of the Belgian Congo the list of known species was doubled largely through the studies of Belgian mineralogists on material from that area, among whom were $\mathrm{H}$. Buttgenbach, J. Thoreau, J. Mélon, and in particular, A. Schoep. Schoep described 12 of the 23 uranium minerals first discovered in the Belgian Congo. The work of the American mineralogist C. Palache on the uranium minerals from this locality also should be mentioned here. No such increase of new species followed the discovery of the Great Bear Lake deposit, owing primarily to the very small extent of surface oxidation at this locality. Ten uranium minerals, together with over 20 vanadium minerals, were first described from uranium deposits in the Colorado Plateau region. Many of these 
have been described since 1950, chiefly by members of the U. S. Geological Survey. The present intensive mining activities in the Colorado Plateau region and associated geologic and mineralogic studies doubtless will result in the finding of additional species in the near future.

The identification of uranium minerals often presents difficulties that are in part inherent in the material. Thus many uranium minerals, such as those of the torbernite family, show a wide variation in optical properties owing to marked variation in the content of zeolitic water at or near room temperature. Optical and other data on such substances may be confusing or nondiagnostic unless obtained on material of known or controlled water content. Many species occur in extremely small amounts, so that conventional analytical or other tests cannot be applied, and others occur at times as extremely fine-grained aggregates and mixtures. It has in fact been found useful in the past to use a generic or pocket term, gummite, to designate various fine-grained uranium minerals that occur chiefly as alteration products of uraninite and whose true identity was unknown. The term found its widest use in the days before the advent of X-ray diffraction and other techniques suited to the study of fine-grained aggregates. Had these techniques been available earlier, the date of recognition of fourmarierite, vandendriesscheite, beta-uranophane, and kasolite, at least, would have been advanced many years, as all are common constituents of gummite and had been examined if not distinguished by many early investigators.

Another source of difficulty in the descriptive mineralogy of uranium is in the inadequacy of the existing descriptions of many uranium minerals, including some described in recent years. In a few instances, the existing data do not permit the recognition of the species with certainty. Recognition of the uranyl carbonates, sulfates, and hydrated oxides is particularly difficult. Many of the known species have been re-examined in recent years, resulting in diagnostic optical, X-ray, and other data, but much remains to be done. Unfortunately, this situation is complicated by the unavailability or lack of authentic specimens of some minerals that have been described in the literature. The science of mineralogy in its descriptive aspects is a specimen science, like botany and entomology, and requires for its practice and progress the preservation and ready availability of type specimens. Mineralogists who describe new species or significant varieties of known species should ensure that specimens are preserved in the leading reference mineral collections of the world, such as the collections of Harvard University, Cambridge, Massachusetts; 
the United States National Museum, Washington, D. C.; and the British Museum of Natural History, London. Particular caution should be exerted by those who describe new species of uranium minerals. It is obligatory to show that a proposed new species differs from all existing species. This may require a definitive reexamination of an ill-defined earlier described mineral whose true relation to the substance at hand is uncertain. The characterization of a new mineral should include X-ray powder-spacing data obtained on a sample of demonstrated purity, together with a statement of the chemical, optical, physical, and crystallographic characters.

The classification of the minerals included in this work is chemical. It is based on the nature of the anion, giving rise to the following broad categories: oxides, carbonates, sulfates, molybdates, phosphates and arsenates, vanadates, silicates, and the niobate-tantalate-titanates or, more properly, multiple oxides. The phosphates and arsenates are described together because in general they are isostructural and form partial or complete solidsolution series. Within each category, minerals of analogous chemical composition and crystal structure are grouped together, such as the torbernite group of minerals within the phosphates in general. No formal distinction is made in the classification between anhydrous species and those containing water or hydroxyl. Almost all of the minerals described are hydrated. A detailed classification of the known uranium and thorium minerals is given on pages 10-11.

The X-ray powder-diffraction interplanar spacings, chemical composition, optical properties, color, specific gravity, and fluorescence behavior described under each species are summarized in the form of determinative tables on pages 344-360.

The mineralogy of uranium and thorium should be studied in context with the inorganic and organic chemistry, crystal chemistry, and geochemistry of these elements. A detailed treatment of these matters, however, is not given here. Summaries of the chemistry of uranium and thorium are given in the well-known reference works by Gmelin $(1928,1936)$ and Mellor $(1927,1932)$ and, for uranium, by Katz and Rabinowitch (1951). Annotated bibliographies of the unclassified literature on uranium and its compounds have been compiled by Croxton (1951) and Allen (1953), on thorium by David (1953) and by Allen (1955), and selected references on the uranium oxides have been published by Lang in a National Bureau of Standards Circular (1953). The crystal chemistry of uranium and thorium has been discussed by C. Frondel (1956a), A. F. Wells (1950), and Garrels 
(1955). Accounts of the general geochemistry of these elements have been given by Tomkeieff (1946), Rankama and Sahama (1949), Fleischer and Rabbitt (1952), C. Frondel (1956a), and Neuerburg (1956). The geochemistry of uranium in sedimentary rocks has been discussed by McKelvey and Nelson (1950), in phosphate rock by Davidson and Atkin (1952), and in coal by Davidson and Ponsford (1954) and by Breger and Deul (1956). Useful general accounts of the mineralogy and geology of uranium and thorium are given in works by Nininger (1954), Weeks and Thompson (1954), Davidson (1949), George (1949), Bain (1950), Bruet (1952), A. Lang (1952), Kohl (1954), and Kerr (1956). A summary account of the origin of uranium deposits is given by McKelvey, Everhart, and Garrels (1956). A comprehensive bibliography and index to the literature on the occurrence of uranium and thorium in the Western United States is given by Cooper $(1953,1954,1955)$. Abstracts of literature that have appeared since the publication of the above works or that supplement them can be found in Chemical Abstracts, Mineralogical Abstracts, and the Annotated Bibliography of Economic Geology. Volume 6, "The geology of uranium and thorium," of the Proceedings of the International Conference on the Peaceful Uses of Atomic Energy (United Nations, 1956), and U. S. Geological Survey Professional Paper 300 (Page, Stocking, and Smith, 1956), containing papers in the field of the geology of uranium and thorium contributed to the Conference by the Geological Survey and the Atomic Energy Commission, are of particular interest. These volumes contain many papers dealing with the occurrence and geochemistry of uranium and thorium minerals; however, they were published after the present volume was completed in manuscript and only a few references to them are made here. Works by Chervet and Branche (1955) and by Geffroy and Sarcia (1955), describing the uranium minerals of France, became available too late for use in the preparation of this volume.

\section{RADIOACTIVITY}

Uranium is the parent of two radioactive disintegration series, one leading from the isotope $\mathrm{U}^{238}$ to the stable lead isotope $\mathrm{Pb}^{200}$ and the other from isotope $\mathrm{U}^{235}$ to the stable lead isotope $\mathrm{Pb}^{207}$. The two isotopes $U^{235}$ and $U^{238}$ are present in natural material in the ratio $1: 138$. Thorium also disintegrates, and its decay series leads from $\mathrm{Th}^{232}$, the only natural isotope of this element, to the stable lead isotope $\mathrm{Pb}^{208}$. The disintegrations are accompanied by the emission of alpha particles, beta particles, and gamma rays. 
The radioactivity of uranium and thorium is of considerable mineralogic and geologic importance, but only very brief mention can be made here of a few aspects of the matter. A review paper by Kohman and Saito (1954) deals with many aspects of radioactivity in geology and cosmology.

\section{AGE DETERMINATION}

The geologic age of uranium and thorium minerals can be measured under favorable circumstances from a knowledge of the rate of decay of the parent elements and a determination by chemical or other means of the amounts of the parent elements and of the stable end product, lead or other daughter products. A number of different methods are used. In the so-called chemical lead:uranium-thorium method, the elements present are determined chemically without regard to their isotopic composition. In a variant of this method, the lead-alpha method developed by Larsen and coworkers (1952), the lead is determined spectrochemically and the uranium is measured from the total alphaparticle emission activity. Thorium, if present, is estimated from a fluorimetric analysis for uranium and the total alpha activity. The chemical lead:uranium-thorium method has been widely used with uraninite, but serious errors can be introduced by differential leaching of lead and uranium from this relatively easily altered mineral. The lead-alpha method is rapid and relatively simple; it is used chiefly with zircon found as an accessory constituent in rocks. Several other methods of age determination are based on more refined procedures involving a determination by the mass spectrometer of the several isotopes of the radiogenic lead. The helium method, probably the least reliable of the various analytical methods based on radioactive disintegration, involves the determination of the content of radiogenic helium in uranium and thorium minerals. It is essential in the lead methods of age determination either that little or no lead was originally present in the mineral at the time of its formation, or that the presence of such lead be established and accurately evaluated. Secondary uranium minerals are normally not useful for age determination for various reasons, particularly because of their relatively low chemical and physical stability and, in many instances, because of the presence of radiogenic lead derived from earlier formed uranium minerals and taken up during crystallization as an essential constituent. Also, these minerals may be of very recent formation and not in radioactive equilibrium. In favorable circumstances when a mineral contains only trace quantities of lead, the mineral can be dated by means of the radium-uranium equilibrium. 
This method can be used only for minerals less than one half million years old. A discussion of the various methods of age determination based on radioactivity is given in Faul (1954).

\section{AUTORADIOGRAPHY}

Photographic emulsions are blackened by the radiation emitted during radioactive decay. The effect can be used in the recognition and measurement of radioactivity, in studying the distribution of radioactivity in rocks or crystals, in aiding in the identification of uranium and thorium minerals, and in other ways. The photographic emulsions range in thickness from 5 to 200 microns and are used either supported on a glass plate or as stripping emulsions or liquid gels. Ordinary photographic emulsions are sensitive to alpha, beta, and gamma radiation and produce a somewhat diffuse image. Special alpha-track emulsions, relatively insensitive to ordinary light and to beta and gamma radiation, are ordinarily used in autoradiography. Beta-sensitive emulsions have been used for the radiography of samples that have been previously activated by bombardment with neutrons (Goodman and Picton, 1941; Goodman and Thompson, 1943). The autoradiography of uraninite and other radioactive substances was early demonstrated by M. Curie (1898), Crookes (1900), Pisani (1904), Stěp and Becke (1904), and Wherry (1908), the latter using an extensive collection of uranium minerals from localities in Pennsylvania. Yagoda (1946a, 1948, 1949) and Bowie (1951) have described the modern technique of taking autoradiographs, and recent summaries are given by Bowie in Faul (1954), by Goldschmidt-Clermont (1953), and Beiser (1952). Localized areas of abnormally high radioactivity in altered uraninite were found by autoradiography and are due to radiocolloid aggregates $\left(\mathrm{Pb}^{206} \mathrm{SO}_{4}\right.$ with $\left.\mathrm{RaSO}_{4}\right)$ (Yagoda, 1946b).

\section{RADIATION DAMAGE IN CRYSTALS}

Crystals containing uranium, thorium, or other radioactive elements either as essential constituents or as vicarious constituents in solid solution are irradiated internally by alpha, beta, and gamma radiation released during radioactive decay. Part of the energy of these radiations is absorbed internally in ionization processes of various kinds, giving rise to coloration of the crystal or to luminescence and thermoluminescence, and a further part is expended in the dislocation of atoms from their normal positions in the crystal structure. The thermoluminescence of minerals and rocks has been used in the measurement of geologic time and in the correlation of rock formations (Daniels and coworkers, 
in Faul, 1954). The atomic disordering or metamictization of minerals containing uranium or thorium by internal irradiation is of much mineralogic and geologic interest. The effect is shown to varying degree by different uranium and thorium minerals. It is conditioned by the geometry of the crystal structure, the type of bonding, the chemical composition of the crystal, the amount of uranium and thorium present, the age of the mineral, and other factors. In general, the effect is least pronounced in minerals with a relatively simple structure and a strong ionic bond, such as uraninite and thorianite, and is marked in minerals with a complex crystal structure and anisodesmic type of bond in which the cation is near the critical radius ratio with the coordinating anions. Metamictization is characteristic of certain silicates, niobate-tantalates, and phosphates containing rare earths or zirconium in addition to uranium and thorium. Well-known examples include thorite, zircon, allanite, gadolinite, monazite, euxenite, samarskite, and microlite-pyrochlore. Metamict zircon has been studied extensively by Bauer (1939), Lietz (1937), Stackelberg and Chudoba (1937), Stackelberg and Rottenbach (1939), Chudoba and Stackelberg (1936), and Holland and Gottfried (1955). Increasing radiation damage in zircon is accompanied by a decrease in specific gravity, hardness, and refractive indices, and by a gradual loss of crystallinity as shown by increasing diffuseness of the X-ray diffraction pattern; there is also a progressive increase in the unit-cell dimensions. When the disorder is extensive or complete the crystal may become optically isotropic and glasslike in its properties. At this stage the material is relatively reactive chemically, and may become altered or hydrated. On heating to a sufficiently high temperature, disordered metamict material may crystallize exothermally, restoring either the original phase or forming one or more new phases. In zircon, the variation in unit-cell dimensions (Hurley and Fairbairn, 1953) and the amount of heat liberated during recrystallization (Holland and Kulp, 1950) have been investigated as a measure of geologic age. An increase in unit-cell dimensions accompanying radiation damage also has been observed in allanite by Ueda and Korekawa (1954) and in quartz, diamond, and silicon carbide by Primak and others (1953). In some instances it has been found that when crystals containing radiation damage are annealed the associated changes in cell dimensions, specific gravity, and other properties are not restored simultaneously (Primak and others, 1953). Reviews of the general subject have been given by Faessler (1942), Pabst (1952), Ueda and Korekawa (1954), Faul (1954), and Billington and Crawford (1956). 


\title{
INDEX AND CLASSIFICATION OF SPECIES
}

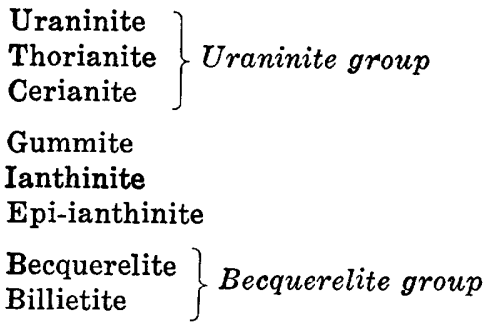

\section{OXIDES}

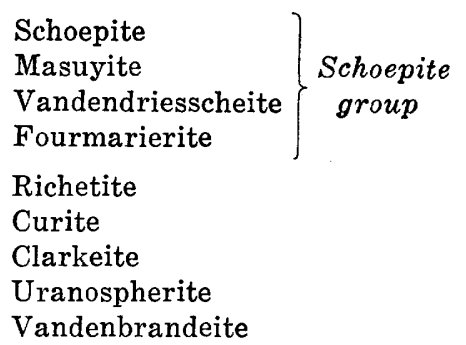

CARBONATES

Swartzite

Rabbittite

Schroeckingerite

Voglite

Unnamed mineral

\section{SULFATES}

Mata-uranopilite

Zippeite

Johannite

Uranopilite

MOLYBDATES

Umohoite

\section{PHOSPHATES AND ARSENATES}

Monazite

Autunite

Torbernite

Uranocircite

Saléeite-Novacekite

Uranospinite

Troegerite

Zeunerite

Uranospathite

Fritzscheite

Sabugalite

Bassetite

Kahlerite

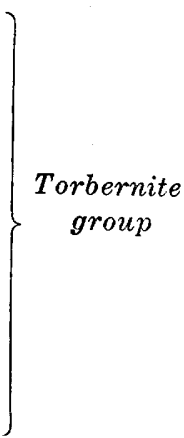

$$
\begin{aligned}
& \left.\begin{array}{l}
\text { Meta-autunite } \\
\text { Metatorbernite } \\
\begin{array}{l}
\text { Meta-uranocircite } \\
\text { Metazeunerite } \\
\text { Abernathyite }
\end{array}
\end{array}\right\} \begin{array}{r}
\text { Metatorbernite } \\
\text { group }
\end{array} \\
& \left.\begin{array}{l}
\text { Phosphuranylite } \\
\text { Renardite } \\
\text { Dewindtite } \\
\text { Parsonsite } \\
\begin{array}{l}
\text { Dumontite } \\
\text { Walpurgite }
\end{array}
\end{array}\right\} \begin{array}{r}
\text { Phosphuranylite } \\
\text { group }
\end{array} \\
&
\end{aligned}
$$

\section{Carnotite}

Tyuyamunite

Metatyuyamunite

Sengierite

\author{
VANADATES \\ Ferghanite \\ Uvanite \\ Rauvite
}




$\left.\begin{array}{l}\text { SILICATES } \\ \text { Thorite } \\ \text { Thorogummite } \\ \text { Coffinite } \\ \text { Uranophane } \\ \begin{array}{l}\text { Sklodowskite } \\ \text { Cuprosklodowskite }\end{array}\end{array}\right\} \begin{aligned} & \text { Cheralite } \\ & \text { Tranophane } \\ & \text { group }\end{aligned}$
$\begin{aligned} & \text { Pilbarite } \\ & \text { Beta-uranophane } \\ & \text { Gastunite } \\ & \text { Soddyite } \\ & \text { Ketafite }\end{aligned}$
$\begin{aligned} & \text { Karochlite } \\ & \text { Pisekite }\end{aligned}$

\section{DESCRIPTIVE MINERALOGY OXIDES}

The anhydrous and hydrated oxides of uranium and thorium include three groups of minerals, the uraninite group, becquerelite group, and schoepite group, together with a number of species without close relatives among other minerals. The uraninite group includes uraninite, the principal ore mineral of uranium, together with its thorium and cerium analogues, thorianite and cerianite. They all are ideally dioxides that are isostructural with fluorite, $\mathrm{CaF}_{2}$, and are isometric in crystallization. The becquerelite group includes becquerelite, $7 \mathrm{UO}_{3} \cdot 11 \mathrm{H}_{2} \mathrm{O}$, and its barium-containing derivative, billietite, $\mathrm{BaO} \cdot 6 \mathrm{UO}_{3} \cdot 11 \mathrm{H}_{2} \mathrm{O}$. The schoepite group comprises schoepite, $4 \mathrm{UO}_{3} \cdot 9 \mathrm{H}_{2} \mathrm{O}$, and three lead-containing hydrated oxides of uncertain composition, masuyite, vandendriesscheite, and fourmarierite, that seem to be structural derivatives of schoepite and possibly are members of a solid-solution series related to that species. The remaining minerals classified here include curite, notable for its high content of lead and bright orange-red color; clarkeite; the copper-uranium oxide vandenbrandeite; and the relatively ill-defined minerals richetite, ianthinite, epi-ianthinite, and uranospherite.

\section{Synonymy}

\section{URANINITE}

Schwarz Beck-Erz [from Joachimsthal] Brückmann (1727). Beck-Blände $=$ Pseudogalena picea pt. [the rest, and possibly all, pitchlike sphalerite] Wallerius (1747). Swart Blende $=$ Pechblende pt. Cronstedt (1758). Pseudogalena nigra compacta, Pechblende von Born (1772). Pechblende [from Joachimsthal] Ferber (1774). Pechblende, Eisenpecherz [put under iron ores] Werner (1789). Uranerz Klaproth $(1792,1797)$. Pecherz Karsten (1800). Urane oxydulé Haüy (1801). Uranin Haidinger (1845). Schweruranerz [from Prǐbram] Breithaupt (1847). Coracite pt. Le Conte 
(1847). Kristallisirtes Uranpecherz Scheerer $(1847)=$ Uranoniobite Hermann (1859). Nasturan von Kobell (1853). Uranatemnite Chapman (1853). Uraninite Dana (1868) [the species was called pitchblende in earlier editions of this work]. Cleveite Nordenskiöld (1878). Bröggerite, Thor-uranin Blomstrand (1884). Nivenite Hidden and Mackintosh (1889). Chlorothorite Hidden (1889). Ulrichite Kirsch (1925). Uranpecherz, Pechuran Germ.

Two names, uraninite and pitchblende, are in common use for this mineral. Uraninite is the correct name for the species as a whole, including all of its varieties. The name pitchblende is commonly used to designate a more or less sharply defined variety of uraninite. Pitchblende occurs chiefly in hydrothermal metalliferous veins. It forms microcrystalline masses that often show concentric banding and have a botryoidal or rounded surface when developed as crusts. The particle size of pitchblende is small, in general below about $10^{-2} \mathrm{~mm}$, to less than $10^{-6} \mathrm{~mm}$. The particles or fibers that compose pitchblende may be randomly arranged or show a preferred orientation with the [111] direction, which is also the direction of elongation of the fibers, arranged perpendicular to the surface of the crusts or globules. The small particle size is a consequence of rapid crystallization at relatively low temperatures or, as has often been suggested, results from the crystallization of gel masses. It might also be a consequence of the direct crystallization of the mineral in a relatively. highly oxidized state, $\mathrm{UO}_{2+\mathrm{x}}$, in which structural strain arising from the presence of interstitial oxygen impedes normal crystal growth. Pitchblende from hydrothermal veins generally has a relatively small content of rare earths and thorium in solid solution, in contrast to most of the coarsely crystallized uraninite found in pegmatites. These differences in composition reflect geochemical factors that determine the elements present with uranium in the solutions from which the uraninite crystallizes. Coarsely crystallized uraninite low in thorium and rare earths also occurs in hydrothermal veins, as in the Belgian Congo. The relation between the names uraninite and pitchblende is similar to that between quartz and chalcedony.

The names bröggerite, cleveite, and nivenite were applied originally to minerals thought to be distinct from uraninite, and this usage has continued in some recent literature. All of these substances have been found by X-ray study, however, to be only compositional variants of uraninite marked by a relatively high content of rare earths. The name ulrichite was proposed to designate the hypothetical pure $\mathrm{UO}_{2}$ following the realization that 
uraninite was not a definite compound of both $\mathrm{U}^{+4}$ and $\mathrm{U}^{+6}-a$ uranyl uranate-but is more or less oxidized $\mathrm{UO}_{2}$. The above names serve no useful purpose and should be completely abandoned. Varieties of uraninite that contain significant amounts of other elements in solid solution should be designated by chemical adjectival modifiers, such as cerian uraninite, thorian uraninite, and the like, following the widely accepted modern convention. Thorianite, $\mathrm{ThO}_{2}$, is isostructural with uraninite and forms a complete solid-solution series with it. The names uraninite and thorianite are here applied to the two halves of the series with $\mathrm{U}>\mathrm{Th}$ and $\mathrm{Th}>\mathrm{U}$ in atomic percent, respectively.

The name uraninite, like that of the element uranium, is derived from the planet Uranus, discovered by Herschel in 1781 shortly before the element was discovered by Klaproth. Uranus in Greek mythology was the husband of Gaea or Ge (Earth) and father of the Cyclopes and the Titans. Bröggerite was named after W. C. Brögger (1851-1940), Norwegian mineralogist and geologist; cleveite after the Swedish chemist P. T. Cleve (1840-1905) ; and ulrichite after the Austrian radiochemist Carl Ulrich (died

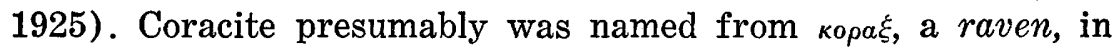
allusion to the black color and luster. Nasturan was named from varros, compact, and uran, uranium, because it is a massive uranium mineral. Nivenite was named after William Niven (1850 1937), American mineral collector and archeologist. The name pitchblende, and its earlier German forms pecherz, pechuran, pechblende, allude to the pitchlike color and luster of some varieties of the mineral.

\section{Composition}

Uraninite has the ideal chemical composition $\mathrm{UO}_{2}$, uranium dioxide. Material of this ideal composition, however, has not been found in nature. The mineral always is more or less oxidized with conversion of the $\mathrm{U}^{+4}$ in part to $\mathrm{U}^{+6}$. This oxidation takes place without destruction of the crystal structure up to a not clearly defined limit. Valence compensation is effected by a concomitant entrance of oxygen into vacant positions in the crystal structure, and the mechanism may be formulated $\left(\mathrm{U}^{+4}{ }_{1-\mathrm{x}} \mathrm{U}_{\mathrm{x}}\right) \mathrm{O}_{2+\mathrm{x}}$. This matter is discussed further in a later section on phase relations in the system U-O. (See also under Thorianite.)

The least degree of oxidation in any natural uraninite so far analyzed is that of the material of analyses 3 (p. 16) and 41 (p. 20), with ratios of $\mathrm{U}^{+4}$ to $\mathrm{U}^{+6}$ of 1 to 0.17 and 1 to 0.21 , respectively. Analysis 3 corresponds to $\mathrm{UO}_{2.15}$ if constituents other than uranium are disregarded. Both samples have a relatively high specific 
gravity, and the material of analysis 3 was described as a black crystal with unusually high luster. The upper limit of oxidation of natural material is uncertain. Seven of the 40 analyses reported in the table (p. 16-20) have $\mathrm{U}^{+6}>\mathrm{U}^{+4}$. Analysis 39 has $\mathrm{U}^{+4}$ : $\mathrm{U}^{+6}=1: 2.58$. This corresponds to $\mathrm{UO}_{2.72}$ if constituents other than uranium are disregarded. Analysis 15 has $\mathrm{U}^{+4}: \mathrm{U}^{+6}=1: 2.22$, but a reanalysis of this material (no. 16) did not confirm the earlier results. The material of analysis 5 , with $U^{+4}: U^{+6}=1: 1.22$, contained admixed yellow (uranyl) alteration products, and analysis 14 with $\mathrm{U}^{+4}: \mathrm{U}^{+6}=1: 1.66$ may be in error according to Hillebrand (1892). Brooker and Nuffield (1952) report measurements of the $\mathrm{U}^{+4}: \mathrm{U}^{+6}$ ratio in highly oxidized material, and they place the upper limit of oxidation at about $\mathrm{UO}_{2.6}$ or $\mathrm{U}^{+4}: \mathrm{U}^{+6}=1: 1.5$. Much lower limits have been found in synthetic material, usually near $\mathrm{UO}_{2.6}$. As discussed beyond, the unit cell edge, $a_{0}$, of $\mathrm{UO}_{2}(5.468 \mathrm{~A})$ decreases with increasing oxidation and the value $a_{0} 5.39 \mathrm{~A}$ has been estimated for the composition $\mathrm{UO}_{2.6}$. The measured $a_{0}$ values of natural uraninite range down to about 5.36 (see table, p. 24-29), indicating a high degree of oxidation in these (unanalyzed) samples, but the interpretation of the data is complicated by the presence of radiogenic lead and other elements in solid solution, radiation damage, and other factors. The uraninites of the sandstone-type deposits of the Colorado Plateau in general have relatively small cell dimensions, indicating that they are highly oxidized, but complete quantitative chemical analyses are lacking.

The oxidation of uraninite seems in general to be a secondary feature, due to weathering processes, but the possibility cannot be ignored that the mineral may crystallize directly in a more or less oxidized condition depending on the temperature and other environmental conditions. The content of $\mathrm{U}^{+6}$ and of interstitial oxygen in synthetic $\mathrm{UO}_{2}$ can be varied widely by heating under controlled pressures of oxygen, the equilibria being reversible. The surface adsorption and diffusion of oxygen into $\mathrm{UO}_{2}$ has a zero or very low activation energy and takes place readily at room temperature and at $-183^{\circ} \mathrm{C}$ (Roberts, 1954); the preparation of absolutely stoichiometric $\mathrm{UO}_{2}$ requires special care. The oxidation of natural material is influenced by the presence of other elements in solid solution, but data are lacking other than for the series to thorianite (which see). It also has been suggested that the presence of $\mathrm{U}^{+6}$ in natural uraninite is due to an auto-oxidation involving radioactive-decay processes independent of the environment (Ellsworth, 1925; Khlopin, 1938; and Tomkeieff, 1946). Attempts based on this assumption to use the $\mathrm{U}^{+4}: \mathrm{U}^{+0}$ ratio for age calculations have been unsatisfactory. 
The chemical composition of uraninite further varies extensively owing to the entrance of other elements in solid solution. This matter is discussed in the following section.

The interpretation of uraninite (and pitchblende) as essentially $\mathrm{UO}_{2}$ that has become oxidized in part was first clearly established by Goldschmidt and Thomassen (1923). This view was earlier suggested by Dunstan and Blake (1905). Most earlier authors believed that the mineral contained both $\mathrm{U}^{+4}$ and $\mathrm{U}^{+6}$ as essential constituents and was a uranyl uranate (Blomstrand, 1884, and Dana, 1892); the composition $\mathrm{U}_{3} \mathrm{O}_{8}$ was accepted by some. Ebelmen showed in 1843 that uraninite was not $\mathrm{U}_{3} \mathrm{O}_{8}$, and concluded from analyses of material from Joachimsthal that the composition was $\mathrm{U}_{2} \mathrm{O}_{5}$. Pitchblende usually is more highly oxidized than uraninite and is relatively low in its content of thorium and rare earths. Pitchblende has been thought in the past to be a different species from the coarsely crystallized uraninite, but the essential identity of the two types has been firmly established by X-ray and other evidence.

The heat of formation $\left(\Delta \mathrm{H}_{25}\right)$ of $\mathrm{UO}_{2}$ is -1084.3 kilojoules per mole, that of $\mathrm{ThO}_{2}$ is -1226.9 kilojoules per mole (Huber and others, 1952).

Chemical analyses.-A selection of the reported analyses of uraninite that are of superior quality or are of relatively recent date is given in the table on pages 16-20. Additional complete analyses are listed by Doelter (1929), Hintze (1929), Palache, Berman, and Frondel (1944), Harada (1948), and Geffroy and Sarcia (1954). Many partial analyses for $\mathrm{U}$, $\mathrm{Th}$, and $\mathrm{Pb}$, made for purposes of age determination, have also been reported. Many of these are listed by Doelter (1929), and in publications of the Committee on the Measurement of Geologic Time of the National Research Council (Annual reports, 1924 to date). The older analytical methods for the determination of uranium have been described by Doelter (1929); more recent methods are described by Rodden (1950), Rodden and Tregoning (1950), Harvey (1951), and Grimaldi, May, Fletcher, and Titcomb (1954).

When uraninite is dissolved in acid or by fusion with an alkaline carbonate small amounts of $\mathrm{He}, \mathrm{N}, \mathrm{A}$, and other gases may be evolved. These have been reported in amounts up to several weight percent, but they are not often determined or separately identified by analysts. (See Hillebrand, 1891, 1892, 1903, and Doelter, 1929.) Much of the $\mathrm{N}$ reported in old analyses (before the discovery of terrestrial helium in 1895) is He. Isotopic analyses have been reported of the $\mathrm{N}$ in uraninite (White and Yagoda, 1950). 
Chemical analyses of uraninite, in weight percent

\begin{tabular}{|c|c|c|c|c|c|c|c|c|c|}
\hline & 1 & 2 & 3 & 4 & 5 & 6 & 7 & 8 & 9 \\
\hline $\mathrm{CaO}$ & 0.08 & 0.11 & 0.18 & 0.84 & 0.85 & 0.23 & 0.37 & 0.30 & 0.77 \\
\hline $\mathrm{PbO}$ & $3 . \overline{14}$ & 3.08 & 4.35 & .70 & 4.20 & 4.53 & 9.04 & 8.41 & 10.06 \\
\hline $\mathrm{MgO}$ & & - & - & - & - & - & - & & 1.10 \\
\hline$(\mathrm{Y}, \mathrm{Er})_{2} \mathrm{O}_{3}$ & & $\overline{10}$ & - & - & $.20\}$ & & 1.11 & 2.42 & - \\
\hline $\begin{array}{l}(\mathrm{Ce}, \mathrm{La})_{2} \mathrm{O}_{3} \\
\mathrm{La}_{2} \mathrm{O}_{3}\end{array}$ & 9.57 & 11.10 & 二 & - & $\overline{50}$ & 3.04 & & .38 & \\
\hline $\begin{array}{l}\mathrm{LaO}_{3} \\
\mathrm{CeO}_{2}\end{array}$ & & & - &.$\overline{22}$ & .26 & & .18 & - & .21 \\
\hline $\mathrm{UO}_{2}$ & 59.13 & 59.93 & 72.25 & 58.51 & 39.31 & 46.56 & 46.13 & 43.62 & 50.74 \\
\hline $\mathrm{UO}_{3}$ & 22.08 & $23 . \overline{03}$ & 13.27 & 25.26 & 50.83 & 44.11 & 30.63 & 36.31 & 25.36 \\
\hline $\mathrm{ThO}_{2}$ & - & -3 & 7.20 & & 2.78 & & 6.00 & 5.64 & 8.48 \\
\hline $\mathrm{ZrO}_{2}$ & - & $-j$ & 7.20 & 7.59 & - & - & .06 & - & .08 \\
\hline $\mathrm{SiO}_{2}$ & 1.06 & .16 & .03 & 2.79 & .08 & .13 & .22 & .81 & .38 \\
\hline $\begin{array}{l}\mathrm{Al}_{2} \mathrm{O}_{3} \\
\mathrm{Fe}_{2} \mathrm{O}_{3}\end{array}$ & 1.21 & .29 & $\overline{11}$ & - & - & - & $\overline{25}$ & $\overline{40}$ & $\overline{21}$ \\
\hline $\mathrm{N}_{3}$ & 1.21 & $.2 Y$ & .11 & 二 & $=$ & - & .20 & 1.40 & .21 \\
\hline & .97 & .43 & .68 & 1.96 & 1.21 & - & .74 & .83 & .73 \\
\hline Insol. & .85 & .89 & .04 & & .10 & .06 & 4.42 & - & .45 \\
\hline Rem. & .96 & 2.47 & - & 1.92 & .67 & .25 & 1.19 & - & 1.32 \\
\hline Total & 99.05 & 101.49 & 98.21 & 99.95 & 100.99 & 98.91 & 100.61 & 100.12 & 100.21 \\
\hline
\end{tabular}

\begin{tabular}{lllllllll}
\hline $\mathrm{Sp} \mathrm{gr}$ & 9.139 & 9.622 & 9.733 & 8.068 & 8.086 & 9.492 & 8.893 & -9.145
\end{tabular}

1. Uraninite. Crystal from pegmatite. Hale's quarry, Glastonbury, Conn. Average of two analyses. Hillebrand (1891, p. 62). Remainder is $\mathrm{Nb}_{2} \mathrm{O}_{5}$. (The correct locality is Strickland's quarry, Portland, Conn.)

2. Uraninite. As above but different specimen. Hillebrand $(1891$, p. 62). Remainder is $\mathrm{He} 2.41, \mathrm{P}_{2} \mathrm{O}_{5} 0.02, \mathrm{~F} 0.04$.

3. Uraninite. Pure lustrous crystal from pegmatite. Branchville, Conn. Same sample as that earlier analyzed by Comstock (1880). Hillebrand (1891, p. 64).

4. Pitchblende. Vein deposit near Black Hawk, Gilpin County, Colo. Hillebrand (1891, p. 65). Contains admixed sulfides; average of 2 analyses. Remainder is $\mathrm{ZnO} 0.44, \mathrm{FeO} 0.32$, $\mathrm{He} 0.15, \mathrm{P}_{2} \mathrm{O}_{5} 0.22, \mathrm{As}_{2} \mathrm{O}_{5} 0.43, \mathrm{CuFeS}_{2} 0.12$, $\mathrm{FeS}_{2}$ 0.24.

5. Uraninite. Crystal from pegmatite. Veined with yellow alteration products. Flat Rock mine, Mitchell County, N. C. Hillebrand (1891, p. 65). Remainder is alkalies 0.30 , He 0.37 . 0.25 .

6. Uraninite. As above. Hillebrand (1891, p. 65). Remainder is alkalies

7. Uraninite (bröggerite). Crystal from pegmatite. Gustavsgruben, Anneröd, Norway. Hillebrand $\left(1891\right.$, p. 68). Remainder is $\mathrm{He} 1.17, \mathrm{P}_{2} \mathrm{O}_{5} 0.02$.

8. Uraninite (bröggerite). Gustavsgruben, Anneröd, Norway. Blomstrand (1884) corrected by Hillebrand (1891, p. 69).

9. Uraninite. Crystal from pegmatite. Elvestad, Norway. Hillebrand (1891). Remainder is $\mathrm{He} 1.28, \mathrm{P}_{2} \mathrm{O}_{5} 0.04$. 
Chemical analyses of uraninite, in weight percent-Continued

\begin{tabular}{|c|c|c|c|c|c|c|c|c|c|}
\hline & 10 & 11 & 12 & 13 & 14 & 15 & 16 & 17 & 18 \\
\hline $\mathrm{CaO}$ & 0.37 & 0.36 & 0.41 & 0.61 & 0.86 & 一 & 0.32 & 0.41 & 0.39 \\
\hline $\mathrm{PbO}$ & $8 . \overline{58}$ & 9.46 & 9.44 & 10.95 & 10.92 & 10.16 & 10.08 & 3.58 & 11.27 \\
\hline$(\mathrm{Yg}, \mathrm{Er})_{2} \mathrm{O}_{3}$ & 二 & .97 & $1 . \overrightarrow{03}$ & $9 . \overline{05}$ & $\begin{array}{c}.14 \\
12.24\end{array}$ & - & $9 . \overline{46}$ & 6.16 & 2.57 \\
\hline$(\mathrm{Ce}, \mathrm{La})_{2} \mathrm{O}$ & - & - & - & - & $-\}$ & 11.22\{ & 0.70 & 0.10 & 2.00 \\
\hline $\mathrm{La}_{2} \mathrm{O}_{3}$ & 一 & .36 & .23 & .67 & - & 一 & 2.36 & 2.05 & 1.11 \\
\hline $\mathrm{CeO}_{2}$ & $\overline{10}$ & .17 & .20 & None & & $\overline{0}$ & .34 & .19 & .40 \\
\hline $\mathrm{UO}_{2}$ & 43.03 & 43.88 & 43.38 & 44.18 & 23.07 & 19.89 & 44.17 & & 41.06 \\
\hline $\mathrm{UO}_{3}$ & 22.04 & 32.00 & 35.54 & 26.80 & 40.60 & 46.75 & 20.89 & - & 34.67 \\
\hline $\mathrm{ThO}_{2}$ & 8.43 & 8.98 & 6.63 & 4.15 & 4.60 & 7.57 & 6.69 & 1.65 & 6.41 \\
\hline $\mathrm{SiO}$ & .29 & .53 & .49 & .50 & 二 & - & .446 & -20 & .19 \\
\hline $\begin{array}{l}\mathrm{Al}_{2} \\
\mathrm{Fe}_{2}\end{array}$ & .30 & .09 & .32 & .24 & 1.02 & .58 & .14 & $\mathbf{T r}$ & .10 \\
\hline & & & & & & & & & \\
\hline & .74 & .77 & .79 & - & 4.96 & 2.54 & 1.48 & 5 & 1.47 \\
\hline Insol. & 15.45 & 1.54 & .42 & 1.19 & 2.34 & 1.22 & 1.47 & .20 & .13 \\
\hline Rem. & 1.21 & 1.03 & 1.21 & 1.43 & & & .54 & & .95 \\
\hline Total & 100.44 & 100.14 & 100.09 & 99.77 & 100.75 & 99.93 & 98.74 & 98.39 & 100.72 \\
\hline gr & 8.320 & 8.966 & 8.930 & - & - & 8.01 & 8.29 & - & 一 \\
\hline
\end{tabular}

10. Uraninite. As above. Hillebrand (1891, p. 68). $\mathrm{ThO}_{2}$ includes rare earths. Remainder is alkalies $0.13, \mathrm{He} 1.08$.

11. Uraninite. Crystal from pegmatite. Skraatorp, Norway. Hillebrand (1891, p. 68).

12. Uraninite. Crystal from pegmatite. Huggenäskilen, Norway. Hillebrand $(1891$, p. 68). Remainder is alkalies 0.13 , He 1.08 .

13. Uraninite (cleveite). Crystal from pegmatite. Arendal, Norway. Hillebrand (1891). Remainder is MgO 0.04, alkalies 0.15, He 1.24.

14. Uraninite (cleveite). Crystal from pegmatite. Arendal, Norway. Lindström, analyst, in Nordenskiöld (1878), $\mathrm{H}_{2} \mathrm{O}$ is ignition loss.

15. Uraninite (nivenite). Crystal from pegmatite. Baringer Hill, Llano County, Tex. Hidden and Mackintosh (1889). $\mathrm{H}_{2} \mathrm{O}$ is ignition loss.

16. Uraninite (nivenite). As above, on original material of Hidden and Mackintosh (1889). Hillebrand (1892). Remainder is He 0.54.

17. Uraninite. Crystal admixed with alteration products. Marietta, Greenville County, S. C. Hillebrand (1892).

18. Uraninite. Crystal admixed with alteration products. Villeneuve, Ottawa County, Quebec, Canada. Hillebrand (1892, p. 23). Remainder is $\mathrm{He} 0.86, \mathrm{Bi}_{2} \mathrm{O}_{3} 0.09$. 
Chemical analyses of uraninite, in weight percent-Continued

\begin{tabular}{|c|c|c|c|c|c|c|c|c|c|}
\hline & 19 & 20 & 21 & 22 & 23 & 24 & 25 & 26 & 27 \\
\hline $\mathrm{CaO}$ & 1.00 & 0.30 & 0.69 & 0.09 & 1.01 & 0.35 & 0.46 & 1.72 & 0.72 \\
\hline $\mathrm{MnO}$ & .09 & 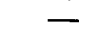 & .002 & & .03 & .14 & .001 & .13 & \\
\hline $\mathrm{PbO}$ & 6.39 & .40 & 7.02 & 7.07 & 10.95 & 11.69 & 16.42 & 16.71 & 19.50 \\
\hline $\mathrm{MgO}$ & .17 & - & .01 & & .08 & .06 & .01 & .06 & - \\
\hline $\begin{array}{l}(\mathrm{Y}, \mathrm{Er})_{2} \mathrm{O}_{3} \\
(\mathrm{Ce}, \mathrm{La})_{2} \mathrm{O}_{3}\end{array}$ & None & 3.41 & .35 & $\begin{array}{r}.55 \\
3.29\end{array}$ & $\begin{array}{l}2.14 \\
1.88\end{array}$ & $\begin{array}{l}.73 \\
.06\end{array}$ & 1.01 & $\left.\begin{array}{r}1.19 \\
.28\end{array}\right\}$ & 5.60 \\
\hline $\mathrm{La}_{2} \mathrm{O}_{3}$ & None & 1.02 & .155 & 5.29 & 1.80 & .00 & .80 & - & - \\
\hline $\mathrm{CeO}_{2}$ & None & .71 & .22 & — & - & - & .265 & - & - \\
\hline $\mathrm{UO}_{2}$ & 59.30 & 70.09 & 52.77 & & 39.10 & $\overline{10}$ & 48.87 & & 34.49 \\
\hline $\mathrm{U}_{3} \mathrm{O}_{8}$ & 20 20 & & & 88.12 & - & 86.16 & $08 \overline{500}$ & 64.86 & \\
\hline $\mathrm{UO}_{2}$ & 22.33 & 22.69 & 37.537 & 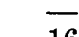 & 32.40 & $\overline{10}$ & 28.582 & $12 \overrightarrow{04}$ & 36.94 \\
\hline $\begin{array}{l}\mathrm{ThO}_{2} \\
\mathrm{ZrO}_{2}\end{array}$ & None & .20 & $\overrightarrow{14}$ & .16 & 10.60 & .10 & $\begin{array}{r}2.15 \\
.22\end{array}$ & 13.94 & .15 \\
\hline$i$ & .50 & - & .095 & .10 & .19 & .21 & .055 & .37 & - \\
\hline $\mathrm{Al}_{2} \overline{\mathrm{O}}_{3}$ & .20 & .25 & $-?$ & 49 & $.09\}$ & 35 & 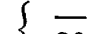 & $.12\}$ & $\mathrm{Tr}$ \\
\hline $\mathrm{Fe}_{2} \mathrm{O}_{3}$ & .21 & .10 & $.15\}$ & .48 & $.43\}$ & .00 & .30 & $.75\}$ & $1 \Gamma$ \\
\hline $\mathrm{CO}$ & & & .24 & - & $\overline{70}$ & - & $\bar{a}$ & - & $\overline{1}$ \\
\hline H. & 3.17 & .41 & .38 & & .70 & - & .44 & 一 & 1.40 \\
\hline Insol. & & & .09 & .06 & .15 & 一 & .15 & 一 & .53 \\
\hline Rem. & 4.59 & .12 & .50 & - & .31 & 一 & .39 & 一 & .25 \\
\hline Total & 97.95 & 99.70 & 100.349 & 99.93 & 100.06 & 99.85 & 100.123 & 100.13 & 99.56 \\
\hline $\mathrm{gr}$ & 6.89 & 10.63 & 9.660 & - & 9.062 & 8.95 & 9.182 & 8.968 & - \\
\hline
\end{tabular}

19. Pitchblende. Johanngeorgenstadt, Saxony. Hillebrand (1892). Remainder is $\mathrm{He} 0.02, \mathrm{Na}_{2} \mathrm{O} 0.31, \mathrm{Bi}_{2} \mathrm{O}_{3} 0.75, \mathrm{CuO} 0.17, \mathrm{P}_{2} \mathrm{O}_{5} 0.06, \mathrm{As}_{2} \mathrm{O}_{5} 2.34$, (V,W,Mo) oxide $0.75, \mathrm{SO}_{3} 0.19$.

20. Uraninite. Placer de Guadalupe, Chihuahua, Mexico. Average of 2 analyses. Wells (1930). Remainder is $\mathrm{TiO}_{2} 0.06, \mathrm{As}_{2} \mathrm{O}_{5} 0.06$.

21. Uraninite. Shinkolobwe, Katanga, Belgian Congo. Davis (1926). Remainder is $\mathrm{He} 0.159, \mathrm{~N} 0.076, \mathrm{O} 0.005, \mathrm{BaO} 0.06$, alkalies $0.01, \mathrm{MoO}_{3} 0.07$, $\mathrm{As}_{2} \mathrm{O}_{5}$ 0.09, $\mathrm{P}_{2} \mathrm{O}_{5} 0.03$.

22. Uraninite. Crystal from pegmatite. Morogoro, Uluguru Mountains, East Africa. Average of 3 analyses. Hecht, analyst, in Hecht and Körner (1928).

23. Uraninite. Crystal from pegmatite. Wilberforce, Haliburton County, Ontario, Canada. Ellsworth $(1929,1930)$. Remainder is $\mathrm{He}$ and other gases. $\mathrm{H}_{2} \mathrm{O}$ includes $\mathrm{H}_{2} \mathrm{O}+0.05$ and $\mathrm{H}_{2} \mathrm{O}-0.65$.

24. Uraninite. Crystal from pegmatite. Lac Pied des Monts, Saguenay district, Quebec, Canada. Ellsworth, analyst, in Ellsworth and Osborne (1934). 25. Uraninite. Crystal from pegmatite. Ingersoll mine, Pennington County, $\mathrm{S}$. Dak. Davis (1926). Remainder is $\mathrm{He} 0.08$, $\mathrm{BaO} 0.08$, alkalies $0.02, \mathrm{MoO}_{3}$ trace, $\mathrm{As}_{2} \mathrm{O}_{5}$ 0.15, $\mathrm{P}_{2} \mathrm{O}_{5} 0.06$.

26. Uraninite. Winnipeg River area, southeastern Manitoba, Canada. Ellsworth, analyst, in DeLury and Ellsworth (1931).

27. Uraninite. Sinyaya Pala, Karelia, U. S. S. R. Analysis stated to be mean value of material from this locality. Nenadkevich (1926). Remainder is $\mathrm{Cl}$. 
Chemical analyses of uraninite, in weight percent-Continued

\begin{tabular}{|c|c|c|c|c|c|c|c|c|c|}
\hline & 28 & 29 & 30 & 31 & 32 & 33 & 34 & 35 & 36 \\
\hline $\mathrm{CaO}$ & 0.41 & 0.28 & 0.55 & 2.45 & 0.16 & 一 & 0.42 & 0.81 & - \\
\hline $\mathrm{MnO}$ & .01 & .04 & & .04 & & - & & .09 & - \\
\hline $\mathrm{PbO}$ & 11.67 & 10.40 & 8.11 & 4.63 & 16.64 & 1.01 & 5.71 & 3.63 & 5.78 \\
\hline $\mathrm{MgO}$ & 一 & .19 & & .19 & .03 & & - & .17 & - \\
\hline$(\overline{\mathrm{Y}}, \mathrm{Er})_{2} \mathrm{O}_{3}$ & 2.19 & 2.74 & $.04)$ & & - & 14.60 & -3 & 21 & 4.72 \\
\hline$(\mathrm{Ce}, \mathrm{La})_{2} \mathrm{O}_{3}$ & .98 & 1.82 & 41 & .52 & .12 & .41 & $一$ & .21 & \\
\hline $\begin{array}{l}\mathrm{La}_{2} \mathrm{O}_{3} \\
\mathrm{CeO}_{3}\end{array}$ & 一 & - & .11 & & 二 & E & - & 一 & - \\
\hline$U_{2}$ & $53 . \overline{63}$ & $45 . \overline{18}$ & .09 & & - & $55 . \overline{40}$ & $41 . \overline{94}$ & - & - \\
\hline $\mathrm{U}_{3} \mathrm{O}_{8}$ & & -60.0 & 83.73 & 76.82 & 74.4 & & & 90.06 & 81.35 \\
\hline $\mathrm{UO}_{3}$ & 26.32 & 24.90 & & - & & 22.23 & 49.21 & - & \\
\hline $\mathrm{ThO}_{2}$ & 3.22 & 11.40 & .006 & 一 & 1.12 & 3.86 & None & .43 & .31 \\
\hline $\mathrm{Zr}$ & & & .002 & & & - & & & \\
\hline & .29 & .43 & .64 & 5.07 & .16 & .11 & .92 & .80 & 1.91 \\
\hline $\left.\mathrm{H}_{2} \mathrm{O}_{3}\right\}$ & .17 & & .05 & 400 & & .44 & 30 & $.44\}$ & 3.72 \\
\hline & 一 & .08 & .13 & 4.00 & .03 & .17 & .30 & .665 & - \\
\hline & .72 & .61 & 一 & 3.25 & - & .50 & 1.22 & .73 & - \\
\hline & .13 & & .046 & & 6.42 & & & .54 & - \\
\hline Rem. & 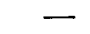 & .35 & 1.42 & 4.33 & . & .74 & 一 & 1.94 & 2.52 \\
\hline Total & 99.74 & 98.92 & 94.924 & 101.30 & 99.08 & 99.75 & 99.72 & 100.51 & 100.31 \\
\hline
\end{tabular}

Sp gr

$9.116 \quad 9.082-7.1-7.4$

28. Uraninite. Crystal from pegmatite. Parry Sound district, Ontario, Canada. Ellsworth (1921).

29. Uraninite. Wilberforce, Cardiff township, Ontario, Canada. Todd, analyst, in Walker (1924). Remainder is He.

30. Uraninite. Katanga, Belgian Congo. Hecht and Körner (1928). Remainder is $\mathrm{BaO} 0.03, \mathrm{CuO} 0.12, \mathrm{MoO}_{3} 1.23, \mathrm{As}_{2} \mathrm{O}_{5} 0.04, \mathrm{P}_{2} \mathrm{O}_{5} 0.03$.

31. Pitchblende. Joachimsthal, Bohemia. Jannasch, analyst, in Becker and Jannasch (1915). Remainder is $\mathrm{Bi}_{2} \mathrm{O}_{3} 0.67, \mathrm{As}_{2} \mathrm{O}_{5} \quad 0.82, \mathrm{Sb}$ trace, $\mathrm{ZnO} 0.22$, $\mathrm{K}_{2} \mathrm{O} \quad 0.28, \mathrm{Na}_{2} \mathrm{O} 1.19$, $\mathrm{S}$ 1.15. Total not corrected for $\mathrm{O}=\mathrm{S}$. A duplicate analysis is cited.

32. Uraninite. Crystal from pegmatite. Varuträsk, Sweden. Berggren, analyst, in Quensel (1940). Insol. includes 6.1 percent volatile material, probably native $\mathrm{Sb}$ and $\mathrm{As}$.

33. Uraninite. Disseminated grains in pegmatite. Iisaka, Abukuma Range, Japan. T. Iimori (1941). Remainder is $\mathrm{Nb}_{2} \mathrm{O}_{5}$.

34. Uraninite. Rio Branco, Minas Gerais, Brazil. Florencio and Castro (1943) $\mathrm{H}_{2} \mathrm{O}$ is ignition loss.

35. Uraninite. Ruggles pegmatite, Grafton Center, N. H. Hecht, analyst, in Shaub (1938). Remainder is $\mathrm{P}_{2} \mathrm{O}_{5} 0.16, \mathrm{~S} 0.04$, ignition loss 1.74 . $\mathrm{H}_{2} \mathrm{O}$ is $\mathrm{H}_{2} \mathrm{O}$ -

36. Uraninite. Thorsgruva, Haugesund Peninsula, Norway. Rosenqvist (1947). Remainder is $(\mathrm{Nb}, \mathrm{Ta})_{2} \mathrm{O}_{5} \quad 0.47, \mathrm{P}_{2} \mathrm{O}_{5}$ 2.05. The high content of $(\mathrm{Al}, \mathrm{Fe})_{2} \mathrm{O}_{3}, \mathrm{P}_{2} \mathrm{O}_{5}$, and $\mathrm{SiO}_{2}$ indicates that the material was impure. 
Chemical analyses of uraninite, in weight percent-Continued

\begin{tabular}{|c|c|c|c|c|c|c|c|}
\hline & 37 & 38 & 39 & 40 & 41 & 42 & 43 \\
\hline $\mathrm{CaO}$ & 0.58 & 一 & 0.70 & $\operatorname{Tr}$ & 0.30 & 2.22 & 2.40 \\
\hline $\begin{array}{l}\text { Mno } \\
\text { Pbo }\end{array}$ & 7.63 & $0 . \overline{13}$ & 5.00 & 5.20 & 3.94 & .74 & $\begin{array}{r}.22 \\
1.48\end{array}$ \\
\hline $\mathrm{MgO}$ & .13 & 0.10 & - & -10 & $\begin{array}{r}.04 \\
.13\end{array}$ & - & 1.40 \\
\hline $\left.\begin{array}{l}(\mathrm{Y}, \mathrm{Er})_{2} \mathrm{O}_{3} \\
(\mathrm{Ce}, \mathrm{La})_{2} \mathrm{O}_{3}\end{array}\right\}$ & .15 & 5.84 & 二 & $-\}$ & .28 & $=$ & $=$ \\
\hline $\mathrm{La}_{2} \mathrm{O}_{3}$ & 一 & - & 二 & -1 & - & Z & $\overline{-}$ \\
\hline $\mathrm{CeO}_{2}$ & $\bar{\pi}$ & - & $\overline{-}$ & $\overline{0}$ & $\overline{-11}$ & $\overline{0}$ & - \\
\hline $\mathrm{UO}_{2}$ & 47.5 & {$[87 \overline{197}$} & 23.10 & 28.38 & 75.41 & 52.28 & 42.49 \\
\hline $\mathrm{UO}_{3}$ & 40.8 & - & 63.00 & 61.12 & $14 . \overline{83}$ & $31 . \overline{08}$ & $20 . \overline{58}$ \\
\hline $\mathrm{ThO}_{2}$ & - & 5.68 & 1.67 & .25 & 2.59 & None & 一 \\
\hline $\mathrm{ZrO}_{2}$ & $\overline{17}$ & - & - & $\operatorname{Tr}$ & $\overline{01}$ & 287 & 425 \\
\hline $\mathrm{SiO}_{2}$ & .47 & - & $\overline{T r}$ & $\overline{\operatorname{Tr}}$ & .01 & $\begin{array}{r}2.87 \\
20\end{array}$ & $\begin{array}{l}4.35 \\
1.18\end{array}$ \\
\hline $\begin{array}{l}\mathrm{Al}_{2} \mathrm{U}_{3} \\
\mathrm{Fe}_{2} \mathrm{O}_{3}\end{array}$ & $\overline{.15}$ & $\overline{.13}$ & $\operatorname{Tr}$ & $\operatorname{Tr}\{$ & .53 & 1.21 & $\begin{array}{l}1.10 \\
1.93\end{array}$ \\
\hline $\mathrm{CO}_{2}$ & .29 & - & - & - & - & & \\
\hline $\mathrm{H}_{2} \mathrm{O}$ & 1.34 & - & - & - & .12 & 1.27 & 1.87 \\
\hline Insol. & $\overline{-}$ & $\overline{0}$ & .30 & 1.00 & .58 & & \\
\hline Rem. & .44 & 1.03 & 5.55 & 2.41 & - & 5.57 & 15.84 \\
\hline Total & 99.48 & {$[100.00]$} & 99.32 & 98.36 & 98.72 & 97.54 & 92.34 \\
\hline Sp gr & - & - & 5.43 & 6.08 & 一 & 9.1 & 8.6 \\
\hline
\end{tabular}

37. Uraninite. Shinkolobwe, Katanga, Belgian Congo. Rodden, analyst, in Kerr (1950). Remainder is $\mathrm{NiO} 0.13, \mathrm{MoO}_{3} 0.31$.

38. Uraninite. Kawasaki, Hukuoka Prefecture, Japan. Kimura and Iimori (1936). Remainder is insol.

39 and 40. Uraninite. Cerro Blanco, Cordoba, Argentina. Chaudet, analyst, in Ahlfeld and Angelelli $(1948, \mathrm{p} .125)$. Remainder is $\mathrm{H}_{2} \mathrm{O}, \mathrm{He}$, and, in analysis $40, \mathrm{P}_{2} \mathrm{O}_{5} 0.06$.

41. Uraninite. Strickland pegmatite, Portland, Conn. Hecht, analyst, in Foye and Lane (1934).

42. Uraninite. Happy Jack mine, White Canyon, Utah. Contains quartz, pyrite, chalcocite, and chalcopyrite as minor impurities. G. Edgington, analyst (A. Weeks, R. Coleman, and M. Thompson, written communication, 1956). Remainder is $\mathrm{CuO} 2.96,(\mathrm{Ba}, \mathrm{Sr}) \mathrm{O} 0.15, \mathrm{~V}_{2} \mathrm{O}_{5} 0.54, \mathrm{~S} 1.70, \mathrm{As} 0.005, \mathrm{~F} 0.21$. $\mathrm{H}_{2} \mathrm{O}$ includes $\mathrm{H}_{2} \mathrm{O}-0.28$. Total not corrected for $\mathrm{F}=0$.

43. Uraninite. Shinarump No. 1 mine, Seven Mile Canyon, Grand County, Utah. Contains pyrite, quartz, calcite, and barite as minor impurities. G. Edgington, analyst (Weeks, Coleman, and Thompson, written communication, 1950). Remainder is $\mathrm{Ni}_{2} \mathrm{O}_{3} 0.40, \mathrm{Co}_{2} \mathrm{O}_{3} 0.64, \mathrm{TiO}_{2} 0.29, \mathrm{ZnO} 4.09, \mathrm{BaO}$ 5.21, $\mathrm{SrO} 0.34, \mathrm{~V}_{2} \mathrm{O}_{5} 0.22, \mathrm{~S} 4.35$, As 0.013 , Se $0.003, \mathrm{~F} 0.28, \mathrm{H}_{2} \mathrm{O}$ includes $\mathrm{H}_{2} \mathrm{O}-0.70$. Total not corrected for $\mathrm{F}=0$.

Solid solutions.-In synthetic material, $\mathrm{UO}_{2}$ can take $\mathrm{CaO}$ into solid solution up to about $47 \mathrm{~mol}$. percent of $\mathrm{CaO}$ at $2,080^{\circ} \mathrm{C}$, the solubility decreasing to about $20 \mathrm{~mol}$. percent at $1,650^{\circ} \mathrm{C}$ (Alberman, Blakey, and Anderson, 1951). In the system $\mathrm{UO}_{2}-\mathrm{ZrO}_{2}$, there are 2 solid-solution regions, separated by a 2-phase region, with isometric $\mathrm{UO}_{2}$ containing up to about $52 \mathrm{~mol}$. percent $\mathrm{ZrO}_{2}$ and tetragonal $\mathrm{ZrO}_{2}$ containing up to about 20 mol. percent $\mathrm{UO}_{2}$ (Lambertson and Mueller, 1953). A complete series extends between $\mathrm{UO}_{2}$ and $\mathrm{ThO}_{2}$ in synthetic material (Hillebrand, 1893; Trzebiatowski and Selwood, 1950; and Lambertson, Mueller, and Gunzel, 1953), and in natural material. (See tables on pages 29 and 30.) Complete solid-solution series also exist between $\mathrm{UO}_{2}$ 
and $\mathrm{CeO}_{2}$, and between $\mathrm{UO}_{2}$ and $\mathrm{PrO}_{2}$ (Rudorff and Valet, 1952; Hund, Wagner, and Peetz, 1952; and Magneli and Kihlborg, 1951). No solid solutions are formed in synthetic material with $\mathrm{MgO}, \mathrm{Al}_{2} \mathrm{O}_{3}, \mathrm{BeO}$, or $\mathrm{SiO}_{2}$.

Natural uraninite contains more or less radiogenic lead in solid solution due to decay of the uranium and of any thorium present. It may also contain lead due to mechanical admixture of lead minerals or to the inclusion of lead in solid solution in the crystal structure at the time of the initial growth of the crystal. The several isotopes of lead present can be identified by massspectrometer analysis, and the matter is of importance in geologic-age determinations. The lead is conventionally reported by analysts as $\mathrm{Pb}^{+2}$, but may be present as $\mathrm{Pb}^{+4}$. Natural uraninite also may contain large amounts of other elements in solid solution, especially Th, Ce, and Y. These elements often are present in relatively large amounts in the uraninite of pegmatites, and are virtually lacking in the uraninite of hydrothermal veins and sandstone-type deposits. In varieties containing rare earths, either the cerium earths or the yttrium earths may predominate but yttrium usually is in excess. Although often reported by analysts as in the trivalent state, the Ce probably is present in the crystals in the quadrivalent state. In a study of leaching residues from Joachimsthal uraninite, Marsh (1929) found that europium was many times more abundant relative to the other rare earths than in any other source then known. Plutonium, $\mathrm{Pu}^{239}$, occurs in uraninite by spontaneous fission of $\mathrm{U}^{238}$ in amounts of $\mathrm{Pu}^{239} / \mathrm{UO}_{2}$ $=4 \times 10^{-12}$ to $9 \times 10^{-13}$ parts by weight, and smaller amounts are present in other uranium and thorium minerals (Levine and Seaborg, 1951). The $\mathrm{Zr}$ reported in some analyses of uraninite may be present in solid solution but this supposition requires verification; admixture of uraninite with zircon is a possible interpretation as the two minerals often are intimately associated in pegmatites. The $\mathrm{Bi}, \mathrm{Zn}, \mathrm{Cu}, \mathrm{Fe}, \mathrm{Al}, \mathrm{Mn}, \mathrm{Ca}, \mathrm{Ba}, \mathrm{Na}$, and other elements reported in small amounts in many analyses have not been shown to be part of the uraninite composition and, particularly in the case of pitchblende, which often contains microscopic inclusions of sulfides and gangue minerals, probably are due to admixture. This doubtless is true of the $\mathrm{P}_{2} \mathrm{O}_{5}, \mathrm{As}_{2} \mathrm{O}_{5}$, and $\mathrm{SiO}_{2}$ sometimes reported in small amounts in analyses. The $\mathrm{H}_{2} \mathrm{O}$ commonly observed in small amounts has not been shown to be an essential constituent and may be due to alteration and admixture. It may also be present as $\mathrm{OH}$ in valence compensation for $\mathrm{U}^{+\bullet}$. Indium has been detected in uraninite from Joachimsthal (Wleugel, 1878). 
Phase relations in the system $\mathrm{U}-\mathrm{O} .-\mathrm{UO}_{2}$ is the only phase in this system that has been found in nature, although extensive search has been made for $\mathrm{U}_{3} \mathrm{O}_{8}, \mathrm{UO}_{3}$, and other phases found in synthetic preparations. In $\mathrm{UO}_{2}$, it has been shown by Goldschmidt and Thomassen (1923), Biltz and Müller (1927), Alberman and Anderson (1949), and others, that oxygen can go into the vacant $\left(\frac{1}{2} 00\right)$ positions of the fluorite-type structure. Valence compensation is provided by the concomitant oxidation of the $\mathrm{U}^{+4}$ to $\mathrm{U}^{+6}$. The oxidation is accompanied by an increase in specific gravity and a decrease in the unit-cell dimension. In natural uraninite, this series apparently extends up to about $\mathrm{UO}_{2.6}$ with preservation of the $\mathrm{UO}_{2}$ structure (Brooker and Nuffield, 1952). The series would end at $\mathrm{UO}_{2.75}$ in any case, because the available vacancies are then completely filled. There is an accompanying decrease in $a_{\mathrm{o}}$ from 5.47 $\mathrm{A}$ for $\mathrm{UO}_{2}$ to $5.39 \mathrm{~A}$ (extrapolated) for $\mathrm{UO}_{2.8}$. Even smaller unit-cell dimensions have been reported in natural material (see table on next page), but in these the effect of other elements in solid solution and other influences on the cell size have not been evaluated. The oxidation of synthetic material carrying thorium in solid solution has been investigated by Anderson and others (1954). (See further under Thorianite.)

A large number of anhydrous synthetic phases have been reported in the system U-O. The older observations together with the work of Biltz and Müller (1927), Alberman and Anderson (1949), and Rundle and others (1948) have been summarized by Katz and Rabinowitch (1951). Additional data are given by Perio (1953a, b, c), Boullé and Dominé-Berges (1948, 1950), Boullé, Jary, and Dominé-Berges (1951), Anderson and others (1954), Hoekstra and others (1955), Anderson (1953), Roberts (1954), and Hering and Perio (1952). The data are conflicting in part, and further work must be done to establish both the validity of many of the phases that have been reported and the extent of solid solution of oxygen therein. The reported phases include UO, $\mathrm{U}_{4} \mathrm{O}_{7}, \mathrm{UO}_{2}, a-\mathrm{UO}_{2}, \beta-\mathrm{UO}_{2}\left(=\mathrm{U}_{4} \mathrm{O}_{9}\right), \mathrm{UO}_{2.25}\left(=\mathrm{U}_{4} \mathrm{O}_{9}\right)$, tetragonal polymorphs stable over about the range $\mathrm{UO}_{2.2}$ to $\mathrm{UO}_{2.3}, \mathrm{U}_{4} \mathrm{O}_{9}$, $\mathrm{U}_{3} \mathrm{O}_{7}, \mathrm{U}_{2} \mathrm{O}_{5}$, orthorhombic $\mathrm{UO}_{2.6}, 2$ polymorphs of $\mathrm{U}_{3} \mathrm{O}_{8}, \mathrm{U}_{6} \mathrm{O}_{17}$, at least 4 polymorphs of $\mathrm{UO}_{3}$, and $\mathrm{U}_{2} \mathrm{O}_{7}$. In addition, there are many hydrated uranyl oxides, most of them known as minerals.

Solubility.-Coarsely crystallized unoxidized $\mathrm{UO}_{2}$ is insoluble in cold or warm dilute $\mathrm{HCl}$ or $\mathrm{H}_{2} \mathrm{SO}_{4}$. It slowly dissolves in hot concentrated $\mathrm{HCl}$ or $\mathrm{H}_{2} \mathrm{SO}_{4}$, and it dissolves easily in $\mathrm{HNO}_{3}$ and aqua regia. The action of the acids is increased if the sample is heated above $100^{\circ} \mathrm{C}$ in a sealed tube. Natural, partly oxidized or altered uraninite is relatively strongly attacked by acids. 
Varieties containing much rare earths in solid solution are also said to be relatively soluble. The action of the acids, if under oxidizing conditions, results in the formation of uranyl salts. Strong solutions of hydrogen peroxide acidified by $\mathrm{HCl}$ react with $\mathrm{UO}_{2}$ to form a hydrate that rapidly oxidizes to a mixture of hydrated uranyl oxides.

\section{Crystallography}

Uraninite is isometric, crystallizing in the hexoctahedral crystal class $(4 / m \overline{3} 2 / m)$. The crystal structure of $\mathrm{UO}_{2}$, first described by Goldschmidt and Thomassen (1923), is analogous to that of fluorite, $\mathrm{CaF}_{2}$. The $\mathrm{U}^{+4}$ ions are each surrounded by $8 \mathrm{O}^{-2}$ ions at the corners of a cube, and each $\mathrm{O}^{-2}$ ion by $4 \mathrm{U}^{+4}$ ions at the corner of a regular tetrahedron. Other oxides isostructural with $\mathrm{UO}_{2}$ are $\mathrm{ThO}_{2}, \mathrm{CeO}_{2}, \mathrm{PrO}_{2}, \mathrm{HfO}_{2}, \mathrm{NpO}_{2}, \mathrm{PuO}_{2}, \mathrm{AmO}_{2}$, and the isometric high-temperature polymorph of $\mathrm{ZrO}_{2}$. The space group is $F m 3 m$. The unit-cell contents are $4\left[\mathrm{UO}_{2}\right]$.

Unit-cell dimensions.-A number of superior measurements of the unit-cell edge, $a_{0}$, have been reported for synthetic $\mathrm{UO}_{2}$. These are summarized in the following table. The figures mostly are of only moderate accuracy because of failure to state or control the temperature at which the measurements were made, lack of evidence that the composition actually was stoichiometric $\mathrm{UO}_{2}$ and otherwise pure, and inadequate refinement of the experimental data to remove systematic error.

\section{Unit-cell dimensions, $a_{0}$, for synthetic $\mathrm{UO}_{2}$}

\begin{tabular}{|c|c|c|c|}
\hline$a_{0}(\mathrm{~A})$ & $\begin{array}{l}\text { REFERENCE AND } \\
\text { REMARKS }\end{array}$ & $a_{0}(\mathrm{~A})$ & $\begin{array}{l}\text { REFERENCE AND } \\
\text { REMARKS }\end{array}$ \\
\hline $5.455 \pm 0.003$ & $\begin{array}{l}\text { Trzebiatowski and } \\
\text { Selwood (1950). }\end{array}$ & 5.468 & $\begin{array}{l}\text { Grönvold and } \\
\text { Haraldsen (1948). }\end{array}$ \\
\hline $5.457 \pm .0015$ & $\begin{array}{l}\text { Slowinski and } \\
\text { Elliot (1952). }\end{array}$ & $\begin{array}{l}5.468 \pm 0.002 \\
5.468 \pm .002\end{array}$ & $\begin{array}{l}\text { E. Berman (1955). } \\
\text { Roberts (1954). }\end{array}$ \\
\hline $5.461 \pm .008$ & $\begin{array}{l}\text { Hydrothermal syn- } \\
\text { thesis at } 135^{\circ}- \\
190^{\circ} \mathrm{C} \text {; Miller } \\
\text { and Kerr (1954). }\end{array}$ & $\begin{array}{l}5.4682 \\
5.4690\end{array}$ & $\begin{array}{l}\text { At } 26^{\circ} \mathrm{C} \text {; Swanson } \\
\text { and Fuyat }(1953) . \\
\text { Rundle and others } \\
(1948) .\end{array}$ \\
\hline $5.467 \pm .002$ & $\begin{array}{l}\text { Hydrothermal syn- } \\
\text { thesis at } 215^{\circ} \mathrm{C} \text {; } \\
\text { Miller and Kerr } \\
\text { (1954). }\end{array}$ & $\begin{array}{l}5.4696 \pm .0005 \\
5.470\end{array}$ & $\begin{array}{l}\text { Katz and Rabino- } \\
\text { witch (1951). } \\
\text { Wasserstein (1951). }\end{array}$ \\
\hline 5.468 & $\begin{array}{l}\text { Alberman and } \\
\text { Anderson (1949). }\end{array}$ & $5.4708 \pm .0002$ & $\begin{array}{c}\text { Lambertson and } \\
\text { others (1953). }\end{array}$ \\
\hline
\end{tabular}

Measurements of the unit-cell edge, $a_{0}$, of natural uraninite and pitchblende are summarized in the table below. These mostly are of very low accuracy and were made for the most part on unanalyzed material. The observed wide variation in $a_{0}$ is due principally to the varying extent of oxidation of $\mathrm{U}^{+4}$ to $\mathrm{U}^{+6}$, 
the cell size decreasing with increasing oxidation owing to the relatively small size of the $\mathrm{U}^{+6}$ ion. Additional factors are the content of radiogenic lead, the content of Th, rare earths, or other elements in substitution for $\mathrm{U}$, the amount of $\mathrm{O}$ or $\mathrm{OH}$ present interstitially in valence compensation for the $\mathrm{U}^{+6}$, and the amount of structural damage by internal alpha-particle bombardment. In natural material the oxidation of $\mathrm{U}^{+4}$ to $\mathrm{U}^{+6}$ is accompanied by line-broadening due to decrease in particle size (Croft, 1954) and to admixture of material of different degrees of oxidation (and different cell size) as shown by Brooker and Nuffield (1952). In a general way, the uraninite of pegmatites has relatively large cell dimensions and that of hydrothermal veins and sandstonetype deposits relatively small cell dimensions (E. Berman, 1955).

Unit-cell dimensions, $a_{0}$, of untreated natural uraninite

[Type of occurrence: $V$, vein; $P$, pegmatite; S, sandstone]

TYPE OF

OCCUR-

$a_{0}$ (A) RENCE

LOCALITY

REFERENCE

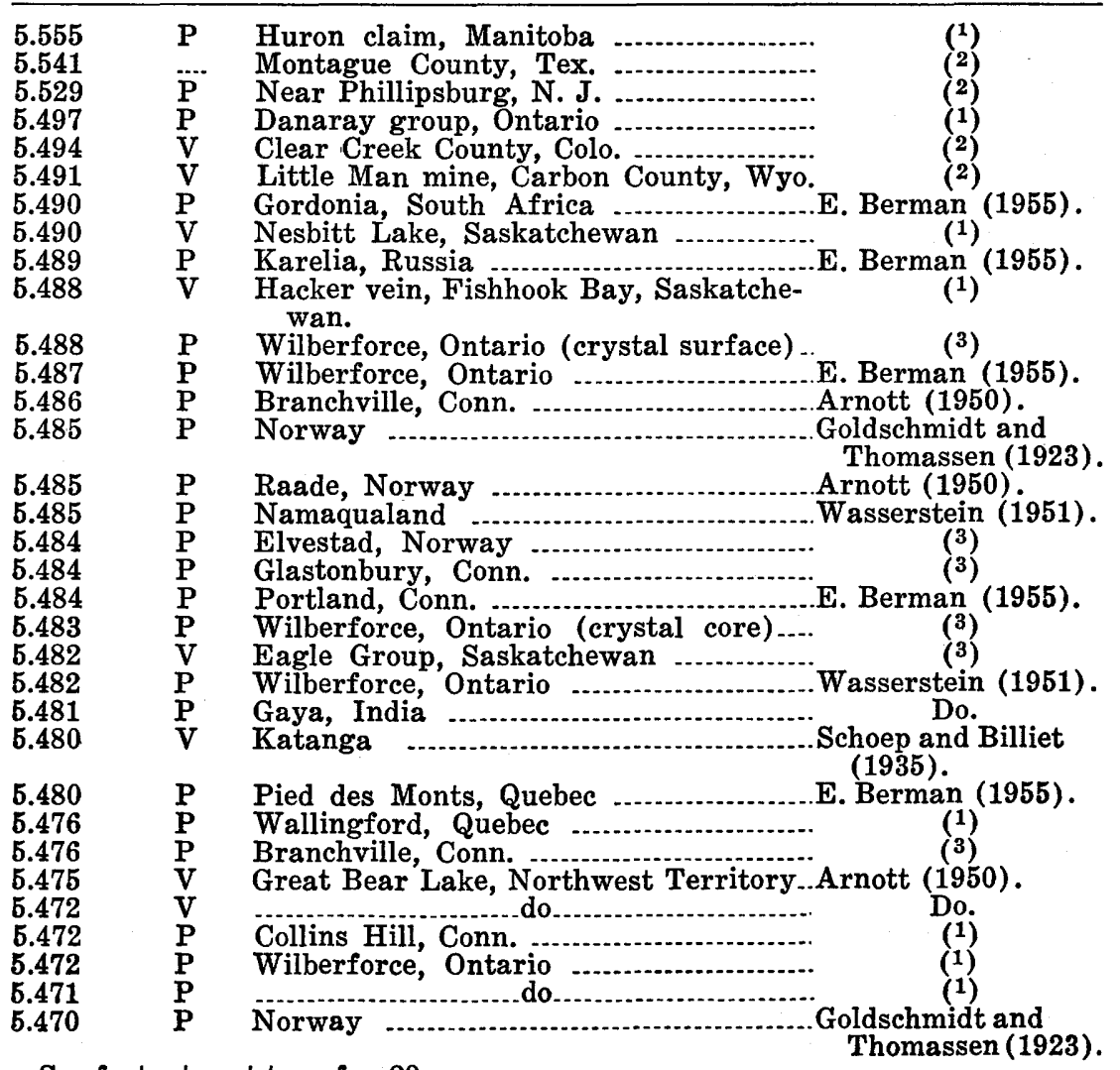

See footnotes at top of p. 29. 
Unit-cell dimensions, $a_{0}$, of untreated natural uraninite-Continued

TYPE OF

OCCUR-

$a_{0}$ (A) RENCE

LOCALITY

REFERENCE

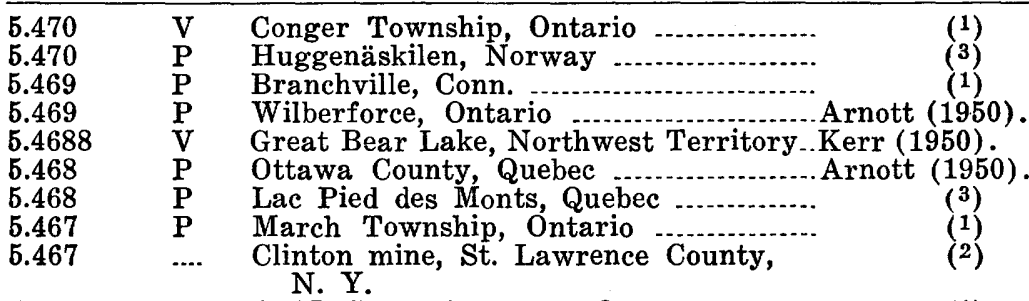

A. H. Shore, Bancroft, Ontario

5.466 Nicholson min
katchewan.

rooker and Nuffield

(1952).

5.465

5.465

5.465

5.461

5.461

5.461

5.461

5.460

5.460

5.46

5.46

5.459

5.459

5.459

5.458

5.458

5.458

5.457

5.456

5.456

5.4560

5.4544

5.454

5.454

5.454

5.454

5.453

5.453

5.45

V

Haddam Neck, Conn.

Do.

P Beryl Mountain, N. H.

E. Berman (1955).

V Breen mine, Ouray, Colo.

V Little Gem mine, British Columbia ......

V Wood-Calhoun mine, Central City, Colo...

V Great Bear Lake, Northwest Territory...Arnott (1950).

P Pied des Monts, Quebec

P Pampacolo, Peru Bueno (1951).

Fichtelgebirge, Germany ....................

S Weatherly mine, Placerville, Colo........

V Cherokee mine, Central City, Colo. .......

Joe Group, Saskatchewan

Carbon County, Wyo. .......................

V Mammoth mine, Central City, Colo. ....

V Belgian Congo ......................................

Arnott (1950).

A. H. Shore, Bancroft,

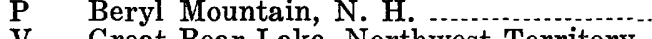

E. Berman (1955).

V Great Bear Lake, Northwest Territory..

Cherokee mine, Central City, Colo.

(1)

Great Bear Lake, Northwest Territory..Kerr (1950).

Gordonia, South Africa

Do.

Giauque Group, Northwest Territory...

(3)

P... Witwatersrand $\quad$ Besner mine, Ontario .........................................

(1)

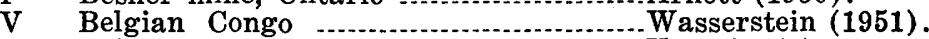

V Shinkolobwe, Belgian Congo .............. Kerr (1951).

V Black Lake, Saskatchewan

Conybeare and

5.45

5.4523

5.452

5.451

5.451

5.451

5.449

5.449

5.449

5.448

5.448

5.448

5.447

5.447

$\begin{array}{ll}\text { V Great Bear Lake, Northwest Territory .. } & \text { Do. } \\ \text { V Lake Athabaska, Saskatchewan .........Kerr (1950). }\end{array}$ Ferguson (1950).

V Nicholson mine, Saskatchewan ........... (1)

$P \quad$ Satersdalen, Norway .........................

V Eagle Group, Saskatchewan ............ (1)

V Shinkolobwe, Belgian Congo

$P$ Yancey County, N. C.

Arnott (1950).

Great Bear Lake, Northwest Territory..

(3)

V Iron mine, Central City, Colo.

V Katanga, Belgian Congo

$P \quad$ Bisundi, India

(3)

... Sagard Township, Quebec ........................ (1)

Wasserstein (1951).

$\dddot{P} \quad$ Ruggles mine, Grafton Center, N. H....E. Berman (1955).

P Besner mine, Ontario

(1)

See footnotes at top of p. 29 . 
Unit-cell dimensions, $a_{0}$, of untreated natural uraninite-Continued TYPE OF OCCUR-

$a_{0}$ (A) RENCE

\begin{tabular}{|c|c|c|c|}
\hline 5.447 & V & Great Bear Lake, Northwest Territory.. & (2) \\
\hline 5.447 & $\mathbf{P}$ & Newry, Maine ...... & E. Berman (1955). \\
\hline 5.446 & $\mathbf{P}$ & Deer Park, N. C. & Arnott (1950). \\
\hline & $\mathbf{S}$ & Placerville, Colo. & (2) \\
\hline & $\mathbf{P}$ & Morogoro, Tanganyika & (3) \\
\hline & V & Martha E. mine, Idaho Springs, Colo. & $(4)$ \\
\hline 45 & $\mathbf{S}$ & Yellow Cat area, Grand County, Utah & $\stackrel{(2)}{(2)}$ \\
\hline & V & $\begin{array}{l}\text { Martin Lake, Lake Athabaska, Sas- } \\
\text { katchewan. }\end{array}$ & $\begin{array}{l}\text { Brooker and Nuffield } \\
(1952) \text {. }\end{array}$ \\
\hline 444 & $\mathbf{P}$ & Ruggles mine, Grafton Center, N. H. & E. Berman (1955). \\
\hline & Y & $\begin{array}{l}\text { Nicholson mine, Lake Athabaska, } \\
\text { Saskatchewan. }\end{array}$ & (1) \\
\hline 5.444 & $\mathbf{P}$ & Butt Township, Ontario & (1) \\
\hline 444 & $\mathrm{~V}$ & Shinkolobwe, Belgian Congo & Kerr (1950) \\
\hline 5.4439 & $\stackrel{P}{\mathbf{V}}$ & $\begin{array}{l}\text { Namaqualand } \\
\text { Sunshine mine, Idaho }\end{array}$ & $\begin{array}{l}\text { Wasserstein (1951). } \\
\text { Kerr and Kulp }\end{array}$ \\
\hline & & & \\
\hline
\end{tabular}

5.443

5.442

5.441

5.441

5.44

5.44

5.44

5.44

5.44

5.440

5.440

5.439

5.439

5.438

5.438

5.4376

5.437

Grafton, N. H.

$$
\stackrel{\text { P }}{\mathbf{P}} \quad \text { Grafton, N. H. }
$$

P Crabtree Creek, N. C

Hottah Lake, Northwest Territory

Arnott (1950).

Wind River Basin, Wyo.

Happy Jack mine, White Canyon, Utah.

Pay Day mine, Emery County, Utah....

S Notch mine, San Juan County, Utah.

Black King mine, Placerville, Colo.

Rosenzweig and others (1954)

V Mansfeld, Germany

E. Berman (1955)

Witwatersrand

Wasserstein (1951)

P Palermo mine, North Groton, N. H...... E. Berman (1955).

V Hottah Lake, Northwest Territory

V Shinkolobwe, Belgian Congo................Kerr (1951).

V Buckman adit, Jefferson County, Colo...

V Shinkolobwe, Belgian Congo

S Lucky Strike No. 2 mine,

Emery County, Utah.

5.437

5.437

5.436

5.435

5.435

5.435

5.435

V

Sunnyside mine, Idaho S

V Sudbury district, Ontario

Lanark County, Ontario

Kerr (1950)

Lanark County, Ontario

S
S
V
V

Gas Hills area, Wyo.

Marienberg, Saxony

Martin Lake, Lake Athabaska, Saskatchewan.

Arnott (1950).

(2)

(2)

5.435

5.435

5.435

5.434

5.434

5.4338

5.433

5.4328

5.432

5.431

5.431

5.430

5.430

E. Berman (1955)

Brooker and Nuffield (1952).

Central City district, Colo.

V Old Town mine, Russell Gulch, Colo.....

(4)

(4)

(4)

(1)

(1)

Colorado

Mattawan Township, Ontario

Santander, Columbia

Kerr (1950).

Matawan Township, Ontario

Arnott (1950).

Lake Athabaska, Saskatchewan

Kerr (1950).

Acari, Brazil

Spruce Pine, N. C.

Tavora (1951).

Payday mine, San Rafael Swell, Utah....

(3)

Placerville, Colo.

Shinarump No. 1 mine, Grand County, Utah. 
Unit-cell dimensions, $a_{0}$, of untreated natural uraninite-Continued

TYPE OF

OCCUR-

$a_{0}$ (A) RENCE

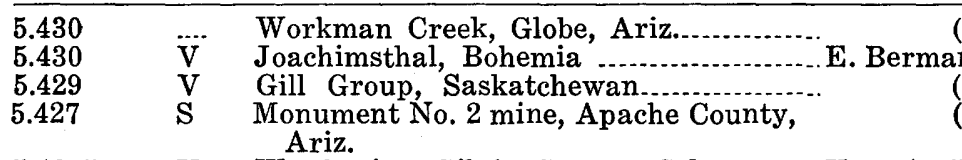
Ariz.

5.4265

5.425

Wood mine, Gilpin County, Colo.

Kerr (1950).

5.425

Martin Lake, Saskatchewan

Pennland, N. C

5.425

Lucky Strike mine, Emery County, Utah.

5.425

5.422

5.422

5.421

Mi Vida mine, San Juan County, Utah..

S Delta mine, San Rafael Swell, Utah....

V Joachimsthal, Bohemia

S Monument No. 2 mine, Apache County, Ariz.

5.421 S Mi Vida mine, San Juan County, Utah..

5.420

5.420

Mi Vida mine, San Juan County,

5.42

5.42

Ranwick claims, Ontario.

Krieger well, Kiowa County, Okla

Marysville, Utah.

$(1955)$

5.42

V

S

Circle Cliffs area, Garfield County,

Kerr (1950).

5.419 Utah.

E. Berman (1955).

Dahl and Kerr (1953).

5.419

S Happy Jack mine, White Canyon, Utah..

(2)

5.418

5.417

5.4165

5.416

5.415

5.415

Horseshoe No. 2 mine, Elk Ridge, Utah..

(2)

(2)

Joachimsthal, Bohemia

Johanngeorgenstadt, Saxony ................ Kerr (1950).

Stanley mine, Idaho Springs, Colo..........

Villeneuve, Quebec

Monument No. 2 mine, Apache County, Ariz.

5.415

Eritria, Africa

5.415

S Shinarump No. 1 mine, Grand County,

E. Berman (1955). Utah.

5.414 S Lucky strike No. 2 mine, Emery County, Utah.

5.414

V Camray group, Ontario

5.413

5.413

5.413

5.412

V Schmiedeberg, Silesia

an (1955).

V Theano Point, Ontario Ariz.

5.411

5.411

5.411

5.411

5.411

S Markey mine, San Juan County, Utah..

S

West Wilson mine, Mont...................

E. Berman (1955).

\section{Utah}

Kerr (1951).

Shinkolobwe, Belgian Congo

Do.

5.41

Temple Mountain, Utah

Rosenzweig and others (1954).

5.41

5.409

5.407

5.407

5.406

Al-Job mine, Natrona County, Wyo.

Arnott (1950)

Rebolerra, Portugal

Whale mine, Bonanza, Colo. ................

Happy Jack mine, White Car

See footnotes at top of p. 29. 
Unit-cell dimensions, $a_{0}$, of untreated natural uraninite-Continued TYPE OF OCCUR$a_{0}$ (A) RENCE

LOCALITY

REFERENCE

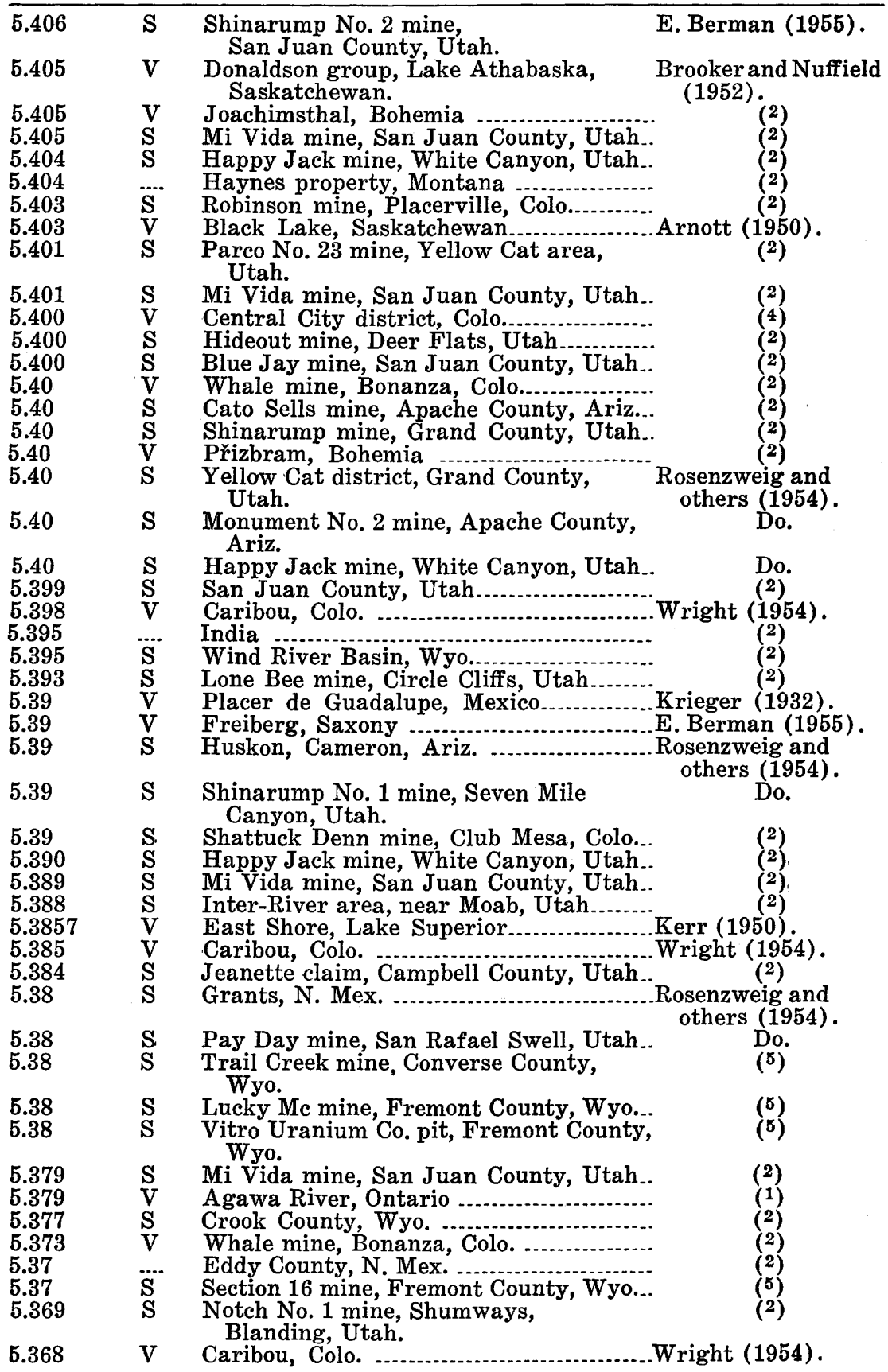

See footnotes at top of p. 29 . 
1 Robinson, S. C., Geological Survey of Canada. Written communication, 1954.

2 Berman, E., Harvard University. Written communication, 1955. Cell dimensions calculated from X-ray films supplied in 1955 by the U. S. Geological Survey.

3 Berman, R., Harvard University. Written communication, 1955.

4 Tooker, E. W., U. S. Geological Survey. Written communication, 1955.

5 Gruner, J. W., and Smith, D. K., University of Minnesota. Written communication, 1955.

The unit-cell edge of $\mathrm{UO}_{2}$ increases linearly with increasing substitution of Th. Data on the variation in cell size with content of Th in natural material and in synthetic material are given in the following tables.

Variation in unit-cell size of natural uraninite with content of thorium ${ }^{1}$

\begin{tabular}{|c|c|c|c|c|c|c|c|c|}
\hline \multirow{2}{*}{\multicolumn{3}{|c|}{ Locality }} & \multicolumn{6}{|c|}{ Unit-cell size, $a_{0}(\mathrm{~A})$} \\
\hline & & & $\begin{array}{l}\text { Not } \\
\text { treated }\end{array}$ & \multicolumn{2}{|c|}{$\begin{array}{l}\text { Heated } \\
5 \text { min }\end{array}$} & \multicolumn{2}{|c|}{$\begin{array}{l}\text { Heated } \\
30 \text { min }\end{array}$} & $\begin{array}{l}\text { Change } \\
\text { in size }\end{array}$ \\
\hline \multicolumn{3}{|c|}{$\begin{array}{l}\text { Huron Claim, Winnipeg River, Mani- } \\
\text { toba }\end{array}$} & \multirow{2}{*}{$\begin{array}{l}5.555 \\
5.472\end{array}$} & \multirow{2}{*}{\multicolumn{2}{|c|}{$\begin{array}{l}5.490 \\
5.454\end{array}$}} & \multirow{2}{*}{\multicolumn{2}{|c|}{$\begin{array}{l}5.472 \\
5.453\end{array}$}} & -0.083 \\
\hline \multirow{2}{*}{\multicolumn{3}{|c|}{$\begin{array}{l}\text { Wilberforce, Ontario } \\
\text { Wilberforce, Ontario (very hard crys- } \\
\text { tal) }\end{array}$}} & & & & & & -.019 \\
\hline & & & 5.471 & \multirow{4}{*}{\multicolumn{2}{|c|}{$\begin{array}{l}5.453 \\
5.443 \\
5.451 \\
5.445\end{array}$}} & \multirow{4}{*}{\multicolumn{2}{|c|}{$\begin{array}{l}5.454 \\
5.440 \\
5.450 \\
5.441\end{array}$}} & -.017 \\
\hline Shore Property, Bancroft, & Ontari & on--- & 5.458 & & & & & -.018 \\
\hline Villeneuve, Ottawa Count & y, Queb & ec.. & 5.415 & & & & & +.035 \\
\hline \multirow{2}{*}{\multicolumn{3}{|c|}{ Conger Township, Parry Sound, On- }} & 5.467 & & & & & \\
\hline & & & \multirow{2}{*}{$\begin{array}{l}5.470 \\
5.447 \\
5.460\end{array}$} & \multirow{2}{*}{\multicolumn{2}{|c|}{$\begin{array}{l}5.444 \\
5.417 \\
5.448\end{array}$}} & \multirow{2}{*}{\multicolumn{2}{|c|}{$\begin{array}{r}5.444 \\
5.403 \\
25.439\end{array}$}} & -.026 \\
\hline \multicolumn{3}{|c|}{$\begin{array}{l}\text { Besner mine, Ontario } \\
\text { Pied des Monts, Quebec. }\end{array}$} & & & & & & $\begin{array}{l}-.046 \\
-.021\end{array}$ \\
\hline \multirow[b]{2}{*}{ Locality } & \multicolumn{7}{|c|}{ Chemical analysis (weight percent) } & \multirow{2}{*}{$\begin{array}{c}\text { Age } \\
\left(\times 10^{6}\right. \\
\text { years })\end{array}$} \\
\hline & $\mathrm{UO}_{2}$ & $\mathrm{UO}_{3}$ & $\mathrm{U}_{3} \mathrm{O}_{8}$ & $\mathrm{ThO}_{2}$ & $\mathrm{PbO}$ & $\begin{array}{c}\text { Ce } \\
\text { group }\end{array}$ & $\underset{\text { group }}{\mathrm{Y}}$ & \\
\hline \multicolumn{3}{|l|}{$\begin{array}{l}\text { Huron Claim, Winnipeg } \\
\text { River, Manitoba }\end{array}$} & 63.08 & \multirow{2}{*}{$\begin{array}{l}14.18 \\
11.4\end{array}$} & \multirow{2}{*}{$\begin{array}{l}16.63 \\
10.4\end{array}$} & \multirow{2}{*}{$\begin{array}{l}0.37 \\
1.82\end{array}$} & 2 & \multirow{2}{*}{$\begin{array}{l}1,775 \\
1,100\end{array}$} \\
\hline Wilberforce, Ontario & 45.18 & 24.9 & 00.00 & & & & 2.74 & \\
\hline \multirow{2}{*}{$\begin{array}{l}\text { Wilberforce, Ontario } \\
\text { (very hard crystal) } \\
\text { Shore Property, Bancroft, } \\
\text { Ontario }\end{array}$} & 39.1 & 32.4 & \multirow{3}{*}{72.29} & 10.6 & 10.95 & 1.88 & 2.14 & 1,100 \\
\hline & & & & 7.26 & 12.31 & & \\
\hline \multicolumn{3}{|l|}{$\begin{array}{l}\text { Ontario } \\
\text { Villeneuve, Ottawa }\end{array}$} & & & & \multicolumn{2}{|c|}{5.99} & \\
\hline $\begin{array}{l}\text { County, Quebec } \\
\text { March Township, Ontario }\end{array}$ & 34.67 & 41.06 & & 6.41 & 11.27 & 1.51 & 2.57 & 1,100 \\
\hline $\begin{array}{l}\text { March Township, Ontario } \\
\text { Conger Township, Parry }\end{array}$ & 49.44 & 24.28 & & 4.92 & 11.61 & 2.10 & 2.30 & 1,150 \\
\hline Sound, Ontario & 53.63 & 26.32 & & 3.22 & 11.67 & .98 & 2.19 & 1,050 \\
\hline Besner mine, Ontario & 49.35 & 29.76 & & 1.78 & 8.66 & 1.47 & 1.48 & 792 \\
\hline Pied des Monts, Quebec . & $-\ldots$ & & 86.16 & .10 & 11.69 & .06 & .73 & 992 \\
\hline
\end{tabular}

${ }^{1}$ Data of S. C. Robinson, Geological Survey of Canada, written communication, 1954. 


\section{Composition and unit-cell dimensions of natural members of the uraninite-thorianite series}

[Data of Robinson and Sabina (1955)]

\begin{tabular}{|c|c|c|c|c|c|c|}
\hline \multirow[b]{2}{*}{ Locality 1} & \multirow[b]{2}{*}{$\begin{array}{l}\text { U:Th } \\
\text { ratio }\end{array}$} & \multicolumn{2}{|c|}{$a_{0}(\mathrm{~A})$} & \multicolumn{3}{|c|}{$\begin{array}{l}\text { Composition (weight } \\
\text { percent) }\end{array}$} \\
\hline & & $\begin{array}{c}\text { Un- } \\
\text { heated }\end{array}$ & $\begin{array}{c}\text { Heated in } \\
\text { air at } 1,000^{\circ} \\
\mathrm{C} \text { for } 10 \\
\text { min }\end{array}$ & $\mathrm{U}_{3} \mathrm{O}_{8}$ & $\mathrm{ThO}_{2}$ & $\mathrm{PbO}$ \\
\hline 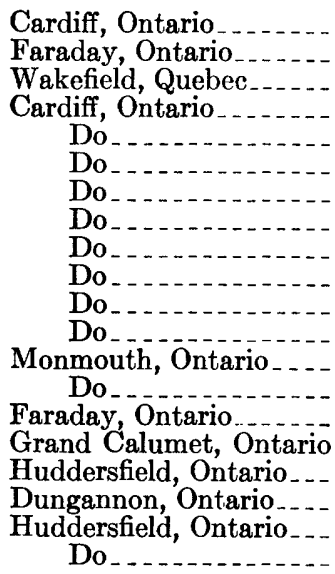 & $\begin{array}{l}9.2 \\
8.8 \\
8.25 \\
8.1 \\
7.59 \\
6.79 \\
6.43 \\
4.44 \\
4.24 \\
3.86 \\
3.53 \\
3.24 \\
1.89 \\
1.61 \\
1.27 \\
.94 \\
.88 \\
.83 \\
.70 \\
.43\end{array}$ & $\begin{array}{l}5.454 \\
5.460 \\
5.449 \\
5.461 \\
5.461 \\
5.468 \\
5.469 \\
5.497 \\
5.491 \\
5.475 \\
5.477 \\
5.488 \\
5.510 \\
5.519 \\
5.540 \\
5.539 \\
5.540 \\
5.553 \\
5.547 \\
5.564\end{array}$ & $\begin{array}{l}5.404 \\
5.414 \\
5.413 \\
5.423 \\
5.433 \\
5.438 \\
5.434 \\
5.454 \\
5.460 \\
5.454 \\
5.455 \\
5.457 \\
5.486 \\
5.489 \\
5.512 \\
5.509 \\
5.515 \\
5.521 \\
5.523 \\
5.537\end{array}$ & $\begin{array}{l}73.0 \\
70.0 \\
69.0 \\
65.0 \\
66.7 \\
64.5 \\
66.7 \\
62.8 \\
62.7 \\
68.0 \\
59.6 \\
59.0 \\
53.0 \\
48.0 \\
46.0 \\
39.8 \\
36.8 \\
40.0 \\
36.3 \\
25.0\end{array}$ & $\begin{array}{r}7.7 \\
7.7 \\
8.1 \\
7.7 \\
8.5 \\
9.2 \\
10.0 \\
13.6 \\
14.3 \\
17.0 \\
16.3 \\
17.6 \\
27.0 \\
28.8 \\
35.0 \\
41.0 \\
40.1 \\
46.4 \\
49.7 \\
55.5\end{array}$ & $\begin{array}{c}10.75 \\
13.7 \\
13.9 \\
11.9 \\
11.4 \\
11.9 \\
8.4 \\
12.8 \\
10.7 \\
10.75 \\
10.3 \\
10.5 \\
10.0 \\
9.4 \\
9.0 \\
8.4 \\
7.7 \\
8.0 \\
8.6 \\
6.8\end{array}$ \\
\hline
\end{tabular}

1 Exact location and description of deposit given in original paper.

2 Analyses by $X$-ray spectrographic method; precision better than \pm 5 percent of cited values.

Unit-cell dimensions of synthetic solid solutions in the series $\mathrm{UO}_{2}-\mathrm{ThO}_{2}{ }^{1}$ [Samples prepared by sintering at $1,200^{\circ} \mathrm{C}$.]

\begin{tabular}{|c|c|c|c|c|c|}
\hline $\begin{array}{c}\mathrm{ThO}_{2} \\
\text { (MOL. } \\
\text { PERCENT) }\end{array}$ & $\begin{array}{c}a_{0}(\mathrm{~A}) \\
(\mathrm{ALL} \pm 0.003)\end{array}$ & $\begin{array}{c}\text { SPECIFIC } \\
\text { GRAVITY } \\
\text { (CALCULATED) }\end{array}$ & $\begin{array}{c}\mathrm{ThO}_{2} \\
\text { (MOL. } \\
\text { PERCENT) }\end{array}$ & $\begin{array}{c}a_{0}(\mathrm{~A}) \\
(\mathrm{ALL} \pm 0.003)\end{array}$ & $\begin{array}{c}\text { SPECIFIC } \\
\text { GRAVITY } \\
\text { (CALCULATED) }\end{array}$ \\
\hline $\begin{array}{r}0 \\
10 \\
20 \\
30 \\
40 \\
57\end{array}$ & $\begin{array}{l}\mathbf{5 . 4 5 5} \\
\mathbf{5 . 4 6 9} \\
\mathbf{5 . 4 8 2} \\
\mathbf{5 . 4 9 2} \\
\mathbf{5 . 5 0 9} \\
\mathbf{5 . 5 2 6}\end{array}$ & $\underline{11.05}$ & $\begin{array}{r}70 \\
80 \\
90 \\
95 \\
98 \\
100\end{array}$ & $\begin{array}{l}\mathbf{5 . 5 5 8} \\
\mathbf{5 . 5 7 5} \\
\mathbf{5 . 5 8 0} \\
\mathbf{5 . 5 8 0} \\
\mathbf{5 . 5 8 9} \\
\mathbf{5 . 5 8 7}\end{array}$ & $\overline{10.06}$ \\
\hline
\end{tabular}

${ }^{1}$ Data of Trzebiatowski and Selwood (1950). Material with 50 and 54. mol. percent $\mathrm{ThO}_{2}$ gave a diffuse pattern.

When natural uraninite is heated and $\mathrm{UO}_{2}\left(\right.$ or $\mathrm{UO}_{2+\mathrm{x}}$ ) is the product or one of the products formed (see further under Thermal behavior), the cell dimension $a_{0}$ of the recrystallized material is in general smaller than that of the original material. The change in $a_{0}$ is primarily due to alteration of the $\mathrm{U}^{+4}: \mathrm{U}^{+6}: 0$ ratio and to 
the removal of radiation damage; loss of radiogenic lead by volatilization at high temperatures may be a factor. The duration and temperature of heating, the ambient atmosphere, and the composition of the original uraninite are also involved. Some typical data are cited in the foregoing tables. The matter has been discussed by Anderson and others (1954), Robertson and Sabina (1955), Wasserstein $(1951,1954)$, and Brooker and Nuffield (1952).

The variation in $a_{0}$ as a function of the content of radiogenic lead has been suggested as a measure of geologic age by Wasserstein $(1951,1954)$. He has classified uraninite into three types: a-uraninite, corresponding to $\mathrm{UO}_{2}$, with cell dimensions that decrease as a consequence of radioactive decay to lead by an amount proportional to the age; $\beta$-uraninites, thought to correspond to $\mathrm{U}_{3} \mathrm{O}_{7}$; and $\tau$-uraninites, thought to correspond to $\mathrm{U}_{4} \mathrm{O}_{8}$. The $\beta$-type requires heat treatment under reducing conditions and the $\tau$-type under oxidizing conditions in order to bring their cell dimensions to age values consistent with those of the $a$-type. No evidence has been presented, however, of the existence of $\mathrm{U}_{3} \mathrm{O}_{7}$ or $\mathrm{U}_{4} \mathrm{O}_{9}$ in nature; see also Hoekstra and Katz (1955).

Crystal habit

Uraninite crystals are commonly cubes or cubes modified by octahedral or, rarely, dodecahedral faces; also as unmodified octahedra or dodecahedra. Typical habits are shown in figure 1.

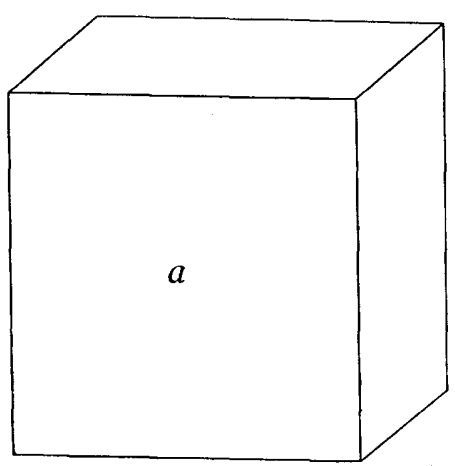

A

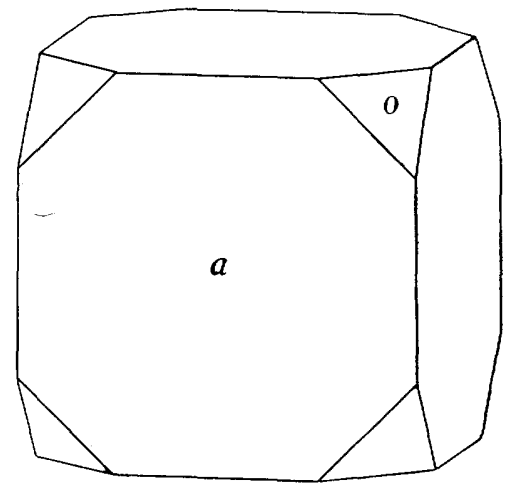

$B$

Figure 1.-Uraninite. A. Cube, $a\{100\}$. B. Cubo-octahedron, $a\{100\}$ and $o\{111\}$.

Additional forms have been observed as modifying faces in single instances: $\{520\}$ by Rogers (1947), $\{114\}$ by Parsons (1932), and $\{335\}$ by Shaub (1938). The crystals usually are large, rough, and 
coated by brightly colored alteration products. The largest crystals known are from Wilberforce, Ontario, where cubes and modified dodecahedra several inches in size have been found. One broken crystal from this locality weighed about 5 pounds (Meen, 1948). Uraninite also occurs as large dendritelike aggregates of small crystals, notably in the Ruggles pegmatite, New Hampshire (Shaub, 1938). A radiograph of a sawed section through such an intergrowth is shown on plate 1 . Uraninite may be massive, dense to granular; occasionally pulverulent or almost graphitic. Found as reniform or botryoidal crusts and masses with more or less distinct concentric banding and at times a suggestion of a radial fibrous or columnar structure (pitchblende).

Twins on $\{111$ \} have been observed but are rare. They have been described from Cardiff Township, Ontario (Parsons, 1932), Katanga (Aubel, 1927), Parry Sound, Ontario (Spence, 1930b), and St. Lawrence County, N. Y. (Shaub, 1940). Fine examples occur at Wilberforce, Ontario. The twins are of the interpenetration type as in fluorite and not of the contact type as in spinel; similar twins occur in thorianite.

Physical properties

Cleavage is not observed in large crystals. Octahedral cleavage cracks have been observed in polished sections (Ramdohr, 1955). The fracture varies from uneven or splintery to rough-conchoidal. Brittle. Hardness of crystals $51 / 2-6$, somewhat less in altered material. Specific gravity 10.95 for synthetic $\mathrm{UO}_{2} ; 10.97$ calculated for $a_{0} 5.468 \mathrm{~A}$. The specific gravity of natural uraninite is relatively low and variable, ranging ordinarily between about 7.5 and 9.7, owing to alteration. The variety pitchblende has somewhat lower values, usually 6.5-9.0. The variation in specific gravity with the entrance of other elements in solid solution, and with the entrance of oxygen accompanying variation in the $\mathrm{U}^{+4}: \mathrm{U}^{+8}$ ratio, is not clearly shown by natural material. Summaries of the numerous measurements of the specific gravity are given by Hintze (1929), Mellor (1932), Katz and Rabinowitch (1951), and Perio (1953c). The reported specific gravity of synthetic powders and sintered masses also is low and variable.

Luster submetallic and ironlike in unaltered crystals; usually dull, or pitchlike to slightly greasy in altered material. Color dark steel gray to velvety black in crystals, becoming brownish black, dark brown, greenish black, or dark greenish gray in oxidized and altered material. The color of powdery synthetic $\mathrm{UO}_{2}$ varies from black or bluish black to dark brown and brown depending on particle size and the content of oxygen. Streak and powder 


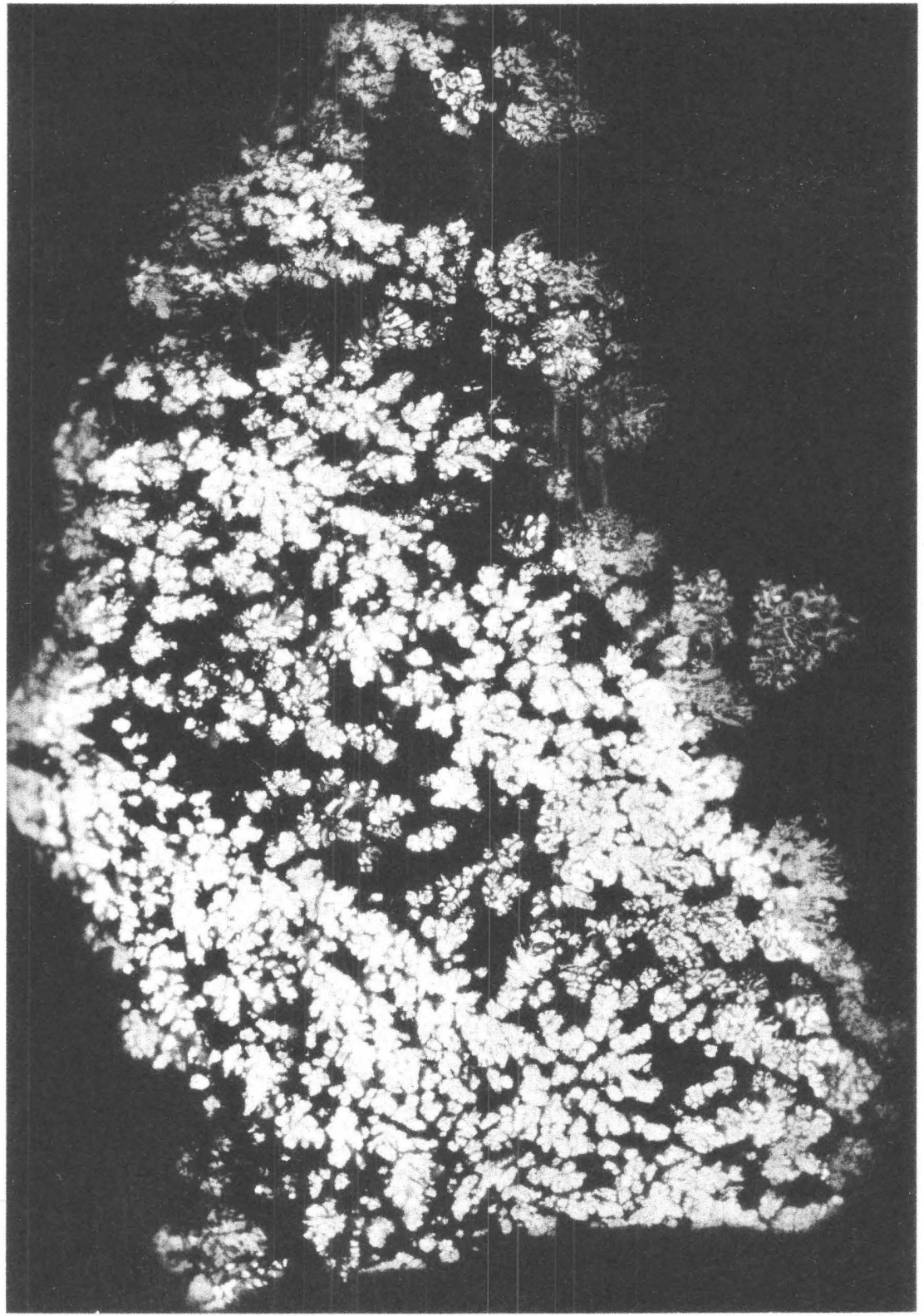

AUTORADIOGRAPH OF DENDRITIC AGGREGATE OF URANINITE CRYSTALS. RUGGLES PEGMATITE, GRAFTON CENTER, N. H. 
variable in color, black to brownish black, grayish or dull olive green. Opaque in masses or coarse grains. Uraninite is a semiconductor. The melting point in air is $2,500^{\circ}-2,600^{\circ} \mathrm{C}$. It does not fluoresce in ultraviolet light, and is not triboluminescent.

\section{Optical properties}

Transmitted light.-Uraninite is opaque in large pieces, but fine grains may be translucent or transparent with a deep greenish-gray, brown, or yellowish color. Isotropic. The index of refraction is not known, but is very high.

Reflected light.-Viewed in air, polished sections of uraninite crystals are light gray and about as highly reflecting as magnetite; pitchblende is light gray with a brownish tint and is distinctly darker than magnetite. Viewed in oil, the color tends more toward brown. Optically isotropic. Very dark-brown internal reflections are sometimes observed. Usually negative toward all etching agents. Relatively highly oxidized pitchblende may give positive reactions with certain reagents.

Two types of uraninite can be distinguished in polished section. The first comprises euhedral or anhedral single crystals, sometimes skeletal in outline. These typically occur in pegmatites, but microscopic euhedral crystals sometimes are found in association with pitchblende in hydrothermal vein deposits. The second type of material, pitchblende, appears in polished section as concentrically banded aggregates with a more or less well-marked radial-fibrous structure; also internally structureless. It almost always is minutely cracked, owing to mechanical deformation or, as has been suggested, to shrinkage attending crystallization from a gel. The cracks generally are filled with chalcopyrite, pyrite, and other metallic or gangue minerals. Descriptions of uraninite in polished section are given by Zuckert (1925), Kidd and Haycock (1935), George (1949), Ramdohr (1950, 1955), Bastin (1950), Thurlow and Wright (1950), Wimmenauer (1952), Rosenzweig, Gruner and Gardiner (1954), Geffroy and Sarcia (1954), H. D. Wright (1954), and Robinson (1955).

\section{Thermal behavior}

Pure synthetic $\mathrm{UO}_{2}$ is stable in air at room temperature, but it oxidizes to $\mathrm{U}_{3} \mathrm{O}_{8}$ when in the colloidal range of size. When heated in air $\mathrm{UO}_{2}$ oxidizes to $\mathrm{U}_{3} \mathrm{O}_{8}$; heated in oxygen it converts rapidly to $\mathrm{U}_{3} \mathrm{O}_{8}$ at temperatures as low as $185^{\circ} \mathrm{C}$. $\mathrm{UO}_{2}$ is not reduced by hydrogen even at high temperatures and pressure, but it reacts at red heat with $\mathrm{Cl}$ and $\mathrm{Br}$, and at about $1,600^{\circ} \mathrm{C}$ or over with carbon to form uranium carbide. 
When natural uraninite is heated it recrystallizes (depending on the temperature, the duration of the heating, the ambient atmosphere, and the extent of original oxidation) into $\mathrm{UO}_{2}, \mathrm{U}_{3} \mathrm{O}_{8}$, or a mixture of $\mathrm{UO}_{2}$ (or $\mathrm{UO}_{2+\mathrm{x}}$ ) and either $\mathrm{U}_{3} \mathrm{O}_{8}, \mathrm{U}_{4} \mathrm{O}_{9}$, or an unidentified phase (Brooker and Nuffield, 1952) that may be $\mathrm{U}_{4} \mathrm{O}_{9}$. There is an accompanying decrease in the unit-cell size of the $\mathrm{UO}_{2}$ formed. If heated sufficiently high and sufficiently long in oxygen only $\mathrm{U}_{3} \mathrm{O}_{8}$ is formed. If coarse uraninite powder is heated briefly under conditions of limited access of oxygen, as in a closed crucible, the amount of $\mathrm{U}_{3} \mathrm{O}_{8}$ formed roughly increases with increasing oxidation of the original material. The thermal behavior is complicated by the fact that uraninite is itself not always entirely homogeneous but may vary inwardly in the extent of oxidation. The presence of rare earths, radiogenic lead, and other elements in solid solution is an added complicating factor. Observations on the thermal behavior of uraninite are given by Conybeare and Ferguson (1950), and Brooker and Nuffield (1952). (See also foregoing tables.) A differential thermal analysis curve of uraninite is given by Kerr and Holland (1951).

When finely powdered uraninite is strongly heated in a closed crucible a relatively highly radioactive sublimate of polonium may be obtained (Behrendsen, 1902).

\section{Synthesis}

$\mathrm{UO}_{2}$ can be prepared as a powder in a variety of ways, among them by (a) reducing $\mathrm{U}_{3} \mathrm{O}_{8}, \mathrm{UO}_{3}$, and other higher oxides by heating with carbon or hydrogen; (b) igniting uranyl oxalate in the absence of air; (c) fusing $\mathrm{Na}_{2} \mathrm{U}_{2} \mathrm{O}_{7}$ with $\mathrm{NaCl}$ and $\mathrm{C}$; (d) heating uranous chloride in the presence of moisture, or by heating uranyl chloride with a reducing agent such as $\mathrm{H}, \mathrm{Mg}$, or $\mathrm{Al}$; (e) igniting uranous or uranyl sulfate in a stream of $\mathrm{H}$; (f) evaporating a solution of $\mathrm{UO}_{2} \mathrm{Cl}_{2}$ with $\mathrm{NaCl}$ and $\mathrm{NH}_{4} \mathrm{Cl}$ to dryness and fusing the residue. Large lustrous black crystals can be obtained by fusing 20 parts of anhydrous magnesium chloride with 5 parts of sodium uranate in a covered porcelain crucible. Octahedral crystals of $\mathrm{UO}_{2}$ can be obtained by fusing $\mathrm{U}_{3} \mathrm{O}_{8}$ over a long time with borax in a platinum crucible; solid solutions to thorianite can be obtained by adding $\mathrm{ThO}_{2}$. Fine-grained precipitates of $\mathrm{UO}_{2}$, including minute botryoidal aggregates with a fibrous structure ("pitchblende") have been obtained by heating uranyl sulfate solutions with $\mathrm{H}_{2} \mathrm{~S}$ or organic reducing agents at temperatures from $50^{\circ}$ to $215^{\circ} \mathrm{C}$ (Gruner, 1952, and Miller and Kerr, 1954). Summaries of the methods of preparation of $\mathrm{UO}_{2}$ are given by Gmelin (1936), Mellor (1932), Croxton (1951), and S. M. Lang (1953). 
Alteration

Uraninite alters easily under natural conditions. The alteration is of two types. In one, the mineral may oxidize with partial conversion of the $U^{+4}$ to $U^{+6}$ but without destruction of the crystal structure, as discussed in preceding sections. This alteration may be accompanied by a change in color from black to dark brown and by the assumption of a dull or pitchlike luster. There usually is also some degree of hydration, and uranium and especially thorium may be leached from the crystal relative to lead as alteration progresses.

In the second type of alteration, the mineral is wholly reconstituted by chemical reaction with water solutions with which it comes into contact. The first formed alteration products generally are hydrated uranyl oxides. These commonly contain lead as an essential constituent, this being the radiogenic lead of the original uraninite. These minerals, chief of which are fourmarierite, vandendriesscheite, clarkeite, curite, becquerelite, and schoepite, are bright orange red, orange, or yellow and constitute the traditional gummite (which see). The hydrated oxides may in turn alter by reaction with siliceous meteoric waters to form silicates such as uranophane, beta-uranophane, kasolite, and soddyite. The uranyl carbonate rutherfordine also is a rather common alteration product. Complete pseudomorphs after the original uraninite crystals are often formed by the alteration products. The pseudomorphs ultimately may be leached away, often with the formation of minerals such as autunite, phosphuranylite, parsonsite, uranophane, and beta-uranophane in cracks and crevices in the matrix rock in the near vicinity. Pseudomorphs of thucholite after uraninite from a pegmatite at Parry Sound, Ontario, have been described by Spence (1930b) and from Pied des Monts, Charlevoix County, Quebec (Spence, 1940). The extensive literature on the oxidation and alteration of uraninite has been summarized by C. Frondel (1956b).

\section{Identification}

Uraninite is characterized by its extremely high specific gravity, isometric form when crystallized, and its black to dark steel-gray color and submetallic luster when fresh and unaltered. It is then likely to be confused only with thorianite (which see). There is a superficial resemblance to various niobate-tantalates, particularly the uranium-containing varieties of microlite-pyrochlore, and to heavy, black metallic oxides such as magnetite and ilmenite. The high radioactivity of uraninite is a characteristic and often a convenient diagnostic feature. Pitchblende also is heavy and black; it often has a botryoidal surface with more or less distinct banding 
on fracture surfaces, and has a coarse to fine radial-fibrous or dense structure. The fine-granular to pulverulent types of uraninite resemble uvanite and other black vanadium minerals and also coffinite; they are best identified by their X-ray powder pattern. The brownish, highly oxidized types of uraninite can be confused with clarkeite and the dense, brownish types of vandendriesscheite and fourmarierite (these usually are orange red).

The X-ray powder-spacing data for uraninite are given in the following table. The pattern closely resembles that of pure thorianite, but the latter has larger $d$-spacings and a larger unit-cell dimension; as a complete solid-solution series exists between the two species, however, the $d$-spacings are gradational. Pure cerianite, $\mathrm{CeO}_{2}$, also has an analogous pattern, but its $d$-spacings and unit-cell dimension are smaller than those of essentially stoichiometric $\mathrm{UO}_{2}$; the value for $\mathrm{CeO}_{2}, a_{0} 5.41 \mathrm{~A}$, overlaps those of highly oxidized uraninite, which range down to about $a_{0} 5.36 \mathrm{~A}$. Further, both $\mathrm{U}$ and Th can enter into solid solution in $\mathrm{CeO}_{2}$, with accompanying increase in $d$-spacings and $a_{0}$, so that a positive distinction cannot be made between these solid solutions by X-ray means alone. There are also more or less close resemblances between the patterns of these species and those of sphalerite, pyrite, bindheimite, and fluorite.

\begin{tabular}{|c|c|c|c|c|c|}
\hline \multirow[b]{2}{*}{$d(\mathrm{~A})$} & \multicolumn{4}{|c|}{$\begin{array}{c}X \text {-ray powder-spacing data for uraninite }{ }^{1} \\
\text { [Copper radiation, nickel filter] }\end{array}$} & \multirow[b]{2}{*}{$h k l$} \\
\hline & $I$ & $h k l$ & $d(\mathrm{~A})$ & $I$ & \\
\hline $\begin{array}{l}3.14 \\
2.73 \\
1.926 \\
1.645 \\
1.574 \\
1.365 \\
1.251 \\
1.220 \\
1.115\end{array}$ & $\begin{array}{r}10 \\
5 \\
8 \\
9 \\
4 \\
4 \\
3 \\
6 \\
6 \\
6\end{array}$ & $\begin{array}{l}111 \\
002 \\
022 \\
113 \\
222 \\
004 \\
133 \\
024 \\
224\end{array}$ & $\begin{array}{l}.051 \\
.966 \\
.924 \\
.911 \\
.864 \\
.833 \alpha_{1} \\
.824 \alpha_{1} \\
.789 \alpha_{1}\end{array}$ & $\begin{array}{l}7 \\
4 \\
7 \\
5 \\
6 \\
5 \\
5 \\
3\end{array}$ & $\begin{array}{l}333,115 \\
044 \\
135 \\
006,244 \\
026 \\
335 \\
226 \\
444\end{array}$ \\
\hline
\end{tabular}

${ }^{1}$ Data on essentially stoichiometric synthetic $\mathrm{UO}_{2}$, with $a_{0}=5.46 \mathrm{~A}$.

Natural formation and geochemistry

The element uranium is present in the rocks of the outer crust of the earth in the average amount of about 0.0001-0.0002 percent (1-2 parts per million). Among igneous rocks it is relatively concentrated in those of felsic types, notably granite with an average uranium content of about 0.0004 percent. Uranium is present largely or entirely in primary rocks or magmas in the quadrivalent ionic state. Because of its low concentration it does not crystallize directly as a compound during the crystallization of magmas. Further, because of the relatively large size and high charge of 
the quadrivalent uranium ion, it is not entrapped in solid solution in significant amounts in the normal rock-forming silicates formed during the crystallization of a magma, but tends to become concentrated in the hydrothermal solutions and pegmatites that are formed during the consolidation process. Small amounts of uranium may be retained, however, in solid solution in certain accessory minerals of the parent rock, notably zircon, monazite, and thorite.

The uranium present in the hydrothermal solutions or pegmatitic magmas, when it crystallizes as a uranium compound, does so most commonly as the dioxide, uraninite, but coffinite occurs in some hydrothermal vein deposits. In the pegmatites proper, the uranium also may be dispersed in small variable amounts in solid solution in other minerals chief among which are thorite, thorianite, monazite, zircon, brannerite, and a variety of niobate-tantalates. In such deposits, few of which are presently of economic interest, uranium is characteristically associated with thorium, zirconium, and the rare-earth elements. In hydrothermal deposits of magmatic origin, uranium has become separated geochemically from thorium, zirconium, and the rare earths and instead shows a characteristic but not invariable association with cobalt, nickel, bismuth, and arsenic. The commonest and most abundant primary uranium compound found in such hydrothermal deposits is again the dioxide, uraninite, particularly the fine-grained massive variety, pitchblende.

Sedimentary rocks also contain uranium in amounts ordinarily ranging up to about 0.0001 percent. The carbonaceous black marine shales and certain coals, such as the kolm beds found in the alum shales of southern Sweden, are particularly rich in uranium. They may contain as much as several hundredths of a percent of the element. The manner in which uranium is contained in carbonaceous shales, coal, and lignite is not clearly understood. Sedimentary phosphate rocks also may be relatively high in uranium carried in solid solution in apatite (Altschuler and others, 1955). In clastic sediments the uranium is chiefly contained in accessory, heavy detrital minerals, chiefly thorite, zircon, and monazite, that carry uranium in solid solution. Relatively rich placer deposits of uranium-containing minerals such as brannerite or thorite also occur and may be of economic importance.

Aside from uraninite, almost all minerals that contain uranium as an essential constituent are characterized by the presence of hexavalent uranium as the so-called uranyl ion, $\left(\mathrm{UO}_{2}\right)^{+2}$. These minerals are formed principally by the weathering of uraninite or minerals carrying quadrivalent uranium in solid solution that are 
contained in igneous rock, pegmatites, or magma-derived hydrothermal deposits, or by the reworking and concentration through meteoric waters or other agencies, under oxidizing conditions, of the uranium contained in sedimentary and other rocks. Under strongly reducing conditions, however, deposits formed in sedimentary or other rocks by meteoric or telethermal solutions may contain compounds of quadrivalent uranium, notably the uranium silicate, coffinite, and uraninite. Certain of the sandstone-type deposits of the Colorado Plateau seem to be of this nature.

Minerals containing quadrivalent uranium generally are primary, black or brownish black, do not fluoresce in ultraviolet radiation, and chemically are chiefly oxides, silicates, and niobatetantalates that either are anhydrous or contain water as hydroxyl ion. Minerals containing hexavalent uranium generally are secondary, light in color, variously orange, yellow, yellow green or green, fluoresce strongly in ultraviolet radiation, and chemically are hydrated oxides, carbonates, sulfates, vanadates, arsenates, phosphates, molybdates, and silicates.

The geochemical distribution and mineralogic expression of uranium both as an essential constituent and as a vicarious constituent of minerals show striking similarities and dissimilarities to thorium, cerium, and zirconium. The existence of close geochemical resemblances between these elements is suggested by similarities in their general chemical behavior and, more fundamentally, in the electronic structure of their atoms. The dissimilarities that exist between these elements are owing primarily to the small size of the $\mathrm{Zr}^{+4}$ ion as compared to the $\mathrm{Th}^{+4}, \mathrm{Ce}^{+4}$ and $\mathrm{U}^{+4}$ ions as a group, and to the assumption by uranium of a hexavalent state and by cerium of a trivalent state stable under geologic conditions in addition to the quadrivalent states of these elements. In their quadrivalent states, $\mathrm{U}, \mathrm{Th}, \mathrm{Ce}$, and $\mathrm{Zr}$ show the same general geochemical behavior in the magmatic cycle, and tend to occur together both as separate minerals and as substitutes one for the other in solid-solution series. Uranium, alone among these elements, has a stable hexavalent state and forms a linear complex cation, the uranyl ion, O-U-O or $\left(\mathrm{UO}_{2}\right)^{+2}$, that acts as a unit in crystal structures. The uranyl uranium minerals, comprising most of the known uranium minerals, have no mineral analogues containing $\mathrm{Th}, \mathrm{Ce}$, or $\mathrm{Zr}$ in place of uranium. The uranyl ion in general does not enter into solid solution in substitution for these or for other elements, because its large size and unusual dumbbell shape do not allow it to proxy for the normal spherical ions composing crystal structures. The geochemical behavior of the uranyl ion also differs from that of $\mathrm{U}^{+4}, \mathrm{Zr}, \mathrm{Ce}$, and $\mathrm{Th}$, owing primarily 
to the relatively large solubility of uranyl compounds. It is only quadrivalent uranium that forms compounds isostructural with those of $\mathrm{Zr}, \mathrm{Ce}$, and $\mathrm{Th}$, as in the dioxides and nesosilicates, or that proxies for these elements in solid solution. Cerium has a trivalent state, stable under geologic conditions, in addition to the quadrivalent state, and then forms an assemblage of minerals that does not have analogues among the compounds of $\mathrm{U}^{+4}, \mathrm{U}^{+6}, \mathrm{Zr}$, or $\mathrm{Th}$. $\mathrm{A}$ further discussion of these matters is given by C. Frondel (1956a).

\section{occurrence}

Only a few of the typical or more important localities for uraninite are mentioned here, as the list of known occurrences is very large. The localities are grouped according to the genetic type of occurrence.

The chief source of uraninite has been the deposits in hydrothermal veins, and most of the world's supply of uranium previous to World War II was obtained from three deposits of this type, at Joachimsthal and adjacent places in the Erzgebirge of Saxony and Bohemia; Great Bear Lake, Northwest Territory, Canada; and the Katanga district, Belgian Congo. The uraninite veins in general seem to have been formed at moderate temperatures and pressures (mesothermal), although some show characteristics that suggest deposition at somewhat higher or lower temperatures. The ore mineral generally is massive fine-grained uraninite (pitchblende), sometimes showing crustification and botryoidal surfaces. In some localities, however, microscopic euhedral crystals of uraninite, best seen in polished section under the microscope, are associated with typical pitchblende, the former usually as an earlier generation, and in other localities, such as the Shinkolobwe deposit in the Katanga district, Belgian Congo, the uraninite occurs as coarsely granular aggregates of anhedral crystals with a few large euhedral crystals. The hydrothermal-vein types of occurrence can be separated into a number of minor groups, chiefly on the basis of the mineralogic nature of the associated metallic and gangue minerals, but the divisions are not sharp. In the principal or classical type, the uraninite is associated with a variety of $\mathrm{Co}, \mathrm{Ni}, \mathrm{Bi}$, and As minerals, including smaltite, chloanthite, safflorite, gersdorffite, loellingite, niccolite, bismuthinite, and native bismuth, together with native silver, silver sulfosalts, pyrite, chalcopyrite, galena, sphalerite, and tetrahedrite-tennantite, in a gangue composed chiefly of dolomite, calcite, and quartz with minor barite and fluorite. The occurrences at Joachimsthal, Scheeberg, Johanngeorgenstadt, and nearby localities in the Erzgebirge of Saxony, Germany, and Bohemia, Czechoslovakia, are of this type, together with those of Great Bear Lake, Canada; the 
Shinkolobwe mine, Katanga, Belgian Congo; and Cornwall, England. In other occurrences, the $\mathrm{Co}, \mathrm{Ni}, \mathrm{Bi}, \mathrm{As}$, and $\mathrm{Ag}$ minerals are of minor development or are lacking, and the uraninite occurs in a quartz-carbonate-fluorite gangue with the common sulfides such as pyrite, chalcopyrite, and galena, sometimes with gold and silver in traces. The vein deposits in Gilpin County, Colo., are of this nature, as are some of the deposits in Cornwall. Vein deposits of uraninite in a carbonate gangue with relatively small amounts of other metallic minerals occur in the Beaverlodge area of Saskatchewan, Canada, (Robinson, 1955), and other places. Native tin has been found with uraninite in the Nesbitt LaBine mines, Beaverlodge, Saskatchewan (Silman, 1954). Uraninite associated with relatively large amounts of fluorite together with quartz, carbonates, and minor sulfides occurs at Wölsendorf, Bavaria; in the Marysvale district, Utah; at Urgeiriça, Portugal ; in the Plateau Central, France; and elsewhere. In some deposits of this type the uraninite has a fine-grained, pulverulent to almost sooty character. The carbonate gangue of uraninite veins often is stained red by disseminated hematite, and the fluorite immediately associated with ore characteristically is deep purple to almost black; both features are aids in prospecting. Veins and other deposits containing $\mathrm{Co}, \mathrm{Ni}, \mathrm{As}$, and $\mathrm{Ag}$ minerals in a carbonate gangue with few or no other metallic minerals or quartz sometimes contain uraninite, as at the Solitaria mine, Jaguel district, Argentina, but some large deposits of this nature, as at Sudbury, Ontario, lack uranium in significant amounts. A summary description of the hydrothermal-vein type of occurrence of uraninite is given by Everhart and Wright (1953).

The vein deposits at Joachimsthal and other places in the Erzgebirge were the earliest known localities for uranium. Pitchblende was recognized in this area as a distinct substance in the first half of the 18th Century, and possibly earlier, as the mines had been worked for silver and cobalt for hundreds of years before, but the presence of uranium in the mineral-called pechblend by the miners-was not established until the analysis by Klaproth in 1789. Radium was first isolated by the Curies in 1898 in pitchblende from Joachimsthal. The deposition of uraninite in the veins was relatively early and was accompanied by the Co, $\mathrm{Ni}$, As minerals. This was followed by the carbonates and common sulfides and, still later, by the deposition of native silver, argentite, stephanite and other silver sulfosalts, and tetrahedrite-tennantite. Oxidation of the veins was extensive, and a number of arsenates and other secondary uranium minerals were first described from this region. A summary account of the deposits is given by Froh- 
berg (1950) and Kohl (1954). Similar vein deposits occur in the Black Forest of Germany (Kirchheimer, 1952, 1953; Schneiderhöhn, 1952).

The deposit at Great Bear Lake, Canada, was discovered in 1930 when yellow, orange, and green gossans were noticed from a plane flying over the eastern shore of the lake. Specimens of oxidized uraninite were then collected by Gilbert LaBine at the water's edge on LaBine Point, near the present site of the Eldorado mine. Cobalt-nickel mineralization predominates in the veins, which follow fracture zones in Precambrian metamorphosed sediments and tuffs intruded by granitic rocks. Oxidation is not extensive, as in the Belgian Congo, owing to recent glaciation and to climatic factors. A summary account of the Great Bear Lake and other Canadian occurrences of uraninite is given by A. H. Lang (1952).

The Shinkolobwe mine in the Katanga district of the Belgian Congo is the largest and richest known deposit of uraninite in the world. Uraninite also has been found in smaller amounts at Luishia, Kambove, and other copper mines in the Katanga copper belt. The general geology of the Belgian Congo has been described by Cahen (1954) and the Shinkolobwe deposit has been described by Derriks and Vaes (1956). The Shinkolobwe deposit was discovered in 1915 and was first systematically developed in 1921. The chief ore bodies occur along crushed and faulted zones in a Precambrian sequence of metamorphic rocks, the. Mines series, consisting chiefly of dolomitic limestones, in part siliceous and weathering to cellular rocks, with dolomitic chlorite-talc schists containing carbonaceous or graphitic horizons. Massive uraninite occurs in short and discontinuous veins, ranging in thickness from a few inches up to several feet and in length up to about 50 feet, that tend to group in zones. The veins dip steeply for the most part and transect the strata of the Mines series at an angle. Stockworks of small anastomosing veins occur, and there are also disseminated deposits, chiefly of secondary torbernite, in the country rocks. The deposit is hydrothermal and probably was formed at moderate temperatures. The mineralization began with the deposition of magnesite as veins and replacements and was followed by the introduction of massive granular uraninite. Uraninite cubes up to $4 \mathrm{~cm}$ in size have been found. The fine-grained fibrous and banded or botryoidal types of uraninite (pitchblende) are lacking. The deposition of uraninite was followed by the formation of minor amounts of pyrite, molybdenite, monazite, and chlorite. These minerals were followed by quartz and cobalt and nickel sulfides including cattierite, vaesite, and siegenite. Bornite and chalcopyrite are rare, and primary galena or other lead minerals 
are very scarce. Minor elements in the ore include selenium (present in solid solution in the vaesite and siegenite), tellurium, gold, and palladium. Oxidation of the primary ores is extensive and has given rise to a spectacular suite of secondary uranyl minerals. The veins near the surface are encased in concentric, differently colored alteration zones, and there has been some dispersal of uranium into the country rocks, chiefly as torbernite. In an idealized case, the weathered veins show a black central core of unaltered uraninite, a surrounding brown to orange zone composed chiefly of becquerelite and schoepite, a succeeding orange zone containing soddyite, kasolite, and curite, a following yellow zone containing mostly dewindtite, renardite, parsonsite, and uranophane with curite and torbernite, and an outermost green zone composed chiefly of torbernite. Autunite is not present. The lead of the secondary minerals has been derived by the reworking of the radiogenic lead of the uraninite. The bulk content of lead in the secondary minerals is greater than that of the primary ores owing to solution and dispersion of uranium in the meteoric waters. The phosphorus, silicon, calcium, magnesium, and boron of the secondary minerals have been derived from the country rocks by meteoric waters. Black $\mathrm{Co}$ and $\mathrm{Ni}$ oxides also occur in the secondary ores. The molybdenum content of the primary ores appears in the oxidized zone chiefly as wulfenite and partly as $\left(\mathrm{MoO}_{4}\right)^{-2}$ in solid solution in the phosphate. An elliptical body of agglomerate with a matrix of red clay occurs in the deposit; it apparently is a slump breccia due to solution of subjacent limestone.

In Cornwall, England, uraninite occurs widely in the coppertin veins, notably at the South Terras and Trenwith mines in Cornwall and the King's Wood mine in Devon. The veins and lodes occur around the margin of granitic intrusives into folded Paleozoic slates and sandstones. The deposits show a crude zonal arrangement with the tin, carried as cassiterite, representing an earlier and higher temperature phase developed chiefly in depth or close to or in the granitic intrusives. The copper, formed at lower temperatures, is accompanied by uraninite; the principal minerals in the copper veins are chalcopyrite, bornite, pyrite, galena, silver minerals, bismuthinite, and minor amounts of $\mathrm{Co}$, $\mathrm{Ni}$, and As minerals. The principal gangue mineral is quartz, with minor carbonates, fluorite, and barite (Everhart and Wright, 1953).

The only commercial production of uraninite from veins in the United States before 1949 was from the Central City district in Gilpin County, about 35 miles west of Denver, Colo. The mineral was first recognized about 1871, and there was a small production from the Wood, Calhoun, German, and Belcher mines on Quartz 
Hill. The uraninite occurs as small pods or stringers in large gold-silver-lead veins in Precambrian gneiss and schist; $\mathrm{Co}, \mathrm{Ni}$, $\mathrm{Bi}$, and As minerals are absent, and oxidation of the deposits is negligible. Descriptions of these deposits are given by Moore and Butler (1952) and King and others (1953). Similar deposits occur elsewhere in this region, as at Caribou near Nederland, Colo. (H. D. Wright, 1954) ; there quartz, calcite, siderite, pyrite, chalcopyrite, sphalerite, and galena were deposited first in the veins, followed by chalcedony, gersdorffite, and uraninite, with silver minerals, sphalerite, chalcopyrite, and pyrite closing the mineralization.

Uraninite occurs in many pegmatites, but it is found only in small amounts and few if any of these deposits at present are of much economic interest. The uraninite generally occurs as isolated, relatively well-formed crystals and irregular single-crystal masses up to a few inches in size, although large lumps or aggregates weighing 10 pounds or more have been found. The mineral, unlike the uraninite (pitchblende) of hydrothermal veins, typically contains considerable amounts of rare earths and thorium in solid solution. Much of it alters by weathering or through the agency of late-pegmatitic hydrothermal solutions to brightly colored pseudomorphs consisting of hydrated lead uranyl oxides such as fourmarierite and vandendriesscheite with an outer zone of uranyl silicates such as uranophane and kasolite.

Uraninite is contained chiefly in the so-called granite pegmatites, derived from salic magmas, and for this discussion these pegmatites can be grouped loosely into three types. In the normal pegmatites, the principal minerals are microcline, quartz, and muscovite mica, with uraninite, zircon (usually the altered form known as cyrtolite), garnet, and allanite present as accessory constituents. Such pegmatites lack a well-defined lithium-rich phase, albite generally is subordinate, and rare-earth minerals and niobate-tantalates are scarce. Pegmatites of this general nature occur widely, in New England, the Black Hills of South Dakota, in North Carolina and elsewhere in the Appalachian region; in Ontario and Quebec in Canada; in Brazil, Norway, India, and many other places over the world.

In the second type, the so-called rare-earth pegmatites, the principal minerals again are quartz and microcline but with biotite as the principal mica. The characteristic features are the relative abundance of rare-earth minerals, including niobate-tantalates, titanates, phosphates, and silicates; fergusonite, samarskite, betafite, euxenite-polycrase, monazite, xenotime, zircon, thalenite, thorite, gadolinite, chevkinite, and allanite. Uraninite is less 
abundant than in the normal pegmatites, and the uranium contained in the pegmatite largely is present in solid solution in the rare-earth, thorium, and zirconium minerals. Pegmatites of this kind are represented at Baringer Hill, Tex., various localities in North Carolina, numerous places in southern Norway, at Ytterby in Sweden, Russia, Finland, Brazil, Western Australia, and especially in Madagascar.

A third type of uranium-bearing pegmatites can be recognized. This type is characterized by the abundance of microlite-pyrochlore containing more or less uranium in solid solution and by the development of a well-marked lithium-rich phase. Typical minerals here, in addition to quartz and feldspar, are lepidolite, columbite-tantalite, spodumene, amblygonite, topaz, triphylitelithiophilite, beryl, and abundant albite. Uraninite itself is rare. Pegmatites of this nature are represented by the Harding mine in New Mexico, and the Brown Derby mine in Gunnison County, Colo., among other localities. Descriptions of the mineralogy and petrology of some uraninite occurrences of the pegmatitic type are given by Page (1950), Rowe (1952), A. H. Lang (1952), and Ford (1955).

In its third major type of occurrence, uraninite is found in essentially flat-lying deposits in bedded sedimentary rocks, chiefly conglomerates and sandstones, that have not been materially folded or metamorphosed. Oxidized deposits of uranium and vanadium (carnotite type) have been known in the Colorado Plateau since 1898, but unoxidized deposits in which uraninite is associated with black, low-valence vanadium minerals and coffinite, or with copper minerals were first recognized in the Plateau area of Colorado, Utah, New Mexico, and Arizona in 1948-49. The sandstone-type deposits have been extensively developed, and now unoxidized as well as oxidized ores contribute a substantial part of the uranium produced in the United States. The origin of these deposits is problematic. The uranium and the associated vanadium, copper, selenium, and other heavy metals may have been leached and concentrated by meteoric waters from sedimentary rocks of the region that contain very small amounts of these elements. The deposits also may have been formed by warm ascending hydrothermal waters ultimately of igneous origin that derived their content of metals either from a deep source or from the sediments. The deposition has been localized within sedimentary rock formations at places of favorable structure, porosity, or composition. The principal ore zones are in the Salt Wash member of the Morrison formation of Jurassic age and the Shinarump member of the Chinle formation of Triassic age. The 
deposition apparently took place under strongly reducing conditions, as evidenced by the occurrence of sulfides, low-valence vanadium minerals, chiefly montroseite and roscoelite, and of carbonized wood and other vegetal matter, with the formation of compounds of quadrivalent uranium. The deposits are oxidized at or near the surface, with the formation of yellow uranyl compounds, such as carnotite and tyuyamunite, that overlie the black ores. Hewettite, metahewettite, barnesite, navajoite, rossite, metarossite, pascoite, hummerite, melanovanadite, corvusite, and other oxidized vanadium minerals occur in the vanadiferous uranium deposits. Meta-autunite, metatorbernite, schroeckingerite, becquerelite, uranophane, bayleyite, andersonite, and other uranyl compounds are present in the oxidized zone of the lowand nonvanadiferous ores. Johannite, zippeite, and uranopilite are particularly common in the oxidized zone of copper-uranium deposits that carry considerable amounts of sulfides and lack vanadium. Lead-bearing secondary uranium minerals such as kasolite, fourmarierite, vandendriesscheite, curite, parsonsite, renardite, and dumontite are very rare or are absent in the Colorado Plateau deposits, in marked contrast to their abundant occurrence in the Belgian Congo. This condition is due to the small quantity of lead-containing minerals such as galena in the unoxidized ores and to the low content of radiogenic lead in the uraninite. The uranium in the oxidized ores in the Plateau deposits occurs principally in combination with vanadium as carnotite and tyuyamunite. The uraninite in the unoxidized ores in part occurs as pseudomorphic replacements of wood and vegetal matter. It also occurs as disseminations and as cementing material between the sand grains and pebbles. The uraninite in general is fine grained. The ore bodies generally are tabular in shape and roughly parallel to the bedding of the enclosing rock; many are localized within lenticular sands or in ancient stream channels. The numerous deposits in the Morrison formation along the Uravan mineral belt (Fischer and Hilpert, 1952)-especially the deposits of Club Mesa (Fischer, 1942), Long Park, Calamity and Outlaw Mesas, Jo Dandy area, and the Slickrock district in Mesa, Montrose, and San Miguel Counties of Colorado-have been mined for many years and have had a large total production, but only since 1951 have uraninite and coffinite been recognized in these ores. Uraninite and coffinite are also present in the Jackpile mine, a large recently discovered deposit in the Morrison formation near Laguna, east of Grants, N. Mex. Important deposits in the Shinarump and other members of the Chinle include the Mi Vida mine, Big Indian Wash, near Moab (Gross; 1956), 
and at the Happy Jack mine, White Canyon (Trites and Chew, 1955; Miller, 1955), both in San Juan County, Utah; at the Delta mine on the west side of the San Rafael Swell, Emery County, Utah; and at the Monument No. 2 mine, Apache County, Ariz. Numerous other localities have been listed by Weeks and Thompson (1954), and Rosenzweig and others (1954). Descriptions of some uranium deposits of this type are given by Gruner and others (1954a), R. P. Fischer (1950), and Rosenzweig and others (1954). The general geology of the uranium deposits of the Colorado Plateau has been summarized in papers published in the Proceedings of the Geneva Congress on the Peaceful Uses of Atomic Energy (v. 6, 1956), in U. S. Geological Survey Professional Paper 300, and in geologic quadrangle maps published by the U. S. Geological Survey. In 1955 several hundred mines were being worked or were under development on the Colorado Plateau.

Many other types of occurrence have been observed for uraninite, but only a few are mentioned here. At Rum Jungle, in the Northern Territory, Australia, fine-grained uraninite is disseminated in a crushed and fractured zone of a highly folded slate. It is associated with copper minerals, and extensive leaching and oxidation have taken place near the surafce. The uraninite is too fine grained to be observed by the unaided eye, and it can be detected only by radioactivity-detection or chemical methods. Descriptions of the deposit are given by Stillwell (1952), Sullivan and Matheson (1952), and Fisher and Sullivan (1954). Uraninite also occurs in the Todilto limestone in the Grants district of New Mexico, associated with carnotite, tyuyamunite, uranophane, calcite, fluorite, and carbonaceous matter. Uraninite occurs in small amounts in sheared and fractured silicified zones in rhyolitic flow rocks in the southwestern United States. It is associated with calcite, fluorite, quartz, and galena and other sulfides.

In the Blind River area in Ontario, Canada, about 60 miles east of Sault St. Marie, uranium occurs as uraninite and brannerite in extensive pyritic conglomerate beds of Precambrian age. The origin of the deposit is uncertain; it may be detrital, but there is evidence of hydrothermal action and the problem is very similar to that of the origin of deposits in the Rand conglomerates. The gold-bearing conglomerates of the Witwatersrand in the Transvaal and Orange Free State, Africa, carry small amounts of uranium. The deposits are of great importance as a source of uranium, as this element can be recovered as a byproduct of the gold production and the ores extend over a very large area. The gold and uraninite, together with pyrite and carbonaceous 
material, occur as thin seams and as detrital grains in a hard, cemented quartz pebble conglomerate and only rarely can be seen by the unaided eye. The origin of the deposits is in dispute. One view holds that they are old placers, perhaps with some minor local rearrangement by reheated, essentially connate waters, and another view holds that the deposits are hydrothermal with the metallic constituents introduced and deposited in favorable horizons in the sedimentary series. Discussions of the origin are given by Graton (1930), Davidson and Bowie (1951), Davidson (1953, 1955), Miholič (1954), Louw (1955), and Ramdohr (1955). Uraninite is very rarely found in modern placer deposits. An occurrence in black sand in British Columbia is mentioned by Steacy (1953). At Azegour, Morocco, uraninite occurs in tactite with molybdenite, hematite, and garnet and in fractures in this rock with pyrite, chalcopyrite, hematite, carbonates, and barite (Permingeat, 1952): Also found in the Kupferschiefer at Mansfeld, Germany (Kohl, 1941).

\section{Synonymy}

\section{THORIANITE}

"Uraninite" Coomaraswamy (1904). Thorianite Dunstan (1904) ; Dunstan and Blake (1905); Dunstan and Jones (1906); Büchner (1906). Alpha-, beta-, and gamma-thorianite Kobayashi (1912). Uranothorianite Wells, Fairchild, and Ross (1933). Aldanite Bespalov (1941).

Named in allusion to the composition. The Ceylon mineral, originally identified as uraninite by Coomaraswamy, was first recognized as a new species by Dunstan (1904). Thorianite and uraninite form a complete solid-solution series. The two species are here described separately, rather than as a single series, as a matter of convenience. The names thorianite and uraninite are restricted to the halves of the series with $\mathrm{Th}>\mathrm{U}$ and $\mathrm{U}>\mathrm{Th}$, respectively, in atomic percent.

\section{Composition}

Selected analyses of thorianite, $\mathrm{ThO}_{2}$, are given in the table below. Additional analyses are listed by Hintze (1907) and Doelter (1918), and partial analyses of Canadian material are given in the tables on pages 29 and 30. Hecht and Kroupa (1936) give a partial analysis of Ceylon material with $\mathrm{Pb} 2.19, \mathrm{U}$ 9.04, Th 36.52 percent, and a partial analysis of Ceylon material is given by Nag-Chowdhury and Mousuf (1946). The name aldanite has been given to a variety of thorianite containing 14.9 to 29.0 percent $\mathrm{UO}_{3}$ and 11.2 to 12.5 percent $\mathrm{PbO}$ (Bespalov, 1941). Uranium apparently is always present in considerable amounts in substitution for thorium. A complete solid-solution series exists 
Chemical analyses of thorianite, in weight percent

\begin{tabular}{|c|c|c|c|c|c|}
\hline & 1 & 2 & 3 & 4 & 5 \\
\hline $\begin{array}{l}\mathrm{CaO} \\
\mathrm{PbO}\end{array}$ & $\begin{array}{l}0.97 \\
5.21\end{array}$ & $1 \overline{80}$ & $2 . \overline{87}$ & $\begin{array}{l}0.59 \\
2.29 \\
\end{array}$ & $2 . \overline{25}$ \\
\hline $\begin{array}{l}\mathrm{CeO}_{2} \\
(\mathrm{Ce}, \mathrm{La})_{2} \mathrm{O}_{3}\end{array}$ & $2 \overline{49}$ & 二 & 8.04 & $\sqrt{84}$ & 6.90 \\
\hline $\mathrm{Fe}_{2} \mathrm{O}_{3}$ & $\begin{array}{l}1.57 \\
4.44\end{array}$ & $\begin{array}{r}. \overline{29} \\
473\end{array}$ & .35 & $\begin{array}{r}1.04 \\
1.11\end{array}$ & 1.92 \\
\hline $\mathrm{U}_{3} \mathrm{O}_{8}$ & & 0.10 & 12.33 & 10.02 & - \\
\hline $\mathrm{UO}_{3}$ & 33.15 & - & & 18.88 & - \\
\hline $\mathrm{ThO}_{2}$ & 38.47 & 93.02 & 76.22 & 62.16 & 72.24 \\
\hline $\mathrm{H}_{2} \mathrm{O}$ & 4.39 & 一 & $\overline{10}$ & 1.05 & $5 \overline{0}$ \\
\hline Rem. & 8.70 & - & .12 & .77 & 5.43 \\
\hline Total & 99.39 & 99.84 & 99.93 & 99.01 & 99.93 \\
\hline \multirow[t]{2}{*}{ Sp gr } & 6.68 & 9.33 & 9.5 & - & 一 \\
\hline & 6 & 7 & 8 & 9 & 10 \\
\hline $\mathrm{CaO}$ & 0.170 & $\overline{00}$ & $\overline{c 0}$ & 0.13 & 0.42 \\
\hline $\mathrm{PbO}$ & 2.867 & 3.80 & 2.66 & 2.42 & 3.99 \\
\hline$(\mathrm{Ce}, \mathrm{La})_{2} \mathrm{O}_{3}$ & 0.285 & 1.05 & 1.41 & 1.96 & - \\
\hline $\mathrm{Fe}_{2} \mathrm{O}_{3}$ & 3.480 & 1.83 & 1.54 & 2.05 & - \\
\hline $\mathrm{U}_{3} \mathrm{O}_{8}$ & 23.470 & 33.27 & 14.54 & 13.12 & 27.94 \\
\hline $\mathrm{UO}_{3}$ & & & & & \\
\hline $\mathrm{ThO}_{2}$ & 65.370 & 68.37 & 78.00 & 70.96 & 64.61 \\
\hline $\begin{array}{l}\mathrm{H}_{2} \mathrm{O} \\
\mathrm{Rem} \text {. }\end{array}$ & $\begin{array}{r}.600 \\
3.424\end{array}$ & 2.01 & 2.04 & 1.50 & $\begin{array}{r}.14 \\
2.18\end{array}$ \\
\hline Total & 99.671 & 100.33 & 100.19 & - & 99.28 \\
\hline Sp gr & - & 9.245 & 9.073 & - & - \\
\hline
\end{tabular}

1. Thorianite. Easton, Pa. Fairchild, analyst, in Wells, Fairchild, and Ross (1933). Remainder is $\mathrm{MnO} 0.31, \mathrm{MgO} 0.53$, insoluble 7.86 .

2. Thorianite. Betroka, Madagascar. Pisani, analyst, in Lacroix (1922).

3. Thorianite. Ceylon. Dunstan and Blake (1905). Remainder is insoluble.

4. Thorianite. Galle district, Ceylon. Dunstan and Jones (1906). Remainder is insoluble. Additional analyses are cited of samples from different parts of the same crystal.

5. Thorianite. Ceylon. Dunstan and Blake (1905). Remainder is $\mathrm{ZrO}_{2}$ 3.68, $\mathrm{SiO}_{2} 1.34$, insoluble 0.41 .

6. Thorianite. Ceylon. Jakob and Tolloczko (1911). Remainder is $\mathrm{SiO}_{2}$ 0.250 , insoluble $0.150, \mathrm{Bi}_{2} \mathrm{O}_{3}(?) \quad 0.003, \mathrm{CuO} 0.008, \mathrm{Y}_{2} \mathrm{O}_{3} \quad 0.030, \mathrm{Al}_{2} \mathrm{O}_{3} 0.260$, $\mathrm{TiO}_{2} 1.295, \mathrm{ZrO}_{2} 0.920$, RhO (?) $0.008, \mathrm{CO}_{2} 0.275$, $\mathrm{He} 0.225$.

7. Thorianite. Ceylon. Kobayashi (1912). Remainder is $\mathrm{Sc}_{2} \mathrm{O}_{3} 0.12, \mathrm{CuO}$ $0.02, \mathrm{SiO}_{2} 0.20, \mathrm{TiO}_{2} 0.88, \mathrm{ZrO}_{2} 0.15, \mathrm{Al}_{2} \mathrm{O}_{3} 0.03, \mathrm{MnO}$ trace, ignition loss 0.61 . Another very similar analysis also is cited.

8. Thorianite. Ceylon. Kobayashi (1912). Remainder is $\mathrm{Sc}_{2} \mathrm{O}_{3} 0.46, \mathrm{CuO}$ $0.02, \mathrm{SiO}_{2} 0.20, \mathrm{ZrO}_{2} 0.09, \mathrm{Al}_{2} \mathrm{O}_{3} \quad 0.15$, ignition loss 1.12 .

9. Thorianite. Ceylon. Büchner (1906). Remainder is $\mathrm{HgO}$ trace, $\mathrm{CuO} 0.08$, $\mathrm{SnO}_{2}$ 0.05, $\mathrm{Sb}_{2} \mathrm{O}_{4} 0.11, \mathrm{Bi}_{2} \mathrm{O}_{3}$ (?) $0.21, \mathrm{As}_{2} \mathrm{O}_{3}$ (?) trace, CdO trace, $\mathrm{Al}_{2} \mathrm{O}_{3} 0.15$, $\mathrm{ZrO}_{2}$ 0.23. The analysis represents acid-soluble material; a separate analysis of the acid-insoluble portion gave: $\mathrm{HgO}$ trace, $\mathrm{Bi}_{2} \mathrm{O}_{3}($ ?) 0.15 , CdO (?) trace, $\mathrm{Fe}_{2} \mathrm{O}_{3} 1.30, \mathrm{Al}_{2} \mathrm{O}_{3} 0.06, \mathrm{U}_{3} \mathrm{O}_{8} 0.02, \mathrm{ZrO}_{2}$ trace, $\mathrm{TiO}_{2} 0.45$, unknown substance $0.04, \mathrm{P}_{2} \mathrm{O}_{5}$ trace, $\mathrm{CO}_{2} 0.10, \mathrm{He} 0.15, \mathrm{H}_{2} \mathrm{O} 3.20$ (total 98.84).

10. Thorianite. Ceylon. Hecht (1933). Remainder is insoluble 0.15, $\mathrm{SnO}_{2}(?)$ 0.31 , rare earths $0.031,(\mathrm{Fe}, \mathrm{Al})_{2} \mathrm{O}_{3} \quad 0.80, \mathrm{TiO}_{2} \quad 0.33, \mathrm{ZrO}_{2} 0.56 . \mathrm{H}_{2} \mathrm{O}$ includes loss $110^{\circ}-300^{\circ} \mathrm{C} 0.04$, loss $300^{\circ}-1,000^{\circ} \mathrm{C} 0.10$. 
between $\mathrm{ThO}_{2}$ and $\mathrm{UO}_{2}$ in synthetic material (Hillebrand, 1893; Lambertson and others, 1953; Magneli and Kihlborg, 1951) and also in natural material. Material containing more or less equal amounts of thorium and uranium, however, is rare. The $U$ is reported by the analysts as $U^{+6}$ in part or entirety, but it probably was originally present in the crystals as $\mathrm{U}^{+4}$. A similar partial oxidation of the $\mathrm{U}^{+4}$ to $\mathrm{U}^{+6}$ due to alteration is well known in uraninite. Lead is always present, usually in amounts of several percent, and presumably is radiogenic. Rare earths, chiefly $\mathrm{Ce}$, substitute for $T h$ in amounts up to about 8 weight percent $(\mathrm{Ce}, \mathrm{La})_{2} \mathrm{O}_{3}$ (analysis 3). The Ce probably is present as $\mathrm{Ce}^{+4}$, and complete series are known in synthetic material between $\mathrm{CeO}_{2}$ $\mathrm{PrO}_{2}-\mathrm{ThO}_{2}-\mathrm{UO}_{2}$ (Magneli and Kihlborg, 1951). Zirconium is reported in some analyses and doubtless substitutes for Th, as it is known that a partial series extends between $\mathrm{ThO}_{2}$ and isometric $\mathrm{ZrO}_{2}$ in synthetic material (Ruff and others, 1929). The role of the $\mathrm{Fe}^{+3}$ reported in the analyses is uncertain. The $\mathrm{H}_{2} \mathrm{O}$ reported undoubtedly is secondary. Kobayashi (1912) has distinguished three types of thorianite, called $\alpha^{-}, \beta-$, and $\gamma$-thorianite, that differ in color, specific gravity, and composition but probably chiefly in degree of alteration. Wasserstein (1954) has suggested that thorianite has the composition $\mathrm{Th}_{4} \mathrm{O}_{7}$, analogous to the known compound $\mathrm{Th}_{4} \mathrm{~S}_{7}$. Gas, principally $\mathrm{He}$, is evolved when the mineral is dissolved in acids; Strutt (1905) found $8.9 \mathrm{cc} \mathrm{He} \mathrm{per} \mathrm{g}$ of mineral (analysis 6). Dunstan and Blake (1905) found $10.5 \mathrm{cc}$ of gas, chiefly $\mathrm{He}$, in $\mathbf{1} \mathbf{g}$ of thorianite.

Brauer and Gradinger (1951) discuss the solid solubility between $\mathrm{ThO}_{2}$ and $\mathrm{Y}_{2} \mathrm{O}_{3}, \mathrm{La}_{2} \mathrm{O}_{3}, \mathrm{Nd}_{2} \mathrm{O}_{3}, \mathrm{Sm}_{2} \mathrm{O}_{3}$ and $\mathrm{Gd}_{2} \mathrm{O}_{3}$. Data on the systems $\mathrm{ThO}_{2}-\mathrm{TiO}_{2}-\mathrm{CaO}, \mathrm{ThO}_{2}-\mathrm{ZrO}_{2}-\mathrm{TiO}_{2}$, and $\mathrm{ThO}_{2}-\mathrm{La}_{2} \mathrm{O}_{3}-\mathrm{TiO}_{2}$ are given by Rath (1951), and on the system $\mathrm{ThO}_{2}-\mathrm{MgO}-\mathrm{BeO}$ by Lang and others (1949).

Thorianite is infusible before the blowpipe, and at high temperatures emits a strong white glow, due to the Ce. Melting point is $3,300^{\circ} \pm 100^{\circ} \mathrm{C}$. Insoluble in $\mathrm{HCl}$, but soluble in $\mathrm{HNO}_{3}$ or $\mathrm{H}_{2} \mathrm{SO}_{4}$.

crystallography and crystal habit

Isometric, in the hexoctahedral crystal class $(4 / m \overline{3} 2 / m)$. Found as embedded grains or rough crystals, and as rounded water-worn crystals in alluvial deposits. The crystals usually are simple cubes; sometimes modified by $\{111\}$ or $\{113\}$ as on Madagascar crystals described by Lacroix (1922) (fig. 2). The form $\{011\}$ has been observed on synthetic crystals. Interpenetration twins on $\{111\}$ are very common (fig. 2), much more so than in the isostructural species uraninite. 


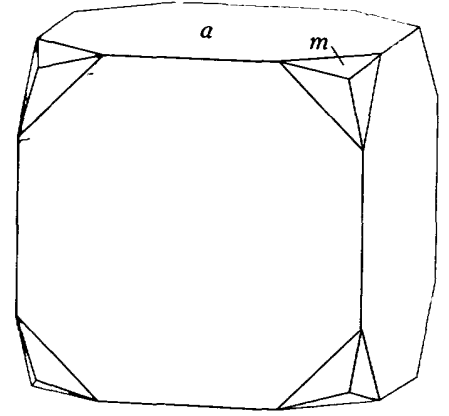

$A$

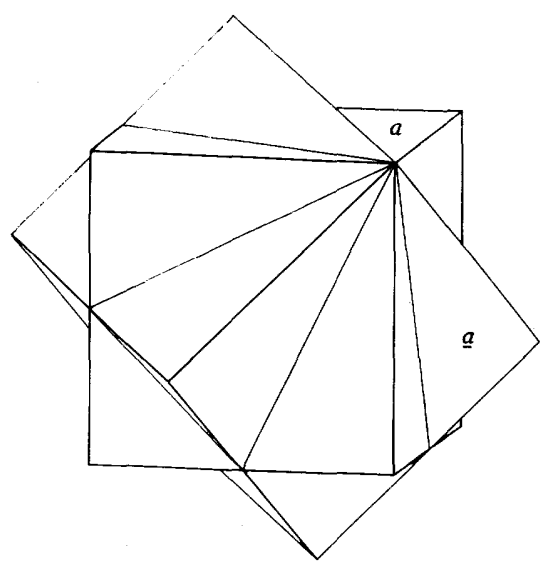

$B$

FIGURE 2.-Thorianite. $A$. Forms: $a\{100\}$ and $m\{113\} . B$. Interpenetration twin on (111).

The isostructural relation of thorianite to uraninite was first established by Goldschmidt and Thomassen (1923). Space group $F m 3 m$. Unit cell contents $4\left[\mathrm{ThO}_{2}\right]$. The unit-cell dimensions of synthetic $\mathrm{ThO}_{2}$ and of natural thorianite are cited in the following table. (See also corresponding tables under Uraninite.)

Unit-cell dimensions, $a_{0}$, of synthetic $\mathrm{ThO}_{2}$ and natural thorianite 1

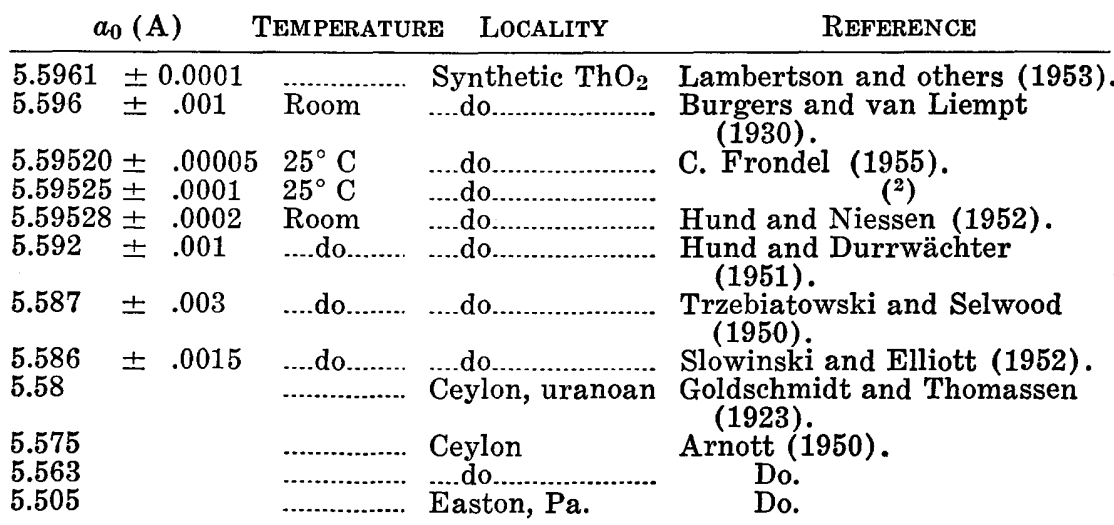

${ }^{1}$ Near $25^{\circ} \mathrm{C}$, the unit-cell edge, $a_{0}$, of pure $\mathrm{ThO}_{2}$ increases $0.00004 \mathrm{~A}$ per degree $\mathrm{C}$ increase in temperature (Skinner, 1955).

${ }_{2}^{2}$. Skinner, Harvard University. Written communication (1955).

The cell dimension increases linearly in the series from $\mathrm{UO}_{2}$ $\left(a_{0} 5.468 \mathrm{~A}\right)$ to $\mathrm{ThO}_{2}\left(a_{0} 5.595 \mathrm{~A}\right)$ in synthetic material. In natural material the relation is complicated by the presence of other elements in solid solution, particularly rare earths and radiogenic lead. Oxidation of original $\mathrm{U}^{+4}$ to $\mathrm{U}^{+6}$ and radiation damage are added factors. Study of natural members of the series by 
Robinson and Sabina (1955) has shown that $a_{0}$ decreases and the variation in $a_{0}$ with the $\mathrm{U}: \mathrm{Th}$ ratio becomes more nearly linear after the samples have been heated in air for 10 minutes at $1,000^{\circ} \mathrm{C}$ (see table on p. 30). A study has been made by Anderson and others (1954) of the effect of oxidation on synthetic members of the series $\left(\mathrm{U}_{1-\mathrm{x}} \mathrm{Th}_{\mathrm{x}}\right) \mathrm{O}_{2}$. In material with $\mathrm{x}>0.5$, conversion of $\mathrm{U}^{+4}$ to $\mathrm{U}^{+6}$ is accompanied by entrance of compensating oxygen into interstitial positions up to a limit of 1.4 oxygen atoms per cell. In material with $\mathrm{x}<0.5$, the concentration of interstitial oxygen comes to a reversible equilibrium with the ambient oxygen pressure at high temperatures; the cell edge $a_{0}$ contracts as the average valence of the uranium ions increases from 4.0 to 5.0, and expands as the average valence increases from 5.0 to 5.5. Data on the adsorption of oxygen by members of the series $(\mathrm{U}, \mathrm{Th}) \mathrm{O}_{2}$ are given by L. E. J. Roberts (1954).

\section{Physical properties}

Cleavage $\{001\}$ poor. Fracture uneven to conchoidal. Brittle. Hardness $61 / 2-7$ in unaltered material. Specific gravity 9.7-9.8; 10.0 calculated for $a_{0} 5.596 \mathrm{~A}$. The specific gravity and hardness decrease with increasing alteration. There is an essentially linear variation in specific gravity with substitution of $U$ for $T h$ up to 10.9 for $\mathrm{UO}_{2}$, but the variation in natural material in both minerals is obscured by the presence of rare earths and other elements in solid solution and by alteration. Luster submetallic when fresh, changing to resinous or hornlike. Color black and brownish black to dark reddish brown and dark gray, sometimes with a bronzy tarnish. Streak gray to greenish gray. Pure synthetic $\mathrm{ThO}_{2}$ is white or pale yellowish white. Opaque. Diamagnetic. Data on the absorption spectra and electrical conductivities of $\mathrm{UO}_{2}-\mathrm{ThO}_{2}$ solid solutions are given by Gruen (1954). Not fluorescent. Not metamict.

optical properties

In transmitted light, dark brown, reddish brown, or greenish. Isotropic, with $n$ variable, 2.2-2.35 (Larsen, 1921). Sometimes shows weak anomalous birefringence.

Thermal behavior

Up to $1,000^{\circ} \mathrm{C}, \mathrm{ThO}_{2}$ does not show thermal anomalies. Synthesis

Obtained as a finely divided powder by ignition of thorium hydroxide or of thorium nitrate or other salts of volatile oxyacids. As crystals by fusing the precipitated or powdered oxide with borax or potassium orthophosphate, by fusion with a mixture of sodium fluoride and sodium carbonate, and in other ways (Mellor, 1927; Gmelin, 1928). 
Identification

Thorianite very closely resembles uraninite, from which it can be distinguished by chemical tests or analysis to determine the ratio of $T h$ and $U$. Thorianite is less readily soluble in acids and harder than uraninite. The X-ray powder-diffraction pattern closely resembles that of uraninite and cerianite but thorianite has different cell dimensions and the spacings are distinctive for samples relatively low in $U$; the spacing data are given in the following table. There is a less close resemblance of thorianite to the uranoan varieties of pyrochlore-microlite and to betafite, thorite, huttonite, and dark zircon. There also is possibility of confusion with baddeleyite and dark varieties of rutile; these have lower specific gravity, lack $U$ and $T h$, and have different X-ray patterns.

\section{$X$-ray powder-spacing data for thorianite ${ }^{1}$}

[Copper radiation; nickel filter]

\begin{tabular}{|c|c|c|c|c|c|}
\hline$d(\mathrm{~A})$ & $I$ & $h k l$ & $d(\mathrm{~A})$ & $I$ & $h k l$ \\
\hline $\begin{array}{l}3.21 \\
2.78 \\
1.971 \\
1.682 \\
1.611 \\
1.396 \\
1.280 \\
1.248 \\
1.141 \\
1.076\end{array}$ & $\begin{array}{r}10 \\
4 \\
8 \\
9 \\
2 \\
2 \\
2 \\
4 \\
4 \\
4 \\
4\end{array}$ & $\begin{array}{l}111 \\
200 \\
220 \\
311 \\
222 \\
400 \\
331 \\
420 \\
422 \\
511,333\end{array}$ & $\begin{array}{r}0.988 \\
.945 \\
.932 \\
.884 \\
.853 \\
.844 \\
.808 \\
.784 \\
.776\end{array}$ & $\begin{array}{l}3 \\
6 \\
3 \\
4 \\
3 \\
3 \\
3 \\
2 \\
7 \\
8\end{array}$ & $\begin{array}{l}440 \\
531 \\
600,442 \\
620 \\
533 \\
622 \\
\mathbf{4 4 4}\end{array}$ \\
\hline
\end{tabular}

${ }^{1}$ Data on pure synthetic $\mathrm{ThO}_{2}$ with $a_{0}=5.59 \mathrm{~A}$. The unit-cell edge of natural thorianite varies from at least 5.50 to $5.58 \mathrm{~A}$ owing to substitution of uranium and other elements for thorium, and the spacings vary accordingly. See further under Uraninite.

\section{Natural formation and occurrence}

Thorianite is a primary mineral found chiefly in pegmatites. It is best known as a detrital mineral and probably is widespread in small amounts but is hard to identify. Originally found associated with thorite, zircon, ilmenite, cassiterite, allanite, and other heavy minerals in stream gravels at many localities in Ceylon, notably in the Galle district, Southern Province, in the Balangoda district and near Kondrugala in Sabaragamuwa Province. The mineral has been derived from pegmatites and has been found in place in disintegrated pegmatite in the Bambarabotuwa area. Nine tons of thorianite are said to have been exported from Ceylon in the years 1904-10. Found in alluvial deposits in Madagascar at Betroka and Andolobe (Lacroix, 1922), in Travancore (Viswanathan, 1953), and in the black sands of a gold placer on the Boshogoch River, Transbaikalia, Siberia, U.S.S.R. Occurs in the United States at Easton, Pa., in serpentine formed by the alteration of 
magnesium silicates at the contact of limestone with pegmatite. The mineral occurs there as irregular grains and cubic or cubooctahedral crystals up to about 1 inch in size, and alters to thorogummite, uranophane, and unidentified substances (Wells, Fairchild, and Ross, 1933). Thorianite also has been found in black sands in the Missouri River near Helena, Mont., and the Scott River, Siskiyou County, Calif. (George, 1949), and in black sands in the Nixon Fork and Wiseman districts, Alaska (M. G. White, 1952; White and Stevens, 1953). Reported as an accessory mineral in granite in the Belgian Congo (Ledoux, 1913); also reported with uraninite in pegmatite on Charlebois Lake east of Lake Athabaska, Saskatchewan, Canada (A. H. Lang, 1952). Uranoan varieties of thorianite are described by Robinson and Sabina (1955) from pegmatites, calcite-fluorite-apatite veins transitional to pegmatites, and metasomatized zones in crystalline limestones from many localities in Quebec and Ontario. (See table on page 30, under Uraninite.) Thorianite occurs with baddeleyite as an accessory mineral in a carbonatite at Phalabora, eastern Transvaal (Hiemstra, 1955).

Synonymy

CERIANITE

Cerianite Graham (1955). Named in allusion to the composition, analogous to thorianite and uraninite.

\section{Composition}

Cerium dioxide, $\mathrm{CeO}_{2}$. A semiquantitative spectrographic analysis (see below) by W. O. Taylor (Graham, 1955) on $2 \mathrm{mg}$ of material from the only known occurrence, taken in conjunction with X-ray powder-diffraction study, has established the identity of the mineral with the well-known synthetic compound $\mathrm{CeO}_{2}$.

\begin{tabular}{|c|c|}
\hline & Weight percent \\
\hline $\begin{array}{l}\mathrm{CeO}_{2} \\
\mathrm{ThO}_{2} \\
\mathrm{Nb}_{2} \mathrm{O}_{5} \\
\mathrm{La}_{2} \mathrm{O}_{3} \\
\mathrm{Y}_{2} \mathrm{O}_{3}\end{array}$ & $\begin{array}{l}80 \pm 20 \\
5.1 \pm 5 \\
1.8 \pm \quad .2 \\
1.5 \pm .2 \\
1.2 \pm .2\end{array}$ \\
\hline
\end{tabular}

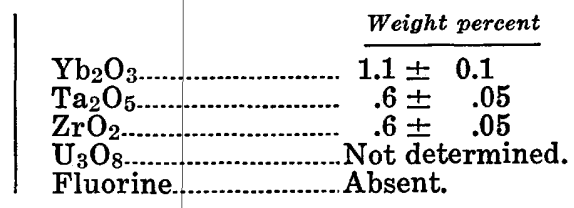

The relatively large unit-cell dimension observed in the natural material is due to the presence of Th in solid solution.

In synthetic material, $\mathrm{CeO}_{2}$ has been found to form complete solid-solution series with $\mathrm{ThO}_{2}$ and $\mathrm{UO}_{2}$ and partial series with $\mathrm{Y}_{2} \mathrm{O}_{3}, \mathrm{In}_{2} \mathrm{O}_{3}$, and $\mathrm{ZrO}_{2}$ (Padurow and Schusterius, 1953; Rüdorff and Valet, 1952; Duwez and Odell, 1950). Synthetic $\mathrm{CeO}_{2}$ also can accommodate a small amount of $\mathrm{Ce}^{+3}$ in solid solution, valence compensation being effected by omissions in the oxygen positions (Bruno, 1950; Courtel and Loriers, 1950). Ce often is present in small amounts in uraninite from pegmatites and in thorianite; 
it also substitutes for uranium and thorium in thorite and thorogummite.

\section{Crystallography}

Cerianite is isometric, in the hexoctahedral class $(4 / m \overline{3} 2 / m)$. Natural crystals are octahedral in habit.

Cerium dioxide, $\mathrm{UO}_{2}$, and $\mathrm{ThO}_{2}$ all are isostructural with fluorite, $\mathrm{CaF}_{2}$. The crystal structure was first established by Goldschmidt and Thomassen (1923). Space group $F m 3 m$. Unit-cell contents $4\left[\mathrm{CeO}_{2}\right]$. Unit-cell dimensions follow.

\section{Unit-cell dimensions of cerianite}

\begin{tabular}{|c|c|c|}
\hline$a_{0}(\mathrm{~A})$ & LOCALITY & REFERENCE \\
\hline $\begin{array}{l}.42 \pm 0.01 \\
5.397 \\
5.397 \\
5.399 \pm .002 \\
5.40 \\
5.411 \\
5.416\end{array}$ & 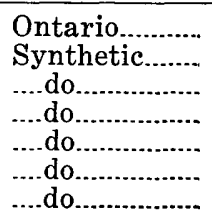 & $\begin{array}{l}\text { Graham (1955). } \\
\text { Zachariasen (1948). } \\
\text { Bruno (1950). } \\
\text { Duwez and Odell (1950). } \\
\text { Padurow and Schusterius (1953). } \\
\text { Courtel and Loriers (1950). } \\
\text { Passerini (1930). }\end{array}$ \\
\hline
\end{tabular}

Physical properties

No data on the cleavage, hardness, and specific gravity. The calculated specific gravity for synthetic $\mathrm{CeO}_{2}$ with $a_{0} 5.416 \mathrm{~A}$ is 7.195. Color of natural material dark greenish amber; pure synthetic $\mathrm{CeO}_{2}$ is white or yellowish. Translucent. No optical data, presumably isotropic with $n>2$.

\section{Synthesis}

Obtained as a powder by ignition in air of ceric nitrate or other salts; under reducing or neutral conditions $\mathrm{Ce}_{2} \mathrm{O}_{3}$ or $\mathrm{CeO}_{2}$ containing $\mathrm{Ce}^{+3}$ in solid solution may be formed. Crystals have been obtained by fusing $\mathrm{CeO}_{2}$ in borax, sodium chloride, or potassium acid sulfate, and by fusing the anhydrous chloride with borax.

\section{Identification}

Cerianite resembles microlite-pyrochlore and thorianite in the hand specimen. The X-ray powder-diffraction pattern is similar to that of thorianite and uraninite. The cell dimension of pure $\mathrm{CeO}_{2}\left(a_{0} 5.40 \mathrm{~A}\right)$ is considerably smaller than that of pure $\mathrm{ThO}_{2}$ $\left(a_{0} 5.59 \mathrm{~A}\right)$ and that of essentially stoichiometric $\mathrm{UO}_{2}\left(a_{0} 5.46 \mathrm{~A}\right)$. The value for $\mathrm{CeO}_{2}$ is overlapped, however, by oxidized uraninites, which extend from 5.46 A down to at least 5.36 A. Further, because a series can extend from $\mathrm{CeO}_{2}$ to $\mathrm{ThO}_{2}$, with accompanying increase in cell dimensions, a positive distinction of thorian cerianite cannot be made from uraninite, thorian uraninite, or uranoan thorianite by $\mathrm{X}$-ray means alone. X-ray powder-spacing data for synthetic $\mathrm{CeO}_{2}$ are given in the following table. 
$X$-ray powder-spacing data for cerianite ${ }^{1}$

[Copper radiation, nickel filter]

\begin{tabular}{|c|c|c|c|c|c|}
\hline$d(\mathrm{~A})$ & $I$ & $h k l$ & $d(\mathrm{~A})$ & $I$ & $h k l$ \\
\hline $\begin{array}{l}3.124 \\
2.706 \\
1.913 \\
1.632 \\
1.562 \\
1.353 \\
1.241 \\
1.210\end{array}$ & $\begin{array}{r}100 \\
29 \\
51 \\
44 \\
5 \\
5 \\
15 \\
6\end{array}$ & $\begin{array}{l}111 \\
200 \\
220 \\
311 \\
222 \\
400 \\
331 \\
420\end{array}$ & $\begin{array}{r}1.1044 \\
1.0412 \\
.9565 \\
.9146 \\
.9018 \\
.8556 \\
.8251 \\
8158\end{array}$ & $\begin{array}{r}12 \\
9 \\
\cdot \quad 5 \\
13 \\
7 \\
7 \\
6 \\
5\end{array}$ & $\begin{array}{l}422 \\
511 \\
440 \\
531 \\
600 \\
620 \\
533 \\
622\end{array}$ \\
\hline
\end{tabular}

1 Data from ASTM card file. Synthetic $\mathrm{CeO}_{2}$, with $a_{0}=5.411 \mathrm{~A}$.

Natural formation and occurrence

Cerianite is found very sparingly as minute crystals in Lackner Township, Sudbury mining district, Ontario. The cerianite occurs in pod-shaped inclusions in a dikelike zone of impure sugary carbonate rock cutting a hybrid nepheline gneiss. The inclusions, apparently partly absorbed fragments of wall rock, contain feldspar, nepheline, carbonate, tremolite, magnetite, ilmenite, and apatite.

\section{GUMMITE}

Gummite is a vague term that has been used in a generic sense to designate fine-grained, dense to gumlike uranium minerals, usually alteration products of uraninite, whose true identity is unknown. In this usage gummite is analogous to limonite and wad. The term found its widest use in the days before the development of X-ray diffraction and other specialized techniques suited to the study of fine-grained aggregates. It is now usually possible to identify or characterize the specific mineral species present in what has been termed gummite.

Most of the material hitherto designated as gummite comprised pseudomorphic alteration products of uraninite. Gummite typically occurs as an alteration product of uraninite in pegmatites. When a partly altered uraninite crystal is broken across, one finds in the ideal case: (a) A veined or embayed central core of uraninite. The color may be black or, in relatively highly oxidized material, greenish black, brownish black, or deep brown. (b) A surrounding zone of orange red, orange, or yellow material that constituted the traditional gummite. This material is dense in structure, although usually microscopically crystalline, and ranges from vitreous or gumlike to dull and earthy in appearance. It consists chiefly of hydrated uranyl oxides, often containing large amounts of essential lead. The commonest mineral constituents are fourmarierite and vandendriesscheite, but clarkeite, becquerelite, schoepite, and several unidentified minerals have been found. 
Several minerals commonly are present in intimate admixture. (c) An outer zone of uranyl silicates. This zone generally is hard, dense, and microcrystalline with a greenish-yellow color and vitreous luster, but may be soft and earthy with a straw-yellow to yellowish-brown color and dull luster. The silicate zone grades into the hydrated oxide zone, from which it has been derived, and it also veins both the hydrated oxide zone and the inner core. The principal minerals of this zone are uranophane, beta-uranophane, and kasolite, but soddyite, sklodowskite, and unidentified minerals also occur.

The above sequence may vary considerably in detail. Thus, the original uraninite may be completely oxidized leaving a pseudomorph of orange gummite, with a more or less thick rind of uranyl silicate, or the pseudomorph may consist largely or entirely of uranyl silicate. The uranyl carbonate rutherfordine has been observed as the outermost zone in some specimens, usually more or less admixed with uranyl silicates.

Chemically, the formation of the minerals of the gummite zone at the expense of the original uraninite is characterized by the oxidation of $\mathrm{U}^{+4}$ to $\mathrm{U}^{+6}$ and by hydration. The lead in the minerals of this zone is the original radiogenic lead of the uraninite. There is usually little or no addition of material other than $\mathrm{H}_{2} \mathrm{O}$ at this stage, but leaching of uranium relative to lead may take place. The alteration apparently takes place in the zone of weathering. Clarkeite, which contains sodium and calcium as essential constituents, may have formed by hydrothermal alteration of uraninite. The silicates of the outermost zone are formed by reaction of the hydrated oxides of the gummite zone with meteoric waters carrying silicon and usually also calcium. The thorium and rare earths contained in the original uraninite usually are wholly removed during the formation of the silicates. The lead usually is removed, but it may be retained in part or entirety.

A review of the history of the term gummite together with a description of the mineral composition of many specimens of the traditional gummite has been given by C. Frondel (1956b).

\section{Synonymy}

\section{IANTHINITE}

Ianthinite Schoep (1926a, 1927a, b). Ianthite. Named from ıav $\theta$ vos violet, in allusion to the color of the mineral.

\section{Composition}

A hydrated oxide of uranium, of uncertain formula. The uranium is considered to be in the quadrivalent state from the 
qualitative chemical tests of Schoep (1927a) on Katanga material. This idea is consistent with the violet-black color of the mineral and with the readiness with which it turns yellow (oxidizes) on exposure. The presence of quadrivalent uranium also was established by Branche and others (1951) in material from France. A partial microanalysis, in percent, by Schoep (1927a) gave: $\mathrm{U}_{3} \mathrm{O}_{8}$ [82.90], $\mathrm{Fe}_{2} \mathrm{O}_{3} 1.25$, ignition loss 15.85 , total [100.00]. This corresponds approximately to $2 \mathrm{UO}_{2} \cdot 7 \mathrm{H}_{2} \mathrm{O}$. No spectrographic analyses. Infusible.

Bignand (1955) has described a violet synthetic oxide with the composition $\mathrm{UO}_{2.84} \cdot n \mathrm{H}_{2} \mathrm{O}\left(\mathrm{U}^{+4}: \mathrm{U}^{+6}=1: 4.9\right)$, that has an X-ray powder pattern identical with that of a violet natural hydrated uranous oxide from Bois Noirs, Puy-de-Dôme, France. This substance probably is identical with the original ianthinite of Schoep from Katanga, but proof is lacking and, in view of the readiness with which the natural mineral oxidizes, will be difficult to obtain. The material of Bignand may be slightly oxidized $\mathrm{U}_{3} \mathrm{O}_{8} \cdot 2 \mathrm{H}_{2} \mathrm{O}$, already known, with $\mathrm{UO}_{2} \cdot 2 \mathrm{H}_{2} \mathrm{O}$, as a synthetic compound (Katz and Rabinowitch, 1951). A violet hydrated carbonate of $\mathrm{Ca}, \mathrm{U}^{+4}$, and $\mathrm{U}^{+6}$ to which the name ianthinite also has been applied is described on page 128.

\section{Crystallography}

Orthorhombic, crystal class not known. The crystals commonly are very small plates or laths flattened on $\{001\}$ and elongated along the $b$-axis. Also thick tabular on $\{001\}$, or short prismatic along the $b$-axis. An angle table for the known forms is given below. The calculations are based on the angles of Schoep

Angle table for ianthinite

Orthorhombic

$$
\begin{aligned}
a: b: c=0.9996: 1: 1.2964 ; & p_{0}: q_{0}: r_{0}=1.2969: 1.2964: 1 \\
q_{1}: r_{1}: p_{1}=0.9996: 0.7711: 1 ; & r_{2}: p_{2}: q_{2}=0.7714: 1.0004: 1
\end{aligned}
$$

\begin{tabular}{|c|c|c|c|c|c|c|}
\hline FoRMs & $\phi$ & $\rho=C$ & $\phi_{1}$ & $\rho_{1}=A$ & $\phi_{2}$ & $\rho 2=B$ \\
\hline $\begin{array}{ll}c & 001 \\
f & 230 \\
d & 011\end{array}$ & $\begin{array}{c}33^{\circ} 42^{\prime} \\
000\end{array}$ & $\begin{array}{l}0^{\circ} 00^{\prime} \\
9000 \\
52 \quad 211 / 2\end{array}$ & $\begin{array}{l}0^{\circ} 00^{\prime} \\
9000 \\
52211 / 2\end{array}$ & $\begin{array}{l}90^{\circ} 00^{\prime} \\
5618 \\
9000\end{array}$ & $\begin{array}{rl}90^{\circ} & 00^{\prime} \\
0 & 00 \\
90 & 00\end{array}$ & 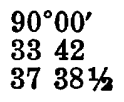 \\
\hline $\begin{array}{ll}M & 203 \\
g & 201\end{array}$ & $\begin{array}{ll}90 & 00 \\
90 & 00\end{array}$ & $\begin{array}{ll}40 & 15 \\
68 & 55\end{array}$ & $\begin{array}{ll}0 & 00 \\
0 & 00\end{array}$ & \begin{tabular}{l|l}
49 & 45 \\
21 & 05
\end{tabular} & $\begin{array}{ll}49 & 45 \\
21 & 05\end{array}$ & $\begin{array}{ll}90 & 00 \\
90 & 00\end{array}$ \\
\hline
\end{tabular}

(1926a), but are given in the orientation of Palache (1934) with the unit selected to conform to that of schoepite and becquerelite (Palache, Berman, and Frondel, 1944, v. 1, p. 633). Transfor- 
mations: Schoep to present, $0 \frac{2}{3} 0 / 001 / 100$; Palache to present, 200/010/001. Crystal drawings in the old and new orientations are given by Schoep (1926a) and Palache, Berman, and Frondel (1944).

Physical properties

Cleavage $\{001\}$ perfect. Hardness 2-3. Specific gravity not known. Color violet black. Luster submetallic. On exposure the mineral may oxidize, turning violet brown and finally yellow. The powder is violet brown. Not fluorescent in ultraviolet light.

Optical properties

In transmitted light, dark violet in color.

\begin{tabular}{cll} 
ORIENTATION & & $n$ (KATANGA) \\
\cline { 1 - 1 }$X=c$ & & $1.674 \pm 0.003$ \\
$Y=b$ & & $1.90 \pm .02$ \\
$Z=a$ & & $1.92 \pm .02$
\end{tabular}

\begin{tabular}{l} 
PleochroisM \\
\hline Colorless. \\
Violet. \\
Dark violet.
\end{tabular}

Biaxial
negative;
$2 V$ small.

The values for $n_{Y}$ and $n_{Z}$ were determined by Billiet (1926a) in sulfur-selenium melts and may be high owing to thermal dehydration of the mineral. (See also Schoep, 1927a.) The optical properties of the unheated mineral doubtless vary with the degree of oxidation and hydration within the limits of stability of the phase, but data are lacking. The ill-defined oxidation product of ianthinite called epi-ianthinite has much lower indices of refraction.

Thermal behavior and alteration

On exposure to air at room temperature ianthinite slowly turns brownish and finally becomes greenish yellow or yellow. The change begins along the edges of the crystals. Spencer (1928) observed that violet specimens in the British Museum became greenish yellow in 5 years, although crystals embedded in Canada balsam retained their original color and pleochroism. Schoep and Stradiot (1947) found that ianthinite when heated at $50^{\circ} \mathrm{C}$ for some minutes in a very dilute solution of $\mathrm{H}_{2} \mathrm{O}_{2}$ afforded a yellow product with a mean index of refraction of 1.60. A natural yellow alteration product of ianthinite has been described by Schoep and Stradiot (1947), and a similar or identical violet-colored mineral has been described by J. W. Frondel and Cuttitta (1954). Natural ianthinite also has been observed by Schoep (1926a) to alter to becquerelite, schoepite, and an unidentified yellow uranyl 
oxide which may be the mineral later described by Schoep and Stradiot (1947) under the name epi-ianthinite.

Synthetic, violet black $\mathrm{UO}_{2} \cdot 2 \mathrm{H}_{2} \mathrm{O}$ and $\mathrm{U}_{3} \mathrm{O}_{8} \cdot 2 \mathrm{H}_{2} \mathrm{O}$ readily oxidize to yellow hydrated uranyll oxide on exposure to air; the rate varies with the particle size of the material and with the temperature. In 1951 the author found that a preparation of violet black $\mathrm{U}_{3} \mathrm{O}_{8} \cdot 2 \mathrm{H}_{2} \mathrm{O}$ (?) made by the photochemical reduction of uranyl acetate in an alcoholic water solution oxidized to schoepite on standing in the solution. Bignand (1955) found that a synthetic violet preparation with the composition $\mathrm{UO}_{2.84} \cdot n \mathrm{H}_{2} \mathrm{O}$ oxidized to schoepite on standing under water, but on oxidation in air formed a different compound, $4 \mathrm{UO}_{3} \cdot 5 \mathrm{H}_{2} \mathrm{O}$, for which X-ray spacing data and a dehydration curve are given.

\section{Synthesis}

Numerous syntheses have been reported of violet hydrated uranous oxides. (See references cited in Croxton, 1951; Mellor, 1932; and Katz and Rabinowitch, 1951.) The preparations are flocculent precipitates that rapidly oxidize to yellow hydrated uranyl oxides on exposure to air, and the properties and chemical composition of the material are not definitely established in most instances. The methods of synthesis used include the photochemical reduction by sunlight or artificial ultraviolet radiation of water solutions of uranyl salts containing alcohol or other organic reducing agents, and by adding alcohol or ether to a hot nearly neutral solution of uranyl nitrate. A crystalline product that affords an X-ray pattern has been obtained by Bignand (1955) by heating cupric acetate with two parts of uranyl acetate in water at $160^{\circ} \mathrm{C}$.

\section{Identification}

Ianthinite differs from the other hydrated uranium oxides in its deep violet-black color. The ill-defined mineral richetite also is black, but is said to contain lead in addition to uranium. The extent of the stability range of ianthinite on oxidation is not known, and oxidized brownish or yellow material may still be ianthinite structurally. The optical properties are of uncertain value as a means of identification. X-ray powder-spacing data for natural ianthinite (?) from Bois Noirs, Puy-de-Dôme, France, is given in the following table. The pattern of this material is identical with that of the synthetic $\mathrm{UO}_{2.84} \cdot n \mathrm{H}_{2} \mathrm{O}$ of Bignand (1955). 


\section{$X$-ray powder-spacing data for ianthinite ${ }^{1}$}

[Symbols : $f$, faint; $m$, moderate; $m f$, moderately faint; ms, moderately strong; vs, very strong. Copper radiation, nickel filter]

\begin{tabular}{|c|c|c|c|c|c|c|}
\hline$d(\mathrm{~A})$ & $I$ & $d(\mathrm{~A})$ & $I$ & $d(\mathrm{~A})$ & $I$ & $d(\mathrm{~A})$ \\
\hline 7.60 & vs & 2.68 & $f$ & 2.02 & $\mathrm{mf}$ & 1.74 \\
\hline 3.79 & $\mathrm{~ms}$ & 2.61 & $\mathrm{mf}$ & 1.98 & $f$ & 1.67 \\
\hline 3.59 & $\mathrm{~ms}$ & 2.53 & $\mathrm{mf}$ & 1.95 & $f$ & 1.64 \\
\hline 3.35 & $\mathrm{~ms}$ & 2.38 & $f$ & 1.92 & $f$ & 1.34 \\
\hline 3.28 & $\mathrm{~m}$ & 2.25 & $f$ & 1.89 & $\mathrm{mf}$ & 1.32 \\
\hline 2.96 & $\mathrm{mf}$ & 2.14 & $f$ & 1.83 & $f$ & \\
\hline 2.89 & $m f$ & 206 & & 1.79 & $m f$ & \\
\hline
\end{tabular}

1 Data from Bignand (1955) on natural material from Bois Noirs, Puy-deDôme, France.

\section{Natural formation}

Ianthinite is a secondary mineral formed by the alteration of uraninite presumably under reducing or nonoxidizing conditions.

\section{Occurrence}

Found encrusting or veining altered uraninite at Shinkolobwe, Katanga, Belgian Congo, where it is associated with schoepite and becquerelite (both later formed). Reported by Schoep and Scholz (1931) from Wölsendorf, Bavaria, as crystals of thick tabular habit, but details are lacking; the mineral occurs with fourmarierite and other secondary uranium minerals as an alteration of uraninite in a fluorite deposit. The mineral is extremely rare at both localities. Also found at Bigay and LaCrouzille, Puy-de-Dôme, France (Branche and others, 1951); and at Bois Noirs, Puy-de-Dôme, France (Bignand, 1955).

\section{Synonymy}

\section{EPI-IANTHINITE}

Epi-ianthinite Schoep and Stradiot (1947). Named in allusion to its secondary, pseudomorphous relation to ianthinite.

\section{Composition}

Believed to be a hydrated uranyl oxide, because it is a yellow hexavalent oxidation product of ianthinite, which contains quadrivalent uranium; but there are no chemical analyses.

\section{Crystallography and physical properties}

Found as yellow alteration pseudomorphs after crystals of ianthinite. The epi-ianthinite pseudomorphs seem to be single crystals in crystallographic continuity with the original ianthinite, and may contain shredlike, oriented remnants of ianthinite of a violet-brown color with relatively high indices of refraction and intense pleochroism. A sketch of an altered crystal is given by Schoep and Stradiot (1947). The epi-ianthinite also occurs as 
thin translucent edge zones around ianthinite crystals. The mineral is believed to be orthorhombic. The crystal habit is that of the parent ianthinite-ordinarily thin laths flattened on $\{001\}$ and elongated along the $b$-axis. There is a perfect cleavage on $\{001\}$, but this may be a parting inherited from the $\{001\}$ cleavage of the ianthinite. There are no data on hardness, specific gravity, fluorescence, or X-ray properties.

Optical properties

Color yellow in transmitted light.

\begin{tabular}{cll} 
ORIENTATION & & $\frac{n}{}$ \\
\cline { 1 - 1 }$X=c$ & & 1.70 \\
$Y=b$ & 1.79 \\
$Z=a$ & 1.793
\end{tabular}

\section{PleOChROISM \\ Pale yellow. \\ Yellow. \\ Deep yellow.}

Biaxial negative; $2 V$ very small.

Identification

Epi-ianthinite is an ill-defined substance and its species status is very uncertain. Its distinction from the other hydrated uranyl oxides-several of which themselves are ill defined-is based largely on the optical properties. These may not be diagnostic if there is any significant variation in the water content or chemical composition of the mineral. Material found as yellow alteration pseudomorphs after ianthinite in general falls within the intent of the name, but such material may also include schoepite and other substances.

$X$-ray powder-spacing data for epi-ianthinite ${ }^{1}$

[Symbols : b, broad; d, diffuse; vb, very broad; vd, very diffuse. Copper radiation, nickel filter]

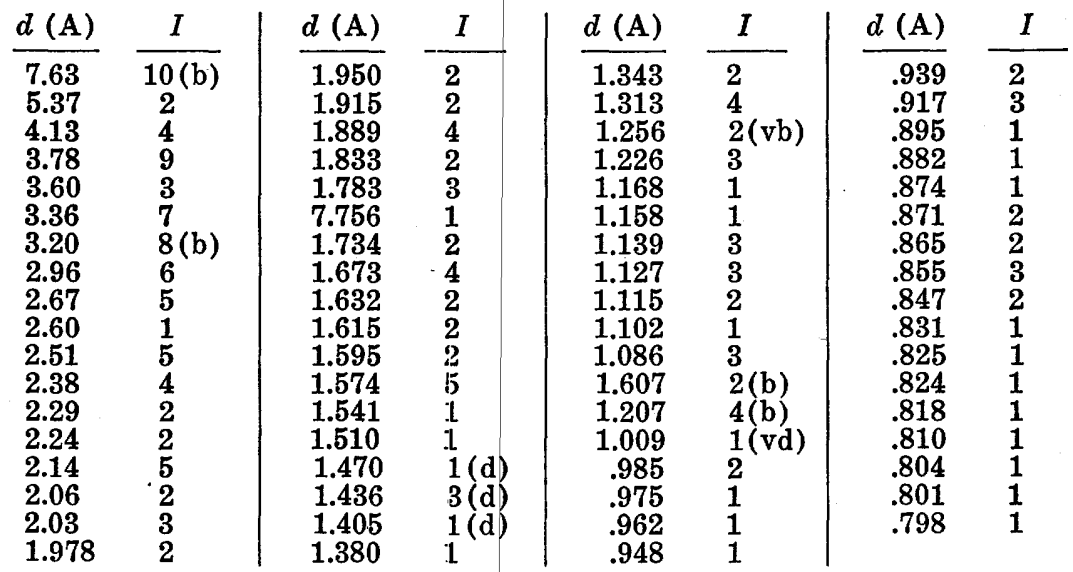

${ }^{1} \mathrm{X}$-ray powder data for authentic or type epi-ianthinite are lacking. Data have been published, however, by J. W. Frondel and Cuttitta (1954) for an alteration product of ianthinite that very probably represents epi-ianthinite. These data are given above. 
Natural formation and occurrence

A secondary mineral, known from Shinkolobwe, Katanga, Belgian Congo. Branche and others (1951) have referred a yellow alteration product of ianthinite from Bigay, Puy-de-Dôme, France, to epi-ianthinite; it has indices of refraction between 1.72 and 1.83 , with negative elongation.

\section{UNNAMED MINERAL RELATED TO IANTHINITE}

A mineral that very closely resembles ianthinite in its color and crystal habit, and that probably is an alteration product of that species, has been recognized by J. W. Frondel and F. Cuttitta (1954). It may be identical with epi-ianthinite but conclusive proof of this is lacking.

Chemically, the mineral is a hydrated oxide of hexavalent uranium. The formula probably is $\mathrm{UO}_{3} \cdot 2 \mathrm{H}_{2} \mathrm{O}$. A microanalysis by Cuttitta gave: $\mathrm{UO}_{3} 87.83, \mathrm{H}_{2} \mathrm{O}+11: 26, \mathrm{H}_{2} \mathrm{O}-1.06$, total 100.15 percent. Only a trace of quadrivalent uranium was detected, although the mineral has a violet-black color. A single-crystal X-ray study by J. W. Frondel gave an orthorhombic cell with $a_{0} 7.17 \mathrm{~A}, b_{0} 11.46, c_{0} 15.20 ; a_{0}: b_{0}: c_{0}=0.6257: 1: 1.311$. This ratio is fairly close to the morphological ratio of ianthinite, but with the $a$-axis halved. The crystals are tiny laths, unsuited for morphological measurement, and occur as thin velvety crusts on uraninite. Color violet black, inclining on the edges to brownish black. Optically biaxial negative, with $n_{X} 1.695$ (pale pink), $n_{Y} 1.730$ (brownish orange), $n_{Z} 1.790$ (dark reddish purple); $2 \mathrm{~V}$ about $50^{\circ} ; r>v$ weak. Specific gravity 3.50 (measured), 3.467 (calculated for 8 units of $\mathrm{UO}_{3} \cdot 2 \mathrm{H}_{2} \mathrm{O}$ in the cell). Found on a specimen from Shinkolobwe, Katanga district, Belgian Congo. The X-ray powder spacings, given in the preceding table, differ from those of the other hydrated uranium oxides, although the pattern of epi-ianthinite is lacking. After standing in the open air for about a year after the above data had been obtained the color of the mineral had changed from violet black to brownish yellow.

Synonymy

BECQUERELITE

Becquerelite Schoep (1922a). Named after Henri Becquerel (1852-1908), French physicist, who discovered radioactivity in 1896.

\section{Composition}

A hydrated oxide of hexavalent uranium. The exact formula is not known, but seems to be $7 \mathrm{UO}_{3} \cdot 11 \mathrm{H}_{2} \mathrm{O}$ or close thereto. The available analyses are given in the table below. 
Chemical analyses of becquerelite, in weight percent

\begin{tabular}{|c|c|c|c|c|c|c|c|}
\hline & 1 & 2 & 3 & 4 & 5 & 6 & 7 \\
\hline $\mathrm{O}_{3}$ & $\begin{array}{l}91.24 \\
{[8.76]}\end{array}$ & $\begin{array}{l}91.30 \\
{[8.70]}\end{array}$ & $\begin{array}{r}90.09 \\
9.91\end{array}$ & $\begin{array}{r}89.53 \\
8.95\end{array}$ & {$\left[\begin{array}{c}90.09] \\
9.91\end{array}\right.$} & $\begin{array}{l}82.73 \\
10.02\end{array}$ & $\begin{array}{r}91.00 \\
9.00\end{array}$ \\
\hline$U_{2}$ & $=$ & $=$ & I & 1.82 & $=$ & 5.38 & 二 \\
\hline tot & $00]$ & $00]$ & 100.00 & 100.30 & $00.00]$ & 98.13 & 100.00 \\
\hline
\end{tabular}

1, 2. Becquerelite. Katanga. Cuvelier, analyst, in. Billiet and de Jong (1935).

3. Becquerelite. Katanga. Schoep and Stradiot (1948).

4. Becquerelite. Katanga. Cuttitta, analyst, in J. W. Frondel and Cuttitta (1953).

5. Becquerelite. Katanga. Schoep (1930). Made on $39.55 \mathrm{mg}$; 2 additional determinations of lesser accuracy on 14.5 and $9.1 \mathrm{mg}$ gave 9.72 and 10.94 percent $\mathrm{H}_{2} \mathrm{O}$.

6. Becquerelite (or billietite?). Katanga. Schoep (1922a, 1923a, 1924a).

7. Theoretical weight percentages, $7 \mathrm{UO}_{3} \cdot 11 \mathrm{H}_{2} \mathrm{O}$.

The formula was originally given by Schoep (1922a, 1923a, $1924 \mathrm{a}, \mathrm{b}, \mathrm{c})$ as $\mathrm{UO}_{3} \cdot 2 \mathrm{H}_{2} \mathrm{O}$ on the basis of analysis 6 . This formula was later modified by Schoep (1930) to $4 \mathrm{UO}_{3} \cdot 7 \mathrm{H}_{2} \mathrm{O}$ from the water determination of analysis 5 . Billiet and de Jong (1935) cited new water determinations (analyses 1 and 2) and derived the formula $2 \mathrm{UO}_{3} \cdot 3 \mathrm{H}_{2} \mathrm{O}$; their determination of the X-ray unitcell contents, however, afforded $13\left[2 \mathrm{UO}_{3} \cdot 3 \mathrm{H}_{2} \mathrm{O}\right]$, which is unlikely from symmetry requirements. Brasseur (1946) discussed the work of Billiet and de Jong (1985) and suggested that the formula was $3 \mathrm{UO}_{3} \cdot 5 \mathrm{H}_{2} \mathrm{O}$ and that there were $8\left[3 \mathrm{UO}_{3} \cdot 5 \mathrm{H}_{2} \mathrm{O}\right]$ in the unit cell. This formula was accepted by Schoep and Stradiot (1948). Brasseur (1948), discussing the matter in light of new specificgravity determinations, says that the formula is closer to $\mathrm{UO}_{3} \cdot 2 \mathrm{H}_{2} \mathrm{O}$ than to $2 \mathrm{UO}_{3} \cdot 3 \mathrm{H}_{2} \mathrm{O}$ or $3 \mathrm{UO}_{3} \cdot 5 \mathrm{H}_{2} \mathrm{O}$; this would give $24\left[\mathrm{UO}_{3} \cdot 2 \mathrm{H}_{2} \mathrm{O}\right]$ in the unit cell. J. W. Frondel and Cuttitta (1953) recognized from $\mathrm{X}$-ray study that becquerelite is isostructural with billietite, for which the formula $\mathrm{BaO} \cdot 6 \mathrm{UO}_{3} \cdot 11 \mathrm{H}_{2} \mathrm{O}$ seems to be well established, and from this evidence and an X-ray study of the material of analysis 4 , concluded that the formula was $7 \mathrm{UO}_{3} \cdot 11 \mathrm{H}_{2} \mathrm{O}$ with $4\left[7 \mathrm{UO}_{3} \cdot 11 \mathrm{H}_{2} \mathrm{O}\right]$ in the unit cell. The very close morphological resemblance between billietite and becquerelite was recognized by Schoep and Stradiot (1948). A synthetic compound for which the formula $2 \mathrm{UO}_{3} \cdot 3 \mathrm{H}_{2} \mathrm{O}$ is given on the basis of dehydration curves seem to be identical with becquerelite. (See further under Schoepite, p. 77).

The question whether $\mathrm{Pb}$ can substitute for $\mathrm{U}$ in becquerelite, and whether a series extends to billietite by substitution of $\mathrm{Ba}$ for $\mathrm{U}$, remains open. The $\mathrm{Pb}$ reported by Schoep in the becquerelite of analysis 6 was originally ascribed to admixture, but later was thought by Schoep and Stradiot (1948) to be in substitution 
for U. Schoep and Stradiot (1948) also suggest that billietite is merely a variety of becquerelite that contains some Ba substituting for U. These views were controverted by Vaes (1949), who believes that the $\mathrm{Pb}$ reported in the original analysis of becquerelite was actually $\mathrm{Ba}$ and that the specimen was billietite. The specimen was lost during World War II and cannot be checked. However, the evidence clearly shows that a mineral free from $\mathrm{Ba}$ and $\mathrm{Pb}$ with the formula $7 \mathrm{UO}_{3} \cdot 11 \mathrm{H}_{2} \mathrm{O}$ (?) exists, for which the name becquerelite is appropriate, and that billietite is a related but distinct species with the end-composition, at least, of $\mathrm{BaO} \cdot 6 \mathrm{UO}_{3} \cdot 11 \mathrm{H}_{2} \mathrm{O}$. J. W. Frondel and Cuttitta (1953) suggest that a series between becquerelite and billietite may be represented by the general formula $\left[\mathrm{U}_{1-\mathrm{x}^{+6}}(\mathrm{Ba}, \mathrm{Pb})_{\mathrm{x}}{ }^{+2}\right] \mathrm{U}_{6}{ }^{+6} \mathrm{O}_{20-4 \mathrm{x}}(\mathrm{OH})_{2+4 \mathrm{x}^{\circ}}$ $(10-2 \mathrm{x}) \mathrm{H}_{2} \mathrm{O}$.

The small variation observed in the optical properties indicates that there is a variation of some nature in the chemical composition of becquerelite.

Spectrographic analyses are lacking. Becquerelite is easily soluble in acids. Infusible.

\section{Crystallography}

Becquerelite is orthorhombic, in the dipyramidal crystal class $(2 / m 2 / m 2 / m)$. An angle table for the known forms is given below; it is calculated from the morphological angles of Palache (1934) in the orientation of Schoep (1923a) and the unit of the

Angle table for becquerelite

Orthorhombic; dipyramidal, $(2 / \mathrm{m} 2 / \mathrm{m} 2 / \mathrm{m})$

$a: b: c:=1.1182: 1: 1.2100 ; \quad p_{0}: q_{0}: r_{0}=1.0821: 1.2100: 1$
$q_{1}: r_{1}: p_{1}=1.1182: 0.9241: 1 ; \quad r_{2}: p_{2}: q_{2}=0.8265: 0.8943: 1$

\begin{tabular}{|c|c|c|c|c|c|c|}
\hline ForMs & $\phi$ & $\rho=C$ & $\phi_{1}$ & $\rho_{1}=A$ & $\phi_{2}$ & $\rho_{2}=B$ \\
\hline $\begin{array}{ll}c & 001 \\
b & 010 \\
a & 100\end{array}$ & $\begin{array}{r}0^{\circ} \overline{00} \\
9000\end{array}$ & $\begin{array}{c}0^{\circ} 00^{\prime} \\
9000 \\
9000\end{array}$ & $\begin{array}{r}0^{\circ} 00^{\prime} \\
9000 \\
-\end{array}$ & $\begin{array}{c}90^{\circ} 00^{\prime} \\
9000 \\
000\end{array}$ & $\begin{array}{r}90^{\circ} 00^{\prime} \\
0 \overline{00}\end{array}$ & $\begin{array}{rl}90^{\circ} & 00^{\prime} \\
0 & 00 \\
90 & 00\end{array}$ \\
\hline $\begin{array}{ll}n & 230 \\
M & 210 \\
e & 011\end{array}$ & $\begin{array}{rl}30 & 48 \\
60 & 471 / 2 \\
0 & 00\end{array}$ & $\begin{array}{ll}90 & 00 \\
90 & 00 \\
50 & 251 / 2\end{array}$ & $\begin{array}{ll}90 & 00 \\
90 & 00 \\
50 & 251 / 2\end{array}$ & $\begin{array}{ll}59 & 12 \\
29 & 121 / 2 \\
90 & 00\end{array}$ & $\begin{array}{rr}0 & 00 \\
0 & 00 \\
90 & 00\end{array}$ & $\begin{array}{ll}30 & 48 \\
60 & 471 / 2 \\
39 & 341 / 2\end{array}$ \\
\hline $\begin{array}{ll}i & 103 \\
f & 102 \\
k & 305\end{array}$ & $\begin{array}{ll}90 & 00 \\
90 & 00 \\
90 & 00\end{array}$ & $\begin{array}{ll}19 & 50 \\
28 & 25 \\
32 & 591 / 2\end{array}$ & $\begin{array}{ll}0 & 00 \\
0 & 00 \\
0 & 00\end{array}$ & $\begin{array}{ll}70 & 10 \\
61 & 35 \\
57 & 001 / 2\end{array}$ & $\begin{array}{ll}70 & 10 \\
61 & 35 \\
57 & 001 / 2\end{array}$ & $\begin{array}{ll}90 & 00 \\
90 & 00 \\
90 & 00\end{array}$ \\
\hline $\begin{array}{ll}A & 203 \\
j & 304 \\
d & 101\end{array}$ & $\begin{array}{ll}90 & 00 \\
90 & 00 \\
90 & 00\end{array}$ & $\begin{array}{ll}35 & 481 / 2 \\
39 & 031 / 2 \\
47 & 151 / 2\end{array}$ & $\begin{array}{ll}0 & 00 \\
0 & 00 \\
0 & 00\end{array}$ & $\begin{array}{ll}54 & 111 / 2 \\
50 & 5611 / 2 \\
42 & 441 / 2\end{array}$ & $\begin{array}{ll}54 & 111 / 2 \\
50 & 561 / 2 \\
42 & 441 / 2\end{array}$ & $\begin{array}{ll}90 & 00 \\
90 & 00 \\
90 & 00\end{array}$ \\
\hline $\begin{array}{ll}x & 111 \\
p & 211 \\
w & 311\end{array}$ & $\begin{array}{ll}41 & 481 / 2 \\
60 & 471 / 2 \\
69 & 331 / 2\end{array}$ & $\begin{array}{ll}58 & 22 \\
68 & 02 \\
73 & 54\end{array}$ & $\begin{array}{ll}50 & 251 / 2 \\
50 & 251 / 2 \\
50 & 251 / 2\end{array}$ & $\begin{array}{ll}55 & 25 \\
35 & 57 \\
25 & 481 / 2\end{array}$ & $\begin{array}{ll}42 & 441 / 2 \\
24 & 48 \\
17 & 071 / 2\end{array}$ & $\begin{array}{ll}50 & 361 / 2 \\
63 & 0511 / 2 \\
70 & 231 / 2\end{array}$ \\
\hline
\end{tabular}


X-ray cell. Different units were used by Schoep (1923a) and Palache (1934); transformations, Schoep to new 200/010/002, Palache to new 200/010/001.

The X-ray single-crystal data on becquerelite follow.

\begin{tabular}{|c|c|c|c|}
\hline & \multicolumn{2}{|c|}{ Unit-cell dimensions of becquerelite } & \multirow[b]{2}{*}{3} \\
\hline & 1 & 2 & \\
\hline $\begin{array}{l}a_{0} \\
b_{0} \\
c_{0}\end{array}$ & $\begin{array}{l}13.96 \mathrm{~A} \\
12.36 \\
14.87\end{array}$ & $\begin{array}{l}13.9 \mathrm{~A} \\
12.58 \\
14.9\end{array}$ & $\begin{array}{l}13.92 \mathrm{~A} \\
12.45 \\
15.09\end{array}$ \\
\hline
\end{tabular}

\begin{tabular}{lll|l}
\hline$a_{0}: b_{0}: c_{0}$ & $1.129: 1: 1.203$ & $1.105: 1: 1.184$ & $1.118: 1: 1.212$
\end{tabular}

Space group Pmma (J. W. Frondel and Cuttitta, 1953), or Pnma (Wolfe, in Palache, Berman, and Frondel, 1944).

1. Wolfe, cited in Palache, Berman, and Frondel (1944).

2. Billiet and de Jong (1935).

3. J. W. Frondel and Cuttitta (1953).

Brasseur (1948) states that he verified the cell dimensions of Billiet and de Jong (1935) within the experimental error.

Twinning on $\{110\}$ was described by Schoep (1922a, 1923a, $1924 \mathrm{a}$ ) in the lead-bearing material of analysis 6 , but this mineral according to Vaes (1949) is billietite. Twinning has not been observed in undoubted becquerelite.

\section{Crystal habit}

Crystals are usually tabular on $\{001\}$ with a pseudohexagonal outline, or slightly elongated along the $b$-axis into thick laths. Also short prismatic by extension along the $b$-axis; said to occur sometimes as long needles; $\{010\}$ usually is striated parallel to the $a$-axis and $\{101\}$ parallel to the $b$-axis. The crystals ordinarily range up to 1 or $2 \mathrm{~mm}$ in length; Schoep (1930) mentions a crystal $6 \mathrm{~mm}$ long and Buttgenbach (1947) one $3 \mathrm{~cm}$ long. Crystal drawings are given in Palache, Berman, and Frondel (1944), Ungemach (1929), Schoep (1930), and Schoep and Stradiot (1948) (includes the so-called lead-becquerelite). Some becquerelite occurs as fine-grained aggregates and as coatings.

A summary account of the morphological studies reported of becquerelite by Schoep (1923a, 1924b, 1930), Buttgenbach (1925), and Ungemach (1929) is given by Palache (1934).

\section{Physical properties}

Cleavage $\{001\}$, perfect; $\{101\},\{010\}$, and $\{110\}$, imperfect (Schoep and Stradiot, 1948; Brasseur, 1949; and Vaes, 1949). Brittle. Hardness 21/2. Specific gravity 5.09 (measured, Brasseur, 1948), 5.68 (measured, Schoep, 1930), 5.2 (measured, Billiet and de Jong, 1935); 5.60 (calculated from formula $7 \mathrm{UO}_{3} \cdot 11 \mathrm{H}_{2} \mathrm{O}$ and cell dimensions of J. W. Frondel and Cuttitta, 1953). Luster 
adamantine, inclining to greasy. Color amber yellow or brownish yellow; also yellow or yellow orange in fine-granular aggregates. Powder yellow. Transparent. Not fluorescent in ultraviolet light.

Optical properties

\begin{tabular}{|c|c|c|c|c|}
\hline \multirow{2}{*}{$\begin{array}{l}\text { ORIENTA- } \\
\text { TION }\end{array}$} & \multicolumn{4}{|c|}{$n$} \\
\hline & 1 & 2 & 3 & 4 \\
\hline $\begin{array}{l}X=c \\
Y=a \\
Z=b\end{array}$ & $\begin{array}{l}1.730 \\
1.805 \\
1.820\end{array}$ & $\begin{array}{l}1.735 \\
1.82 \\
1.83\end{array}$ & $\begin{array}{l}1.725 \\
1.825 \\
1.83\end{array}$ & $\begin{array}{l}1.750 \\
1.825 \\
1.835 \\
\end{array}$ \\
\hline $2 \mathrm{~V}$ & $\approx 30^{\circ}$ & $\approx 30^{\circ}$ & $\approx 30^{\circ}$ & $30^{\circ}-40^{\circ}$ \\
\hline \multirow{2}{*}{$\begin{array}{l}\text { ORIENTA- } \\
\text { TION } \\
\end{array}$} & $n(578 \mathrm{~m} \mu)$ & $n(541 \mathrm{~m} \mu)$ & \multirow[b]{2}{*}{ PLEOCHROISM } & \multirow{5}{*}{$\begin{array}{l}\text { Biaxial negative; } \\
\text { dispersion } \\
r>v \text { strong. }\end{array}$} \\
\hline & 5 & 6 & & \\
\hline$X=c$ & - & \multirow[b]{2}{*}{$\approx 1.839$} & \multirow{2}{*}{$\begin{array}{c}\text { Pale yellow } \\
\text { to nearly } \\
\text { colorless. } \\
\text { Deep yellow. } \\
\text { Deep yellow. }\end{array}$} & \\
\hline $\begin{array}{l}Y=a \\
Z=b\end{array}$ & $\approx 1.822$ & & & \\
\hline $2 \mathrm{~V}$ & - & - & & \\
\hline $\begin{array}{ll}\text { 1. J. W } \\
\text { 2. Lars } \\
\text { 3. Scho }\end{array}$ & $\begin{array}{l}\text { ondel and C } \\
\text { and Berman } \\
\text { and Stradio }\end{array}$ & $\begin{array}{l}\text { itta }(1953) . \\
934) . \\
(948) .\end{array}$ & $\begin{array}{l}\text { 4. George (1 } \\
5,6 \text {. Brasse }\end{array}$ & ar (1948). \\
\hline
\end{tabular}

George (1949) gives the pleochroism as $X$ colorless, $Y$ deep greenish yellow, $Z$ very deep greenish yellow; Buttgenbach (1947) gives $X$ colorless, $Y$ yellow, $Z$ dark yellow.

Thermal behavior

A phase whose composition is given as $2 \mathrm{UO}_{3} \cdot 3 \mathrm{H}_{2} \mathrm{O}$, which is probably identical with becquerelite, is formed by dehydration of schoepite and of synthetic $\mathrm{UO}_{3} \cdot 2 \mathrm{H}_{2} \mathrm{O}$. (See further under Schoepite, p. 77.)

Dehydration data on the material of analysis 6 is given by Schoep (1924a), but as already noted this material may be billietite; Schoep found that 1.60 percent $\mathrm{H}_{2} \mathrm{O}$ was lost at $110^{\circ} \mathrm{C}$ and the balance is not lost until about $500^{\circ} \mathrm{C}$. Vaes (1949) found that becquerelite (without $\mathrm{Pb}$ or $\mathrm{Ba}$ ) did not alter in $2 \mathrm{~V}$ when heated to $100^{\circ}-110^{\circ} \mathrm{C}$, in contrast to billietite.

\section{Synthesis}

Obtained by Gruner (1953) by reaction of uranyl sulfate solution with calcium bicarbonate solution at $\mathrm{pH} \approx 5.6$; also by reaction of uranyl sulfate solution with $\mathrm{NH}_{4} \mathrm{OH}$ at a $\mathrm{pH}$ of about 5 or more. Numerous syntheses have been reported in the literature of hydrated uranyl oxides close in composition to becquerelite, but their identity with this species has not been established. (See Croxton, 1951; Gmelin, 1936; and Mellor, 1932.) 
Identification

Becquerelite is practically indistinguishable at sight from billietite and some other hydrated uranyl oxides. Optically, schoepite has lower and masuyite higher indices of refraction, but billietite cannot be distinguished from becquerelite on optical grounds alone. The X-ray pattern differs distinctly from that of schoepite, but closely resembles that of billietite. Negative tests for $\mathrm{Ba}$ and $\mathrm{Pb}$ are indicative of becquerelite, and with optical and X-ray data enable identification. Morphological measurements also are useful but of limited application. The X-ray powder-spacing data are given in the following table.

\section{$X$-ray powder-spacing data for becquerelite}

[Copper radiation, nickel filter]

\begin{tabular}{|c|c|c|c|c|c|c|}
\hline$d(\mathrm{~A})$ & $I$ & $d(\mathrm{~A})$ & $I$ & $d(\mathrm{~A})$ & $I$ & $d(\mathrm{~A})$ \\
\hline 8.51 & 1 & 2.47 & 2 & 1.614 & 2 & 1.121 \\
\hline 7.50 & 10 & 2.44 & 2 & 1.600 & 2 & 1.108 \\
\hline 6.63 & 2 & 2.38 & $\overline{2}$ & 1.564 & $\overline{2}$ & 1.054 \\
\hline 6.24 & 1 & 2.31 & $\overline{3}$ & 1.541 & $\overline{1}$ & 1.029 \\
\hline 5.63 & 1 & 2.21 & 1 & 1.451 & 2 & .987 \\
\hline 4.71 & 6 & 2.11 & 2 & 1.411 & 3 & .967 \\
\hline 4.31 & 1 & 2.07 & 3 & 1.378 & 3 & .955 \\
\hline 3.75 & 8 & 2.04 & 4 & 1.332 & 1 & .944 \\
\hline 3.56 & 8 & 1.944 & 4 & 1.289 & 1 & .933 \\
\hline 3.48 & 2 & 1.943 & 5 & 1.271 & 1 & .914 \\
\hline 3.39 & 2 & 1.893 & 2 & 1.240 & 1 & .887 \\
\hline 3.22 & $\overline{9}$ & 1.875 & 2 & 1.224 & 1 & .859 \\
\hline 3.13 & 1 & 1.848 & 2 & 1.207 & 1 & .842 \\
\hline 2.97 & 2 & 1.814 & 1 & 1.188 & 1 & .836 \\
\hline 2.88 & 3 & 1.773 & 3 & 1.169 & 1 & .834 \\
\hline 2.73 & 1 & 1.725 & 3 & 1.152 & 1 & \\
\hline 2.58 & 7 & 1.681 & 2 & 1.134 & 1 & \\
\hline
\end{tabular}

1 Data from J. W. Frondel and Cuttitta (1953) for material from the Katanga district, Belgian Congo. A nearly identical pattern is given by synthetic material.

Natural formation and occurrence

Becquerelite is a secondary mineral usually found closely associated with uraninite, from which it has been derived. Typical associated minerals include schoepite, fourmarierite, curite, soddyite, and dewindtite. Known chiefly from Kasolo and Shinkolobwe, Katanga, Belgian Congo. Found rarely at Wölsendorf, Bavaria, as an alteration of uraninite in a fluorite deposit (Schoep and Scholz, 1931). A mineral from Bigay, Puy-de-Dôme, France, has been referred to becquerelite by Branche and others (1951) ; it has somewhat discordant properties $\left(n_{X} 1.75, n_{Y} 1.87, n_{Z} 1.88\right)$. Becquerelite occurs sparingly as an alteration product of uraninite in deposits of the sandstone type on the Colorado Plateau. It occurs with small amounts of schoepite and fourmarierite as crusts around unaltered cores of uraninite in the oxidized part 
of the deposits, and precedes the formation of the vanadates carnotite and tyuyamunite. Found at the Monument No. 2 mine and Cato Sells mine in Monument Valley, Apache County, Ariz.; at the Lucky Strike No. 2 mine, San Rafael Swell, and the Posey mine, White Canyon district, in Utah (Weeks and Thompson, 1954). Reported from the Consolidated mine on Green Vein mesa and the Delta Group mine on the San Rafael Swell, Emery County; the Frey No. 4 mine in Frey Canyon, San Juan County; the Oyler Tunnel claim near Fruita, Wayne County, all in Utah, and at claims 6 miles north of Holbrook, Ariz. (Gruner and others, 1954a) ; at the F. and B. claim, Echo Cliffs near Navajo Bridge, and the Huscon No. 10 mine near Cameron, in Arizona (Gruner and Smith, 1955); at the Section 16 mine, Fremont County, Wyo. (Gruner and Smith, written communication, 1955) and in the Lake Athabaska district, Canada (C. Frondel, 1956b).

\section{BIILIETITE}

Synonymy

Billietite Vaes (1947). Named after Valère Billiet (1903-1944), Belgian crystallographer, of the University of Ghent.

Composition

A hydrated oxide of barium and hexavalent uranium. Formula $\mathrm{BaO} \cdot 6 \mathrm{UO}_{3} \cdot 11 \mathrm{H}_{2} \mathrm{O}=\mathrm{Ba}\left(\mathrm{UO}_{2}\right)_{6}(\mathrm{OH})_{14} \cdot 4 \mathrm{H}_{2} \mathrm{O}$. The three reported analyses are cited in the table below. The composition was established only qualitatively in the original description of Vaes (1947). Vaes (1949) reported analysis 2, and derived the formula $\mathrm{BaO} \cdot 6 \mathrm{UO}_{3} \cdot 10 \mathrm{H}_{2} \mathrm{O}$. Brasseur (1949) described an X-ray study of

Chemical analyses of billietite, in weight percent

\begin{tabular}{|c|c|c|c|c|c|}
\hline & 1 & 2 & 3 & 4 & 5 \\
\hline $\mathrm{BaO}$ & 7.42 & 6.95 & 6.88 & 7.41 & 7.41 \\
\hline $\mathrm{UO}_{3}$ & 83.00 & $83 . \overline{86}$ & 82.76 & $84 . \overline{39}$ & 82.88 \\
\hline $\mathrm{H}_{2} \mathrm{O}$ & 9.58 & 10.49 & 8.97 & 8.68 & 9.56 \\
\hline $\mathrm{SiO}_{2}$ & - & & .76 & - & - \\
\hline Total & 100.00 & 101.30 & 99.67 & 100.48 & 99.85 \\
\hline Spgr: & & & & & \\
\hline Meas. & $\overline{30}$ & - & 5.32 & 5.36 & 5.18 \\
\hline Calc. & 5.30 & - & 5.33 & 5.40 & \\
\hline
\end{tabular}

1. Theoretical weight percentages, $\mathrm{BaO} \cdot 6 \mathrm{UO}_{3} \cdot 11 \mathrm{H}_{2} \mathrm{O}$.

2. Billietite. Katanga. Analysis by Laboratoire des Usines de Panda, in Vaes (1949) $\mathrm{H}_{2} \mathrm{O}$ is ignition loss. Stated to contain a little becquerelite.

3, 4. Billietite. Katanga. Cuttitta, analyst, in J. W. Frondel and Cuttitta (1953). Analysis 3 is on a sample supplied by Vaes.

5. Billietite. Synthetic. Protas (1956). 
the mineral and suggested the formula $\mathrm{BaO} \cdot 6 \mathrm{UO}_{3} \cdot 11 \mathrm{H}_{2} \mathrm{O}$ with $2\left[\mathrm{BaO} \cdot 6 \mathrm{UO}_{3} \cdot 11 \mathrm{H}_{2} \mathrm{O}\right]$ in the unit cell. Two new analyses were reported by J. W. Frondel and Cuttitta (1953) who derive the same formula but find the cell contents to be $4\left[\mathrm{BaO} \cdot 6 \mathrm{UO}_{3} \cdot 11 \mathrm{H}_{2} \mathrm{O}\right]$ as a consequence of doubling the $a$-axis of the cell of Brasseur. Billietite is isostructural with becquerelite, as shown by J. W. Frondel and Cuttitta (1953). There is no analytical evidence of a series to becquerelite or of a substitution of $\mathrm{Pb}$ for $\mathrm{U}$. (See also discussion under Becquerelite.) Nevertheless, the observed variation in the optical properties of different specimens suggests that there is a variation in the chemical composition of the mineral.

A spectrographic analysis of billietite by van Tassel in Vaes (1947) showed the presence of much $\mathrm{Ba}$ and traces of $\mathrm{Pb}$. Billietite is easily soluble in acids.

Crystallography

Orthorhombic, crystallizing in the dipyramidal crystal class $(2 / m 2 / m 2 / m)$. An angle table for the known forms in the unit and orientation of the X-ray unit cell is given below.

Angle table for billietite

Orthorhombic; dipyramidal, $(2 / \mathrm{m} 2 / \mathrm{m} 2 / \mathrm{m})$

$a: b: c=1.184: 1: 1.251 ; \quad p_{0}: q_{0}: r_{0}=1.057: 1.251: 1$

$q_{1}: r_{1}: p_{1}=1.184: 0.9464: 1 ; \quad r_{2}: p_{2}: q_{2}=0.7994: 0.8446: 1$

\begin{tabular}{|c|c|c|c|c|c|c|}
\hline FoRMS & $\phi$ & $\rho$ & $\phi_{1}$ & $\rho_{1}=A$ & $\phi_{2}$ & $\rho_{2}=B$ \\
\hline $\begin{array}{ll}c & 001 \\
b & 010 \\
& 021\end{array}$ & $\begin{array}{l}0^{\circ} \overline{00^{\prime}} \\
000\end{array}$ & $\begin{array}{c}0^{\circ} 00^{\prime} \\
9000 \\
6813\end{array}$ & $\begin{array}{l}0^{\circ} 00^{\prime} \\
9000 \\
6813\end{array}$ & $\begin{array}{l}90^{\circ} 00^{\prime} \\
9000 \\
9000\end{array}$ & $\begin{array}{l}90^{\circ} 00^{\prime} \\
90 \overline{00}\end{array}$ & $\begin{array}{rl}90^{\circ} & 00^{\prime} \\
0 & 00 \\
21 & 47\end{array}$ \\
\hline $\begin{array}{l}212 \\
232 \\
423\end{array}$ & $\begin{array}{l}5923 \\
29231 / 2 \\
5923\end{array}$ & $\begin{array}{ll}50 & 51 \\
65 & 051 / 2 \\
58 & 351 / 2\end{array}$ & $\begin{array}{ll}32 & 011 / 2 \\
61 & 57 \\
39 & 491 / 2\end{array}$ & $\begin{array}{ll}48 & 08 \\
63 & 34 \\
42 & 44\end{array}$ & $\begin{array}{ll}43 & 25 \\
43 & 25 \\
35 & 211 / 2\end{array}$ & $\begin{array}{ll}66 & 441 / 2 \\
37 & 471 / 2 \\
64 & 14\end{array}$ \\
\hline 211 & 5923 & 6751 & 5122 & 3709 & 2519 & $61511 / 2$ \\
\hline
\end{tabular}

The crystals were originally described by Vaes (1947) with the perfect cleavage as $\{010\}$. (See figure 3.) Thoreau (1948) took a new orientation, with Thoreau $a b c=c a b$, so that the perfect cleavage became $\{001\}$ following the general practice in describing these oxides initiated by Palache (1934). This orientation was followed in the X-ray study of Brasseur (1949). A later X-ray study by J. W. Frondel and Cuttitta (1953) showed that the $a$-axis of the unit found by Brasseur (1949) should be doubled, and this unit and orientation is the one used here. The reported X-ray single-crystal data follow. 


\section{Unit-cell dimensions of billietite}

\begin{tabular}{|c|c|c|c|}
\hline & 1 & 2 & 3 \\
\hline $\begin{array}{l}a_{0} \\
b_{0} \\
c_{0}\end{array}$ & $\begin{array}{l}14.25 \mathrm{~A} \\
12.04 \\
15.06\end{array}$ & $\begin{array}{l}13.98 \mathrm{~A} \\
12.08 \\
15.06\end{array}$ & $\begin{array}{l}7.11(\times 2=14.22) \mathrm{A} \\
12.08 \\
15.09\end{array}$ \\
\hline$a_{0}: b_{0}: c_{0}$ & $1.1836: 1: 1.2508$ & $1.1573: 1: 1.2467$ & $0.5887: 1: 1.2486$ \\
\hline $\begin{array}{l}\text { Meas. } \\
\text { Calc. }\end{array}$ & $\begin{array}{l}5.32 \\
5.33\end{array}$ & $\begin{array}{l}5.36 \\
5.40\end{array}$ & $\begin{array}{l}5.28 \\
5.30\end{array}$ \\
\hline
\end{tabular}

Space group $P m m a$; unit-cell contents $4\left[\mathrm{BaO} \cdot 6 \mathrm{UO}_{3} \cdot 11 \mathrm{H}_{2} \mathrm{O}\right]$.

1, 2. J. W. Frondel and Cuttitta (1953). 3. Brasseur (1949).

Crystal habit

Billietite so far has been found only as crystals up to about 2 $\mathrm{mm}$ in size. These are tabular on $\{001\}$ and are pseudohexagonal in appearance. The crystals sometimes are slightly elongated along [110]. Drawings of crystals of billietite are given by Vaes (1947, 1949) and by Schoep and Stradiot (1948). Morphological descriptions are given by Thoreau (1948) and by Brasseur (1949), who both derive elements. Billietite very closely resembles becquerelite in crystal habit and angles.

Twinning is common on $\{111\}$ and on $\{110\}$, the latter law often repeated to give pseudohexagonal, aragonite-like groups.

Physical properties

Cleavage $\{001\}$ perfect, $\{110\}$ and $\{010\}$ imperfect. Brittle. Hardness not known. Specific gravity 5.28-5.36 (measured), 5.30-5.40 (calculated). (See tabulation of unit-cell measurements.) Luster adamantine. Color amber yellow to golden yellow and yellow. Transparent. Observations on the fluorescence are lacking.

0ptical properties

\begin{tabular}{|c|c|c|c|c|c|c|}
\hline \multirow{2}{*}{$\begin{array}{l}\text { ORIENTA- } \\
\text { TION }\end{array}$} & $n(578 \mathrm{~m} \mu)$ & $n(546 \mathrm{~m} \mu)$ & \multicolumn{3}{|c|}{$n$} & \multirow[b]{2}{*}{ Pleochroism } \\
\hline & 1 & 2 & 3 & 4 & 5 & \\
\hline$X=c$ & 1.730 & 1.733 & $\overline{1.730}$ & $\overline{1.725}$ & $\overline{1.73}$ & $\begin{array}{l}\text { Pale yellow } \\
\text { to nearly }\end{array}$ \\
\hline$Y=a$ & 1.822 & 1.832 & 1.810 & 1.780 & 1.82 & Deep golden \\
\hline$Z=b$ & 1.829 & 1.839 & 1.815 & 1.790 & 1.83 & $\begin{array}{l}\text { Deep golden } \\
\text { yellow. }\end{array}$ \\
\hline
\end{tabular}

$2 V \quad \approx 47^{\circ} \quad-\quad \approx 35^{\circ} \approx 35^{\circ} \approx 36^{\circ}$

Biaxial negative; dispersion $r>v$ strong.

1. Brasseur (1949). 3,4. J. W. Frondel and Cuttitta (1953).

2. Brasseur (1949). - 5. Schoep and Stradiot (1948). 
Schoep and Stradiot (1948) give the pleochroism as $X$ colorless, $Y$ yellow, and $Z$ amber yellow; Vaes (1949) gives $X$ colorless, $Y$ greenish yellow, and $Z$ amber yellow. The supposed lead-bearing becquerelite described by Schoep (1922a), and later considered by Vaes (1949) to be billietite, has $n_{X} 1.75$ (colorless), $n_{Y} 1.87$ (yellow), $n_{z} 1.88$ (deep yellow), $2 V \approx 30^{\circ}, X=c, Y=a$, according to Schoep and Stradiot (1948).

Vaes (1949) states that at $100^{\circ}-110^{\circ} \mathrm{C}$ billietite becomes uniaxial negative and develops a series of cracks on $\{001\}$ parallel to the $a$ and $b$ axes; the mineral becomes biaxial again on cooling.

A plane projection on (010), showing the optical orientation, is given in figure 3 .

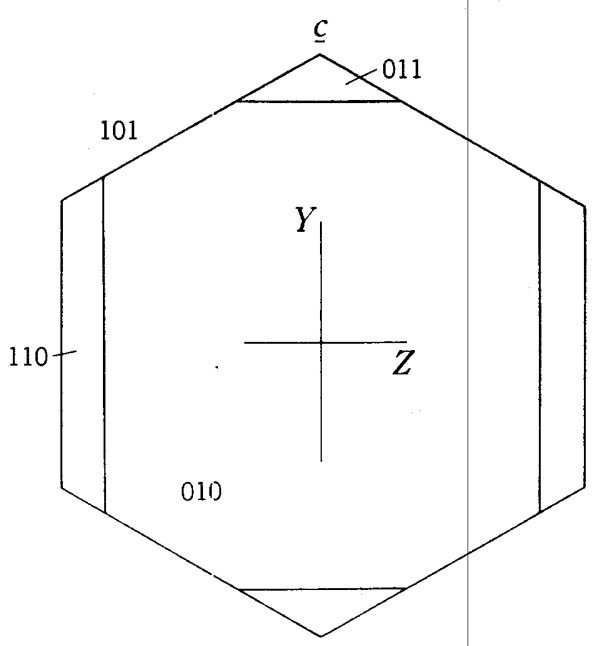

Figure 3. - Billietite. Belgian Congo. Plane projection on (010), in the orientation and unit of Vaes (1947), showing the optical orientation.

Thermal behavior

No data.

\section{Synthesis}

A phase with an X-ray powder pattern very similar to billietite was obtained by E. Berman (oral communication, 1954) by reaction of barium chloride and uranyl chloride solutions at room temperature. Obtained by Protas (1956) by reaction of uranyl acetate and barium nitrate solutions. 
Identification

Billietite is the only hydrated uranyl oxide containing $\mathrm{Ba}$ as a major and essential constituent. It can be distinguished from becquerelite, which it very closely resembles in morphology, optical properties, and X-ray powder-diffraction pattern, by a qualitative or quantitative determination of $\mathrm{Ba}$; a test for $\mathrm{Pb}$ also is advisable. The X-ray powder-spacing data are given in the following table.

\section{$X$-ray powder-spacing data for billietite ${ }^{ \pm}$}

[Symbols: b, broad; d, diffuse; vd, very diffuse. Copper radiation, nickel filter]

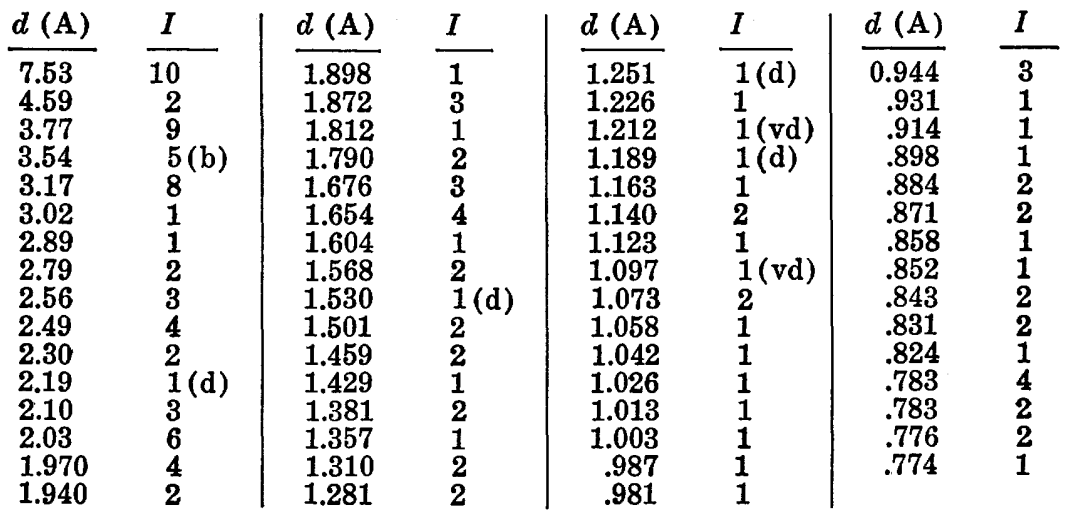

${ }^{1}$ Material from Shinkolobwe, Katanga district, Belgian Congo. (See also J. W. Frondel and Cuttitta, 1953.)

Natural formation and occurrence

Billietite is a rare secondary mineral, found as an alteration product of uraninite at Shinkolobwe, Katanga district, Belgian Congo. It occurs intimately associated with fourmarierite, uranophane, and torbernite.

\section{SCHOEPITE}

Synonymy

Schoepite Walker (1923). Paraschoepite Schoep and Stradiot (1947). Named after Alfred Schoep (1881- ), Belgian mineralogist, who has contributed much to the mineralogy of uranium. Paraschoepite is morphologically identical with schoepite, as shown by Schoep and Stradiot (1948), and otherwise is practically identical with that species except for higher indices of refraction. J. W. Frondel (oral communication, 1954) found that a sample supplied by Schoep gave X-ray single-crystal and powder photographs identical with those of schoepite, and failed to verify the reported higher indices of refraction, so that the identity of the substance with schoepite seems definitely established. 
Composition

A hydrated oxide of hexavalent uranium. The exact formula is doubtful. This is owing primarily, as in the other hydrated uranyl oxides, to the very large difference of the molar combining weights of $\mathrm{UO}_{3}$ and $\mathrm{H}_{2} \mathrm{O}$. The calculated unit-cell contents indicate that the formula is close to $4 \mathrm{UO}_{3} \cdot 9 \mathrm{H}_{2} \mathrm{O}$ or $2 \mathrm{UO}_{3} \cdot 5 \mathrm{H}_{2} \mathrm{O}$. Both the X-ray work and the analytical work, discussed below, indicate that the ratio of $\mathrm{H}_{2} \mathrm{O}$ to $\mathrm{UO}_{3}$ is greater than $2: 1$. This is of interest because $\mathrm{UO}_{3} \cdot 2 \mathrm{H}_{2} \mathrm{O}$ is the most highly hydrated of the various hydrates of $\mathrm{UO}_{3}$ reported in studies of synthetic material (see under Thermal behavior).

The reported chemical analyses of schoepite are given in the table below.

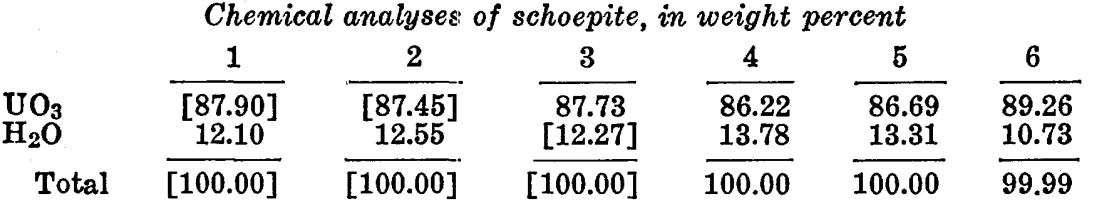

1, 2. Schoepite. Katanga. Schoep (1930). On 9.3 and $5.8 \mathrm{mg}$.

3. Schoepite. Katanga. Cuvelier, analyst, in Billiet and de Jong (1935). Average of 4 determinations on 10- to $16-\mathrm{mg}$ samples.

4 , 5. Schoepite. Katanga. Cuttitta, analyst, written communication, 1954. Analysis 4 recalculated to 100 percent after deducting $\mathrm{SiO}_{2} 2.58$ as soddyite; analysis 5 after deducting $\mathrm{SiO}_{2} 1.95$ percent as soddyite. Microanalyses.

6. Schoepite (paraschoepite). Katanga. Schoep and Stradiot (1947).

The formula was first given as $\mathrm{UO}_{3} \cdot 2 \mathrm{H}_{2} \mathrm{O}$ by Schoep (1924a), and the mineral was considered to be dimorphous with becquerelite, for which the formula also was then given as $\mathrm{UO}_{3} \cdot 2 \mathrm{H}_{2} \mathrm{O}$. Schoep (1930) later wrote the formula as $3 \mathrm{UO}_{3} \cdot 7 \mathrm{H}_{2} \mathrm{O}$ on the basis of the water determinations cited in analyses 1 and 2. Billiet and de Jong (1935) wrote it as $4 \mathrm{UO}_{3} \cdot 9 \mathrm{H}_{2} \mathrm{O}$ from the $\mathrm{UO}_{3}$ determination of analysis 3 , and found 8 of these formula-units in their $\mathrm{X}$-ray unit cell on the basis of their measured specific gravity of 4.8 (calculated specific gravity 4.83). Analyses 4 and 5 of Cuttitta, made on material containing a very small amount of soddyite, give the ratio $2 \mathrm{UO}_{3} \cdot 5 \mathrm{H}_{2} \mathrm{O}$; the X-ray study of J. W. Frondel (oral communication, 1954) on this material gives 16 formula-units in the $\mathrm{X}$-ray unit cell, using the measured specific gravity 4.96 of Schoep (1930) (calculated specific gravity 5.02 for analysis 4 and 5.04 for analysis 5). Analysis 6 of paraschoepite (= schoepite) reported by Schoep and Stradiot (1947) is close to $\mathrm{UO}_{3} \cdot 2 \mathrm{H}_{2} \mathrm{O}$. A complete analysis of very impure material is given by Schoep (1924a). The resolution of the problem will require $\mathrm{X}$-ray, chemical, and specificgravity measurements of higher accuracy than those so far reported. The possibility of variation in water content at ordinary temperatures is an added consideration. 
No analytical evidence has been found of a substitution of $\mathrm{Ba}$ or $\mathrm{Pb}$ for $\mathrm{U}$. Spectrographic analyses are lacking. Schoepite is easily soluble in dilute acids.

\section{Crystallography}

Orthorhombic, in the dipyramidal crystal class $(2 / \mathrm{m} 2 / \mathrm{m} 2 / \mathrm{m})$. An angle table for the known forms is given below. The unit cor-

Angle table for schoepite

Orthorhombic; dipyramidal, $(2 / \mathrm{m} 2 / \mathrm{m} 2 / \mathrm{m})$

\begin{tabular}{|c|c|c|c|c|c|c|}
\hline \multirow[b]{2}{*}{ FORMS } & \multicolumn{3}{|c|}{$\begin{array}{l}a_{0}: b_{0}: c_{0}=0.8516: 1: 0.8745 \\
q_{1}: r_{1}: p_{1}=0.8516: 0.9738: 1\end{array}$} & \multicolumn{2}{|c|}{$\begin{array}{l}p_{0}: q_{0}: r_{0}=1.0269: 0.8745: 1 \\
r_{2}: p_{2}: q_{2}=1.1435: 1.1743: 1\end{array}$} & \multirow[b]{2}{*}{$\rho_{2}=B$} \\
\hline & $\phi$ & $\rho=C$ & $\phi_{1}$ & $\rho_{1}=A$ & $\phi_{2}$ & \\
\hline $\begin{array}{ll}c & 001 \\
b & 010 \\
a & 100\end{array}$ & $\begin{array}{r}0^{\circ} \overline{00} \\
9000\end{array}$ & $\begin{array}{r}0^{\circ} 00^{\prime} \\
9000 \\
9000\end{array}$ & $\begin{array}{r}0^{\circ} 00^{\prime} \\
9000 \\
-\end{array}$ & $\begin{array}{c}90^{\circ} 00^{\prime} \\
9000 \\
000\end{array}$ & $\begin{array}{r}90^{\circ} 00^{\prime} \\
0 \frac{00}{0}\end{array}$ & $\begin{array}{r}90^{\circ} 00^{\prime} \\
000 \\
9000\end{array}$ \\
\hline $\begin{array}{ll}M & 210 \\
d & 011 \\
f & 021\end{array}$ & $\begin{array}{rl}66 & 56 \\
0 & 00 \\
0 & 00\end{array}$ & $\begin{array}{ll}90 & 00 \\
41 & 10 \\
60 & 141 / 2\end{array}$ & $\begin{array}{ll}90 & 00 \\
41 & 10 \\
60 & 141 / 2\end{array}$ & $\begin{array}{ll}23 & 04 \\
90 & 00 \\
90 & 00\end{array}$ & $\begin{array}{rr}0 & 00 \\
90 & 00 \\
90 & 00\end{array}$ & $\begin{array}{ll}66 & 56 \\
48 & 50 \\
29 & 451 / 2\end{array}$ \\
\hline $\begin{array}{ll}q & 112 \\
o & 111 \\
p & 211 \\
\end{array}$ & $\begin{array}{ll}49 & 35 \\
49 & 35 \\
66 & 56 \\
\end{array}$ & $\begin{array}{ll}33 & 591 / 2 \\
53 & 27 \\
65 & 521 / 2\end{array}$ & $\begin{array}{ll}23 & 37 \\
41 & 10 \\
41 & 10\end{array}$ & 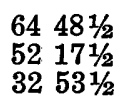 & $\begin{array}{ll}62 & 491 / 2 \\
44 & 141 / 2 \\
25 & 571 / 2\end{array}$ & $\begin{array}{l}68441 / 2 \\
58361 / 2 \\
6903\end{array}$ \\
\hline
\end{tabular}

responds to that of the X-ray cell, the orientation is that taken by Walker (1923), and the angles are the mean of the morphological measurements of Walker (1923), Palache (1934), and Ungemach (1929). The morphological data, and the X-ray single-crystal measurements that follow, were obtained on crystals from Katanga.

Unit-cell dimensions of schoepite

\begin{tabular}{|c|c|c|c|c|}
\hline & 1 & 2 & 3 & 4 \\
\hline $\begin{array}{l}a_{0} \\
b_{0} \\
c_{0}\end{array}$ & $\begin{array}{l}14.29 \mathrm{~A} \\
16.58 \\
14.69\end{array}$ & $\begin{array}{l}14.32 \mathrm{~A} \\
16.58 \\
14.75\end{array}$ & $\begin{array}{l}14.10 \mathrm{~A} \\
16.71 \\
14.75\end{array}$ & $\begin{array}{l}14.43 \mathrm{~A} \\
16.92 \\
14.78\end{array}$ \\
\hline
\end{tabular}

$a_{0}: b_{0}: c_{0} \quad 0.8619: 1: 0.8860 \quad 0.8637: 1: 0.8896 \quad 0.8438: 1: 0.8827 \quad 0.8528: 1: 0.8735$ Analysis no. 1 Opties no. 2

Space group not known.

1 See table, p. 73.

2 See table, p. 75.

1, 2, 3. J. W. Frondel (oral communication, 1954).

4. Billet and de Jong (1935).

The morphological studies of schoepite by Walker (1923), Schoep (1923a, 1924b), Buttgenbach (1925) and Ungemach (1929) are summarized by Palache (1934). The $a$-axis of the unit used by Walker (1923) and Palache (1934) was doubled by Unge- 
mach (1929). The latter unit, used in Palache, Berman and Frondel (1944, p. 627) and this publication, corresponds to the X-ray unit cell. The recent morphological study of "paraschoepite" by Schoep and Stradiot $(1947,1948)$ is in the unit and orientation of Walker (1923). Transformation, Walker to present, 200/010/ 001.

Twinning has not been observed in schoepite.

\section{Crystal habit}

Crystals of schoepite usually are tabular on $\{001\}$, and are then sometimes slightly elongated along the $b$-axis. Also equant in development, or short prismatic along the $c$-axis. $\{001\}$ may be striated parallel to the $a$-axis or the $b$-axis. Crystal drawings are given by Walker (1923), Schoep (1924b, 1930), Ungemach (1929), Palache, Berman, and Frondel (1944, p. 627), and by Schoep and Stradiot (1947).

Schoepite also occurs rarely as dense microcrystalline aggregates.

\section{Physical properties}

Cleavage $\{001\}$ perfect. Brittle. Hardness about $21 / 2$. Specific gravity 4.8 (measured, Billiet and de Jong, 1935), 4.96 (measured, Schoep, 1930); the early value of 5.685 of Schoep (1924a) is erroneous. Specific gravity (calculated), 5.02 from analysis 4 and 5.04 from analysis 5 . The value $4.49 \pm 0.05$ was reported by Bignand (1955) for natural material. Luster adamantine. Color sulfur yellow to lemon yellow, occasionally brownish yellow to amber. Powder yellow. Transparent. Fluoresces pale green in ultraviolet radiation. The fluorescence of a number of synthetic hydrates of $\mathrm{UO}_{3}$ has been described by Vier and others (1948).

Optical properties

The following data were obtained on Katanga material.

\begin{tabular}{|c|c|c|c|c|c|c|}
\hline \multirow{2}{*}{$\begin{array}{l}\text { ORIENTA- } \\
\text { TION }\end{array}$} & \multicolumn{5}{|c|}{$n$} & \multirow[b]{2}{*}{ PLeochroism } \\
\hline & 1 & 2 & 3 & 4 & 5 & \\
\hline$X=c$ & 1.690 & $\overline{1.685}$ & $\overline{1.690}$ & $\overline{1.690}$ & 1.705 & Almost color- \\
\hline$Y=b$ & 1.714 & 1.715 & 1.715 & 1.720 & 1.730 & $\begin{array}{l}\text { Bright yellow to } \\
\text { lemon yellow. }\end{array}$ \\
\hline$Z=a$ & 1.735 & 1.737 & 1.735 & 1.730 & 1.740 & $\begin{array}{l}\text { Bright yellow to } \\
\text { lemon yellow. }\end{array}$ \\
\hline $2 V$ & $85^{\circ}$ & Large & Large & $\approx 50^{\circ}$ & Large & \\
\hline
\end{tabular}

Biaxial negative; dispersion $r>v$ strong.

1. Billiet (1926).

5. George (1949).

2, 3, 4. J. W. Frondel (1954). 
The acute bisectrix is perpendicular to the perfect cleavage. The pleochroism ordinarily is as stated, but some specimens show $X$ almost colorless, $Y$ deep yellow, and $Z$ golden yellow; Buttgenbach (1947) gives $X$ and $Z$ yellow, $Y$ colorless. Schoep (1930) measured $2 \mathrm{~V}=89^{\circ} 20^{\prime}$ on Katanga material. Schoep and Stradiot (1947) give the following data for "paraschoepite": $n_{X} 1.705$ (colorless), $n_{Y}$ 1.760 (yellow), $n_{z} 1.770$ (yellow) $; 2 V \approx 46^{\circ} ; r>v ; X=c$, $Y=b$; but J. W. Frondel (1954) obtained the data of column 4 on a sample supplied by Schoep.

The small variation observed in the optical properties suggests a variation in the chemical composition, possibly a variation in water content or a substitution of $\mathrm{Pb}$ or $\mathrm{Ba}$ for $\mathrm{U}$.

Thermal behavior

A dehydration study by Schoep (1924a) of two samples of schoepite, one impure (with analysis) and the other stated to be pure, indicates that the mineral loses about three-fourths of its water $\left(\approx 7.9\right.$ percent $\left.\mathrm{H}_{2} \mathrm{O}\right)$ below $110^{\circ} \mathrm{C}$ and all of the remainder by $325^{\circ} \mathrm{C}$. At $350^{\circ} \mathrm{C}$ the mineral is orange brown in color, at $450^{\circ}-500^{\circ} \mathrm{C}$ brown, and at $850^{\circ} \mathrm{C}$ black $\left(\mathrm{U}_{3} \mathrm{O}_{8}\right)$. The data were obtained by heating the sample in air for 2 hours at each temperature. A dehydration study of natural schoepite by J. W. Frondel (oral communication, 1954), made on the material of analysis 4 by heating to constant weight in air, showed that water was lost from $\mathrm{UO}_{3} \cdot 21 / 2 \mathrm{H}_{2} \mathrm{O}$ at $35^{\circ} \mathrm{C}$ down to $\mathrm{UO}_{3} \cdot \mathrm{H}_{2} \mathrm{O}$ at $62^{\circ} \mathrm{C}$, where there was a sharp inflection in the curve with water then being lost gradually down to $\mathrm{UO}_{3} \cdot 1 / 2 \mathrm{H}_{2} \mathrm{O}$ at $200^{\circ} \mathrm{C}$; here the remaining water was lost abruptly, leaving $\mathrm{UO}_{3}$. There was no change in X-ray pattern between $62^{\circ} \mathrm{C}$ and $200^{\circ} \mathrm{C}$, but the indices of refraction increased (at $62^{\circ} \mathrm{C} n_{Y} 1.820, n_{Z} 1.827$; at $95^{\circ} \mathrm{C} n_{Y} 1.838, n_{Z} 1.845$; at $\left.180^{\circ} \mathrm{C} n_{Y} 1.857, n_{Z} 1.862\right)$; at $220^{\circ} \mathrm{C}$ the $\mathrm{UO}_{3}$ was uniaxial negative with $n_{o} 1.864$ and virtually opaque. Between $35^{\circ}$ and $62^{\circ} \mathrm{C}$ there was evidence of an inflection in the curve and an X-ray pattern at $44^{\circ} \mathrm{C}$ showed the presence of a small amount of becquerelite with the schoepite, indicating that $\mathrm{UO}_{3} \cdot 11 / 2 \mathrm{H}_{2} \mathrm{O}$ exists in this region; at $54^{\circ} \mathrm{C}$ the pattern was largely that of $\mathrm{UO}_{3} \cdot \mathrm{H}_{2} \mathrm{O}$. Somewhat different results were obtained by Bignand (1955), who found a loss of 1.5 percent $\mathrm{H}_{2} \mathrm{O}$ between $20^{\circ}$ and $60^{\circ} \mathrm{C}$ without change in the X-ray diffraction pattern; between $60^{\circ}$ and $180^{\circ} \mathrm{C} 5.4$ percent more $\mathrm{H}_{2} \mathrm{O}$ was lost, with the formation of $\mathrm{UO}_{3} \cdot \mathrm{H}_{2} \mathrm{O}$; between $180^{\circ}$ and $380^{\circ} \mathrm{C}$ another 5.4 percent $\mathrm{H}_{2} \mathrm{O}$ was lost and anhydrous $\mathrm{UO}_{3}$ was formed; over $380^{\circ} \mathrm{C}$ oxygen was lost with the formation ultimately of $\mathrm{U}_{3} \mathrm{O}_{8}$. It also has been observed that a transparent 
crystal of schoepite was converted to an opaque, yellow pseudomorph of a lower hydrate when exposed to sunlight at room temperature.

A summary discussion of the phase relations in the system $\mathrm{UO}_{3}-\mathrm{H}_{2} \mathrm{O}$ is given by Katz and Rabinowitch (1951). The following synthetic hydrates have been reported: $2 \mathrm{UO}_{3} \cdot \mathrm{H}_{2} \mathrm{O}$, monoclinic with a perfect cleavage; $\mathrm{UO}_{3} \cdot \mathrm{H}_{2} \mathrm{O}$ in 4 polymorphic modifications, 1 hexagonal, 1 triclinic(?) and 2 orthorhombic; $2 \mathrm{UO}_{3} \cdot 3 \mathrm{H}_{2} \mathrm{O} ; \mathrm{UO}_{3} \cdot$ $2 \mathrm{H}_{2} \mathrm{O}$ in 2 polymorphic modifications, tetragonal(?) and orthorhombic; and $\mathrm{UO}_{3}$, with maybe 4 or 6 polymorphs. A natural material with the composition $\mathrm{UO}_{3} \cdot 2 \mathrm{H}_{2} \mathrm{O}$, orthorhombic in crystallization and distinct from schoepite and masuyite, has been described by J. W. Frondel and Cuttitta (1954) as an alteration of ianthinite (see p. 62). The upper limit of stability of $\mathrm{UO}_{3} \cdot 2 \mathrm{H}_{2} \mathrm{O}$ in contact with liquid water is at about $60^{\circ} \mathrm{C}$. A study of the thermal decomposition of $\mathrm{UO}_{2} \cdot 2 \mathrm{H}_{2} \mathrm{O}$ by heating under constant $\mathrm{H}_{2} \mathrm{O}$ pressure of about $15 \mathrm{~mm}$ of $\mathrm{Hg}$, by Hüttig and von Schroeder (1922), showed that $\mathrm{UO}_{2} \cdot 2 \mathrm{H}_{2} \mathrm{O}$ gradually lost $1 / 2 \mathrm{H}_{2} \mathrm{O}$ between $30^{\circ}$ and $100^{\circ} \mathrm{C}$ where the composition was $2 \mathrm{UO}_{3} \cdot 3 \mathrm{H}_{2} \mathrm{O}$, another $1 / 2 \mathrm{H}_{2} \mathrm{O}$ was lost suddenly at $100^{\circ} \mathrm{C}$ leaving $\mathrm{UO}_{3} \cdot \mathrm{H}_{2} \mathrm{O}$, a third $1 / 2 \mathrm{H}_{2} \mathrm{O}$ was lost gradually between $100^{\circ}$ and $300^{\circ} \mathrm{C}$, where the composition was $2 \mathrm{UO}_{3} \cdot \mathrm{H}_{2} \mathrm{O}$, and the last $1 / 2 \mathrm{H}_{2} \mathrm{O}$ was lost suddenly at $300^{\circ} \mathrm{C}$ leaving $\mathrm{UO}_{3}$.

\section{Synthesis}

A yellow hydrate obtained by oxidizing in air a moist violetblack precipitate of $\mathrm{UO}_{2} \cdot n \mathrm{H}_{2} \mathrm{O}($ ?), formed by the photochemical reduction of an alcoholic solution of uranyl acetate, was identified as schoepite by its X-ray powder pattern (C. Frondel, written communication, 1952). Obtained by reaction of uranyl sulfate solution with solid calcite or aragonite by Gruner (1953) ; also by boiling a solution of $50 \mathrm{mg}$ of uranyl acetate in $500 \mathrm{cc}$ of water (Bignand, 1955).

\section{Identification}

The indices of refraction of schoepite are lower than those of any other hydrated uranyl oxide with or without barium or lead. The X-ray powder photograph is distinctive, but bears a resemblance to those of fourmarierite, vandendriesscheite, and masuyite. In its crystal habit and general appearance schoepite closely resembles other uranyl oxides and cannot be recognized with certainty at sight. The X-ray powder-spacing data are given in the following table. 
$X$-ray powder-spacing data for schoepite ${ }^{1}$

[Copper radiation, nickel filter]

\begin{tabular}{lr|ll|ll|ll}
$\frac{d(\mathrm{~A})}{7.49}$ & $\frac{I}{10}$ & $\frac{d(\mathrm{~A})}{2.48}$ & $\frac{I}{3}$ & $\frac{d(\mathrm{~A})}{1.766}$ & $\frac{I}{3}$ & $\frac{d(\mathrm{~A})}{1.373}$ & $\frac{I}{3}$ \\
6.74 & 1 & 2.35 & 2 & 1.681 & 1 & 1.347 & 1 \\
6.09 & 2 & 2.27 & 1 & 1.648 & 5 & 1.298 & 2 \\
4.08 & 2 & 2.21 & 1 & 1.604 & 3 & 1.231 & 1 \\
3.64 & 8 & 2.10 & 4 & 1.561 & 1 & 1.211 & 2 \\
3.26 & 9 & 2.05 & 6 & 1.523 & 1 & 1.199 & 2 \\
3.01 & 1 & 1.981 & 1 & 1.481 & 2 & 1.170 & 3 \\
2.83 & 2 & 1.910 & 2 & 1.457 & 2 & 1.141 & 2 \\
2.60 & 7 & 1.835 & 4 & 1.393 & 2 & &
\end{tabular}

1 Analyzed specimen from the Katanga district, Belgian Congo.

Natural formation

Schoepite is a secondary mineral usually formed by the alteration of uraninite and found closely associated with that species. Typical associated minerals include becquerelite, billietite, vandendriesscheite, fourmarierite, ianthinite, curite, and soddyite.

\section{Occurrence}

Originally found at Kasolo, Katanga district, Belgian Congo; later found at Shinkolobwe (paraschoepite). Reported from Wölsendorf, Bavaria, with ianthinite and becquerelite (Schoep and Scholz, 1931). Found as fine-grained pseudomorphs after uraninite at Beryl Mountain near Acworth, N. H. (Frondel, 1956b). The mineral is relatively abundant in the Katanga district, but good specimens are rare. Schoepite has been found in very small amounts as an alteration product of uraninite at localities on the Colorado Plateau, as at the Consolidated mine on Green Vein Mesa, San Rafael Swell, Emery County; the Happy Jack mine in White Canyon, and the Frey No. 4 mine in Red Canyon, San Juan County, and the Oyler Tunnel claim, near Fruita, Wayne County, all in Utah (Gruner and others, 1954a); also at the Monument No. 2 mine, Monument Valley, Navajo County, Ariz. (C. Frondel, 1956a). Reported from the Beckey Lynn claim in Carbon County, Wyo. (Gruner and Smith, written communication, 1955). Found at Margnac II, Haute-Vienne, France (Guillemin and Pierrot, 1956a).

\section{MASUYITE}

Synonymy

Masuyite Vaes (1947). Named after Gustave Masuy (d.1945), Belgian geologist.

Composition

Originally said on the basis of qualitative tests to be a lead uranyl oxide, probably hydrated. A microchemical analysis of a sample supplied by Vaes, however, has proved the mineral to be 
a hydrated uranyl oxide, without lead, with the formula $\mathrm{UO}_{3} \cdot 2 \mathrm{H}_{2} \mathrm{O}$. Masuyite, epi-ianthinite, schoepite, and becquerelite all have the same or nearly the same chemical composition. Chemical analysis, in weight percent, is as follows:

\begin{tabular}{|c|c|c|}
\hline & 1 & 2 \\
\hline $\begin{array}{l}\mathrm{UO}_{3} \\
\mathrm{H}_{2} \mathrm{O}\end{array}$ & $\begin{array}{l}88.81 \\
11.19\end{array}$ & $\begin{array}{l}88.84 \\
11.05\end{array}$ \\
\hline Total & 100.00 & 99.89 \\
\hline
\end{tabular}

1. Theoretical weight percentages, $\mathrm{UO}_{3} \cdot 2 \mathrm{H}_{2} \mathrm{O}$.

2. Masuyite. Katanga. Cuttitta, analyst (written communication, 1953), microanalysis. Contains traces of $\mathrm{Ba}, \mathrm{Ca}, \mathrm{Li}$. $\mathrm{H}_{2} \mathrm{O}$ determined as loss on ignition.

Crystallography

Orthorhombic, crystal class not known. Crystals from the material of analysis 2 , examined by J. W. Frondel (oral communication, 1953), were tabular on $\{001\}$ with a perfect cleavage parallel thereto, with $\{100\},\{010\},\{110\}$, and $\{150\}$. Measured $\varphi$ angles and calculated $\varphi$ angles (from the structure cell) for the prism forms are: $\{110\} 42^{\circ} 30^{\prime}$ measured, $42^{\circ} 32^{\prime}$ calculated; $\{150\}$ $10^{\circ} 03^{\prime}$ measured, $10^{\circ} 03^{\prime}$ calculated.

$\mathrm{X}$-ray single-crystal study of material from Shinkolobwe gave the following data:

\begin{tabular}{cccc}
\multicolumn{4}{c}{ Unit-cell alimensions of masuyite } \\
$a_{0}$ & $\frac{1}{13.90 \mathrm{~A}}$ & $14.09 \mathrm{~A}$ & Space group Pcna (Brasseur, \\
$b_{0}$ & 12.31 & 12.08 & $1950) ;$ unit-cell contents \\
$c_{0}$ & 14.92 & 14.27 & $24\left[\mathrm{UOO}_{3} \cdot 2 \mathrm{H}_{2} \mathrm{O}\right]$. \\
\hline
\end{tabular}

$a_{0}: b_{0}: c_{0}$

$1.129: 1: 1.212$

1. J. W. Frondel (oral communication, 1953).

2. Brasseur (1950).

The material described by Brasseur (1950) differs slightly from that of J. W. Frondel; it has smaller cell dimensions, smaller $2 \mathrm{~V}$ $\left(401 / 2^{\circ}\right)$, and higher $n_{y}(\approx 2.13)$. X-ray powder and single-crystal data indicate that masuyite is closely related structurally to vandendriesscheite and fourmarierite; there also are dimensional relations to billietite and becquerelite.

The crystals originally described by Vaes (1947) were tablets with the plane angles (measured under the microscope) and axes shown in figure 4. This morphology does not agree closely with that of the crystals described above. Assuming that the two substances are the same, then on the basis of the observed optical orientations the axes $a b c$ of Vaes correspond to $a c b$, respectively, in the orientation taken above. The latter orientation corresponds to that taken for the hydrated uranyl oxides in general 
by Palache (1934) and Palache, Berman, and Frondel (1944); in it the plane of flattening and cleavage is taken as $\{001\}$ and the vibration direction $X$ is perpendicular thereto, uniformly.

Vaes notes both simple and repeated twins on two different laws (fig. 4), with $\{001\}$ coplanar in each.

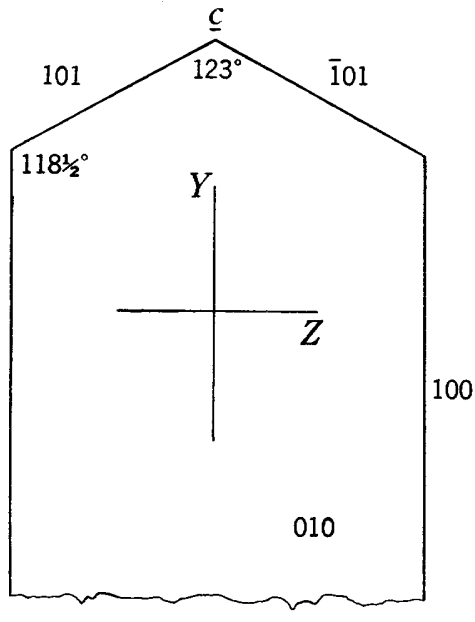

$A$

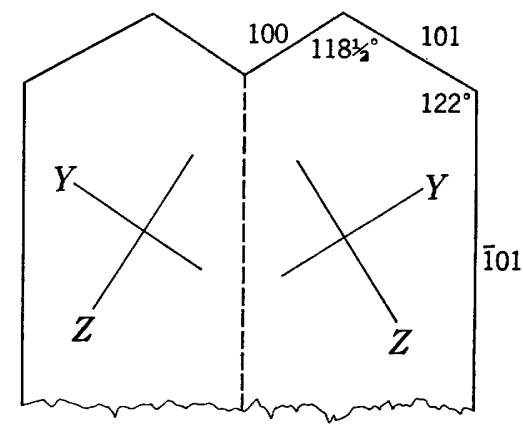

$B$

Fraurg 4.-Masuyite. Belgian Congo. A. Plane projection on (010), after Vaes (1947), showing the optical orientation. B. Plane projection (010), after Vaes (1947), of a twin crystal.

Physical properties

Cleavage $\{001\}$ perfect. Hardness not known. Specific gravity 5.08 (measured) ; 5.028 (calculated). Color orange red to orange. Transparent. Not fluorescent in ultraviolet light.

Optical properties

\begin{tabular}{|c|c|c|c|}
\hline ORIENTATION & $n$ & Pleochroism & \\
\hline $\begin{array}{l}X=c \\
Y=b \\
Z=a\end{array}$ & $\begin{array}{l}1.785 \\
1.906 \\
1.917\end{array}$ & $\begin{array}{l}\text { Pale yellow. } \\
\text { Deep golden. } \\
\text { Deep golden. }\end{array}$ & $\begin{array}{l}\text { Biaxial negative; } r>v \\
\quad \text { moderate; } 2 V \text { about } 50^{\circ} .\end{array}$ \\
\hline
\end{tabular}

The acute bisectrix is perpendicular to the perfect cleavage. The above data were obtained by J. W. Frondel (oral communication, 1953 ) on the material of analysis 2 . The optical orientation refers to the new crystal orientation. Vaes (1947) gives the same optical orientation (in his crystal orientation), but he gives $n_{X}$ and $n_{Z}$ between 2.11 and 2.15 and $2 \mathrm{~V}$ large. His optical measurements were made in sulfur-selenium melts and the high indices may be due to partial dehydration due to heat; his values, however, are consistent with his statement that the mineral contains lead. 
Identification

Not easily distinguished from the other hydrated uranyl oxides by outward appearance. The indices of refraction are lower than those of curite and fourmarierite and higher than those of vandendriesscheite, schoepite, and becquerelite. The X-ray powder pattern, obtained on the sample from Vaes for which optics and an analysis are cited above, is very close to that of vandendriesscheite. The X-ray powder-spacing data are given in the following table.

$X$-ray powder-spacing data for masuyite ${ }^{1}$

[Symbols: d, diffuse; vd, very diffuse. Copper radiation, nickel filter]

\begin{tabular}{|c|c|c|c|c|c|c|c|}
\hline$d(\mathrm{~A})$ & $I$ & $d(\mathrm{~A})$ & $I$ & $d(\mathrm{~A})$ & $I$ & $d(\mathrm{~A})$ & $I$ \\
\hline $\begin{array}{l}\mathbf{8 . 5 3} \\
\mathbf{7 . 1 0} \\
\mathbf{6 . 4 3} \\
\mathbf{4 . 8 0} \\
\mathbf{4 . 3 5} \\
\mathbf{3 . 9 2} \\
\mathbf{3 . 5 4}\end{array}$ & $\begin{array}{r}1 \\
10 \\
2 \\
1 \\
4 \\
2 \\
8\end{array}$ & $\begin{array}{l}3.15 \\
2.97 \\
2.74 \\
2.51 \\
2.38 \\
2.06 \\
1.984\end{array}$ & $\begin{array}{l}9 \\
1 \\
3 \\
5 \\
2 \\
1 \\
6\end{array}$ & $\begin{array}{l}1.908 \\
1.784 \\
1.727 \\
1.697 \\
1.662 \\
1.598 \\
1.510\end{array}$ & $\begin{array}{l}3 \\
4 \text { (d) } \\
2 \\
1 \\
1 \\
2 \\
2\end{array}$ & $\begin{array}{l}1.421 \\
1.380 \\
1.349 \\
1.329\end{array}$ & $\begin{array}{l}1(d) \\
1(v d) \\
2 \\
2\end{array}$ \\
\hline
\end{tabular}

1 Material from the Katanga district, Belgian Congo.

Natural formation and occurrence

Masuyite is a secondary mineral, found as tiny crystals lining cavities in uraninite at Shinkolobwe, Katanga district, Belgian Congo.

\section{VANDENDRIESSCHEITE}

Synonymy

"Mineral X" Palache and Berman (1933); Palache (1934). Vandendriesscheite Vaes (1947). Vandendriesscheite was named after Adrien Vandendriessche (1914-40), Belgian mineralogist and geologist. The identity of vandendriesscheite with "Mineral X" (the better defined of the two substances) was established by J. W. Frondel (oral communication, 1954) by study of the type material of Palache and Berman from Great Bear Lake and of a specimen supplied by Vaes of vandendriesscheite from Katanga. Although there seems to be no doubt that vandendriesscheite is a valid species, our knowledge of the mineral is unsatisfactory in several respects and a unified treatment cannot be presented of all of the crystallographic and other data that have been reported. Composition

A hydrated oxide of lead and hexavalent uranium of uncertain formula. The three available analyses, cited in the table below, afford ratios fairly close to $\mathrm{PbO}^{2} \cdot 7 \mathrm{UO}_{3} \cdot 12 \mathrm{H}_{2} \mathrm{O}$. 
Chemical analyses of vandendriesscheite, in weight percent

\begin{tabular}{|c|c|c|c|c|}
\hline & 1 & 2 & 3 & 4 \\
\hline $\begin{array}{l}\mathrm{UO}_{3} \\
\mathrm{PbO} \\
\mathrm{H}_{2} \mathrm{O} \\
\mathrm{SiO}_{2}\end{array}$ & $\begin{array}{r}82.00 \\
9.14 \\
8.86 \\
\end{array}$ & $\begin{array}{r}82.36 \\
8.86 \\
9.26 \\
\end{array}$ & $\begin{array}{r}81.63 \\
9.64 \\
8.73 \\
\end{array}$ & $\begin{array}{r}80.48 \\
11.25 \\
6.86 \\
.65\end{array}$ \\
\hline Total & $\overline{100.00}$ & 100.48 & 100.00 & $\overline{99.24}$ \\
\hline $\begin{array}{l}\text { Spgr: } \\
\text { Meas. } \\
\text { Calc. }\end{array}$ & $=$ & $\begin{array}{l}5.46 \\
5.61\end{array}$ & $4 . \overline{66}$ & $\begin{array}{l}4.72 \\
4.69\end{array}$ \\
\hline
\end{tabular}

1. Theoretical weight percentages, $\mathrm{PbO} \cdot 7 \mathrm{UO}_{3} \cdot 12 \mathrm{H}_{2} \mathrm{O}$.

2. Vandendriesscheite. Katanga. Cuttitta, analyst (written communication, 1954). Sample obtained from Vaes.

3. "Mineral X." Great Bear Lake. Gonyer, analyst, in Palache and Berman (1933). Recalculated to 100 percent after deducting 4.10 percent insoluble; original sum 97.65 .

4. Vandendriesscheite. Katanga. Cuttitta, analyst (written communication, 1954). Sample identified as vandendriesscheite by $\mathrm{X}$-ray study. The $\mathrm{SiO}_{2}$ may be due to admixture, but the analyzed sample appeared to be homogeneous.

There is a wide variation in the optical properties, unit-cell dimensions, and specific gravity of vandendriesscheite, presumably stemming from a variation in the $\mathrm{Pb}: \mathrm{U}$ ratio and perhaps also from variation in the degree of hydration, for which the analyses themselves provide some evidence, but the exact mechanism of the variation has not been identified. The X-ray powder pattern of vandendriesscheite is very similar to that of masuyite, which does not contain lead, and a series possibly extends between these species.

Crystallography and crystal habit

Orthorhombic; the crystal class is not known, but probably is dipyramidal $\left(2 / \mathrm{m}^{2} / \mathrm{m} 2 / \mathrm{m}\right)$. The crystals are small and imperfect, and are commonly intergrown in subparallel position or are composite. In habit, they generally are tablets flattened on $\{001\}$ with a pseudohexagonal or diamond-shaped outline (fig. 5). Also found as short laths flattened on $\{001\}$ and elongated along the $b$-axis with acute terminations; or short prismatic along the $c$-axis. Sometimes found as dense, microcrystalline aggregates.

Several morphological studies have been made of vandendriesscheite, but the data, summarized in the accompanying table, are in poor agreement. This doubtless is due largely to the small size and poor quality of the available crystals. The crystals are here described in the orientation of Palache and Berman (1933) on "Mineral X" from Great Bear Lake, in which the plane of perfect cleavage and flattening is taken as $\{001\}$, but with the $a$-axis of his unit doubled to conform to the X-ray structure cell of J. W. Frondel (oral communication, 1954). Palache's morphological elements, obtained on very inferior crystals, diverge considerably from the $\mathrm{X}$-ray elements obtained on the same crystals. Vaes 


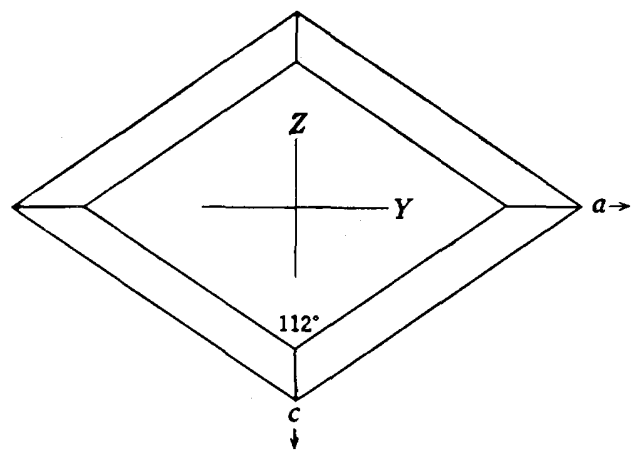

$A$

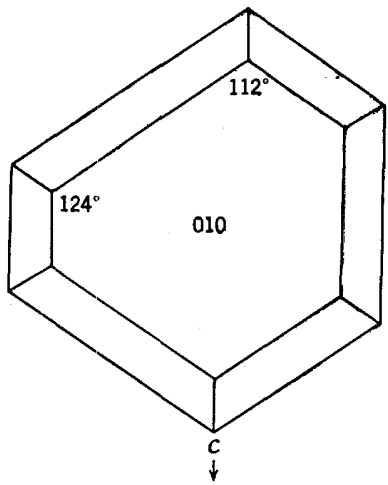

$B$

Figure 5.-Vandendriesscheite. Belgian Congo. $A, B$. Plane projection on $(010)$, in the orientation of Vaes (1947).

(1947) describes the vandendriesscheite crystals from Katanga in another orientation, with Vaes $c a b=a b c$ of Palache, and reports a few plane angles measured under the microscope. Thoreau (1948) measured Katanga crystals of poor quality; he used the orientation of Palache and Berman (1933) on "Mineral X," although unaware that this mineral was identical with vandendriesscheite, but his unit cannot be reconciled with that of Palache and Berman (1933) or those of the morphological or X-ray cells of the Katanga material described by J. W. Frondel (oral communication, 1954). Thoreau's material was supplied by Vaes and must be presumed to be authentic. One of the two Katanga specimens described by J. W. Frondel also was supplied by Vaes.

The unit-cell dimensions of four different specimens of vandendriesscheite, three of them analyzed chemically, have been determined by single-crystal methods by J. W. Frondel. These data are summarized in the table below. There is reasonably good agreement between the measured morphological angles and the calculated angles from the unit cell for the material of analysis 2 . The measured and calculated angles of the material of analysis 3 differ

Unit-cell dimensions of vandendriesscheite

\begin{tabular}{|c|c|c|c|c|}
\hline & 1 & 2 & 3 & 4 \\
\hline $\begin{array}{l}a_{0} \\
b_{0} \\
c_{0}\end{array}$ & $\begin{array}{l}13.96 \mathrm{~A} \\
14.36 \\
14.41\end{array}$ & $\begin{array}{l}14.12 \mathrm{~A} \\
16.75 \\
14.72\end{array}$ & $\begin{array}{l}14.01 \mathrm{~A} \\
16.80 \\
14.68\end{array}$ & $\begin{array}{l}13.99 \mathrm{~A} \\
16.44 \\
14.30\end{array}$ \\
\hline
\end{tabular}

$a_{0}: b_{0}: c_{0} \quad 0.9722: 1: 1.003 \quad 0.8430: 1: 0.8788 \quad 0.8339: 1: 0.8738 \quad 0.8510: 1: 0.8698$

Analysis no. ${ }^{1}$

Morphol. no. ${ }^{2}$

Optics no. ${ }^{3}$

Locality

$\mathbf{2}$
$\mathbf{3}$
$\mathbf{2}$

Katanga district.

1 See table, p. 82.

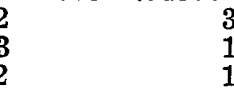

3
1
1

Great Bear

Lake.

${ }^{2}$ See table, p. 84.

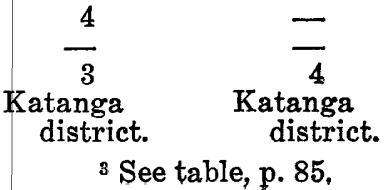


considerably. The X-ray Weissenberg photographs generally showed a faint system of extra spots superposed on and irrationally related to the main diffraction pattern. The crystals did not show any twinning that could be detected optically.

Morphological data for vandendriesscheite

[Indices given in the orientation and unit of the respective authors]

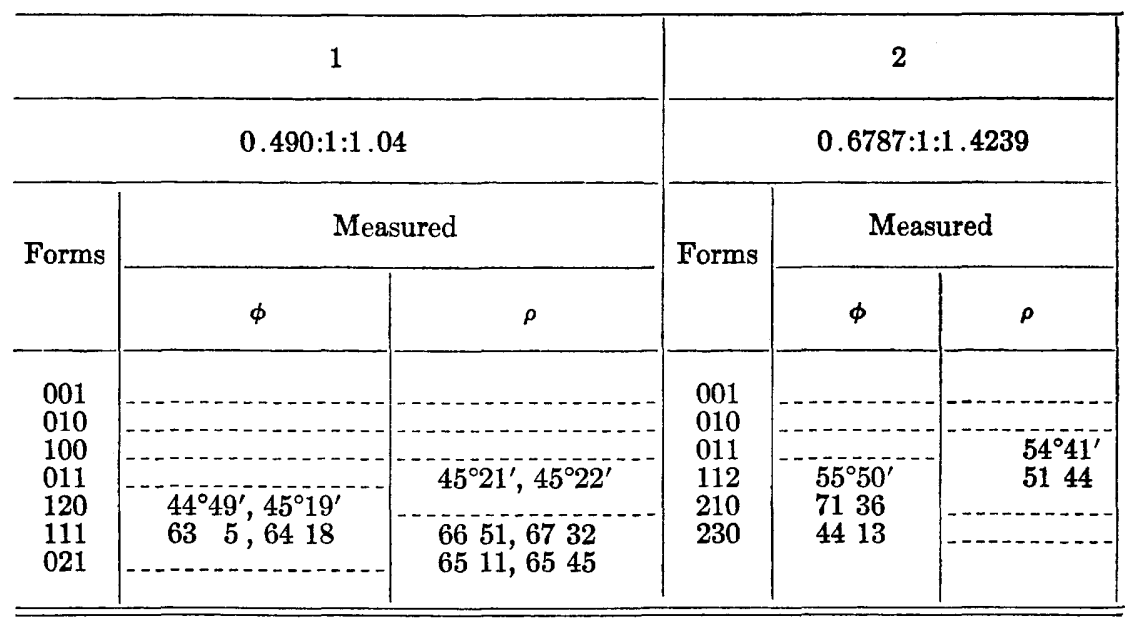

3

$0.9722: 1: 1.003$ (X-ray)

\begin{tabular}{|c|c|c|c|c|}
\hline \multirow{2}{*}{ Forms } & \multicolumn{2}{|c|}{ Measured } & \multicolumn{2}{|c|}{ Calculated (X-ray) } \\
\hline & $\phi$ & $\rho$ & $\phi$ & $\rho$ \\
\hline $\begin{array}{l}001 \\
010 \\
100 \\
110 \\
210 \\
310 \\
120 \\
130 \\
403 \\
233\end{array}$ & $\begin{array}{rr}0^{\circ} & 00^{\prime} \\
90 & 00 \\
45 & 43 \\
64 & 17 \\
18 & 32 \\
27 & 35 \\
71 & 5 \\
90 & 00 \\
34 & 23\end{array}$ & $\begin{array}{lll}90^{\circ} & 00^{\prime} \\
90 & 00 \\
90 & 00 \\
90 & 00 \\
90 & 00 \\
90 & 00 \\
90 & 00 \\
54 & 39 \\
51 & 34\end{array}$ & 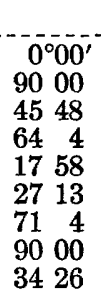 & $\begin{array}{lll}90^{\circ} & 00^{\prime} \\
90 & 00 \\
90 & 00 \\
90 & 00 \\
90 & 00 \\
90 & 00 \\
90 & 00 \\
54 & 00 \\
50 & 35\end{array}$ \\
\hline
\end{tabular}

1. Great Bear Lake. Analysis 3 (see table, p. 82). Palache and Berman (1933).

2. Katanga district. Thoreau (1948).

3. Katanga district. Analysis 2 (see table, p. 82). J. W. Frondel (oral communication, 1954). 
Physical properties

Cleavage $\{001\}$ perfect. Hardness about 3 . The specific gravity varies widely between at least 4.6 and 5.6, for reasons not known. Color commonly orange amber to golden brown and yellowish brown; also orange to reddish orange. Luster adamantine. Transparent. Not fluorescent in ultraviolet radiation.

Optical properties

\begin{tabular}{|c|c|c|c|c|c|c|}
\hline \multirow{2}{*}{$\begin{array}{l}\text { ORIENTA- } \\
\text { TION }\end{array}$} & \multicolumn{4}{|c|}{$n$} & \multirow{2}{*}{$\begin{array}{l}\text { PLEOCH- } \\
\text { ROISM }\end{array}$} & \multirow{3}{*}{$\begin{array}{l}\text { Biaxial } \\
\text { s. negative. }\end{array}$} \\
\hline & 1 & 2 & 3 & 4 & & \\
\hline$X=c$ & 1.785 & $\overline{1.790}$ & 1.760 & - & Near & \\
\hline$Y=b$ & 1.810 & 1.840 & 1.824 & 1.882 & Golden & \\
\hline$Z=a$ & 1.820 & 1.845 & 1.828 & 1.890 & $\begin{array}{l}\text { Golden } \\
\text { yellow. }\end{array}$ & \\
\hline
\end{tabular}

\begin{tabular}{ccccc}
\hline $2 V$ & Med. & Med. & $50^{\circ}$ & Med. \\
Analysis no. & 3 & 2 & 4 & - \\
Unit cell no. & $\mathbf{2}$ & $\mathbf{1}$ & $\mathbf{3}$ & $\mathbf{4}$
\end{tabular}

1 See table, p. 82 .

2 See table, p. 83.

1. Great Bear Lake. Palache and Berman (1933).

2, 3, 4. Katanga. J. W. Frondel (oral communication, 1954).

Vaes (1947) gave a corresponding optical orientation in his position for the crystals, with $2 V$ large, $r>v$ strong, and corresponding pleochroism. The indices $n_{Z}$ and $n_{Y}$ are described by Vaes as between 1.884 and $n_{z}$ of fourmarierite $(\approx 1.94)$; these high indices probably are due to partial dehydration in the melts used. It is stated that the crystals when heated develop a rectangular series of cracks on the cleavage plane, one set, more distinct than the other, parallel to $Z$.

Only the mean index of refraction can be measured on most of the fine-grained vandendriesscheite that forms the substance of some gummite pseudomorphs after uraninite. This index usually varies from about 1.77-1.82. Some material tentatively identified as vandendriesscheite on the basis of X-ray powder patterns has $n_{X}$ down to 1.71-1.74. The indices of refraction of vandendriesscheite vary by at least 0.04 , presumably owing to variation in composition or water content.

Thermal behavior and synthesis

No data. 
Identification

Best distinguished from the other hydrated lead-uranyl and uranyl oxides by its $\mathrm{X}$-ray powder-diffraction pattern and optics. Color is not a reliable criterion, although fourmarierite and especially curite generally are a deeper shade of orange red to scarlet. The platy, pseudohexagonal habit resembles that of many other hydrated uranyl oxides. The indices of refraction are less than those of curite and fourmarierite and greater than those of schoepite, billietite, and becquerelite. The X-ray powder-spacing data are given in the following table.

\section{$X$-ray powder-spacing data for vandendriesscheite ${ }^{1}$}

[Symbol: $d$, diffuse. Copper radiation, nickel filter]

\begin{tabular}{|c|c|c|c|c|c|c|c|}
\hline$d(\mathrm{~A})$ & $I$ & $d(\mathrm{~A})$ & $I$ & $d(\mathrm{~A})$ & $I$ & $d(\mathrm{~A})$ & $I$ \\
\hline $\begin{array}{l}7.41 \\
6.49 \\
4.58 \\
4.27 \\
3.94 \\
3.61 \\
3.22 \\
2.83 \\
2.55 \\
2.43 \\
2.32 \\
2.05 \\
2.01 \\
1.886 \\
1.811 \\
1.783\end{array}$ & $\begin{array}{l}8 \\
2 \\
2(\mathrm{~d}) \\
1 \\
1 \\
9 \\
10 \\
2 \\
4 \\
3 \\
2 \\
3 \\
4 \\
1(\mathrm{~d}) \\
3 \\
3\end{array}$ & $\begin{array}{l}1.734 \\
1.687 \\
1.646 \\
1.613 \\
1.563 \\
1.524 \\
1.420 \\
1.381 \\
1.338 \\
1.304 \\
1.266 \\
1.202\end{array}$ & $\begin{array}{l}2 \\
1 \\
1 \\
2 \\
1 \\
2 \\
1(d) \\
1(d) \\
2 \\
1 \\
2 \\
1\end{array}$ & $\begin{array}{l}8.27 \\
7.31 \\
6.49 \\
4.85 \\
4.39 \\
4.14 \\
3.93 \\
3.58 \\
3.37 \\
3.19 \\
3.00 \\
2.73 \\
2.53 \\
2.40 \\
2.32 \\
2.05\end{array}$ & $\begin{array}{r}2 \\
10 \\
3 \\
1 \\
2 \\
1 \\
2 \\
8 \\
1 \\
9 \\
1 \\
3 \\
5 \\
2 \\
1 \\
2\end{array}$ & $\begin{array}{l}1.989 \\
1.908 \\
1.797 \\
1.773 \\
1.726 \\
1.699 \\
1.657 \\
1.601 \\
1.566 \\
1.510 \\
1.419 \\
1.349 \\
1.332 \\
1.312 \\
1.263\end{array}$ & $\begin{array}{l}7 \\
3 \\
3 \\
5 \\
3 \\
2 \\
3 \\
4 \\
2 \\
2 \\
2 \\
2 \\
2 \\
1 \\
2\end{array}$ \\
\hline
\end{tabular}

1 Material from the Katanga district, Belgian Congo. Optical and other evidence indicate that the two sets of slightly divergent data here reported both represent essentially the same mineral.

Natural formation

Vandendriesscheite is a secondary mineral formed by the alteration of uraninite and found associated chiefly with fourmarierite.

\section{Occurrence}

Originally described as "Mineral $\mathrm{X}$ " from Great Bear Lake, Canada, where it occurs as minute crystals associated with fourmarierite on altered uraninite. Later described under the name vandendriesscheite from Shinkolobwe, Katanga, Belgian Congo. A mineral identified as vandendriesscheite on the basis of qualitative chemical tests and its X-ray diffraction pattern and optics, occurs as a constituent of the orange-red oxidic zone of alteration of the so-called "gummite" pseudomorphs after uraninite (C. Frondel, 1956b). The following localities have been reported: Newry, Maine; the Palermo and Ruggles pegmatites in New Hampshire; numerous pegmatites in the Spruce Pine district, Mitchell County, and Crabtree Creek, Yancey County, both in North Carolina; 
Joachimsthal, Bohemia; and Katanga, Belgian Congo. It was doubtfully identified from a number of other places, and the mineral seems to be more common than fourmarierite.

\section{FOURMIARIERITE}

\section{Synonymy}

Fourmarierite Buttgenbach (1924). Named after Paul Fourmarier (1877- ), Belgian geologist.

\section{Composition}

A hydrated oxide of lead and hexavalent uranium. The formula is uncertain. None of the reported analyses cited in the table below was made on wholly pure material and the summations are unsatisfactory. Mélon (1924) proposed the formula $\mathrm{PbO} \cdot 5 \mathrm{UO}_{3} \cdot 10 \mathrm{H}_{2} \mathrm{O}$ from analyses 4 and 5 after deducting impurities, and Schoep (1924a) derived $\mathrm{PbO} \cdot 4 \mathrm{UO}_{3} \cdot 5 \mathrm{H}_{2} \mathrm{O}$ from analyses 6 and 7. Brasseur (1948), extending earlier work (Brasseur, 1941, 1946) in the light of a new measurement of the specific gravity, finds that the most probable formula for the mineral is either $\mathrm{PbO} \cdot 4 \mathrm{UO}_{3} \cdot 7 \mathrm{H}_{2} \mathrm{O}$ or $\mathrm{PbO} \cdot 4 \mathrm{UO}_{3} \cdot 8 \mathrm{H}_{2} \mathrm{O}$. The synthetic material of analysis 8 is close to $\mathrm{PbO} \cdot 4 \mathrm{UO}_{3} \cdot 51 / 2 \mathrm{H}_{2} \mathrm{O}$. The question whether the lead-uranium ratio is variable (see Schoep, 1924a) or is fixed remains open. There is evidence that a series may extend to hydrated lead diuranate $\left(\mathrm{PbU}_{2} \mathrm{O}_{7} \cdot n \mathrm{H}_{2} \mathrm{O}\right)$. (See Synthesis.) Barium has not been reported in fourmarierite. A hydrated barium uranyl oxide with nearly the same X-ray powder pattern as fourmarierite has been synthesized.

\begin{tabular}{|c|c|c|c|c|c|c|c|c|}
\hline & 1 & 2 & 3 & 4 & 5 & 6 & 7 & 8 \\
\hline $\mathrm{bo}$ & 15.31 & 12.26 & 15.83 & 18.31 & 12.93 & 15.25 & 12.11 & 15.7 \\
\hline$U$ & $78 . \overline{51}$ & $77 . \overline{67}$ & 77.79 & 66.87 & $\begin{array}{r}1.05 \\
73.32\end{array}$ & 75.13 & 77.23 & 77.2 \\
\hline $\mathrm{Fe}_{2} \mathrm{O}_{3}$ & - & - & & 1.79 & 1.74 & - & - & - \\
\hline $\mathrm{SiO}_{2}$ & - & - & - & 2.70 & .94 & 2.07 & - & 一 \\
\hline $\mathrm{P}_{2} \mathrm{C}$ & 一 & 一 & - & .60 & 1.73 & & 一 & - \\
\hline $\mathrm{H}_{2} \mathrm{C}$ & 6.18 & 10.07 & 6.21 & 8.35 & 10.22 & 6.00 & 7.84 & 6.9 \\
\hline Total & 100.00 & 100.00 & 99.83 & 98.92 & 101.97 & 98.45 & 97.18 & 99.8 \\
\hline
\end{tabular}

1. Theoretical weight percentages, $\mathrm{PbO} \cdot 4 \mathrm{UO}_{3} \cdot 7 \mathrm{H}_{2} \mathrm{O}$.

2. Average of analyses 4 and 5 after deduction of torbernite $\left(\mathrm{CuO} \cdot 2 \mathrm{UO}_{3}\right.$. $\mathrm{P}_{2} \mathrm{O}_{5} \cdot 8 \mathrm{H}_{2} \mathrm{O}$ ) and kasolite (as $\left.3 \mathrm{PbO} \cdot 3 \mathrm{UO}_{3} \cdot 3 \mathrm{SiO}_{2} \cdot 4 \mathrm{H}_{2} \mathrm{O}\right)$.

3. Analysis 6 after deduction of $\mathrm{SiO}_{2}$.

4. 5. Fourmarierite. Katanga. Mélon (1925). Admixed with torbernite, kasolite, and limonite.

6. Fourmarierite. Katanga. Schoep (1924c). Contains quartz, otherwise pure.

7. Fourmarierite. Katanga. Schoep (1924c). Contains schoepite. Also another analysis containing a relatively large amount of schoepite.

8. Synthetic fourmarierite. Bignand (1955). 
Easily soluble in acids to a yellow solution. Fourmarierite blackens when heated in air but does not fuse. Spectrographic analyses are lacking.

\section{Crystallography}

Fourmarierite is orthorhombic. The crystal class is uncertain, but probably is dipyramidal $(2 / \mathrm{m} 2 / \mathrm{m} 2 / \mathrm{m})$. A holohedral crystal drawing, perhaps idealized, is given in Buttgenbach (1924). An angle table for the known forms is given below in the crystal orientation of Palache, Berman, and Frondel (1944) and the unit of Buttgenbach (1924). This unit was confirmed by the X-ray single-crystal study of Brasseur (1941), who obtained: $a_{0} 16.75 \mathrm{~A}, b_{0} 14.10, c_{0} 14.55, a_{0}: b_{0}: c_{0}:=1.188: 1: 1.032$.

\section{Angle table for fourmarierite}

Orthorhombic; dipyramidal, $\left(2 / \mathrm{m}_{2} / \mathrm{m} 2 / \mathrm{m}\right)$

$a: b: c=1.235: 1: 1.089 ; \quad p_{0}: q_{0}: r_{0}=1.132: 1.089: 1$

$q_{1}: r_{1}: p_{1}=1.233: 0.883: 1 ; \quad r_{2}: p_{2}: q_{2}=0.918: 0.811: 1$

\begin{tabular}{lcccccc}
\hline ForMS & $\phi$ & $\rho=C$ & $\phi_{1}$ & $\rho_{1}=A$ & $\phi_{2}$ & $\rho_{2}=B$ \\
\hline$c 001$ & $-\bar{c}$ & $0^{\circ} 00^{\prime}$ & $0^{\circ} 00^{\prime}$ & $90^{\circ} 00^{\prime}$ & $90^{\circ} 00^{\prime}$ & $90^{\circ} 00^{\prime}$ \\
$M 101$ & $90^{\circ} 00^{\prime}$ & 4833 & 000 & 4127 & 4127 & 9000 \\
$o \quad 111$ & 4607 & $57311 / 2$ & 4726 & $52331 / 2$ & 4127 & $54121 / 2$ \\
\hline
\end{tabular}

Unit-cell contents probably $8\left[\mathrm{PbO} \cdot 4 \mathrm{UO}_{3} \cdot 7 \mathrm{H}_{2} \mathrm{O}\right]$. Palache (1934) used a different unit in his description of the morphology. Transformations: Buttgenbach (1924) to present, 010/001/100; Palache (1934) to present, 010/200/001. X-ray single-crystal and powder study indicates that fourmarierite is closely related in crystal structure to synthetic hydrated lead diuranate $\left(\mathrm{PbU}_{2} \mathrm{O}_{7}\right.$. $n \mathrm{H}_{2} \mathrm{O}$ ), masuyite, vandendriesscheite, and probably also to schoepite.

\section{Physical properties}

Cleavage $\{001\}$ perfect. Hardness $3-4$. Specific gravity 5.74 (Brasseur, 1948). Luster subadamantine. Color orange red to golden red, not as deep colored as curite but resembling it, especially in compact masses; rarely reddish brown to brown. Crystals are transparent. Not fluorescent in ultraviolet light.

Optical properties

\begin{tabular}{|c|c|c|c|c|}
\hline \multirow[b]{2}{*}{ ORIENTATION } & \multicolumn{2}{|c|}{$n$} & \multirow[b]{2}{*}{ Pleochroism } & \multirow{4}{*}{$\begin{array}{l}\text { Biaxial negative; } \\
\quad r>v \text { strong. }\end{array}$} \\
\hline & 1 & 2 & & \\
\hline $\begin{array}{l}X=c \\
Y=b \\
Z=a\end{array}$ & $\begin{array}{l}1.865 \\
1.900 \\
1.904\end{array}$ & $\begin{array}{l}1.85 \\
1.92 \\
1.94\end{array}$ & $\begin{array}{l}\text { Colorless. } \\
\text { Pale yellow. } \\
\text { Yellow. }\end{array}$ & \\
\hline $2 V$ & $55^{\circ}$ & Large & & \\
\hline
\end{tabular}

1. Katanga. J. W. Frondel (oral communication, 1953).

2. Katanga. Billiet (1926). 
The acute bisectrix is perpendicular to the cleavage and $Y$ is parallel to the usual direction of elongation, $b$. The indices of refraction are considerably lower than those of curite. The above optical description is from Billiet (1926) and Schoep (1930). The indices of refraction of fourmarierite in gummite pseudomorphs after uraninite have been found to vary by at least 0.04 , with $n_{Z}$ 1.95-1.97 in some instances, presumably due to the substitution of $\mathrm{Ba}$ or $\mathrm{Ca}$ for $\mathrm{U}$ or to variation in the $\mathrm{PbO}: \mathrm{UO}_{3}: \mathrm{H}_{2} \mathrm{O}$ ratio. The mean index of refraction of very fine-grained fourmarierite in gummite usually is in the range 1.84-1.90.

\section{Thermal behavior}

Bignand (1955) found that synthetic material lost part of the water at about $120^{\circ} \mathrm{C}$ and the remainder gradually up to about $300^{\circ} \mathrm{C}$.

\section{Synthesis}

Obtained as a fine-grained orange-red to brownish-red precipitate by reaction at room temperature in water solution of the chlorides, nitrates, or acetates of lead and hexavalent uranium (E. Berman, oral communication, 1954 ; Bignand, 1955). Material with identical or nearly identical X-ray pattern is afforded over a wide range of $\mathrm{Pb}: \mathrm{U}$ ratios on both sides of $\mathrm{Pb}: \mathrm{U}=1: 4$. Synthetic hydrated lead diuranate, $\mathrm{PbU}_{2} \mathrm{O}_{7} \cdot n \mathrm{H}_{2} \mathrm{O}$, prepared by standard procedures (Gmelin, 1936; Croxton, 1951) has a practically identical pattern. Gruner (1952) prepared a substance with the X-ray pattern of fourmarierite by reaction of metallic lead with hot uranyl nitrate solution. Analysis of this gave $\mathrm{UO}_{3} 70.1, \mathrm{PbO}$ 26.1, $\mathrm{H}_{2} \mathrm{O} 3.5$, total 99.7, corresponding to $\mathrm{PbO} \cdot 2.1 \mathrm{UO}_{3} \cdot 1.7 \mathrm{H}_{2} \mathrm{O}$; the mean index of refraction was over 1.99. The evidence suggests that a series extends from $\mathrm{PbU}_{2} \mathrm{O}_{7} \cdot n \mathrm{H}_{2} \mathrm{O}$ with decreasing content of lead; an analogous situation apparently exists in clarkeite.

\section{Identification}

Fourmarierite, especially when in dense aggregates, closely resembles two other hydrated lead uranium oxides, curite and vandendreisscheite. It has a lead content and indices of refraction between these species; a positive identification is best made by an $\mathrm{X}$-ray powder-diffraction pattern. The X-ray powder-spacing data are given in the following table. The fourmarierite pattern closely resembles those of vandendriesscheite, masuyite, and, in particular, hydrated lead diuranate $\left(\mathrm{PbU}_{2} \mathrm{O}_{7} \cdot n \mathrm{H}_{2} \mathrm{O}\right)$; also, less closely, that of schoepite. Curite, becquerelite, and billietite have dissimilar patterns. 
$X$-ray powder-spacing data for fourmarierite

[Copper radiation, nickel filter]

\begin{tabular}{|c|c|c|c|c|c|}
\hline \multicolumn{4}{|c|}{ WÖLSENDORF, BAVARIA } & \multicolumn{2}{|c|}{$\begin{array}{l}\text { SYNTHETIC HYDRATED } \\
\text { LEAD DIURANATE }\end{array}$} \\
\hline$d(\mathrm{~A})$ & $I$ & $d(\mathrm{~A})$ & $I$ & $d(\mathrm{~A})$ & $I$ \\
\hline $\begin{array}{l}7.86 \\
6.83 \\
3.45 \\
3.09 \\
2.73 \\
2.44 \\
2.26 \\
2.15 \\
2.09 \\
1.996 \\
1.907 \\
1.817 \\
1.729 \\
1.687 \\
1.669 \\
1.645 \\
1.607 \\
1.544 \\
1.508 \\
1.486\end{array}$ & $\begin{array}{r}2 \\
4 \\
9 \\
10 \\
4 \\
6 \\
5 \\
2 \\
2 \\
6 \\
8 \\
2 \\
7 \\
2 \\
2 \\
3 \\
2 \\
3 \\
1 \\
2\end{array}$ & $\begin{array}{l}1.376 \\
1.346 \\
1.309 \\
1.284 \\
1.252 \\
1.226 \\
1.192 \\
1.177 \\
1.142 \\
1.127 \\
1.114 \\
1.102 \\
1.070 \\
1.055 \\
1.030 \\
1.012 \\
.994 \\
.974 \\
.945\end{array}$ & $\begin{array}{l}2 \\
3 \\
2 \\
2 \\
1 \\
1 \\
1 \\
2 \\
1 \\
1 \\
1 \\
1 \\
2 \\
1 \\
1 \\
1 \\
1 \\
1 \\
2\end{array}$ & $\begin{array}{l}6.81 \\
3.43 \\
3.08 \\
2.755 \\
2.436 \\
2.270 \\
1.990 \\
1.903 \\
1.811 \\
1.719 \\
1.672 \\
1.535 \\
1.497 \\
1.377 \\
1.342 \\
1.299 \\
1.276 \\
1.217 \\
1.132\end{array}$ & $\begin{array}{r}\mathbf{3} \\
\mathbf{9} \\
10 \\
1 \\
\mathbf{3} \\
\mathbf{2} \\
6 \\
7 \\
1 \\
6 \\
4 \\
3 \\
\mathbf{2} \\
\mathbf{3} \\
\mathbf{2} \\
\mathbf{4} \\
5 \\
\mathbf{3} \\
\mathbf{4}\end{array}$ \\
\hline
\end{tabular}

Natural formation

Fourmarierite is a secondary mineral. Its lead content seems in general to be radiogenic and obtained by the reworking of primary uraninite. At Katanga, fourmarierite occurs as crystalline crusts and masses in the oxidized ores and has been deposited chiefly from solutions that derived their uranium and lead content from uraninite or earlier formed secondary uranium minerals. It also occurs as alteration pseudomorphs after crystals of uraninite. Here it is one of the chief constituents of the orange-red intermediate zone of alteration - the traditional gummite-that embays a central core of uraninite and outwardly alters to a greenishyellow zone of uranophane or other silicate. The fourmarierite of the pseudomorphs ordinarily is dense and microcrystalline, without structure apparent to the unaided eye, and varies in color from the typical orange red to deep orange, reddish brown, and brown. Other minerals of this stage of alteration include vandendriesscheite and, less commonly, clarkeite, schoepite, and curite, and distinction from them cannot be made with certainty on the basis of color alone.

\section{Occurrence}

First described from Shinkolobwe, Katanga district, Belgian Congo, where it occurs relatively abundantly with kasolite, torbernite, and other secondary uranium minerals. Later identified, but without analyses, from other localities. It occurs at Wölsendorf, Bavaria, with becquerelite and phosphuranylite, as an alteration 
of uraninite in a fluorite deposit (Schoep and Scholz, 1931). Also found in the oxidized outcropping of the veins at Great Bear Lake, Canada, as thin orange-red crusts with a gumlike appearance on altered uraninite. Fourmarierite is one of the main constituents of the inner, orange-red zone of alteration of gummite pseudomorphs after uraninite. (See C. Frondel, 1956b.) It has been identified in such material from pegmatites in the Spruce Pine district, Mitchell County, N. C.; the Mica Lakes area, Hahns Peak, Colo.; Palermo, near North Groton, N. H. ; Newry, Maine; Tvedestrand, Norway; Rajputana, India; Morogoro, Tanganyika; and Joachimsthal(?), Bohemia. Further work on such pseudomorphs doubtless would expand the list of localities.

Fourmarierite occurs with becquerelite as an alteration of uraninite and galena in mineralized fossil wood at the Monument No. 2 mine, Apache County, Ariz. Also found at the Lucky Strike No. 2 mine in the west San Rafael Swell, Emery County, Utah, with becquerelite and zippeite-like minerals (Weeks and Thompson, 1954).

\section{RICHETITE}

Synonymy

Richetite Vaes (1947). Named after Emile Richet (d.1939), Belgian geologist.

Composition

A hydrated oxide of uranium and lead of unknown formula. Microchemical tests established the absence of $\mathrm{Ba}, \mathrm{Ca}, \mathrm{Mg}$, and $\mathrm{Si}$. The black color of the mineral suggests that the uranium may be present in the quadrivalent state. Soluble in $\mathrm{HCl}$.

\section{Crystallography}

Measurements by X-ray or optical reflecting-goniometer methods are lacking. Apparently monoclinic, on the basis of optical evidence. Crystals are minute pseudohexagonal tablets flattened on $\{010\}$ with a tendency for subparallel, lamellar aggregation on $\{010\}$. Interfacial angles measured in plane section under the microscope are shown in figure 6. The corners of the crystals are truncated by tiny oblique faces. Commonly twinned on a plane or planes in the zone [01.0] to give pseudohexagonal groups (fig. 6).

Physical properties

Cleavage $\{010\}$ perfect, also a second less well developed cleavage in the zone [010]. The trace of this cleavage on $\{010\}$, although not clearly described, seems to be perpendicular to the optical direction $Z$. Hardness and specific gravity not known. Color black. Luster adamantine. 


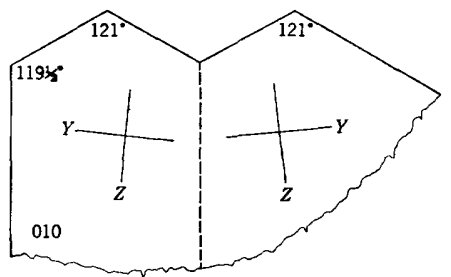

A

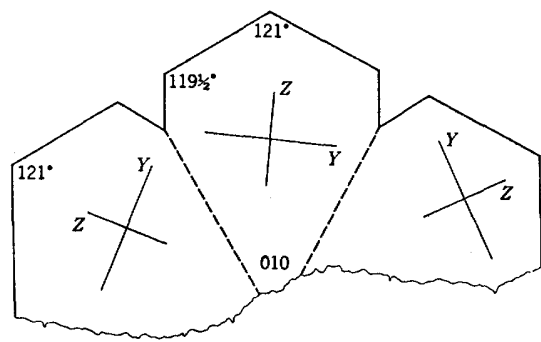

$B$

Figure 6.-Richetite. Belgian Congo. A. Plane projection on (010) of a twinned crystal, after Vaes (1947), showing the optical orientation. B. Plane projection on (010) of a repeated twin. after Vaes (1947), showing the optical orientation.

Optical properties

Biaxial negative. The acute bisectrix, $X$, is perpendicular to $\{010\}$ and at extinction $Z$ makes an angle of about $6^{\circ}$ with one side of the crystals. $2 V$ very large. Pleochroic, with $X$ pale brown to nearly colorless, $Y$ and $Z$ dull brown; flakes resting on the second cleavage show parallel extinction and the maximum absorption. The indices of refraction are not known, but $n_{Y}$ and $n_{Z}$ are between about 2.00 and 2.07. The partial birefringence $n_{Y}-n_{X}$ is very large, so that $n_{X}$ probably is about 1.8. The sense of the extinction direction cannot be described from the available data.

Thermal properties and synthesis

No data.

\section{Identification}

X-ray powder-diffraction data are lacking. Richetite is inadequately characterized and its species validity is uncertain. It is practically identical in habit and angles with the ill-defined mineral masuyite, but differs therefrom in color, optical orientation, and in possessing inclined extinction. The interfacial angles and optical orientation also are similar to those of billietite and becquerelite. In massive granular material richetite cannot be identified with certainty from the available information.

Natural formation and occurrence

Richetite is a secondary mineral, found associated with uranophane on a few specimens from Shinkolobwe, Katanga district, Belgian Congo.

\section{CURITE}

\section{Synonymy}

Curite Schoep (1921a). Named after Pierre Curie (1859-1906), French physicist known for his researches on radioactivity. 


\section{Composition}

A hydrated oxide of lead and hexavalent uranium. The formula is uncertain. It is given by Schoep (1921a, 1930), Palache, Berman, and Frondel (1944), and Buttgenbach (1947) as probably $2 \mathrm{PbO} \cdot 5 \mathrm{UO}_{3} \cdot 4 \mathrm{H}_{2} \mathrm{O}$ on the basis of analyses 4 and 5 . Analysis 6 affords ratios close to $2 \mathrm{PbO} \cdot 6 \mathrm{UO}_{3} \cdot 3 \mathrm{H}_{2} \mathrm{O}$ or $3 \mathrm{PbO} \cdot 8 \mathrm{UO}_{3} \cdot 4 \mathrm{H}_{2} \mathrm{O}$. The latter formula, on the basis of $2\left[3 \mathrm{PbO} \cdot 8 \mathrm{UO}_{3} \cdot 4 \mathrm{H}_{2} \mathrm{O}\right]$ in the X-ray unit cell, gives a somewhat better agreement between the calculated and measured specific gravities than the other formulas proposed. The synthetic curite(?) of analysis 7 has ratios close to $15 \mathrm{PbO} \cdot 35 \mathrm{UO}_{3} \cdot 23 \mathrm{H}_{2} \mathrm{O}$ or $3 \mathrm{FbO} \cdot 7 \mathrm{UO}_{3} \cdot 41 / 2 \mathrm{H}_{2} \mathrm{O}$, and the synthetic material of analysis 8 is close to $\mathrm{PbO} \cdot 3 \mathrm{UO}_{3} \cdot 2 \mathrm{H}_{2} \mathrm{O}$. The reported analyses are given in the table below.

\begin{tabular}{|c|c|c|c|c|c|c|c|c|}
\hline & & mical a & nalyses & curite & in weig & it perce & & \\
\hline & 1 & 2 & 3 & 4 & 5 & 6 & 7 & 8 \\
\hline $\begin{array}{l}\mathrm{PbO} \\
\mathrm{BaO}\end{array}$ & 22.91 & 20.14 & 22.10 & 21.32 & 21.13 & 21.08 & 24.2 & 20.9 \\
\hline $\mathrm{Fe}_{2} \mathrm{O}_{3}$ & & 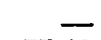 & & .17 & .37 & & & \\
\hline $\mathrm{UO}_{3}$ & 73.39 & 77.42 & 75.52 & 74.22 & 74.28 & 76.49 & 72.4 & 75.6 \\
\hline $\mathrm{H}_{2} \mathrm{O}$ & $3 . \overline{70}$ & $2 . \overline{44}$ & $2 . \overline{38}$ & 3.51 & .14 & 2.43 & $\overline{3.0}$ & 3.2 \\
\hline Total & 100.0 & 100.00 & 100.00 & 99.22 & - & 100.17 & 99.6 & 99.7 \\
\hline Sp gr & - & - & - & 7.192 & 6.98 & 7.4 & - & - \\
\hline
\end{tabular}

1. Theoretical weight percentages, $2 \mathrm{PbO} \cdot 5 \mathrm{UO}_{3} \cdot 4 \mathrm{H}_{2} \mathrm{O}$.

2. Theoretical weight percentages, $2 \mathrm{PbO} \cdot 6 \mathrm{UO}_{3} \cdot 3 \mathrm{H}_{2} \mathrm{O}$.

3. Theoretical weight percentages, $3 \mathrm{PbO} \cdot 8 \mathrm{UO}_{3} \cdot 4 \mathrm{H}_{2} \mathrm{O}$.

4. Curite. Katanga. Schoep (1921a). Average of several partial analyses.

5. Curite. Katanga. Hacquaert (1927). With Te trace.

6. Curite. Katanga. Cuttitta, analyst, in Donnay and Donnay (1955).

7. Synthetic curite. Rodden, analyst, in Gruner (1952).

8. Synthetic curite. Bignand (1955).

The $\mathrm{Ba}$ reported in analysis 6 presumably is in substitution for $\mathrm{Pb}$. Spectrographic analyses are lacking. Curite is easily soluble in dilute acids.

\section{Crystallography}

Orthorhombic; crystal class not known. The angle table below is in the morphological unit and orientation of Palache (1934),

Angle table for curite

Orthorhombic

$\begin{array}{cc}a: b: c=0.9595: 1: 0.6532 ; & p_{0}: q_{0}: r_{0}=0.6808: 0.6532: 1 \\ q_{1}: r_{1}: p_{1}=0.9595: 1: 1.4689 ; & r_{2}: p_{2}: q_{2}=1.5309: 1.0423: 1\end{array}$

\begin{tabular}{|c|c|c|c|c|c|c|}
\hline FORMS & $\phi$ & $\rho=C$ & $\phi_{1}$ & $\rho_{1}=A$ & $\phi_{2}$ & $\rho_{2}=B$ \\
\hline $\begin{array}{ll}a & 100 \\
m & 110 \\
o & 111\end{array}$ & $\begin{array}{l}90^{\circ} 00^{\prime} \\
4611 \\
4611\end{array}$ & $\begin{array}{l}90^{\circ} 00^{\prime} \\
9000 \\
43 \quad 20\end{array}$ & $\begin{array}{l}90^{\circ} \overline{00^{\prime}} \\
3309\end{array}$ & $\begin{array}{r}0^{\circ} 00^{\prime} \\
4349 \\
6019\end{array}$ & $\begin{array}{ll}0^{\circ} 00^{\prime} \\
0 & 00 \\
\mathbf{5 5} & 451 / 2\end{array}$ & $\begin{array}{l}90^{\circ} 00^{\prime} \\
4611 \\
6138\end{array}$ \\
\hline
\end{tabular}


corresponding to the X-ray unit cell. The reported X-ray singlecrystal measurements follow.

\begin{tabular}{cccc} 
& \multicolumn{4}{c}{ Unit-cell dimensions of curite } \\
\cline { 2 - 3 } & 1 & 2 & \\
$a_{0}$ & $12.55 \mathrm{~A}$ & $12.50 \mathrm{~A}$ & Space group Pna2 or Pnam; \\
$b_{0}$ & 13.01 & 13.01 & unit-cell contents \\
$c_{0}$ & 8.37 & 8.40 & $2\left[3 \mathrm{PbO} \cdot 8 \mathrm{UO}_{3} \cdot 4 \mathrm{H}_{2} \mathrm{O}\right](?)$. \\
\hline
\end{tabular}

$a_{0}: b_{0}: c_{0} \quad 0.9646: 1: 0.6434 \quad 0.9608: 1: 0.6457$

1. Shaub, in Palache, Berman, and Frondel (1944).

2. Donnay and Donnay (1955).

Crystal habit

Crystals are long prismatic to acicular by elongation along the $c$-axis. The morphology of the crystals is summarized by Palache (1934) and Schoep (1930). Often massive, either as porous aggregates of fine needles or fine-granular; also as opaline crusts (Schoep and de Leenheer, 1937).

Physical properties

Cleavage $\{100\}$. Brittle. Hardness 4-5. Specific gravity: 7.26 (Schaub, in Palache, Berman, and Frondel, 1944; F. Cuttitta, written communication, 1953) ; 7.4 (H. T. Evans, Jr., written communication, 1953); slightly lower values have also been reported. With the cell dimensions of Donnay and the formula $3 \mathrm{PbO} \cdot 8 \mathrm{UO}_{3} \cdot 4 \mathrm{H}_{2} \mathrm{O}$ the calculated specific gravity is 7.37 . Luster adamantine. Color of crystals deep orange red, darker than the color of fourmarierite; also varying in massive material from light orange red to scarlet. Streak orange. Not fluorescent.

Optical properties

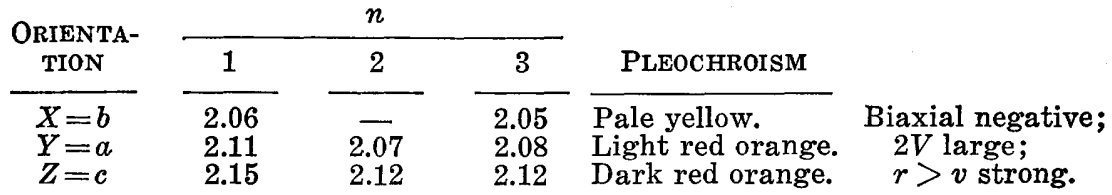

1. Larsen and Berman (1934).

2. Billiet (1926).

3. Branche and others (1951).

Thermal behavior

According to Schoep (1930), curite Ioses about 0.32 percent $\mathrm{H}_{2} \mathrm{O}$ at $110^{\circ} \mathrm{C}$, about 1.33 percent near $250^{\circ} \mathrm{C}$, and the rest at about $450^{\circ} \mathrm{C}$. Bignand (1955) found the water to be completely lost below about $300^{\circ} \mathrm{C}$.

Synthesis

A substance giving essentially a curite X-ray powder pattern but with slight differences in the lower $d$-values was obtained by Gruner (1952) by heating sheet lead in uranyl nitrate solution 
at $180^{\circ}-200^{\circ} \mathrm{C}$, with $\mathrm{CO}_{2}$ atmosphere. Obtained by Bignand (1955) by heating schoepite in a water solution of lead acetate at $160^{\circ} \mathrm{C}$.

\section{Identification}

Distinguished from the other uranyl oxides by its higher indices of refraction, acicular crystal habit, and deep orange-red color (although in massive material the color of curite, vandendriesscheite, and fourmarierite may closely resemble each other). The X-ray powder-spacing data are given in the following table.

\section{$X$-ray powder-spacing data for curite ${ }^{1}$}

[Copper radiation, nickel filter]

\begin{tabular}{|c|c|c|c|c|c|c|}
\hline$d(\mathrm{~A})$ & $I$ & $d(\mathrm{~A})$ & $I$ & $d(\mathrm{~A})$ & $I$ & $d(\mathrm{~A})$ \\
\hline $\begin{array}{l}6.28 \\
4.17 \\
3.97 \\
3.53 \\
3.36 \\
3.14 \\
3.07 \\
2.93 \\
2.81\end{array}$ & $\begin{array}{r}10 \\
1 \\
9 \\
4 \\
4 \\
8 \\
4 \\
2 \\
1\end{array}$ & $\begin{array}{l}2.70 \\
2.55 \\
2.47 \\
2.35 \\
2.24 \\
2.17 \\
2.10 \\
2.04 \\
2.00\end{array}$ & $\begin{array}{l}4 \\
6 \\
3 \\
1 \\
1 \\
1 \\
5 \\
1 \\
1\end{array}$ & $\begin{array}{l}1.95 \\
1.91 \\
1.90 \\
1.87 \\
1.84 \\
1.80 \\
1.74 \\
1.70 \\
1.66\end{array}$ & $\begin{array}{l}1 \\
1 \\
1 \\
1 \\
2 \\
3 \\
5 \\
2 \\
2\end{array}$ & $\begin{array}{l}1.62 \\
1.57 \\
1.54 \\
1.51 \\
1.49 \\
1.47 \\
1.43 \\
1.40\end{array}$ \\
\hline
\end{tabular}

${ }^{1}$ Material from the Katanga district, Belgian Congo.

Natural formation

Curite is a secondary mineral formed with other hydrated uranyl or lead-uranyl oxides by the alteration of uraninite. The lead of the mineral seems to be radiogenic and derived from the uraninite.

\section{occurrence}

Relatively abundant at Shinkolobwe and elsewhere in the Katanga district, Belgian Congo. Typical associated minerals include fourmarierite, vandendriesscheite, schoepite, soddyite, kasolite, dewindtite, and torbernite. Some specimens of the mineral occur at Katanga as dense pseudomorphs after uraninite. The orange-red gummite pseudomorphs after uraninite known from many localities, although supposed to consist of curite on the basis of the color, have been found to contain chiefly fourmarierite and vandendriesscheite (C. Frondel, 1956b). The tentative identification of curite at Great Bear Lake, Canada, by Palache and Berman (1933) was not verified by George (1949). Reported by Branche and others (1951) from La Crouzille, Puy-de-Dôme, France, and Malakialine, Madagascar.

\section{Synonymy}

\section{CLARKEITE}

Clarkeite Ross, Henderson, and Posnjak (1931). Named after Frank W. Clarke (1847-1931), geochemist, of the U. S. Geological Survey. 


\section{Composition}

Clarkeite is essentially a diuranate of sodium, calcium, and lead that is isostructural with synthetic $\mathrm{Na}_{2} \mathrm{U}_{2} \mathrm{O}_{7}$ and $\mathrm{CaU}_{2} \mathrm{O}_{7}$. Water is present in the natural material and in some synthetic preparations; it is not essential to the crystal structure, and apparently occupies vacancies in the cation positions. The relation to $\mathrm{Na}_{2} \mathrm{U}_{2} \mathrm{O}_{7}$ may be formulated $\left[\mathrm{Na}_{2-2 \mathrm{x}}(\mathrm{Ca}, \mathrm{Pb})_{\mathrm{x}} \mathrm{H}_{2} \mathrm{O}_{\mathrm{x}}\right]_{2} \mathrm{U}_{2} \mathrm{O}_{7}$. Valence compensation also may be effected by a substitution of $\mathrm{H}_{2} \mathrm{O}$ or $(\mathrm{OH})$ for oxygen. The three reported analyses of clarkeite are given in the table below. The Rajputana material of analysis 2 corresponds to the formula

$$
\left(\mathrm{Na}_{0.53} \mathrm{Ca}_{0.26} \mathrm{~Pb}_{0.25} \mathrm{Th}_{0.06} \mathrm{U}_{0.02} \mathrm{H}_{2} \mathrm{O}_{0.88}\right)_{2} \mathrm{U}_{2}\left(\mathrm{O}_{6.83} \mathrm{H}_{2} \mathrm{O}_{0.07}\right)_{7} \text {. }
$$

Clarkeite was originally considered by Ross and others (1931) to be a hydrated uranate with the empirical ratios $(\mathrm{Na}, \mathrm{Ca}, \mathrm{Pb}) \mathrm{O}$. $3 \mathrm{UO}_{3} \cdot 3 \mathrm{H}_{2} \mathrm{O}$ and was later thought to be essentially $\mathrm{UO}_{3} \cdot n \mathrm{H}_{2} \mathrm{O}$ (Palache, Berman, and Frondel, 1944). The interpretation as a diuranate isostructural with $\mathrm{Na}_{2} \mathrm{U}_{2} \mathrm{O}_{7}$ was first established by Gruner (1954). According to Wamser and others (1952) the supposed phase $\mathrm{Na}_{2} \mathrm{U}_{2} \mathrm{O}_{7}$ actually has the composition $\mathrm{Na}_{6} \mathrm{U}_{7} \mathrm{O}_{24}$.

Clarkeite is soluble in acids. Spectrographic and thermal analyses are lacking.

Chemical analyses of clarkeite, in weight percent

\begin{tabular}{|c|c|c|c|c|c|c|c|}
\hline & 1 & 2 & 3 & & 1 & 2 & 3 \\
\hline $\mathrm{Na}_{2} \mathrm{O}$ & $\overline{3.44}$ & 2.61 & 2.3 & $\mathrm{UO}_{3}$ & $\overline{81.72}$ & $\overline{82.76}$ & 79.9 \\
\hline $\mathrm{K}_{2} \mathrm{O}$ & .48 & 1.42 & $\overline{0}$ & $\mathrm{UO}_{2}$ & $=$ & - & .8 \\
\hline $\begin{array}{l}\mathrm{CaU} \\
\mathrm{MgO}\end{array}$ & $\begin{array}{r}2.84 \\
28\end{array}$ & & 2.1 & $\begin{array}{l}\mathrm{ThO}_{2} \\
\mathrm{SiO}^{2}\end{array}$ & $\overrightarrow{.50}$ & $\overline{30}$ & 2.4 \\
\hline $\mathrm{PbO}$ & 3.71 & 3.70 & 7.9 & Insol. & .14 & 1.20 & .2 \\
\hline $\mathrm{BaO}$ & $\frac{1}{1}$ & .04 & - & $\mathrm{H}_{2} \mathrm{O}$ & 3.36 & 5.22 & 5.5 \\
\hline $\mathrm{Fe}_{2} \mathrm{O}_{3}$ & $.18\}$ & .50 & - & Total & $\overline{100.19}$ & 99.97 & 101.1 \\
\hline Rare earths & 2.62 & 1.12 & - & Spgr & 6.39 & - & 6.29 \\
\hline
\end{tabular}

1, 2. Clarkeite. Spruce Pine, N. C. Henderson, analyst, in Ross, Henderson, and Posnjak (1931).

3. Clarkeite. Rajputana. Meyrowitz, analyst, in C. Frondel and Meyrowitz (1956).

\section{Crystallography}

Crystal system not known. The optical properties suggest that the symmetry is orthorhombic or lower. Found only as dense, microcrystalline masses formed by the pseudomorphous alteration of uraninite.

\section{Physical properties}

The fracture of the aggregates is conchoidal to splintery. Hardness 4-41/2. Specific gravity 6.39 (Spruce Pine), 6.29 (Rajputana). Color dark brown to mahogany brown and chocolate brown. Streak yellowish brown. Luster slightly waxy. Not fluorescent. 
Optical properties

\begin{tabular}{ccc} 
ORIENTATION & $n$ & \\
\cline { 3 - 4 }$X$ & $1 . \overline{997}$ & Biaxial negative; \\
$Y$ & 2.098 & $r<v$, weak; \\
$Z$ & 2.108 & $2 V 30^{\circ}-50^{\circ}$.
\end{tabular}

The color in transmitted light is reddish brown to orange brown and orange. Weakly pleochroic. The optical data given above are from Ross, Henderson, and Posnjak (1931) on Spruce Pine material. The clarkeite from Rajputana described by C. Frondel and Meyrowitz (1956) is microcrystalline with a variable mean index 1.94-1.97. The composition of clarkeite can vary through mutual substitution of $\mathrm{Na}, \mathrm{Ca}$, and $\mathrm{Pb}$, with attendant variation in the indices of refraction; increase in $\mathrm{Na}$ would lower the indices. Gruner (1954) gives the mean index of synthetic $\mathrm{Na}_{2} \mathrm{U}_{2} \mathrm{O}_{7}$ as $\approx$ 1.84, $\mathrm{CaU}_{2} \mathrm{O}_{7}$ as over 2.00.

Thermal behavior

No data.

Synthesis

Sodium diuranate prepared by the fusion of uranium nitrate with sodium carbonate or sodium nitrate at red heat gives an X-ray pattern very similar to that of clarkeite (Gruner, 1954). Synthetic calcium diuranate gives a similar pattern.

Identification

Clarkeite is best identified by its X-ray powder pattern. It is indistinguishable by the unaided eye from the dark-brown types of oxidized uraninite (with the $\mathrm{UO}_{2} \mathrm{X}$-ray pattern) and from densebrown types of fourmarierite and vandendriesscheite. The indices of refraction are relatively high, but fall in the range of some other secondary uranium oxides. The X-ray powder-spacing data are given in the following table.

$X$-ray powder-spacing data for clarkeite ${ }^{1}$

[Symbol: bd, broad, diffuse. Copper radiation, nickel filter]

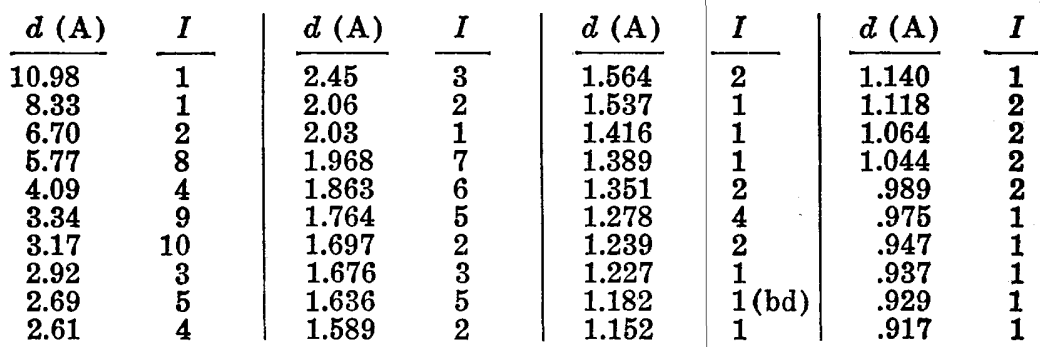

1 Type material from Spruce Pine, N. C. See also Gruner (1954) and C. Frondel and Meyrowitz (1956). The composition of clarkeite apparently can vary widely, with accompanying variation in spacings, but detailed information is lacking. 
Natural formation and occurrence

Clarkeite is formed by the alteration of uraninite. It occurs as the central core in zoned pseudomorphs after uraninite, or immediately surrounds unaltered residuals of uraninite, and is surrounded in turn by an orange-red zone of gummite (usually composed of fourmarierite, vandendriesscheite or an undescribed mineral apparently identical with synthetic hydrated lead diuranate) and an outer zone of uranium silicate. Clarkeite occurs in pegmatites in the Spruce Pine district, North Carolina, and the Ajmer district, Rajputana, India. The mineral may have been formed during the late hydrothermal stage of pegmatite mineralization rather than by weathering.

\section{URANOSPHERITE}

Synonymy

Uranosphärit Weisbäch (1873a). Named in allusion to the content of uranium and form of aggregation.

\section{Composition}

A hydroxide or hydrated oxide of bismuth and hexavalent uranium. The formula is uncertain, perhaps $\mathrm{Bi}_{2} \mathrm{O}_{3} \cdot 2 \mathrm{UO}_{3} \cdot 3 \mathrm{H}_{2} \mathrm{O}=(\mathrm{BiO})$ $\left(\mathrm{UO}_{2}\right)(\mathrm{OH})_{3}$. The only reported analysis, in weight percent, follows.

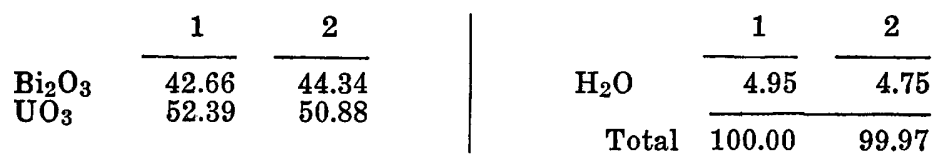

1. Theoretical weight percentages, $\mathrm{Bi}_{2} \mathrm{O}_{3} \cdot 2 \mathrm{UO}_{3} \cdot 3 \mathrm{H}_{2} \mathrm{O}$.

2. Uranospherite. Schneeberg, Saxony. Winkler (1873).

Spectrographic and thermal analyses are lacking. On heating, decrepitates and falls to pieces composed of brown silky needles.

\section{Crystallography}

Inferred to be orthorhombic from the reported optical properties. Occurs in half-globular aggregated forms, sometimes with a dull or slightly lustrous surface, sometimes rough and drusy, made up of minute acutely terminated crystals elongated along the $c$-axis. Structure concentric, also radiated. Morphological and $\mathrm{X}$-ray single-crystal measurements are lacking.

Physical properties

Cleavage $\{100\}$, from the microscope observations of Larsen (1921). Hardness 2-3. Specific gravity 6.36. Luster greasy on fracture surfaces. Color reddish orange to orange yellow and golden. Streak paler than the color. Observations on fluorescence are lacking. 
Optical properties

\begin{tabular}{|c|c|c|}
\hline \multirow[b]{2}{*}{ ORIENTATION } & \multicolumn{2}{|c|}{$n$} \\
\hline & 1 & 2 \\
\hline $\begin{array}{l}X=a \\
Y=b \\
Z=c\end{array}$ & $\begin{array}{l}1.955 \\
1.985 \\
2.05\end{array}$ & $\begin{array}{l}1.959 \\
1.981 \\
2.060\end{array}$ \\
\hline $2 V$ & Large & $56^{\circ}$ (calc.) \\
\hline
\end{tabular}

Biaxial positive;

$r<v$ strong;

pleochroism not observed.

1. Larsen (1921).

2. R. Berman (oral communication, 1954).

The elongation of the crystals is taken as the $c$-axis and the cleavage as $\{100\}$. Under the microscope prismatic fragments resting on the $\{100\}$ cleavage sometimes show a single inclined terminal face with internal plan angles of $40^{\circ}$ and $140^{\circ}$, or two such faces, oppositely inclined, with an acute apical internal angle of $80^{\circ}$.

\section{Synthesis}

Efforts to synthesize uranospherite by precipitation of an aqueous solution of bismuth nitrate and uranyl nitrate with ammonia were unsuccessful (R. Berman, oral communication, 1954).

\section{Identification}

Walpurgite and uranospherite are the only known uranium minerals that contain bismuth as a major, essential constituent. Distinguished from walpurgite by the lack of arsenic and by the optical properties. The X-ray powder-spacing data are given in the following table.

\section{$X$-ray powder-spacing data for uranospherite ${ }^{1}$}

[Copper radiation, nickel filter]

\begin{tabular}{|c|c|c|c|c|c|c|}
\hline$d(\mathrm{~A})$ & $I$ & $d(\mathrm{~A})$ & $I$ & $d(\mathrm{~A})$ & $I$ & $d(\mathrm{~A})$ \\
\hline $\begin{array}{l}5.25 \\
4.74 \\
4.37 \\
4.15 \\
3.87 \\
3.47 \\
3.16 \\
3.05 \\
2.71\end{array}$ & $\begin{array}{r}6 \\
3 \\
4 \\
1 \\
7 \\
6 \\
10 \\
3 \\
1\end{array}$ & $\begin{array}{l}2.60 \\
2.54 \\
2.46 \\
2.39 \\
2.35 \\
2.16 \\
2.08 \\
2.03 \\
1.97\end{array}$ & $\begin{array}{l}1 \\
1 \\
2 \\
2 \\
1 \\
2 \\
2 \\
1 \\
1 \\
4\end{array}$ & $\begin{array}{l}1.90 \\
1.83 \\
1.80 \\
1.73 \\
1.66 \\
1.59 \\
1.56 \\
1.52 \\
1.37\end{array}$ & $\begin{array}{l}5 \\
8 \\
1 \\
2 \\
4 \\
1 \\
1 \\
1 \\
1\end{array}$ & $\begin{array}{l}1.34 \\
1.33 \\
1.26 \\
1.236 \\
1.198 \\
1.181 \\
1.097 \\
1.058\end{array}$ \\
\hline
\end{tabular}

${ }^{1}$ Materiai from Schneeberg, Saxony.

Natural formation and occurrence

Uranospherite is a secondary mineral, formed with various arsenates in the oxidized zone of a vein carrying uraninite, native bismuth, and cobalt-nickel arsenides. Known only from the Walpurgis vein of the Weisser Hirsch mine at Neustädtel near Schneeberg, Saxony. Associated with walpurgite, uranospinite, troegerite, zeunerite, erythrite, and black cobalt oxide. 


\section{VANDENBRANDEITE}

\section{Synonymy}

Vandenbrandéite Schoep (1932). Uranolépidite Thoreau (1933). Vandenbrandeite was named after Pierre van den Brande, the Belgian geologist who discovered the ore deposit at Kalongwe. Uranolépidite from uranium and $\lambda \epsilon \pi \iota s$, scale, in allusion to the lamellar to scaly habit of the material described by Thoreau.

\section{Composition}

A hydrated oxide of divalent copper and hexavalent uranium, $\mathrm{Cu}\left(\mathrm{UO}_{2}\right) \mathrm{O}_{2} \cdot 2 \mathrm{H}_{2} \mathrm{O}=\mathrm{CuO} \cdot \mathrm{UO}_{3} \cdot 2 \mathrm{H}_{2} \mathrm{O}$. The correctness of this formula is indicated by the X-ray study of Milne and Nuffield (1951) and by analysis 5 on synthetic material. Two analyses made on impure natural material have been reported, and are given in the table below. Analysis 2 is close to the formula cited. Schoep (1932) gives a formula with more water, $2 \mathrm{CuO} \cdot 2 \mathrm{UO}_{3} \cdot 5 \mathrm{H}_{2} \mathrm{O}$, but this is based on an inferior analysis of material containing a relatively large amount of impurities. Spectrographic analyses are lacking.

Chemical analyses of vandenbrandeite, in weight percent

\begin{tabular}{|c|c|c|c|c|c|}
\hline & 1 & 2 & 3 & 4 & 5 \\
\hline $\begin{array}{l}\mathrm{CuO} \\
\mathrm{UO}_{3} \\
\mathrm{H}_{2} \mathrm{O} \\
\text { Rem. }\end{array}$ & $\begin{array}{r}19.80 \\
71.23 \\
8.97 \\
\end{array}$ & $\begin{array}{r}18.98 \\
70.40 \\
9.46 \\
1.11\end{array}$ & $\begin{array}{r}19.20 \\
71.23 \\
9.57 \\
\end{array}$ & $\begin{array}{r}15.78 \\
65.45 \\
9.25 \\
8.11\end{array}$ & $\begin{array}{r}19.8 \\
70.7 \\
9.2 \\
\end{array}$ \\
\hline Total & 100.00 & 99.95 & 100.00 & 98.59 & 99.7 \\
\hline Sp $g r$ & - & 5.03 & - & 4.96 & - \\
\hline
\end{tabular}

1. Theoretical weight percentages, $\mathrm{Cu}\left(\mathrm{UO}_{2}\right) \mathrm{O}_{2} \cdot 2 \mathrm{H}_{2} \mathrm{O}$.

2. Vandenbrandeite. Shinkolobwe. Boubnoff, analyst, in Thoreau (1933). Remainder is $\mathrm{CaO} 0.26, \mathrm{MgO} 0.57, \mathrm{SiO}_{2} 0.28$.

3. Analysis 2 recalculated to 100 after deducting $\mathrm{CaO}, \mathrm{MgO}$, and $\mathrm{SiO}_{2}$.

4. Vandenbrandeite. Kalongwe. Schoep (1932). Remainder is $\mathrm{PbO} 4.69$, $\mathrm{SiO}_{2}$ 1.66. $\mathrm{Fe}_{2} \mathrm{O}_{3}$ 1.55, $\mathrm{P}_{2} \mathrm{O}_{5}$ 0.21. Contains admixed kasolite, limonite, and probably dewindtite.

5. Synthetic vandenbrandeite. Bignand (1955).

Crystallography

Vandenbrandeite is triclinic and the morphological evidence indicates that the crystal class is pinacoidal (1). An angle table for the known forms is given below. These data are from the study of Milne and Nuffield (1951) on crystals from Kalongwe; the angles are derived from the X-ray unit-cell constants. The morphological measurements are of lesser accuracy owing to the poor surface quality of the available crystals. The crystals from Kalongwe had earlier been described by Schoep (1932), but without deriving elements and using another orientation in which the plane of perfect cleavage, $\{110\}$, was taken 
Angle table for vandenbrandeite

Triclinic, $P \overline{1}$

$a: b: c:=1.443: 1: 1.120 ; \alpha=91^{\circ} 52^{\prime}, \beta=102^{\circ} 00^{\prime}, \gamma=89^{\circ} 37^{\prime}$

$p_{0}: q_{0}: r_{0}=0.776: 1.096: 1 ; \alpha^{*}=88^{\circ} 10^{\prime}, \beta^{*}=78^{\circ} 00^{\circ}, \gamma^{*}=90^{\circ} 00^{\prime}$

$p_{0}^{\prime}=0.794, q_{0}^{\prime}=1.121, x_{0}^{\prime}=0.2127, y_{0}^{\prime}=0.0327$

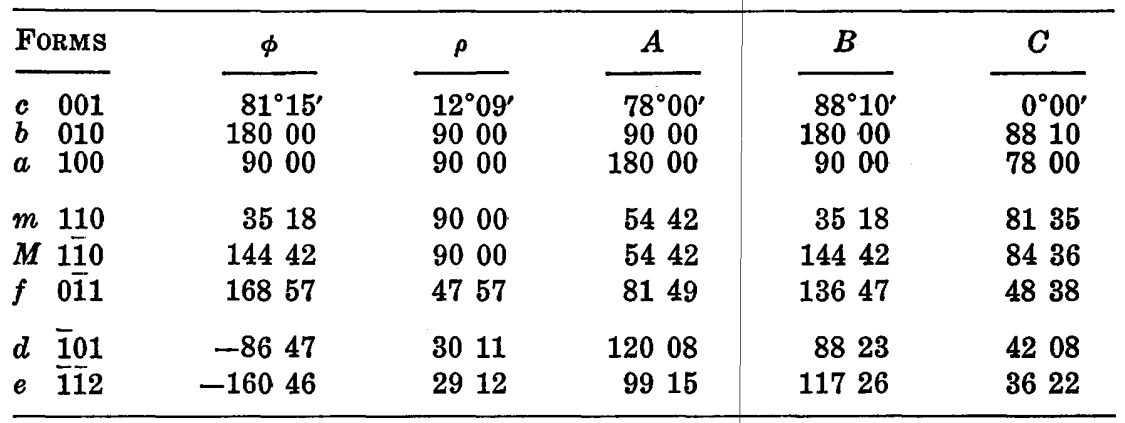

as $\{001\}$ with $\{100\}$ coincident in both orientations. The unitcell constants obtained by Milne and Nuffield (1951) by the Weissenberg method follow:

\begin{tabular}{lrr}
$a_{0} 7.86 \mathrm{~A}$ & $a 91^{\circ} 52^{\prime}$ & Space group $P \overline{1} ;$ \\
$b_{0} 5.44$ & $\beta 102^{\circ} 00^{\prime}$ & cell contents $2\left[\mathrm{CuO} \cdot \mathrm{UO}_{3} \cdot 2 \mathrm{H}_{2} \mathrm{O}\right]$. \\
$c_{0} 6.10$ & $\gamma 89^{\circ} 37^{\prime}$ & \\
\hline$a_{0}: b_{0}: c_{0}=1.445: 1: 1.121$ &
\end{tabular}

Crystal habit

Crystals are tabular $\{001\}$ and somewhat elongated parallel to the edge between $\{001\}$ and $\{110\}$; also scalelike by flattening on $\{001\}$. The crystals range in size up to about $0.5 \mathrm{~mm}$, and commonly are attached to the matrix by a $\{110\}$ face. A crystal drawing is given by Milne and Nuffield (1951). The crystals are imperfectly developed, often with lineage structure and subparallel growth, and the $\{001\}$ faces characteristically are rounded and poorly reflecting. Vandenbrandeite also occurs in massive granular form, with small crystals projecting into cavities; also lamellar.

\section{Physical properties}

Cleavage $\{110\}$ perfect. Two additional cleavages have been reported by Schoep (1932) and Thoreau (1933), but their identity is not known. Hardness 4. Specific gravity 5.0 (measured), 5.26 (calculated); the values 4.96 and 5.03 were reported by Schoep (1932) and Thoreau (1933). Color dark green, inclining to blackish green. Luster weakly vitreous. Transparent in thin flakes. The mineral commonly contains inclusions of kasolite and other material, together with liquid inclusions. Not fluorescent in ultraviolet light. 
Optical properties

\begin{tabular}{|c|c|c|c|c|}
\hline \multirow[b]{2}{*}{ ORIENTATION } & \multicolumn{3}{|c|}{$n$} & \multirow[b]{3}{*}{$\begin{array}{l}\text { Biaxial negative (?) } \\
\text { dispersion strong. }\end{array}$} \\
\hline & 1 & 2 & 3 & \\
\hline $\begin{array}{l}X \\
Y \\
Z\end{array}$ & $\begin{array}{r}1.765 \pm 0.005 \\
1.792 \pm .002 \\
-.\end{array}$ & $\begin{array}{l}1.77 \pm 0.02 \\
1.78 \pm .02 \\
1.80 \pm .02\end{array}$ & $\frac{1.76}{1.80}$ & \\
\hline $2 V$ & Near $90^{\circ}$ & - & Large. & \\
\hline
\end{tabular}

1. Kalongwe. Milne and Nuffield (1951).

2. Katanga. Schoep (1932).

3. Shinkolobwe. Thoreau (1933).

Crushed grains under the microscope show moderately strong pleochroism with colors varying from yellow green to blue green. Fragments lying on the perfect (100) cleavage are blue green in color, are not pleochroic, and have very low birefringence. An optic axis is within $5^{\circ}$ of being perpendicular to this cleavage. Some fragments show a lathlike shape with an extinction angle of $Z$ to the elongation of about $40^{\circ}$.

\section{Thermal behavior}

Schoep (1932) found that vandenbrandeite when heated in air loses only a small amount of nonessential water up to about $300^{\circ} \mathrm{C}$, where all or nearly all of the combined water is lost. This amounts to $2 \mathrm{H}_{2} \mathrm{O}$ in the formula here accepted, $\mathrm{Cu}\left(\mathrm{UO}_{2}\right) \mathrm{O}_{2} \cdot 2 \mathrm{H}_{2} \mathrm{O}$. Schoep took the formula as $2 \mathrm{Cu}\left(\mathrm{UO}_{2}\right) \mathrm{O}_{2} \cdot 5 \mathrm{H}_{2} \mathrm{O}$, and interprets the dehydration data as indicating that $41 / 2 \mathrm{H}_{2} \mathrm{O}$ are lost near $300^{\circ} \mathrm{C}$ and that the remaining $1 / 2 \mathrm{H}_{2} \mathrm{O}$ is lost gradually over about $800^{\circ} \mathrm{C}$. Oxygen apparently begins to be lost over about $1,000^{\circ} \mathrm{C}$.

\section{Synthesis}

Obtained by Bignand (1955) by heating an equimolar water solution of copper acetate and uranyl acetate at $140^{\circ} \mathrm{C}$, and by heating schoepite with an excess of copper acetate in water at $140^{\circ} \mathrm{C}$.

\section{Identification}

The green color and perfect cleavage give a slight resemblance between vandenbrandeite and minerals such as metatorbernite, metazeunerite, and liebigite, but optical and chemical tests and the hardness provide a ready and certain distinction. The X-ray powder-spacing data are given in the following table. 
$X$-ray powder-spacing data for vandenbrandeite ${ }^{1}$

[Copper radiation, nickel filter]

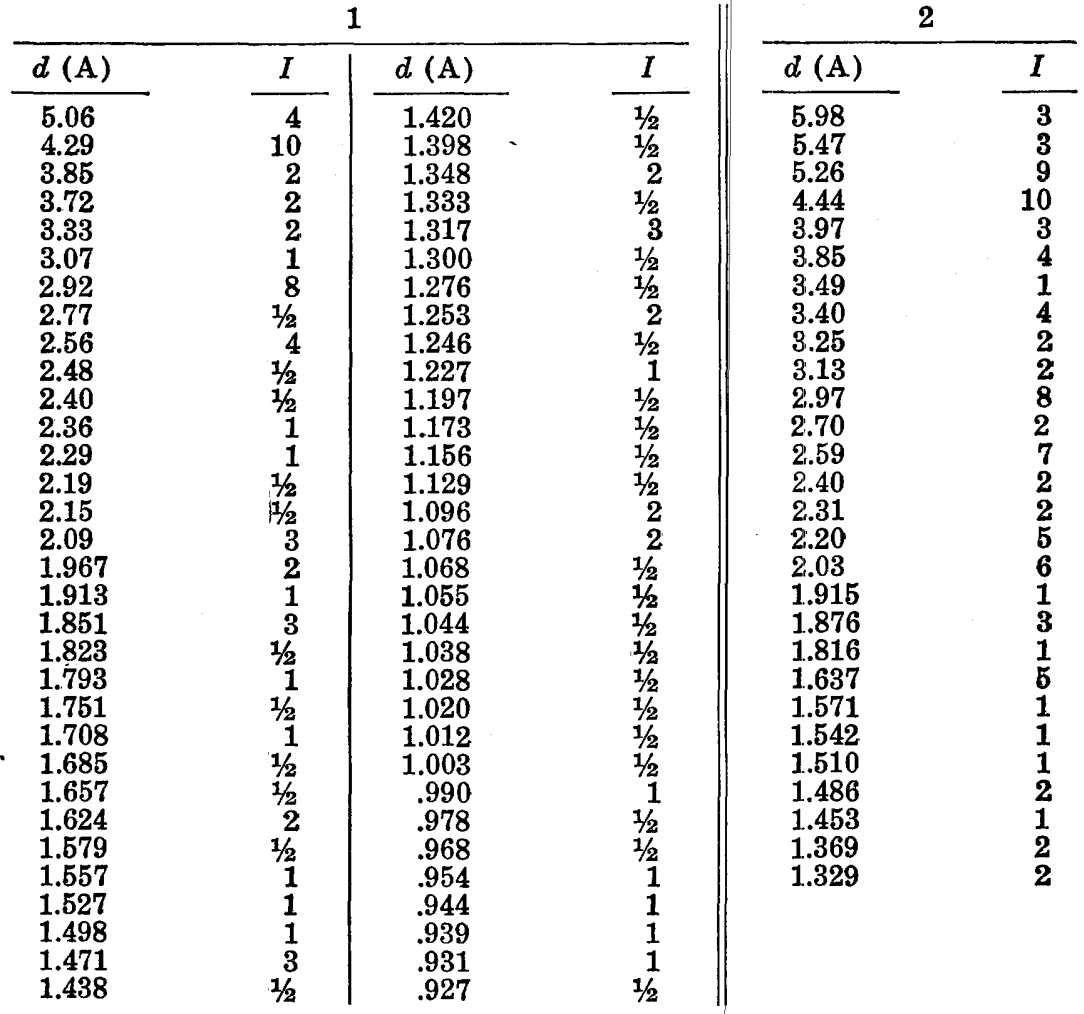

1 The two sets of data are slightly divergent for reasons not known. See also Bignand (1955).

1. Data from Milne and Nuffield (1951) on material from Kalongwe, Katanga district, Belgian Congo; in $\mathrm{kx}$ units, converted to angstrom units.

2. Data from Harvard file on Katanga material.

Natural formation and occurrence

Vandenbrandeite is a secondary mineral, formed by the oxidation of uraninite and associated primary copper minerals. Found at Kalongwe and Shinkolobwe in the Katanga district, Belgian Congo, associated with kasolite, uranophane, sklodowskite, torbernite, malachite, and other secondary products. Said to occur in small amounts in some of the copper-uranium deposits on the Colorado Plateau. 


\section{CARBONATES}

The natural uranyl carbonates with the exception of rutherfordine, $\left(\mathrm{UO}_{2}\right)\left(\mathrm{CO}_{3}\right)$, all contain other cations in addition to uranium. Schroeckingerite, the most abundant and widespread of these minerals, is relatively easily recognized but the others in general require $\mathrm{X}$-ray or other laboratory techniques for their positive identification. Voglite, sharpite, and studite are ill defined and need further study. Almost all of these carbonates are relatively soluble in water and occur chiefly as efflorescences on outcrops or the walls of mine workings.

\section{Synonymy}

\section{RUTHERFORDINE}

Rutherfordin Marckwald (1906). Diderichite Vaes (1947). Rutherfordine is named after Ernest Rutherford (1871-1937), English physicist. Lord Rutherford, professor of physics at Cambridge, was awarded a Nobel Prize in 1908 for his researches on problems of radioactivity, atomic structure, and the electrical nature of matter. Diderichite, named after a Belgian mining engineer, Norbert Diderich, was found by Frondel and Meyrowitz (1956) to be identical with rutherfordine.

Composition

Chemical analyses of rutherfordine, in weight percent

\begin{tabular}{|c|c|c|c|c|c|c|c|c|}
\hline & 1 & 2 & 3 & 4 & 5 & 6 & 7 & 8 \\
\hline $\mathrm{UO}_{3}$ & 86.68 & 86.7 & 85.9 & 86.6 & 87.7 & 83.8 & $\overline{78.6}$ & 85.5 \\
\hline $\mathrm{UO}_{2}$ & - & - & - & - & 一 & 1 & & 2.6 \\
\hline $\mathrm{CaC}$ & - & - & - & - & 一 & 1.1 & .2 & - \\
\hline $\mathrm{PbO}$ & - & - & - & - & - & 1.0 & 4.2 & - \\
\hline $\mathrm{Fe}_{2} \mathrm{O}_{3}$ & - & - & - & - & 一 & .8 & 1.1 & - \\
\hline $\mathrm{SiO}_{2}$ & - & - & 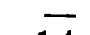 & - & $=$ & .8 & 1.8 & $=$ \\
\hline $\mathrm{H}_{2} \mathrm{O}+$ & - & .2 & 1.4 & - & .5 & .7 & 1.9 & .5 \\
\hline $\mathrm{CO}_{2}$ & $13 . \overline{32}$ & 13.1 & 12.7 & 13.6 & 11.8 & 12.1 & 10.5 & 11.2 \\
\hline Total & 100.00 & 100.0 & 100.0 & 100.2 & 100.0 & 100.3 & 98.9 & 99.8 \\
\hline $\mathrm{Sp} \mathrm{gr}$ & - & 一 & 5.08 & 5.43 & 6.10 & - & 5.08 & 6.10 \\
\hline
\end{tabular}

1. Theoretical weight percentages, $\left(\mathrm{UO}_{2}\right)\left(\mathrm{CO}_{3}\right)$.

2. Rutherfordine. Morogoro. Original analysis of Marckwald (1906), cited in column 6, recalculated to 100 percent after deduction of $\mathrm{Pb}$ and $\mathrm{Ca}$ as kasolite and uranophane together with remaining $\mathrm{CaO}$ and $\mathrm{FeO}$.

3. Rutherfordine. Morogoro. Analysis of Meyrowitz cited in column 7, recalculated to 100 percent after deduction of $\mathrm{Pb}$ and $\mathrm{Ca}$ as kasolite and uranophane together with remaining $\mathrm{SiO}_{2}, \mathrm{Fe}_{2} \mathrm{O}_{3}$, and $\mathrm{H}_{2} \mathrm{O}-$.

4. "Diderichite". Katanga. Meyrowitz, analyst, in Frondel and Meyrowitz (1956). Type material of Vaes (1947). Contains a small but undetermined amount of $\mathrm{H}_{2} \mathrm{O}$.

5. Synthetic uranyl carbonate. Recalculated from the analysis of Meyrowitz, cited in column 8, after deduction of $\mathrm{UO}_{2}$ as $\mathrm{U}_{3} \mathrm{O}_{8}$.

6. Rutherfordine. Morogoro. Original analysis of Marckwald (1906). Fe reported as $\mathrm{FeO}$.

7. Rutherfordine. Morogoro. Meyrowitz, analyst, in C. Frondel and Meyrowitz (1956).

8. Synthetic uranyl carbonate. Meyrowitz, analyst, in C. Frondel and Meyrowitz (1956). Known to contain $\mathrm{U}_{3} \mathrm{O}_{8}$. 
Uranyl carbonate, $\left(\mathrm{UO}_{2}\right)\left(\mathrm{CO}_{3}\right)$. The four analyses reported of natural and synthetic material are given in the above table. Analyses 6 and 7 were made on material containing small amounts of uranophane and kasolite; analysis 4 was made on a nearly pure sample. All of the analyses show a small amount of $\mathrm{H}_{2} \mathrm{O}$ contained on heating above $110^{\circ} \mathrm{C}$, which may be essential to the structure. Spectrographic analyses are lacking. Rutherfordine effervesces vigorously in dilute acids, although the reaction may be slow to start. It decomposes to yellow $\mathrm{UO}_{3}$ when heated gently, and to greenish black $\mathrm{U}_{3} \mathrm{O}_{8}$ when heated strongly. The solubility of synthetic uranyl carbonate in water and in $\mathrm{NaOH}$ solutions at ordinary conditions is negligible (Blake and others, 1950).

Crystallography

Orthorhombic, probably in the dipyramidal crystal class $(2 / m 2 / m 2 / m)$. Morphological data are lacking. The mineral occurs as earthy to pulverulent aggregates of minute fibers or laths and as crusts of tiny laths. The laths are flattened on (100) and are elongated along the $c$-axis.

An X-ray single-crystal study by the precession and Weissenberg methods of crystals from Katanga gave the following data (Christ and others, 1955): $a_{0} 4.845 \pm 0.01 \mathrm{~A}, b_{0} 9.205 \pm 0.008$, $c_{0} 4.296 \pm 0.006, a_{0}: b_{0}: c_{0}=0.5380: 1: 0.4667$. Cell contents $2\left[\mathrm{UO}_{2} \mathrm{CO}_{3}\right]$. Space group $P m 2_{1} n$ or $P m m m$.

Physical properties

Cleavage $\{010\}$ perfect. Hardness not known. Specific gravity 5.7 (measured), 5.72 (calculated) ; lower figures have been reported, owing probably to the porous nature of the material. Color yellow; also inclining to straw yellow and greenish yellow. Luster of the aggregates dull to earthy, inclining to silky in fibrous crusts. Not fluorescent in either long- or short-wave ultraviolet radiation.

Optical properties

\begin{tabular}{|c|c|c|c|}
\hline \multirow[b]{2}{*}{ ORIENTATION } & \multicolumn{2}{|c|}{$n$} & \multirow[b]{2}{*}{ PleochroIsM } \\
\hline & MOROGORO & KATANGA & \\
\hline $\begin{array}{l}X=b \\
Y=c \\
Z=a\end{array}$ & $\begin{array}{l}1.723 \\
1.730 \\
1.760\end{array}$ & $\begin{array}{l}1.720 \\
1.728 \\
1.755\end{array}$ & $\begin{array}{l}\text { Nearly colorless. } \\
\text { Pale yellow. } \\
\text { Pale greenish yellow. }\end{array}$ \\
\hline
\end{tabular}

Biaxial, positive. Extinction parallel, with $Y$ along the elongation and $Z$ perpendicular to the flattening. Optical data from C. Frondel and Meyrowitz (1956).

Thermal behavior

Detailed thermal data are lacking. The $\mathrm{CO}_{2}$ is said to be lost only when heated over $300^{\circ} \mathrm{C}$ (Marckwald, 1906). 


\section{Synthesis}

Obtained as a microcrystalline aggregate by heating precipitated hydrated $\mathrm{UO}_{3}$ in $\mathrm{H}_{2} \mathrm{O}$ at $300^{\circ} \mathrm{C}$ under 15,000 pounds $\mathrm{CO}_{2}$ pressure (C. Frondel and Meyrowitz, 1956). (See also Miller and others, 1949.)

\section{Identification}

Rutherfordine can be distinguished by its effervescence in acid in conjunction with optical measurements. The X-ray powder pattern is distinctive (see following table). Rutherfordine often occurs as a fine-grained mixture with other minerals, and extra lines may then be present in the pattern.

\section{$X$-ray powder-spacing data for rutherfordine $e^{1}$}

[Copper radiation, nickel filter]

\begin{tabular}{lr|ll|ll|ll}
$\frac{d(\mathrm{~A})}{44.60}$ & $\frac{I}{10}$ & $\frac{d(\mathrm{~A})}{2.41}$ & $\frac{I}{2}$ & $\frac{d(\mathrm{~A})}{1.874}$ & $\frac{I}{2}$ & $\frac{d(\mathrm{~A})}{1.435}$ & $\frac{I}{2}$ \\
4.29 & 8 & 2.32 & 3 & 1.734 & 3 & 1.388 & 3 \\
3.90 & 6 & 2.15 & 4 & 1.658 & 1 & 1.373 & 1 \\
3.21 & 9 & 2.05 & 5 & 1.603 & 1 & 1.346 & 1 \\
2.64 & 4 & 1.95 & 1 & 1.588 & 1 & 1.318 & 1 \\
2.51 & 1 & 1.914 & 2 & 1.510 & 2 & 1.275 & 1
\end{tabular}

1 Data from C. Frondel and Meyrowitz (1956) on synthetic material. The pattern is identical with that of natural material.

Natural formation and occurrence

Rutherfordine is a secondary mineral. At Morogoro, Tanganyika, East Africa; the Beryl Mountain pegmatite, New Hampshire; and Newry, Maine. The mineral seems to have formed by the action of carbonated surface waters on hydrated lead uranyl oxides resulting from the alteration of uraninite crystals. The pegmatites of the Morogoro area, where rutherfordine was first discovered, have been described by Williams and Skerl (1940) and von Micke (1950). Also found as crusts at Shinkolobwe, Katanga, Belgian Congo (diderichite), associated with kasolite and uranophane. Reported from the Delta mine, at the southern end of San Rafael Swell, Emery County, and the "C" group, San Juan County, Utah (Weeks, written communication, 1954). At the Lucky Mc No. 20 mine in the Wind River Basin, Fremont County, Wyo. (Gruner and Smith, 1955). Reported from Peak Smelters east of Edwards Creek, South Australia (Whittle, 1954a).

\section{SHARPITE}

Synonymy

Sharpite Mélon (1938). Named after R. R. Sharp, who discovered the Shinkolobwe uranium deposit in 1915. 
Composition

A hydrated basic carbonate of hexavalent uranium. The formula is very uncertain, perhaps $\left(\mathrm{UO}_{2}\right)\left(\mathrm{CO}_{3}\right) \cdot \mathrm{H}_{2} \mathrm{O}$ or $\left(\mathrm{UO}_{2}\right)_{6}\left(\mathrm{CO}_{3}\right)_{5}$ $(\mathrm{OH})_{2} \cdot 7 \mathrm{H}_{2} \mathrm{O}$. An analysis of the acid-soluble part of an impure sample gave the following results:

\section{Chemical analysis of sharpite, in weight percent}

\begin{tabular}{|c|c|c|c|c|c|c|c|}
\hline & 1 & 2 & 3 & & 1 & 2 & 3 \\
\hline & & $\begin{array}{r}2.70 \\
8104\end{array}$ & & $\mathrm{H}_{2} \mathrm{O}$ & 6.93 & 6.81 & 7.09 \\
\hline$U_{5}$ & $\begin{array}{l}82.50 \\
10.57\end{array}$ & $\begin{array}{l}81.04 \\
10.30\end{array}$ & $\begin{array}{r}84.38 \\
8.53\end{array}$ & Total & 100.00 & $\overline{100.85}$ & 100.00 \\
\hline
\end{tabular}

1. Theoretical weight percentages, $\left(\mathrm{UO}_{2}\right)_{6}\left(\mathrm{CO}_{3}\right)_{5}(\mathrm{OH})_{2} \cdot 7 \mathrm{H}_{2} \mathrm{O}$.

2. Sharpite. Kasolo. Mélon (1938). Analysis made on the acid extract of a sample dried at $105^{\circ}-110^{\circ} \mathrm{C}$ which left 1.6 percent of black insoluble material containing much cobalt. The $\mathrm{CaO}$ is considered to be due to admixed calcite, and becquerelite also may have been admixed.

3. Analysis 2 recalculated to 100 percent after deducting the $\mathrm{CaO}$ as $\mathrm{CaCO}_{3}$. Easily soluble in dilute acids with effervescence.

\section{Crystallography}

Inferred from the optical properties to be orthorhombic. The mineral occurs as crusts of thin radiating fibers. Morphological and $\mathrm{X}$-ray data are lacking.

Physical and optical properties

Hardness about $21 / 2$. Specific gravity $>3.33$. Color greenish yellow. The fibers show parallel extinction and positive elongation. Although good interference figures could not be obtained, the fibers seem to be flattened perpendicular to $Y$, and the acute bisectrix, $Z$, is parallel to the elongation. Optically positive(?). Indices of refraction and pleochroism: $n_{X} 1.633$ (brownish), $n_{Z}$ $\approx 1.72$ (light greenish yellow). Birefringence high, about 0.09 . The fibers contain numerous minute inclusions of a black hydrous cobalt oxide.

\section{Thermal properties}

On heating, water is lost in the range $200^{\circ}-275^{\circ} \mathrm{C}$; at $325^{\circ} \mathrm{C}$ all $\mathrm{H}_{2} \mathrm{O}$ and $\mathrm{CO}_{2}$ is lost (16.85 percent) leaving an orange residue; on ignition 1.45 percent more is lost, owing to conversion of $\mathrm{UO}_{3}$ to $\mathrm{U}_{3} \mathrm{O}_{8}$, leaving a brown residue.

\section{Identification}

The distinction from rutherfordine and studtite is not sharp, and the mineral needs further study. X-ray powder-diffraction data are lacking. The optical properties of sharpite apparently are sufficiently different from those of the other minerals to make a tentative identification. The type specimens of sharpite, kept at the University of Liége, were destroyed during World War II and other authentic specimens apparently are not extant. 
Natural formation and occurrence

Sharpite is a very rare secondary mineral found with uranophane as crusts on curite and becquerelite at Shinkolobwe, Katanga district, Belgian Congo.

\section{Synonymy}

\section{STUDTITE}

Studtite Vaes (1947). Named after Franz Edward Studt, Belgian geologist.

\section{Description}

Stated to be a hydrated carbonate of hexavalent uranium on the basis of qualitative tests. Some lead also was found, perhaps due to impurities. Studtite occurs as thin crusts composed of minute fibers, and is presumed from the optical properties to be orthorhombic. Color yellow. The fibers are flexible. Data on the hardness and specific gravity are lacking.

Biaxial positive, with $n_{X} 1.545, n_{Y} 1.555, n_{Z} 1.68 ; 2 V$ large. $Z$ is parallel to the elongation of the fibers. Found sparingly as a secondary mineral associated with uranophane and rutherfordine at Shinkolobwe, Katanga district, Belgian Congo. The optical properties differ from those of any known fibrous uranium mineral. Studtite needs further study.

\section{Synonymy}

\section{LIEBIGITE}

Liebigite Smith $(1848,1851)$. Kalk-uran-carbonate Vogl (1853). Flutherite Weisbach (1875). Uranothallite Schrauf (1882). Named after Justus Liebig (1803-73), German chemist. The identity of liebigite with the calcium uranium carbonate of Vogl, to which the names flutherite and uranothallite were later applied, was established by Evans and Frondel (1950).

\section{Composition}

A hydrated carbonate of calcium and hexavalent uranium, $\mathrm{Ca}_{2}\left(\mathrm{UO}_{2}\right)\left(\mathrm{CO}_{3}\right)_{3} \cdot 10 \mathrm{H}_{2} \mathrm{O}$. The original analysis of liebigite by J. L. Smith (1848) established the qualitative composition but led to a wrong formula. In later analyses of material from Joachimsthal (see table below) the uranium was reported as quadrivalent and this led to another erroneous formula, $\mathrm{Ca}_{2} \mathrm{U}\left(\mathrm{CO}_{3}\right)_{4} \cdot 10 \mathrm{H}_{2} \mathrm{O}$, accepted by Dana (1892) and later by Evans and Frondel (1950). The existence of hexavalent (uranyl) uranium in the mineral was established by the analysis of Meyrowitz (written communication, 1954) on synthetic material (see table below), on which the present formula is based. Bachelet and others (1952) give the same formula for a synthetic preparation. 
Chemical analyses of liebigite, in weight percent

\begin{tabular}{|c|c|c|c|c|c|}
\hline & 1 & 2 & 3 & 4 & 5 \\
\hline $\mathrm{CaO}$ & 15.79 & 15.56 & 16.42 & 16.28 & 15.4 \\
\hline $\mathrm{FeO}$ & - & & & 2.48 & - \\
\hline $\mathrm{UO}_{2}$ & - & 37.11 & 36.29 & 35.45 & - \\
\hline $\mathrm{UO}_{3}$ & 40.27 & & & & 39.9 \\
\hline $\mathrm{CO}_{2}$ & 18.59 & 23.87 & 22.95 & 23.13 & 18.0 \\
\hline $\mathrm{H}_{2} \mathrm{O}$ & 25.35 & 23.35 & 23.72 & 22.44 & 26.8 \\
\hline Total & 100.00 & 99.89 & 99.38 & 99.78 & 100.1 \\
\hline $\mathrm{Sp} g r$ & - & - & - & $14-2.15$ & - \\
\hline
\end{tabular}

1. Theoretical weight percentages for $\mathrm{Ca}_{2}\left(\mathrm{UO}_{2}\right)\left(\mathrm{CO}_{3}\right)_{3} \cdot 10 \mathrm{H}_{2} \mathrm{O}$.

2. Joachimsthal, Bohemia. Average of 3 analyses by Lindacker, in Vogl 1856). The analyses also are quoted by Foullon, in Brezina (1890).

3. Joachimsthal, Bohemia. Analysis by Schrauf (1882).

4. Joachimsthal, Bohemia. Analysis by Foullon, in Brezina (1890). 1954).

5. Synthetic material. Analysis by Meyrowitz (written communication,

The concordance in the optical properties of liebigite from different localities and in different samples indicates that there is no important compositional variation in the mineral. The material of analysis 4, however, apparently contains a small amount of divalent iron in substitution for calcium. Spectrographic analyses have not been reported.

Liebigite is easily soluble in acids, with effervescence. On slight heating it turns yellow, and on ignition it becomes dark but turns orange red on cooling. Infusible. The solubility in water is $1.34 \mathrm{~g}$ per 1, increasing with temperature and pressure of $\mathrm{CO}_{2}$ (Bachelet and others, 1952).

\section{Crystallography}

Liebigite is orthorhombic. The crystal class is pyramidal $(2 \mathrm{~mm})$ (D. E. Appleman, oral communication, 1956). A morphological study by Brezina (1890) of crystals from Joachimsthal, supplementing the earlier observations of Schrauf (1882), afforded the crystal forms listed in the table below.

A single-crystal X-ray study by the precession method on crystals from Joachimsthal, reported by Evans and Frondel (1950), gave: $a_{0}$ 16.71A, $b_{0} 17.55, c_{0} 13.79, a_{0}: b_{0}: c_{0}=0.952: 1: 0.786$. Space group $\mathrm{Bba}$. Unit-cell contents $8\left[\mathrm{Ca}_{2}\left(\mathrm{UO}_{2}\right)\left(\mathrm{CO}_{3}\right)_{3} \cdot 10 \mathrm{H}_{2} \mathrm{O}\right]$. Specific gravity 2.43 (calculated) ; 2.41 (measured).

These data confirmed the unit and orientation of the morphological cell selected by Brezina. Brezina's axial ratio was $a: b: c=$ $0.9539: 1: 0.7826$. The cell used earlier by Schrauf has a different unit. The following angle table is calculated from the X-ray measurements because the morphological measurements were obtained on crystals of poor quality. 


\section{Angle table for liebigite}

Orthorhombic; pyramidal, (2mm)

$a: b: c=0.952: 1: 0.786 ; \quad p_{0}: q_{0}: r_{0}=0.826: 0.786: 1$

$q_{1}: r_{1}: p_{1}=0.952: 1.211: 1 ; \quad r_{2}: p_{2}: q_{2}=1.272: 1.050: 1$

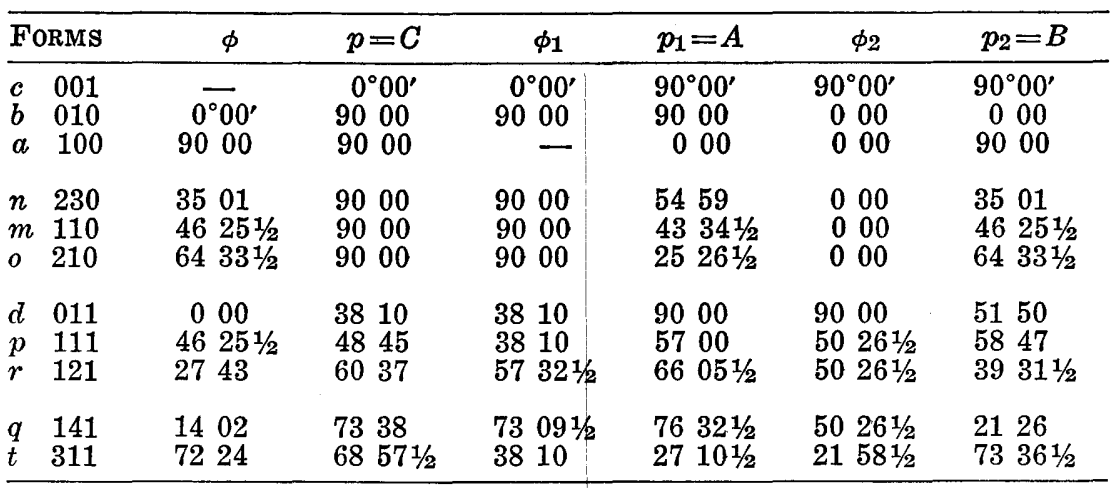

\begin{tabular}{lll|l|l} 
Doubtful : $x 787$ & $u 343$ & $s 232$ & $y$ 8.15.8.
\end{tabular}

Crystal habit

Distinct crystals of liebigite are rare, and generally are indistinct, with rounded edges and convex or vicinal faces. Habit equant or short prismatic [001]. Liebigite usually occurs as granular or scaly crusts and films, sometimes with a small-botryoidal surface. The mineral also occurs as fillings of narrow cracks along the layers of colloform or mammillary masses of pitchblende.

Physical properties

Cleavage distinct on $\{100\}$, but usually observed only in crystals of relatively large size. Hardness $21 / 2-3$. Specific gravity 2.41. Color green to yellowish green. Luster weakly vitreous, inclining to pearly on cleavage surfaces. Transparent to translucent. Liebigite fluoresces green or bluish green in both long- and short-wave ultraviolet light (Haberlandt, Hernegger, and Scheminzky, 1950).

Optical properties

\begin{tabular}{ccc} 
ORIENTATION & & $n$ \\
\cline { 1 - 1 }$X$ & & 1.497 \\
$Y$ & & 1.502 \\
$Z$ & & 1.539
\end{tabular}

PLEOCHRoISM
Nearly colorless.
Pale greenish
yellow.
Pale greenish
yellow.

Biaxial positive; $r>v$, moderate; $2 V 40^{\circ}$.

The above data are the average of numerous measurements summarized by Evans and Frondel (1950). The optical orientation is not known.

\section{Thermal behavior}

The water is largely or entirely lost on heating at about $105^{\circ} \mathrm{C}$ (Schrauf, 1882). (See also Foullon, cited in Brezina, 1890.) A differential thermal analysis curve has been reported by Beck 
(1950). The curve is complex and has not been fully interpreted. Peaks occur at $110^{\circ} \mathrm{C}$ (loss of $\left.\mathrm{H}_{2} \mathrm{O}\right), 175^{\circ} \mathrm{C}$ (loss of $\mathrm{CO}_{2}$ in part?), $475^{\circ} \mathrm{C}, 750^{\circ} \mathrm{C}$, and $890^{\circ} \mathrm{C}$. Bachelet and others (1952) state that synthetic material loses $8 \mathrm{H}_{2} \mathrm{O}$ at $90^{\circ} \mathrm{C}$ and the remaining $\mathrm{H}_{2} \mathrm{O}$ at $180^{\circ} \mathrm{C}$.

\section{Synthesis}

Liebigite has been synthesized by methods similar to those used for bayleyite (M. E. Thompson, written communication). Hydrated uranyl carbonates also have been synthesized by Blinkoff (1906).

\section{Identification}

Liebigite resembles bayleyite but has slightly higher indices of refraction and is greener in color. The green uranium sulfate johannite can be distinguished by chemical and optical tests. The $\mathrm{X}$-ray powder pattern is distinctive (see following table).

\section{$X-r a y$ powder-spacing data for liebigite ${ }^{1}$}

[Copper radiation, nickel filter]

\begin{tabular}{|c|c|c|c|c|c|c|}
\hline$d(\mathrm{~A})$ & $I$ & $d(\mathrm{~A})$ & $I$ & $d(\mathrm{~A})$ & $I$ & $d(\mathrm{~A})$ \\
\hline $\begin{array}{l}8.68 \\
8.27 \\
6.81 \\
6.11 \\
5.40 \\
4.95 \\
4.55 \\
4.17 \\
4.04 \\
3.95 \\
3.75\end{array}$ & $\begin{array}{r}9 \\
1 \\
10 \\
2 \\
9 \\
1 \\
6 \\
1 \\
2 \\
1 \\
2\end{array}$ & $\begin{array}{l}3.58 \\
3.33 \\
3.31 \\
3.19 \\
3.10 \\
3.02 \\
2.84 \\
2.77 \\
2.66 \\
2.57 \\
2.44\end{array}$ & $\begin{array}{l}3 \\
5 \\
5 \\
1 \\
6 \\
1 \\
1 \\
1 \\
1 \\
3 \\
1\end{array}$ & $\begin{array}{l}2.37 \\
2.30 \\
2.26 \\
2.15 \\
2.10 \\
2.02 \\
1.998 \\
1.957 \\
1.911 \\
1.884 \\
1.830\end{array}$ & $\begin{array}{l}2 \\
2 \\
2 \\
4 \\
4 \\
1 \\
1 \\
5 \\
1 \\
1 \\
1 \\
1\end{array}$ & $\begin{array}{l}1.716 \\
1.670 \\
1.561 \\
1.533 \\
1.484 \\
1.473 \\
1.437 \\
1.416 \\
1.397 \\
1.347\end{array}$ \\
\hline
\end{tabular}

${ }^{1}$ Material from Joachimsthal, Bohemia. Slightly different values are given by Evans and Frondel (1950).

\section{Natural formation and occurrence}

Liebigite is a secondary mineral formed from alkaline carbonate solutions. It occurs associated with calcite, schroeckingerite, bayleyite, and gypsum. Found originally as a coating on uraninite from near Adrianople, Turkey. Details of the occurrence are lacking. In a later note, Smith (1851) mentioned that the mineral occurs at Johanngeorgenstadt, Saxony, but the occurrence is not well validated. Liebigite occurs abundantly at Joachimsthal, Bohemia, in the oxidized zone of the uraninite veins and as an efflorescence on the walls of mine workings. The liebigite from this locality (formerly called uranothallite) has been described by Vogl (1853), Schrauf (1882) and Brezina (1890). From the Kinzigthal, Baden. The mineral also occurs at the Wheal Basset, Cornwall, England, and Schneeberg, Saxony (Evans and Frondel, 1950) ; and at Schmiedeberg, Silesia, and Eisleben, Thuringia, in 
Germany (Meixner, 1940a). At the Lucky Mc mine in the Wind River basin, Fremont County, Wyo. (Gruner and Smith, written communication, 1955). Also at the Silver Cliff mine near Lusk, Wyo. (George, 1949). Found at Pumpkin Buttes, Wyo.; at the Black Ape mine, Yellow Cat district, Thompsons, Utah; at the Hanosh mines, near Grants, N. Mex.; and at Mauch Chunk (now Jim Thorpe), Pa. (A. D. Weeks, written communication). In the Mi Vida mine, San Juan County, Utah (Gruner and Smith, 1955).

Synonymy

\section{BAYLEYITE}

Bayleyite Axelrod, Grimaldi, Milton, and Murata (1951). Named after William S. Bayley (1861-1943), for many years Professor of Geology at the University of Illinois and geologist of the U. S. Geological Survey.

Composition

A hydrated carbonate of magnesium and hexavalent uranium, $\mathrm{Mg}_{2}\left(\mathrm{UO}_{2}\right)\left(\mathrm{CO}_{3}\right)_{3} \cdot 18 \mathrm{H}_{2} \mathrm{O}$. The three analyses so far reported are given in the table below. All were made on material known to contain admixed gypsum, which accounts for the $\mathrm{SO}_{3}$ reported.

Chemical analysis of bayleyite, in weight percent

\begin{tabular}{|c|c|c|c|c|c|}
\hline & 1 & 2 & 3 & 4 & 5 \\
\hline $\mathrm{Na}_{2} \mathrm{O}$ & - & - & 0.19 & 0.21 & - \\
\hline $\begin{array}{l}\mathrm{K}_{2} \mathrm{O} \\
\mathrm{MgO}\end{array}$ & $\overline{980}$ & $\overline{9.03}$ & $\begin{array}{r}.09 \\
8.97\end{array}$ & $\begin{array}{r}.10 \\
9.76\end{array}$ & $\overline{92}$ \\
\hline $\mathrm{CaO}$ & - & $\begin{array}{l}5.00 \\
3.42\end{array}$ & 2.75 & -10 & 3.4 \\
\hline $\mathrm{UO}_{3}$ & 34.76 & 30.80 & 32.42 & 35.28 & 30.6 \\
\hline $\mathrm{CO}_{2}$ & 16.04 & 14.60 & 15.36 & 16.72 & 12.2 \\
\hline $\mathrm{SO}_{3}$ & - & 4.43 & 3.95 & .02 & 6.6 \\
\hline $\mathrm{H}_{2} \mathrm{O}$ & 39.40 & 35.19 & 36.60 & 37.91 & 37.6 \\
\hline Insol. & 一 & 2.27 & .45 & - & - \\
\hline Total & 100.00 & 99.74 & 100.78 & 100.00 & 99.6 \\
\hline $\mathrm{Sp} \mathrm{gr}$ & 一 & 2.06 & 2.05 & - & - \\
\hline
\end{tabular}

1. Theoretical composition, $\mathrm{Mg}_{2}\left(\mathrm{UO}_{2}\right)\left(\mathrm{CO}_{3}\right)_{3} \cdot 18 \mathrm{H}_{2} \mathrm{O}$.

2, 3. Bayleyite. Hillside mine, Yavapai County, Ariz. Grimaldi, analyst, in Axelrod and others (1951). Contains admixed gypsum.

4. Analysis 3 recalculated to 100 percent after deduction of 0.45 insoluble and of the $\mathrm{CaO}$ as 8.45 percent gypsum.

5. Azegour, Morocco. Branche, Chervet, and Guillemin (1951). Contains admixed gypsum and epsomite.

\section{Crystallography}

Bayleyite is monoclinic. The X-ray space-group extinction criteria establish the crystal class as prismatic $(2 / m)$. Morphological data are lacking. A single-crystal X-ray Weissenberg study by Axelrod on natural crystals from Arizona gave the following data: $a_{0} 26.65 \pm 0.05 \mathrm{~A}, b_{0} 15.31 \pm 0.05, c_{0} 6.53 \pm 0.02, \beta=93^{\circ} 04^{\prime}$ $\pm 20^{\prime} . a_{0}: b_{0}: c_{0}=1.7407: 1: 0.4265$. Unit-cell contents $4\left[\mathrm{Mg}_{2}\left(\mathrm{UO}_{2}\right)\right.$ 
$\left.\left(\mathrm{CO}_{3}\right)_{3} \cdot 18 \mathrm{H}_{2} \mathrm{O}\right]$. Specific gravity 2.05 (measured), 2.06 (calculated). Space group $P 2_{1} / a$.

Crystal habit

Single crystals are short prismatic along [001] with sharp terminal faces. A photograph of crystals is given by Stern and Weeks (1952). The crystals tend to dehydrate in a dry atmosphere, losing their vitreous luster and finally disintegrate to a yellow powder. Synthetic material forms radial aggregates of needlelike crystals. The natural mineral occurs as crusts.

\section{Physical properties}

Information on the cleavage and hardness is lacking. Fracture conchoidal. Specific gravity 2.05. Color yellow, becoming pale yellow to yellowish white on dehydration to metabayleyite. In long- and short-wave ultraviolet light, bayleyite fluoresces weakly in an ill-defined shade of yellow green.

Optical properties

\begin{tabular}{|c|c|c|c|c|c|}
\hline \multirow[b]{2}{*}{ ORIENTATION } & \multicolumn{3}{|c|}{$n$} & & \\
\hline & UTAH & ARIZONA & MOROCCO & Pleochroism & \\
\hline $\begin{array}{l}X \\
Y \\
Z\end{array}$ & $\begin{array}{l}1.454 \\
1.492 \\
1.502\end{array}$ & $\begin{array}{l}1.455 \\
1.490 \\
1.500\end{array}$ & $\begin{array}{l}1.453 \\
1.492 \\
1.498\end{array}$ & $\begin{array}{l}\text { Pinkish (?). } \\
\text { Pale yellow. } \\
\text { Pale yellow. }\end{array}$ & $\begin{array}{l}\text { Biaxial negative; } \\
2 V 30^{\circ} \\
\text { (calculated for }\end{array}$ \\
\hline$X \wedge c$ & $14^{\circ}$ & $15^{\circ}$ & $8^{\circ}$ & & \\
\hline
\end{tabular}

Thermal behavior

On exposure to dry air, bayleyite may dehydrate to a pulverulent, pale-yellow to whitish-yellow substance (metabayleyite). This material has $n_{X} 1.502, n_{Y} 1.551$, and fluoresces moderately in ultraviolet light with a whitish-green color.

\section{Synthesis}

Bayleyite can be synthesized by a method analogous to that used for andersonite. Also formed by reacting an excess of silver uranyl carbonate with magnesium chloride, filtering off the silver chloride and excess silver uranyl carbonate, and allowing the filtrate to crystallize at room temperature. A gelatinous mass may form in this method, which can be caused to crystallize by seeding. (See also Branche and others, 1951.)

\section{Identification}

Bayleyite is easily distinguished from the other uranyl carbonates by its relatively low indices of refraction and specific gravity. Among the water-soluble carbonates, liebigite, schroeckingerite, andersonite, and swartzite are green or yellowish green in color and rabbittite is pale greenish yellow, but bayleyite is yellow. The X-ray powder-spacing data are given in the following table. 
$X$-ray powder-spacing data for bayleyite ${ }^{1}$

[Symbol: b, broad. Copper radiation, nickel filter]

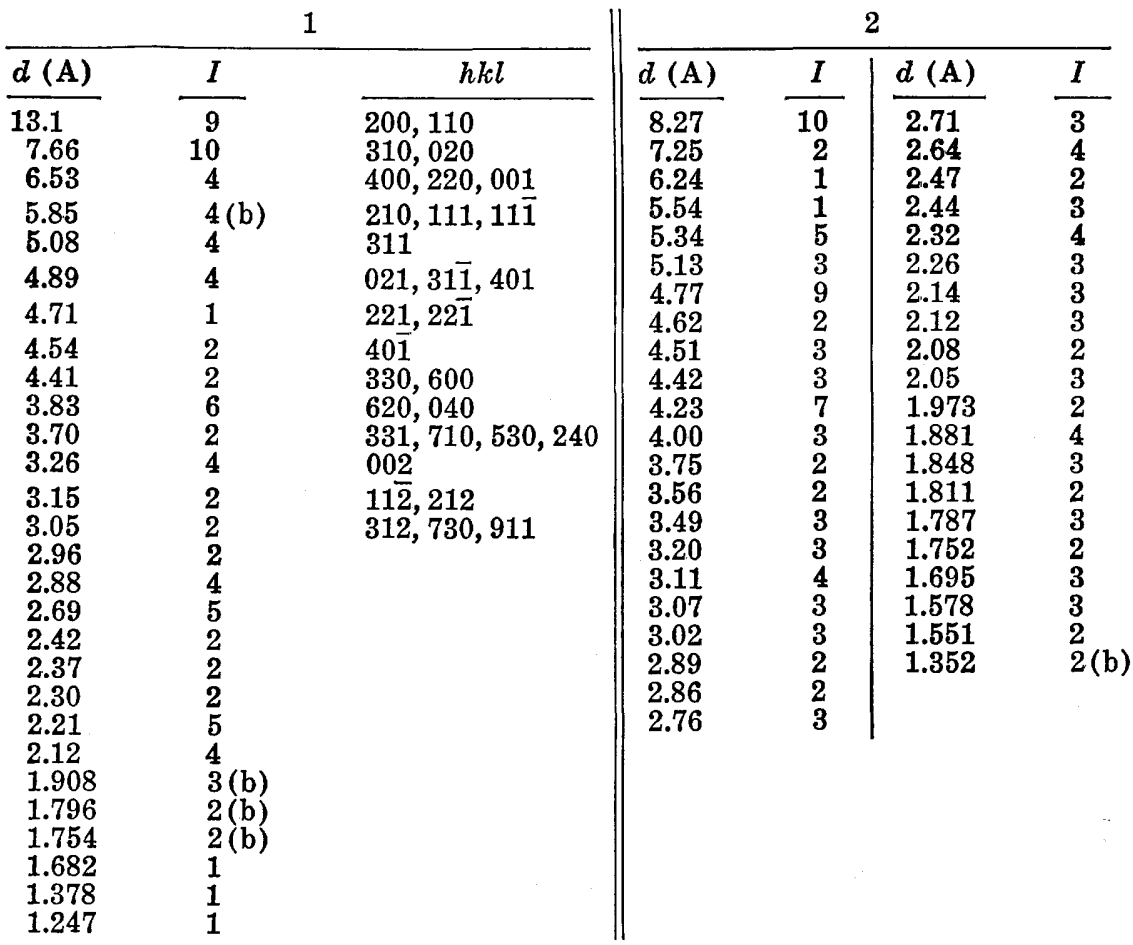

1 Data from Axelrod and others (1951) on material from the Hillside mine, Yavapai County, Ariz. Bayleyite dehydrates readily.

1. Bayleyite. 2. Dehydration product of bayleyite.

Natural formation and occurrence

Bayleyite, like andersonite and swartzite, is a water-soluble secondary mineral originally found with schroeckingerite and gypsum as an efflorescence in a mine tunnel in the Hillside mine near Bagdad, Yavapai County, Ariz. From the Hideout mine on Deer Flats, San Juan County, Utah (Stern and Weeks, 1952) as an efflorescence on a mine wall, associated with schroeckingerite, gypsum, and secondary copper minerals as oxidation products of a uraninite-copper sulfide deposit in conglomerate of Triassic age. Also at the Coral Claim, Elk Ridge, San Juan County, and at the Delta Group mine, (in part dehydrated to metabayleyite), San Rafael Swell, Emery County, Utah (Gruner and others, 1954b). At the Mi Vida mine, San Juan County, Utah (Gruner and Smith, 1955), at the Garfield and Rifle mines, north of Rifle, Colo., and at the J. J. mine, Montrose County, Colo. (A. D. Weeks, written communication). In the Pumpkin Buttes area of the Powder River Basin, Wyo., associated with liebigite as an efflores- 
cence forming at the present time along a line of seepage in the bank of a dry stream (Weeks and Thompson, 1954). Also described by Branche and others (1951) as an efflorescence with epsomite and gypsum in a mine tunnel at Azegour, Morocco.

Synonymy

\section{ANDERSONITE}

Andersonite Axelrod, Grimaldi, Milton, and Murata (1951). Named after Charles A. Anderson (1902- ), geologist, of the U. S. Geological Survey.

Composition

A hydrated carbonate of sodium, calcium, and hexavalent uranium, $\mathrm{Na}_{2} \mathrm{Ca}\left(\mathrm{UO}_{2}\right)\left(\mathrm{CO}_{3}\right)_{3} \cdot 6 \mathrm{H}_{2} \mathrm{O}$. The two analyses, one on synthetic material, that have been reported are given in the table below. The $\mathrm{Mg}$ found in analysis 2 may be in substitution for $\mathrm{Ca}$; the $\mathrm{SO}_{3}$ of this analysis is known to be due to admixed gypsum.

Chemical analyses of andersonite, in weight percent

\begin{tabular}{|c|c|c|c|c|c|c|c|}
\hline \multirow{4}{*}{$\begin{array}{l}\mathrm{Na}_{2} \mathrm{O} \\
\mathrm{MgO} \\
\mathrm{CaO} \\
\mathrm{UO}_{3} \\
\mathrm{CO}_{2}\end{array}$} & 1 & 2 & 3 & \multirow[b]{2}{*}{$\begin{array}{l}\mathrm{SO}_{3} \\
\mathrm{H}_{2} \mathrm{O}\end{array}$} & 1 & 2 & 3 \\
\hline & $\begin{array}{l}9.62 \\
-\end{array}$ & $\begin{array}{r}9.3 \\
5\end{array}$ & 9.61 & & $\overline{16.78}$ & $\begin{array}{c}1.6 \\
{[16.7]}\end{array}$ & $\overline{16.50}$ \\
\hline & 8.71 & 8.9 & $\begin{array}{r}8.80 \\
8.87\end{array}$ & Total & $\overline{100.00}$ & $\overline{[100.0]}$ & $\overline{99.79}$ \\
\hline & 20.49 & 19.6 & 20.61 & $\mathrm{Sp} \mathrm{gr}$ & - & 2.8 & - \\
\hline
\end{tabular}

1. Theoretical composition, $\mathrm{Na}_{2} \mathrm{Ca}\left(\mathrm{UO}_{2}\right)\left(\mathrm{CO}_{3}\right)_{3} \cdot 6 \mathrm{H}_{2} \mathrm{O}$.

2. Andersonite. Hillside mine, Yavapai County, Ariz. Analysis on $3.8 \mathrm{mg}$ by Grimaldi, in Axelrod and others (1951). MgO determined spectrographically by Murata, in Axelrod and others (1951).

3. Synthetic andersonite. M. Eiland, analyst, in Axelrod and others (1951). Crystallography

Andersonite is rhombohedral (hexagonal- $R$ ). The crystal class is uncertain, either $R \overline{3}$ or $R 3$. Morphological data are lacking. An X-ray single-crystal study gave the following data:

\section{Unit-cell dimensions of andersonite}

COORDiNATES

\begin{tabular}{cll}
\hline HEXAGONAL & & RHOMBOHEDRAL \\
\cline { 1 - 1 }$a_{0} 18.04 \pm 0.05 \mathrm{~A}$ & & $a_{\mathrm{rh}} 13.11 \pm 0.02 \mathrm{~A}$ \\
$c_{0} 23.90 \pm .05$ & & $\alpha=86^{\circ} 56^{\prime} \pm 30^{\prime}$ \\
\hline
\end{tabular}

$a_{0}: c_{0}=1: 1.325$
Unit-cell contents $16\left[\mathrm{Na}_{2} \mathrm{Ca}\left(\mathrm{UO}_{2}\right)\left(\mathrm{CO}_{3}\right)_{3} \cdot 6 \mathrm{H}_{2} \mathrm{O}\right]$ in the hexagonal unit; space group $R \overline{3}$ or $R 3$; sp gr 2.8 (measured), 2.86 (calculated).

Data obtained on natural crystals by the Weissenberg method by J. M. Axelrod (Axelrod and others, 1951).

Crystal habit

Found as clusters of minute pseudo-cubic crystals. A photograph of crystals is given by Axelrod and others (1951) [photograph captions of andersonite and swartzite in this paper should be reversed]. 


\section{Physical properties}

Information on the cleavage and hardness is lacking. Specific gravity 2.8. Color bright yellow green. Fluoresces bright yellow green in both short- and long-wave ultraviolet radiation. Synthetic andersonite is greenish yellow rather than bright yellow green, and the fluorescence is yellow green and weaker than the natural material.

Optical properties

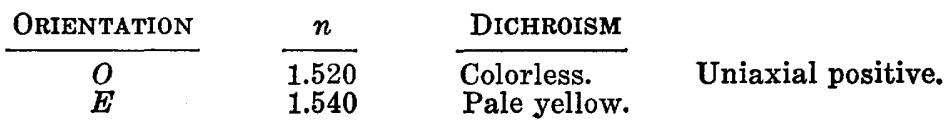

Thermal behavior

Data on dehydration are lacking. The mineral is stable under ordinary conditions.

\section{Synthesis}

Obtained as microscopic crystals by adding uranyl nitrate solution to potassium carbonate solution in the molar ratio $1: 3$, adjusting the acidity with potassium carbonate until phenolphthalein indicator is just pink, and then adding a mixed solution of sodium nitrate and calcium nitrate in the molar ratios $1: 2$. The acidity of the solution is then adjusted as before, and the solution is allowed to crystallize at room temperature.

\section{Identification}

Andersonite is not known to be closely related to any other mineral. Bayleyite, liebigite, rabbittite, and swartzite belong to the same general formula type, but differ in their content of water of crystallization. A number of artificial compounds also are known of the same general nature, including $\left(\mathrm{NH}_{4}\right)_{4}\left(\mathrm{UO}_{2}\right)$ $\left(\mathrm{CO}_{3}\right)_{3} \cdot n \mathrm{H}_{2} \mathrm{O}$ and the $\mathrm{Na}_{4}, \mathrm{~K}_{4}, \mathrm{Ag}_{4}, \mathrm{Tl}_{4}, \mathrm{Ca}_{2}$, and $\mathrm{Ba}_{2}$ analogues (Hedvall, 1925). The structural relation of these substances to each other and to the natural carbonate is not known. The X-ray powder-spacing data are given in the following table.

\section{$X$-ray powder-spacing data for andersonite ${ }^{1}$}

[Copper radiation, nickel filter]

\begin{tabular}{|c|c|c|c|c|c|c|}
\hline$d(\mathrm{~A})$ & $I$ & $d(\mathrm{~A})$ & $I$ & $d(\mathrm{~A})$ & $I$ & $d(\mathrm{~A})$ \\
\hline 13.0 & 10 & 3.71 & 8 & 2.04 & 4 & 1.393 \\
\hline 9.51 & 3 & 3.49 & 2 & 2.01 & 4 & 1.344 \\
\hline 7.97 & 10 & 3.34 & $\overline{2}$ & 1.977 & 4 & 1.262 \\
\hline 6.56 & 2 & 3.15 & 5 & 1.957 & 4 & 1.232 \\
\hline 5.68 & 10 & 3.00 & 7 & 1.933 & 4 & 1.038 \\
\hline 5.22 & 10 & 2.79 & 6 & 1.895 & 4 & .980 \\
\hline 4.35 & 6 & 2.45 & 5 & 1.852 & 6 & .951 \\
\hline 4.19 & 6 & 2.39 & 5 & 1.749 & 5 & .819 \\
\hline 4.04 & 4 & 2.36 & 4 & 1.684 & 3 & .801 \\
\hline 3.82 & 3 & 2.21 & 7 & 1.573 & 4 & \\
\hline
\end{tabular}

${ }^{1}$ Data from Axelrod, Grimaldi, Milton, and Murata (1951) on material from the Hillside mine, Yavapai County, Ariz. 
Andersonite resembles closely a number of uranium minerals in its yellow-green color and bright yellow-green fluorescence, but its optical properties, solubility in water, and other properties are distinctive. It is the only uranium mineral that is known to be rhombohedral in crystallization.

\section{Natural formation and occurrence}

Andersonite is a water-soluble secondary mineral, originally found closely associated with schroeckingerite, gypsum, bayleyite, and swartzite as an efflorescence in an adit in the Hillside mine near Bagdad, Yavapai County, Ariz. The Hillside vein carries pyrite, arsenopyrite, galena, sphalerite, chalcopyrite, tetrahedrite, and argentite as the principal sulfide minerals, and uraninite has been found in places. The oxidized zone carries cerussite, anglesite, smithsonite, hemimorphite, cerargyrite, and andersonite and its associates locally. Zippeite and johannite have been found as oxidation products of uraninite elsewhere in the mine. At the Atomic King No. 2 and nearby mines in Cane Wash near Moab, San Juan County, Utah, andersonite occurs as thick crusts and veinlets and has been mined as an ore; crystals up to one-half inch in size have been reported. Andersonite also has been found at the Parco No. 23 mine and at the Skinny No. 1 mine southeast of Thompsons, Grand County, Utah, as an efflorescence on mine walls in a vanadiferous uranium deposit (Weeks and Thompson, written communication, 1954). Found at Mauch Chunk (now Jim Thorpe), Pa., as efflorescence with liebigite at the carnotite locality (Montgomery, 1954).

\section{SWARTZITE}

Synonymy

Swartzite Axelrod, Grimaldi, Milton, and Murata (1951). Named after Charles K. Swartz (1861-1949), Professor of Geology and Mineralogy at The Johns Hopkins University.

Composition

Chemical analysis of swartzite, in weight percent

\begin{tabular}{|c|c|c|c|c|c|c|c|}
\hline & 1 & 2 & 3 & & 1 & 2 & 3 \\
\hline $\begin{array}{l}\mathrm{Na}_{2} \mathrm{O} \\
\mathrm{K}_{2} \mathrm{O}\end{array}$ & & $\begin{array}{r}0.25 \\
47\end{array}$ & $\begin{array}{r}0.26 \\
.49\end{array}$ & $\begin{array}{l}\mathrm{CO}_{2} \\
\mathrm{SO}_{3}\end{array}$ & 18.07 & $\begin{array}{r}17.16 \\
1.98\end{array}$ & 17. \\
\hline $1 g 0$ & 5.52 & 5.24 & 5.47 & $\mathrm{H}_{2} \mathrm{O}$ & $29 . \overline{59}$ & 29.31 & 29.69 \\
\hline $\mathrm{O}_{3}$ & $\begin{array}{r}7.67 \\
39.15\end{array}$ & $\begin{array}{r}8.40 \\
37.19\end{array}$ & $\begin{array}{r}7.32 \\
38.85\end{array}$ & Total & 100.00 & $\overline{100.30}$ & 100.0 \\
\hline
\end{tabular}

1. Theoretical weight percentages, $\mathrm{CaMg}\left(\mathrm{UO}_{2}\right)\left(\mathrm{CO}_{3}\right)_{3} \cdot 12 \mathrm{H}_{2} \mathrm{O}$.

2. Swartzite, Hillside mine, Arizona. Grimaldi, analyst, in Axelrod and others (1951). Total includes insoluble 0.30 .

3. Analysis 2 recalculated to 100 percent after deducting the $\mathrm{SO}_{3}$ as 4.26 percent $\mathrm{CaSO}_{4} \cdot 2 \mathrm{H}_{2} \mathrm{O}$. 
A hydrated carbonate of calcium, magnesium, and hexavalent uranium, $\mathrm{CaMg}\left(\mathrm{UO}_{2}\right)\left(\mathrm{CO}_{3}\right)_{3} \cdot 12 \mathrm{H}_{2} \mathrm{O}$. The only analysis so far reported is given above. The analyzed material was shown to contain a small amount of admixed gypsum. Soluble in water.

\section{Crystallography}

Swartzite is monoclinic, but the crystal class is not known. Morphological measurements are lacking. An X-ray single-crystal study of natural material by the Weissenberg method gave the following data (Axelrod and others, 1951): $a_{0} 11.12 \pm 0.05 \mathrm{~A}$, $b_{0} 14.72 \pm 0.05, c_{0} 6.74 \pm 0.02, a_{0}: b_{0}: c_{0}=0.7554: 1: 0.4395$. Space group $P 2_{1} / m$ or $P 2_{1}$. Unit-cell contents $2\left[\mathrm{CaMg}\left(\mathrm{UO}_{2}\right)\left(\mathrm{CO}_{3}\right)_{3}{ }^{*}\right.$ $\left.12 \mathrm{H}_{2} \mathrm{O}\right] . \beta=99^{\circ} 26^{\prime} \pm 30^{\prime}$.

\section{Crystal habit}

Individual crystals are prismatic along [001] and are very small in size. Microscopic synthetic crystals are equant in shape. Found in crusts intergrown with andersonite and schroeckingerite. A photograph of swartzite crystals is given by Axelrod and others (1951) [the captions of the photographs of swartzite and andersonite in this paper should be reversed].

\section{Physical properties}

The cleavage and hardness are not known. Specific gravity 2.3. Color green, somewhat darker and more vivid than the color of andersonite. Turns dull yellowish white on dehydration. Swartzite fluoresces bright yellowish green in short-wave ultraviolet radiation.

Optical properties

\begin{tabular}{|c|c|c|c|}
\hline ORIENTATION & $n$ & PLEOCHROISM & \\
\hline $\begin{array}{l}X \\
Y \\
Z\end{array}$ & $\begin{array}{l}\overline{1.465} \\
1.51 \\
1.540\end{array}$ & $\begin{array}{l}\text { Colorless. } \\
\text { Yellow. } \\
\text { Yellow. }\end{array}$ & $\begin{array}{l}\text { Biaxial negative; } \\
\quad 2 V 40^{\circ} \text { (calculated). }\end{array}$ \\
\hline
\end{tabular}

The optical orientation is not known. Swartzite dehydrates on standing in dry air to a new phase whose optical properties have not been described.

\section{Thermal behavior}

On standing in dry air swartzite dehydrates to a whitish dullyellow product that fluoresces weakly with an uncertain color in ultraviolet light.

\section{Synthesis}

Obtained as a microcrystalline product by procedures similar to those used for bayleyite and andersonite. 


\section{Identification}

Swartzite is not closely related to any other known mineral. It is somewhat similar in formula, however, to rabbittite, bayleyite, liebigite, and a series of artificial carbonates of the general type $\mathrm{X}_{4}\left(\mathrm{UO}_{2}\right)\left(\mathrm{CO}_{3}\right)_{3} \cdot n \mathrm{H}_{2} \mathrm{O}$. Swartzite is distinguished from andersonite by its darker color, inclined extinction, and lower indices of refraction. It differs from the platy green uranyl phosphates and arsenates such as metatorbernite and metazeunerite in its optics, solubility in water, and chemical composition. The dark-green carbonates voglite and liebigite and the sulfate johannite can be distinguished by similar tests. The X-ray powderspacing data for swartzite are given in the following table.

$X$-ray powder-spacing data for swartzite ${ }^{1}$

[Copper radiation, nickel filter]

\begin{tabular}{|c|c|c|c|c|c|c|}
\hline$d(\mathrm{~A})$ & $I$ & $d(\mathrm{~A})$ & $I$ & $d(\mathrm{~A})$ & $I$ & $d(\mathrm{~A})$ \\
\hline $\begin{array}{l}8.76 \\
7.31 \\
6.37 \\
5.83 \\
5.50 \\
5.13 \\
4.82 \\
4.62 \\
4.46\end{array}$ & $\begin{array}{r}10 \\
9 \\
5 \\
1 \\
10 \\
1 \\
8 \\
2 \\
2\end{array}$ & $\begin{array}{l}4.37 \\
3.85 \\
3.66 \\
3.53 \\
3.39 \\
3.31 \\
3.25 \\
3.19 \\
3.11\end{array}$ & $\begin{array}{l}2 \\
2 \\
7 \\
5 \\
1 \\
1 \\
1 \\
1 \\
7 \\
2\end{array}$ & $\begin{array}{l}3.04 \\
2.91 \\
2.82 \\
2.61 \\
2.28 \\
2.23 \\
2.19 \\
2.10 \\
2.06\end{array}$ & $\begin{array}{l}1 \\
8 \\
2 \\
5 \\
4 \\
4 \\
3 \\
2 \\
2 \\
2 \\
8\end{array}$ & $\begin{array}{r}1.817 \\
1.707 \\
1.375 \\
1.268 \\
1.217 \\
.962\end{array}$ \\
\hline
\end{tabular}

${ }^{1}$ Data from Axelrod, Grimaldi, Milton, and Murata (1951) on material from the Hillside mine, Yavapai County, Utah.

Natural formation and occurrence

Swartzite is a secondary mineral, found as an efflorescence in the Hillside mine, Yavapai County, Ariz., associated with gypsum, schroeckingerite, andersonite, and bayleyite. Reported from the Coral claim, Elk Ridge, San Juan County, Utah (Gruner and others, 1954a).

\section{RABBITTITE}

synonymy

Rabbittite Thompson, Weeks, and Sherwood (1955). Named after John C. Rabbitt (1907--57), geologist, of the U. S. Geological Survey.

\section{Composition}

A hydrated basic carbonate of calcium, magnesium, and uranium, probably $\mathrm{Ca}_{3} \mathrm{Mg}_{3}\left(\mathrm{UO}_{2}\right)_{2}\left(\mathrm{CO}_{3}\right)_{6}(\mathrm{OH})_{4} \cdot 18 \mathrm{H}_{2} \mathrm{O}$. The only analysis that has been made is as follows: 
Chemical analyses of rabbittite, in weight percent

\begin{tabular}{|c|c|c|c|c|c|}
\hline & 1 & 2 & & 1 & 2 \\
\hline $\begin{array}{l}\mathrm{CaO} \\
\mathrm{MgO}\end{array}$ & $\begin{array}{r}11.32 \\
8.09\end{array}$ & $\begin{array}{r}10.6 \\
9.2\end{array}$ & $\begin{array}{l}\mathrm{H}_{2} \mathrm{O} \\
\text { Insol. }\end{array}$ & $\begin{array}{r}24.26 \\
- \\
\end{array}$ & $\begin{array}{r}24.5 \\
.5 \\
\end{array}$ \\
\hline $\begin{array}{l}\mathrm{CO}_{3} \\
\mathrm{CO}_{2}\end{array}$ & $\begin{array}{l}38.54 \\
17.79\end{array}$ & $\begin{array}{l}37.4 \\
17.8\end{array}$ & & $\overline{100.00}$ & 100.0 \\
\hline
\end{tabular}

1. Theoretical weight percentages, $\mathrm{Ca}_{3} \mathrm{Mg}_{3}\left(\mathrm{UO}_{2}\right)_{2}\left(\mathrm{CO}_{3}\right)_{6}(\mathrm{OH})_{4} \cdot 18 \mathrm{H}_{2} \mathrm{O}$.

2. Rabbittite. Utah. Sherwood, analyst, on $75 \mathrm{mg}$.

A spectrographic analysis showed the presence of small amounts of $\mathrm{Si}, \mathrm{Al}$, and $\mathrm{Y}$. Rabbittite is slowly soluble in cold water and dissolves with effervescence in dilute $\mathrm{HCl}$.

\section{Crystallography and crystal habit}

Rabbittite probably is monoclinic, on the basis of the optical properties. Morphological data are lacking. Found as an efflorescence composed of bundles of extremely small acicular crystals elongated on the c-axis. The bundles sometimes appear bent or twisted due to displacement on a transverse cleavage, probably $\{001\}$.

An X-ray study of a bundle of fibers by the rotation method (Evans, in Thompson and others, 1955) gave the fiber period, $c_{0}$, as $9.45 \pm 0.05 \mathrm{~A}$ and the tentative values $a_{0} 32.6 \pm 0.1, b_{0} 23.8$ \pm 0.1 , with $\beta$ close to $90^{\circ}$. The number of formula units in this cell is probably 8 ; the cell is one of the largest in the mineral kingdom.

\section{Physical properties}

Under the microscope rabbittite shows a cleavage across the fibers, probably $\{001\}$, and two easy and perfect prismatic cleavages. Hardness about $21 / 2$. Not brittle; a finely ground powder shows broadened X-ray powder lines. Specific gravity 2.57. Luster of aggregates silky. Color pale green. Fluoresces cream yellow in short-wave ultraviolet light.

Optical properties

\begin{tabular}{|c|c|}
\hline ORIENTATION & $n$ \\
\hline $\begin{array}{l}X \\
Y=b \\
Z \wedge c \approx 15^{\circ}\end{array}$ & $\begin{array}{l}1.502 \pm 0.005 \\
1.508 \pm .005 \\
1.525 \pm .003\end{array}$ \\
\hline
\end{tabular}
Biaxial positive (?);
not pleochroic.

Synthesis and thermal behavior

No data.

\section{Identification}

Rabbittite resembles swartzite (which has the same qualitative chemical composition), bayleyite, and other water-soluble uranyl carbonates of the same general type of formula, from which it is best distinguished by its X-ray powder-diffraction pattern (see following table) and its optical properties. 
$X$-ray powder-spacing data for rabbittite ${ }^{1}$

[Symbol: b, broad. Copper radiation, nickel filter]

\begin{tabular}{|c|c|c|c|c|c|c|c|}
\hline$d(\mathbf{A})$ & $I$ & $d(\mathrm{~A})$ & $l$ & $d(\mathrm{~A})$ & $I$ & $d(\mathrm{~A})$ & $I$ \\
\hline $\begin{array}{r}19.4 \\
18.6 \\
11.28 \\
8.63 \\
8.24 \\
7.79\end{array}$ & $\begin{array}{r}3 \\
1 \\
5 \\
3 \\
10 \\
8\end{array}$ & $\begin{array}{l}7.15 \\
6.81 \\
6.47 \\
6.35 \\
5.83(\mathrm{~b}) \\
5.72\end{array}$ & $\begin{array}{l}3 \\
\mathbf{1} \\
3 \\
1 \\
\mathbf{5} \\
\mathbf{5}\end{array}$ & $\begin{array}{l}5.22 \\
4.81 \\
4.71 \\
4.51 \\
4.37 \\
4.28\end{array}$ & $\begin{array}{l}3 \\
5 \\
7 \\
1 \\
8 \\
1\end{array}$ & $\begin{array}{l}4.05 \\
4.03 \\
3.84 \\
3.71(b) \\
3.60 \\
3.33\end{array}$ & $\begin{array}{l}\mathbf{3} \\
\mathbf{3} \\
\mathbf{3} \\
\mathbf{1} \\
\mathbf{3} \\
\mathbf{5}\end{array}$ \\
\hline
\end{tabular}

1 Data of Thompson, Weeks, and Sherwood (1955) on material from Emery County, Utah. Data obtained from diffractometer chart; on film, the two inner lines may not register and the lines at 8.24 and 7.79 may overlap.

Natural formation and occurrence

Rabbittite is a secondary mineral, found as an efflorescence on mine walls in the Lucky Strike No. 2 mine, Emery County, Utah. The mine is in a uraninite deposit in the Shinarump member of the Chinle formation of Triassic age. Oxidation of the uraninite has formed rabbittite, fourmarierite, zippeite, and several unidentified uranium sulfates. Gypsum and the cobalt minerals bieberite and cobaltocalcite are associated secondary minerals.

\section{SCHROECKINGERITE}

Synonymy

Schröckingerite Schrauf (1873). Dakeite Larsen and Gonyer (1937). Neogastunite Haberlandt and Schiener (1951) ; Haberlandt, Hernegger, and Scheminzky (1950). Named after J. von Schroeckinger, Austrian geologist, who found and described the occurrence at Joachimsthal. The identity of dakeite with schroeckingerite was proved by Nováček (1939).

\section{Composition}

A hydrated fluo-carbonate-sulfate of sodium, calcium, and uranium, $\mathrm{NaCa}_{3}\left(\mathrm{UO}_{2}\right)\left(\mathrm{CO}_{3}\right)_{3}\left(\mathrm{SO}_{4}\right) \mathrm{F} \cdot 10 \mathrm{H}_{2} \mathrm{O}$. The true formula was first established by the analysis reported by Jaffe, Sherwood, and Peterson (1948) and confirmed by that of Axelrod, Grimaldi, Milton, and Murata (1951) on material from Wyoming and Arizona. These analyses are given in the table below. No $F$ was reported in earlier analyses by Schrauf (1873), Larsen and Gonyer (1937), and Nováček (1939).

Spectrographic analysis of the material from the Hillside mine, Arizona, showed the presence of minor amounts of $\mathrm{Al}, \mathrm{Fe}, \mathrm{Mn}$, and $\mathrm{K}$ and the absence of $\mathrm{Ba}, \mathrm{Sr}, \mathrm{Th}, \mathrm{Zr}$, and a number of other elements (Axelrod and others, 1951). Schroeckingerite is soluble in water and in dilute acids. Before the blowpipe it intumesces and leaves a brown infusible residue. 
Chemical analyses of schroeckingerite, in weight percent

\begin{tabular}{|c|c|c|c|c|c|c|c|}
\hline & 1 & 2 & 3 & & 1 & 2 & 3 \\
\hline $\begin{array}{l}\mathrm{Na}_{2} \mathrm{O} \\
\mathrm{K}_{2} \mathrm{O}\end{array}$ & $\begin{array}{r}3.49 \\
-\end{array}$ & $\begin{array}{r}3.19 \\
.23\end{array}$ & $\begin{array}{c}3.63 \\
-\end{array}$ & $\begin{array}{l}\mathrm{F} \\
\text { Insol. }\end{array}$ & 2.14 & $\begin{array}{l}2.09 \\
1.53\end{array}$ & $\begin{array}{l}2.15 \\
1.03\end{array}$ \\
\hline $\mathrm{MgO}$ & - & .63 & - & & & & \\
\hline $\mathrm{CaO}$ & 18.91 & 18.44 & 18.14 & $\mathrm{O}^{\text {Total }}=\mathrm{F}$ & $\begin{array}{r}100.90 \\
.90\end{array}$ & $\begin{array}{r}101.50 \\
.88\end{array}$ & $\begin{array}{r}99.91 \\
.90\end{array}$ \\
\hline $\mathrm{CO}_{2}$ & 14.86 & 14.67 & $\begin{array}{l}1.44 \\
14.20\end{array}$ & Tatal & 10000 & & \\
\hline $\mathrm{SO}_{3}$ & 9.02 & 9.24 & 9.17 & Total & 100.00 & 100.62 & 99.01 \\
\hline $\mathrm{H}_{2} \mathrm{O}$ & 20.27 & 20.20 & 20.15 & Sp gr & - & 2.5 & - \\
\hline
\end{tabular}

1. Theoretical weight percentages, $\mathrm{NaCa}\left(\mathrm{UO}_{2}\right)\left(\mathrm{CO}_{3}\right)_{3}\left(\mathrm{SO}_{4}\right) \mathrm{F} \cdot 10 \mathrm{H}_{2} \mathrm{O}$.

2. Schroeckingerite. Hillside mine, Arizona. Grimaldi, analyst, in Axeirod and others (1951).

3. Schroeckingerite. Wyoming. Sherwood, analyst, in Jaffe and others (1948). Insol. includes $\mathrm{R}_{2} \mathrm{O}_{3} 0.08$, $\mathrm{SiO}_{2} 0.95$.

Crystallography

Orthorhombic, in the dipyramidal crystal class $\left(2 / \mathrm{m}^{2} / \mathrm{m} 2 / \mathrm{m}\right)$. An angle table for the known forms, based on the unit and orientation of the X-ray unit cell of Hurlbut (1954), is given below. The

Angle table for schroeckingerite

Orthorhombic; dipyramidal, $\left(2 / \mathrm{m}_{2} / \mathrm{m} 2 / \mathrm{m}\right)$

$a: b: c=0.5738: 1: 0.8473 ; \quad p_{0}: q_{0}: r_{0}=1.4715: 0.8473: 1$

$q_{1}: r_{1}: p_{1}=0.5758: 0.6796: 1 ; \quad r_{2}: p_{2}: q_{2}=1.1802: 1.7367: 1$

\begin{tabular}{|c|c|c|c|c|c|c|}
\hline Forms & $\phi$ & $\rho=C$ & $\phi_{1}$ & $\rho_{1}=A$ & $\phi_{2}$ & $\rho_{2}=B$ \\
\hline $\begin{array}{ll}c & 001 \\
b & 010 \\
m & 110\end{array}$ & $\begin{array}{r}0^{\circ} \overline{00} \\
6004\end{array}$ & $\begin{array}{r}0^{\circ} 00^{\prime} \\
9000 \\
9000\end{array}$ & $\begin{array}{r}0^{\circ} 00^{\prime} \\
9000 \\
9000\end{array}$ & $\begin{array}{l}90^{\circ} 00^{\prime} \\
9000 \\
2956\end{array}$ & ${ }_{0}^{90^{\circ} 00^{\prime}}$ & $\begin{array}{rl}90^{\circ} & 00 \\
0 & 00 \\
60 & 04\end{array}$ \\
\hline $\begin{array}{ll}f & 014 \\
r & 012 \\
8 & 011\end{array}$ & $\begin{array}{ll}0 & 00 \\
0 & 00 \\
0 & 00\end{array}$ & $\begin{array}{ll}11 & 571 / 2 \\
22 & 571 / 2 \\
40 & 061 / 2\end{array}$ & $\begin{array}{ll}11 & 571 / 2 \\
22 & 571 / 2 \\
40 & 161 / 2\end{array}$ & $\begin{array}{ll}90 & 00 \\
90 & 00 \\
90 & 00\end{array}$ & $\begin{array}{ll}90 & 00 \\
90 & 00 \\
90 & 00\end{array}$ & $\begin{array}{ll}78 & 021 / 2 \\
67 & 021 / 2 \\
49 & 431 / 2\end{array}$ \\
\hline $\begin{array}{ll}t & 021 \\
u & 041 \\
h & 118\end{array}$ & $\begin{array}{rl}0 & 00 \\
0 & 00 \\
60 & 04\end{array}$ & $\begin{array}{ll}59 & 271 / 2 \\
73 & 331 / 2 \\
11 & 59\end{array}$ & $\begin{array}{rl}59 & 271 / 2 \\
73 & 331 / 2 \\
6 & 05\end{array}$ & $\begin{array}{ll}90 & 00 \\
90 & 00 \\
79 & 361 / 2\end{array}$ & $\begin{array}{ll}90 & 00 \\
90 & 00 \\
79 & 341 / 2\end{array}$ & $\begin{array}{ll}30 & 321 / 2 \\
16 & 261 / 2 \\
84 & 03\end{array}$ \\
\hline $\begin{array}{ll}n & 114 \\
o & 112 \\
p & 111\end{array}$ & $\begin{array}{ll}60 & 04 \\
60 & 04 \\
60 & 04\end{array}$ & $\begin{array}{ll}23 & 00 \\
40 & 20 \\
59 & 301 / 2\end{array}$ & $\begin{array}{l}11571 / 2 \\
22.571 / 2 \\
40161 / 2\end{array}$ & $\begin{array}{ll}68 & 25 \\
55 & 53 \\
41 & 411 / 2\end{array}$ & $\begin{array}{ll}69 & 48 \\
53 & 391 / 2 \\
34 & 12\end{array}$ & $\begin{array}{ll}77 & 46 \\
71 & 091 / 2 \\
64 & 32\end{array}$ \\
\hline
\end{tabular}

forms are those reported by Hurlbut (1954) on crystals from Argentina and Utah. The crystals are of poor quality and the angle table hence has been calculated from the elements of the X-ray unit cell rather than from the morphological measurements. X-ray unit cell data : $a_{0} 9.69 \mathrm{~A}, b_{0} 16.83, c_{0} 14.26, a_{0}: b_{0}: c_{0}=0.5758: 1: 8473$. Space group Cmcm. Unit-cell contents $4\left[\mathrm{NaCa}_{3}\left(\mathrm{UO}_{2}\right)\left(\mathrm{CO}_{3}\right)_{3}\right.$ $\left(\mathrm{SO}_{4}\right) \mathrm{F} \cdot 10 \mathrm{H}_{2} \mathrm{O}$ ]. Specific gravity 2.544 (measured), 2.547 (calculated).

Schroeckingerite was originally interpreted as orthorhombic by Schrauf (1873), who described the 6-sided scales as flattened 
on $\{001\}$ with $\{110\}$ and $\{100\} ;(110) \wedge(100)=5812^{\circ}$. Nováček (1939) found the prism angle to be $60^{\circ}$, and suggested that the mineral was hexagonal with anomalous biaxial character. Orthorhombic symmetry was first definitely established by Hurlbut (1954).

\section{Crystal habit}

Ordinarily found as crusts, clusters, rosettes, or globular aggregates of scales flattened on $\{001\}$. Distinct crystals are rare (fig. 7). These are greatly flattened on $\{001\}$ and have a marked pseudohexagonal appearance, with the observed forms all in $\{0 k l\}$ and $\{h k l\}$ zones virtually $60^{\circ}$ apart. The crystals often show subparallel growth of individuals joined on $\{001\}$, and the faces may be curved or dull. Photographs of schroeckingerite crystals are given by Haberlandt and Schiener (1951).

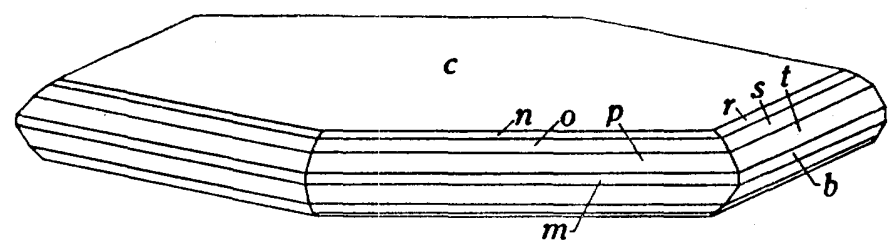

FIGURE 7.-Sehroeckingerite. Argentina. Forms: $n\{114\}, \quad o\{112\}, p\{111\}$, $m\{110\}, r\{012\}, s\{011\}, t\{021\}, b\{010\}, c\{001\}$. From Hurlbut $(1954\}$.

Physical properties

Cleavage $\{001\}$ perfect, micaceous. Thin crystals and cleavage laminae are flexible. Hardness $21 / 2$. Specific gravity 2.55, presumably varying slightly with the water content at ordinary conditions. Luster weakly vitreous, inclining to pearly on the cleavage surfaces. Color greenish yellow. Transparent. Brightly fluorescent in yellowish green in ultraviolet light. (On the fluorescence spectrum, see Haberlandt, Hernegger, and Scheminsky, 1950.)

Optical properties

The water content of the mineral varies zeolitically at essentially ordinary conditions of temperature and humidity, with accompanying small variation in the indices of refraction and $2 \mathrm{~V}$. Air-dried material from Argentina, when placed over water at room temperature for 24 hours, changed in $n_{Y}$ from 1.543 to 1.541, although the material from Utah, apparently fully hydrated, did not change when treated in the same way (Hurlbut, 1954).

On desiccation over concentrated $\mathrm{H}_{2} \mathrm{SO}_{4}$ at room temperature, schroeckingerite is converted to a hexagonal hydrate containing $4 \mathrm{H}_{2} \mathrm{O}$. This material is uniaxial negative with $n_{o} 1.581$ (pale yellow), $n_{E} 1.532$ (colorless). In moist air this phase reconverts to orthorhombic schroeckingerite with ordinary optical properties. 
Optical properties of schroeckingerite

$n$

\begin{tabular}{|c|c|c|c|c|c|c|}
\hline & & & & & & \\
\hline ORIENTATION & 1 & 2 & 3 & 4 & 5 & 6 \\
\hline $\begin{array}{l}X=c \\
Y=b \\
Z=a\end{array}$ & $\begin{array}{l}1.496 \\
1.540 \\
1.542\end{array}$ & $\begin{array}{l}1.496 \\
1.539-1.545 \\
1.539-1.545\end{array}$ & $\begin{array}{l}1.489 \\
1.541 \\
1.541\end{array}$ & $\begin{array}{l}1.489 \\
1.542 \\
1.542\end{array}$ & $\begin{array}{l}1.492 \\
1.543 \\
1.544\end{array}$ & $\begin{array}{l}1.490 \\
1.537 \\
1.538\end{array}$ \\
\hline $2 V$ & Very small & $0^{\circ}-40^{\circ}$ & $\approx 5^{\circ}$ & $0^{\circ}-5^{\circ}$ & $10^{\circ}$ & $18^{\circ}$ \\
\hline
\end{tabular}

\begin{tabular}{|c|c|c|c|}
\hline \multirow{2}{*}{ ORIENTATION } & $n$ & \multirow[b]{2}{*}{ PleOCHROISM } & \multirow[b]{3}{*}{$\begin{array}{l}\text { Biaxial negative; } \\
\text { dispersion not } \\
\text { perceptible. }\end{array}$} \\
\hline & 7 & & \\
\hline $\begin{array}{l}X=c \\
Y=b \\
Z=a\end{array}$ & $\begin{array}{l}1.495 \\
1.543 \\
1.544\end{array}$ & $\begin{array}{l}\text { Colorless to very, very pale yellow. } \\
\text { Pale greenish yellow to yellowish green. } \\
\text { Pale greenish yellow to yellowish green. }\end{array}$ & \\
\hline $2 V$ & $16^{\circ}$ & & \\
\hline
\end{tabular}

1. Joachimsthal. George (1949).

2. Joachimsthal. Nováček (1939).

3. Wyoming. Jaffe and others (1948).

4. Wyoming. Larsen and Gonyer (1937).
5. Argentina. Hurlbut (1954).

6. Utah. Idem.

7. Synthetic. Ross (1955a).

The optical descriptions of so-called schroeckingerite given by Larsen (1921), Larsen and Berman (1934), and Winchell (1933) [but not Winchell (1951)] are in error and refer to beta-uranophane as shown by Nováček (1939).

\section{Thermal behavior}

Nováček (1939) reported dehydration curves obtained by heating material from Wyoming and Joachimsthal in air. These showed that the mineral lost about 15 percent $\mathrm{H}_{2} \mathrm{O}$ (20 percent originally present) at roughly $75^{\circ} \mathrm{C}$ and that the balance was lost gradually up to about $300^{\circ} \mathrm{C}$. Hurlbut (1954) found that material from Wyoming, after 6 days in a desiccator over concentrated $\mathrm{H}_{2} \mathrm{SO}_{4}$ at room temperature, lost 11.7 percent $\mathrm{H}_{2} \mathrm{O}$ and reached equilibrium. The crystals then contained $\approx 4 \mathrm{H}_{2} \mathrm{O}$ and were uniaxial negative with specific gravity 2.86 (measured), 2.874 (calculated). $\mathrm{X}$-ray single-crystal study by the Weissenberg method gave a cell dimensionally hexagonal, with $a_{0} 9.72 \mathrm{~A}, c_{0} 11.03 ; a_{0}: c_{0}=1: 1.1348$. The cell contains four formula units (with $4 \mathrm{H}_{2} \mathrm{O}$ ). The dehydration product fluoresces strongly, but less brilliantly than the original schroeckingerite. A differential thermal analysis curve for schroeckingerite is given by Beck (1905) ; it shows a major endothermic peak at $190^{\circ} \mathrm{C}$, minor endothermic peaks at $385^{\circ} \mathrm{C}$ and $700^{\circ} \mathrm{C}$, and a minor exothermic peak at $410^{\circ} \mathrm{C}$.

\section{Synthesis}

Obtained by dissolving 0.05 mole $\mathrm{NaF}$ and 0.15 mole $\mathrm{Na}_{2} \mathrm{CO}_{3} \cdot$ $10 \mathrm{H}_{2} \mathrm{O}$ in $600 \mathrm{ml} \mathrm{H} \mathrm{H}_{2} \mathrm{O}, 0.05$ mole $\mathrm{UO}_{2} \mathrm{SO}_{4} \cdot 3 \mathrm{H}_{2} \mathrm{O}$ in $200 \mathrm{ml} \mathrm{H}_{2} \mathrm{O}$, and 0.15 mole $\mathrm{Ca}\left(\mathrm{NO}_{3}\right)_{2} \cdot 4 \mathrm{H}_{2} \mathrm{O}$ in $100 \mathrm{ml} \mathrm{H}_{2} \mathrm{O}$ and combining all 
these solutions (Ross, 1955a). The yield of schroeckingerite is increased by reducing the $\mathrm{pH}$ to below neutrality. The precipitate is fine grained and admixed with gypsum. Efforts to synthesize the $\mathrm{Cl}, \mathrm{OH}, \mathrm{K}, \mathrm{Li}$, and $\mathrm{Mg}$ analogues were unsuccessful. Schroeckingerite is soluble in water; the solubility decreases with increasing $\mathrm{pH}$ at $22^{\circ}$ from $5.911 \times 10^{-3}$ moles per 1 at $\mathrm{pH} 3$ to $3.507 \times 10^{-3}$ moles per $\mathrm{l}$ at $\mathrm{pH} 9.31$. The solubility increases with temperature from $5.195 \times 10^{-3}$ moles per 1 at $\mathrm{pH} 4.5$ at $22^{\circ}$ to $10.174 \times 10^{-3}$ moles per 1 at $\mathrm{pH} 4.5$ at $50^{\circ}$. Large crystals can be obtained by evaporation of the water solution.

\section{Identification}

In the hand specimen schroeckingerite closely resembles the fibrous to scaly type of johannite, which has higher indices of refraction, does not fluoresce, and contains copper. Resemblance is less close to liebigite, voglite, and the various green members of the torbernite and metatorbernite groups. The low indices of refraction and strong yellowish-green fluorescence are useful diagnostic criteria. The X-ray powder-spacing data for schroeckingerite are given in the following table.

\section{$X$-ray powder-spacing data for schroeckingerite ${ }^{1}$}

[Copper radiation, nickel filter]

\begin{tabular}{|c|c|c|c|c|c|}
\hline$d(\mathrm{~A})$ & $I$ & $h k l$ & $d(\mathrm{~A})$ & $I$ & $h k l$ \\
\hline $\begin{array}{c}14.28 \\
8.48 \\
7.26 \\
5.421 \\
4.796 \\
4.167 \\
4.044 \\
3.591\end{array}$ & $\begin{array}{r}3 \\
7 \\
10 \\
2 \\
8 \\
2 \\
1 \\
1\end{array}$ & $\begin{array}{l}001 \\
020 \\
021,111 \\
022,112 \\
200,003 \\
220,113,023 \\
041,221,132 \\
042,222,004\end{array}$ & $\begin{array}{l}3.303 \\
3.13 \\
\\
2.876 \\
2.767 \\
2.706 \\
2.393 \\
2.304\end{array}$ & $\begin{array}{l}1 \\
1 \\
7 \\
1 \\
1 \\
2 \\
1\end{array}$ & $\begin{array}{l}024,114 \\
310,043,223,151, \\
241,311 \\
134,204 \\
061,331 \\
025,115 \\
261,401 \\
171,351,262,421\end{array}$ \\
\hline
\end{tabular}

${ }^{1}$ Data from V. Ross (1955a) on synthetic material.

Natural formation and occurrence

Schroeckingerite is a secondary mineral, and at several of the known occurrences seems to be of very recent formation. It was originally described from Joachimsthal, Bohemia, where it occurs very sparingly as an incrustation on pitchblende (Schroeckinger, 1875) ; also reported from Johanngeorgenstadt, Saxony (Nováček, 1939). The mineral occurs relatively abundantly along Lost Creek, about 36 miles north-northwest of Wamsutter, Sweetwater County, Wyo. (Wyant, 1952). It is found here as small pisolitic or concretionary aggregates of flaky crystals in gypsum-containing clays and silts; the mineral is a near-surface, caliche-type deposit from meteoric waters and is of recent formation. Schroeckingerite occurs at the Hillside mine, Yavapai County, Ariz., associated 
with bayleyite, swartzite, andersonite, and gypsum as an efflorescence on tunnel walls (Axelrod and others, 1951). Found in Utah with bayleyite at the Hideout mine, White Canyon district; at several mines southeast of Thompsons, as a near-surface deposit in clay; as an alteration of uraninite in the Crabapple and Shinarump No. 1 and No. 3 mines in the Green River district (Weeks and Thompson, 1954). Reported from Marysvale, Piute County, the Trader Smith's claims west of Cisco, Grand County, and the Sevastopol claims and Riggs claims on the Colorado River in the Bow Knot area, Inter River region, Emery County, all in Utah (Gruner and others, 1954a). In the Poison Basin area, Carbon County, Wyo. (Vine and Prichard, 1954). From the La Soberania mine, San Isidro, Mendoza Province, Argentina (Hurlbut, 1954). From the Radhausberg near Badgastein, Austria [neogastunite] (Haberlandt and Schiener, 1951).

Synonymy

VOGIITE

Uran-Kalk-Kupfer Carbonat Vogl (1853). Voglite Haidinger (1853, p. 223). Voglite was named after Jos. Flor. Vogl, Austrian mining official and mineralogist, who published on the uranium minerals and mines of Joachimsthal.

\section{Composition}

A hydrated carbonate of calcium, copper, and hexavalent uranium. The formula is uncertain. The original analysis by Lindacker (cited in Vogl, 1853) reported the uranium as quadrivalent. The occurrence of the mineral as an oxidation product and the observations of $R$. Berman (oral communication, 1954) on natural and synthetic material show that the uranium actually is hexavalent. On this basis, the original analysis affords ratios near $\mathrm{Ca}_{2} \mathrm{Cu}\left(\mathrm{UO}_{2}\right)\left(\mathrm{CO}_{3}\right)_{4} \cdot 6 \mathrm{H}_{2} \mathrm{O}$. The analysis by $\mathrm{R}$. Meyrowitz of synthetic material gives very different results, probably in part because of the (undemonstrated) presence of admixed malachite(?) and potassium uranyl carbonate(?). The analyses are given below, in weight percent.

\begin{tabular}{lrr|lll} 
& 1 & 2 & & 1 & 2 \\
\cline { 2 - 4 } & $-\bar{O}$ & 0.9 & $\mathrm{UO}_{3}$ & $-\overline{1}$ & 10.9 \\
$\mathrm{CaO}$ & 14.09 & 3.5 & $\mathrm{CO}_{2}$ & 26.41 & 18.2 \\
$\mathrm{CuO}$ & 8.40 & 49.4 & $\mathrm{H}_{2} \mathrm{O}$ & 13.90 & 16.8 \\
$\mathrm{UO}_{2}$ & 37.00 & - & Total & $\overline{99.80}$ & $\overline{99.7}$
\end{tabular}

1. Voglite. Joachimsthal. Lindacker, analyst, in Vogl (1853). The total was given in the original as 100.00 .

2 . Voglite. Synthetic, prepared by R. Berman (oral communication, 1954). R. Meyrowitz, analyst (written communication, 1954). Probably impure. 
Voglite is soluble in acids with effervescence. In the closed tube, blackens and yields water. Infusible.

\section{Crystallography}

Triclinic or monoclinic, according to the optical evidence. Morphological and X-ray single-crystal measurements are lacking. Found as coatings and aggregates of tiny scales. The scales are rhomboidal in outline, resembling gypsum, with an interior acute angle variously given as about $78^{\circ}$ (Vogl, 1853), 80 (Haidinger, 1853), $78^{\circ}-80^{\circ}$ (Schrauf, 1873), about $75^{\circ}$ (Larsen, 1921), $75.8^{\circ}$ (R. Berman, oral communication, 1954). The scales are striated on the flat side parallel to an edge.

\section{Physical properties}

Cleavage $\{010\}$ perfect. Hardness and specific gravity not known. Luster pearly on the cleavages. Color emerald green to bright grass green. Observations on the fluorescence are lacking.

Optical properties

\begin{tabular}{|c|c|c|c|c|}
\hline \multirow[b]{2}{*}{ ORIENTATION } & \multicolumn{2}{|c|}{$n$} & \multicolumn{2}{|c|}{ Pleochroism } \\
\hline & 1 & 2 & 1 & 2 \\
\hline $\begin{array}{l}X=b \\
Y=c \\
Z=a\end{array}$ & $\begin{array}{l}\overline{1.541} \\
1.547 \\
1.564\end{array}$ & $\begin{array}{l}\overline{1.513} \\
1.525 \\
1.542\end{array}$ & $\begin{array}{l}\text { Deep bluish green } \\
\text { Deep bluish green } \\
\text { Pale yellowish }\end{array}$ & $\begin{array}{l}\text { Deep blue } \\
\text { Bluish green } \\
\text { Yellow }\end{array}$ \\
\hline $\begin{array}{c}2 V \\
\text { Disp. }\end{array}$ & $\begin{array}{c}60^{\circ}(\mathrm{Na}) \\
r<v\end{array}$ & $\begin{array}{c}90^{\circ} \\
\text { Not obs. }\end{array}$ & & - \\
\hline
\end{tabular}

1. Larsen (1921).

2. R. Berman (oral communication, 1954).

Under the microscope, voglite appears as rhomboidal plates slightly elongated along a pair of edges. The flattening, parallel to which there is a perfect cleavage, is taken as $\{010\}$ and the elongation, parallel to which there is a set of striations, is taken as the $c$-axis. Larsen (1921) states that $X$ is nearly normal to the flattening and that $Z$ makes an angle of about $33^{\circ}$ with the elongation in the acute angle. Schrauf (1873) gave the extinction angle as $36^{\circ}$. Turned on edge, the plates show lamellar twinning with small extinction angles. Larsen considers the mineral to be triclinic. George (1949) confirms the optical data of Larsen and notes that the crystals are rimmed and crisscrossed by a deeper green alteration product(?) with $n \approx 1.60$.

The material examined by $R$. Berman also seems from the specimen label to be authentic, but the optical properties and twinning differ. The indices of refraction are lower, and $2 \mathrm{~V}$ is larger; the extinction angle $Z \wedge c$ on $\{010\}$ is $29.7^{\circ}$. Turned on edge, the plates show perpendicular faces and give parallel extinc- 
tion; the symmetry appears to be monoclinic. Some grains show very fine lamellar twinning on $\{100\}$ with symmetrical extinction angles to the twin plane up to $30^{\circ}$. The indices of refraction are not changed by keeping the material over $\mathrm{CaCl}_{2}$ for 6 weeks.

Thermal behavior

No data.

Synthesis

No data.

Identification

Voglite superficially resembles liebigite and also the platy green uranium minerals such as zeunerite and torbernite. It is best identified by its crystal habit, optical properties, and qualitative chemical tests. Authentic X-ray powder-spacing data are lacking.

Natural formation and occurrence

Voglite is a secondary mineral found with liebigite as an alteration product of uraninite. Known only from the Elias mine, Joachimsthal, Bohemia, voglite is one of the rarest and least known of the uranium minerals, and only a few specimens seem to be extant. A mineral from Turkestan described by Antipov (1900) may be voglite.

\section{Synonymy}

\section{UNNAMED MINERAI}

"Ianthinite" Bignand (1955). The original ianthinite of Schoep (1926a, 1927a) was described as a hydrated oxide of quadrivalent uranium, and, although our knowledge of the formula and properties of the mineral is deficient in several regards, this general composition seems established by the work of Schoep and the description by J. W. Frondel and Cuttitta (1954) of oxidized ianthinite (epi-ianthinite). The existence of a natural and synthetic violet-colored hydrated quadrivalent oxide, corresponding to the intent and substantially to the facts of the original description of ianthinite, also has been established by Bignand (1955) and others. Because the present mineral contains $\mathrm{Ca}$ and $\mathrm{CO}_{2}$ as essential constituents, the use of the name ianthinite for it, in lack of a re-examination of the type material of Schoep to demonstrate the presence of these constituents, is not justified.

Composition

A hydrated carbonate of calcium and uranium. Both hexavalent and quadrivalent uranium are present, the former probably due 
to oxidation. The ratios of the analysis are close to $3 \mathrm{CaO} \cdot \mathrm{UO}_{2} \cdot$ $6 \mathrm{UO}_{3} \cdot 2 \mathrm{CO}_{2} \cdot 10 \mathrm{H}_{2} \mathrm{O}$. A semimicrochemical analysis by Bignand (1955) gave $\mathrm{CaO} 6.8, \mathrm{UO}_{2} 10.9, \mathrm{UO}_{3} 71.6, \mathrm{CO}_{2} 3.6, \mathrm{H}_{2} \mathrm{O} 7.2$, total 100.1 .

The mineral is easily soluble with effervescence in dilute acids.

Crystallography and crystal habit

Orthorhombic, crystal class unknown. Goniometric measurements are lacking. The crystals, up to about $0.66 \mathrm{~mm}$, are laths flattened on $\{001\}$ and elongated along the $b$-axis with terminal faces of $\{110\}$; the internal plane angle between (110) and (100), measured under the microscope, is $122^{\circ}$. Unit-cell dimensions, obtained by the single-crystal rotation method, are: $a_{0} 11.25 \pm$ $0.03 \mathrm{~A}, b_{0} 7.08 \pm 0.02, c_{0} 20.98 \pm 0.05, a_{0}: b_{0}: c_{0}=1.588: 1: 2.963$. Space group not known.

Physical properties

Cleavage $\{001\}$ perfect and easy, also cleavage on $\{100\}$ and $\{010\}$. Hardness 3-4. Specific gravity $4.94 \pm 0.03$. Color violet to violet black, changing to yellow brown on alteration; powder violet brown. Translucent.

Optical properties

\begin{tabular}{|c|c|c|c|}
\hline ORIENTATION & $n$ & Pleochroism & \\
\hline $\begin{array}{l}X=c \\
Y=b \\
Z=a\end{array}$ & $\begin{array}{c}\overline{1.89 \pm 0.02} \\
1.91 \pm .02\end{array}$ & $\begin{array}{l}\text { Violet. } \\
\text { Blue lavender. }\end{array}$ & $\begin{array}{l}\text { Biaxial negative; } \\
\quad 2 V 48^{\circ} \text {. }\end{array}$ \\
\hline
\end{tabular}

Thermal behavior

On heating, 1.2 percent $\mathrm{H}_{2} \mathrm{O}$ is lost between $20^{\circ} \mathrm{C}$ and $60^{\circ} \mathrm{C}$, and the remainder between $80^{\circ} \mathrm{C}$ and $260^{\circ} \mathrm{C}$; the $\mathrm{CO}_{2}$ is lost at $650^{\circ} \mathrm{C}$. Heated at $1,000^{\circ} \mathrm{C}$, the mineral becomes reddish brown.

\section{Identification}

This mineral is distinguished from the other known carbonates of uranium by its violet color and the content of quadrivalent uranium. It resembles ianthinite in color and crystal habit, with the same optical orientation and comparable indices of refraction, but the X-ray powder patterns differ and ianthinite lacks $\mathrm{Ca}$ and $\mathrm{CO}_{2}$. The powder pattern, however, resembles that of the violet oxidation product of ianthinite described by J. W. Frondel and Cuttitta. (See Epi-ianthinite.) The indices of refraction are higher than those of epi-ianthinite, but these may vary with the extent of oxidation and hydration. The X-ray powder-spacing data are given in the following table. 
$X$-ray powder-spacing data for the hydrated uranium calcium carbonate of Bignand $(1955)^{1}$

[Symbols : $\mathbf{f}$, faint; $\mathrm{m}$, moderate; mf, moderately faint; ms, moderately strong ; vf, very faint; vs, very strong. Copper radiation, nickel filter]

\begin{tabular}{|c|c|c|c|c|c|c|}
\hline$d(\mathrm{~A})$ & $I$ & $d(\mathrm{~A})$ & $I$ & $d(\mathrm{~A})$ & $I$ & $d(\mathrm{~A})$ \\
\hline $\begin{array}{r}10.29 \\
7.60 \\
5.19 \\
4.07 \\
3.35\end{array}$ & $\begin{array}{c}\text { vs } \\
\text { vf } \\
\mathrm{ms} \\
\mathrm{m} \\
\mathrm{f}\end{array}$ & $\begin{array}{l}3.28 \\
3.01 \\
2.59 \\
2.52 \\
2.47\end{array}$ & $\begin{array}{c}\mathrm{ms} \\
\mathrm{m} \\
\mathrm{m} \\
\mathbf{f} \\
\mathbf{f}\end{array}$ & $\begin{array}{l}2.20 \\
2.03 \\
2.00 \\
1.96 \\
1.77\end{array}$ & $\begin{array}{c}f \\
m f \\
\text { vf } \\
\text { vf } \\
f\end{array}$ & $\begin{array}{l}1.73 \\
1.66 \\
1.57 \\
1.53 \\
1.50\end{array}$ \\
\hline
\end{tabular}

${ }^{1}$ Material from Shinkolobwe, Katanga district, Belgian Congo. Data of Bignand (1955).

Natural formation and occurrence

A secondary mineral, found as an alteration product of uraninite at Shinkolobwe, Katanga district, Belgian Congo.

\section{SULFATES}

There are known at present only three well-defined natural sulfates of uranium-johannite, uranopilite, and zippeite (proper). Several distinctive natural uranyl sulfates that closely resemble zippeite have been observed, but have not yet been named or fully described; partial descriptions of these are given under zippeite. Also, a number of very ill-defined uranium sulfates have been described, mostly in very old literature, that seem to be invalid as species. These include voglianite, medjidite, uraconite, uranochalcite, and various uranium-ochres. The recently described sulfate, peligotite, very probably is identical with johannite.

Synonymy

JOHANNITE

Uranvitriol John (1821). Johannit Haidinger (1830). Sulfate vert d'urane Beudant (1832). Gilpinite Larsen and Brown (1917). Named after the Archduke Johann (1782-1859) of Austria. The name uranvitriol also has been used in a generic sense for uranium sulfates in the German literature. The supposed species gilpinite was shown to be identical with johannite by Larsen and Brown (1926).

Composition

A hydrated sulfate of copper and hexavalent uranium, $\mathrm{Cu}$ $\left(\mathrm{UO}_{2}\right)_{2}\left(\mathrm{SO}_{4}\right)_{2}(\mathrm{OH})_{2} \cdot 6 \mathrm{H}_{2} \mathrm{O}=\mathrm{CuO} \cdot 2 \mathrm{UO}_{3} \cdot 2 \mathrm{SO}_{3} \cdot 7 \mathrm{H}_{2} \mathrm{O}$. This formula is based on a microchemical analysis by Nováček (1935a and cited in Peacock, 1935) and an X-ray study by Hurlbut (1950) on material from Joachimsthal. This analysis, in weight percent, is given below. Earlier analyses were reported by Lindacker (cited in Vogl, 1857) of material from Joachimsthal and by Larsen and Brown (1917) of material from Colorado. These analyses, dis- 
cussed by Nováček (1935b), are widely divergent and of little practical value. John (1821) recognized the mineral as a sulfate of uranium, and Berzelius (1824) established the presence of copper.

\begin{tabular}{|c|c|c|c|c|c|}
\hline \multirow{3}{*}{$\begin{array}{l}\mathrm{CuO} \\
\mathrm{UO}_{3} \\
\mathrm{SO}_{3}\end{array}$} & 1 & 2 & & 1 & 2 \\
\hline & 8.48 & 8.07 & $\mathrm{H}_{2} \mathrm{O}$ & 13.45 & 13.84 \\
\hline & 17.07 & 16.59 & Total & 100.00 & 99.84 \\
\hline
\end{tabular}

1. Theoretical weight percentages for $\mathrm{Cu}\left(\mathrm{UO}_{2}\right)_{2}\left(\mathrm{SO}_{4}\right)_{2}(\mathrm{OH})_{2} \cdot 6 \mathrm{H}_{2} \mathrm{O}$.

2. Joachimsthal, Bohemia. Microchemical analysis on $35 \mathrm{mg}$ by Nováček (1935a ; Peacock, 1935), $\mathrm{Pb}, \mathrm{Fe}, \mathrm{Ca}$, and $\mathrm{Mg}$ shown to be absent; $\mathrm{H}_{2} \mathrm{O}-0.0$. The $\mathrm{H}_{2} \mathrm{O}$ is lost entirely between $100^{\circ}$ and $210^{\circ} \mathrm{C}$.

Spectrographic analyses are lacking. Johannite is partly decomposed by water and is completely soluble in $\mathrm{HCl}$. It yields water in the closed tube, and when heated to a high temperature loses $\mathrm{SO}_{3}$ and turns brown and finally black. There are no data on compositional variation in johannite. Divalent $\mathrm{Fe}$ and $\mathrm{Mg}$ could be expected to substitute for $\mathrm{Cu}$ to a small extent at least. The observed variation in the indices of refraction (Larsen and Berman, 1926) may be due to such substitution or to variation in water content.

\section{Crystallography}

Johannite is triclinic, crystallizing in the pinacoidal class (1). An angle table for the known forms based on the morphological study of Peacock (1935) on crystals from Joachimsthal is given below. The mineral was earlier considered to be monoclinic by Ježek (1916) and Haidinger (1830). The triclinic symmetry was established optically by Larsen and Berman (1926), morphologically by Peacock (1935), and by X-ray single-crystal study by

Angle table for johannite

Triclinic; pinacoidal, $(\overline{1})$

$$
\begin{gathered}
a: b: c=0.9182: 1: 0.3799 ; \quad \alpha 90^{\circ} 54^{\prime}, \beta 90^{\circ} 38^{\prime}, \gamma 110^{\circ} 37^{\prime} \\
p_{0}: q_{0}: r_{0}=0.4419: 0.4059: 1 ; \quad \lambda 88^{\circ} 48^{\prime}, \mu 88^{\circ} 59^{\prime}, \nu 69^{\circ} 22^{\prime} \\
p_{0}^{\prime} 0.4420, q_{0}^{\prime} 0.4060, x_{0}^{\prime} 0.0110, y_{0}^{\prime} 0.0210
\end{gathered}
$$

\begin{tabular}{|c|c|c|c|c|c|}
\hline Forms & $\phi$ & $\rho$ & $A$ & $B$ & $C$ \\
\hline $\begin{array}{ll}b & 010 \\
a & 100 \\
m & 110\end{array}$ & $\begin{array}{rl}0^{\circ} 00^{\prime} \\
69 & 22 \\
36 & 211 / 2\end{array}$ & $\begin{array}{l}90^{\circ} 00^{\prime} \\
9000 \\
9000\end{array}$ & $\begin{array}{l}69^{\circ} 22^{\prime} \\
33 \overline{001 / 2}\end{array}$ & $\begin{array}{l}69^{\circ} \overline{22} \\
36211 / 2\end{array}$ & $\begin{array}{l}88^{\circ} 48^{\prime} \\
8859 \\
88391 / 2\end{array}$ \\
\hline $\begin{array}{ll}N & 1 \overline{2} 0 \\
M & 1 \overline{10} \\
p & 111\end{array}$ & $\begin{array}{rr}147 & 461 / 2 \\
121 & 101 / 2 \\
36 & 041 / 2\end{array}$ & $\begin{array}{ll}90 & 00 \\
90 & 00 \\
35 & 471 / 2\end{array}$ & $\begin{array}{ll}78 & 241 / 2 \\
51 & 481 / 2 \\
60 & 44\end{array}$ & $\begin{array}{rr}147 & 461 / 2 \\
121 & 101 / 2 \\
69 & 511 / 2\end{array}$ & $\begin{array}{ll}90 & 41 \\
90 & 05 \\
34 & 27\end{array}$ \\
\hline $\begin{array}{ll}Q & 1 \overline{11} \\
q & \overline{1} 11 \\
P & \overline{1} 11\end{array}$ & $\begin{array}{rl}118 & 211 / 2 \\
-56 & 02 \\
-143 & 20\end{array}$ & $\begin{array}{ll}25 & 451 / 2 \\
25 & 531 / 2 \\
33 & 591 / 2\end{array}$ & $\begin{array}{rl}73 & 26 \\
104 & 39 \\
118 & 03 \frac{1}{2}\end{array}$ & $\begin{array}{rl}101 & 55 \\
75 & 521 / 2 \\
116 & 381 / 2\end{array}$ & $\begin{array}{ll}25 & 481 / 2 \\
25 & 461 / 2 \\
35 & 20\end{array}$ \\
\hline$R \overline{3} \overline{1} 1$ & $-124431 / 2$ & $56141 / 2$ & 14345 & 11816 & 5627 \\
\hline
\end{tabular}


Hurlbut (1950). Transformation: Ježek to Peacock $\overline{2} 0 \overline{1} / 20 \overline{1} / 010$; Goldschmidt (1918, v. 4, p. 216) to Peacock $\overline{1} 0 \overline{1} / \overline{1} 0 \overline{1} / 0 \overline{1} 0$. The crystals are markedly pseudomonoclinic in habit.

An X-ray single-crystal Weissenberg study by Hurlbut (1950) on the crystals measured by Peacock (1935) gave: $a_{0} 16.54 \mathrm{~A}, b_{0}$ 18.02, $c_{0} 6.84, a_{0}: b_{0}: c_{0}=0.9179: 1: 0.3796$. a $90^{\circ} 54^{\prime}, \beta 90^{\circ} 38^{\prime}$, and $\gamma 110^{\circ} 37^{\prime}$. Unit-cell contents $4\left[\mathrm{Cu}\left(\mathrm{UO}_{2}\right)_{2}\right.$ $\left.\left(\mathrm{SO}_{4}\right)_{2}(\mathrm{OH})_{2} \cdot 6 \mathrm{H}_{2} \mathrm{O}\right]$. The diffraction effects confirm triclinic symmetry but permit the selection of a multiple cell that is face-centered with marked monoclinic pseudosymmetry. This F-cell corresponds to the morphological cell taken by Peacock and is here retained for purposes of crystallographic description. The unit-cell dimensions given are in terms of this unit. The F-cell is related to the smaller primitive triclinic cell by the transformation, F-cell to P-cell, $\frac{1}{2} 0 \frac{\overline{1}}{2} / 0 \frac{1}{2} \frac{1}{2} / 01$. The angles used in the calculation of the unit-cell dimensions are those obtained from morphological study. The triclinic P-cell has the following elements :

$$
\begin{gathered}
a_{0}: b_{0}: c_{0}=0.9382: 1: 0.7143 ; \quad \alpha 108^{\circ} 50^{\prime}, \beta 112^{\circ} 03^{\prime}, \gamma 64^{\circ} 52^{\prime} \\
p_{0}^{\prime} 0.884, q_{0}^{\prime} 0.812, x_{0}^{\prime} 0.425, y_{0}^{\prime} 0.228 ; \lambda 78^{\circ} 9^{\prime}, \mu 73^{\circ} 22^{\prime}, \nu 110^{\circ} 37^{\prime} \\
p_{0} 0.7962, q_{0} 0.7314
\end{gathered}
$$

Crystal habit

Johannite occurs chiefly as small spheroidal aggregates and coatings composed of scales or lathlike fibers; also as distinct crystals. The crystals, chiefly from Joachimsthal, Bohemia, occur as subparallel or drusy aggregates. They usually are thick tabular on $\{100\}$ and elongated along the $c$-axis; also prismatic. Twins with the twin axis [001] and the composition plane $\{010\}$ or near thereto are common, both as simple twins between two individuals and as repeated lamellae. Crystal drawings are given by Peacock (1935) and Ježek (1916).

\section{Physical properties}

Cleavage $\{100\}$ good. Discordant observations on the cleavage are given by various observers, and only the $\{100\}$ cleavage is well established (Peacock, 1935). Not brittle. Hardness 2-21/2. Specific gravity 3.32 (measured), 3.27 (calculated). Luster vitreous. Color of crystals dark emerald green to dark green; scaly or fibrous aggregates have a lighter color, usually grass green to apple green or greenish yellow. Streak pale green. Transparent to translucent. Taste bitter. Not fluorescent in ultraviolet light. 
Optical properties

In transmitted light, green in color and strongly pleochroic.

\begin{tabular}{|c|c|c|c|c|c|c|}
\hline \multirow{2}{*}{\multicolumn{3}{|c|}{ ORIENTATION }} & \multicolumn{3}{|c|}{$n$} & \multirow{3}{*}{ PLeOCHROISM } \\
\hline & & & \multirow{2}{*}{$\begin{array}{l}\text { JOACHIMS- } \\
\text { THAL }\end{array}$} & \multirow[b]{2}{*}{ CORNWALL } & \multirow[b]{2}{*}{ COLORADO } & \\
\hline & $\phi$ & $\rho$ & & & & \\
\hline $\begin{array}{l}X \\
Y \\
Z\end{array}$ & $\begin{array}{r}-101^{\circ} \\
37^{\circ} \\
169^{\circ}\end{array}$ & $\begin{array}{r}85^{\circ} \\
8^{\circ} \\
85^{\circ}\end{array}$ & $\begin{array}{l}1.572 \\
1.595 \\
1.614\end{array}$ & $\begin{array}{l}1.575 \\
1.592 \\
1.612\end{array}$ & $\begin{array}{l}1.577 \\
1.597 \\
1.616\end{array}$ & \multirow{2}{*}{$\begin{array}{l}\text { Colorless. } \\
\text { Pale yellow. } \\
\text { Greenish } \\
\text { yellow or } \\
\text { canary } \\
\text { yellow. }\end{array}$} \\
\hline & ion & & $\begin{array}{c}\approx 90^{\circ} \\
r>v \text { strong }\end{array}$ & $\begin{array}{c}\approx 90^{\circ} \\
+ \\
r<v \text { strong }\end{array}$ & $\begin{array}{c}\approx 90^{\circ} \\
+ \\
r<\text { strong }\end{array}$ & \\
\hline
\end{tabular}

The optical orientation is from Peacock (1935) and the indices of refraction from Larsen and Berman (1926). The extinction angle of $Y$ to the elongation is $5^{\circ}-8^{\circ}$. Cleavage flakes show the nearly normal emergence of $X$. Twinned crystals resting on a face in the prism zone with the c-axis running right-left on the microscope stage are sharply demarcated by their strongly different absorption and their considerably different extinction positions; when the $c$-axis is turned $90^{\circ}$ the junction between the twinned individuals vanishes because the extinction positions then practically coincide.

Thermal behavior

No data.

\section{Synthesis}

Obtained by adding solid calcite or aragonite to a solution of uranyl sulfate and copper sulfate in the molar ratio 1:1 (Gruner, 1953). Also formed by the oxidation of a moist mixture of powdered uraninite, pyrite, and chalcopyrite (Guillemin and Pierrot, 1956b).

\section{Identification}

Johannite is distinguished from the other known uranium sulfates, uranopilite, zippeite, and meta-uranopilite, by its content of copper, and by its green rather than yellow or orange color. The fibrous types resemble schroeckingerite except for lack of fluorescence, but the latter lacks copper and is a sulfatecarbonate. The green members of the torbernite and metatorbernite groups bear a superficial resemblance to johannite; they have a platy tetragonal crystal habit, with perfect basal cleavage and different optical properties. The X-ray powder-spacing data for johannite are given in the following table. 
$X$-ray powder-spacing data for johannite ${ }^{1}$

[Copper radiation, nickel filter]

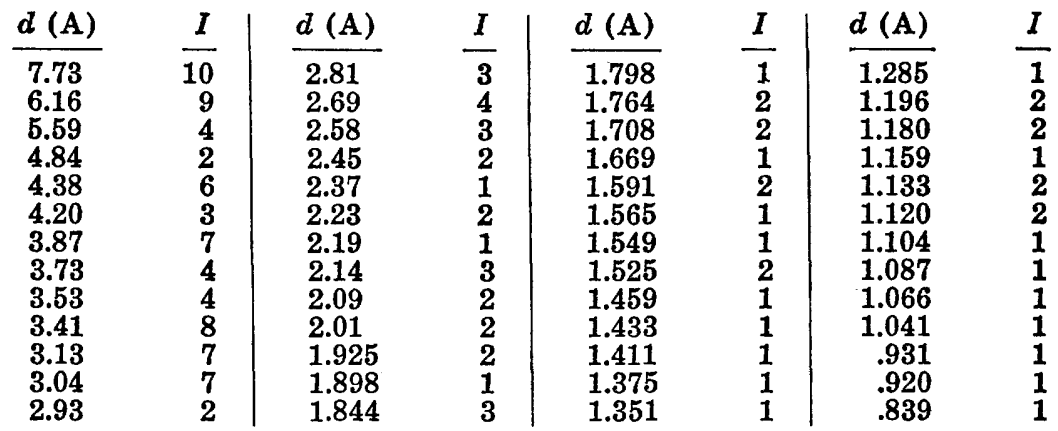

${ }^{1}$ Material from Great Bear Lake, Northwest Territory, Canada. Identical patterns are given by material from other localities.

Natural formation

Johannite is a secondary mineral, formed principally in the oxidized zone of sulfide ore deposits carrying uraninite. The sulfate content comes from the oxidation of the sulfides, chiefly pyrite and chalcopyrite. The uranium sulfates are relatively soluble, especially in acid solutions (Phair and Levine, 1953) and tend to leach from the oxidized zone or from mine-dump material. In nonsulfide deposits the uranium may be fixed in the zone of oxidation as relatively insoluble hydrated oxides, silicates, or phosphate-arsenates. In some occurrences the mineral is an efflorescence of very recent formation.

Occurrence

Originally found as crystals at Joachimsthal, Bohemia, where it occurs closely associated with gypsum and zippeite. Found in a similar occurrence at Johanngeorgenstadt, Saxony. Later described as fibrous to scaly spheroidal aggregates from the oxidized zone of uraninite veins in the Central City district, Gilpin County, Colo. Some museum specimens are labeled from the Wood mine, but most are designated only as Gilpin County, Colo.; the mineral occurs associated with zippeite, an unidentified apricot-colored uranium sulfate, and various efflorescent sulfates that do not carry uranium. Reported from Cornwall, England, on the basis of a specimen in the U.S. National Museum (Larsen and Brown, 1917); earlier reported as doubtful by Spencer (1898). Found very sparingly at Great Bear Lake, Canada, as fibrous to scaly aggregates associated with uranopilite, zippeite, fourmarierite, and erythrite on altered uraninite in the outcroppings of the veins (C. Frondel, 1952). In Utah at the Oyler mine, Henry Mountains district; the Frey No. 4 mine, White Canyon district, 
and at Marysvale. Johannite occurs abundantly as an efflorescence on the walls of mine adits at the Happy Jack mine, White Canyon, San Juan County, Utah; the mine is described by Miller (1955).

Synonymy

\section{PELIGOTITE}

Peligotite Melkov (1942). Named after E. M. Péligot (181190), French chemist, who in 1841 first isolated the element uranium.

Description

Peligotite is a hydrated copper uranyl sulfate. The formula is given as $\mathrm{CuO} \cdot 2 \mathrm{UO}_{3} \cdot 2 \mathrm{SO}_{3} \cdot 3 \mathrm{H}_{2} \mathrm{O}$ from the following two analyses, in weight percent, by Egorov (cited in Melkov, 1942) :

\begin{tabular}{|c|c|c|c|c|c|}
\hline & 1 & 2 & & 1 & 2 \\
\hline $\begin{array}{l}\mathrm{Na}_{2} \mathrm{O} \\
\mathrm{K}_{2} \mathrm{O} \\
\mathrm{MgO}\end{array}$ & $\left.\begin{array}{r}0.2 \\
.3 \\
.5\end{array}\right\}$ & 1.27 & $\begin{array}{l}\mathrm{R}_{2} \mathrm{O}_{3} \\
\mathrm{SO}_{3} \\
\mathrm{H}_{2} \mathrm{O}\end{array}$ & $\begin{array}{l}1 \overline{17.5} \\
16.5\end{array}$ & $\begin{array}{r}.81 \\
17.59 \\
17.56 \\
2.50\end{array}$ \\
\hline $\begin{array}{l}\mathrm{CaO} \\
\mathrm{CuO}\end{array}$ & $\overline{7.5}$ & $\begin{array}{r}.50 \\
7.64 \\
51.37\end{array}$ & Insol. & $\frac{5.6}{090}$ & $\frac{2.00}{0090}$ \\
\hline
\end{tabular}

Found as platy-fibrous reniform aggregates. Luster vitreous. Color green yellow. Indices of refraction and pleochroism: $n_{x}$ 1.575 (colorless), $n_{Y} 1.592$ (pale greenish), $n_{z} 1.618$ (yellow green) $; 2 V \approx 85^{\circ}$. Extinction nearly parallel, not more than $3^{\circ}$. Shows a feeble green-yellow fluorescence in short-wave ultraviolet radiation. On heating, loses 11.47 percent $\mathrm{H}_{2} \mathrm{O}$ at $110^{\circ} \mathrm{C}$, 6.04 percent $\mathrm{H}_{2} \mathrm{O}$ at $200^{\circ}-400^{\circ} \mathrm{C}$, and 17.64 percent $\mathrm{SO}_{3}$ at $700^{\circ} \mathrm{C}$. Found associated with chalcanthite as an efflorescence on the walls of mine workings in the Taboshar uranium deposit in the Kara-Mazar Mountains, North Tadjikistan, U.S.S.R.

Peligotite is close in composition and optical properties to johannite and may be identical with that species.

Synonymy

\section{URANOPILITE}

Uranopilit Weisbach (1882). Basisches Uransulphat Dauber (1854). The names uranocher, uranoker, and uranium ocher have been used in the older literature as generic terms for uranium sulfates including uranopilite. The vague term uraconite also has been applied to ill-defined uranium sulfates that, in part at least, probably are uranopilite or zippeite, and the name zippeite as used by some authors does not clearly distinguish between this species and uranopilite. (For a review of the synonymy of the natural uranium sulfates see C. Frondel, 1952.) 
Composition

A hydrated basic uranyl sulfate. The composition of the mineral probably is best represented by the formula $\left(\mathrm{UO}_{2}\right)_{6}\left(\mathrm{SO}_{4}\right)$ $(\mathrm{OH})_{10} \cdot 12 \mathrm{H}_{2} \mathrm{O}$. All of the reported analyses of uranopilite are given in the table below. The $\mathrm{UO}_{3}: \mathrm{SO}_{3}$ ratio found analytically ranges from 5:1 to 7:1 probably owing to analytical error, and the reported content of water of crystallization ranges mostly from $11 \mathrm{H}_{2} \mathrm{O}$ to $13 \mathrm{H}_{2} \mathrm{O}$. The water is in part loosely held and the variation observed may reflect the temperature and humidity at which the sample was held prior to analysis. (See Thermal behavior.) The small amount of $\mathrm{CaO}$ reported in some analyses is due to admixed gypsum. Evidence of compositional variation by substitution for the uranyl or sulfate ions is lacking. Spectrographic analyses have not been reported.

Chemical analyses of uranopilite, in weight percent

\begin{tabular}{|c|c|c|c|c|c|c|c|}
\hline & 1 & 2 & 3 & 4 & 5 & 6 & 7 \\
\hline $\mathrm{CaO}$ & 2.08 & 1.96 & - & 1.63 & 0.18 & $\mathrm{Tr}$ & 0.93 \\
\hline $\begin{array}{l}\mathrm{Fe}_{2} \mathrm{O}_{3} \\
\mathrm{UO}_{3}\end{array}$ & 7717 & 7746 & 799 & $70^{\mathrm{Tr}}$ & 8114 & Tr & $81 ? 0$ \\
\hline $\begin{array}{l}\mathrm{UU}_{3} \\
\mathrm{SO}_{3}\end{array}$ & $\begin{array}{r}7.17 \\
3.18\end{array}$ & $\begin{array}{r}7.46 \\
4.56\end{array}$ & $\begin{array}{r}79.9 \\
4.0\end{array}$ & 4.24 & $\begin{array}{r}81.14 \\
3.78\end{array}$ & $\begin{array}{r}80.18 \\
4.18\end{array}$ & $\begin{array}{r}81.20 \\
4.04\end{array}$ \\
\hline $\mathrm{H}_{2} \mathrm{O}$ & 16.59 & 14.69 & 14.3 & 13.98 & 14.68 & 14.32 & 14.03 \\
\hline Rem. & .39 & 1.33 & - & .08 & & 20.00 & \\
\hline \multirow[t]{2}{*}{ Total } & 99.41 & 100.00 & 98.2 & 99.82 & 99.78 & 99.28 & 100.20 \\
\hline & 8 & 9 & 10 & \multicolumn{2}{|c|}{11} & 12 & 13 \\
\hline $\mathrm{CaO}$ & 0.60 & - & - & \multicolumn{2}{|r|}{ - } & - & - \\
\hline $\mathrm{Fe}_{2} \mathrm{O}_{3}$ & 1.17 & $\mathrm{Tr}$ & 0.05 & \multirow{4}{*}{\multicolumn{2}{|c|}{$\begin{array}{r}80 . \overline{10} \\
4.88 \\
14.16 \\
.33\end{array}$}} & - & $\overrightarrow{0}$ \\
\hline $\mathrm{UO}_{3}$ & 80.19 & 81.43 & 79.44 & & & $\begin{array}{r}80.7 \\
3.8\end{array}$ & 81.63 \\
\hline $\mathrm{SO}_{3}$ & $\begin{array}{r}4.15 \\
1381\end{array}$ & $\begin{array}{r}3.62 \\
1388\end{array}$ & $\begin{array}{r}3.30 \\
15.68\end{array}$ & & & $\begin{array}{r}3.8 \\
151\end{array}$ & $\begin{array}{r}3.80 \\
1457\end{array}$ \\
\hline Rem. & 13.01 & 13.88 & $\begin{array}{r}10.08 \\
1.72\end{array}$ & & & 10.1 & \\
\hline Total & 99.92 & 98.93 & 100.19 & \multicolumn{2}{|c|}{99.47} & 99.6 & 100.00 \\
\hline
\end{tabular}

1, 2. Uranopilite. Johanngeorgenstadt, Saxony. Schulze analyst, in Weisbach (1882). Remainder is insoluble.

3. Uranopilite. Joachimsthal, Bohemia. Dauber (1854). Called "basisches Uransulphat". Remainder is insoluble.

4. Uranopilite. St. Just, Cornwall. Nováček (1935b). Remainder is PbO.

5. Uranopilite. Johanngeorgenstadt, Saxony. Nováček (1935b).

6. Uranopilite. Př́bram. Bohemia. Nováček (1935b).

7, 8, 9. Uranopilite. Joachimsthal, Bohemia. Nováček (1935b). No. 8 has As as trace.

10. Uranopilite. Wheal Owles, Cornwall. Meyrowitz, analyst, in C. Frondel (1952). Remainder is insoluble.

11. Uranopilite. Katanga. Mélon, analyst, in Buttgenbach (1935).

12. Uranopilite. Grury, France. Branche, Chervet, and Guillemin (1951).

13. Theoretical weight percentages, $6 \mathrm{UO}_{3} \cdot \mathrm{SO}_{3} \cdot 17 \mathrm{H}_{2} \mathrm{O}$.

Crystallography

Uranopilite occurs only as microscopic crystals, and both morphological and complete single-crystal X-ray measurements are 
lacking. Traill (1952) found by the rotation method that the identity period along the elongation, probably $c_{0}$, was $8.91 \mathrm{~A}$. The optical properties of the mineral indicate that it probably is monoclinic.

\section{Crystal habit}

The mineral occurs as thin crusts and films, sometimes with a small-botryoidal surface, and as warty, globular, or reniform aggregates of small size. The aggregates have a fine-fibrous to felted structure. Also as rosettes of tiny fibers. Under the microscope individual crystals are lathlike with oblique terminations. (See fig. 8, and also Nováček, 1935b.)

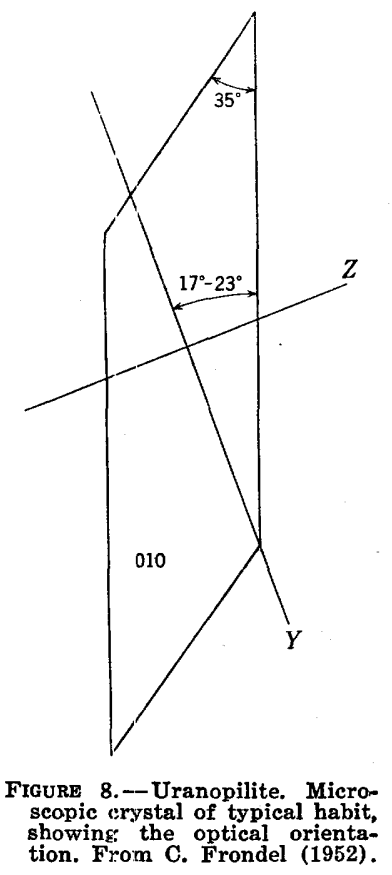

Physical properties

Cleavage perfect parallel to the plane of flattening of the laths, (010), but observed only in crushed samples under the microscope. Hardness not known accurately; soft. Specific gravity 3.96. Color bright lemon yellow, sometimes straw yellow in compact crusts. Luster faintly silky. Fluoresces strongly bright lemon yellow under both short- and long-wave ultraviolet light (Haberlandt, 1949). 
Optical properties

The following optical description, from Nováček (1935b) and C. Frondel (1952), refers to air-dried material that has not been heated.

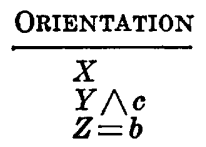

$\begin{array}{ll}\frac{n}{1.621-1.623} & \text { Pleochroism } \\ \text { Colorless. } \\ 1.623-1.625 & \text { Yellow. } \\ \text { Yellow. }\end{array}$

Biaxial positive;
$r>v$ strong.

Extinction angle, $Y$ to the elongation $(c)$, equals $17^{\circ}-23^{\circ}$ in the obtuse angle of the termination. The optical orientation is shown in figure 8. Sections parallel to (100) show parallel extinction with abnormal blue interference colors. A slight variation in the indices is observed in air-dried samples. There are marked optical changes when the mineral is dehydrated. The optical data given by Larsen and Berman (1934) for zippeite actually refer to uranopilite.

\section{Thermal behavior}

The dehydration studies of Nováček (1941) and C. Frondel (1952) show that uranopilite loses $6 \mathrm{H}_{2} \mathrm{O}$ between $60^{\circ} \mathrm{C}$ and $70^{\circ} \mathrm{C}$ and loses the rest of the water gradually up to about $250^{\circ}-300^{\circ} \mathrm{C}$. Above about $250^{\circ}-270^{\circ} \mathrm{C}$ the $\mathrm{SO}_{3}$ begins to be lost as well, and below red heat the mineral is decomposed completely, leaving $\mathrm{U}_{3} \mathrm{O}_{8}$. The color of the mineral changes during dehydration from the original lemon-yellow color to orange at $60^{\circ}-70^{\circ} \mathrm{C}$ and to deep orange and reddish orange at higher temperatures. The property of fluorescing in ultraviolet light is lost simultaneously. The optical properties also change during dehydration. The extinction becomes parallel, the pleochroism is less marked, and the indices of refraction increase depending on the temperature: $n_{Y}=n_{Z} \approx 1.71$ at $72^{\circ} \mathrm{C}, n_{Y}=n_{Z} \approx 1.84$ at $112^{\circ} \mathrm{C}, n_{Y}=n_{Z}$ $\approx 1.89$ at $152^{\circ} \mathrm{C}$. The birefringence decreases from the initial value of 0.011 and some grains become almost isotropic at higher temperatures. Dehydrated material gives very weak and diffuse X-ray powder patterns.

The dehydration is completely reversible in material heated as high as $152^{\circ} \mathrm{C}$. When the heated samples are held at room temperature in air or are immersed in cold water, the original water content and all of the original properties are quickly restored.

Synthesis

Synthetic uranopilite was obtained by Gruner (1953) (also Gruner and others, 1953) by reaction of dilute $\mathrm{H}_{2} \mathrm{SO}_{4}$ with solid $\left(\mathrm{UO}_{2}\right)(\mathrm{OH})_{2}$. Also synthesized by Bignand (1955) by keeping a pulverized mixture of pyrite and uraninite or $\mathrm{U}_{3} \mathrm{O}_{8}$ in a moist atmosphere. 
Identification

Uranopilite closely resembles zippeite in the hand specimen. A positive distinction between the two species is best made by optical or X-ray diffraction methods. Qualitatively, uranopilite has a bright lemon-yellow color with a fine-fibrous and silky appearance, whereas zippeite is deeper yellow and orange-yellow with a fine-granular to rather earthy and dull appearance. Fluorescence is not a reliable means of discrimination between the two minerals. Uranopilite uniformly fluoresces a bright yellow green in both long- and short-wave ultraviolet light, but zippeite varies from yellow green through dull olive green and some material apparently fluoresces weakly if at all. Chemical tests are not conclusive because both minerals are qualitatively of the same composition. Uranopilite is insoluble in cold water but easily soluble in dilute acids. The X-ray powder pattern is distinctive (see following table).

\section{$X$-ray powder-spacing data for uranopilite ${ }^{1}$}

[Copper radiation, nickel filter]

\begin{tabular}{|c|c|c|c|c|c|c|}
\hline$d(\mathrm{~A})$ & $I$ & $d(\mathrm{~A})$ & $I$ & $d(\mathrm{~A})$ & $I$ & $d(\mathrm{~A})$ \\
\hline $\begin{array}{l}9.18 \\
8.21 \\
7.12 \\
5.99 \\
5.51 \\
5.13 \\
4.76 \\
4.61 \\
4.28 \\
4.02\end{array}$ & $\begin{array}{r}8 \\
2 \\
10 \\
2 \\
4 \\
1 \\
1 \\
1 \\
8 \\
1\end{array}$ & $\begin{array}{l}3.86 \\
3.65 \\
3.48 \\
3.31 \\
3.08 \\
2.99 \\
2.90 \\
2.75 \\
2.69 \\
2.59\end{array}$ & $\begin{array}{l}2 \\
5 \\
2 \\
4 \\
1 \\
3 \\
3 \\
1 \\
2 \\
2\end{array}$ & $\begin{array}{l}2.42 \\
2.36 \\
2.28 \\
2.24 \\
2.19 \\
2.13 \\
2.08 \\
2.04 \\
2.01 \\
1.932\end{array}$ & $\begin{array}{l}1 \\
1 \\
1 \\
1 \\
3 \\
1 \\
1 \\
1 \\
1 \\
2\end{array}$ & $\begin{array}{l}1.880 \\
1.826 \\
1.757 \\
1.732 \\
1.700 \\
1.674 \\
1.638 \\
1.604\end{array}$ \\
\hline
\end{tabular}

${ }^{1}$ Data from C. Frondel (1952) on material from Wheal Owles, Cornwall, England. Identical patterns are afforded by material from other localities.

Natural formation

Uranopilite is a secondary mineral. It occurs locally in small amounts as a coating on oxidized vein material in which a uranium mineral, usually uraninite, and sulfides were primary constituents. The sulfate content of the mineral is derived by oxidation of the sulfides. Most or all of the uranium is usually leached out by the ground water in such environments, owing to the high solubility of uranium sulfate in acid solutions. Some uranopilite is of recent formation as an efflorescence on the walls of mine workings. Typical associated minerals are gypsum and zippeite. At Great Bear Lake, Canada, uranopilite is associated with johannite, zippeite, fourmarierite, gypsum, and erythrite. The age relations of uranopilite and zippeite are not clear, but both minerals seem always to be of later formation than secondary uranium silicates or hydrated oxides with which they may be associated. 


\section{Occurrence}

Uranopilite was first described from the uranium veins at Johanngeorgenstadt, Saxony. The occurrence of the mineral at this place and at Joachimsthal and Přibram, Bohemia, and Cornwall, England, was later verified by Nováček (1935b) and C. Frondel (1952). It occurs in Cornwall at the Wheal Owles near St. Just, and probably at other localities in this region where it may have been confused with zippeite (James, 1947). Uranopilite also has been described from Shinkolobwe in the Belgian Congo (Buttgenbach, 1935, 1947); the Urgeiriça mine in the Vizeu district, Portugal (George, 1949) ; at La Crouzille, Haute-Vienne, and Grury, Saône-et-Loire, in France (Branche, Chervet, and Guillemin, 1951) ; at Great Bear Lake and Hottah Lake, Northwest Territory, Canada (C. Frondel, 1952) ; at Goldfields, Saskatchewan, Canada (Traill, 1952) ; and at the Happy Jack mine, San Juan County, Utah, where it is reported as thick coatings on mine walls associated with johannite and zippeite-like minerals. Reported (Gruner and Smith, written communication, 1955) from the Snowball claim, Fremont County, Wyo. It is probable that further occurrences of uranopilite are included among the localities cited in the literature for uraconite (listed in C. Frondel, 1952) and zippeite.

\section{META-URANOPILITE}

Synonymy

Beta-uranopilite Nováček (1935a, b, 1941). Meta-uranopilite C. Frondel (1952).

\section{Description}

This ill-defined substance was first described by Nováček $(1935 \mathrm{a}, \mathrm{b})$, who considered it to have formed by the natural dehydration of uranopilite. Found at Joachimsthal, Bohemia, as needle- to lath-like aggregates of a grayish, dirty green, or brownish color. An analysis in which $\mathrm{Ca}$ and $\mathrm{Cu}$ could not be determined for lack of sufficient material gave: $\mathrm{UO}_{3} 82.40, \mathrm{Fe}_{2} \mathrm{O}_{3} 2.03, \mathrm{SO}_{3}$ $4.17, \mathrm{H}_{2} \mathrm{O} 9.40$, total 98.00. The iron oxide was considered to be due to admixture. The analysis corresponds approximately to the formula $\left(\mathrm{UO}_{2}\right)_{6}\left(\mathrm{SO}_{4}\right)(\mathrm{OH})_{10} \cdot 5 \mathrm{H}_{2} \mathrm{O}$. Optically biaxial, negative, with parallel extinction; $Y$ is parallel to the elongation, and $X$ is perpendicular to the flattening of the laths. Not perceptibly pleochroic. Indices of refraction: $n_{X} 1.72, n_{Y}, 1.76, n_{Z} 1.76$. The optical properties are consistent with orthorhombic symmetry.

A mineral from Cornwall, England, has been tentatively referred to meta-uranopilite by George (1949). It is fibrous, yellow in color, with variable optical properties. Indices of refraction: 
$n_{X} 1.64-1.66, n_{Y} 1.69-1.71, n_{Z} 1.70-1.72 ; 2 \mathrm{~V} 40^{\circ}-50^{\circ}$, dispersion weak, extinction angle $Y \wedge c 12^{\circ}$. Optically negative. Pleochroism: $X$ colorless, $Y$ and $Z$ pale to deep yellow or greenish yellow.

A study by C. Frondel (1952) indicates that a phase corresponding to meta-uranopilite is not formed by dehydration of uranopilite.

\section{ZIPPEITE AND ZIPPEITE-LIKE MINERALS}

\section{Synonymy}

Uranblüthe(?) Zippe (1824). Basisches schwefelsaures Uranoxyd(?) John (1821, 1845). Zippeit Haidinger (1845). Uranoker pt. (?) Vogl (1857). Dauberit(?) Adam (1869). Named after Franz X. M. Zippe (1791-1863), Austrian mineralogist.

The history of the numerous supposed uranium sulfates that in the past have been more or less closely associated with the name zippeite has been reviewed by Nováček (1935b) and C. Frondel (1952). The mineralogy of zippeite is confused, and in the current literature the name includes a number of minerals whose true relations are uncertain and which may not all be identical. In the present work, the name zippeite proper has been restricted to a particular mineral from Joachimsthal, Bohemia, that conforms to the traditional, if inexact, description of the species. This mineral affords distinctive optical and X-ray data, and is identical with certain synthetic materials but uncertainties still remain as to its properties. It is apparently orthorhombic in crystallization, with the composition $2 \mathrm{UO}_{3} \cdot \mathrm{SO}_{3} \cdot 5 \mathrm{H}_{2} \mathrm{O}$ or near thereto.

\section{Composition}

A hydrated basic uranyl sulfate. The reported analyses are given in the table below. The analyses are poor in quality, and it is not known if they all refer to the same mineral. The Ca reported in the analyses is due to admixed gypsum, and uranopilite also may have been admixed in some samples. Nováček (1935b) indicated that the formula is $2 \mathrm{UO}_{3} \cdot \mathrm{SO}_{3} \cdot n \mathrm{H}_{2} \mathrm{O}$, with $n$ usually about 5 or 6 , representing a series of hydrates. Hess (1924) states that the material from Fruita, Utah, probably is $2 \mathrm{UO}_{3} \cdot \mathrm{SO}_{3} \cdot 3 \mathrm{H}_{2} \mathrm{O}$ (analysis 8 ). Analysis 9 , of synthetic material shown by X-ray powder study to be identical with certain natural specimens from Joachimsthal, affords ratios close to $2 \mathrm{UO}_{3}{ }^{\cdot}$ $\mathrm{SO}_{3} \cdot 5 \mathrm{H}_{2} \mathrm{O}$. This may be the composition of zippeite proper. Analyses 10 and 11 are interpreted by Traill (1952) in the light of an X-ray single-crystal determination of the unit-cell contents as $3 \mathrm{UO}_{3} \cdot 2 \mathrm{SO}_{3} \cdot 9 \mathrm{H}_{2} \mathrm{O}$; this substance is monoclinic and apparently is different from zippeite proper. Further analyses of both natural and synthetic material, together with correlated optical and 
X-ray data, would be highly desirable. Some of the unanalyzed material referred to zippeite may contain alkalies, $\mathrm{Ca}, \mathrm{Zn}$, or other cations in addition to uranium as essential constituents.

Spectrographic analyses of zippeite are lacking. The mineral is insoluble in water but dissolves readily in dilute acids.

Chemical analyses of zippeite and zippeite-like substances, in weight percent

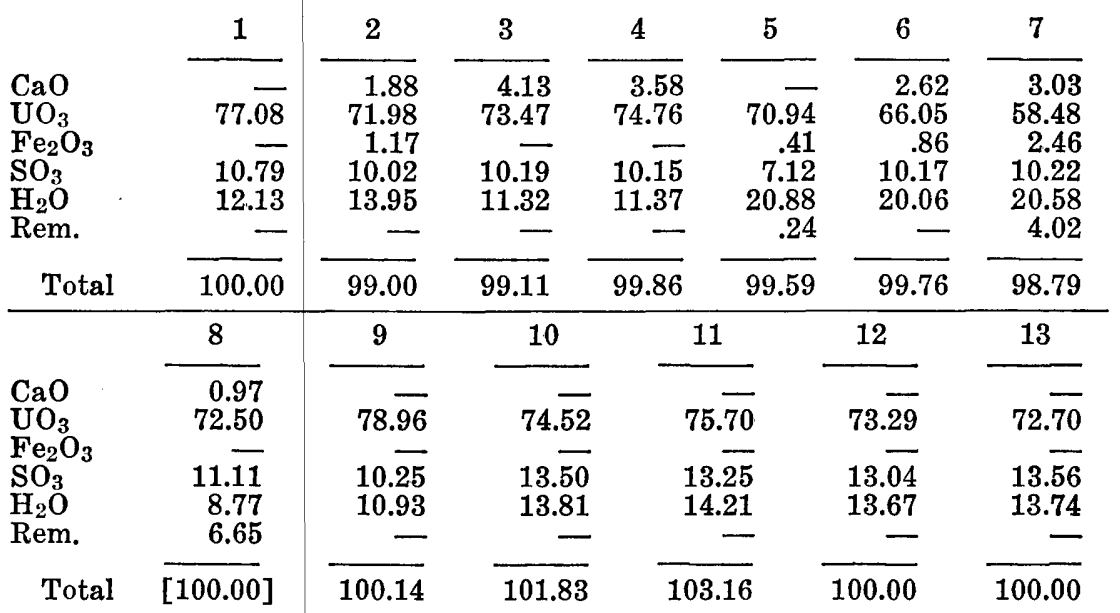

1. Theoretical weight percentages, $2 \mathrm{UO}_{3} \cdot \mathrm{SO}_{3} \cdot 5 \mathrm{H}_{2} \mathrm{O}$.

$2,3,4$. Joachimsthal. Microchemical analyses by Nováček $(1935 \mathrm{~b})$.

$5,6,7$. Joachimsthal. Lindacker, analyst, in Vogl (1857). Remainder in no. 5 is $\mathrm{CuO}$; in no. $7, \mathrm{PbO} 2.21, \mathrm{MnO} 0.35, \mathrm{SiO}_{2} 1.46$.

8. Fruita, Utah. Schaller, analyst, in Hess (1924). Remainder includes $\mathrm{SiO}_{2} 1.96, \mathrm{CuO} 0.96,(\mathrm{P}, \mathrm{As})_{2} \mathrm{O}_{5} 3.73$ by difference. Contains admixed gypsum and libethenite(?).

9. Synthetic material of Frondel (written communication, 1953). Analyst, Cuttitta (written communication, 1953).

10, 11. Synthetic material, prepared and analyzed by Traill (1952).

12. Average of analyses 10 and 11 recalculated to 100 percent.

13. Theoretical weight percentages, $3 \mathrm{UO}_{3} \cdot 2 \mathrm{SO}_{3} \cdot 9 \mathrm{H}_{2} \mathrm{O}$.

Crystallography and crystal habit

The crystal system of zippeite proper is orthorhombic. The synthetic material of Traill (1952) is monoclinic, and some natural so-called zippeite seems to be monoclinic. Zippeite and the various zippeite-like minerals that have been reported occur as thin coatings or isolated small-botryoidal to warty aggregates. The material appears earthy and fine grained to the unaided eye, with a dull luster, and the crystalline-fibrous and silky appearance of uranopilite is lacking. The aggregates are compact but incoherent and fall into small clods at the point of a needle. Occasionally pulverulent. Under the microscope all of the natural material referred to this species, regardless of the observed variation in optical properties, shows essentially the same features. The microscopic crystals typically have a petal, spindle, or lens shape; occasionally they have a rounded rhomboidal or lathlike shape, 
and vermicular aggregates or stacks of rhombs or petals loosely joined by their flat faces also occur. The microscopic natural crystals apparently have parallel extinction, leading to the belief that the mineral is orthorhombic, but accurate measurements are not possible because of the curved and irregular shape. Twinned crystals are common. (See Optical properties.) Morphological and $\mathrm{X}$-ray single-crystal measurements on natural crystals are lacking.

The X-ray powder data for zippeite proper, obtained on natural material and given in the table on page 146, have been indexed by Thompson (written communication, 1954) in terms of an orthorhombic cell with $a_{0} 7.14 \mathrm{~A}, b_{0} 17.34, c_{0} 4.43$. Traill (1952) found that the synthetic material of analyses 10 and 11 was monoclinic, and obtained the following data by single-crystal methods: $a_{0} 8.81 \mathrm{~A}, b_{0} 14.13, c_{0} 8.85, \beta 104^{\circ} 15^{\prime} ; a_{0}: b_{0}: c_{0}=0.6235: 1: 0.6263$; space group $\mathrm{C} 2 / \mathrm{m}$; unit-cell contents $2\left[3 \mathrm{UO}_{3} \cdot 2 \mathrm{SO}_{3} \cdot 9 \mathrm{H}_{2} \mathrm{O}\right]$.

\section{Physical properties}

There is probably a perfect cleavage in one direction. Hardness not known. Specific gravity of natural material not known; the synthetic material of Traill (1952) has 3.66 (measured), 3.68 (calculated). Luster dull to earthy. Color orange yellow to golden yellow, and lacking the lemon-yellow to pale-yellow cast of uranopilite. Some specimens grade through orange to orange red and reddish brown; these tints are usually associated with relatively high indices of refraction, and the identity of this material is uncertain. Transparent in crushed grains. Observations on the fluorescence are not uniform. The synthetic material of analysis 9 fluoresces golden yellow as does the corresponding natural material. Other natural specimens fluoresce lemon yellow to green and olive green, and some specimens fluoresce weakly if at all.

\section{Optical properties}

The optical data reported for so-called zippeite are given here in two groups: (a) Zippeite proper, comprising a group of specimens all found to give the X-ray powder-spacing data cited in the table on page 146 that is identical in X-ray pattern with the synthetic material of C. Frondel (written communication, 1953) and Gruner (written communication, 1950); (b) zippeite (?), comprising material for which X-ray data are lacking and which may not be identical with the foregoing material.

In natural material, $X$ is perpendicular to the flattening and $Z$ bisects the acute terminations of the petals or rounded laths and rhombs. In the vermicular aggregates or rows of crystals, $X$ is perpendicular to the layering. Twinning is common, as petals 
Optical properties of zippeite proper

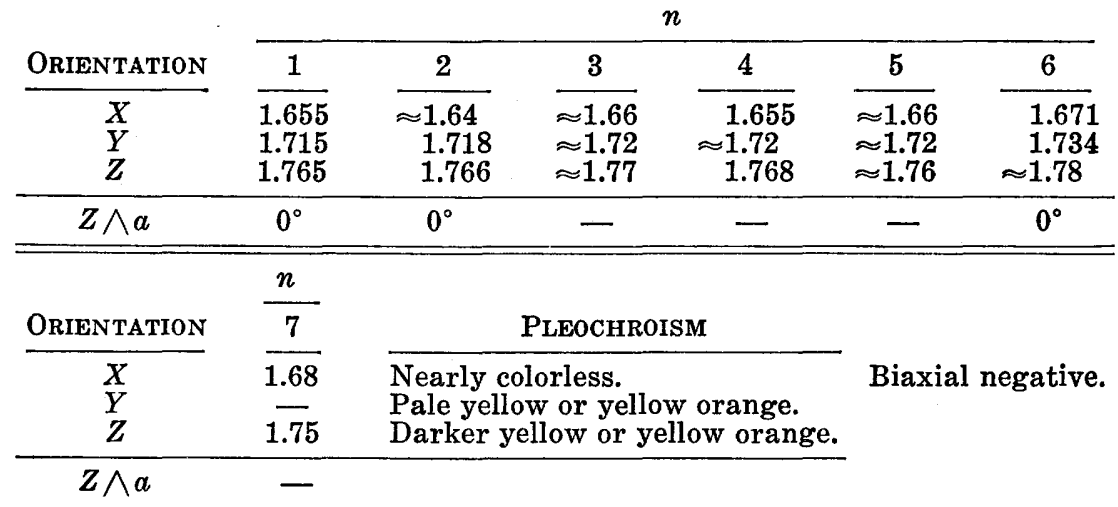

1, 2, 3, 4. Joachimsthal. C. Frondel (written communication, 1953).

5. Hillside mine, Arizona. Idem.

6. Synthetic. Idem.

7. Happy Jack mine, Utah. Gruner (written communication, 1950).

with the twin plane parallel to the elongation and symmetrical extinction to the elongation of $13^{\circ}-15^{\circ}$; also petal-like twins in which the two individuals are not quite planar with unsymmetrical extinction of about $6^{\circ}$ and $13^{\circ}$. Much natural material is too fine grained and admixed to permit satisfactory optical study. Frondel's synthetic crystals were rounded laths with $X$ perpendicular to the flattening and $Y$ parallel to the elongation; in part as cruciform twins.

Optical properties of zippeite(?)

\begin{tabular}{|c|c|c|c|c|c|c|c|}
\hline \multirow[b]{2}{*}{ ORIENTATION } & \multicolumn{7}{|c|}{$n$} \\
\hline & 1 & 2 & 3 & 4 & 5 & 6 & 7 \\
\hline $\begin{array}{l}X \\
Y \\
Z\end{array}$ & $\begin{array}{l}\overline{1.630} \\
1.69 \\
1.720\end{array}$ & $\begin{array}{l}\overline{1.630} \\
1.689 \\
1.739\end{array}$ & $\begin{array}{l}\overline{1.660} \\
1.710 \\
1.760\end{array}$ & $\begin{array}{l}\overline{1.61} \\
1.64 \\
1.71\end{array}$ & $\begin{array}{c}1.62-1.63 \\
1.68-1.70 \\
1.720\end{array}$ & $\begin{array}{l}\overline{1.575} \\
1.615 \\
1.646\end{array}$ & $\begin{array}{l}\overline{1.616} \\
1.677 \\
1.700\end{array}$ \\
\hline$Z \wedge \underset{2 V}{\text { elong. }}$ & - & $\begin{array}{c}41^{\circ} \\
\text { Large }\end{array}$ & $42^{\circ}$ & - & $\begin{array}{l}\approx 32^{\circ} \\
\text { Large }\end{array}$ & - & - \\
\hline
\end{tabular}

\begin{tabular}{|c|c|c|}
\hline & $n$ & \\
\hline ORIENTATIO & 8 & PLeOChroism \\
\hline $\begin{array}{l}X \\
Y \\
Z\end{array}$ & $\begin{array}{l}1.636 \\
1.694 \\
1.732\end{array}$ & $\begin{array}{l}\text { Nearly colorless. } \\
\text { Yellow to orange yellow. } \\
\text { Darker yellow or orange yellow. }\end{array}$ \\
\hline
\end{tabular}

Biaxial negative; dispersion weak.

$Z \wedge$ elong.

$2 \mathrm{~V}$

1. Kirk mine, Colorado. George (1949).

2. Fruita, Utah. Larsen (1921).

3. Telegraph mine, Gilpin County, Colo. Idem.

4. Hillside mine, Yavapai County, Ariz. C. Frondel (written communication, 1953).

5. Joachimsthal. Larsen (1921).

$6,7,8$. Joachimsthal. Nováček (1935a). 
$X$ is perpendicular to the flattening. The appearance of the material under the microscope is similar to that of zippeite proper.

An unidentified uranium sulfate from Gilpin County, Colo., has been described by Larsen (1921) and George (1949). This material has $n_{X} 1.71$ (colorless), $n_{Y} 1.75$ (greenish yellow), $n_{Z} 1.82$ (deep to greenish yellow); optically positive with $2 \mathrm{~V}$ medium to large; another sample had $n_{X} 1.75, n_{Y} 1.79, n_{Z} 1.85$, optically positive with $2 V$ medium, $r<v$ strong. The name uraconite used for this mineral by Larsen (1921) and George (1949) is inappropriate.

The synthetic material of Traill (1952) is described as being monoclinic: flat plates on $\{010\}$ with elongate, doubly terminated outlines; $X=b$ and $Z \wedge a=3^{\circ}$, in the orientation of the X-ray cell; invariably twinned on $\{001\}$ as fourlings. Biaxial negative, with $n_{X} 1.655, n_{Y} 1.717, n_{Z} 1.765$.

\section{Thermal behavior}

Zippeite, in the broad sense, is described by Nováček (1935a), Hess (1924), and others as varying either zeolitically in water content or as passing through a series of hydrates. The only basis for this statement, however, is the wide variation observed in the optical properties. Frondel (written communication, 1953) found that the synthetic material of analysis 9 when heated between $84^{\circ} \mathrm{C}$ and $110^{\circ} \mathrm{C}$ is converted to a new phase. This substance had a pure-yellow rather than a golden-yellow color, fluoresced bright lemon yellow and had lower indices of refraction: biaxial positive, $n_{X} 1.648$ (colorless), $n_{Y} 1.699$ (pale yellow), $n_{Z} 1.727$ (yellow). There was no change in the optical properties when heated at $163^{\circ} \mathrm{C}$. The X-ray pattern was distinctive but similar to that of zippeite proper.

\section{Synthesis}

Obtained as microscopic orthorhombic crystals by Gruner (written communication, 1950) and Frondel (written communication, 1953) by adding very dilute $\mathrm{NH}_{4} \mathrm{OH}$ dropwise with stirring to a dilute solution of uranyl sulfate until a precipitate just forms and then allowing to stand, when a heavy golden-yellow precipitate will form (analysis 9). In the presence of Ca ion, gypsum also forms. Becquerelite or a mixture of becquerelite with zippeite will form if the solution is not sufficiently acid $(\mathrm{ph} \approx 4)$. An apparently monoclinic phase was obtained by Traill (1952) by adjusting a water solution of uranyl nitrate and potassium sulfate in the molecular ratio of $6: 1$ to $\mathrm{pH} 3.3$ with $\mathrm{NH}_{4} \mathrm{OH}$ and allowing to stand (analyses 10,11 ). This phase is stated by Traill to be identical with that of C. Frondel (written communication, 1953), but as noted there is disagreement in the composition, 
optical properties, and symmetry reported for these materials. Basic hydrated uranyl sulfates also have been synthesized by others, but the relation to the natural minerals is not known. (See Athanasesco, 1886; Giolitti and Liberi, 1906; Coninck, 1903; Gmelin, 1936; Mellor, 1932.) Traill (1952) gives X-ray powder and optical data for four uranyl sulfates different from zippeite.

\section{Identification}

As already remarked, several different minerals apparently are confused under the name zippeite. The name is here specifically applied to the mineral with the optical properties listed under zippeite proper and the X-ray powder-spacing data given in the table below. Slightly different X-ray powder data are given for another specimen of the same mineral by C. Frondel (1952).

So-called zippeite of other described occurrences may be identical with this particular mineral in part, but the indices of refraction are generally different. X-ray powder-spacing data for one of these minerals are given in the table below. Zippeite and the

\section{$X$-ray powder-spacing data for zippeite}

[Symbols: b, broad; d, diffuse. Copper radiation, nickel filter]

\begin{tabular}{|c|c|c|c|c|c|}
\hline \multicolumn{4}{|c|}{1} & \multicolumn{2}{|c|}{2} \\
\hline$d(\mathrm{~A})$ & $I$ & $d(\mathrm{~A})$ & $I$ & $d(\mathrm{~A})$ & $I$ \\
\hline $\begin{array}{l}8.65 \\
7.06 \\
6.45 \\
5.44 \\
4.27 \\
3.88 \\
3.63 \\
3.51 \\
3.12 \\
2.86 \\
2.71 \\
2.65 \\
2.47 \\
2.34 \\
2.21 \\
2.14 \\
2.09 \\
2.05 \\
1.935 \\
1.876 \\
1.856 \\
1.816 \\
1.745 \\
1.694 \\
1.666 \\
1.632\end{array}$ & $\begin{array}{r}4 \\
10 \\
2 \\
4 \\
5 \\
3 \\
4 \\
8 \\
9 \\
6 \\
2 \\
5 \\
5 \\
2 \\
4 \\
3 \\
2 \\
5 \\
6 \\
2 \\
2 \\
5 \\
6 \\
1 \\
1 \\
1\end{array}$ & $\begin{array}{l}1.598 \\
1.563 \\
1.519 \\
1.494 \\
1.458 \\
1.424 \\
1.396 \\
1.367 \\
1.326 \\
1.299 \\
1.258 \\
1.236 \\
1.219 \\
1.198 \\
1.180 \\
1.162 \\
1.139 \\
1.106 \\
1.093 \\
1.067 \\
1.056 \\
1.037 \\
1.024 \\
1.011 \\
1.001\end{array}$ & $\begin{array}{l}5 \\
2 \\
2 \\
1 \\
2 \\
4 \\
1 \\
1 \\
1 \\
1 \\
1 \\
1 \\
1 \\
1 \\
1 \\
1 \\
1(d) \\
2 \\
2 \\
1 \\
1 \\
1 \\
1 \\
1 \\
1\end{array}$ & $\begin{array}{l}9.61 \\
7.31 \\
5.57 \\
4.77 \\
4.27 \\
4.10 \\
3.99 \\
3.66 \\
3.51 \\
3.22 \\
3.15 \\
2.86 \\
2.66 \\
2.53 \\
2.45 \\
2.25 \\
2.22 \\
2.12 \\
2.002 \\
1.96 \\
1.884 \\
1.855 \\
1.821 \\
1.791 \\
1.749 \\
1.731 \\
1.701 \\
1.621 \\
1.583 \\
1.517\end{array}$ & $\begin{array}{c}1 \\
10 \\
1 \\
1 \\
1 \\
4 \\
1 \\
9 \\
5 \\
1 \\
8 \\
4 \\
3 \\
4 \\
1 \\
2 \\
2 \\
4 \\
4 \\
2(\mathrm{~b}) \\
2(\mathrm{~b}) \\
1 \\
2(\mathrm{~b}) \\
1(\mathrm{~b}) \\
4 \\
1 \\
4 \\
2 \\
3 \\
1\end{array}$ \\
\hline
\end{tabular}

1. Zippeite (proper) from Joachimsthal, Bohemia (C. Frondel, 1952). 2. Zippeite-like mineral from the Happy Jack mine, White Canyon, Utah (Weeks, written communication, 1951). 
other zippeite-like minerals are easily distinguished from uranopilite by optical and $\mathrm{X}$-ray means. In the hand specimen, uranopilite has a lemon-yellow color and fibrous to silky appearance; zippeite is usually golden yellow to orange in color with an earthy appearance.

Natural formation

Zippeite is a secondary mineral, in part of recent formation as efflorescences on the walls of mine workings or on dump heaps. Gypsum and uranopilite are characteristic associates; also, less commonly, johannite, uranophane, and glassy crusts or shellaclike films of a brown amorphous uranium sulfate.

Occurrence

Zippeite proper has been identified at Joachimsthal, Bohemia; the Hillside mine, Yavapai County, Ariz. (in part); the Happy Jack mine, White Canyon, and the Lucky Strike No. 2 mine, Emery County, Utah. The same mineral probably occurs at the Telegraph mine, Gilpin County, Colo., on the basis of the optical properties reported by Larsen (1921); an unidentified uranium sulfate also occurs at this place.

Other minerals referred to zippeite but of uncertain identity have been reported from Fruita, Utah (Hess, 1924); Great Bear Lake, Canada (Palache and Berman, 1933) ; Př́ibram and Schlaggenwald, Bohemia, and Cornwall, England (Nováček, 1935b). Zippeite-like minerals are found at many localities on the Colorado Plateau (Weeks and Thompson, 1954; Gruner and others, 1954a). They are found either alone or associated with johannite, uranopilite, and gypsum as joint and fracture coatings or as efflorescences on mine walls. A notable locality is at the Happy Jack mine in White Canyon, San Juan County, Utah, where two or three apparently different basic uranyl sulfates occur abundantly as coatings on the walls of the mine workings. Several uranyl sulfates also occur at the Woodrow mine, Valencia County, N. Mex.

Uranochalcite

DISCREDITED URANIUM SULFATES

Uranochalzit Breithaupt (1841, p. 173). Urangrün Hartmann (cited in Haidinger, 1845, p. 510).

Voglianite

Basisch-schwefelsaures Uranoxidoxidul Vogl (1857). Voglianite Dana (1868, p. 668) .

Uraconite

Uranocker pt. Vogl (1857). Uraconise Beudant (1832). Uraconite Dana (1868, p. 668). 


\section{Medjidite}

Medjidite Smith (1848).

The above names have been proposed for ill-defined substances, supposedly uranium sulfates. The reported chemical analyses, summarized by Dana (1892) and Nováček (1935b), probably are not reliable. All of the names are devoid of any exact meaning and can hardly be applied to uranium sulfates of new occurrences in lieu of a definitive redescription of the original material. As type specimens unfortunately do not seem to be extant it is desirable and justifiable to abandon the names entirely. Specimens reputedly of these minerals have proved on examination by Nováček (1935b) and C. Frondel (1952) to be cuprosklodowskite, liebigite, metatorbernite, and other known species. The name uraconite also has been used to a certain extent as a generic or field designation for uranium sulfates, but this usage seems unnecessary.

\section{MOLYBDATES}

Only one natural molybdate of uranium is known, the rare and not yet fully described mineral umohoite.

\section{Synonymy}

\section{UMOHOITE}

Umohoite Brophy and Kerr (1953). Named from the chemical composition, uranium, molybdenum, hydrogen, and oxygen.

Composition

A hydrated molybdate of uranium. The reported analysis, in weight percent, cited below, is close to the formula $\left(\mathrm{UO}_{2}\right)\left(\mathrm{MoO}_{4}\right) \cdot$ $4 \mathrm{H}_{2} \mathrm{O}$. The uranium is reported by the analyst as hexavalent.

\begin{tabular}{lcc|ccc} 
& $\frac{1}{46.99}$ & $\frac{2}{57.65}$ & $\mathrm{H}_{2} \mathrm{O}$ & $\frac{1}{14.33}$ & $\frac{2}{14 \pm 1}$ \\
$\mathrm{UO}_{3}$ & 28.68 & 28.23 & Total & $\frac{100.00}{-}$ & -
\end{tabular}

1. Theoretical weight percentages, $\left(\mathrm{UO}_{2}\right)\left(\mathrm{MoO}_{4}\right) \cdot 4 \mathrm{H}_{2} \mathrm{O}$.

2. Umohoite. Marysvale, Utah. Kallman, analyst, in Brophy and Kerr (1953).

A sample examined by X-ray fluorescence spectrography showed small amounts of Fe and As and traces of $\mathrm{Ru}$ or $\mathrm{Pd}, \mathrm{La}, \mathrm{Ba}, \mathrm{Mn}$, and $\mathrm{Sb}$.

Polished surfaces are strongly anisotropic, and yield the following etch tests: $\mathrm{HNO}_{3}(1+1)$ effervesces then turns yellow and yellow brown; $\mathrm{HCl}(1+1)$ negative; $\mathrm{KOH}$ (40 percent) negative; $\mathrm{HgCl}_{2}$ (5 percent) negative; $\mathrm{H}_{2} \mathrm{O}_{2}$ negative; $\mathrm{FeCl}_{2}$ (20 percent) etches strongly; aqua regia etches quickly and strongly. 
Crystallography and crystal habit

Hexagonal, the lattice type and crystal class not known. Found as platy or foliated aggregates. The plates sometimes show triangular markings. Laue photographs show a hexagonal pattern with few poorly developed spots. Indexed X-ray powder photographs gave the cell constants: $a_{0} 8.597 \mathrm{~A}, c_{0} 14.453, a_{0}: c_{0}=$ $1: 1.6812$.

The mineral is said to be altered by irradiation with X-rays, possibly by dehydration, with accompanying variation in the line spacings. The data given above were obtained on a sample previously irradiated with X-rays, and presumably refer to a dehydration product or to a mixture with such material.

Physical properties

Not cleavable. Hardness about 2. Specific gravity 4.55-4.66. Luster bright submetallic. Color black to bluish black. Opaque.

Thermal behavior and synthesis

No data.

\section{Identification}

Umohoite is the only known uranium mineral that contains molybdenum as a major constituent. The polished-section reactions, low hardness, and X-ray pattern distinguish it from other black, opaque uranium minerals such as uraninite, davidite, uranoan thorite, and uranoan niobate-tantalates. Ianthinite is black or violet black in color, but is transparent in crushed grains, and fragments turn yellow when treated with $\mathrm{H}_{2} \mathrm{O}_{2}$. The X-ray powder-spacing data are given in the following table.

\section{$X$-ray powder-spacing data for umohoite ${ }^{1}$}

\begin{tabular}{rr|lr|rr|rr}
$\frac{d(\mathrm{~A})}{14.29}$ & $\frac{I}{52}$ & $\frac{d(\mathrm{~A})}{4.30}$ & $\frac{I}{3}$ & $\frac{d(\mathrm{~A})}{3.06}$ & $\frac{I}{7}$ & $\frac{d(\mathrm{~A})}{2.061}$ & $\frac{I}{45}$ \\
8.57 & 23 & 3.72 & 2 & 2.891 & 17 & 1.807 & 8 \\
7.19 & 264 & 3.60 & 62 & 2.402 & 1 & 1.606 & 3 \\
4.80 & 176 & 3.22 & 10 & 2.149 & 2 & 1.443 & 4
\end{tabular}

1 Data of Brophy and Kerr (1953) on material from Marysvale, Utah. Relative intensities from spectrometer-chart peaks. The pattern varies owing to effects of X-ray irradiation, and the present data were obtained on a sample previously irradiated for 2 days.

Natural formation and occurrence

Found in the Freedom No. 2 mine at Marysvale, Utah. The mineral occurs as thin veinlets or disseminated specks in an alteration zone of clay minerals along a uranium-bearing vein. It is found either alone, associated with fluorite, pyrite, quartz, and uraninite, or accompanying ilsemannite and jordisite. Also occurs at the Lucky Mc mine, Fremont County, Wyo. (R. G. Coleman, written communication, 1955.) 


\section{PHOSPHATES AND ARSENATES}

The uranyl phosphates and arsenates include two of the largest groups of isostructural phases that are known, the torbernite and metatorbernite groups. The members of these groups are layer structures of the general composition $\mathrm{A}\left(\mathrm{UO}_{2}\right)_{2}\left(\mathrm{XO}_{4}\right)_{2} \cdot n \mathrm{H}_{2} \mathrm{O}$, where $\mathrm{A}=\mathrm{Ca}, \mathrm{Ba}, \mathrm{Mg}, \mathrm{Sr}, \mathrm{Cu}, \mathrm{Pb}, \mathrm{Fe}, \mathrm{Mn}, \mathrm{Co}, \mathrm{Ni}, \mathrm{Al}, \mathrm{Na}, \mathrm{K}$, $\left(\mathrm{NH}_{4}\right)$, or $\mathrm{H}$, and $\mathrm{X}=\mathrm{P}, \mathrm{As}$, or, in small part, $\mathrm{V}$. Many of these phases are known only as synthetic products. The value of $n$ varies zeolitically in 2 ranges, roughly from 0 to 6 or 8 in the metahydrate group and from 8 to 12 in the fully hydrated group; the transition between the 2 groups of hydrates is reversible in some instances. The minerals of the phosphuranylite group, comprising phosphuranylite, renardite, and the problematic mineral dewindtite also seem to have layer-structures, but details are lacking; analogues of these minerals containing $\mathrm{As}, \mathrm{Ba}$, and $\mathrm{Cu}$ are not known. The remaining phosphates and arsenates, parsonsite, dumontite, and walpurgite, do not have close relatives among other minerals. Monazite, an anhydrous rare-earth phosphate, is included here because it contains thorium in solid solution and is the principal ore mineral of that element.

\section{Synonymy}

\section{MONAZITE}

Monazit Breithaupt (1829). Monacite bad orthography. Mengite Brooke (1831). Edwardsite Shepard (1837a). Eremite Shepard (1837b). Monazitoid Hermann (1847). Urdit Forbes and Dahll (1855). Turnerite Lévy (1823). Kryptolith Wöhler (1846a, b). Cryptolite. Phosphocerite Watts (1849). Kararfveit Radominski (1874). Korarfveite.

Monazite is named from $\mu o v a \xi \epsilon \iota$, to be solitary, in allusion to the rare occurrence of the mineral in its first known localities. Turnerite, first described in 1823 from the French Alps, and monazite, first described in 1829 from the Ilmen Mountains, Russia, were considered to be separate species until the work of J. D. Dana (1866) and Des Cloizeaux (1873), which proved their identity. Monazite was the better described of the two minerals and this name has been preserved for the species although turnerite has priority. The presence of thorium in monazite was first established by Kersten (1839) in material from the Ilmen Mountains. The element thorium, discovered by Berzelius in 1828, had earlier been known only as a constituent of thorite. The radioactivity of thorian monazite was first recognized by $\mathbf{M}$. Curie (1898). Thorium is not an essential constituent of monazite, as 
it is of the other thorium minerals described in this volume, and occurs in monazite only as a vicarious constituent in solid solution in varying amounts. Monazite, however, is the principal ore mineral of thorium and a full description of it is given here for this reason.

\section{Composition}

An anhydrous phosphate of cerium and the lanthanum group of rare-earth elements, (Ce,La,Nd) $\left(\mathrm{PO}_{4}\right)$. The $\mathrm{Ce}$ exists in the crystal structure in the trivalent state, but is sometimes arbitrarily reported in chemical analyses as $\mathrm{CeO}_{2}$ instead of $\mathrm{Ce}_{2} \mathrm{O}_{3}$. The La earths consist principally of La and ordinarily are present in about a 1:1 ratio with Ce. The yttrium group of rare earths occur in substitution for Ce and La only in relatively small amounts. This is owing primarily to the smaller ionic radii of the $\mathrm{Y}$ earths relative to $\mathrm{Ce}$ and $\mathrm{La}$, and to the fact that the $\mathrm{Y}$ earths generally crystallize separately in association with monazite as the tetragonal phase xenotime, $\mathrm{YPO}_{4}$. In the rare earths of a series of monazite samples examined by Murata and others (1953), (La,Nd) were nearly constant at $42 \pm 2$ atomic percent, Pr was nearly constant at $5 \pm 1$ atomic percent; (Ce,Sm,Gd, and Y) were nearly constant at $53 \pm 3$ atomic percent; no correlation was found between the content of Th and that of any rare earth.

Thorium is usually present in monazite in substitution for (Ce,La). The amount of Th present ordinarily ranges from a few weight percent $\mathrm{ThO}_{2}$ up to 10 or 12 percent, and monazite with about 4 to 9 percent $\mathrm{ThO}_{2}$ is common. The upper limit of substitution of thorium is not known, but may be near 30 weight percent $\mathrm{ThO}_{2}$. Monazite free from thorium is very rare. As Th is quadrivalent any substitution for the trivalent rare earths may be compensated electrostatically in the crystal structure by a concomitant substitution. Silicon is often found in monazite in substitution for $\mathrm{P}$, in amounts up to at least 6 weight percent $\mathrm{SiO}_{2}$, suggesting the operation of a coupled substitution with Th by the mechanism $\left(\mathrm{Ce}_{1-\mathrm{x}}{ }^{+3} \mathrm{Th}_{\mathbf{x}}{ }^{+4}\right)\left(\mathrm{P}_{1-\mathrm{x}}{ }^{+5} \mathrm{Si}_{\mathrm{x}}{ }^{+4} \mathrm{O}_{4}\right)$. Starynkevic (1922) found a 1:1 ratio of $\mathrm{Th}$ and $\mathrm{Si}$ in his analyses of pure, unaltered monazite from localities in the U.S.S.R. (see table on p. 152) and concluded that it was a case of solid solution (of " $\mathrm{ThSiO}_{4}$ ", as then described). Coupled substitutions of this general type are well known in silicated apatite, and in structural derivatives of apatite that contain thorium, such as caryocerite, melanocerite, and abukamalite. The Si present in monazite is not always present in 1:1 ratio with Th, as has been noted by Wylie (1948) and 
Content of Th and Si in some monazite of the U.S.S.R. (Starynkevic, 1922)

\begin{tabular}{|c|c|c|c|c|c|c|}
\hline & 1 & 2 & 3 & 4 & 5 & 6 \\
\hline $\begin{array}{l}\mathrm{R}_{2} \mathrm{O}_{3} \\
\mathrm{P}_{2} \mathrm{O}_{5} \\
\mathrm{ThO}_{2} \\
\mathrm{SiO}_{2} \\
\mathrm{ThO}_{2}: \mathrm{SiO}_{2}\end{array}$ & $\begin{array}{r}56.58 \\
25.21 \\
8.63 \\
2.00 \\
.98\end{array}$ & $\begin{array}{r}60.68 \\
25.84 \\
9.57 \\
2.05 \\
1.06\end{array}$ & $\begin{array}{r}62.32 \\
27.26 \\
6.87 \\
1.51 \\
1.03\end{array}$ & $\begin{array}{r}63.30 \\
26.91 \\
6.87 \\
1.19 \\
1.31\end{array}$ & $\begin{array}{r}49.53 \\
20.16 \\
21.68 \\
4.74 \\
1.04\end{array}$ & $\begin{array}{r}47.55 \\
22.1 \\
17.32 \\
4.20 \\
.94\end{array}$ \\
\hline $\mathrm{pgr}$ & - & 5.289 & 5.329 & - & 5.398 & 5.076 \\
\hline
\end{tabular}

1,2. Listwenny Kolok, Bortschowka, Transbaikalia.

3,4. Zolotaja Gora, Bortschowka, Transbaikalia.

5,6 . Ilmen Mountains, Urals.

others. (See also the analyses below.) The substitution of the Th for Ce and La also can be compensated by a coupled substitution of divalent cations such as $\mathrm{Ca}$ and $\mathrm{Mg}$ or by cation omissions. The $\mathrm{Si}$ in monazite also has been ascribed to alteration and to mechanically admixed thorite, a view taken particularly in the early literature. (For discussion see Hintze, 1922.) Actual inclusions of thorite(?) have been reported in some instances (Penfield, 1882; Hidden, 1886, p. 208). The content of thorium in detrital monazite from any particular region is usually fairly constant. The following ranges of $\mathrm{ThO}_{2}$ are reported by Johnstone (1954):

\begin{tabular}{lc|lc} 
& Weight percent & & Weight percent \\
\cline { 2 - 3 } & $8.6-10.2$ & Malaya & $3.4-9.4$ \\
Travancore & $6-6.5$ & Nyasaland & $4-7$ \\
Ceylon & $9.5-10.7$ & United States & $\mathbf{2 . 5}-\mathbf{5 . 1}$ \\
Nigeria & $3.2-8$ & &
\end{tabular}

Mertie (1953) gives the range 2.5 to 7.8 percent $\mathrm{ThO}_{2}$ for detrital monazite of the southeastern United States.

Uranium has been frequently reported in monazite, but in amounts up to only about 1 weight percent $\mathrm{U}_{3} \mathrm{O}_{8}$. Helium is generally present owing to radioactive decay (Strutt, 1905; Ramsay and others, 1895; Erichsen, 1951). Monazite has been used for the measurement of geologic age, by determination of the $\mathrm{Pb}$ : $(\mathrm{Th}, \mathrm{U})$ ratio (Holmes, 1948), but this mineral is less reliable for the purpose than uraninite or zircon.

A selection of the chemical analyses reported of monazite is given in the table below. Additional analyses are cited in Hintze (1923), Doelter (1914), Niggli and Faesy (1925), Zemel (1936), Spence and Muench (1935), Kimura and Iimori (1936), Mawson (1944), Johnstone (1954), Souza (1952), Peixoto and O. Guimarães (1953), and Ueda (1953). Numerous partial analyses for 
Chemical analyses of monazite, in weight percent

\begin{tabular}{|c|c|c|c|c|c|c|}
\hline & 1 & 2 & 3 & 4 & 5 & 6 \\
\hline $\begin{array}{l}\mathrm{CaO} \\
\mathrm{MgO}\end{array}$ & $=$ & $\begin{array}{r}0.34 \\
.22\end{array}$ & $\underline{0.39}$ & $\begin{array}{r}0.35 \\
.02\end{array}$ & $\begin{array}{r}0.52 \\
.27\end{array}$ & $\begin{array}{r}0.83 \\
.09\end{array}$ \\
\hline $\mathrm{Ce}_{2} \mathrm{O}_{3}$ & 34.99 & 31.41 & 31.63 & 22.63 & 21.08 & 22.00 \\
\hline$(\mathrm{La}, \mathrm{Nd})_{2} \mathrm{O}_{3}$ & 34.74 & 33.19 & 29.68 & 34.63 & 31.27 & 32.72 \\
\hline $\mathrm{Y}_{2} \mathrm{O}_{3}$ & 一 & 5.08 & 2.86 & 4.66 & 3.53 & 1.15 \\
\hline $\mathrm{Fe}_{2} \mathrm{O}_{3}$ & - & - & .68 & .08 & .66 & .44 \\
\hline $\mathrm{Al}_{2} \mathrm{O}_{3}$ & - & - & - & .10 & .80 & 1.20 \\
\hline $\mathrm{ThO}_{2}$ & - & nil & 5.65 & 7.32 & 11.08 & 12.00 \\
\hline $\mathrm{SiO}_{2}$ & - & .27 & 1.22 & 1.54 & 2.98 & 1.56 \\
\hline $\mathrm{P}_{2} \mathrm{O}_{5}$ & 30.27 & 29.29 & 26.81 & 27.89 & 27.52 & 27.22 \\
\hline $\mathrm{H}_{2} \mathrm{O}$ & - & - & $\overline{10}$ & .40 & .56 & .63 \\
\hline Ignition loss & 一 & 一 & .40 & $\overline{c 5}$ & $\overline{10}$ & $\overline{0}$ \\
\hline Rem. & - & 一 & .84 & .65 & .42 & .80 \\
\hline Total & 100.00 & 99.80 & 100.16 & 100.27 & 100.69 & 100.64 \\
\hline \multirow[t]{2}{*}{ Sp gr } & - & 5.173 & - & 5.27 & 5.17 & 5.16 \\
\hline & 7 & 8 & 9 & & 10 & 11 \\
\hline $\mathrm{CaO}$ & 0.36 & 0.91 & 0.10 & & 1.55 & - \\
\hline $\begin{array}{l}\mathrm{MgO} \\
\mathrm{Ce}_{2} \mathrm{O}_{3}\end{array}$ & 34.90 & 25.98 & 20.65 & 1 & 8 & 36.19 \\
\hline$(\mathrm{La}, \mathrm{Nd})_{2} \mathrm{O}_{3}$ & 17.60 & 23.62 & 21.63 & \} & 35.85 & $\begin{array}{l}0.19 \\
31.64\end{array}$ \\
\hline $\mathrm{Y}_{2} \mathrm{O}_{3}$ & .43 & - & .94 & & - & - \\
\hline $\mathrm{Fe}_{2} \mathrm{O}_{3}$ & .43 & 一 & 1.13 & & - & - \\
\hline $\mathrm{Al}_{2} \mathrm{O}_{3}$ & & - & .29 & & - & - \\
\hline $\mathrm{ThO}_{2}$ & 17.82 & 18.01 & 28.20 & & 32.42 & 3.01 \\
\hline $\mathrm{SiO}_{2}$ & 2.90 & - & 6.09 & & & .70 \\
\hline $\mathrm{P}_{2} \mathrm{O}_{5}$ & 25.09 & 28.43 & 20.20 & & 28.15 & 29.23 \\
\hline $\mathrm{H}_{2} \mathrm{O}$ & .56 & - & - & & 1.50 & - \\
\hline Ignition Loss & & $\overline{0}$ & - & & - & $\overline{-}$ \\
\hline Rem. & .43 & 2.95 & - & & - & .12 \\
\hline Total & 100.52 & 99.90 & 99.23 & & 99.47 & 100.89 \\
\hline Sp gr & 5.266 & - & 5.47 & & 5.412 & 4.98 \\
\hline
\end{tabular}

1. Theoretical weight percentages, $(\mathrm{Ce}, \mathrm{La})\left(\mathrm{PO}_{4}\right)$ with $\mathrm{Ce}: \mathrm{La}=1: 1$.

2. Monazite. Llallagua, Bolivia. Gordon (1939). The Th content is less than 10 parts per million. From hydrothermal sulfide vein.

3. Monazite. Impilaks, Finland. Remainder is $\mathrm{SnO}_{2}$. Ramsay and Zilliacus (1897).

4. Monazite. Dickens Township, Nipissing district, Ontario. Remainder is $\mathrm{PbO} 0.33, \mathrm{U}_{3} \mathrm{O}_{8} 0.32, \mathrm{C}$ trace. Ellsworth (1932a).

5. Monazite. Ishikawa, Japan. Remainder is $\mathrm{UO}_{3} 0.42$. Shibata and Kimura (1921).

6. Monazite. Gaya district, Bihar, India. Remainder is $\mathrm{U}_{3} \mathrm{O}_{8} \mathbf{0 . 2 6 7 7 ,} \mathrm{PbO}$ 0.5331, Mn tr., $\mathrm{H}_{2} \mathrm{O}$ includes $\mathrm{H}_{2} \mathrm{O}+0.48, \mathrm{H}_{2} \mathrm{O}-0.15$. Sarkar (1941).

7. Ilmenite. Ilmen Mountains, Russia. Blomstrand (1890). Remainder is $\mathrm{SnO}_{2}$.

8. Monazite. North Carolina. Thorpe (1895). Remainder is $\mathrm{SnO}_{2} 1.62$, MnO 1.33.

9. Monazite. Ratnapura, Ceylon. Johnstone (1914).

10. Monazite. Ilmen Mountains, Russia. Hermann (1864). A poor and probably erroneous analysis, of interest because of the very high apparent content of $\mathrm{ThO}_{2}$.

11. Monazite. Mountain Pass, Calif. Remainder is $\mathrm{PbO}$. (La, Nd) ${ }_{2} \mathrm{O}_{3}$ includes $\mathrm{La}_{2} \mathrm{O}_{3} 19.65, \mathrm{Nd}_{2} \mathrm{O}_{3} 8.20, \mathrm{Pr}_{2} \mathrm{O}_{3}$ 2.94, $\mathrm{Sm}_{2} \mathrm{O}_{3}$ 0.85. Sherwood and Rose, analysts, in Jaffe (1955). 
$\mathrm{Th}, \mathrm{U}$, and $\mathrm{Pb}$ made for the purpose of age determination also have been published. Analyses by X-ray and optical-spectrographic methods of the rare-earth content of monazite have been reported by Bearth (1934), Matveyeff (1932), Wylie (1950), Murata and coworkers (1953), and others. Numerous analyses of black sands containing monazite and of monazite concentrates therefrom have been reported in the technical literature.

\section{Crystallography}

Monoclinic, in the prismatic crystal class $(2 / m)$. An angle table for the more common crystal forms is given below; additional rare or doubtful forms are listed in Palache, Berman, and Frondel (1951). The morphological elements used here are based on the angular measurements of E. S. Dana (1882a, 1892) on unanalyzed crystals from Milholland's Mill, Alexander County, N. C., and the form list is taken from the summaries of Parker (1937) and V. Goldschmidt (1913-23). The angles vary measurably for crystals from different localities because of variation in chemical composition.

Angle table for monazite

Monoclinic, prismatic, $(2 / \mathrm{m})$

\begin{tabular}{|c|c|c|c|c|c|c|c|}
\hline \multirow{2}{*}{\multicolumn{2}{|c|}{$\begin{array}{r}r_{2}: \\
\text { FORMs }\end{array}$}} & \multicolumn{3}{|c|}{$\begin{array}{l}.9256 ; \beta 103^{\circ} 40^{\prime} \\
617: 1 ; \mu 76^{\circ} 20^{\prime}\end{array}$} & \multicolumn{3}{|c|}{$\begin{array}{c}p_{0}: q_{0}: r_{0}=0.9549: 0.8994: 1 \\
p_{0^{\prime}} 0.9827, q_{0^{\prime}} 0.9256, x_{0}^{\prime} 0.2432\end{array}$} \\
\hline & & $\phi$ & $\rho$ & $\phi_{2}$ & $\rho_{2}=B$ & $C$ & $\bar{A}$ \\
\hline & 001 & $90^{\circ} 00^{\prime}$ & $13^{\circ} 40^{\prime}$ & $76^{\circ} 20^{\prime}$ & $90^{\circ} 00^{\prime}$ & $0^{\circ} 00^{\prime}$ & $76^{\circ} 20^{\prime}$ \\
\hline & 010 & 000 & 9000 & - & 000 & 9000 & 9000 \\
\hline & 100 & 9000 & 9000 & 000 & 9000 & 7620 & - \\
\hline & 120 & 275 & 90 & 000 & $71 / 2$ & $81 / 2$ & $62021 / 2$ \\
\hline & 110 & 4 & 9 & 000 & & & 4317 \\
\hline & 210 & 644 & 9000 & 000 & 6447 & $91 / 2$ & 2513 \\
\hline & 310 & 7 & & 000 & 7 & 76 & 1726 \\
\hline & 012 & $27431 / 2$ & & 7620 & & & 7733 \\
\hline & 021 & 729 & $61491 / 2$ & 7620 & $2904 \frac{1}{2}$ & $51 / 2$ & $83241 / 2$ \\
\hline & 011 & $14431 / 2$ & $43441 / 2$ & 7620 & & 41 & 7953 \\
\hline & 101 & 9000 & $50471 / 2$ & $3912 \frac{1}{2}$ & & $3707 \frac{1}{2}$ & $39121 / 2$ \\
\hline & $\overline{1} 01$ & -9000 & 3629 & 12629 & 9000 & 5009 & 12629 \\
\hline & 111 & 5267 & & $39121 / 2$ & & & $48 \quad 011 / 2$ \\
\hline & $\overline{1} 12$ & -2812 & 2742 & 10356 & $65481 / 2$ & 3611 & $102411 / 2$ \\
\hline & I11 & $-38371 / 2$ & 4950 & 12629 & $53201 / 2$ & 5904 & $118291 / 2$ \\
\hline & 121 & 3331 & 6545 & $39121 / 2$ & 4031 & 5848 & $59461 / 2$ \\
\hline & 121 & $-21461 / 2$ & $63211 / 2$ & 12629 & $33531 / 2$ & $69031 / 2$ & 10922 \\
\hline & $\overline{2} 11$ & $-61441 / 2$ & $62541 / 2$ & $14951 \frac{1}{2}$ & $65041 / 2$ & 7506 & 14139 \\
\hline & $\overline{3} 11$ & $\begin{array}{ll}-71 & 07\end{array}$ & $70431 / 2$ & 15943 & $72121 / 2$ & 8342 & 15316 \\
\hline
\end{tabular}


Measurements of the unit-cell dimensions by X-ray singlecrystal methods are cited in the table below. The space group is $P 2_{1} / n$, and the unit-cell contents are $4\left[(\mathrm{Ce}, \mathrm{La}, \mathrm{Th})\left(\mathrm{PO}_{4}\right)\right]$. The crystal structure of monazite has been described by Ueda (1953). It is based on distorted $\left(\mathrm{PO}_{4}\right)$ tetrahedra with the metal ions in 9-coordination with oxygen; Ce-O 2.43-2.63 A. Monazite is isostructural with huttonite (the monoclinic polymorph of $\mathrm{ThSiO}_{4}$ ) and with cheralite and synthetic $\mathrm{CaTh}\left(\mathrm{PO}_{4}\right)_{2}$ (Bowie and Horne, 1953). Monazite also is isostructural with synthetic $\mathrm{LaPO}_{4}, \mathrm{PrPO}_{4}$, $\mathrm{NdPO}_{4}$, and $\mathrm{BiPO}_{4}$. Synthetic $\mathrm{CePO}_{4}$ has a hexagonal polymorph not known in nature.

\begin{tabular}{cccc}
\multicolumn{4}{c}{ Unit-cell dimensions of monazite } \\
& 1 & $\frac{2}{3}$ & $\frac{3}{a_{0}}$ \\
$b_{0}$ & $6.795 \mathrm{~A}$ & $6.77 \mathrm{~A}$ & $6.77 \mathrm{~A}$ \\
$c_{0}$ & 7.007 & 7.01 & 6.98 \\
\hline$\beta$ & 6.458 & 6.43 & 6.47 \\
\hline$a_{0}: b_{0}: c_{0}$ & $103^{\circ} 38^{\prime}$ & $\overline{4}$ & $103^{\circ} 40^{\prime}$ \\
\hline \hline & $0.970: 1: 0.923$ & $0.966: 1: 0.917$ & $0.969: 1: 0.925$ \\
$a_{0}$ & $\overline{4}$ & $\overline{5}$ & $\frac{6}{6.77 \mathrm{~A}}$ \\
$b_{0}$ & 6.99 & 7.01 & 7.06 \\
$c_{0}$ & 6.45 & 6.45 & 6.49 \\
\hline$\beta$ & $103^{\circ} 38^{\prime}$ & $103^{\circ} 34^{\prime}$ & $103^{\circ} 38^{\prime}$ \\
$a_{0}: b_{0}: c_{0}$ & $0.968: 1: 0.923$ & $0.966: 1: 0.920$ & $0.969: 1: 0.919$
\end{tabular}

1. Perdatsch, Switzerland. Gliszczynski (1939).

2. Llallagua, Bolivia. Parrish (1939).

3. Locality not stated. Ramdohr (1936).

4. India. Ueda (1953).

5. Synthetic CePO 4 . Mooney (1948).

6. Synthetic $\mathrm{LaPO}_{4}$. Idem.

Crystal habit

Commonly found as euhedral crystals, usually less than a few millimeters in size, but sometimes found in pegmatites as large coarse individuals weighing several pounds. The crystals often are thick tabular on $\{100\}$ or are flattened on this form and somewhat elongated along the $c$-axis or the $a$-axis; also wedge-shaped by the large development of $\{100\}$ and $\{\overline{1} 11\}$, or equant. Typical crystal habits are shown in figure 9 . The crystal faces are often rough, uneven, or striated, or are dull because of superficial alteration. Also massive granular. Monazite is a common detrital mineral.

Oriented growths of monazite and xenotime have been described by Hussak (1899).

Twins on $\{100\}$ are common; the twins usually are much flattened on the composition plane (100) and show a re-entrant 
angle at one end of the c-axis. Cruciform twins of four individuals on $\{100\}$ have been observed. Lamellar twinning on $\{001\}$ is rare (Hidden, 1886, p. 207).

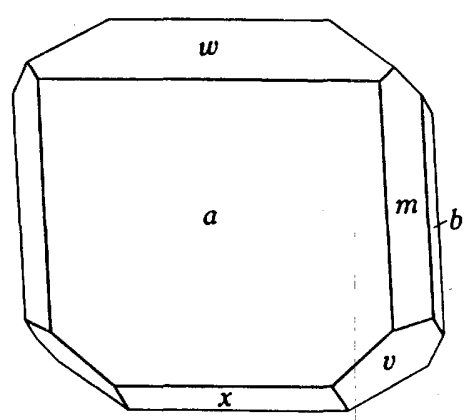

$A$

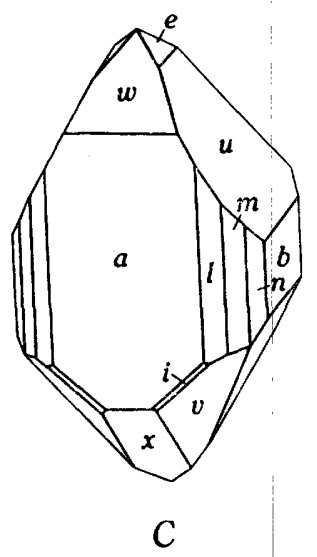

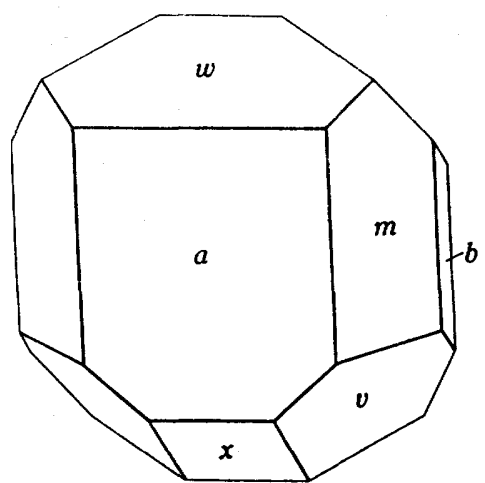

$B$

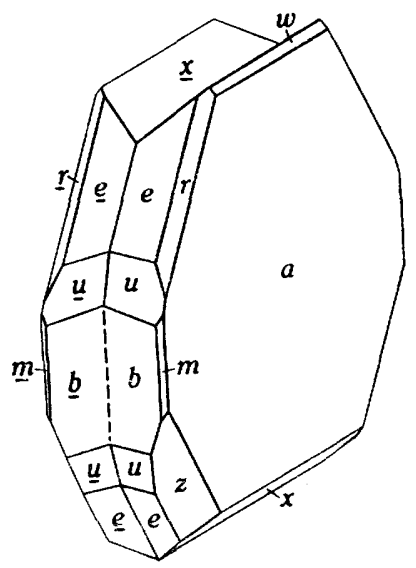

$D$

c'iuuke 9.-Monazite. $A, B$. Typical habit. Forms: $a\{100\}, b\{010\}, m\{110\}, w\{101\}, x\{101\}$, $v\{111\}$. C. New York. Forms: $a\{100\}, b\{010\}, l\{210\}, m\{110\}, n\{120\}, w\{101\}, e\{011\}, u\{201\}$, $i\{\tilde{2} 11\}, x\{\overline{101}\}, v\{\overline{1} 11\} . D$. Tavetsch, Switzerland. Twin on (100). Forms: $a\{100\}, b\{010\}$, $e\{011\}, \boldsymbol{u}\{021\}, r\{111\}, w\{101\}, m\{110\}, \pi\{311\}, x\{101\}$.

\section{Physical properties}

Cleavage on $\{100\}$ is distinct, on $\{010\}$ usually less distinct and difficult to produce; also indistinct cleavages are sometimes observed on $\{110\},\{101\}$ and $\{011\}$. The ease and quality of the $\{100\}$ and $\{010\}$ cleavages varies, apparently owing to alteration of the crystals. The $\{010\}$ cleavage is perfect in most monazite from Alpine localities. A well-marked parting is often present on $\{001\}$, probably owing to lamellar twinning on this plane; parting on $\{\overline{1} 11\}$ also has been observed. Fracture conchoidal to uneven. 
Brittle. Hardness 5-51/2; sometimes surficially soft due to alteration. Specific gravity variable, 4.6-5.4, depending on the chemical composition and degree of alteration of the crystals; essentially pure $(\mathrm{Ce}, \mathrm{La})\left(\mathrm{PO}_{4}\right)$ is $5.15 \pm 0.05$, the value increasing up to at least 5.4 with increasing content of thorium. Luster variable, usually resinous or waxy, but inclining to vitreous or subadamantine in transparent crystals. Color yellowish or reddish brown to brown, also shades of yellow, greenish, nearly white. Transparent to subtranslucent. Streak white or faintly colored. Moderately paramagnetic. Not fluorescent in ultraviolet light.

Monazite undergoes radiation damage owing to the content of thorium and uranium. On heating, the X-ray powder pattern sharpens and there are accompanying increases in the indices of refraction, birefringence, and specific gravity (Karkhanavala and Shankar, 1954).

Optical properties

In crushed grains or in thin section monazite is pale yellowish brown or yellow to almost colorless.

\begin{tabular}{|c|c|c|c|c|c|}
\hline \multirow[b]{2}{*}{ ORIENTATION } & \multicolumn{3}{|c|}{$n(\mathrm{Na})$} & \multicolumn{2}{|c|}{$n$} \\
\hline & 1 & 2 & 3 & 4 & 5 \\
\hline $\begin{array}{l}X=b \\
Y \\
Z \wedge c 2^{\circ}-6^{\circ}\end{array}$ & $\begin{array}{l}1.7902 \\
1.7912 \\
1.8441\end{array}$ & $\begin{array}{l}1.8004 \\
1.8008 \\
1.8494\end{array}$ & $\begin{array}{l}1.7938 \\
1 . \overline{8452}\end{array}$ & $\begin{array}{l}1.779 \\
1.781 \\
1.833\end{array}$ & $\begin{array}{l}1.785 \\
1.787 \\
1.840\end{array}$ \\
\hline $2 V$ & $15^{\circ} 33^{\prime}$ & $11^{\circ} 00^{\prime}$ & $12^{\circ} 42^{\prime}$ & $26^{\circ}$ & - \\
\hline
\end{tabular}

Biaxial positive; $r<v$, sometimes $r>v$; horizontal dispersion, weak.

1. Dattas, Brazil. Busz (1914).

2. Madagascar. Sabot (1920).

3. Norway. Schetelig (1913).

4. Mountain Pass, Calif. Jaffe (1955).

5. Bolivia. Gordon (1939).

Pleochroism faint or not perceptible. Absorption distinct $Y>$ $X=Z$. Indices and $2 V$ for various wavelengths are given by Busz (1914) and Sabot (1920), and the older optical descriptions are summarized by Hintze (1922). The absorption spectrum of monazite has been described by Becquerel (1888).

The optical properties of monazite doubtless vary with changing Th content and other substituting elements, but correlated data are lacking.

Thermal behavior

Monazite apparently undergoes no chemical or structural changes on heating to about $1,000^{\circ} \mathrm{C}$.

Synthesis

Obtained as tiny crystals by fusion of admixed phosphate and chloride of cerium and lanthanum or of cerium alone (Radominsky, 1875). 
Identification

Readily distinguished from xenotime and zircon by its crystal form, relatively high indices of refraction, and biaxial character. Sphene has much higher birefringence. The variable absorption in yellow of monazite is a useful diagnostic criterion, as is the small optic angle. Thorite, usually metamict and isotropic, has a lower index of refraction and a slightly lower specific gravity. X-ray powder-spacing data, from Karkhanavala and Shankar (1954), are given in the following table.

\section{X-ray powder-spacing data for monazite}

[Symbols: $\mathrm{m}$, moderate; s, strong; $\mathrm{w}$, weak; vs, very strong; $v \mathrm{w}$, very weak; vvw, very, very weak. Copper radiation, nickel filter]

\begin{tabular}{|c|c|c|c|c|c|}
\hline$d(\mathrm{~A})$ & $I$ & $h k l$ & $d(\mathrm{~A})$ & $I$ & $h k l$ \\
\hline $\begin{array}{l}5.19 \\
4.66 \\
4.17\end{array}$ & $\begin{array}{l}w \\
w \\
m\end{array}$ & $\begin{array}{l}101 \\
011 \\
111\end{array}$ & $\begin{array}{l}1.97 \\
1.95 \\
1.90\end{array}$ & $\begin{array}{c}\mathrm{s} \\
\mathbf{v w} \\
\mathrm{m}\end{array}$ & $\begin{array}{l}\overline{212} \\
312 \\
213\end{array}$ \\
\hline $\begin{array}{l}4.11 \\
3.51\end{array}$ & $\begin{array}{l}\mathrm{vw} \\
\mathrm{m}\end{array}$ & $\begin{array}{l}\overline{1} 01 \\
020\end{array}$ & $\begin{array}{l}1.87 \\
1.83\end{array}$ & $\mathrm{~s}$ & $\begin{array}{l}032, \overline{1} 03 \\
123\end{array}$ \\
\hline $\begin{array}{l}3.29 \\
3.10\end{array}$ & $\begin{array}{c}\text { S } \\
\mathbf{v s}\end{array}$ & $\begin{array}{l}200 \\
120\end{array}$ & 1.81 & vw & $\underline{1} 13$ \\
\hline 2.98 & w & 210 & 1.77 & $\mathrm{~m}$ & $\overline{2} 22,322$ \\
\hline 2.87 & vs & 012,112 & 1.75 & $\mathbf{s}$ & $040^{\circ}$ \\
\hline 2.61 & $\mathrm{~m}$ & 202 & 1.72 & $\mathrm{~m}$ & 303,223 \\
\hline 2.53 & $\mathbf{w}$ & $\overline{2} 11$ & 1.71 & $w$ & $\overline{3} 21$ \\
\hline 2.44 & $\mathrm{~m}$ & $\overline{1} 12$ & 1.67 & $\mathrm{~m}$ & 313 \\
\hline 2.40 & $\mathrm{vw}$ & 220 & 1.65 & $\mathbf{w}$ & $400,411, \overline{1} 23$ \\
\hline 2.34 & vow & 022,122 & 1.63 & $\mathbf{w}$ & 402 \\
\hline 2.25 & vvw & 301 & 1.61 & $\mathrm{~m}$ & 410 \\
\hline 2.19 & $\mathrm{~m}$ & 031 & 1.59 & vw & 004 \\
\hline 2.14 & $\mathbf{s}$ & 103,311 & 1.54 & $\mathrm{~m}$ & 033 \\
\hline 2.07 & vvw & 122,222 & 1.49 & m & 124 \\
\hline 2.02 & $\mathrm{vw}$ & 113 & 1.47 & $\mathrm{~m}$ & $\overline{3} 22, \overline{4} 11,422$ \\
\hline 2.00 & $\mathrm{w}$ & 013 & 1.46 & $\mathbf{w}$ & $\overline{2} 23$ \\
\hline
\end{tabular}

\section{Natural formation}

Monazite is widely disseminated as an accessory mineral in granitic igneous rocks and gneissic or schistose metamorphic rocks, and is typically associated with zircon, xenotime, and sphene. A summary account of monazite and other accessory heavy minerals in eruptive rocks is given by Hoppe (1951). The detrital sands derived from regions of such rocks may contain monazite in commercial quantities. It also occurs in geologically old placer deposits (consolidated and cemented conglomerates) as in the Witwatersrand, South Africa, and the Deadwood formation of the Black Hills. Monazite often occurs relatively well crystallized in pegmatitic and quartz-rich segregation veinlets in metamorphic rocks. It is a typical mineral of drusy veins of the so-called Alpine type in metamorphic and igneous rocks, and is 
associated with anatase, rutile, zircon, epidote, sphene, ilmenite, and albite. Monazite occurs coarsely crystallized in pegmatites derived from granitic or syenitic igneous rocks; associated minerals include zircon, xenotime, allanite, apatite, gadolinite, magnetite, and various niobate-tantalates. Monazite is often found outwardly altered to or veined by fine-grained yellowish or reddish-brown products of unknown nature. Crystals of exceptional size have been found in the potassium-rich pegmatites of Madagascar, and one weighing 59 pounds has been described by Schaller (1933) from a pegmatite near Mars Hill, Madison County, N. C. Vein deposits of massive granular monazite are uncommon. Occurrences of this nature are known in the Mountain Pass area, San Bernardino County, Calif., and at Rhynsdorp, South Africa. The pleochroic halos in quartz and other minerals are sometimes due to monazite (Hutton, 1947; Lemmlein, 1945).

\section{Occurrence}

Monazite is a widely distributed mineral and only a few typical localities can be mentioned here. A lengthy list of localities, most of which are only of mineralogic interest, is given by Hintze (1922), and descriptions of numerous further occurrences can be found in more recent literature.

Monazite is a typical detrital mineral because of its physical and chemical stability and is of worldwide occurrence in beach and river sands and placer deposits. It tends to concentrate in the black sands, because of its relatively high specific gravity, and is found with magnetite, ilmenite, zircon, garnet, rutile, and other heavy minerals. The world's supply of thorium is almost entirely drawn from monazite deposits of this kind. Important commercial deposits are found in the beach sands of Travancore in southwestern India; in the states of Espirito Santo and Bahia, Brazil; in New South Wales and Queensland; and in Ceylon. In the United States deposits of detrital monazite are found in Florida, in North and South Carolina and elsewhere in the Appalachian region (Mertie, 1953), and in Idaho and Montana. Monazite also occurs as a byproduct in the mining of alluvial tin deposits, as in Malaya, the island of Billiton, and Nigeria. The proportion of monazite and other heavy minerals in beach sands varies from place to place. One deposit in Travancore contained monazite $0.5-1.0$ percent, ilmenite and magnetite $65-80$ percent, rutile 3-6 percent, zircon 4-6 percent, sillimanite 2-5 percent, garnet 1-5 percent. The crude beach sands usually are given a 
preliminary wet concentration, sometimes on Wilfley tables, and, after drying, are further separated by a series of magnetic separators of varying intensity. The weakest magnetic field removes magnetite, intermediate field strengths remove ilmenite, and the strongest field attracts monazite. The nonmagnetic residues are variously treated by gravity, flotation, or electrostatic-concentration processes to give salable concentrates of zircon, rutile, and sillimanite. The separated ilmenite is the mineral that usually yields the largest revenue. The garnet ordinarily is not marketable as an abrasive because the grains are rounded and too small for crushing.

Pegmatite localities include Sordavala and Impilaks Parishes on Lake Ladoga, Finland; Mt. Volhambohitra and elsewhere in the Ankazobe district, and at Ampangabe and Ambatofotsikely, in Madagascar; numerous localities in Norway, including Arendal and nearby points, Hitterö, Dillingö, and Raade near Moss, Tvedestrand and Risör; in the Petaca district, Rio Arriba County, New Mexico; Amelia Court House district, Virginia; Pisek, Bohemia. Monazite occurs in veins of the Alpine type in the Swiss Alps as in the Binnenthal, Valais, and in the Val Tavetsch and Val Cornera, Grisons (Parker, 1954). Similar occurrences in metamorphic rocks are found at Milholland's Mill and Stony Point in Alexander County, N. C., and in New York City and Westchester County, N. Y. Found with wolframite in the Torrington district, New South Wales, and in the tin deposit at Mt. Bischoff, Tasmania. Monazite occurs in Precambrian marble in northern Lemhi County, Idaho (Abbott, 1954), and in dolomitic marble at Shinkolobwe in the Katanga district, Belgian Congo. It occurs with dense hematite in lodes in the Mt. Painter field, South Australia (Mawson, 1944).

\section{AUTUNITE}

\section{Synonymy}

A variety of Uranglimmer, Urankalk, or Chalcolite [Torbernite] prior to 1819. Sel à base de chaux, où l'oxide d'urane joue le rôle d'acide Berzelius (1819). Uranit Berzelius (1824). KalkUranit, Kalk Uranglimmer Germ. Lime-Uranite. Autunite Brooke and Miller (1852). Calcouranit Breithaupt (1865). The name autunite is from the locality near Autun, France, which supplied the specimens on which in 1824 Berzelius made the first analysis. Berzelius called the substance a sel à base de chaux où l'oxide d'urane joue le rôle d'acide, and the name autunite was first given to it in 1852 by Brooke and Miller. The mineral was confused with torbernite before 1824, and probably in some 
later literature. The early study by W. Phillips (1816) on the crystallization of "oxide of uranium" from Cornwall included both torbernite and autunite. The so-called metakalkuranit of Rinne (1901a), obtained by heating autunite, probably is a lower hydrate, meta-autunite II.

\section{Composition}

A hydrated phosphate of calcium and hexavalent uranium, $\mathrm{Ca}\left(\mathrm{UO}_{2}\right)_{2}\left(\mathrm{PO}_{4}\right)_{2} \cdot n \mathrm{H}_{2} \mathrm{O}$. In natural material, $n \mathrm{H}_{2} \mathrm{O}$ ranges zeolitically between about $10 \mathrm{H}_{2} \mathrm{O}$ and $12 \mathrm{H}_{2} \mathrm{O}$, but the upper limit may be higher. The reported analyses of autunite are given in the table below. Substantiating evidence of the identity of the mineral as autunite and not the lower hydrate meta-autunite is usually lacking, but the relatively high water content indicates that the cited analyses are of autunite.

Chemical analyses of autunite, in weight percent

\begin{tabular}{|c|c|c|c|c|c|c|c|}
\hline & 1 & 2 & 3 & 4 & 5 & 6 & 7 \\
\hline $\mathrm{CaO}$ & 5.69 & 5.31 & 6.09 & 6.01 & 6.06 & 6.56 & 7.17 \\
\hline $\mathrm{BaO}$ & - & - & 1.57 & - & - & $\vec{a}$ & - \\
\hline $\mathrm{MgO}$ & & $\overline{01}$ & $\overline{\pi n}$ & $\overline{c 0}$ & $\overline{0}$ & .26 & $\overline{00}$ \\
\hline $\mathrm{UO}_{3}$ & 58.00 & 60.84 & 61.70 & 60.62 & 60.95 & 58.85 & 63.00 \\
\hline $\mathrm{P}_{2} \mathrm{O}_{5}$ & 14.39 & 13.40 & 15.21 & 14.52 & 14.61 & 14.80 & 15.95 \\
\hline & 21.92 & 20.33 & 14.90 & 18.47 & 18.32 & 19.60 & 13.84 \\
\hline Total & 100.00 & 99.88 & 99.47 & 99.62 & 99.94 & 100.07 & 99.96 \\
\hline $\mathrm{gr}$ & - & - & - & - & - & 3.20 & - \\
\hline
\end{tabular}

1. Theoretical weight percentages, $\mathrm{CaO} \cdot 2 \mathrm{UO}_{3} \cdot \mathrm{P}_{2} \mathrm{O}_{5} \cdot 12 \mathrm{H}_{2} \mathrm{O}$.

2. Autunite. Autun, France. Church (1875).

3. Autunite. Autun, France. Berzelius (1824). Perhaps meta-autunite.

4. Autunite. Leupoldsdorf, Bavaria. Ewald, analyst, in Henrich (1922).

5. Autunite. Beira Alta province, Portugal. Ewald, analyst, in Henrich (1922).

6. Autunite. Mount Painter, South Australia. Greig, analyst, in Smith (1926).

7. Autunite. Synthetic. Fairchild (1929). $n_{0} \approx 1.600, n_{E} \approx 1.590$.

Probably meta-autunite.

Small amounts of $\mathrm{Ba}$ and $\mathrm{Mg}$ occur presumably in substitution for $\mathrm{Ca}$, but in natural material there is no evidence of extensive or complete series toward other members of the torbernite group. Copper apparently does not substitute in significant amounts to give a series toward torbernite, and $\left(\mathrm{AsO}_{4}\right)$ has not been reported in substitution for $\left(\mathrm{PO}_{4}\right)$ to give a series toward uranospinite. Vanadium, presumably in substitution for $\mathrm{P}$, together with $\mathrm{Pb}$ and other elements, has been reported in trace amounts by spectrographic analysis (Forjaz, 1917).

Autunite is fusible, and easily soluble in acids. It is very slightly soluble in water (Starik, Samartzeva, and Yashchenko, 1941). 


\section{Crystallography}

Tetragonal, crystallizing in the ditetragonal dipyramidal crystal class $(4 / m 2 / m 2 / m)$. An angle table for the known forms in the unit and orientation of the $\mathrm{X}$-ray unit cell is given below. The dimensions of the X-ray cell, obtained by Beintema (1938) by the powder method on both natural and artificial material, are: $a_{0} 7.003 \mathrm{~A}, c_{0} 20.67, a_{0}: c_{0}=1: 2.952$. Space group $I 4 / \mathrm{mmm}$. Unit-cell contents $2\left[\mathrm{Ca}\left(\mathrm{UO}_{2}\right)_{2}\left(\mathrm{PO}_{4}\right)_{2} \cdot 10-12 \mathrm{H}_{2} \mathrm{O}\right]$.

Angle table for autunite

Tetragonal; ditetragonal-dipyramidal, $\left(4 / \mathrm{m}^{2} / \mathrm{m} 2 / \mathrm{m}\right)$ $a: c=1: 2.952 ; \quad p_{0}: r_{0}=2.952: 1$

\begin{tabular}{|c|c|c|c|c|}
\hline FORMS & $\phi$ & $\rho$ & $A$ & $\bar{M}$ \\
\hline $\begin{array}{ll}c & 001 \\
a & 010 \\
m & 110\end{array}$ & $\begin{array}{r}0^{\circ} \overline{00} \\
4500\end{array}$ & $\begin{array}{rl} & 0^{\circ} 00^{\prime} \\
90 & 00 \\
90 & 00\end{array}$ & 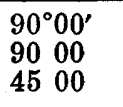 & $\begin{array}{l}90^{\circ} 00^{\prime} \\
4500 \\
9000\end{array}$ \\
\hline $\begin{array}{ll}l & 120 \\
d & 011 \\
p & 111\end{array}$ & $\begin{array}{rr}26 & 34 \\
0 & 00 \\
45 & 00\end{array}$ & $\begin{array}{ll}90 & 00 \\
71 & 17 \\
76 & 32\end{array}$ & $\begin{array}{ll}63 & 26 \\
90 & 00 \\
46 & 331 / 2\end{array}$ & $\begin{array}{ll}71 & 34 \\
47 & 571 / 2 \\
90 & 00\end{array}$ \\
\hline$q \quad 112$ & 2634 & 6424 & 5023 & 9000 \\
\hline
\end{tabular}

The observations on the morphology of autunite are summarized by Goldschmidt (1913-23), Dana (1892), and Palache, Berman, and Frondel (1951). The mineral generally has been considered to be orthorhombic or monoclinic with marked tetragonal pseudosymmetry. (See especially Des Cloizeaux, 1854, 1858, and Brezina, 1879.) Orthorhombic or monoclinic symmetry also has been proposed for some other related minerals, including torbernite (Walker, 1898), meta-autunite, saléeite (Schoep, 1939; Thoreau and Vaes, 1932), uranospinite (Weisbach, 1873a), troegerite (Schrauf, 1872), meta-uranocircite, and bassetite. The chief basis for this belief has been the biaxial optical character commonly observed. Other evidence has been found in small apparent departures of the morphology from tetragonal symmetry (although the quality of the crystals generally is too poor to give weight to the argument), supposed inequalities in the perfection and ease of the vertical cleavages, and asymmetrical etching effects. X-ray studies, however, indicate that the symmetry of these minerals is tetragonal, with the exception of bassetite, and the biaxial optical behavior has been shown to be dependent on the amount and distribution of the zeolitic water present (Beintema, 1938; Nuffield and Milne, 1953). 


\section{Crystal habit}

Thin to thick tabular on $\{001\}$ with a rectangular or, less commonly, an octagonal outline. The crystals closely approximate those of torbernite in form and angles. The lateral faces usually are striated or serrated. Subparallel growth is very common, grading into fanlike aggregates. Also as thick crusts with a serrated surface, composed of crystals standing on edge, and as foliated or scaly aggregates. Sharp, measurable crystals are rare. Drawings of autunite crystals are summarized by Goldschmidt (1913-23). A typical habit of autunite (and meta-autunite) is shown in figure 10.

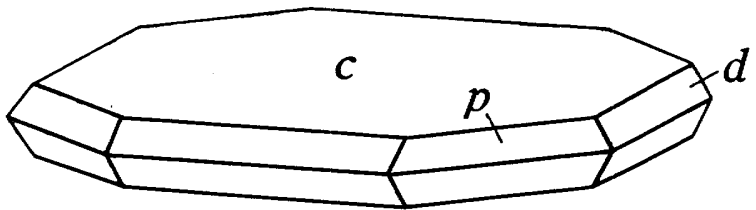

Figure 10.-Autunite. Forms: $c\{001\}, d\{011\}, p\{111\}$.

Twinning on $\{110\}$ has been reported in autunite on the basis of optical studies, but the feature represents optical anomalies associated with variation in the water content and is not a true twinning of the lattice. A true interpenetration twin on (110) is figured by Lacroix (1910) and Des Cloizeaux (1873).

Oriented growths have been observed of autunite with torbernite, the latter appearing as cores in crystals of autunite.

\section{Physical properties}

Cleavage $\{001\}$ perfect, $\{100\}$ indistinct; traces of cleavage on (110). Not brittle. Hardness 2-21/2. Specific gravity 3.05-3.2; 3.14 (calculated for $101 / 2 \mathrm{H}_{2} \mathrm{O}$ ). The specific gravity increases to $\approx 3.5$ as the crystals pass on dehydration to meta-autunite. Luster vitreous, pearly on $\{001\}$. Color usually lemon yellow to sulfur yellow; sometimes greenish yellow to pale yellowish green, or superficially stained brown. Streak pale yellow. Transparent to translucent. Strong fluorescence to yellowish green in ultraviolet light (Iimori and Iwase, 1938; Meixner, 1940b) ; weathered surfaces sometimes are not fluorescent or only weakly fluorescent, a brighter fluorescence appears on fracture surfaces. The dehydration product, meta-autunite, is less strongly fluorescent.

The percussion figure on $\{001\}$ shows rays parallel to $\{100\}$ and $\{110\}$ (Mügge, 1884). 
Optical properties

\begin{tabular}{|c|c|c|c|c|}
\hline \multirow{2}{*}{$\begin{array}{l}\text { ORIENTA- } \\
\text { TION }\end{array}$} & \multicolumn{3}{|c|}{$n$} & \multirow[b]{2}{*}{ PleOChROISM } \\
\hline & 1 & 2 & 3 & \\
\hline $\begin{array}{l}E^{n} \text { or } \underset{Y}{X}=c \\
O \text { or } Z\end{array}$ & $\begin{array}{l}1.553 \\
1.575 \\
1.577\end{array}$ & $\begin{array}{l}\overline{1.555} \\
1.575 \\
1.578\end{array}$ & $\begin{array}{l}1.58-1.59 \\
1.59-1.60\end{array}$ & $\begin{array}{l}\text { Colorless to pale yellow. } \\
\text { Yellow to dark yellow. } \\
\text { Yellow to dark yellow. }\end{array}$ \\
\hline
\end{tabular}

1. Autun, France. Michel-Lévy and Lacroix (1888).

2. Maryland. Shannon (1926).

3. Meixner (1940b).

Sometimes uniaxial negative; usually biaxial negative with $2 \mathrm{~V}$ variable and ranging up to $53^{\circ}$ but commonly $10^{\circ}-30^{\circ}$. In the biaxial material, $r>v$ strong, with $X=c$ and $Y$ parallel $\{100\}$. Depending on the external habit, $Y$ may be parallel to the sides or the diagonals of the square tablets. $2 \mathrm{~V}$ decreases with decreasing content of water and is $0^{\circ}$ at or near the conversion point to meta-autunite. (See Thermal behavior.) Some of the reported optical descriptions of so-called autunite probably refer to metaautunite, which has much higher indices.

Thermal behavior

A detailed study of the dehydration of autunite is given by Beintema (1938). (See also Rinne, 1901a, and Nuffield and Milne, 1953.) The dehydration of autunite brought about by gentle heating or by exposure to dry air was first established by Church (1875). The fully hydrated phase, autunite, contains about $10 \mathrm{H}_{2} \mathrm{O}$ at ordinary conditions. This is at or near the lower limit of water content required for the stability of the phase. Water can be taken up by the structure in amounts greater than this, at least to $12 \mathrm{H}_{2} \mathrm{O}$, but the upper limit is not known. Autunite breaks down to a new hydrate, meta-autunite I, at different temperatures depending on the vapor pressure: $\approx 90 \mathrm{~mm} \mathrm{Hg}$ at $57^{\circ} \mathrm{C} ; \approx 25 \mathrm{~mm}$ $\mathrm{Hg}$ at $38^{\circ} \mathrm{C} ; \approx 5 \mathrm{~mm} \mathrm{Hg}$ at $15^{\circ} \mathrm{C}$. (See graphs in Beintema, 1938.) The change from autunite to meta-autunite is reversible, at what are essentially ordinary conditions of temperature and humidity. The water content of meta-autunite varies zeolitically between about $61 / 2 \mathrm{H}_{2} \mathrm{O}$ and $21 / 2 \mathrm{H}_{2} \mathrm{O}$, and on heating to over about $80^{\circ} \mathrm{C}$, the material breaks down to a new hydrate, meta-autunite II. The latter phase varies zeolitically in water content between zero $\mathrm{H}_{2} \mathrm{O}$ and $6 \mathrm{H}_{2} \mathrm{O}$; it does not reconvert to meta-autunite $\mathrm{I}$ in water at room temperature. Meta-autunite II is orthorhombic, with $a_{0} 6.46 \mathrm{~A}, b_{0} 6.98 \mathrm{~A}, c_{0} 8.67 \mathrm{~A}$ (Beintema, 1938).

The optical properties of both autunite and meta-autunite vary considerably with the water content in their respective ranges of stability. Beintema (1938) found for synthetic autunite that as the temperature was increased or as the vapor tension decreased 
at constant temperature (thus reducing the water content), material that was initially biaxial with $2 V$ moderate and $Y$ parallel $\{100\}$ decreased in $2 \mathrm{~V}$ until at $18^{\circ} \mathrm{C}$ and $0.4 \mathrm{~mm} \mathrm{Hg}$ the crystals were uniaxial. At slightly higher water content the crystals were divided into four biaxial sectors with the plane of the optic axes in each parallel to $\{110\}$. At slightly lower water content the crystals converted to meta-autunite. At first they were again divided into four biaxial sectors with $Y$ parallel to $\{100\}$ and $2 \mathrm{~V}$ moderate; on heating, with loss of water, $2 \mathrm{~V}$ decreased and became zero at $60^{\circ} \mathrm{C}$. The sectors do not reappear immediately on cooling. Des Cloizeaux $(1854,1858)$ found that for red light $2 E$ at $20^{\circ} \mathrm{C}$ was $59^{\circ} 46^{\prime}-60^{\circ} 51^{\prime}$; at $91^{\circ} \mathrm{C}$, it was $50^{\circ} 12^{\prime}-54^{\circ} 10^{\prime}$; and above $100^{\circ} \mathrm{C}$ it was $0^{\circ}$ (material from Autun).

The minerals and synthetic compounds of the formula type $\mathrm{A}\left(\mathrm{UO}_{2}\right)_{2}\left(\mathrm{XO}_{4}\right)_{2} \cdot n \mathrm{H}_{2} \mathrm{O}$, where $\mathrm{A}=\mathrm{Ca}, \mathrm{Cu}, \mathrm{Ba}, \mathrm{Mg}, \mathrm{Co}, \mathrm{Fe}, \mathrm{Mn}$, $\mathrm{HAl}, \mathrm{Na}, \mathrm{NH}_{4}, \mathrm{H}$, and $\mathrm{X}=\mathrm{P}, \mathrm{As}, \mathrm{V}$, form at least three isostructural groups of hydrates. These comprise: (a) The so-called fully hydrated phase, here called the torbernite group, in which $n \mathrm{H}_{2} \mathrm{O}$ ranges zeolitically between limits. The upper and lower limits of variation are not clearly established for all members of the group and may not be identical in all, but the limits seem to be $10 \mathrm{H}_{2} \mathrm{O}$ and $16 \mathrm{H}_{2} \mathrm{O}$. (b) The so-called meta-I hydrates, here called the metatorbernite group, in which $n \mathrm{H}_{2} \mathrm{O}$ ranges zeolitically between limits. Here again the limits are not clearly established for all members of the group, and may not be identical in all. The upper limit apparently is $8 \mathrm{H}_{2} \mathrm{O}$ and various values, from $1 \mathrm{H}_{2} \mathrm{O}$ to $5 \mathrm{H}_{2} \mathrm{O}$ have been reported for the lower limit. (c) The so-called meta-II hydrates, not known in nature, in which $n \mathrm{H}_{2} \mathrm{O}$ ranges zeolitically between limits that are not clearly established for all members of the group and that may be different in some or all. The limits in general are between zero $\mathrm{H}_{2} \mathrm{O}$ and $61 / 2 \mathrm{H}_{2} \mathrm{O}$. (d) In addition, a monohydrate has been reported for $\mathrm{Cu}\left(\mathrm{UO}_{2}\right)_{2}$ $\left(\mathrm{PO}_{4}\right)_{2} \cdot n \mathrm{H}_{2} \mathrm{O}$; and uranospathite may represent a new hydrated phase containing more water than the members of the torbernite group. The meta-I hydrate seems to be lacking in the $\mathrm{HAl}$ member, sabugalite, of the torbernite group. Much further work is needed to establish both the transition temperatures under standard conditions and the limits of water content for the members of the various groups of hydrates. There is no doubt that systematic relations will be found between the variation in inversion temperature and limits of water content in the members of each group and crystallochemical factors such as the size, polarizability, and ionic hydration of the $\mathrm{A}$ and $\mathrm{X}$ ions. The transition between the meta-II and meta-I hydrates is not reversible, and 
that between the meta-I and fully hydrated phases is reversible in some instances and not in others. Nuffield and Milne (1953) find that under like conditions of temperature and pressure the stability of the fully hydrated phase increases with decreasing radius of the $\mathrm{A}$ ion.

The members of both the torbernite and metatorbernite groups are tetragonal with $a_{0} \approx 7 \mathrm{~A}$, but in the torbernite group $c_{0}$ is about $20 \mathrm{~A}$ and in the metatorbernite group $c_{0}$ is halved (with the exception of meta-uranocircite). The close structural relations between these two groups of hydrates were worked out by Beintema (1938) and have been discussed by Nuffield and Milne (1953) and C. Frondel (1951a).

\section{Cation exchange}

Autunite and meta-autunite readily undergo cation exchange, as do some and probably all of the other members of the torbernite and metatorbernite groups (Fairchild, 1929; Mrose, 1953; and Beintema, 1938). Both autunite and meta-autunite are readily prepared by treating hydrogen autunite or sodium autunite in strong solutions of calcium acetate or chloride, and similarly hydrogen autunite and sodium autunite can be made from the calcium compounds by exchange from acid solutions or strong brine. Solutions of cation-exchangeable monovalent cations such as $\mathrm{Na}, \mathrm{K}, \mathrm{NH}_{4}$ or $\mathrm{H}$ convert autunite into the corresponding meta-I hydrate but do not affect the structure of meta-autunite. This is connected with the fact that the Ca ions in the structure of meta-autunite occupy statistically only half of the available structural positions, leaving room for the two monovalent cations needed for valence compensation after exchange, whereas the Ca positions in autunite are wholly occupied. The absence of a meta-I hydrate in the $\mathrm{HAl}$ member, sabugalite, of the torbernite group also seems to be connected with this situation.

\section{Synthesis}

Obtained by reaction of monocalcium acid phosphate with uranyl nitrate in water solution, and probably generally by reaction of water-soluble salts affording Ca, uranyl, and $\left(\mathrm{PO}_{4}\right)$ ions. The precipitation should be made in cold dilute solutions to avoid the formation of the lower hydrate, meta-autunite. If the solution is strongly acid the precipitate can be deficient in $\mathrm{Ca}$, apparently with substitution of $\mathrm{H}^{+}$or $\left(\mathrm{H}_{3} \mathrm{O}\right)^{+}$in a series toward hydrogen autunite. The deficiency can be remedied by cation exchange of the precipitate in a cold solution of calcium acetate (Beintema, 1938). 
Almost all of the natural members of both the torbernite and metatorbernite groups have been synthesized. A large number of additional members of these groups are known as synthetic products. These substances are summarized in the table below. The

Synthetic compounds of the torbernite and metatorbernite groups Composition

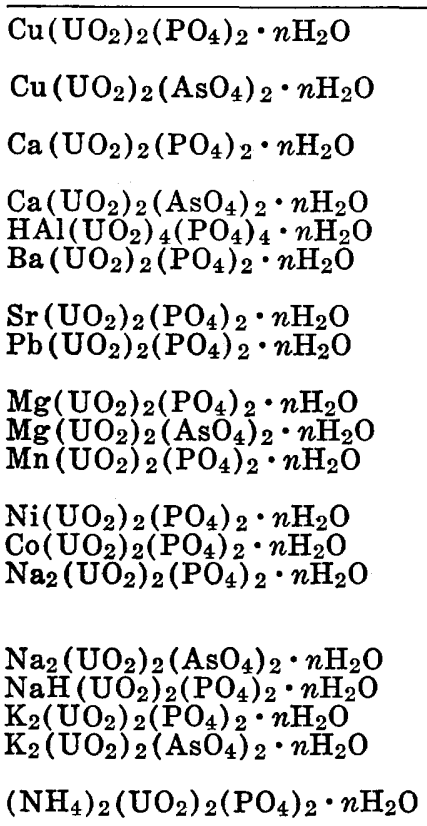

$\left(\mathrm{NH}_{4}\right)_{2}\left(\mathrm{UO}_{2}\right)_{2}\left(\mathrm{AsO}_{4}\right)_{2} \cdot n \mathrm{H}_{2} \mathrm{O}$ $\mathrm{H}_{2}\left(\mathrm{UO}_{2}\right)_{2}\left(\mathrm{PO}_{4}\right)_{2} \cdot n \mathrm{H}_{2} \mathrm{O}$

$\mathrm{H}_{2}\left(\mathrm{UO}_{2}\right)_{2}\left(\mathrm{AsO}_{4}\right)_{2} \cdot n \mathrm{H}_{2} \mathrm{O}$

$\mathrm{Li}_{2}\left(\mathrm{UO}_{2}\right)_{2}\left(\mathrm{PO}_{4}\right)_{2} \cdot n \mathrm{H}_{2} \mathrm{O}$ $\mathrm{Li}_{2}\left(\mathrm{UO}_{2}\right)_{2}\left(\mathrm{AsO}_{4}\right)_{2} \cdot n \mathrm{H}_{2} \mathrm{O}$
REFERENCE

Fairchild (1929), R. Berman (1956), Werther (1848).

Winkler (1873), Kraft (1938), J. W. Frondel (1951).

Beintema (1938), Chretien and Kraft (1938), Fairchild (1929).

Winkler (1873), Kraft (1938), Mrose (1953).

G. J. Jansen (written communication, 1952).

Blinkoff (1906), Fairchild (1929), Beintema (1938).

Blinkoff (1906).

Fairchild (1929), Ross (written communication, 1955).

Fairchild (1929).

C. Frondel (1951b).

Fairchild (1929), G. J. Jansen (written communication, 1952).

Fairchild (1929).

Bergman (1925), Fairchild (1929).

Werther (1848), Fairchild (1929), Chretien and Kraft (1938), Beintema (1938), Howes and Wilber (1916).

Kraft (1938).

Fairchild (1929).

Fairchild (1929), Chretien and Kraft (1938).

Lienau (1898), Rimbach (1904), Kraft (1938).

Palmqvist (1936), Chretien and Kraft (1938), Harris and Scott (1949), Saito (1927), Knop (1856), Arendt and Knop (1857).

Puller (1871), Lienau (1898), Kraft (1938).

Werther (1848), Heintz (1869), Bourgeois (1898), Lienau (1898), Beintema (1938), Harris and Scott (1949), Montignie (1937), Chretien and Kraft (1938), Dominé-Berges (1953), V. Ross (1955b).

Werther (1848), Lienau (1898), Bourgeois (1898), Kraft (1938), Mrose (1953).

Not stable. (See Lienau, 1898.)

Not stable. (See Lienau, 1898.)

substances are listed in this table without regard to their state of hydration. The methods used in the syntheses are based on: (a) The reaction in water solution of salts affording uranyl ion, phosphate or arsenate ion, and the desired divalent or monovalent ion. The cations can be dissolved as the acetate, nitrate, or chloride, and the mixed solution then reacted with phosphoric or arsenic acid. The precipitate may be deficient in the divalent or monovalent cation even though it has been added in stoichiometric amount, especially if the solution is strongly acid, and the precipitate should be allowed to stand in a strong, nearly neutral 
solution of the desired divalent or monovalent cation in order te remove any $\mathrm{H}$ present by cation exchange. The formation of the meta-I hydrate is favored in hot solutions and the fully hydrated phase in cold solutions. Large crystals often can be obtained by diffusion through a large volume of water (Fairchild, 1929) or by boiling the precipitated solution, adding just enough very dilute acid to dissolve the precipitate, and allowing to cool very slowly. (b) Cation exchange, preferably with a concentrated, nearly neutral solution of the desired divalent or monovalent cation in contact with precipitated hydrogen uranyl phosphate or arsenate. (c) Precipitating hydrogen uranyl phosphate or arsenate, dissolving the washed precipitate in just enough acid, and reprecipitating with a solution of the desired divalent or monovalent cation. Hydrogen uranyl phosphate or arsenate can be prepared by precipitating a water solution of a uranyl salt with phosphoric or arsenic acid in stoichiometric ratio.

Hydrogen uranyl phosphate (hydrogen autunite) with the formula $\mathrm{H}_{2}\left(\mathrm{UO}_{2}\right)_{2}\left(\mathrm{PO}_{4}\right)_{2} \cdot 8 \mathrm{H}_{2} \mathrm{O}$ has been described by V. Ross (1955b) as tetragonal with the cell dimensions $a_{0} 7.020 \mathrm{~A}, c_{0} 9.043( \pm 0.005$ A) ; indices of refraction $n_{o} 1.579 ; n_{E} 1.568$. It is isostructural with meta-autunite. Indexed X-ray powder-spacing data are given in the table below.

\section{X-ray powder-spacing data for hydrogen autunite ${ }^{1}$}

[Symbol: b, broad. Copper radiation, nickel filter]

\begin{tabular}{|c|c|c|c|c|c|}
\hline$d(\mathrm{~A})$ & $I$ & $h k l$ & $d(\mathrm{~A})$ & $I$ & $h k l$ \\
\hline $\begin{array}{l}9.032 \\
5.556 \\
4.971 \\
4.542 \\
4.360 \\
3.799 \\
3.511 \\
3.270 \\
2.964 \\
2.765 \\
2.576 \\
2.488 \\
2.397 \\
2.267 \\
2.216 \\
2.163 \\
2.075 \\
1.902 \\
1.844\end{array}$ & $\begin{array}{r}10 \\
5 \\
4 \\
1 / 2 \\
3 \\
9 \\
7 \\
8 \\
6 \\
7 \\
3 \\
3 \\
4 \\
2 \\
3 \\
5 \\
4 \\
2 \\
3\end{array}$ & $\begin{array}{l}001 \\
011 \\
110 \\
002 \\
111 \\
102 \\
200 \\
021 \\
121 \\
022,103 \\
122,113 \\
220 \\
221 \\
301,004 \\
310 \\
311,104 \\
302 \\
321,204 \\
303\end{array}$ & $\begin{array}{l}1.789 \\
1.755 \\
1.722 \\
1.697 \\
1.633 \\
1.61-1.57 \\
1.546 \\
1.477 \\
1.439 \\
1.401 \\
1.383 \\
1.359 \\
1.338 \\
1.288 \\
1.270 \\
1.249 \\
1.221 \\
1.194\end{array}$ & $\begin{array}{l}3 \\
2 \\
2 \\
3 \\
3 \\
3(\mathrm{~b}) \\
1 \\
1 \\
1 \\
2 \\
1 \\
1 \\
1 / 2 \\
1 / 2 \\
1 \\
2 \\
1 / 2 \\
3\end{array}$ & $\begin{array}{l}322,313 \\
400,105 \\
401 \\
115 \\
402,323 \\
314, \text { etc. } \\
421, \\
324,106 \\
116 \\
315 \\
206,511 \\
414,216 \\
334,256 \\
424,226 \\
107,306 \\
316 \\
335 \\
531,504,326\end{array}$ \\
\hline
\end{tabular}

1 The data, from V. Ross (1955b), are for synthetic material with $8 \mathrm{H}_{2} \mathrm{O}$. Identification

Autunite is indistinguishable at sight from meta-autunite, metauranocircite, and other yellow members of the torbernite and metatorbernite groups. It is distinguished from meta-autunite by 
its lower indices of refraction and lower specific gravity, and from this species and others by its X-ray diffraction pattern. The X-ray powder-spacing data are given in the table below. Very inconspicuous films or disseminations of autunite (and metaautunite) in mine workings and outcrops can be detected by examination in the dark with a portable ultraviolet lamp.

$X$-ray powder-spacing data for autunite ${ }^{1}$

[Symbol: d, diffuse. Copper radiation, nickel filter]

\begin{tabular}{|c|c|c|c|c|c|c|}
\hline$d(\mathrm{~A})$ & $I$ & $d(\mathrm{~A})$ & $I$ & $d(\mathrm{~A})$ & $I$ & $d(\mathrm{~A})$ \\
\hline $\begin{array}{r}10.33 \\
8.97 \\
6.70 \\
4.96 \\
4.48 \\
3.59 \\
3.49 \\
3.33 \\
3.12 \\
2.88 \\
2.71 \\
2.49\end{array}$ & $\begin{array}{r}10 \\
\mathbf{1} \\
\mathbf{2} \\
\mathbf{8} \\
\mathbf{6} \\
7 \\
7 \\
7 \\
1 \\
5 \\
\mathbf{2} \\
\mathbf{2}\end{array}$ & $\begin{array}{l}2.40 \\
2.21 \\
2.15 \\
2.03 \\
1.911 \\
1.871 \\
1.823 \\
1.750 \\
1.720 \\
1.644 \\
1.617 \\
1.566\end{array}$ & $\begin{array}{l}2 \\
3 \\
3 \\
2 \\
1 \text { (d) } \\
1 \text { (d) } \\
1 \text { (d) } \\
2 \\
1 \\
1 \\
4 \\
2\end{array}$ & $\begin{array}{l}1.539 \\
1.506 \\
1.473 \\
1.412 \\
1.357 \\
1.323 \\
1.288 \\
1.261 \\
1.223 \\
1.191 \\
1.159 \\
1.133\end{array}$ & $\begin{array}{l}2 \\
2 \\
1 \\
1 \\
4 \\
2 \\
1 \\
2 \\
2(d) \\
3 \\
1 \\
1\end{array}$ & $\begin{array}{r}1.101 \\
1.072 \\
1.036 \\
1.027 \\
.985 \\
.971 \\
.966 \\
.949 \\
.935 \\
.930 \\
.916 \\
.905\end{array}$ \\
\hline
\end{tabular}

${ }^{1}$ Data on fully hydrated synthetic material.

Natural formation

Autunite is a secondary mineral, formed at essentially ordinary conditions of temperature and pressure. It occurs chiefly in the zone of oxidation and weathering of hydrothermal veins or other deposits carrying primary uraninite. Autunite is one of the most abundant and widespread of the secondary uranium minerals, and has constituted a minor ore of uranium at some localities (Portugal and Madagascar). Typical associated minerals include phosphuranylite, meta-autunite (as an alteration product), torbernite, saléeite, uranophane, and beta-uranophane. Autunite has been observed altered to phosphuranylite. The phosphate content of the autunite found in small amounts in the Morrison formation on the Colorado Plateau may have been derived in part from fossil bone.

\section{Occurrence}

Only a few of the very many known localities for autunite are mentioned here. An extended list is given in Hintze (1931, v. 1, pt. 4 , no. 36, p. 979), and numerous additional localities are mentioned in more recent literature. The distinction between autunite and meta-autunite has not been made for most of the reported occurrences. Among the more notable localities are Saint-Symphorien and other places near Autun, Saône-et-Loire, France (Lacroix, 1910). The Saint-Symphorien locality, discovered in 1800 by Champeaux (1801), has afforded some of the best specimens yet found of the mineral. Spectacular specimens showing 
thick crusts and masses of greenish crystals more than an inch on edge have been found in the Daybreak mine, Opportunity, Spokane County, Wash. Thick masses occur at Mount Painter in the Flinders Range, South Australia; the mineralogy and geology of this deposit is described by Stillwell and Edwards (1954) and by Dickinson and others (1954). In the Rum Jungle area, Northern Territory, Australia. Found at various places in Cornwall, England, but less abundant than torbernite; at Shinkolobwe and other places in the Katanga district, Belgian Congo, but much less common than torbernite; in Germany in various mines in the Johanngeorgenstadt-Eibenstock district, Saxony; in a peaty alluvium and clay near Vinaninkarena, Madagascar. At Yanai, Yamaguti Prefecture, Japan (Kimura and Iimori, 1936). Found with torbernite as a concentration by meteoric waters in a fracture zone at Bukhovo near Sofia, Bulgaria. At various places in the Erzgebirge of Bohemia (Kratochvil, 1952); at Dolni Bory, Czechoslovakia (Kašpárek and Němec, 1951). Autunite formerly occurred abundantly in the oxidized zone of uranium vein deposits at Urgeiriça, Rosmaniera, and other places in Portugal; the geology of some of these deposits has been described by Bernardo Ferreira and Cotelo Neiva (1945) and Cerveira (1951). Found in the United States in many minor occurrences, as in the sandstone-type uranium deposits of the Colorado Plateau (Weeks and Thompson, 1954) and as an alteration product of uraninite in pegmatite at numerous places in New England, the Appalachian region, and elsewhere. The best New England specimens are from the Ruggles pegmatite near Grafton Center, N. H., where the mineral occurs as crusts along cracks in feldspar and quartz adjacent to the altered dendritic aggregates of uraninite for which the locality is known; at various localities in Maine (Smith and Maslowski, 1937). An autunite occurrence in Lawrence County, S. Dak., has been described by Vickers (1953).

\section{TORBERNITE}

Synonymy

Mica viridis cryst. [from Joachimsthal] von Born (1772). Grüner Glimmer [from Saxony] Werner (1780). Torberit Werner (in Karsten, 1793). Chalkolith Werner (1789); Urankalk durch Kupfer gefärbt, Uranites spathosus pt. Klaproth $(1789,1797)$. Uranglimmer Werner (1800) (in Ludwig, 1803). Urane oxydé Haüy (1801). Uranit Aikin (1814). Uran-Mica Jameson (1820). Uranphyllit Breithaupt (1820). Phosphate of Uranium containing Phosphate of Copper R. Phillips (1823). Phosphate of Uranium and Copper Berzelius (1823). Kupfer-Uranit Germ. 
Copper-Uranite. Torberite Brooke and Miller (1852). Cuprouranit Breithaupt (1865). Kupferuranglimmer. Torbernite.

Torbernite is named after Torber Bergmann (1735-84), Swedish chemist. It was the first mineral to be named after a person. This action was criticized by Karsten, and the name was then displaced by chalcolith by Werner in 1789, in the belief that the substance was a "copper-containing stone" in allusion to Bergmann's determination of the mineral as a copper chloride. When the presence of uranium was demonstrated by Klaproth in 1797 the names uranglimmer and uranphyllit, from the content of uranium and the micaceous structure, came into use. These in turn were supplanted by the original name, torberite and, later, torbernite. Klaproth (1797) considered copper to be a nonessential pigmenting agent in the green uranglimmer, and found copper to be absent in a yellow variety of this mineral (autunite). Autunite was classed as a variety of uranglimmer or chalcolith until 1819, when Berzelius showed that it was a distinct species containing calcium instead of copper as an essential constituent. Zeunerite (metazeunerite) was not separated from torbernite until 1872 and metatorbernite not until 1916.

\section{Composition}

A hydrated phosphate of copper and hexavalent uranium, $\mathrm{Cu}\left(\mathrm{UO}_{2}\right)_{2}\left(\mathrm{PO}_{4}\right)_{2} \cdot 12 \mathrm{H}_{2} \mathrm{O}$. The water content presumably varies zeolitically, but most specimens that have been kept in the open air prior to analysis are at or near $12 \mathrm{H}_{2} \mathrm{O}$. On desiccation or slight heating in air, torbernite readily breaks down to a lower hydrate, metatorbernite, with a maximum of $8(?) \mathrm{H}_{2} \mathrm{O}$ of zeolitic water. It is uncertain whether some of the reported analyses of so-called torbernite have been made on that species or on metatorbernite.

The reported analyses of torbernite are given in the table below. There is no evidence of a series extending between torbernite and autunite in natural material by mutual substitution of $\mathrm{Cu}$ or $\mathrm{Ca}$. There has been substitution of $\left(\mathrm{AsO}_{4}\right)$ for $\left(\mathrm{PO}_{4}\right)$ in small amounts, and a complete series probably can exist to zeunerite (or between metatorbernite and metazeunerite). The $\mathrm{Pb}$ reported in the analyses of Katanga material by Steinkuhler (1923) probably is due to admixture of a lead uranyl phosphate, although a lead member of the autunite group has been synthesized, suggesting that $\mathrm{Pb}$ can go into solid solution in torbernite.

Spectrographic analyses by Forjaz (1917) showed the presence of $\mathrm{V}, \mathrm{Ba}, \mathrm{Mn}, \mathrm{Mg}, \mathrm{Ca}$, and other elements; the $\mathrm{V}$, the presence of which in torbernite was early shown by Kersten, doubtless is present as $\left(\mathrm{VO}_{4}\right)$ in substitution for $\left(\mathrm{PO}_{4}\right)$. (See also Fritzscheite.) 
Te and Mo are present in the torbernite from Katanga (analysis 5). Torbernite is easily soluble in acids and easily fusible to a black mass.

\begin{tabular}{|c|c|c|c|c|c|c|c|c|c|}
\hline & 1 & 2 & 3 & 4 & 5 & 6 & 7 & 8 & 9 \\
\hline uO & 7.88 & 8.49 & 7.73 & 8.13 & 7.15 & 8.56 & 9.3 & 8.1 & 8.09 \\
\hline $\mathrm{UO}_{3}$ & $56 . \overline{65}$ & $61 . \overline{00}$ & $57 . \overline{03}$ & $60 . \overline{71}$ & 60.35 & $61 . \overline{00}$ & $5 \overline{5.8}$ & $6 \overline{0.5}$ & $58 . \overline{02}$ \\
\hline $\begin{array}{l}\mathrm{P}_{2} \mathrm{O}_{5} \\
\mathrm{As}_{2} \mathrm{O}_{5}\end{array}$ & 14.06 & 15.14 & 14.50 & 13.54 & 14.42 & 13.94 & 17.4 & 14.7 & 14.91 \\
\hline$v_{5}$ & - & - & $\overrightarrow{59}$ & & 1 & $\begin{array}{l}1.96 \\
62\end{array}$ & 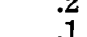 & 二 & 06 \\
\hline & $21 . \overline{41}$ & $15 . \overrightarrow{37}$ & 20.30 & $15 . \overline{36}$ & 14.31 & 14.16 & 17.2 & 16.7 & 17.04 \\
\hline otal & 100.00 & 00.00 & 100.15 & 100.98 & 00.87 & 100.24 & 00.0 & 100.0 & 100.12 \\
\hline
\end{tabular}

1. Theoretical weight percentages, $\mathrm{CuO} \cdot 2 \mathrm{UO}_{3} \cdot \mathrm{P}_{2} \mathrm{O}_{5} \cdot 12 \mathrm{H}_{2} \mathrm{O}$ (torbernite). ite).

2. Theoretical weight percentages, $\mathrm{CuO} \cdot 2 \mathrm{UO}_{3} \cdot \mathrm{P}_{2} \mathrm{O}_{5} \cdot 8 \mathrm{H}_{2} \mathrm{O}$ (metatorbern-

3. Torbernite. Leupoldsdorf, Bavaria. Remainder is $\mathrm{SiO}_{2}$. Henrich (1922).

4. Metatorbernite(?). Cornwall. Winkler (1873).

5. Metatorbernite(?). Katanga. Steinkuhler (1923). Remainder is $\mathrm{Al}_{2} \mathrm{O}_{3}$ 0.88 , Te 0.63 , insoluble $0.18, \mathrm{MoO}_{3}$ trace. Also a partial analysis of $\mathrm{PbO}$ 3.88 , Te 0.76 .

6. Metatorbernite (?). Cornwall. Church (1865). Remainder is CaO.

7. Torbernite(?). Temple Mountain, Utah. Schaller, analyst, in Hess (1924). Recalculated to 100 percent after deducting 35.76 percent insoluble. Remainder is $\mathrm{CaO}$.

8. Torbernite. Synthetic. Debray (1861).

9. Torbernite. Mount Painter, South Australia. Dalwood, analyst, in Stillwell and Edwards (1954). Remainder is $\mathrm{SiO}_{2} 1.24, \mathrm{AL}_{2} \mathrm{O}_{3} 0.38, \mathrm{Fe}_{2} \mathrm{O}_{3} 0.38$, $\mathrm{CaO} 0.06$.

\section{Crystallography}

Tetragonal, in the ditetragonal dipyramidal crystal class $(4 / m 2 / m 2 / m)$. An angle table for the known forms based on the unit and orientation of Hallimond (1916), corresponding to the $\mathrm{X}$-ray structure cell, is given below. The unit-cell dimensions are

\section{Angle table for torbernite}

Tetragonal; ditetragonal-dipyramidal, $(4 / \mathrm{m} 2 / \mathrm{m} 2 / \mathrm{m})$

$$
a: c=1.2 .974 ; \quad p_{0}: r_{0}=2.974: 1
$$

\begin{tabular}{|c|c|c|c|c|}
\hline FORMS & $\phi$ & $\rho$ & $A$ & $M$ \\
\hline $\begin{array}{ll}c & 001 \\
a & 010 \\
m & 110\end{array}$ & $\begin{array}{r}0^{\circ} 00^{\prime} \\
4500\end{array}$ & $\begin{array}{rl}0^{\circ} 00^{\prime} \\
90 & 00 \\
90 & 00\end{array}$ & $\begin{array}{l}90^{\circ} 00^{\prime} \\
9000 \\
4500\end{array}$ & $\begin{array}{l}90^{\circ} 00^{\prime} \\
4500 \\
9000\end{array}$ \\
\hline $\begin{array}{ll}o & 013 \\
e & 011 \\
l & 112\end{array}$ & $\begin{array}{rl}0 & 00 \\
0 & 00 \\
45 & 00\end{array}$ & $\begin{array}{ll}44 & 45 \\
71 & 25 \\
64 & 34\end{array}$ & $\begin{array}{ll}90 & 00 \\
90 & 00 \\
50 & 19\end{array}$ & $\begin{array}{ll}60 & 081 / 2 \\
47 & 55 \\
90 & 00\end{array}$ \\
\hline$p \quad 111$ & 4500 & $76371 / 2$ & 4632 & 9000 \\
\hline
\end{tabular}

given in the table on the following page.

The morphological data on torbernite are summarized by Hallimond (1916) and Goldschmidt (1918). Early accounts of the morphology were given by Bernhardi (1809), W. Phillips 


\begin{tabular}{cccc} 
& \multicolumn{3}{c}{ Unit-cell dimensions of torbernite } \\
& $\frac{1}{7.025 \mathrm{~A}}$ & $\frac{2}{7.06 \mathrm{~A}}$ & Unit-cell contents \\
$a_{0}$ & 20.63 & 20.5 & $2\left[\mathrm{Cu}\left(\mathrm{UO}_{2}\right)_{2}\left(\mathrm{PO}_{4}\right)_{2} \cdot 12 \mathrm{H}_{2} \mathrm{O}\right]$. \\
$c_{0}$ & $1: 2.937$ & $1: 2.904$ &
\end{tabular}

1. Synthetic; fully hydrated (wet). R. Berman (1956).

2. Natural. Goldsztaub (1932).

(1816) on Cornwall crystals, and by Lévy (1837). The numerous reported measurements are not in good agreement because of the poor surface quality of the crystals or because of alteration to metatorbernite, and some of the earlier observations may have been made on metazeunerite or related species. Goldschmidt (1918) used a unit with the $c$-axis half of the present cell. As with some other members of the torbernite and metatorbernite groups, there has been discussion of the true symmetry of the mineral. The morphological and X-ray single-crystal data conform to tetragonal symmetry, but observations on optical anomalies, cleavage, and etch pits of supposed torbernite (probably actually metatorbernite) have led to suggestions that the mineral is monoclinic or orthorhombic. (See Walker, 1898, and Rinne, 1901b.) This matter was discussed further under Autunite.

\section{Crystal habit}

Crystals of torbernite are commonly thin to thick tabular on $\{001\}$, with a rectangular or octagonal shape; rarely pyramidal and terminated by small faces of $\{001\}$. The lateral faces commonly are striated or serrated horizontally, or are rough and dull and afford poor measurements. The crystals are often arranged as subparallel or slightly divergent groups or as crusts. Less commonly found as lamellar or scaly aggregates; rarely as granular to almost earthy masses and then generally appearing somewhat paler in color. Also observed as fine-grained impregnations in sandstone.

Crystals containing an hour-glass type of sectoral coloration are described by Hallimond (1916) and have been observed on specimens from Portugal and other places. Twinning has been reported in the mineral on the basis of optical observations, but this feature probably arises in optical anomalies connected with variation in the water content and is not a true twinning of the lattice. Etch figures generally conform to tetragonal holohedral symmetry (Traube, 1895; Walker, 1898; and Rinne, 1901b).

Torbernite has been found as parallel growths with autunite, uranospinite, bassetite, and metazeunerite, the minerals forming rims one about the other as seen on $\{001\}$. 
Drawings of torbernite crystals are given by Hallimond (1916), V. Goldschmidt (1913-23), Palache, Berman, and Frondel (1951), and others. Some typical habits (which refer also to metatorbernite) are shown in figure 11.

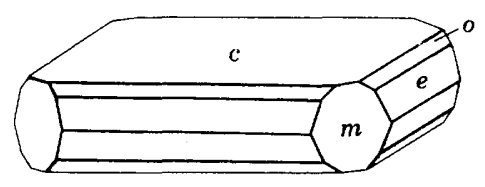

A

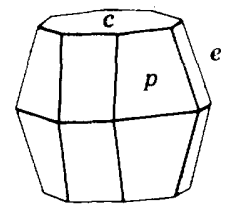

$B$

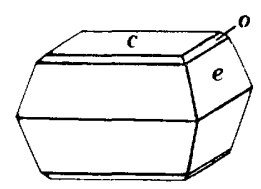

C

Figure 11.-Torbernite. A. Forms: $c\{001\}, m\{110\}, e\{011\}, o\{013\} . \quad B$. Forms: $c\{001\} . p\{111\}$, $e\{011\}$, C. Forms: $c\{001\}$. $e\{011\}$, o\{013\}.

\section{Physical properties}

Cleavage $\{001\}$ perfect, $\{100\}$ indistinct. Cleavage laminae are rather brittle, more so than autunite. Hardness 2-21/2. Specific gravity 3.22 (measured, Hallimond, 1916) ; slightly higher values, 3.4-3.6, have been reported and may refer to metatorbernite; 3.28 (calculated for $12 \mathrm{H}_{2} \mathrm{O}$ ). Luster vitreous to subadamantine, pearly on $\{001\}$. Color emerald green to grass green, less commonly leek green, apple green, or siskin green. Streak paler than the color. Transparent to translucent. Observations on the fluorescence are contradictory; apparently not fluorescent or very weakly fluorescent in green in ultraviolet light. The percussion figure on $\{001\}$ has been described by Mügge (1884).

Optical properties

\begin{tabular}{|c|c|c|c|c|c|}
\hline \multirow{2}{*}{$\begin{array}{l}\text { ORIENTA- } \\
\text { TION }\end{array}$} & \multicolumn{3}{|c|}{$n$} & \multirow[b]{2}{*}{ DICHROISM } & \multirow{4}{*}{$\begin{array}{l}\text { Uniaxial } \\
\text { negative. }\end{array}$} \\
\hline & 1 & 2 & 3 & & \\
\hline$E$ or $X=c$ & $\overline{1.581}$ & $\overline{1.582}$ & $\overline{1.581}$ & $\begin{array}{l}\text { Colorless to pale } \\
\text { greenish blue. }\end{array}$ & \\
\hline $\boldsymbol{Y}$ & 1.592 & - & - & Pale green & \\
\hline$O$ or $Z$ & 1.592 & 1.592 & 1.590 & $\begin{array}{l}\text { Pale green } \\
\text { to dark green. }\end{array}$ & \\
\hline
\end{tabular}

1. New Mexico. George (1949).

2. Cornwall. Hallimond (1920).

3. Gunnis Lake. Millosevich (1912).

Optical anomalies, common in metatorbernite, seem to be lacking in torbernite. Most of the optical data reported for so-called torbernite are of uncertain affiliation and probably refer to metatorbernite. The indices of refraction probably vary with the water content to above $12 \mathrm{H}_{2} \mathrm{O}$ but correlated data are lacking. Data on the absorption spectrum are given by Wherry (1929) and Rinne (1901b). 
Thermal behavior

Dehydration data on torbernite are given by Rinne (1901b), Church (1865), Buchholz (1903), and Hallimond (1916, 1920). At ordinary temperatures the mineral contains about $12 \mathrm{H}_{2} \mathrm{O}$. This is at or near the lower limit of water content of the phase. Data are lacking on the upper limit of water content; it may be $16 \mathrm{H}_{2} \mathrm{O}$ as in synthetic zeunerite. Heated in water or in air saturated with moisture, torbernite loses $4 \mathrm{H}_{2} \mathrm{O}$ at $75^{\circ} \mathrm{C}$ and passes into metatorbernite with $8 \mathrm{H}_{2} \mathrm{O}$. Heated in air at lower humidities the temperature of breakdown decreases (See graph in Hallimond, 1916.) The passage from torbernite to metatorbernite apparently is irreversible and both phases can coexist metastably over extended periods in water at room temperature. Metatorbernite breaks down, apparently irreversibly, into an orthorhombic(?) phase, metatorbernite-II, when heated in air to about $130^{\circ} \mathrm{C}$ or if held over a desiccant at $100^{\circ} \mathrm{C}$ or somewhat less (Hallimond, 1916). Metatorbernite-II has not been observed in nature. It apparently contains $4 \mathrm{H}_{2} \mathrm{O}$ as an upper limit and breaks down to a monohydrate (?) a.t not much higher temperatures.

Synthesis

Obtained by ion exchange of synthetic sodium autunite with concentrated copper chloride solution (possibly metatorbernite) (Fairchild, 1929). As crystals by adding uranyl nitrate to a solution of copper carbonate in phosphoric acid and allowing the liquid to stand for some time, best at $50^{\circ}-60^{\circ} \mathrm{C}$ and then at about $10^{\circ} \mathrm{C}$.

\section{Identification}

Torbernite cannot be distinguished at sight from metatorbernite, zeunerite, and metazeunerite. It has lower indices of refraction than those species, and its X-ray pattern is distinctive. The $\mathrm{X}$-ray powder-spacing data are given in the table below. Torbernite and the other green members of the torbernite group somewhat resemble the basic copper arsenate chalcophyllite.

$X$-ray powder-spacing data for torbernite 1

[Copper radiation, nickel filter]

\begin{tabular}{|c|c|c|c|c|c|c|}
\hline$d(\mathrm{~A})$ & $I$ & $d(\mathrm{~A})$ & $I$ & $d(\mathrm{~A})$ & $I$ & $d(\mathrm{~A})$ \\
\hline $\begin{array}{c}10.3 \\
6.61 \\
5.18 \\
4.94 \\
4.48 \\
3.67\end{array}$ & $\begin{array}{r}10 \\
4 \\
3 \\
9 \\
4 \\
4\end{array}$ & $\begin{array}{l}3.58 \\
3.51 \\
3.10 \\
2.90 \\
2.85 \\
2.73\end{array}$ & $\begin{array}{l}9 \\
8 \\
1 \\
3 \\
2 \\
1\end{array}$ & $\begin{array}{l}2.67 \\
2.48 \\
2.41 \\
2.37 \\
2.32 \\
2.24\end{array}$ & $\begin{array}{l}1 \\
1 \\
2 \\
1 \\
1 \\
1\end{array}$ & $\begin{array}{l}2.21 \\
2.158 \\
2.040 \\
1.917 \\
1.873\end{array}$ \\
\hline
\end{tabular}

1 Data from R. Berman (1956) on fully hydrated synthetic material. 


\section{Natural formation}

Torbernite is a secondary mineral, found typically in the gossan of veins or other deposits containing uraninite together with chalcopyrite or other copper-containing minerals. The uranium and copper have been derived by the oxidation of these primary minerals, but the source of the phosphorus is often not clear. Associated minerals include metatorbernite (as an alteration product of the torbernite), metazeunerite, autunite, and various secondary uranium minerals, notably silicates and phosphates such as uranophane, parsonsite, and dewindtite.

\section{Occurrence}

Torbernite is one of the commonest of the secondary uranium minerals. It is not now an important ore mineral, however, although it was found in large amounts in the upper part of the oxidized ores in the Katanga district, Belgian Congo. The mineral was more important in this regard in the late 18th and early 19th centuries, being found together with pitchblende in the vein deposits of the Erzegebirge in Saxony and Bohemia. Only a few of the many known localities are mentioned here. A comprehensive list of localities reported up to about 1930 is given by Hintze (1931), and many additional localities have been reported in more recent literature. A distinction between torbernite and metatorbernite was not made prior to 1916, when the existence of the latter species was recognized by Hallimond, so that localities cited before this date are ambiguous as to the identity of the species; the name torbernite also is used conventionally in technical literature, field reports, and the like without regard to the state of hydration.

Torbernite was early known at various localities in Saxony and Bohemia, notably Schneeberg, Johanngeorgenstadt, Altenberg, Joachimsthal, Zinnwald and Schlaggenwald; in France at Cap Garonne and various places in the Puy-de-Dôme district (Lacroix, 1910) ; widespread in small amounts and often finely crystallized in oxidized uraninite veins in Cornwall, England, notably the Tincroft, Gunnis Lake, Stenna Gwyn, and Caharrack mines, Wheal Basset, and the South Terras mine (James, 1947, and Gregory, 1950). In Portugal with autunite at many places. In the phosphate beds of the Albalá area, Cáceres, Spain (HernándezPacheco, 1945); in altered granite in the Sunnyside area, Victoria (Crohn, 1950) ; in a tungsten deposit at Bakerville, Queensland, Australia (Connah, 1953) ; in pegmatite in the Delianova region, Calabria, Italy (Anfosso, 1943). Reported from Goten, Bulgaria (Konjarov, 1938). The largest known deposits of the mineral are in the Katanga district of the Belgian Congo, notably 
at Shinkolobwe, where it occurs with a variety of other secondary uranium minerals as oxidation products of uraninite. At Shinkolobwe, torbernite occurs as drusy crusts, some of them thick and covering areas of several square feet, making spectacular specimens, as large granular to porous aggregates, and as a dissemination in a cellular dolomitic limestone adjacent to the uraninite veins. In the United States, torbernite is widespread in very minor amounts. It occurs in the copper-uranium deposits of the Colorado Plateau, in the oxidized zone of some sulfide vein deposits in western States, and as an alteration of uraninite in pegmatites. It has been found with metatorbernite in fire clay in Missouri (Keller, 1952; Grawe, 1943). Torbernite and metatorbernite are abundant in the Mount Painter-East Painter deposits, South Australia, and there is some evidence that the torbernite may here be a primary, low-temperature hydrothermal mineral (Stillwell and Edwards, 1954).

\section{URANOCIRCITE}

The mineral to which this name was originally given by Weisbach (1877a) has been shown to be isostructural with the meta-I hydrates of the metatorbernite group, and the name has been altered to meta-uranocircite to give parallelism of nomenclature. The name uranocircite may be held in a reserve status for natural occurrences of the fully hydrated phase, isostructural with the torbernite group, that may later be demonstrated.

\section{Synonymy}

\section{SALÉEITE-NOVACEKITE SERIES}

Saléeite Thoreau and Vaes (1932). Saléite, Saleite, Saleeite erroneous spellings. Novacekite $C$. Frondel (1951b). The pure phosphate end-member of this series was first described from the Belgian Congo under the name saléeite. Later, the essentially pure arsenate analogue and several members of intermediate composition were described from Schneeberg, Saxony, as novacekite. These minerals are here described as a single series, with the species names saleeite and novacekite applied to the halves of the series with $\mathrm{P}>\mathrm{As}$ and $\mathrm{As}>\mathrm{P}$, respectively, in atomic percent. Novacekite was named after Radim Nováček (1905-42), Czech mineralogist, and saléeite after Professor Achille Salée of Louvain, Belgium.

\section{Composition}

A hydrated phosphate-arsenate of magnesium and hexavalent uranium, $\mathrm{Mg}\left(\mathrm{UO}_{2}\right)_{2}\left(\mathrm{PO}_{4}, \mathrm{AsO}_{4}\right)_{2} \cdot 8-10 \mathrm{H}_{2} \mathrm{O}$. The four analyses so far reported of members of the series are cited in the table below. 
Chemical analyses of saléeite-novacekite, in weight percent

\begin{tabular}{|c|c|c|c|c|c|c|}
\hline & 1 & 2 & 3 & 4 & 5 & 6 \\
\hline & 一 & - & & 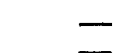 & 1.73 & - \\
\hline $\begin{array}{c}\mathrm{MgO} \\
\mathrm{Al}^{2} \mathrm{O}_{3}\end{array}$ & 4.40 & 5.01 & $\begin{array}{l}0.21 \\
4.04\end{array}$ & $4 . \overline{31}$ & $3 . \overline{41}$ & 4.01 \\
\hline $\begin{array}{l}\mathrm{UO}_{3} \mathrm{U}_{3} \\
\mathrm{P}_{2} \mathrm{O}_{5}\end{array}$ & $62 . \overline{41}$ & $64 . \overline{07}$ & 63.05 & 60.32 & 59.74 & 56.96 \\
\hline $\begin{array}{l}\mathrm{As}_{2} \mathrm{O}_{5} \\
\mathrm{As}_{2} \mathrm{O}_{5} \\
\mathrm{H}_{2} \mathrm{O}\end{array}$ & 15.50 & 14.44 & $\begin{array}{l}14.97 \\
\text { nil }\end{array}$ & $\begin{array}{r}4.50 \\
4.50\end{array}$ & 11.23 & $22 . \overline{88}$ \\
\hline $\mathrm{H}_{2} \mathrm{O}$ & 17.69 & 16.48 & 17.42 & [18.89] & {$[17.02]$} & 16.15 \\
\hline Total & 100.00 & 100.00 & 100.06 & {$[100.00]$} & {$[100.00]$} & 100.00 \\
\hline$g r$ & - & $<3.3$ & - & 3.27 & 3.3 & 3.6 \\
\hline
\end{tabular}

1. Theoretical composition, $\mathrm{Mg}\left(\mathrm{UO}_{2}\right)_{2}\left(\mathrm{PO}_{4}\right)_{2} \cdot 9 \mathrm{H}_{2} \mathrm{O}$.

2. Saléeite. Shinkolobwe. Mollet, analyst, in Thoreau and Vaes (1932). Recalculated to 100 percent after deducting 2.79 percent insoluble.

3. Saléeite. Portugal. Hallowell, analyst, in C. Frondel (1951b).

4. Arsenatian saléeite. Schneeberg, Saxony. Gonyer, analyst, in Mrose (1950).

5. Phosphatian novacekite. Schneeberg, Saxony. Gonyer, analyst, in C. Frondel $(1951 \mathrm{~b})$. Recalculated to 100 percent after deducting insoluble $\mathrm{SiO}_{2}$ and $\mathrm{Fe}_{2} \mathrm{O}_{3}$.

6. Theoretical composition, $\mathrm{Mg}\left(\mathrm{UO}_{2}\right)_{2}\left(\mathrm{AsO}_{4}\right)_{2} \cdot 9 \mathrm{H}_{2} \mathrm{O}$.

In addition, qualitative chemical tests and other lines of evidence have established the existence of the essentially pure arsenate end member (Stern and Annell, 1954, and C. Frondel, 1951b). $P$ and As substitute mutually, and doubtless a complete series extends between the two end members. The material of analysis 5 from Schneeberg contains a small amount of $\mathrm{Cu}$ in substitution for $\mathrm{Mg}$ and indicates at least a partial series extending toward zeunerite. Also, Mrose (1953) indicates that at least a partial series extends by substitution of $\mathrm{Ca}$ for $\mathrm{Mg}$ between novacekite and uranospinite. The water content found analytically ranges from $8 \mathrm{H}_{2} \mathrm{O}$ to $10 \mathrm{H}_{2} \mathrm{O}$. The $\mathrm{X}$-ray unit-cell dimensions indicate that the saléeite-novacekite series is isostructural with the fully hydrated phases of the autunite group. The meta-I hydrate of novacekite and doubtless also that of saléeite can be prepared artificially but have not been identified in nature. Spectrographic analyses (Harrison, in Mrose, 1950) of the Schneeberg material of analysis 4 showed the presence of minor amounts of $\mathrm{Ca}, \mathrm{Pb}$, $\mathrm{V}, \mathrm{Bi}, \mathrm{Cu}$, and $\mathrm{Ag}$.

\section{Crystallography}

Saléeite and novacekite are tetragonal. The crystal class is not known with certainty from direct evidence, but probably is ditetragonal-dipyramidal, $4 / m 2 / m 2 / m$, by analogy to the isostructural minerals autunite and torbernite. The saléeite of analysis 4 from Schneeberg conforms wholly to tetragonal symmetry as shown by the study of Mrose (1950). Other samples of both saléeite and novacekite show an anomalous biaxial optical char- 
acter. Saléeite was originally considered on such grounds by Thoreau and Vaes (1932) to be orthorhombic pseudo-tetragonal, and by Schoep (1939) to be monoclinic. In Schoep's interpretation, the plane of flattening and cleavage, taken as $\{001\}$ in the tetragonal orientation, was made $\{010\}$ and the biaxial sectors seen in polarized light in the plane of flattening were considered to be separate individuals twinned on $\{\overline{2} 01\}$. The other members of the autunite group and also the members of the meta-autunite group similarly show in part an anomalous biaxial character. The symmetry of these minerals is discussed further under Autunite.

An angle table of the known forms of saléeite, taken from the study of Mrose (1950), is given below. The table is calculated

Angle table for saléeite

Tetragonal; ditetragonal-dipyramidal, (4/m 2/m 2/m?)

$a: c=1: 2.839 ; \quad p_{0}: r_{0}=2.839: 1$

\begin{tabular}{|c|c|c|c|c|}
\hline Forms & $\phi$ & $\rho$ & $A$ & $\bar{M}$ \\
\hline $\begin{array}{ll}c & 001 \\
a & 010 \\
d & 120 \\
e & 012\end{array}$ & $\begin{array}{rl} & - \\
0^{\circ} 00^{\prime} \\
36 & 34 \\
0 & 00\end{array}$ & $\begin{array}{l}0^{\circ} 00^{\prime} \\
9000 \\
9000 \\
5450\end{array}$ & $\begin{array}{ll}90^{\circ} 00^{\prime} \\
90 & 00 \\
63 & 26 \\
90 & 00\end{array}$ & 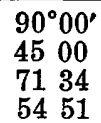 \\
\hline
\end{tabular}

from the X-ray unit cell $\left(a_{0} 6.98 \mathrm{~A}, c_{0}\right.$ 19.813) obtained on the measured crystal, as this is more accurate than the optical goniometer measurements. 'The X-ray unit-cell dimensions of saléeite-novacekite, from C. Frondel (1951b), are given in the table below. The space group is $P 4 / \mathrm{mmm}$ if holohedry is assumed. The

Unit-cell dimensions of saléeite and novacekite

\begin{tabular}{ccccccc} 
& \multicolumn{3}{c}{ SALÉEite } & & \multicolumn{2}{c}{ NovaCEKITE } \\
\cline { 2 - 4 } \cline { 6 - 7 }$a_{0}$ & $\frac{2}{7.02 \mathrm{~A}}$ & $\frac{2}{7.01 \mathrm{~A}}$ & $\frac{3}{7.05 \mathrm{~A}}$ & & $\frac{4}{7.12 \mathrm{~A}}$ & $\frac{5}{7.16 \mathrm{~A}}$ \\
$c_{0}$ & 19.81 & 19.84 & 19.87 & & 20.14 & 20.19 \\
\hline$a_{0}: c_{0}$ & $1: 2.823$ & $1: 2.830$ & $1: 2.819$ & $1: 2.829$ & $1: 2.820$ \\
Analysis no. & - & 3 & 4 & & 5 & -
\end{tabular}

1 See table, p. 178.

1. No arsenic. Shinkolobwe.

2. Portugal.

3. Arsenatian. Schneeberg.

4. Phosphatian. Schneeberg.

5. Trace of phosphorus. Schneeberg.

unit-cell dimensions increase with increasing substitution of As for $P$ in the series.

A Schneeberg specimen, referred to novacekite by G. Donnay and J. D. H. Donnay (1955), gave $a_{0} 7.11 \mathrm{~A}, c_{0} 20.06 ; c / a 2.823$; space group $P 4_{2} / n$, pseudo-space group $P 4 / n m m$. Specific gravity 3.23 (measured), 3.23 (calculated for $9 \mathrm{H}_{2} \mathrm{O}$ ). 
Crystal habit

Single crystals of saléeite-novacekite are rectangular plates flattened on $\{001\}$ and ranging in size to as much as $0.5 \mathrm{~mm}$ on an edge (fig. 12). Modifying faces usually are indistinct and not measurable. Both minerals ordinarily occur as crusts or as porous interlocking aggregates of thin plates and scales. Novacekite also occurs as lamellar aggregates filling tiny veinlets and cavities. Novacekite crystals have been observed with parallel intergrown cores of zeunerite.

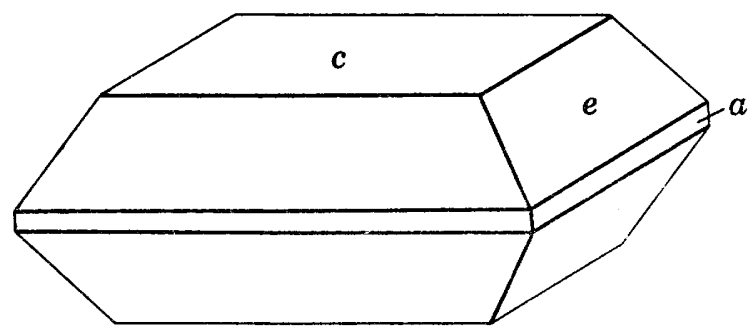

Figure 12.-Saléeite. Schneeberg, Saxony. Forms: $c\{001\}, e\{012\}, a\{010\}$. From Mrose (1950).

Physical properties

Cleavage $\{001\}$ perfect; also on $\{010\}$ and $\{110\}$ indistinct. Hardness $21 / 2$. Specific gravity about 3.2 for saléeite end member and about 3.7 for novacekite end member. Color usually pale yellow to straw yellow, also lemon yellow. Luster weak to waxy in translucent material. Transparent to weakly translucent. Saléeite fluoresces a bright lemon yellow in long-wave and less brightly in short-wave ultraviolet radiation. Phosphatian novacekite and novacekite end member fluoresce dull green.

Optical properties

Some specimens of saléeite and novacekite are uniaxial, but more commonly they show an anomalous biaxial character with $2 \mathrm{~V}$ up to $65^{\circ}$ but usually between $0^{\circ}$ and $15^{\circ}$. Biaxial material may extinguish uniformly or, as in the original material described by Thoreau and Vaes (1932), it may show a mosaic interference structure with a division into two or more sectors on $\{001\}$ with $X=$ [001] and $Y$ in the separate parts parallel to the edges of the rectangular plates. The indices of refraction reported for the series are given in the table below. The indices in general increase with increasing substitution of As for $P$. The observed variation, however, is rather irregular owing to the fact that the different samples measured were not all hydrated to the same degree. 
Optical properties of the saléeite-novacekite series

$n$

\begin{tabular}{|c|c|c|c|c|c|c|c|}
\hline \multirow{3}{*}{$\begin{array}{l}\text { ORIENTA- } \\
\text { TION }\end{array}$} & \multirow{2}{*}{\multicolumn{4}{|c|}{ SALÉEITE }} & \multirow{2}{*}{\multicolumn{3}{|c|}{ NOVACEKITE }} \\
\hline & & & & & & & \\
\hline & 1 & 2 & 3 & 4 & 5 & 6 & 7 \\
\hline $\begin{array}{l}X \text { or } E \\
Y \text { or } O \\
\end{array}$ & $\begin{array}{l}1.559 \\
1.570 \\
1.574\end{array}$ & $\begin{array}{l}1.554 \\
1.571 \\
1.571\end{array}$ & $\begin{array}{l}1.565 \\
1.582 \\
1.585\end{array}$ & $\begin{array}{l}1.559 \\
1.574 \\
1.574\end{array}$ & $\begin{array}{c}-\overline{1}-620-1.623 \\
1.620-1.623\end{array}$ & $\begin{array}{l}1.620 \\
1.637 \\
1.637\end{array}$ & $\begin{array}{l}1.625 \\
1.641 \\
1.641\end{array}$ \\
\hline $\begin{array}{c}2 V \\
\text { Dispersion } \\
\text { Analysis no. }\end{array}$ & $\underset{2}{r>v}$ & $\begin{array}{c}0^{\circ}-10^{\circ} \\
=\end{array}$ & $\begin{array}{c}65^{\circ} \\
r>0 \\
3\end{array}$ & $\frac{0^{\circ}}{4}$ & $\begin{array}{c}0^{\circ}-15^{\circ} \\
r>v^{\circ}\end{array}$ & $\begin{array}{c}0^{\circ}-15^{\circ} \\
r>v\end{array}$ & $\begin{array}{c}5^{\circ}-20^{\circ} \\
=\end{array}$ \\
\hline
\end{tabular}

1 See table, p. 178.

1. Shinkolobwe. Thoreau and Vaes (1932).

2. No As. Shinkolobwe. C. Frondel (1951b).

3. Portugal. Idem.

4. Arsenatian. Mrose (1950).

5. Phosphatian. Schneeberg. C. Frondel (1951b).

6. Trace of $P$. Schneeberg. Idem.

7. No P. New Mexico. Stern and Annell (1954).

Thermal behavior

Complete thermal analyses have not been reported. C. Frondel (1951b) observed that the indices of refraction of air-dried saléeite from Portugal (analysis 3) varied when the sample was kept in moist air at room ternperature for 30 days or when heated at $92^{\circ} \mathrm{C}$ for 48 hours, as follows (white light) :

Original air-dried sample, analysis 3

\begin{tabular}{|c|c|c|c|}
\hline$n_{x}$ & $n_{Y}$ & $n_{z}$ & $2 V$ \\
\hline 1.565 & 1.582 & 585 & $65^{\circ}$ \\
\hline 1.592 & $\begin{array}{l}1.578 \\
1.603\end{array}$ & $\begin{array}{l}1.081 \\
1.614\end{array}$ & Large. \\
\hline
\end{tabular}

Moist air, room temperature, 30 days

Heated to $92^{\circ} \mathrm{C}, 48$ hours (meta-I phase)

Synthesis

Saléeite has been synthesized by Fairchild (1929). The meta-I hydrate of the novacekite end member has been prepared (C. Frondel, 1951b) by reacting magnesium chloride, uranyl acetate, and ammonium acid arsenate solutions in the molar ratio of $1: 2: 2$ and then heating the precipitate in contact with the mother liquid at $50^{\circ} \mathrm{C}$ for several weeks. The precipitate, as first formed at room temperature, is flocculent and too fine grained for satisfactory study.

\section{Identification}

In the hand specimen, the saléeite end member very closely resembles several other minerals belonging to the autunite and meta-autunite groups, especially sabugalite, meta-autunite, autunite, uranospinite, and to a less extent uranocircite. It is best distinguished by chemical tests to establish the presence of $\mathbf{M g}$ and $\mathrm{PO}_{4}$. The optical properties are not diagnostic because of their variation and the overlap in these minerals attending change in the content of water. The indices of uranospinite are higher than those of the saléeite end member but overlap in part the indices in the arsenate-rich part of the series (novacekite). Novacekite 
high in arsenate can be distinguished from saléeite by its relatively high indices, and, better, from saléeite and other species by chemical tests for $\mathrm{Mg}$ and $\mathrm{AsO}_{4}$. The properties of the saléeite end member and sabugalite are virtually identical.

The fluorescence in ultraviolet light of the saléeite end member is almost identical with that of sabugalite and some other members of the autunite and meta-autunite groups and does not offer a means of identification. Arsenatian saléeite and novacekite fluoresce less brightly and in green rather than lemon-yellow tints in comparison to the saleeite end member, but it is not certain if this is a reliable means of discrimination. The color of saleeitenovacekite tends in general to pale-yellow and straw-yellow tints rather than to yellow and lemon yellow as in sabugalite, autunite, and uranocircite, but this difference cannot be relied on in separating these species in the hand specimen.

The X-ray powder-diffraction patterns of the saléeite end member and the novacekite end member differ only slightly in spacings attending the mutual substitution of $\mathrm{P}$ and As. The pattern as a whole very closely resembles those of uranospinite and sabugalite, and somewhat less closely those of bassetite, uranospathite, and fully hydrated autunite. Because of the close resemblance and especially because the patterns often are not very sharp, complete reliance should not be placed on the powder pattern as a means of identification. The X-ray powder-spacing data for the end-member compositions of the saléeite-novacekite series are given in the following table.

$X$-ray powder-spacing data for saléeite and novacekite ${ }^{1}$

[Symbols: d, diffuse; vd, very diffuse. Copper radiation, nickel filter]

\begin{tabular}{|c|c|c|c|c|c|c|c|}
\hline \multicolumn{4}{|c|}{ SALÉEIte } & \multicolumn{4}{|c|}{ NOVACEKITE } \\
\hline$d(\mathrm{~A})$ & $I$ & $d(\mathrm{~A})$ & $I$ & $d(\mathrm{~A})$ & $I$ & $d(\mathrm{~A})$ & $I$ \\
\hline $\begin{array}{l}9.85 \\
8.60 \\
6.50 \\
5.46 \\
4.95 \\
4.51 \\
4.19 \\
3.64 \\
3.49 \\
3.37 \\
3.23 \\
3.09 \\
2.95 \\
2.84 \\
2.65 \\
2.45\end{array}$ & $\begin{array}{c}10 \\
3 \\
2 \\
3 \\
8 \\
4 \\
2 \\
1 \\
9 \\
3 \\
5 \\
2 \\
5 \\
1 \\
1(\mathrm{~d}) \\
6\end{array}$ & $\begin{array}{l}2.39 \\
2.30 \\
2.25 \\
2.19 \\
2.14 \\
2.10 \\
2.04 \\
1.919 \\
1.860 \\
1.798 \\
1.731 \\
1.599 \\
1.554 \\
1.526 \\
1.422 \\
1.371\end{array}$ & $\begin{array}{l}5 \\
2 \\
1 \\
7 \\
1 \\
1 \\
1 \\
2(\mathrm{vd}) \\
1 \\
3 \\
3 \\
2 \\
2 \\
1 \\
1(\mathrm{~d}) \\
2(\mathrm{~d})\end{array}$ & $\begin{array}{r}10.15 \\
6.80 \\
5.68 \\
5.06 \\
4.50 \\
3.83 \\
3.58 \\
3.35 \\
3.17 \\
3.03 \\
2.89\end{array}$ & $\begin{array}{c}10 \\
4 \\
2 \\
8 \\
1(d) \\
1 \\
9 \\
5 \\
1 \\
2 \\
1\end{array}$ & $\begin{array}{l}2.79 \\
2.52 \\
2.26 \\
2.15 \\
2.01 \\
1.939 \\
1.787 \\
1.698 \\
1.596 \\
1.552 \\
1.508\end{array}$ & $\begin{array}{l}1 \\
3 \\
3 \\
2 \\
2 \\
1(d) \\
3 \\
1(d) \\
3 \\
1 \\
1\end{array}$ \\
\hline
\end{tabular}

1 Data from C. Frondel, Riska, and Frondel (1956) on saléeite from Sabugal, Portugal, and novacekite from Schneeberg, Saxony. 
Natural formation

Both saléeite and novacekite are secondary minerals but of different association. The arsenate-rich members of the series are known chiefly from the oxidized zone of the uraninite veins at Schneeberg. These veins contain abundant arsenides of cobalt and nickel, and on oxidation give rise to novacekite and a number of other secondary arsenates, including erythrite, pharmacosiderite, walpurgite, and atelestite. Saléeite can derive its phosphate content more widely and resembles autunite in its occurrence and association. The $\mathrm{Mg}$ content of both saleite and novacekite probably is obtained principally by the alteration of wall rock or of primary magnesium-containing carbonates in the vein material. Saléeite is commonly associated with phosphates, particularly autunite, torbernite, dewindtite, sabugalite, and phosphuranylite.

\section{Occurrence}

Saleieite was originally described from Shinkolobwe in the Belgian Congo (Thoreau and Vaes, 1932). It was later described from the Mina da Quarta Feira, Sabugal County, Beira Alta Province, Portugal, where it occurs in the weathered outcrops of uraninite veins (C. Frondel, 1951b). Saléeite may be very easily confused with autunite in the hand specimen, and probably is more common than has been thought. Novacekite and intermediate members of the series toward saléeite, including arsenatian saléeite, are found at Schneeberg, Saxony (Mrose, 1950; C. Frondel, 1951b). Novacekite also occurs as a coating on sandstone in the Woodrow area, Laguna Reservation, Valencia County, N. Mex. (Stern and Annell, 1954).

\section{ORANOSPINITE}

Synonymy

Uranospinite Weisbach (1873a, 1877b). Named from uranium and ortvos, siskin, in allusion to its composition and color.

\section{Composition}

A hydrated arsenate of calcium and hexavalent uranium, $\mathrm{Ca}\left(\mathrm{UO}_{2}\right)_{2}\left(\mathrm{AsO}_{4}\right)_{4} \cdot 10 \mathrm{H}_{2} \mathrm{O}$. It is uncertain whether natural uranospinite belongs to the fully hydrated torbernite group or to the meta-I hydrates of the metatorbernite group. The mineral apparently passes reversibly between the two states of hydration at or near ordinary conditions of temperature and humidity (see Thermal behavior), and the problem is analogous to that of autunite and meta-autunite. The calculated amount of water in the single reported analysis of natural material, cited below, is ap- 
proximately $10 \mathrm{H}_{2} \mathrm{O}$, whereas in two analyses of synthetic material there is approximately $8 \mathrm{H}_{2} \mathrm{O}$, and one of these is known definitely to represent the meta-I hydrate (meta-uranospinite). The synthetic material of analysis 4 is deficient in $\mathrm{Ca}$, and apparently represents an intermediate member of a series toward hydrogen-uranospinite; a similar situation is known in synthetic meta-autunite (Beintema, 1938). Spectrographic analyses of uranospinite are lacking. The mineral is easily soluble in acids.

Chemical analyses of uranospinite, in weight percent

\begin{tabular}{|c|c|c|c|c|c|}
\hline & 1 & 2 & 3 & 4 & 5 \\
\hline $\begin{array}{l}\mathrm{CaO} \\
\mathrm{UO}_{3} \\
\mathrm{As}_{2} \mathrm{O}_{5} \\
\mathrm{H}_{2} \mathrm{O}\end{array}$ & $\begin{array}{r}\mathbf{5 . 4 0} \\
\mathbf{5 5 . 1 1} \\
22.14 \\
17.35\end{array}$ & $\begin{array}{r}5.47 \\
59.18 \\
19.37 \\
16.19\end{array}$ & $\begin{array}{r}5.62 \\
59.01 \\
23.01 \\
14.27\end{array}$ & $\begin{array}{r}3.10 \\
58.56 \\
23.54 \\
14.60\end{array}$ & $\begin{array}{r}5.60 \\
57.09 \\
22.93 \\
14.38\end{array}$ \\
\hline Total & 100.00 & 100.21 & $\overline{101.91}$ & 99.80 & 100.00 \\
\hline
\end{tabular}

1. Theoretical weight percentages, $\mathrm{Ca}\left(\mathrm{UO}_{2}\right)_{2}\left(\mathrm{AsO}_{4}\right)_{2} \cdot 10 \mathrm{H}_{2} \mathrm{O}$.

2. Uranospinite. Schneeberg, Saxony. Winkler (1873).

3. Synthetic uranospinite. Winkler (1873). Probably the meta-I hydrate.

4. Synthetic uranospinite. Gonyer, analyst, in Mrose (1953). Meta-I hydrate.

5. Theoretical weight percentages, $\mathrm{Ca}\left(\mathrm{UO}_{2}\right)_{2}\left(\mathrm{AsO}_{4}\right)_{2} \cdot 8 \mathrm{H}_{2} \mathrm{O}$.

Crystallography and crystal habit

Tetragonal, probably in the ditetragonal-dipyramidal crystal class $(4 / m 2 / m 2 / m)$. Crystals are thin rectangular plates flattened on $\{001\}$. An angle table for the known forms in the unit, orientation, and ratio of Goldschmidt (1923) on natural crystals is given below. This unit corresponds to the structure cell, but the morphological and X-ray ratios are not in good agreement. An X-ray single-crystal study of the synthetic material of analysis 4 by Mrose (1953) gave the following data: $a_{0} 7.19 \mathrm{~A}, c_{0} 8.81, a_{0}: c_{0}=1: 1.1225$. Space group $P 4 / \mathrm{nmm}$, if holohedral.

\section{Angle table for uranospinite}

Tetragonal; ditetragonal-dipyramidal, (4/m $2 / \mathrm{m} 2 / \mathrm{m})$

$$
a: c=1: 1.4561 ; \quad p_{0}: r_{0}=1.4561: 1
$$

\begin{tabular}{|c|c|c|c|c|}
\hline FORMS & $\phi$ & $\rho$ & $\boldsymbol{A}$ & $\bar{M}$ \\
\hline $\begin{array}{ll}c & 001 \\
q & 015 \\
d & 011\end{array}$ & $\begin{array}{l}0^{\circ} \overrightarrow{00^{\prime}} \\
000\end{array}$ & $\begin{array}{r}0^{\circ} 00^{\prime} \\
1614 \\
5531\end{array}$ & 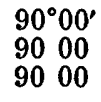 & $\begin{array}{l}90^{\circ} 00^{\prime} \\
7836 \\
54 \quad 21\end{array}$ \\
\hline $\begin{array}{ll}r & 021\end{array}$ & 000 & 7103 & 9000 & 4801 \\
\hline
\end{tabular}

Uranospinite was originally considered by Weisbach (1873a, $1877 \mathrm{~b})$ to be orthorhombic, on the basis of the optically biaxial character. Tetragonal symmetry was first assigned by Goldschmidt (1889), who found the synthetic material of Winkler 
(1873) to be uniaxial. The optical anomalies are now known to be due to variation in the zeolitic water content of the substance.

Crystals have been observed with parallely intergrown cores of zeunerite (Larsen, 1921).

\section{Physical properties}

Cleavage $\{001\}$ perfect, $\{100\}$ distinct. Hardness 2-3. Specific gravity 3.45 (Weisbach, 1873a) ; the calculated value for synthetic material is 3.65. Luster pearly on $\{001\}$. Color lemon yellow to siskin green. Both natural and synthetic uranospinite fluoresce bright lemon yellow in ultraviolet light. The meta-I hydrate when reduced in water content by heating at $110^{\circ} \mathrm{C}$ fluoresces a weak olive green (Mrose, 1953).

Optical properties

\begin{tabular}{|c|c|c|c|c|c|c|c|c|}
\hline \multirow{2}{*}{$\begin{array}{l}\text { ORIENTA- } \\
\text { TION }\end{array}$} & \multicolumn{8}{|c|}{$n$} \\
\hline & 1 & 2 & 3 & 4 & 5 & 6 & 7 & 8 \\
\hline$E$ or $\underset{Y}{X}=c$ & 1.560 & 1.560 & 1.55 & 1.560 & 1.591 & 1.562 & 1.566 & 1.596 \\
\hline$O$ or $Z$ & $\begin{array}{l}1.002 \\
1.587\end{array}$ & $1.5 \overline{86}$ & 1.572 & $\begin{array}{l}1.084 \\
1.586\end{array}$ & $\begin{array}{l}1.019 \\
1.621\end{array}$ & $1.5 \overline{89}$ & $\begin{array}{l}1.092 \\
1.596\end{array}$ & $1.6 \overline{18}$ \\
\hline $2 V$ & $46^{\circ}$ & $0^{\circ}$ & $62^{\circ}$ & $45^{\circ}$ & $0^{\circ}-5^{\circ}$ & $0^{\circ}$ & $25^{\circ}-35^{\circ}$ & $0^{\circ}$ \\
\hline
\end{tabular}

1, 2, 3. Schneeberg. Larsen (1921).

4. Utah. Mrose (1953).

5. Synthetic (analysis 4, p. 184). Idem.

6. Synthetic (analysis 4, p. 184, hydrated). Idem.

7, 8. Schneeberg(?). George (1949).

Uniaxial negative or biaxial negative. Biaxial material has $r>v$ moderate, with variable $2 V$. Pleochroic, with $X$ nearly colorless, $Y$ and $Z$ pale lemon yellow or yellow.

The indices of refraction and $2 \mathrm{~V}$ vary with the water content. The synthetic material of analysis 3 was found by Goldschmidt (1899) to be uniaxial. The material of analysis 4 , with relatively high indices, was found by Mrose (1953) to be the meta-I hydrate; when this material was placed in water for 1 week it converted to the fully hydrated phase, with $2 \mathrm{~V} 0^{\circ}$, and the indices decreased to the values cited. Larsen (1921) found that a natural crystal from Schneeberg was zoned, with a central core of metazeunerite, a main zone that was biaxial with the indices cited in the first column above, and a narrow border zone with the indices cited in the second column. Of the two samples for which George (1949) described the optics the one with the higher indices probably is the meta-I hydrate (meta-uranospinite) and the other probably is the fully hydrated phase.

\section{Thermal behavior}

The synthetic material of analysis 4 , made by heating a precipitate in the mother solution for 5 months at $50^{\circ} \mathrm{C}$, was found 
by Mrose (1953) to be the meta-I hydrate. This material lost 11.3 percent of zeolitic(?) water when heated at $110^{\circ} \mathrm{C}$, and the indices of refraction increased to $n_{O} 1.637, n_{E} 1.615$, with $2 \mathrm{~V} 0^{\circ}$; when exposed to air at room temperature the material regained most of the water and the indices decreased. The same synthetic material when immersed in water at room temperature converted to the fully hydrated phase, with $n_{O} 1.589, n_{E} 1.562,2 \mathrm{~V} 0^{\circ}$, and when exposed again to air reverted to the meta-I hydrate with $\approx 8 \mathrm{H}_{2} \mathrm{O}$. A sample heated to $1,000^{\circ} \mathrm{C}$ formed $\mathrm{CaU}_{2} \mathrm{O}_{7}($ ?) ; it was uniaxial negative, with $n_{E} 1.765, n_{o} 1.778$, and fluoresced clove brown in ultraviolet light. Mrose (1953) found by X-ray powder study that unanalyzed uranospinite from Spanish Forks, Utah, corresponded to the fully hydrated phase, but an unanalyzed specimen from Schneeberg, Saxony, was the meta-I hydrate.

\section{Synthesis}

Obtained as crystals by precipitating the stoichiometric amounts of calcium chloride, uranyl nitrate, and monosodium arsenate and then warming the precipitate in the mother liquid for an extended time (C. Frondel cited in Mrose, 1953). Also obtained by a saltingout procedure analogous to that used by Fairchild (1929) for autunite, and by reaction of uranyl nitrate with a solution of $\mathrm{CaO}$ in excess arsenic acid (Winkler, 1873).

Identification

\section{$X$-ray powder-spacing data for uranospinite}

[Symbol: b, broad. Copper radiation, nickel filter]

\begin{tabular}{|c|c|c|c|c|c|c|c|}
\hline \multicolumn{4}{|c|}{1} & \multicolumn{4}{|c|}{2} \\
\hline$d(\mathrm{~A})$ & $I$ & $d(\mathrm{~A})$ & $I$ & $d(\mathrm{~A})$ & $I$ & $d(\mathrm{~A})$ & $I$ \\
\hline $\begin{array}{l}8.85 \\
5.57 \\
5.10 \\
4.40 \\
3.74 \\
3.59 \\
3.34 \\
3.02 \\
2.81 \\
2.68 \\
2.55 \\
2.44 \\
2.29 \\
2.20 \\
2.16\end{array}$ & $\begin{array}{r}10 \\
6 \\
7 \\
2 \\
5 \\
9 \\
8 \\
4 \\
1 \\
1 \\
5 \\
4 \\
3 \\
2 \\
2\end{array}$ & $\begin{array}{l}2.10 \\
2.00 \\
1.945 \\
1.845 \\
1.804 \\
1.755 \\
1.704 \\
1.642 \\
1.608 \\
1.575 \\
1.499 \\
1.414 \\
1.384 \\
1.361\end{array}$ & $\begin{array}{r}2 \\
1 \\
1 \\
1 / 2 \\
5 \\
1 \\
1 \\
3 \\
3 \\
3 \\
1 / 2 \\
1 / 2 \\
1 / 2 \\
1 / 2\end{array}$ & $\begin{array}{c}10.16 \\
6.71 \\
5.13 \\
4.90 \\
4.53 \\
3.56 \\
3.39 \\
3.16 \\
2.91 \\
2.82 \\
2.70 \\
2.52 \\
2.46 \\
2.37 \\
2.27 \\
2.21 \\
2.16 \\
2.05 \\
1.90 \\
1.848\end{array}$ & $\begin{array}{l}10 \\
4 \\
7 \\
6 \\
3 \\
9 \\
8 \\
1(\mathrm{~b}) \\
4(\mathrm{~b}) \\
1(\mathrm{~b}) \\
4(\mathrm{~b}) \\
5(\mathrm{~b}) \\
5 \\
1 \\
5(\mathrm{~b}) \\
2 \\
4(\mathrm{~b}) \\
3(\mathrm{~b}) \\
6 \\
2\end{array}$ & $\begin{array}{l}1.791 \\
1.765 \\
1.689 \\
1.645 \\
1.618 \\
1.600 \\
1.580 \\
1.535 \\
1.514 \\
1.492 \\
1.404 \\
1.361 \\
1.339 \\
1.302 \\
1.285 \\
1.258 \\
1.229 \\
1.185 \\
1.159 \\
1.127\end{array}$ & $\begin{array}{c}4 \\
3(\mathrm{~b}) \\
3(\mathrm{~b}) \\
1 \\
3 \\
3 \\
3 \\
1 \\
2 \\
1 / 2(\mathrm{~b}) \\
3 \\
2(\mathrm{~b}) \\
2(\mathrm{~b}) \\
1 / 2(\mathrm{~b}) \\
1 / 2(\mathrm{~b}) \\
1(\mathrm{~b}) \\
1(\mathrm{~b}) \\
1(\mathrm{~b}) \\
1 \text { (b) } \\
2(\mathrm{~b})\end{array}$ \\
\hline
\end{tabular}

1. Synthetic material containing $8 \mathrm{H}_{2} \mathrm{O}$. Mrose (1953).

2. Synthetic material containing $\approx 10 \mathrm{H}_{2} \mathrm{O}$. C. Frondel, Riska, and Frondel (1956). 
Easily confused with other yellow members of the torbernite and metatorbernite groups, including troegerite, novacekite, and meta-autunite. It is best identified by chemical tests for $\mathrm{Ca}$ and As in conjunction with optical and X-ray powder data. The $\mathrm{X}$-ray powder-spacing data are given in the above table.

\section{Natural formation and occurrence}

Uranospinite is a secondary mineral, originally found associated with walpurgite, troegerite, and metazeunerite in the Weisser Hirsch mine at Neustädtl, near Schneeberg, Saxony. It is derived from the alteration of uraninite and primary arsenides such as smaltite in a hydrothermal vein. Reported from near Pahreah, Kane County, Utah, by Butler and others (1920); also from Spanish Forks, Utah (possibly the same locality as the preceding). Uranospinite probably occurs at the Solitaria mine in Argentina as an alteration product of uraninite associated with niccolite (George, 1949). Reported from the Radium Hill mine, Mount Painter, South Australia (Whittle, 1954b).

\section{Synonymy}

\section{TROEGERITE}

Trögerit Weisbach (1871, 1873b). Troegerite Palache, Berman, and Frondel (1951). Named after R. Tröger, a mining official at Schneeberg.

\section{Composition}

A hydrated arsenate of hexavalent uranium. The mineral was originally considered by Winkler (1873) and Weisbach (1873a) to have the composition $\left(\mathrm{UO}_{2}\right)_{3}\left(\mathrm{AsO}_{4}\right)_{2} \cdot 12 \mathrm{H}_{2} \mathrm{O}$, on the basis of the analysis cited below. The properties of the mineral, however, are

Chemical analyses of troegerite, in weight percent

\begin{tabular}{|c|c|c|c|}
\hline & 1 & 2 & 3 \\
\hline $\begin{array}{l}\mathrm{UO}_{3} \\
\mathrm{As}_{2} \mathrm{O}_{5} \\
\mathrm{H}_{2} \mathrm{O}\end{array}$ & $\begin{array}{l}65.81 \\
17.62 \\
16.57\end{array}$ & $\begin{array}{l}59.34 \\
23.84 \\
16.82\end{array}$ & $\begin{array}{l}63.76 \\
19.64 \\
14.81\end{array}$ \\
\hline Total & 100.00 & 100.00 & 98.21 \\
\hline
\end{tabular}

1. Theoretical weight percentages, $\left(\mathrm{UO}_{2}\right)_{3}\left(\mathrm{AsO}_{4}\right)_{2} \cdot 12 \mathrm{H}_{2} \mathrm{O}$.

2. Theoretical weight percentages, $\mathrm{H}_{2}\left(\mathrm{UO}_{2}\right)_{2}\left(\mathrm{AsO}_{4}\right)_{2} \cdot 8 \mathrm{H}_{2} \mathrm{O}$.

3. Troegerite. Schneeberg, Saxony. Winkler (1873).

similar to those of the torbernite and metatorbernite groups, and the work of Mrose (1953) on synthetic and natural material indicates that the substance almost certainly has the composition $\mathrm{H}_{2}\left(\mathrm{UO}_{2}\right)_{2}\left(\mathrm{AsO}_{4}\right)_{2} \cdot 8 \mathrm{H}_{2} \mathrm{O}$. The mineral then would be the hydrogencontaining equivalent of uranospinite (called hydrogen uranospinite by Mrose, 1953), analogous to the well-known synthetic 
hydrogen-containing equivalent of autunite called hydrogen autunite, $\mathrm{H}_{2}\left(\mathrm{UO}_{2}\right)_{2}\left(\mathrm{PO}_{4}\right)_{2} \cdot 8 \mathrm{H}_{2} \mathrm{O}$. The difference of Winkler's analysis from the ratios expected on the basis of the new formula may well be due to analytical error, as the analysis itself has a poor summation, and his analyses of uranospinite, the composition of which is not in doubt, show an almost equally large departure from theory. New analyses of natural material are desirable.

Meixner (1953) found that so-called troegerite specimens in the collection of the Natural History Museum, Vienna, contained $\mathrm{Ca}$ and were uranospinite. Specimens labeled troegerite in the Harvard and U. S. National Museum collections were variously identified as saléeite, novacekite, and uranospinite; some lacked divalent cations and appear to be $\mathrm{H}_{2}\left(\mathrm{UO}_{2}\right)_{2}\left(\mathrm{AsO}_{4}\right)_{2} \cdot 8 \mathrm{H}_{2} \mathrm{O}$. (See Mrose, 1953.)

The original troegerite was said to lose water in the closed tube and to turn brown; soluble in acids. Spectrographic analyses are lacking.

\section{Crystallography}

Probably tetragonal, in the ditetragonal-dipyramidal crystal class $(4 / m 2 / m 2 / m)$. An angle table for the known forms in the unit, orientation, and ratio used by Goldschmidt (1899) on natural crystals from Schneeberg is given below. X-ray single-crystal measurements of natural crystals are lacking. The mineral was considered by Weisbach $(1871,1873 a)$ and Schrauf (1872) to be monoclinic, on the basis of the crystal habit and the optical properties. V. Goldschmidt (1899) interpreted the mineral as probably tetragonal on geometrical grounds, and the recognized monoclinic optics were regarded as anomalous. This problem of the true symmetry arises in almost all members of the torbernite and metatorbernite groups.

Angle table for troegerite

Tetragonal (?)

$$
a: c=1: 2.16 ; \quad p_{0}: r_{0}=2.16: 1
$$

\begin{tabular}{|c|c|c|c|c|}
\hline FORMS & $\phi$ & $\rho$ & $A$ & $\bar{M}$ \\
\hline $\begin{array}{ll}c & 001 \\
a & 010 \\
l & 120\end{array}$ & $\begin{array}{r}0^{\circ} \overline{00^{\prime}} \\
2634\end{array}$ & $\begin{array}{rl}0^{\circ} & 00^{\prime} \\
90 & 00 \\
90 & 00\end{array}$ & $\begin{array}{l}90^{\circ} 00^{\prime} \\
9000 \\
6326\end{array}$ & 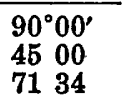 \\
\hline $\begin{array}{ll}e & 012 \\
d & 011 \\
i & 021\end{array}$ & $\begin{array}{ll}0 & 00 \\
0 & 00 \\
0 & 00\end{array}$ & $\begin{array}{ll}47 & 12 \\
65 & 091 / 2 \\
76 & 58\end{array}$ & $\begin{array}{ll}90 & 00 \\
90 & 00 \\
90 & 00\end{array}$ & $\begin{array}{ll}58 & 441 / 2 \\
50 & 05 \\
46 & 271 / 2\end{array}$ \\
\hline p 111 & 4500 & $71521 / 2$ & $47461 / 2$ & 9000 \\
\hline
\end{tabular}


Crystals of artificial $\mathrm{H}_{2}\left(\mathrm{UO}_{2}\right)_{2}\left(\mathrm{AsO}_{4}\right)_{2} \cdot 8 \mathrm{H}_{2} \mathrm{O}$ were found by Mrose (1953) to be tetragonal tablets on $\{001\}$ with $\{110\}$ and $\{010\}$. X-ray single-crystal study by the Weissenberg method indicated tetragonal symmetry with the space group $P 4 / \mathrm{nmm}$, if holohedral symmetry is assumed. Unit-cell dimensions: $a_{0} 7.16 \mathrm{~A}$, $c_{0} 8.80, a_{0}: c_{0}=1: 1.230$. Unit-cell contents $\mathrm{H}_{2}\left(\mathrm{UO}_{2}\right)_{2}\left(\mathrm{AsO}_{4}\right)_{2} \cdot 8 \mathrm{H}_{2} \mathrm{O}$. Specific gravity 3.55 (measured); 3.55 (calculated).

The unit of the X-ray cell differs from the morphological unit of Goldschmidt (1899) on natural crystals in that the $c$-axis is halved, and the agreement in ratios is not close.

Crystal habit

Natural crystals are thin tabular on $\{001\}$. The nonpinacoidal forms are often asymmetrically developed, and the crystals then simulate monoclinic symmetry with $\{001\}$ in the tetragonal setting taken as $\{010\}$; the angles conform to tetragonal symmetry. The crystals were early described by Schrauf (1872) in a monoclinic setting intended to show a supposed analogy to gypsum. Crystal drawings are given by Goldschmidt (1899) and Schrauf (1872). The crystals usually are composite with uneven faces and occur in subparallel aggregates. The inclined faces are small and are striated horizontally.

Parallel growths of troegerite and zeunerite were described by Goldschmidt (1899).

\section{Physical properties}

Cleavage $\{001\}$ perfect; also $\{100\}$ good, and probably also a cleavage on $\{011\}$. Hardness 2-3. Specific gravity 3.3 (Weisbach, 1871) ; synthetic $\mathrm{H}_{2}\left(\mathrm{UO}_{2}\right)_{2}\left(\mathrm{AsO}_{4}\right)_{2} \cdot 8 \mathrm{H}_{2} \mathrm{O}$ has a specific gravity of 3.55. Luster nearly vitreous, pearly on $\{001\}$. Color lemon yellow. Transparent. Synthetic material, and presumably also natural troegerite, fluoresces lemon yellow in ultraviolet light.

optical properties

\begin{tabular}{|c|c|c|c|c|c|c|}
\hline \multirow[b]{2}{*}{ ORIENTATION } & \multicolumn{5}{|c|}{$n$} & \multirow[b]{2}{*}{ PLEOChROISM } \\
\hline & 1 & 2 & 3 & 4 & 5 & \\
\hline$E$ or $X=c$ & 1.585 & 1.580 & 1.600 & 1.584 & 1.584 & \multirow{3}{*}{$\begin{array}{l}\text { Nearly colorless. } \\
\text { Lemon yellow. } \\
\text { Lemon yellow. }\end{array}$} \\
\hline$O$ or $Z$ & $\begin{array}{l}1.050 \\
1.630\end{array}$ & $1.62 \overline{4}$ & $\begin{array}{l}1.020 \\
1.630\end{array}$ & $\begin{array}{l}1.020 \\
1.623\end{array}$ & $1.6 \overline{12}$ & \\
\hline $2 V$ & $\begin{array}{l}\text { Very } \\
\text { small }\end{array}$ & $0^{\prime \prime}$ & $0^{\circ}-40^{\circ}$ & $\approx 20^{\circ}$ & $0^{\circ}$ & \\
\hline
\end{tabular}

1, 2. Schneeberg. Larsen (1921).

3, 4. Joachimsthal. Mrose (1953).

5. Synthetic. Idem.

Uniaxial negative or biaxial negative. In biaxial material, $r>v$ moderate, with variable $2 \mathrm{~V}$. It is probable but not entirely certain that the optical properties given above for unanalyzed natural material actually refer to troegerite. 
V. Goldschmidt (1899) stated that the crystals described morphologically by him were biaxial negative, with $X=c$, and had inclined extinction with $Z \wedge a 10^{\circ}-12^{\circ}$; Schrauf (1872) gave $Z \wedge a 14^{\circ}$. If troegerite is a member of the metatorbernite group, as here classed, the axial angle, inclined extinction, and the indices of refraction may be expected to vary with the content of zeolitic water within the limits of stability of the phase, as in other members of the group.

\section{Thermal behavior}

X-ray powder-diffraction study shows that $\mathrm{H}_{2}\left(\mathrm{UO}_{2}\right)_{2}\left(\mathrm{AsO}_{4}\right)_{2}$. $8 \mathrm{H}_{2} \mathrm{O}$ belongs in the metatorbernite group of hydrates. No structural change was produced by heating at $90^{\circ} \mathrm{C}$, but an unidentified phase was formed between $90^{\circ} \mathrm{C}$ and $200^{\circ} \mathrm{C}$ (Mrose, 1953).

\section{Synthesis}

Crystals of $\mathrm{H}_{2}\left(\mathrm{UO}_{2}\right)_{2}\left(\mathrm{AsO}_{4}\right)_{2} \cdot 8 \mathrm{H}_{2} \mathrm{O}$ were obtained by Mrose (1953) by adding the stoichiometric amount of uranyl nitrate to a boiling solution of arsenic acid and cooling very slowly.

\section{Cation exchange}

The compounds $\mathrm{Na}_{2}\left(\mathrm{UO}_{2}\right)_{2}\left(\mathrm{AsO}_{4}\right)_{2} \cdot 8 \mathrm{H}_{2} \mathrm{O}$ and $\left(\mathrm{NH}_{4}\right)_{2}\left(\mathrm{UO}_{2}\right)_{2}$ $\left(\mathrm{AsO}_{4}\right)_{2} \cdot 8 \mathrm{H}_{2} \mathrm{O}$, both isostructural with metatorbernite, were obtained by Mrose (1953) by immersing crystals of $\mathrm{H}_{2}\left(\mathrm{UO}_{2}\right)_{2}$ $\left(\mathrm{AsO}_{4}\right)_{2} \cdot 8 \mathrm{H}_{2} \mathrm{O}$ in $1 \mathrm{~N}$ solutions of $\mathrm{NaCl}$ or $\mathrm{NH}_{4} \mathrm{Cl}$ for 2 weeks at room temperature. The properties of these two phases, neither of which has been identified in nature, are summarized below and their X-ray powder-spacing data are given by Mrose (1953). The $\mathrm{Ca}, \mathrm{Ba}, \mathrm{Mg}$, and $\mathrm{Cu}$ analogues probably can be prepared by similar procedures.

\begin{tabular}{llll} 
& $\mathrm{Na}_{2}\left(\mathrm{UO}_{2}\right)_{2}\left(\mathrm{AsO}_{4}\right)_{2} \cdot 8 \mathrm{H}_{2} \mathrm{O}$ & & $\left(\mathrm{NH}_{4}\right)_{2}\left(\mathrm{UO}_{2}\right)_{2}\left(\mathrm{AsO}_{4}\right)_{2} \cdot 8 \mathrm{H}_{2} \mathrm{O}$ \\
\cline { 2 - 2 }$a_{0}$ & $7.12 \mathrm{~A}$ & & $7.21 \mathrm{~A}$ \\
$c_{0}$ & 8.70 & 8.85 \\
\hline Sp gr (calc. $)$ & 3.80 & 3.60 \\
$n_{0}$ & 1.617 & 1.611 \\
$n_{\#}$ & 1.586 & & 1.601
\end{tabular}

Identification

Troegerite, on the basis of its original description, very closely resembles uranospinite, novacekite, and other yellow members of the metatorbernite and torbernite groups. It is best distinguished by chemical tests to establish the presence of As and the absence of $\mathrm{Ca}, \mathrm{Mg}, \mathrm{Al}$, or other cations in the $\mathrm{A}$ position of the general formula. Optical and X-ray data on unquestionably authentic analyzed troegerite are lacking. If the reported optical data are accepted, troegerite can be distinguished optically from certain 
of the related minerals, including meta-autunite, autunite, saléeite, and sabugalite, but there is possibility of confusion with novacekite and others. The X-ray powder-spacing data for synthetic $\mathrm{H}_{2}\left(\mathrm{UO}_{2}\right)_{2}\left(\mathrm{AsO}_{4}\right)_{2} \cdot 8 \mathrm{H}_{2} \mathrm{O}$ are given in the following table.

$X$-ray powder-spacing data for troegerite ${ }^{1}$

[Copper radiation, nickel filter]

\begin{tabular}{|c|c|c|c|c|c|c|c|}
\hline$d(\mathrm{~A})$ & $I$ & $d(\mathrm{~A})$ & $I$ & $d(\mathrm{~A})$ & $I$ & $d(\mathrm{~A})$ & $I$ \\
\hline $\begin{array}{l}8.59 \\
5.50 \\
5.04 \\
4.35 \\
3.79 \\
3.56 \\
3.30 \\
3.14 \\
2.99 \\
2.76 \\
2.70 \\
2.59 \\
2.53 \\
2.43 \\
2.30\end{array}$ & $\begin{array}{r}10 \\
7 \\
4 \\
7 \\
9 \\
6 \\
8 \\
1 / 2 \\
5 \\
2 \\
7 \\
3 \\
6 \\
5 \\
3\end{array}$ & $\begin{array}{l}2.26 \\
2.19 \\
2.16 \\
2.10 \\
2.01 \\
1.931 \\
1.873 \\
1.845 \\
1.807 \\
1.787 \\
1.752 \\
1.705 \\
1.685 \\
1.658 \\
1.643\end{array}$ & $\begin{array}{r}3 \\
7 \\
4 \\
5 \\
7 \\
3 \\
2 \\
2 \\
3 \\
4 \\
4 \\
4 \\
1 \\
1 / 2 \\
7 \\
2\end{array}$ & $\begin{array}{l}1.613 \\
1.598 \\
1.576 \\
1.541 \\
1.508 \\
1.492 \\
1.473 \\
1.462 \\
1.437 \\
1.427 \\
1.388 \\
1.360 \\
1.335 \\
1.316 \\
1.297\end{array}$ & $\begin{array}{r}3 \\
3 \\
7 \\
1 / 2 \\
1 / 2 \\
1 \\
1 / 2 \\
1 \\
4 \\
4 \\
6 \\
3 \\
4 \\
1 \\
1 / 2\end{array}$ & $\begin{array}{l}1.285 \\
1.275 \\
1.265 \\
1.252 \\
1.239 \\
1.230 \\
1.217 \\
1.211 \\
1.182 \\
1.169 \\
1.139 \\
1.133 \\
1.122 \\
1.110 \\
1.098\end{array}$ & $\begin{array}{r}3 \\
1 / 2 \\
1 / 2 \\
2 \\
2 \\
2 \\
2 \\
1 / 2 \\
5 \\
4 \\
1 / 2 \\
2 \\
4\end{array}$ \\
\hline
\end{tabular}

${ }^{1}$ Data of Mrose (1953) on synthetic hydrogen uranyl arsenate.

Natural formation and occurrence

Troegerite was originally found as a secondary mineral associated with metazeunerite and walpurgite in the Walpurgis vein of the Weisser Hirsch mine at Neustädtl near Schneeberg, Saxony; also at the Daniel mine, Schneeberg (V. Goldschmidt, 1899). The mineral possibly also occurs at Joachimsthal, Saxony (Mrose, 1953). Reported with uraninite in the Bald Mountains mining district, Pennington County, S. Dak. (E. S. Dana, 1892, p. 860).

\section{HÖRNBERGITE}

Hörnbergite is an undescribed mineral mentioned by Adam (1869) as an arsenate of manganese. Later it was erroneously listed by Spencer (1903) and some later authors as an arsenate of uranium.

\section{ZEUNERITE}

Synonymy

Zeunerite Weisbach (1872, 1873a, 1877b). Named after Gustav A. Zeuner (1828-1907), Director of the School of Mines at Freiberg, Saxony. Almost all specimens of so-called zeunerite that have been examined proved to be the lower hydrate, metazeunerite, belonging in the metatorbernite group. Probably all of this material has formed by dehydration of the fully hydrated phase, zeunerite, here described. The phase identity of the original zeunerite from 
Schneeberg described by Weisbach is not known with certainty. Weisbach's analysis shows $\approx 8 \mathrm{H}_{2} \mathrm{O}$, indicating that it is the metahydrate. Fully hydrated crystals have been identified from Schneeberg, however, and Weisbach's material very probably was a dehydration product rather than a direct deposit of the metahydrate.

\section{Composition}

A hydrated arsenate of copper and hexavalent uranium, $\mathrm{Cu}\left(\mathrm{UO}_{2}\right)_{2}\left(\mathrm{AsO}_{4}\right)_{2} \cdot 10-16 \mathrm{H}_{2} \mathrm{O}$. The only reported analysis of natural material apparently was made on the metahydrate and is cited under the species metazeunerite. Fully hydrated zeunerite has been synthesized; the water content varies zeolitically between $10 \mathrm{H}_{2} \mathrm{O}$ and $16 \mathrm{H}_{2} \mathrm{O}$, and at ordinary conditions is at or near the lower limit. Soluble in dilute acids. Easily fusible.

\section{Crystallography}

Tetragonal; crystallizing in the ditetragonal-dipyramidal crystal class $(4 / m 2 / m 2 / m)$. The morphological observations of Schrauf (1872) and Weisbach (1877b) on so-called zeunerite from Schneeberg probably were made on metazeunerite. ITnit-cell dimensions, from X-ray powder study by R. Berman (in press), of Schneeberg material: $a_{0} 7.18 \mathrm{~A}, c_{0} 21.06, a_{0}: c_{0}=1: 2.933$. Cell contents $2\left[\mathrm{Cu}\left(\mathrm{UO}_{2}\right)_{2}\left(\mathrm{AsO}_{4}\right)_{2} \cdot 10-16 \mathrm{H}_{2} \mathrm{O}\right]$.

Crystal habit

Found as distinct crystals closely resembling those of torbernite and metatorbernite. The lateral faces of the crystals are striated or serrated horizontally, and subparallel growths are common. Crystals definitely known to belong to the fully hydrated phase have not been measured goniometrically.

\section{Physical properties}

Cleavage $\{001\}$ perfect, $\{100\}$ distinct. Hardness 21/2. Specific gravity 3.47 on the material from Schneeberg. Luster weakly vitreous. Color green to emerald green. Transparent when fully hydrated. The crystals sometimes have a turbid border of lighter color due to partial dehydration to metazeunerite. Synthetic and natural fully hydrated zeunerite do not fluoresce in ultraviolet light.

\section{Optical properties}

Optical anomalies have not been described in natural or synthetic fully hydrated crystals.

See Metazeunerite. 
Optical properties of zeunerite

\begin{tabular}{|c|c|c|c|c|c|c|}
\hline \multirow[b]{2}{*}{ ORIENTATION } & \multicolumn{4}{|c|}{$n$} & \multirow[b]{2}{*}{ DICHROISM } & \\
\hline & 1 & 2 & 3 & 4 & & \\
\hline$\underset{E}{O}$ & $\begin{array}{l}1.610 \\
1.583\end{array}$ & $\begin{array}{l}1.610 \\
1.582\end{array}$ & 1.610 & 1.602 & $\begin{array}{l}\text { Blue green. } \\
\text { Pale blue } \\
\text { green. }\end{array}$ & $\begin{array}{l}\text { Uniaxial } \\
\text { negative. }\end{array}$ \\
\hline
\end{tabular}

1. Utah. M. E. Thompson, in R. Berman (in press).

2. Schneeberg. R. Berman (in press).

3. Synthetic $\left(\approx 10 \mathrm{H}_{2} \mathrm{O}\right)$. J. W. Frondel (1951).

4. Synthetic $\left(\approx 16 \mathrm{H}_{2} \mathrm{O}\right)$. Idem.

Identification

Zeunerite very closely resembles metazeunerite, torbernite, and other green members of the torbernite and metatorbernite groups. It has indices of refraction higher than those of fully hydrated torbernite and lower than those of metazeunerite. This species, as with related species, is best distinguished by a combination of chemical, optical, and X-ray tests. The X-ray powder-spacing data are given in the following table.

\section{$X$-ray powder-spacing data for zeunerite}

[Symbols : b, broad; bd, broad, diffuse; d, diffuse. Copper radiation, nickel filter]

\begin{tabular}{|c|c|c|c|c|c|c|c|}
\hline \multicolumn{4}{|c|}{1} & \multicolumn{4}{|c|}{2} \\
\hline$d(\mathrm{~A})$ & $I$ & $d(\mathrm{~A})$ & $I$ & $d(\mathrm{~A})$ & $I$ & $d(\mathrm{~A})$ & $I$ \\
\hline $\begin{array}{r}10.33 \\
9.40 \\
6.82 \\
5.27 \\
5.07 \\
4.58 \\
3.60 \\
3.40 \\
3.18 \\
2.94 \\
2.86 \\
2.75 \\
2.54 \\
2.47 \\
2.32 \\
2.27 \\
2.19 \\
2.07 \\
1.926 \\
1.869 \\
1.798 \\
1.772 \\
1.707 \\
1.692 \\
1.660 \\
1.642 \\
1.605\end{array}$ & $\begin{array}{c}9 \\
1 \\
4 \\
5 \\
7(\mathrm{~b}) \\
2 \\
10 \\
6 \\
2 \\
4 \\
1 \\
2 \\
3 \\
3 \\
1 \\
3 \\
3 \\
4 \\
4 \\
1 \\
4 \\
1 \\
2 \\
2 \\
2 \\
2 \\
3\end{array}$ & $\begin{array}{r}1.583 \\
1.561 \\
1.536 \\
1.506 \\
1.428 \\
1.404 \\
1.378 \\
1.358 \\
1.313 \\
1.293 \\
1.270 \\
1.242 \\
1.217 \\
1.164 \\
1.138 \\
1.093 \\
1.083 \\
1.056 \\
1.036 \\
1.022 \\
.997 \\
.972 \\
.959 \\
.947 \\
.929\end{array}$ & $\begin{array}{l}1 \\
1 \\
3 \\
1 \\
2 \\
1 \\
2 \\
2 \\
1 \\
1 \\
1 \\
1 \\
1 \\
1 \\
1(d) \\
1 \\
1 \\
1 \\
1 \\
1 \\
1 \text { (bd) } \\
1 \\
1 \\
1 \\
1\end{array}$ & $\begin{array}{r}10.65 \\
6.86 \\
5.04 \\
4.55 \\
3.59 \\
3.39 \\
3.18 \\
3.07 \\
2.93 \\
2.86 \\
2.73 \\
2.54 \\
2.47 \\
2.42 \\
2.38 \\
2.31 \\
2.27 \\
2.19 \\
2.08 \\
1.985 \\
1.926 \\
1.873 \\
1.797 \\
1.768 \\
1.734 \\
1.704\end{array}$ & $\begin{array}{r}10 \\
5 \\
8 \\
2 \\
9 \\
7 \\
2 \\
1 \\
4 \\
4 \\
3 \\
4 \\
4 \\
1 \\
1 \\
2 \\
3 \\
4 \\
5 \\
1 \\
6 \\
2 \\
5 \\
1 \\
1 \\
2\end{array}$ & $\begin{array}{l}1.658 \\
1.642 \\
1.610 \\
1.590 \\
1.563 \\
1.533 \\
1.512 \\
1.429 \\
1.382 \\
1.365 \\
1.332 \\
1.313 \\
1.298 \\
1.275 \\
1.248 \\
1.222 \\
1.211 \\
1.202 \\
1.191 \\
1.181 \\
1.168 \\
1.143 \\
1.118 \\
1.094 \\
1.086 \\
1.060\end{array}$ & $\begin{array}{l}1 \\
4 \\
3 \\
1 \\
2 \\
4 \\
1 \\
3 \\
3 \\
3 \\
1 \\
2 \\
1 \\
3 \\
2 \\
1 \\
2 \\
2 \\
1 \\
1 \\
2 \\
2 \\
1 \\
2 \\
2 \\
1\end{array}$ \\
\hline
\end{tabular}

1. Synthetic material containing $10 \mathrm{H}_{2}$ O. Data from J. W. Frondel (1951).

2. Synthetic material containing $16 \mathrm{H}_{2} \mathrm{O}$. Idem. 
In the field, minerals thought to be zeunerite or some other fully hydrated member of the torbernite group should be kept in moist air in a sealed container to prevent dehydration before laboratory examination.

\section{Natural formation and occurrence}

Zeunerite is a secondary mineral, found in the oxidized zone of deposits containing uraninite together with arsenic-containing primary minerals such as smaltite or enargite. Fully hydrated zeunerite has been identified only from Schneeberg, Saxony (R. Berman, in press) and the Dexter mine on Calf Mesa, San Rafael Swell, Utah (M. E. Thompson, written communication, 1954). Most or all of the localities cited for metazeunerite probably refer to zeunerite as well.

\section{Synonymy}

URANOSPATHITE

Uranospathite Hallimond (1915). Named from uranium and $\sigma \pi a \dot{\theta} \eta, a$ broad blade, in allusion to the lathlike habit of the crystals.

\section{Description}

This name was given by Hallimond (1915) to an unanalyzed mineral from Redruth, Cornwall, England, that was presumed from the presence of uranium and its general characteristics to be related to the torbernite group. The symmetry was assumed to be orthorhombic on the basis of the optical properties. Found as fanlike groups of thin rectangular plates and laths flattened on $\{001\}$ and striated parallel to the elongation, $b$. The corners of the plates often are modified equally by edges approximately at $45^{\circ}$. Stated to be twinned occasionally by the superposition of groups of laths at right angles. Cleavage $\{001\}$ perfect, $\{100\}$ good, $\{010\}$ fibrous. Specific gravity 2.50. Color yellow to pale green and bluish green. Parallel growths are noted with bassetite. The following optical data are given:

\begin{tabular}{|c|c|c|c|}
\hline ORIENTATION & $n$ & Pleochroism & \\
\hline $\begin{array}{l}X=c \\
Y=a \\
Z=b\end{array}$ & $\approx\left[\begin{array}{l}1.49] \\
1.510 \\
1.521\end{array}\right.$ & $\begin{array}{l}\text { Pale yellow. } \\
\text { Deep yellow. } \\
\text { Deep yellow. }\end{array}$ & $\begin{array}{l}\text { Biaxial negative; } \\
2 V 69^{\circ}(\mathrm{Na}) .\end{array}$ \\
\hline
\end{tabular}

Stated to become uniaxial in a desiccator.

Type specimens of uranospathite supplied by Hallimond were examined by C. Frondel (1954). A semiquantitative spectrographic analysis by C. S. Annell and K. E. Valentine, U. S. Geological Survey, showed that U, As, and P, with As $>$ P, were the main constituents, with $\mathrm{Cu}$ and $\mathrm{Fe}$ in smaller amounts. The X-ray 
powder photograph was identical with that of fully hydrated synthetic zeunerite with $16 \mathrm{H}_{2} \mathrm{O}$, but with a few extra lines. The indices of refraction were $n_{X} 1.485-1.495, n_{Y} 1.522-1.527, n_{Z} 1.527-$ 1.532 , with $2 V \approx 55^{\circ}$; there was a slight variation in the sample, with the centers of the larger grains having the lower indices. On standing in air the substance lost water and the indices of refraction increased to $n_{X} 1.558, n_{Y} 1.591-1.593, n_{Z}$ 1.593-1.596, with $2 \mathrm{~V}$ variable $20^{\circ}-30^{\circ}$. It then gave the X-ray pattern of metazeunerite. After standing over $\mathrm{CaCl}_{2}$ for 2 years the indices were $n_{Y} 1.612, n_{Z} 1.612$, with $2 \mathrm{~V} 0^{\circ}$; over water for the same time the indices decreased to $n_{Y} 1.54-1.57, n_{Z} 1.54-1.57$, with $2 \mathrm{~V} 0^{\circ}-10^{\circ}$. An analysis by F. A. Gonyer of Harvard University of a non-type sample, shown to be identical by X-ray and other evidence with the original material, gave: $\mathrm{CuO} 6.65, \mathrm{FeO} 0.72, \mathrm{UO}_{3} 56.16$, $\mathrm{As}_{2} \mathrm{O}_{5}$ 13.76, $\mathrm{P}_{2} \mathrm{O}_{5}$ 4.35, $\mathrm{H}_{2} \mathrm{O}$ 17.94, total 99.58. This corresponds to $\mathrm{Cu}\left(\mathrm{UO}_{2}\right)_{2}\left(\mathrm{AsO}_{4}, \mathrm{PO}_{4}\right)_{2} \cdot 11 \mathrm{H}_{2} \mathrm{O}$, with the ratio $\mathrm{As}: \mathrm{P} \approx 2: 1$.

From these new data, it seems that the original uranospathite is a copper uranyl arsenate-phosphate related to the torbernite group, but more highly hydrated (in view of the very low indices of refraction) than the members of this group. The dehydration product of uranospathite is identical with metazeunerite but contains slightly more water than is normally found in this substance and has slightly lower indices of refraction owing to the higher water content and to the presence of a large amount of $\left(\mathrm{PO}_{4}\right)$ in substitution for $\left(\mathrm{AsO}_{4}\right)$. Guillemin (cited in C. Frondel, 1954) found that an apparently authentic specimen of uranospathite did not contain copper. Further study is needed to establish the species validity of uranospathite.

The X-ray powder patterns of uranospathite and of its dehydration product, phosphatian metazeunerite, are virtually identical with those of fully hydrated zeunerite and metazeunerite, respectively.

\section{FRITZSCHEITE}

Synonymy

Fritzscheite Breithaupt (1865). Named after C. J. Fritzsche (1808-71), German chemist.

\section{Description}

An ill-defined mineral. From qualitative chemical tests it is supposed to be a hydrated phosphate-vanadate of uranium and manganese belonging in the torbernite or metatorbernite group. Found as tetragonal plates, with a perfect basal cleavage and a distinct prismatic cleavage. Hardness $21 / 2-3$. Specific gravity given as 3.50 , but this value may possibly be in error owing to the very 
small sample available. Luster between vitreous and pearly. Color reddish brown to hyacinth red. The crystals are described as too turbid for optical examination. Found at Neuhammer near Neudeck, Bohemia, in a hematite deposit as parallel borders on crystals of autunite, and at the Georg Wagsfort mine, Johanngeorgenstadt, Saxony, with torbernite. On the basis of the color, it is thought to occur at Autun, France, and at Steinig near Elsterberg in Voigtland, Saxony. Several specimens labeled fritzscheite were found by R. Berman (oral communication, 1954) to consist of metatorbernite.

A synthetic manganese uranyl phosphate belonging in the metatorbernite group has been synthesized by Jansen (written communication, 1952). Also obtained by Fairchild (1929), who gives $n_{0} \approx 1.60$ and $2 \mathrm{~V} 0^{\circ}$ to moderate.

Synonymy

\section{SABUGAIITE}

Sabugalite Frondel (1951a). Sabugalite was named after Sabugal county in Beira Alta province, Portugal, in which the mineral was first found.

\section{Composition}

A hydrated acid phosphate of aluminum and hexavalent uranium, $\mathrm{HAl}\left(\mathrm{UO}_{2}\right)_{4}\left(\mathrm{PO}_{4}\right)_{4} \cdot 16 \mathrm{H}_{2} \mathrm{O}$. The two reported analyses are given in the table below. Spectrographic analyses of sabugalite have not been made. The material of analysis 3 contains a small amount of As in substitution for $P$, with $A s: P=1: 8.6$.

Chemical analyses of sabugalite, in weight percent

\begin{tabular}{|c|c|c|c|c|}
\hline & 1 & 2 & 3 & 4 \\
\hline $\begin{array}{l}\mathrm{CaO}_{2} \\
\mathrm{Al}_{2} \mathrm{O}_{3} \\
\mathrm{UO}_{3} \\
\mathrm{P}_{2} \mathrm{O}_{5}\end{array}$ & $\begin{array}{r}2 \overline{87} \\
64.41 \\
15.99\end{array}$ & $\begin{array}{r}2 . \overline{65} \\
65.22 \\
16.08\end{array}$ & $\begin{array}{r}0.36 \\
3.20 \\
65.01 \\
14.02 \\
\end{array}$ & $\begin{array}{r}\overline{4.85} \\
63.10 \\
15.40\end{array}$ \\
\hline $\mathrm{H}_{2} \mathrm{O}$ & $16 . \overline{73}$ & $15 . \overline{93}$ & [14.71] & $16 . \overline{80}$ \\
\hline Total & 100.00 & 99.88 & {$[100.00]$} & 100.15 \\
\hline
\end{tabular}

1. Theoretical composition, $\mathrm{HAl}\left(\mathrm{UO}_{2}\right)_{4}\left(\mathrm{PO}_{4}\right)_{4} \cdot 16 \mathrm{H}_{2} \mathrm{O}$.

2. Sabugalite. Mina da Quarta Feira, Sabugal, Portugal. Gonyer, analyst, in C. Frondel (1951a). Ca, Mg, Ba, Cu, Fe, Mn, and As looked for but not found.

3. Sabugalite. Kariz, Minho, Portugal. Gonyer, analyst. in C. Frondel (1951a). Contains a trace of $\mathrm{MgO}$. The $\mathrm{CaO}$ is due to admixed meta-autunite. A direct water determination on a separate sample probably containing a slightly larger amount of meta-autunite gave 16.78 percent.

4. Synthetic sabugalite. G. B. Magin, U. S. Geological Survey, analyst (written communication, 1952). Average of 2 analyses.

Crystallography

Conclusive morphological and single-crystal X-ray evidence of the symmetry are lacking. The X-ray powder-diffraction data and 
other lines of evidence, however, indicate that sabugalite is isostructural with fully hydrated autunite and hence tetragonal, in the ditetragonal-dipyramidal class, $4 / m 2 / m 2 / m$. The unitcell dimensions of the material of analysis 2 are: $a_{0} 6.96 \mathrm{~A}$, $c_{0} 19.3, a_{0}: c_{0}=1: 2.773$. Cell contents $\mathrm{HAl}\left(\mathrm{UO}_{2}\right)_{4}\left(\mathrm{PO}_{4}\right)_{4} \cdot 16 \mathrm{H}_{2} \mathrm{O}$. Specific gravity 3.2 (measured), 3.15 (calculated). Space group probably $I 4 / \mathrm{mmm}$.

\section{Crystal habit}

Single crystals are very thin plates as much as $1 \mathrm{~mm}$ on an edge. The plates are square or rectangular lathlike in shape and are bounded laterally by very narrow and indistinct faces of $\{100\}$ and $\{h 0 l\}$ with the corners sometimes truncated at $45^{\circ}$ by tiny faces of $\{h k l\}$. The plane of flattening is uneven, warped, or striated, and subparallel growths joined on this face are common. The mineral typically occurs as densely aggregated crusts.

\section{Physical properties}

Cleavage $\{001\}$ perfect. Hardness 21/2. Specific gravity 3.2 (measured) ; 3.15 (calculated). Color bright yellow to lemon yellow, closely resembling that of autunite. Luster weakly vitreous. Transparent to translucent. Sabugalite fluoresces bright lemon yellow in long-wave and less brighly in short-wave ultraviolet radiation.

Optical properties

$n$

\begin{tabular}{|c|c|c|c|c|}
\hline $\begin{array}{l}\text { ORIENTA- } \\
\text { TION }\end{array}$ & $\begin{array}{c}\text { MINA DA QUARTA } \\
\text { FEIRA }\end{array}$ & KARIZ & $\begin{array}{l}\text { MINA DE } \\
\text { CoItos }\end{array}$ & PLEOChROISM \\
\hline $\begin{array}{l}X \text { or } E \\
Y \\
Z \text { or } O\end{array}$ & $\begin{array}{l}1.564 \\
1.582 \\
1.584\end{array}$ & $\begin{array}{r}1.564 \\
1.581-1.583 \\
1.583\end{array}$ & $\begin{array}{r}1.565 \\
1.581-1.582 \\
1.582\end{array}$ & $\begin{array}{l}\text { Colorless. } \\
\text { Pale yellow. } \\
\text { Pale yellow. }\end{array}$ \\
\hline
\end{tabular}

$2 \mathrm{~V}$ Moderate Moderate $\mathrm{O}^{\circ}$ to moderate

Air-dried samples of sabugalite from different localities and also different grains within the same sample show a slight variation in the indices of refraction and a wide variation in $2 \mathrm{~V}$. Some material is uniaxial negative, but most samples are biaxial negative with $2 \mathrm{~V}$ variable but usually moderate. The departure from uniaxiality in this presumably tetragonal species is believed due to variation in the content of zeolitic water within the limits of stability of the phase itself, as discussed under autunite. Biaxial plates usually extinguish uniformly. Sometimes mottled extinction is seen, but the sectoral structure with varying optical orientation therein, such as occurs in many members of the autunite and meta-autunite groups, has not been observed. The optical properties of air-dried material are cited above. 
The $X$ (or $E$ ) vibration direction is perpendicular to the flattening, and in lathlike crystals $Z$ is parallel to the elongation. The indices of refraction and $2 \mathrm{~V}$ change markedly when the material is dehydrated.

\section{Thermal behavior}

When sabugalite is heated in air to $44^{\circ} \mathrm{C}$ or $68^{\circ} \mathrm{C}$, part of the water is lost and the indices of refraction increase (see table below). There is no accompanying change in the X-ray powder pattern. When the heated samples are held in a moist atmosphere at room temperature, water is absorbed and the indices decrease practically to the original values. These changes are attributed to variation in the content of zeolitic water within the limits of stability of the fully hydrated phase.

When sabugalite is heated above $68^{\circ} \mathrm{C}$ it breaks down at a temperature between $68^{\circ}$ and $101^{\circ} \mathrm{C}$ to a new phase isostructural with meta-autunite II. More water is lost in this range and at higher temperatures, with an accompanying increase in the indices of refraction (see table below). When the heated samples are held in a moist atmosphere at room temperature, water is absorbed and the indices of refraction decrease markedly but the $\mathrm{X}$-ray pattern remains that of the meta-II phase. The structural change between the fully hydrated and meta-II phases of sabugalite thus is not reversible. This change is in agreement with the relations observed in other members of the autunite and metaautunite groups, but in these minerals a meta-I hydrate is formed in addition, at about $80^{\circ} \mathrm{C}$, and this phase apparently does not occur in sabugalite. The crystal chemistry of the dehydration is further discussed by C. Frondel (1951a), who cites X-ray powder data for meta-sabugalite II.

Optical properties of dehydrated sabugalite (white light)

\begin{tabular}{|c|c|c|c|c|c|c|}
\hline SAMPLE & Phase & $n_{x}$ & $n_{\mathbf{Y}}$ & $n_{z}$ & $2 V$ & $\begin{array}{l}\text { PERCENT } \\
\text { LOSS OF } \\
\mathrm{H}_{2} \mathrm{O}\end{array}$ \\
\hline $\begin{array}{l}\text { Unheated, } \\
\text { analysis } 2^{1} \text {. }\end{array}$ & $\begin{array}{l}\text { Fully } \\
\text { hydrated. }\end{array}$ & 1.564 & 1.582 & 1.584 & $\overline{\text { Moderate }}$ & 0 \\
\hline $\begin{array}{l}\text { Heated at: } \\
44^{\circ} \mathrm{C}\end{array}$ & $\begin{array}{l}\text { Fully } \\
\text { hydrated. }\end{array}$ & - & 1.591 & 1.594 & Moderate & 3.4 \\
\hline $68^{\circ} \mathrm{C}$ & $\begin{array}{l}\text { Fully } \\
\text { hydrated. }\end{array}$ & 1.575 & 1.596 & 1.597 & Small & 20 \\
\hline $135^{\circ} \mathrm{C}$ & $\begin{array}{l}\text { Meta-II } \\
\text { Meta-II }\end{array}$ & $\begin{array}{r}1.592- \\
1.596\end{array}$ & $1.604-$ & $1.618-$ & & $\begin{array}{l}82 \\
91\end{array}$ \\
\hline $\begin{array}{l}\text { Cooled from } \\
135^{\circ} \mathrm{C} \text { held } \\
\text { over water. }\end{array}$ & Meta-II & - & 21.581 & 21.587 & Large & - \\
\hline 1 See table, & 196. & ${ }^{2}$ Inc & s vari & le, most & e this $v$ & e. \\
\hline
\end{tabular}


Synthesis

Obtained by Jansen (written communication, 1952) by adding uranyl acetate to an excess of aluminum chloride in a large amount of water and then adding the stoichiometric amount of phosphoric acid to the mixture. Also obtained by Guillemin and Pierrot (1956c).

\section{Identification}

Sabugalite resembles in color, habit, and occurrence other yellow members of the torbernite and metatorbernite groups, including autunite, meta-autunite, and uranospinite (all rather similar optically to sabugalite); also saléeite, novacekite, metauranocircite, and troegerite (all rather different optically from sabugalite). Chemical tests to show the presence of $\mathrm{Al}$ and the absence of divalent cations together with X-ray powder photographs are needed for positive identification. The X-ray powderspacing data are given in the following table.

\section{$X$-ray powder-spacing data for sabugalite ${ }^{1}$}

[Copper radiation, nickel filter]

\begin{tabular}{|c|c|c|c|c|c|c|}
\hline$d(\mathrm{~A})$ & $I$ & $d(\mathrm{~A})$ & $I$ & $d(\mathrm{~A})$ & $I$ & $d(\mathrm{~A})$ \\
\hline $\begin{array}{l}9.69 \\
6.56 \\
5.59 \\
4.86 \\
4.39\end{array}$ & $\begin{array}{r}10 \\
1 \\
1 \\
9 \\
4\end{array}$ & $\begin{array}{l}3.47 \\
3.36 \\
3.22 \\
3.06 \\
2.82\end{array}$ & $\begin{array}{r}8 \\
1 \\
1 / 2 \\
1 / 2 \\
1\end{array}$ & $\begin{array}{l}2.45 \\
2.39 \\
2.19 \\
1.792 \\
1.726\end{array}$ & $\begin{array}{l}2 \\
2 \\
6 \\
1 \\
1\end{array}$ & $\begin{array}{l}1.641 \\
1.552 \\
1.364\end{array}$ \\
\hline
\end{tabular}

${ }^{1}$ Data from C. Frondel (1951a) on material from Sabugal, Portugal. The pattern is very similar to those of novacekite and saléeite.

\section{Natural formation}

Sabugalite is a secondary mineral. It occurs in Portugal with saléeite, meta-autunite, and phosphuranylite in the weathered outcrops of uraninite veins. The $\mathrm{Al}, \mathrm{Mg}$, and $\mathrm{Ca}$ content of these minerals probably has been derived by alteration of the wall rock.

\section{Occurrence}

Sabugalite was originally described from three localities in Portugal. These are the Mina da Quarta Feira, Guarda district, Sabugal county, Bendada parish in Beira Alta province; the Mina de Coitos in Bendada parish; and Kariz in Minho province. The localities are not given entirely correctly in the original paper. Later reported from sandstone-type uranium deposits on the Colorado Plateau, as at the Huskon and Arrow Head claims near Cameron, Ariz., and the Happy Jack mine, White Canyon, San Juan County, Utah (Gruner and others, 1954a); from the Lucky Mc No. 20 mine in the Wind River Basin, Fremont County, Wyo. (Gruner and Smith, 1955). Sabugalite also has been reported from Wyoming from the Del Linch claim, Johnson County, the 
Blue Buck claim and Blarco Group in Fremont County, and the Poison Creek claim in Crook County (Gruner and Smith, written communication, 1955). Also described from Margnac II, Haute-Vienne, France, by Guillemin and Pierrot (1956c).

Synonymy

BASSETITE

Bassetite Hallimond (1915). Named from the locality at the Basset mines, Redruth, Cornwall.

Composition

A hydrated phosphate of divalent iron and hexavalent uranium, $\mathrm{Fe}\left(\mathrm{UO}_{2}\right)_{2}\left(\mathrm{PO}_{4}\right)_{2} \cdot 8 \mathrm{H}_{2} \mathrm{O}=\mathrm{FeO} \cdot 2 \mathrm{UO}_{3} \cdot \mathrm{P}_{2} \mathrm{O}_{5} \cdot 8 \mathrm{H}_{2} \mathrm{O}$. The only reported analysis, in weight percent, is cited below.

\begin{tabular}{|c|c|c|c|c|c|}
\hline & 1 & 2 & & 1 & 2 \\
\hline $\begin{array}{l}\mathrm{FeO} \\
\mathrm{CuO}\end{array}$ & & $\begin{array}{r}7.60 \\
.28\end{array}$ & $\begin{array}{l}\mathrm{H}_{2} \mathrm{O} \\
\text { Insol. }\end{array}$ & $\begin{array}{r}15.50 \\
-\end{array}$ & $\begin{array}{r}14.49 \\
.63\end{array}$ \\
\hline $\begin{array}{l}\mathrm{UO}_{3} \\
\mathrm{P}_{2} \mathrm{O}_{5}\end{array}$ & $\begin{array}{l}61.51 \\
15.26\end{array}$ & $\begin{array}{l}61.99 \\
15.21\end{array}$ & Total & 100.00 & 100.20 \\
\hline
\end{tabular}

1. Theoretical weight percentages, $\mathrm{FeO} \cdot 2 \mathrm{UO}_{3} \cdot \mathrm{P}_{2} \mathrm{O}_{5} \cdot 8 \mathrm{H}_{2} 0$.

2. Bassetite. Wheal Bassett, Cornwall. Gonyer, analyst, in C. Frondel (1954).

No chemical data were reported in the original description by Hallimond (1915), who considered the mineral to be a calcium uranyl phosphate from a supposed identity with a Cornwall mineral earlier analyzed by Church (1875) [actually autunite]. Microchemical tests by Meixner (1940b) on a probably authentic specimen indicated, however, that the mineral was an iron uranyl phosphate. Type specimens supplied by Hallimond to C. Frondel (1954) were found on semiquantitative spectrographic analysis to contain $\mathrm{Fe}, \mathrm{U}$, and $\mathrm{P}$ as major essential constituents together with traces of $\mathrm{Si}, \mathrm{Mg}$, and $\mathrm{Al}$. Analysis 2 was made on a nontype specimen shown by X-ray and other evidence to be identical with type material.

Bassetite is easily soluble in dilute acids. Heated in air it loses water and leaves a dark reddish brown pseudomorph containing ferric iron.

Crystallography

Apparently monoclinic with marked tetragonal pseudosymmetry. $\beta \approx 90^{\circ}$. The crystals of analysis 2 were monoclinic in habit, as lozenge-shaped plates flattened on the plane of perfect cleavage. In the monoclinic interpretation, the cleavage is $\{010\}$ and the chief forms are $\{111\},\{101\},\{110\},\{001\}$, and $\{010\}$. The interfacial angles, which could be measured only approximately owing to the very poor surface quality of the crystals, 
were consistent with a tetragonal interpretation in which the cleavage is taken as $\{001\}$; the monoclinic axes $a b c$ then are equivalent to the tetragonal axes $a c a$, respectively (fig. 13).

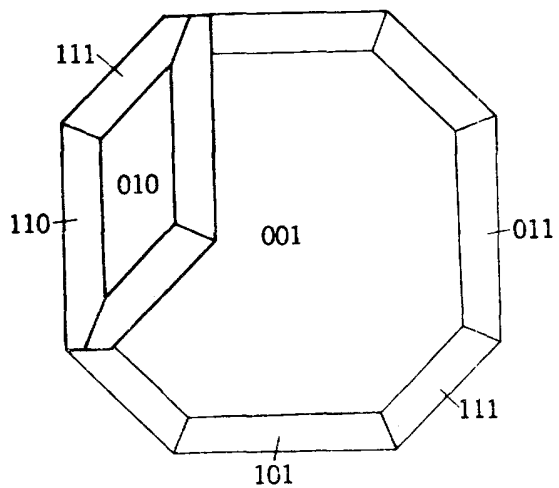

$A$

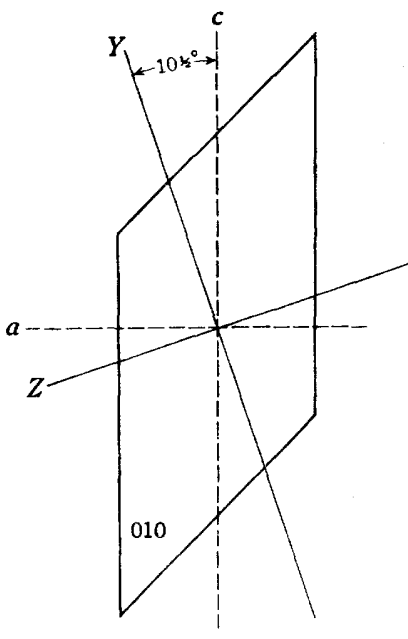

$B$ FIGURe 13.-Bassetite. Cornwall. A. Drawing shows the observed habit (heavy lines) and its
relation to the tetragonal interpretation of the morphology (light lines). From C. Frondel (1954). B. Idealized monoclinic habit showing the optical orientation. From C. Frondel $(1954)$.

Angle tables calculated in the monoclinic and tetragonal interpretations, in the unit and orientation of the X-ray unit cell, are given below.

Angle table for bassetite, monoclinic interpretation

Monoclinic

$a: b: c=0.409: 1: 0.411 ; \quad \beta 90^{\circ} 32^{\prime} ; \quad p_{0}: q_{0}: r_{0}=1.005: 0.411: 1$

$r_{2}: p_{2}: q_{2}=2.433: 2.445: 1 ; \quad \mu 89^{\circ} 28^{\prime} ; \quad p_{0}^{\prime} 1.005, q_{0}^{\prime} 0.411, x_{0}^{\prime} 0.009$

\begin{tabular}{|c|c|c|c|c|c|c|}
\hline FORMS & $\phi$ & $\rho$ & $\phi_{2}$ & $\rho_{2}=B$ & $C$ & $A$ \\
\hline $\begin{array}{ll}c & 001 \\
b & 010 \\
a & 100\end{array}$ & $\begin{array}{rl}90^{\circ} & 00^{\prime} \\
0 & 00 \\
90 & 00\end{array}$ & $\begin{array}{rl} & 0^{\circ} 32^{\prime} \\
90 & 00 \\
90 & 00\end{array}$ & ${ }^{89^{\circ} 28^{\prime}}$ & $\begin{array}{rl}90^{\circ} & 00^{\prime} \\
0 & 00 \\
90 & 00\end{array}$ & $\begin{array}{l}90^{\circ} 00^{\prime} \\
8928\end{array}$ & $\begin{array}{r}89^{\circ} 28^{\prime} \\
9000 \\
000\end{array}$ \\
\hline $\begin{array}{ll}n & 120 \\
m & 110 \\
d & 101\end{array}$ & $\begin{array}{ll}50 & 43 \\
67 & 451 / 2 \\
90 & 00\end{array}$ & $\begin{array}{ll}90 & 00 \\
90 & 00 \\
45 & 24\end{array}$ & $\begin{array}{rl}0 & 00 \\
0 & 00 \\
44 & 36\end{array}$ & $\begin{array}{ll}50 & 43 \\
67 & 451 / 2 \\
90 & 00\end{array}$ & $\begin{array}{ll}89 & 391 / 2 \\
89 & 46 \\
44 & 52\end{array}$ & $\begin{array}{ll}39 & 17 \\
22 & 141 / 2 \\
44 & 36\end{array}$ \\
\hline $\begin{array}{ll}p & 111 \\
q & 121\end{array}$ & $\begin{array}{ll}67 & 56 \\
50 & 58\end{array}$ & $\begin{array}{l}47341 / 2 \\
52321 / 2\end{array}$ & $\begin{array}{ll}4436 \\
4436\end{array}$ & $\begin{array}{l}7354 \\
60001 / 2\end{array}$ & $\begin{array}{ll}4705 \\
5208\end{array}$ & $\begin{array}{ll}46 & 50 \\
51 & 551 / 2\end{array}$ \\
\hline
\end{tabular}

Morphological observations leading to a monoclinic interpretation of the crystallography are given by Hallimond (1915). His material, not all of it known with certainty to be of this species, 
Angle table for bassetite, tetragonal interpretation

Tetragonal

$a: c=1: 2.439 ; \quad p_{0}: r_{0}=2.439: 1$

\begin{tabular}{|c|c|c|c|c|}
\hline FORMS & $\phi$ & $\rho$ & $A$ & $\vec{M}$ \\
\hline $\begin{array}{ll}c & 001 \\
a & 010 \\
m & 110\end{array}$ & $\begin{array}{r}0^{\circ} \overline{00^{\prime}} \\
4500\end{array}$ & $\begin{array}{r}0^{\circ} 00^{\prime} \\
9000 \\
9000\end{array}$ & $\begin{array}{l}90^{\circ} 00^{\prime} \\
9000 \\
4500\end{array}$ & $\begin{array}{l}90^{\circ} 00^{\prime} \\
4500 \\
9000\end{array}$ \\
\hline $\begin{array}{ll}n & 012 \\
d & 011 \\
q & 112\end{array}$ & $\begin{array}{rr}0 & 00 \\
0 & 00 \\
45 & 00\end{array}$ & $\begin{array}{ll}50 & 39 \\
67 & 421 / 2 \\
59 & 531 / 2\end{array}$ & $\begin{array}{ll}90 & 00 \\
90 & 00 \\
52 & 17\end{array}$ & $\begin{array}{l}56511 / 2 \\
4908 \\
9000\end{array}$ \\
\hline$p \quad 111$ & 4500 & 7350 & $47131 / 2$ & 9000 \\
\hline
\end{tabular}

is markedly pseudotetragonal in both habit and angles. The crystals showed optical anomalies interpreted as twins on a nonrational law in which the (monoclinic) $\{010\}$ faces of the two individuals are parallel whereas the $a$-axis of one is parallel to the $c$-axis of the other.

An X-ray single-crystal study by Weissenberg and Laue methods on the material of analysis 2 by C. Frondel (1954) gave cell dimensions consistent with tetragonal symmetry. The film symmetries showed small but apparently significant deviations from tetragonal to monoclinic symmetry. $a_{0} 6.98 \pm 0.04 \mathrm{~A}, b_{0} 17.07$ $\pm 0.04, c_{0} 7.01 \pm 0.07, a_{0}: b_{0}: c_{0}=0.409: 1: 0.411 . \beta=90^{\circ} 32^{\prime}$. Unitcell contents $2\left[\mathrm{FeO} \cdot 2 \mathrm{UO}_{3} \cdot \mathrm{P}_{2} \mathrm{O}_{5} \cdot 8 \mathrm{H}_{2} \mathrm{O}\right]$. Space group not known.

The X-ray powder photographs and single-crystal photographs are very similar to those of members of the torbernite group, particularly saléeite and sabugalite. The cell dimensions in the tetragonal interpretation $a_{0} \approx 7.0 \mathrm{~A}, c_{0} 17.07, a_{0}: c_{0}=1: 2.439$, are close to those of the members of this group, as are the properties in general, and there can be no doubt that regardless of the true symmetry bassetite is isostructural or virtually so with the torbernite group.

Hallimond (1915) notes that bassetite occurs as parallel growths with torbernite and uranospathite.

Physical properties

Cleavage $\{010\}$ perfect. Hardness about $2 \frac{1}{2}$. Specific gravity 3.4 (on material of analysis 2) (Hallimond, 1915, gives 3.10), 3.6 (calculated). Luster on $\{010\}$ bronzy, vitreous on other faces. Color olive green and olive brown; also yellowish brown, bronzy yellow, and yellow. Transparent. Not fluorescent.

Optical properties

Grains resting on the perfect cleavage show anomalous yellowgreen and blue interference colors. The optical orientation is shown in figure 13. 


\begin{tabular}{|c|c|c|}
\hline \multirow{2}{*}{$\begin{array}{l}\text { ORIENTA- } \\
\text { TION }\end{array}$} & \multicolumn{2}{|c|}{ Optical properties of bassetite } \\
\hline & $n(\mathrm{Na})$ & PLEOCHROISM \\
\hline 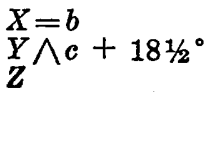 & $\begin{array}{l}1.603 \pm 0.002 \\
1.610 \pm .002 \\
1.617 \pm .002\end{array}$ & $\begin{array}{l}\text { Yellow. } \\
\text { Yellow. } \\
\text { Dark olive brown } \\
\text { to brownish } \\
\text { black. }\end{array}$ \\
\hline
\end{tabular}

Biaxial, the optical sign is uncertain but probably is negative; $2 \mathrm{~V}$ about $90^{\circ}$; $r>v$ strong.

Analysis $^{1}$

Reference

2

1 See table, p. 200.

When the mineral is dried over calcium chloride, zeolitic water is lost and this is accompanied by increases in $2 \mathrm{~V}$, in the partial birefringence $n_{Z}-n_{Y}$, and in the indices of refraction (to about $n_{Y} 1.63, n_{Z}$ 1.67). The absorption of $Z$ also increases relative to that of $Y$. In samples kept over water, the extinction angle decreases to $0^{\circ}, 2 \mathrm{~V}$ becomes small, and the indices decrease (to about $n_{Y}=n_{Z}$ 1.58). Further optical changes doubtless are brought about by partial oxidation of the ferrous iron, but data are lacking.

Thermal behavior and synthesis

No data.

Identification

Bassetite is distinguished from kahlerite by its content of $P$ instead of $\mathrm{As}$, and from the members of the torbernite and metatorbernite groups by its content of Fe. The X-ray powderspacing data are given in the following table.

$X$-ray powder-spacing data for bassetite ${ }^{1}$

[Symbols: $d$, diffuse; vd, very diffuse. Copper radiation, nickel filter]

\begin{tabular}{|c|c|c|c|c|c|c|c|}
\hline$d(\mathrm{~A})$ & $I$ & $d(\mathrm{~A})$ & $I$ & $d(\mathrm{~A})$ & $I$ & $d(\mathrm{~A})$ & $I$ \\
\hline $\begin{array}{l}8.59 \\
4.89 \\
4.66 \\
4.24 \\
4.05 \\
3.46 \\
3.32 \\
3.10\end{array}$ & $\begin{array}{r}6 \\
10 \\
1 / 2 \\
3 \\
3 \\
10 \\
1 / 2 \\
1\end{array}$ & $\begin{array}{l}2.96 \\
2.85 \\
2.72 \\
2.55 \\
2.46 \\
2.34 \\
2.26 \\
2.20\end{array}$ & $\begin{array}{l}3 \\
2 \\
1 / 2 \\
1 / 2(d) \\
2(d) \\
1 / 2 \\
1 / 2 \\
6\end{array}$ & $\begin{array}{l}2.13 \\
2.07 \\
1.921 \\
1.830 \\
1.783 \\
1.741 \\
1.708 \\
1.627\end{array}$ & $\begin{array}{c}1 \\
1 / 2 \\
1 / 2(d) \\
2 \\
1 / 2 \\
2 \\
1 / 2(d) \\
1(v d)\end{array}$ & $\begin{array}{l}1.557 \\
1.429 \\
1.374 \\
1.316 \\
1.191 \\
1.162 \\
1.128 \\
1.106\end{array}$ & $\begin{array}{r}1(\mathrm{vd}) \\
1 / 2(\mathrm{vd}) \\
1 / 2(\mathrm{vd}) \\
1 / 2(\mathrm{vd}) \\
1(\mathrm{vd}) \\
1(\mathrm{vd}) \\
1(\mathrm{vd}) \\
1(\mathrm{vd})\end{array}$ \\
\hline
\end{tabular}

1 Data from C. Frondel (1954) on material from Cornwall, England.

Natural formation and occurrence

Bassetite is a secondary mineral. It occurs in oxidized vein material carrying pyrite and uraninite at the Wheal Basset, Redruth, Cornwall, England. The locality of some of the specimens described by Hallimond (1915) is uncertain, but all probably are from Cornwall. Reported on the basis of X-ray and spectro- 
graphic evidence at the Denise No. 1 mine on the Bowknot of the Green River, Emery County, Utah (Weeks and Thompson, 1954). Said to occur at the Fuemrol mine, Temple Mountain, Emery County, Utah.

\section{MINERALS RELATED TO BASSETITE}

George (1949) briefly describes under the name iron uranite a mineral believed from qualitative tests to be an iron uranyl phosphate of the metatorbernite group. It occurs at the Merry Widow mine, Grant County, N. Mex., as square micaceous tablets very closely resembling autunite in form. Color bronze, pale yellow, pale brown, dark brown, and dark reddish brown. The optical properties are highly variable owing apparently to variation in hydration and the degree of oxidation of the iron. Optically negative, with the following indices of refraction:

\begin{tabular}{|c|c|c|c|}
\hline \multirow[b]{2}{*}{ ORIENTATION } & \multicolumn{2}{|c|}{$n$} & \multirow[b]{2}{*}{ Pleochroism } \\
\hline & $\begin{array}{l}\text { DARK-BROWN } \\
\text { MATERIAL }\end{array}$ & $\begin{array}{c}\text { PaLE-BROWN } \\
\text { MATERIAL }\end{array}$ & \\
\hline$O$ or $X$ & 1.60 & 1.645 & $\begin{array}{l}\text { Colorless to pale yellow } \\
\text { or pale brown. }\end{array}$ \\
\hline$E$ or $\stackrel{Y}{Z}$ & $\begin{array}{l}1.65 \\
1.66\end{array}$ & - & $\begin{array}{l}\text { Reddish brown. } \\
\text { Dark reddish brown to } \\
\text { opaque. }\end{array}$ \\
\hline
\end{tabular}

$2 V$

$40^{\circ}-50^{\circ}$

$0^{\circ}$

This mineral seems to be altered bassetite.

Branche, Chervet, and Guillemin (1951) have referred a mineral from La Crouzille, Puy-de-Dôme, France, to bassetite on the basis of optical characters. Found as plates flattened on $\{010\}$, elongated along the $c$-axis, and terminated by $\{\overline{1} 01\}$; no crystal measurements are cited. Cleavage $\{010\}$ perfect; fracture conchoidal. Hardness 2. Specific gravity 3.08. Color yellowish white to pale yellow. Biaxial negative, with $n_{X} 1.560, n_{Y} 1.574, n_{Z} 1.581$; $X=b$, with inclined extinction, $Z \wedge c 3^{\circ}$. Qualitative chemical tests are said to show the presence of $\mathrm{U}, \mathrm{P}, \mathrm{H}_{2} \mathrm{O}$, and only traces of iron.

\section{KAHLERITE}

Synonymy

Kahlerite Meixner (1953). Named after Franz Kahler, Austrian geologist, of the Carinthian Landesmuseum, Klagenfurt, Austria.

\section{Description}

Shown by qualitative chemical tests to be an arsenate of uranium and ferrous iron. Composition assumed to be $\mathrm{Fe}\left(\mathrm{UO}_{2}\right)_{2}$ 
$\left(\mathrm{AsO}_{4}\right)_{2} \cdot 8 \mathrm{H}_{2} \mathrm{O}$, the arsenate analogue of bassetite, on the basis of these tests and the physical properties. It is here placed in the fully hydrated torbernite group rather than with the metahydrates of the metatorbernite group, although evidence as to the degree of hydration is lacking.

Crystals are tetragonal, as thin tablets flattened on $\{001\}$ with $\{111\},\{021\},\{012\},\{011\}$, and $\{010\}$ (Meixner, 1940b). Color lemon yellow to yellowish green. Data on the hardness and specific gravity are lacking. Cleavage $\{001\}$ perfect. Optically negative, with $n_{Y} 1.632, n_{Z} 1.634$; anomalously biaxial, with $2 V 9^{\circ}-33^{\circ}$. Not fluorescent in ultraviolet light. X-ray powder-diffraction data are lacking.

Kahlerite is a secondary mineral, found in the oxidized zone of the iron ore deposit at Hüttenberg, Carinthia, Austria. It is associated with arseniosiderite, scorodite, and other iron arsenates, and has been derived by the oxidation of uraninite associated with loellingite and native bismuth. The mineral was long known from the locality under the name autunite. Kahlerite resembles bassetite and autunite, from which it can be distinguished by chemical tests.

META-AUTUNITE

Synonymy

Metakalkuranit Rinne (1901a). Meta-autunite I Beintema (1938).

\section{Composition}

A hydrated phosphate of calcium and hexavalent uranium, $\mathrm{Ca}\left(\mathrm{UO}_{2}\right)_{2}\left(\mathrm{PO}_{4}\right)_{2} \cdot n \mathrm{H}_{2} \mathrm{O}$. The value of $n$ ranges zeolitically from $21 / 2 \mathrm{H}_{2} \mathrm{O}-61 / 2 \mathrm{H}_{2} \mathrm{O}$ according to the dehydration studies of Beintema (1938), and at ordinary conditions is at or near the upper limit. This limit, however, may be somewhat higher than that given and possibly may be about 8 . The reported analyses of autunite probably include some of meta-autunite as most of the analyses were made without X-ray or other evidence of the actual hydrate at hand.

\section{Crystallography}

Tetragonal. The crystal class is not known, but the structure derived by Beintema (1938) is holohedral. The morphology is that of autunite because the natural crystals so far as known are dehydration pseudomorphs after that species. Unit-cell dimensions (from Beintema, 1938, on artificial material): $a_{0} 6.99 \mathrm{~A}$, $c_{0} 8.44, a_{0}: c_{0}=1: 1.206$. Space group $P 4 / \mathrm{nmm}$, assuming holohedry. Unit-cell contents $\mathrm{Ca}\left(\mathrm{UO}_{2}\right)_{2}\left(\mathrm{PO}_{4}\right)_{2} \cdot 21 / 2-61 / 2 \mathrm{H}_{2} \mathrm{O}$. 
Different results have been obtained by Donnay and Donnay (1955) in an X-ray precession-method study of a natural unanalyzed single crystal. They obtained a tetragonal cell with $a_{0}$ $19.82 \pm 0.06 \mathrm{~A}, c_{0} 8.487, a_{0}: c_{0}=1: 0.4282, Z=8$, with pseudo-space group $P 4 / \mathrm{nmm}$.

\section{Physical properties}

Cleavage $\{001\}$ perfect, $\{100\}$ indistinct. Hardness $2-21 / 2$. Reliable data on the specific gravity are lacking. It presumably is somewhat higher than that of autunite and varies slightly with the water content; 3.57 (calculated for $61 / 2 \mathrm{H}_{2} \mathrm{O}$ ). Luster pearly to dull. Color lemon yellow to greenish yellow and yellowish green. Translucent to opaque in thick fragments. Meta-autunite fluoresces yellowish green in ultraviolet light, apparently less strongly than autunite.

Optical properties

\begin{tabular}{c} 
ORIENTATION \\
\hline$E$ or $\underset{Y}{X}=c$ \\
$O$ or $Z$
\end{tabular}

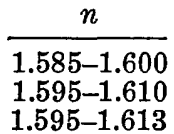

Pleochroism

Colorless to pale yellow. Dark yellow.

Dark yellow.

The range of the indices of refraction cited is that ordinarily reported for meta-autunite. (See George, 1949.) Usually biaxial negative with small and variable $2 \mathrm{~V}$; sometimes distinctly uniaxial. Crystals often show a sectoral structure, with $Y$ in each sector perpendicular to an edge of the tablet and the acute bisectrix $X$ perpendicular to the flattening, and cleavage $\{001\}$. In biaxial material, $r>v$ strong. The indices of refraction and the nature of the biaxial optical anomalies vary with the water content, as shown by Beintema (1938). The indices increase with decreasing water content, but correlated data are lacking. $2 \mathrm{~V}$ decreases on heating (Rinne, 1901a).

\section{Thermal behavior}

Autunite rapidly dehydrates to meta-autunite at or near ordinary conditions of temperature and humidity. The change is reversible. Museum specimens originally of autunite hence may be expected to consist of meta-autunite, and this is generally found to be true. There is no evidence that meta-autunite forms directly in nature. Dehydration data for meta-autunite are given by Beintema (1938). On heating in air, the water content decreases from $61 / 2 \mathrm{H}_{2} \mathrm{O}-21 / 2 \mathrm{H}_{2} \mathrm{O}$ at about $75^{\circ} \mathrm{C}$ and the mineral then passes irreversibly into meta-autunite II. The latter phase, which does not occur in nature, is orthorhombic; space group $P m m m ; a_{0}$ 
6.46 A, $b_{0} 6.98, c_{0}$ 8.67. The water content of meta-autunite II varies zeolitically between 0 and $6 \mathrm{H}_{2} \mathrm{O}$. Meta-autunite I hydrates to autunite in a moist atmosphere at room temperature.

Synthesis

Obtained as crystals by dissolving dicalcium phosphate in just enough $\mathrm{HCl}$, adding to a large volume of hot concentrated $\mathrm{NaCl}$ solution, and adding the calculated amount of uranyl nitrate; crystals are deposited on cooling (Beintema, 1938). Also obtained by treating solid autunite or hydrogen-autunite in a hot concentrated solution of $\mathrm{CaCl}_{2}$, and by heating autunite in air to between $30^{\circ}$ and $75^{\circ}$ C. (See also under Autunite.)

\section{Identification}

Meta-autunite cannot be distinguished at sight from autunite, saléeite, meta-uranocircite, and other yellow members of the torbernite and metatorbernite groups. It can be distinguished from autunite by its X-ray powder photograph and by its relatively high indices of refraction. The X-ray powder photographs of the members of the metatorbernite group closely resemble each other, so that supplementary qualitative chemical tests and optical measurements are desirable. The powder-spacing data for meta-autunite are given in the following table.

\section{$X$-ray powder-spacing data for meta-autunite ${ }^{1}$}

[Symbol: b, broad. Copper radiation, nickel filter]

\begin{tabular}{|c|c|c|c|c|c|c|}
\hline$d(\mathrm{~A})$ & $I$ & $d(\mathrm{~A})$ & $I$ & $d(\mathrm{~A})$ & $I$ & $d(\mathrm{~A})$ \\
\hline $\begin{array}{l}8.51 \\
5.39 \\
4.96 \\
4.28 \\
3.63 \\
3.50 \\
3.24 \\
2.94 \\
2.68 \\
2.61\end{array}$ & $\begin{array}{r}10 \\
7 \\
5 \\
6 \\
8 \\
9 \\
8 \\
4 \\
1 \\
3\end{array}$ & $\begin{array}{l}2.51 \\
2.47 \\
2.38 \\
2.25 \\
2.21 \\
2.14 \\
2.10 \\
2.04 \\
1.941 \\
1.893\end{array}$ & $\begin{array}{l}2 \\
2 \\
3 \\
2 \\
3 \\
3 \\
3 \\
3 \\
2 \\
1\end{array}$ & $\begin{array}{l}1.802 \\
1.757 \\
1.711 \\
1.658 \\
1.599 \\
1.568 \\
1.529 \\
1.454 \\
1.379 \\
1.346\end{array}$ & $\begin{array}{l}2 \\
3(b) \\
2 \\
1(b) \\
4 \\
2 \\
3(b) \\
2 \\
1 \\
2\end{array}$ & $\begin{array}{l}1.328 \\
1.283 \\
1.254 \\
1.186 \\
1.166 \\
1.153 \\
1.126 \\
1.109 \\
1.096 \\
1.065\end{array}$ \\
\hline
\end{tabular}

${ }^{1}$ Data on material from Sabugal, Portugal.

Natural formation and occurrence

Undoubted meta-autunite that formed directly as such by crystallization from solution in nature is not known. Its direct formation could be expected as a secondary mineral in warm, arid regions or under conditions of high salinity, and it may so form in some of the shallow mines on the Colorado Plateau. The mineral as ordinarily found is a dehydration product of autunite specimens that have been kept in the open air; localities are given under Autunite. 
Synonymy

\section{METATORBERNTTE}

Metakupferuranit Rinne (1901b). Meta-torbernite I Hallimond (1916). Meta-chalcolite. Metatorbernite Palache, Berman, and Frondel (1951). Metatorbernite was included under the name torbernite or synonyms thereof prior to the recognition by Rinne (1901b) and Hallimond (1916) that it was a separate phase.

Composition

A hydrated phosphate of copper and hexavalent uranium $\mathrm{Cu}\left(\mathrm{UO}_{2}\right)_{2}\left(\mathrm{PO}_{4}\right)_{2} \cdot 8 \mathrm{H}_{2} \mathrm{O}=\mathrm{CuO} \cdot 2 \mathrm{UO}_{3} \cdot \mathrm{P}_{2} \mathrm{O}_{5} \cdot n \mathrm{H}_{2} \mathrm{O}$. The value of $n$ ranges from 4 (?) to 8 depending on the temperature and humidity. At ordinary conditions the water content is near $8 \mathrm{H}_{2} \mathrm{O}$. The composition and range of water content of this species is well established from studies of torbernite and allied minerals, but analyses are lacking of particular specimens that have been identified by X-ray or dehydration studies to be metatorbernite. Material from the Gunnis Lake mine, Cornwall, has been shown by Hallimond (1916) and others to be metatorbernite, and the old analysis of Pisani (1861) of a specimen from this locality probably represents the mineral. The analysis given by Pelloux (1934) of material from Piedmont, Italy, probably also is of metatorbernite by reason of its low water content. These analyses are cited in the table below. Some of the analyses cited under torbernite may also be of this species. There is a further uncertainty because it is difficult to tell whether metatorbernite, identified as such by X-ray or other means, has formed directly in nature or is a dehydration product formed after the mineral has been collected and stored in the open air.

Chemical analyses of metatorbernite, in weight percent

\begin{tabular}{|c|c|c|c|c|c|c|c|}
\hline & 1 & 2 & 3 & & 1 & 2 & 3 \\
\hline $\begin{array}{l}\mathrm{CuO} \\
\mathrm{UO}_{3} \\
\mathrm{P}_{2} \mathrm{O}_{5}\end{array}$ & $\begin{array}{r}8.48 \\
61.01 \\
15.14\end{array}$ & $\begin{array}{r}8.50 \\
59.67 \\
14.00\end{array}$ & $\begin{array}{l}11.39 \\
58.77 \\
13.43\end{array}$ & $\begin{array}{l}\mathrm{H}_{2} \mathrm{O} \\
\mathrm{SiO}_{2}\end{array}$ & 15.37 & $\begin{array}{r}15.00 \\
.40\end{array}$ & 13.55 \\
\hline $\mathrm{As}_{2} \mathrm{O}_{5}$ & & 12.00 & $\begin{array}{r}10.40 \\
2.83\end{array}$ & Total & 100.00 & 97.57 & 99.97 \\
\hline
\end{tabular}

1. Theoretical weight percentages, $\mathrm{CuO} \cdot 2 \mathrm{UO}_{3} \cdot \mathrm{P}_{2} \mathrm{O}_{5} \cdot 8 \mathrm{H}_{2} \mathrm{O}$.

2. Metatorbernite(?). Gunnis Lake mine, Cornwall. Pisani (1861).

3. Metatorbernite(?). Lurisia, Piedmont, Italy. Bruna, analyst, in Pelloux (1934). no 1.6204 (Na), sp gr 3.7.

The extent of compositional variation in metatorbernite is discussed under Torbernite. Easily soluble in acids. Easily fusible. Spectrographic analyses are lacking.

\section{Crystallography}

Tetragonal, in the ditetragonal-dipyramidal crystal class $(4 / m 2 / m 2 / m)$. An angle table is given below. It is based on the 
morphological angles of Hallimond (1920) on Gunnis Lake crystals, using the unit of the X-ray structure cell in which the $c$-axis of Hallimond is halved. Morphological data on material not known with certainty to be primary metatorbernite are given by Pelloux (1934) and Buttgenbach (1924), and at least some of the observations on material reported as torbernite may be of this species. X-ray single-crystal data on Gunnis Lake material follow (from Berry, cited in Palache, Berman, and Frondel, 1951, p. 991): $a_{0} 6.96 \pm 0.03 \mathrm{~A}, c_{0} 8.62 \pm 0.04, a_{0}: c_{0}=1: 1.239$. Space group $P 4 / n m m$. Unit-cell contents $\mathrm{Cu}\left(\mathrm{UO}_{2}\right)_{2}\left(\mathrm{PO}_{4}\right)_{2} \cdot 8 \mathrm{H}_{2} \mathrm{O}$.

\section{Angle table for metatorbernite}

Tetragonal; ditetragonal-dipyramidal, $\left(4 / \mathrm{m}_{2} / \mathrm{m} 2 / \mathrm{m}\right)$

$a: c=1: 1.14 ; \quad p_{0}: r_{0}=1.14: 1$

\begin{tabular}{|c|c|c|c|c|}
\hline FORMS & $\phi$ & $\rho$ & $A$ & $\bar{M}$ \\
\hline c 001 & - & $0^{\circ} 00^{\prime}$ & $90^{\circ} 00^{\prime}$ & $90^{\circ} 00^{\prime}$ \\
\hline d 011 & $0^{\circ} 00^{\prime}$ & $48441 / 2$ & 9000 & $57551 / 2$ \\
\hline
\end{tabular}

Crystal habit

Found as thin tablets flattened on $\{001\}$. Commonly as sheaflike or subparallel aggregates of irregularly curved and composite crystals, and as rosettes; also as lamellar aggregates.

Torbernite readily dehydrates to metatorbernite, so that crystals identified as metatorbernite by X-ray or other means may be only dehydration pseudomorphs with the morphology of torbernite.

\section{Physical properties}

Cleavage $\{001\}$ perfect. Rather brittle. Hardness 21/2. Specific gravity 3.7-3.8 (measured), 3.76 (calculated). Luster vitreous to subadamantine, pearly on $\{001\}$. The luster usually is dull in pseudomorphs after torbernite, and the crystals are turbid and cracked. Color pale green to dark green. Transparent to translucent. Not fluorescent.

Optical properties

\begin{tabular}{|c|c|c|c|c|c|c|c|}
\hline \multirow{2}{*}{$\begin{array}{l}\text { ORIENTA- } \\
\text { TION }\end{array}$} & \multicolumn{7}{|c|}{$n$} \\
\hline & 1 & 2 & 3 & 4 & 5 & 6 & 7 \\
\hline$E$ & 1.630 & 1.624 & 1.624 & 1.623 & 1.618 & & 1.649 \\
\hline 0 & 1.632 & 1.628 & 1.626 & 1.625 & 1.622 & & 1.646 \\
\hline
\end{tabular}

1. Cornwall. George (1949).

2. Bavaria. Idem.

3. North Carolina. Idem.

4. Gunnis Lake. Hallimond (1920).

5. At $640 \mathrm{~m} \mu$. Bowen (1919).

6. At $515 \mathrm{~m} \mu$. Idem. Isotropic.

7. At $460 \mathrm{~m} \mu$. Idem.

Uniaxial positive in white light and in sodium light. The dispersion data of Bowen (1919) show that the mineral is 'isotropic 
at $515 \mathrm{~m} \mu$ and optically negative at shorter wavelengths. Anomalous interference colors are seen in white light. Weakly dichroic, with absorption $O>E$. Values for the indices of refraction ranging between $n_{0} 1.610$ and $n_{0} 1.628$ have been reported by Pelloux (1934) and Stočes (1918) for material probably but not certainly identical with metatorbernite. The indices of refraction vary with the content of zeolitic water within the limits of stability of the phase, but correlated data are lacking. The mineral occasionally shows an anomalous biaxial character, with $2 \mathrm{~V}$ very small and $r>v$ extreme. The crystals may show four biaxial sectors, with $Y$ in each parallel to the side of the tablet and the acute bisectrix, $X$, perpendicular to the flattening and cleavage (Rinne, 1901b). (See also under Autunite.)

Thermal behavior

See summary under Torbernite.

Synthesis

Presumably formed by metathetical reaction or by ion exchange from solutions held at sufficiently elevated temperatures. Easily obtained by boiling torbernite in water or by desiccating torbernite at ordinary temperatures.

Identification

Metatorbernite cannot be distinguished at sight from torbernite or metazeunerite. Torbernite has lower indices of refraction

$X$-ray powder-spacing data for metatorbernite ${ }^{2}$

[Symbol : d, diffuse. Copper radiation, nickel filter]

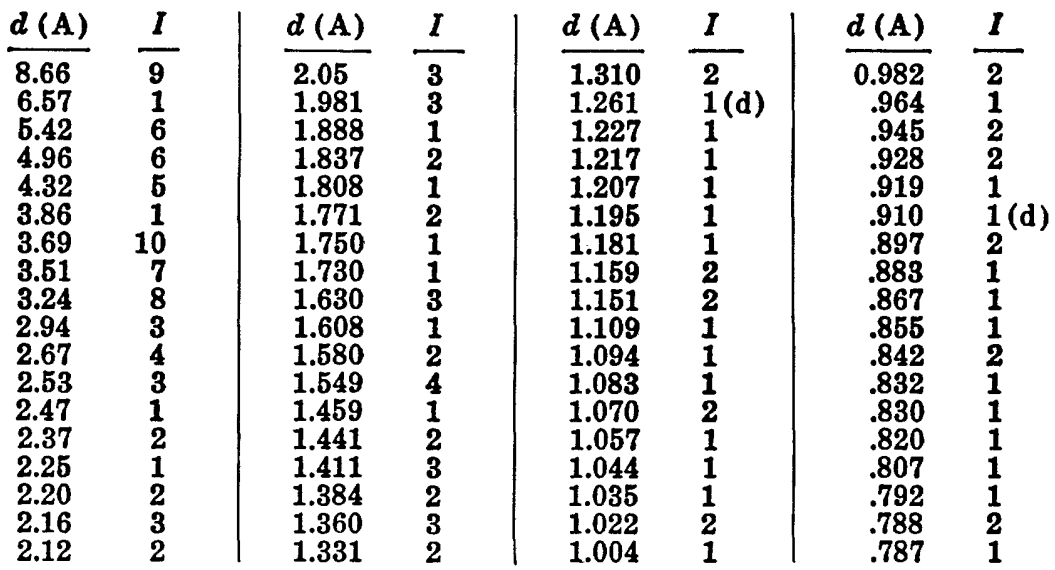

1 Material from Gunnis Lake mine, Calstock, Cornwall. Direct comparison of films of this mineral from many different localities has shown little or no significant variation in spacings. The pattern of metatorbernite differs distinctly from those of the members of the fully hydrated torbernite group. It is similar to those of the other members of the metatorbernite group and is particularly close to that of metazeunerite, Confirmatory chemical tests are desirable. 
and a different X-ray powder pattern; metazeunerite has higher indices of refraction, contains $A s$ instead of $P$, and has a very similar X-ray powder pattern. The X-ray powder-spacing data for metatorbernite are given in the above table.

Natural formation and occurrence

Metatorbernite that has crystallized directly from solution doubtless is a secondary mineral in nature with the same general occurrence and association as torbernite. Hallimond (1916, 1920) considers that the material from the Gunnis Lake mine, Calstock, Cornwall, England, formed directly from solution, chiefly by virtue of the freedom of the crystals from the cracks and turbidity associated with the alteration from torbernite. Metatorbernite specifically identified as such by X-ray or other methods has been reported from many other localities, but it is uncertain if it is an alteration product of torbernite or not. Among these localities are Lurisia in Piedmont, Italy; Wheal Bassett and other places in Cornwall, England; the Katanga district in the Belgian Congo; the Nicholson mines, Lake Athabaska district, Saskatchewan (Hogarth, 1951); Schneeberg, Joachimsthal, and other places in the Erzgebirge of Saxony and Bohemia; Okuma village, Hukusima Prefecture, Japan (Hata and Iimori, 1938). Reported from the Western United States from Utah in the Markey No. 3 mine, White Canyon, district; Grey Dawn mine, Paradox Valley district; Skyline mine, Monument Valley district; the Mineral Ten claim, Green River district (Weeks and Thompson, 1954). In quartzite in the Wilson Creek area, Gila County, Ariz. (Wells and Rambosek, 1954). The mineral probably is widespread in small amounts in the copperuranium deposits of the Colorado Plateau.

\section{META-URANOCIRCITE}

Synonymy

Uranocircite Weisbach (1877a). Meta-uranocircite Gaubert (1904); Nuffield and Milne (1953). Named from uranium and кเрко, a falcon, because it is a uranium mineral from Falkenstein, Saxony.

The name uranocircite was originally given before the complexity of the phase changes in the torbernite and metatorbernite groups accompanying variation in water content was known. Recognition of these changes led to a modification of the nomenclature in which the prefix meta- was used to designate the members of a group of lower hydrates. (See also under Torbernite.) The study of Nuffield and Milne (1953) proves that the present mineral belongs to the meta- series of hydrates of the metatorbern- 
ite group, and the name has been modified accordingly to give parallelism of nomenclature.

Composition

A hydrated phosphate of barium and hexavalent uranium, $\mathrm{Ba}\left(\mathrm{UO}_{2}\right)_{2}\left(\mathrm{PO}_{4}\right)_{2} \cdot 8 \mathrm{H}_{2} \mathrm{O}=\mathrm{BaO} \cdot 2 \mathrm{UO}_{3} \cdot \mathrm{P}_{2} \mathrm{O}_{5} \cdot 8 \mathrm{H}_{2} \mathrm{O}$. The only reported analysis, in weight percent, is cited below.

\begin{tabular}{|c|c|c|c|c|c|}
\hline & 1 & 2 & & 1 & 2 \\
\hline \multirow{2}{*}{$\begin{array}{l}\mathrm{BaO} \\
\mathrm{UO}_{3} \\
\mathrm{P}_{2} \mathrm{O}_{5}\end{array}$} & \multirow{2}{*}{$\begin{array}{l}15.16 \\
56.56 \\
14.04\end{array}$} & \multirow{2}{*}{$\begin{array}{l}14.57 \\
56.86 \\
15.06\end{array}$} & $\mathrm{H}_{2} \mathrm{O}$ & 14.24 & 13.99 \\
\hline & & & Total & 100.00 & 100.48 \\
\hline
\end{tabular}

1. Theoretical weight percentages, $\mathrm{BaO} \cdot 2 \mathrm{UO}_{3} \cdot \mathrm{P}_{2} \mathrm{O}_{5} \cdot 8 \mathrm{H}_{2} \mathrm{O}$.

2. Meta-uranocircite. Falkenstein. Winkler, analyst, in Weisbach (1877a) Partial analyses are given by Church (1877).

A complete series probably can exist between meta-uranocircite and its calcium analogue meta-autunite. This is indicated by the readiness with which $\mathrm{Ba}$ and $\mathrm{Ca}$ can be substituted by ion exchange in the laboratory (Nuffield and Milne, 1953; Beintema, 1938). Optical and $X$-ray evidence indicates that intermediate members of the Ba-Ca series occur at the Madagascar locality for meta-uranocircite. The water content of the mineral varies zeolitically over a considerable range and is close to $8 \mathrm{H}_{2} \mathrm{O}$ at ordinary room conditions of temperature and humidity. Spectographic analyses are lacking. Readily soluble in dilute acids.

\section{Crystallography}

Tetragonal, probably in the ditetragonal-dipyramidal crystal class $(4 / m 2 / m 2 / m)$. Morphological measurements are lacking. The crystals are thin tablets or thin plates flattened on $\{001\}$ with a rectangular outline produced by $\{100\}$ or $\{101\}$. The crystals usually are markedly composite, with a subparallel arrangement on $\{001\}$, and grade into fanlike groups.

X-ray single-crystal study by Nuffield and Milne (1953) of Falkenstein material gave the following data: $a_{0} 6.96 \mathrm{~A}, c_{0} 16.90$, $a_{0}: c_{0}=1: 2.428$. Space group $P 4 / \mathrm{nmm}$. Unit-cell contents $2[\mathrm{BaO} \cdot$ $\left.2 \mathrm{UO}_{3} \cdot \mathrm{P}_{2} \mathrm{O}_{5} \cdot 8 \mathrm{H}_{2} \mathrm{O}\right]$.

Material made by ion exchange of meta-autunite in $\mathrm{BaCl}_{2}$ solution at $100^{\circ} \mathrm{C}$ gave identical $\mathrm{X}$-ray results. The value of $c_{0}$ is approximately twice that of the other members of the metatorbernite group. A series from meta-autunite to meta-uranocircite by substitution of $\mathrm{Ba}$ for $\mathrm{Ca}$ hence must have a structural discontinuity. Material also has been described with $a_{0} 6.95 \mathrm{~A}$, $c_{0} 8.44$, by Baldanza (1953); $n_{0} 1.621, n_{\mathbb{H}} 1.607$ (Na).

Oriented growths of barium chloride have been observed on meta-uranocircite (Gaubert, 1904) and of meta-uranocircite on autunite and torbernite. 
Physical properties

Cleavage $\{001\}$ perfect, $\{100\}$ distinct. Not brittle. Thin plates are flexible. Hardness 2-21/2. Specific gravity 4.08 (Nuffield and Milne, 1953) ; 4.10 (calculated) ; 3.53 (Weisbach, 1877a). Luster pearly on $\{001\}$. Color yellow green. Transparent. Fluoresces green in ultraviolet light.

Optical properties

\begin{tabular}{|c|c|c|c|}
\hline ORIENTATION & $n\left(F_{A}\right.$ & ISTEIN) & PLEOChRoIsM \\
\hline $\begin{aligned} E \text { or } X & =c \\
Y & =a \\
O \text { or } Z & =a\end{aligned}$ & $\begin{array}{l}1 . \overline{621} \\
1.622\end{array}$ & $\begin{array}{l}1.610 \\
1.623 \\
1.623\end{array}$ & $\begin{array}{l}\text { Nearly colorless. } \\
\text { Pale canary yellow. } \\
\text { Pale canary yellow. }\end{array}$ \\
\hline
\end{tabular}

Natural meta-uranocircite apparently always shows an anomalous biaxial negative character, with $2 \mathrm{~V}$ small and variable and the acute bisectrix, $X$, perpendicular to the perfect cleavage $\{001\}$. The crystals also show a lamellar or polysynthetic optical "twinning", resembling that of microcline, in two directions at right angles parallel to $\{100\}$ and $\{010\}$. The extinction of the twins varies to $6^{\circ}$ from the apparent twin plane. The two sets of lamellae have the same index of refraction in a direction approximately $45^{\circ}$ to the apparent twin planes. Both the optical character and the optical twinning are connected with variation in the water content of the mineral and with the distribution of the water molecules in the crystal structure (Nuffield and Milne, 1953; Beintema, 1938). X-ray study of this and of related minerals, which exhibit the same features, shows that the twinning is not connected with a geometrical twinning of the lattice.

A sample of synthetic material crystallized by Fairchild (1929) with $\approx 6 \mathrm{H}_{2} \mathrm{O}$ was uniaxial with $n_{O} \approx 1.613$ and $n_{t} \approx 1.604$. A sample prepared by ion exchange from meta-autunite by Nuffield and Milne (1953) was almost uniaxial with $n_{0}$ 1.619. Gaubert (1904) found that Falkenstein material when heated became uniaxial in part at about $100^{\circ} \mathrm{C}$ and completely at $150^{\circ} \mathrm{C}$ and remained so up to $280^{\circ} \mathrm{C}$, accompanying loss of water to the dihydrate.

Natural material from Madagascar was found by Nuffield and Milne (1953) to vary in optical properties owing to mutual substitution of $\mathrm{Ba}$ and $\mathrm{Ca}$. Material high in $\mathrm{Ca}$ had relatively low birefringence, very small $2 V$, and faint twinning, with $n_{0} 1.607$ and $c_{0} 8.47 \mathrm{~A}$. Material high in $\mathrm{Ba}$ had higher birefringence and large $2 V$, with $n_{Y} 1.620, n_{Z} 1.622$, and $c_{0} 16.9 \mathrm{~A}$.

Data on the absorption spectrum of meta-uranocircite are given by Wherry (1929). 


\section{Natural formation}

Dehydration studies have been reported by Church (1877) on natural material from Falkenstein and by Beintema (1938) on synthetic material. Their work has been discussed by Nuffield and Milne (1953). Three different hydrates have been recognized, in each of which the water varies zeolitically with the temperature and vapor pressure over a range:

1. A phase containing more than about $10 \mathrm{H}_{2} \mathrm{O}$ as the lower limit. It is stable at room temperature only in moist air, and contains $\approx 10 \mathrm{H}_{2} \mathrm{O}$ at $20^{\circ} \mathrm{C}$ and about $11 \mathrm{~mm} \mathrm{Hg}$ (63 percent humidity). This phase, which should correspond to the fully hydrated members of the torbernite group, was found by Nuffield and Milne (1953) to be tetragonal, with $a_{0} 6.97 \mathrm{~A}, c_{0} 17.57$, and the space group $P 4_{2} 2$. Hence it is not isostructural with torbernite, which has the space group $I 4 / \mathrm{mmm}$. The existence of this phase in nature, and certainly its preservation under ordinary atmospheric circumstances in mineral collections, is unlikely.

2. A phase containing $6-10 \mathrm{H}_{2} \mathrm{O}$, stable at $20^{\circ} \mathrm{C}$ with $6 \mathrm{H}_{2} \mathrm{O}$ at vapor pressures between 1 and $5 \mathrm{~mm}$ of $\mathrm{Hg}$ (6-20 percent humidity). This phase corresponds to natural meta-uranocircite as here described. A content of about $8 \mathrm{H}_{2} \mathrm{O}$, as found, corresponds to ordinary laboratory conditions.

3. A phase containing $2-6 \mathrm{H}_{2} \mathrm{O}$, stable at $20^{\circ} \mathrm{C}$ with $2 \mathrm{H}_{2} \mathrm{O}$ at vapor pressures below $0.5 \mathrm{~mm}$ of $\mathrm{Hg}$ (below 3 percent humidity). The water is completely lost only at red heat when the phase is heated in open air. The X-ray powder pattern of this phase is virtually identical with that of the hydrate with $6-10 \mathrm{H}_{2} \mathrm{O}$; Beintema (1938) gives the cell dimensions as $a_{0} 6.96 \mathrm{~A}, c_{0} 8.53$ (after heating to redness).

\section{Synthesis}

Meta-uranocircite can be obtained by cation exchange from meta-autunite using $\mathrm{BaCl}_{2}$ solutions, and also can be crystallized from solution by reaction of phosphoric acid with a mixed water solution of barium chloride and uranyl acetate or nitrate (Beintema, 1938; Fairchild, 1929).

\section{Identification}

Meta-uranocircite closely resembles meta-autunite and other yellow or yellow-green members of the metatorbernite and torbernite groups and cannot be distinguished from them at sight. The indices of refraction are the highest of the phosphate members of these groups, but are near those of the arsenate novacekite. Qualitative tests for $\mathrm{Ba}$ and $\mathrm{P}$ are necessary for identification. The X-ray powder pattern resembles those of other members of 
the metatorbernite group but is distinctive; the powder-spacing data are given in the following table.

\section{$X$-ray powder-spacing data for meta-uranocircite}

[Copper radiation, nickel filter]

\begin{tabular}{|c|c|c|c|c|c|}
\hline$d(\mathrm{~A})$ & $I$ & $h k l$ & $d(\mathrm{~A})$ & $I$ & $h k l$ \\
\hline $\begin{array}{l}8.19 \\
5.37 \\
4.90 \\
4.21 \\
3.58 \\
3.39 \\
3.21 \\
2.91 \\
2.67 \\
2.59 \\
2.41 \\
2.35\end{array}$ & $\begin{array}{r}7 \\
6 \\
3 \\
6 \\
10 \\
2 \\
5 \\
3 \\
1 / 2 \\
4 \\
1 / 2 \\
1\end{array}$ & $\begin{array}{l}002 \\
012 \\
110 \\
004 \\
014 \\
021 \\
022 \\
122 \\
024 \\
016 \\
025 \\
222\end{array}$ & $\begin{array}{l}2.18 \\
2.12 \\
2.08 \\
2.01 \\
1.924 \\
1.883 \\
1.796 \\
1.741 \\
1.676 \\
1.589 \\
1.559 \\
1.518\end{array}$ & $\begin{array}{r}2 \\
1 \\
7 \\
4 \\
3 \\
3 \\
1 / 2 \\
3 \\
3 \\
3 \\
1 / 2 \\
5 \\
1 \\
5\end{array}$ & $\begin{array}{l}130,026 \\
132,224 \\
126 \\
018\end{array}$ \\
\hline
\end{tabular}

1 Data from Nuffield and Milne (1953) on natural material from Falkenstein, Saxony.

\section{Natural formation}

Meta-uranocircite is a secondary mineral in most of its known occurrences, but it may be a primary, low-temperature deposit in the occurrence at Falkenstein, Bavaria.

\section{Occurrence}

Found originally at Bergen near Falkenstein in Voigtland, Saxony, Germany, where it occurs in quartz veins in granite. Also found at Wölsendorf, Bavaria, Germany (Schoep and Scholz, 1931). Reported (Hintze, 1931, v. 1, no. 36, p. 999) from Schneeberg, Saxony; Srdnia Gora in the Banat, Hungary; Rosmaneira, Spain. Found in Madagascar at Vinaninkarena near Antsirabe in an alluvial deposit (Lacroix, 1922, v. 1, p. 360 ; v. 2, p. 133; Benier, 1949). Reported from uranium deposits in sandstone in the Wind River Basin, Pennington County, Wyo. (Moore and Levish, 1955 ) ; and with fluorite in the Honeycomb Hills, Utah (Wilmarth and others, 1952).

\section{METAZEUNERITE}

Synonymy

Zeunerite (part?) Weisbach $(1872,1873 a, 1877 b)$. Metazeunerite Palache, Berman, and Frondel (1951). Kupferuranit, KupferUranglimmer, pt.

The name zeunerite was originally given by Weisbach in 1872 to a hydrated arsenate of copper and uranium that was classed for many years with torbernite and autunite. Later study has shown that these minerals undergo a series of phase changes accompanying variation in water content; these phases comprise what are now called the torbernite group (fully hydrated) and 
the metatorbernite group (a lower hydrate). Almost all specimens of natural so-called zeunerite that have been examined belong to the metatorbernite group, and the name metazeunerite has been given to this material to maintain parallelism of nomenclature.

\section{Composition}

A hydrated arsenate of copper and hexavalent uranium, $\mathrm{Cu}$ $\left(\mathrm{UO}_{2}\right)_{2}\left(\mathrm{AsO}_{4}\right)_{2} \cdot 8 \mathrm{H}_{2} \mathrm{O}=\mathrm{CuO} \cdot 2 \mathrm{UO}_{3} \cdot \mathrm{As}_{2} \mathrm{O}_{5} \cdot 8 \mathrm{H}_{2} \mathrm{O}$. The only reported analysis of natural material, in weight percent, cited below, was given by Weisbach (1872) as of zeunerite but it seems from the relatively low water content to represent the present species.

\begin{tabular}{|c|c|c|c|c|c|}
\hline & 1 & 2 & & 1 & 2 \\
\hline $\mathrm{CuO}$ & $\begin{array}{r}7.76 \\
\end{array}$ & 7.49 & $\mathrm{H}_{2} \mathrm{O}$ & 14.05 & 15.68 \\
\hline $\mathrm{As}_{2} \mathrm{O}_{5}$ & 22.41 & $\begin{array}{l}00.00 \\
20.94\end{array}$ & Total & $\overrightarrow{100.00}$ & 99.97 \\
\hline
\end{tabular}

1. Theoretical weight percentages, $\mathrm{CuO} \cdot 2 \mathrm{UO}_{3} \cdot \mathrm{As}_{2} \mathrm{O}_{5} \cdot 8 \mathrm{H}_{2} \mathrm{O}$.

2. Metazeunerite(?). Schneeberg. Winkler (1873).

Phosphate ion $\left(\mathrm{PO}_{4}\right)$ doubtless can substitute for $\left(\mathrm{AsO}_{4}\right)$, but evidence of this is lacking. $\mathrm{A}$ small amount of $\left(\mathrm{AsO}_{4}\right)$ has been found in substitution for $\left(\mathrm{PO}_{4}\right)$ in the isostructural mineral metatorbernite, and dehydrated uranospathite may be an intermediate member of a series between metatorbernite and metazeunerite. The water content of metazeunerite varies zeolitically between $8 \mathrm{H}_{2} \mathrm{O}$ and $5 \mathrm{H}_{2} \mathrm{O}$. (See further under Thermal behavior.) Spectrographic analyses are lacking. Soluble in dilute acids. Fusible.

\section{Crystallography}

Tetragonal, probably crystallizing in the ditetragonal-dipyramidal crystal class $(4 / \mathrm{m} 2 / \mathrm{m} 2 / \mathrm{m})$. An angle table for the known forms based on the morphological unit and orientation of Schrauf (1872), corresponding to the X-ray unit, is given below. The form list is based on the observations of Weisbach (1877b)

Angle table for metazeunerite

Tetragonal

$a: c=1: 1.250 ; \quad p_{0}: r_{0}=1.250: 1$

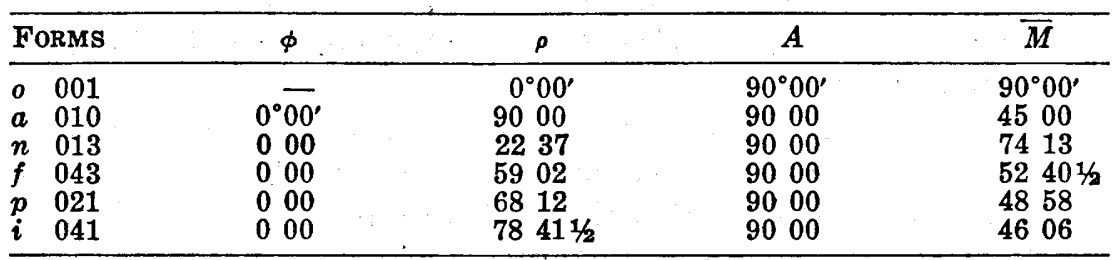

Doubtful: $m$ 110, $g$ 012, s 023, $y$ 011, $v 111$. 
and Schrauf (1872) on crystals from Schneeberg and of J. W. Frondel (1951) on crystals from Tintic, Utah. The Schneeberg crystals described by Weisbach and Schrauf were originally described under the name zeunerite, but this material, from the evidence of the chemical analysis reported, seems to have been metazeunerite. The crystals described by Ježek (1922) from Schneeberg are not certainly of this species.

An X-ray single-crystal study by J. W. Frondel (1951) of unanalyzed crystals from the Tintic district, Utah, gave $a_{0} 7.13 \mathrm{~A}$, $c_{0} 8.83, a_{0}: c_{0}=1: 1.238$. Space group $P 4 / n m m$, assuming holohedry. Cell contents $\mathrm{Cu}\left(\mathrm{UO}_{2}\right)_{2}\left(\mathrm{AsO}_{4}\right)_{2} \cdot 8 \mathrm{H}_{2} \mathrm{O}$.

\section{Crystal habit}

Found only as distinct crystals, closely resembling those of torbernite and metatorbernite. Some of the torbernite crystals figured in the early literature actually may have been of zeunerite. The published figures are summarized by Goldschmidt $(1918$, v. 5, p. 101). Usually rectangular tablets flattened on $\{001\}$; sometimes pyramidal with small terminal faces of $\{001\}$. Forms other than $\{001\}$ ordinarily are rough and striated or serrated horizontally. Also as subparallel to foliated or micaceous aggregates of platy crystals. Parallel growths have been observed of metazeunerite with troegerite and uranospinite (V. Goldschmidt, 1899; Larsen, 1921).

\section{Physical properties}

Cleavage $\{001\}$ perfect, $\{100\}$ distinct. A cleavage on $\{110\}$ is cited by George (1949). Hardness 2-21/2. Specific gravity 3.64 (Schneeberg) ; 3.79 (calculated). Luster vitreous, usually pearly on $\{001\}$. Color grass green to emerald green. Fluoresces weakly in yellow green in both long- and short-wave ultraviolet light.

Optical properties

\begin{tabular}{|c|c|c|c|c|c|c|}
\hline \multirow{2}{*}{$\begin{array}{l}\text { ORIENTA- } \\
\text { TION }\end{array}$} & \multicolumn{4}{|c|}{$n$} & \multirow[b]{2}{*}{ DICHROISM } & \multirow[b]{3}{*}{$\begin{array}{c}\text { Uniaxial } \\
\text { negative. }\end{array}$} \\
\hline & 1 & 2 & 3 & 4 & & \\
\hline 0 & 1.643 & 1.645 & 1.647 & 1.651 & $\begin{array}{l}\text { Grass green } \\
\text { to emerald }\end{array}$ & \\
\hline $\boldsymbol{D}$ & 1.623 & 一 & 1.630 & 1.635 & $\begin{array}{c}\text { green. } \\
\text { Pale green } \\
\text { or bluish } \\
\text { to nearly } \\
\text { colorless. }\end{array}$ & \\
\hline
\end{tabular}

1. Schneeberg.

2. Majuba Hill, Nev.

3. Tintic, Utah.

4. Schneeberg.

Optical anomalies have not been described. The above data are from the summaries of J. W. Frondel (1951) and George (1949), 
who cite additional data. The indices of refraction vary continuously with the content of zeolitic water within the limits of stability of the phase. Artificial material with $8 \mathrm{H}_{2} \mathrm{O}$ has $n_{0}$ 1.6451.648 and with $5 \mathrm{H}_{2} \mathrm{O}$ has $n_{o}$ 1.654. Synthetic material corresponding to the fully hydrated phase isostructural with torbernite has $n_{0} 1.602$ for $16 \mathrm{H}_{2} \mathrm{O}$ and $n_{0} 1.610$ for $10 \mathrm{H}_{2} \mathrm{O}$. The absorption spectrum has been measured by Wherry (1929).

Thermal behavior

Thermal studies of metazeunerite have been described by Bergman (1925) and J. W. Frondel (1951). Three different hydrates of $\mathrm{Cu}\left(\mathrm{UO}_{2}\right)_{2}\left(\mathrm{AsO}_{4}\right)_{2} \cdot n \mathrm{H}_{2} \mathrm{O}$ have been recognized, in each of which the water content varies zeolitically over a range depending on the temperature and vapor pressure: (a) A fully hydrated phase containing $16 \mathrm{H}_{2} \mathrm{O}-10 \mathrm{H}_{2} \mathrm{O}$, isostructural with torbernite and corresponding to zeunerite as here described; this hydrate apparently is stable, with $\approx 10 \mathrm{H}_{2} \mathrm{O}$, at ordinary laboratory conditions of temperature and humidity over short periods of time at least. Heated to $65^{\circ} \mathrm{C}$ in air, this phase breaks down to metazeunerite; the change apparently is irreversible. (b) A meta-I hydrate containing $8 \mathrm{H}_{2} \mathrm{O}$, corresponding to metazeunerite as here described. This phase is stable, with $\approx 8 \mathrm{H}_{2} \mathrm{O}$, at ordinary laboratory conditions of temperature and humidity. Material dehydrated in air by heat to $\approx 5 \mathrm{H}_{2} \mathrm{O}$ rehydrates to $\approx 8 \mathrm{H}_{2} \mathrm{O}$ in air or water at ordinary temperatures, but apparently does not convert to the fully hydrated phase. (c) A meta-II hydrate containing $5 \mathrm{H}_{2} \mathrm{O}-2 \mathrm{H}_{2} \mathrm{O}$ (?), corresponding to the meta-II hydrates of autunite and torbernite.

Synthetic material corresponding to the fully hydrated phase with $16 \mathrm{H}_{2} \mathrm{O}$ does not fluoresce but when dehydrated to the lower limit of water content at $10 \mathrm{H}_{2} \mathrm{O}$ it fluoresces weakly. The meta hydrate fluoresces green like the natural material.

\section{Synthesis}

Obtained as tiny crystals by dissolving freshly precipitated copper carbonate in excess arsenic acid and adding a solution of uranyl nitrate (Winkler, 1873). When precipitated at room temperature the phase contains $\approx 16 \mathrm{H}_{2} \mathrm{O}$ and is isostructural with fully hydrated torbernite; when heated at $65^{\circ} \mathrm{C}$ in air it breaks down to metazeunerite. Metazeunerite doubtless precipitates directly from hot solutions. (See also under Autunite.)

\section{Identification}

Metazeunerite very closely resembles zeunerite, torbernite, metatorbernite, and uranospathite, and cannot be distinguished from these minerals on sight. It differs from zeunerite, torbernite, and metatorbernite in having higher indices of refraction and 
from the latter two species in containing As in place of $P$. The X-ray powder pattern also is distinctive. Dehydrated uranospathite seems to be a variety of metazeunerite containing much $P$ in substitution for As; it has the same powder pattern, but somewhat lower indices of refraction. The X-ray powder-spacing data for natural and synthetic metazeunerite are given in the following table.

\section{$X$-ray powder-spacing data for metazeunerite}

[Copper radiation, nickel filter]

\begin{tabular}{|c|c|c|c|c|c|c|c|}
\hline \multicolumn{4}{|c|}{1} & \multicolumn{4}{|c|}{2} \\
\hline$d(\mathrm{~A})$ & $I$ & $d(\mathrm{~A})$ & $I$ & $d(\mathrm{~A})$ & $I$ & $d(\mathrm{~A})$ & $I$ \\
\hline $\begin{array}{l}8.76 \\
5.47 \\
6.04 \\
4.35 \\
3.71 \\
3.55 \\
\mathbf{3 . 2 8} \\
\mathbf{2 . 9 9} \\
2.75 \\
\mathbf{2 . 6 7} \\
\mathbf{2 . 5 7} \\
\mathbf{2 . 5 1} \\
\mathbf{2 . 4 2} \\
2.29 \\
2.24 \\
2.18 \\
\mathbf{2 . 1 5} \\
\mathbf{2 . 0 8} \\
1.994 \\
1.922 \\
1.841 \\
1.784 \\
1.746\end{array}$ & $\begin{array}{r}10 \\
5 \\
4 \\
3 \\
9 \\
7 \\
7 \\
8 \\
3 \\
2 \\
2 \\
4 \\
4 \\
3 \\
1 \\
2 \\
2 \\
2 \\
3 \\
3 \\
1 \\
1 \\
3 \\
1\end{array}$ & $\begin{array}{l}1.689 \\
1.637 \\
1.600 \\
1.566 \\
1.486 \\
1.451 \\
1.423 \\
1.400 \\
1.375 \\
1.354 \\
1.324 \\
1.281 \\
1.262 \\
1.242 \\
1.224 \\
1.208 \\
1.175 \\
1.160 \\
1.127 \\
1.118 \\
1.088 \\
1.077 \\
1.065\end{array}$ & $\begin{array}{l}1 \\
2 \\
2 \\
6 \\
1 \\
1 \\
1 \\
1 \\
2 \\
1 \\
1 \\
1 \\
1 \\
1 \\
1 \\
1 \\
2 \\
1 \\
1 \\
2 \\
1 \\
1 \\
1 \\
1\end{array}$ & $\begin{array}{l}8.93 \\
6.56 \\
5.95 \\
5.54 \\
5.04 \\
4.35 \\
4.15 \\
3.72 \\
3.56 \\
\mathbf{3 . 3 0} \\
\mathbf{3 . 1 2} \\
\mathbf{3 . 0 1} \\
\mathbf{2 . 7 7} \\
2.71 \\
2.59 \\
2.52 \\
2.42 \\
2.30 \\
2.26 \\
2.19 \\
2.15 \\
2.09 \\
2.01\end{array}$ & $\begin{array}{r}10 \\
1 \\
1 \\
6 \\
5 \\
3 \\
1 \\
9 \\
7 \\
8 \\
1 \\
3 \\
2 \\
2 \\
3 \\
4 \\
3 \\
1 \\
2 \\
2 \\
2 \\
4 \\
4\end{array}$ & $\begin{array}{l}1.937 \\
1.855 \\
1.797 \\
1.749 \\
1.695 \\
1.656 \\
1.605 \\
1.570 \\
1.429 \\
1.406 \\
1.382 \\
1.358 \\
1.329 \\
1.290 \\
1.265 \\
1.247 \\
1.225 \\
1.209 \\
1.176 \\
1.161 \\
1.130 \\
1.092 \\
1.055\end{array}$ & $\begin{array}{l}1 \\
2 \\
3 \\
2 \\
2 \\
2 \\
4 \\
3 \\
3 \\
5 \\
2 \\
2 \\
3 \\
2 \\
2 \\
1 \\
1 \\
1 \\
1 \\
1 \\
1 \\
2 \\
1 \\
1 \\
1 \\
1 \\
1\end{array}$ \\
\hline
\end{tabular}

1. Synthetic material with $8 \mathrm{H}_{2} \mathrm{O}$. J. W. Frondel (1951).

2. Natural material from Eureka, Utah, with $8 \mathrm{H}_{2} \mathrm{O}$. Idem.

Natural formation

Metazeunerite is a secondary mineral, found typically in the oxidized zone of deposits containing uraninite together with primary minerals containing arsenic, such as smaltite or enargite. It usually is associated with other secondary arsenates such as troegerite, walpurgite, uranospinite, erythrite, mimetite, pharmacosiderite, olivenite, and chalcophyllite (which it closely resembles); often with torbernite.

\section{Occurrence}

Originally found in the Walpurgis vein of the Weisser Hirsch mine at Neustädtl near Schneeberg, Saxony; the mineral here apparently has formed by dehydration of zeunerite. Also found at Cap Garonne, France (Lacroix, 1910, p. 553) ; at Wheal Gorland, Cornwall, England (Spencer, 1898); at Cala Mästra on the 
island of Monte Cristo, Italy (Millosevich, 1912). Reported from Wittichen and Heubach in the Black Forest, Baden, Germany (Sandberger, 1877), and from Zinnwald (Frenzel, 1874, p. 358), and Joachimsthal, Bohemia (Hintze, 1931, v. 1, p. 996). Found in the United States at Majuba Hill, Pershing County, Nev., and in the Centennial Eureka mine, Tintic, Utah. Reported from the Free Enterprise mine, Jefferson County, Mont. (Roberts and Gude, 1953a), and from uranium deposits west of Clancey, Jefferson County, Mont. (Roberts and Gude, 1953b). Metazeunerite has been found very sparingly in uranium deposits of the sandstone type on the Colorado Plateau. Found in Utah at several mines on Green Vein Mesa and Calf Mesa, San Rafael Swell, Emery County, at the Happy Jack mine and nearby claims in White Canyon and the Markey No. 3 mine in Red Canyon, San Juan County; in Arizona at the Monument No. 2 mine, Apache County (Weeks and Thompson, 1954; Gruner and others, 1954a). In Canada at the Nicholson mines, Lake Athabaska, Saskatchewan (Hogarth, 1951). At Brooks Mountain, Seward Peninsula, Alaska (West and White, 1952).

\section{ABERNATHYITE}

Synonymy

Abernathyite Thompson, Ingram, and Gross (1956). Named after Jess Abernathy, of Moab, Utah, owner of the uranium mine in which the mineral was first recognized and who found the first specimens.

\section{Composition}

A hydrated potassium uranyl arsenate, $\mathrm{K}_{2}\left(\mathrm{UO}_{2}\right)_{2}\left(\mathrm{AsO}_{4}\right)_{2} \cdot 8 \mathrm{H}_{2} \mathrm{O}$. Abernathyite is isostructural with the meta hydrates of the metatorbernite group. The only reported analysis, in weight percent, is as follows:

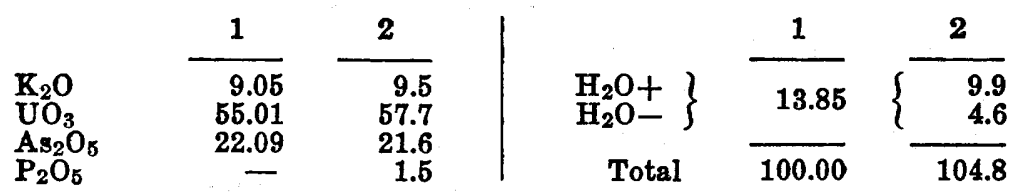

1. Theoretical weight percentages, $\mathrm{K}_{2}\left(\mathrm{UO}_{2}\right)_{2}\left(\mathrm{AsO}_{4}\right)_{2} \cdot 8 \mathrm{H}_{2} \mathrm{O}$.

2. Abernathyite. Fuemrol No. 2 mine, Emery County, Utah. Ingram. analyst, on $\approx 10-\mathrm{mg}$ sample, in Thompson, Ingram, and Gross (1956).

A small amount of $\left(\mathrm{PO}_{4}\right)$ substitutes for $\left(\mathrm{AsO}_{4}\right)$ in the analyzed material, indicating a series toward the isostructural phosphate, $\mathrm{K}_{2}\left(\mathrm{UO}_{2}\right)_{2}\left(\mathrm{PO}_{4}\right)_{2} \cdot 8 \mathrm{H}_{2} \mathrm{O}$, known as an artificial compound. Abernathyite is soluble in dilute acids. 
Crystallography and crystal habit

Tetragonal, crystallizing in the ditetragonal-dipyramidal crystal class $(4 / m 2 / m 2 / m)$, as shown by X-ray study. Crystals are thick tablets flattened on $\{001\}$ and usually are square in outline. Morphological measurements are lacking. Space group $P 4 / \mathrm{nmm}$. Unitcell dimensions: $a_{0} 7.167 \pm 0.003 \mathrm{~A}, c_{0} 9.073 \pm 0.003, a_{0}: c_{0}=$ $1: 1.266$. Unit-cell contents $2\left[\mathrm{~K}\left(\mathrm{UO}_{2}\right)\left(\mathrm{AsO}_{4}\right) \cdot 4 \mathrm{H}_{2} \mathrm{O}\right]$.

Physical properties

Cleavage $\{001\}$ perfect. Luster weakly vitreous. Color yellow. Hardness about 21/2. Specific gravity over 3.32 (measured), 3.74 (calculated for the pure As end member). Fluoresces yellow in ultraviolet light.

Optical properties

ORIENTATION

$\underset{E}{O}$

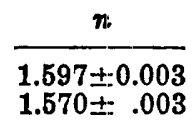

\author{
Uniaxial negative; \\ sometimes shows an \\ anomalous biaxial character \\ with $2 V \approx 5^{\circ}$.
}

The indices of refraction and $2 \mathrm{~V}$ presumably vary as a function of the content of zeolitic water, but data are lacking.

Thermal behavior

No data.

Synthesis

Hydrated potassium uranyl arsenate presumably identical witn abernathyite has been synthesized by reaction in water solution of potassium, uranyl, and arsenate ions by Lienau (1898), Rimbach (1904), and Kraft (1938). The $\mathrm{Na}, \mathrm{NH}_{4}, \mathrm{H}, \mathrm{Ca}$, and $\mathrm{Cu}$ analogues have been synthesized by Kraft (1938), Werther (1848), Mrose (1953), and others.

Identification

Abernathyite can be identified as a member of the metatorbernite group by its X-ray pattern and general physical and optical characters. It can be distinguished from other members of the group by close comparison of the X-ray patterns, but the identification should be confirmed by chemical tests for $K$ and As. The optical properties are not diagnostic. The X-ray powder-spacing data are given in the table on the following page.

Natural formation and occurrence

Abernathyite is a secondary mineral, found coating a fracture in sandstone at the Fuemrol No. 2 mine, Temple Mountain, Emery County, Utah. The mine is in bleached asphaltic conglomerate and 
sandstone of the Shinarump member of the Chinle formation that contain small nodules composed of sand grains, asphaltic material, and pyrite, with native arsenic, sphalerite, and metazeunerite on the outer surfaces. Other associated minerals are scorodite, pitticite, orpiment, realgar, and two uranyl arsenates of uncertain composition. Abernathyite is extremely rare at the locality.

\section{$X$-ray powder-spacing data for abernathyite ${ }^{1}$}

[Symbol: b, broad. Copper radiation, nickel filter]

\begin{tabular}{|c|c|c|c|c|}
\hline$d(\mathrm{~A})$ & $I$ & $h k l$ & $d(\mathrm{~A})$ & $I$ \\
\hline $\begin{array}{l}9.14 \\
5.63 \\
5.11 \\
4.58 \\
4.43 \\
3.84 \\
3.59 \\
3.34 \\
3.16 \\
3.02 \\
2.79 \\
2.61 \\
2.54 \\
2.45 \\
2.32 \\
2.28 \\
2.21 \\
2.17 \\
2.12 \\
2.07 \\
1.948 \\
1.919\end{array}$ & $\begin{array}{l}10(\mathrm{~b}) \\
7 \\
4 \\
4 \\
4 \\
8(\mathrm{~b}) \\
7 \\
8 \\
1 \\
5 \\
6(\mathrm{~b}) \\
5(\mathrm{~b}) \\
3 \\
5 \\
3 \\
6 \\
6 \\
2 \\
6 \\
6 \\
3 \\
1\end{array}$ & $\begin{array}{l}001 \\
101 \\
110 \\
002 \\
111 \\
102 \\
200 \\
112,201 \\
\\
003,211 \\
202,103 \\
113,212 \\
220 \\
221 \\
203,301 \\
310,004 \\
222,213,311 \\
104 \\
302 \\
114\end{array}$ & $\begin{array}{l}1.879 \\
1.855 \\
1.822 \\
1.797 \\
1.780 \\
1.712 \\
1.667 \\
1.625 \\
1.606 \\
1.582 \\
1.514 \\
1.482 \\
1.458 \\
1.421 \\
1.372 \\
1.359 \\
1.300 \\
1.280 \\
1.261 \\
1.240 \\
1.212 \\
1.206 \\
1.198 \\
1.187\end{array}$ & $\begin{array}{l}3 \\
1 \\
5 \\
3 \\
3 \\
6 \\
3 \\
3 \\
6 \\
3 \\
3 \\
3 \\
3 \\
6 \\
3 \\
1 \\
1 \\
5 \\
4 \\
1 \text { (b) } \\
1 \text { (b) } \\
3 \\
3 \\
1\end{array}$ \\
\hline
\end{tabular}

${ }^{1}$ Data from Thompson, Ingram, and Gross (1956) on material from Fuemrol No. 2 mine, Temple Mountain, Emery County, Utah.

Synonymy

\section{PHOSPHURANYIITE}

Phosphuranylite Genth (1879). Named in allusion to the composition, a phosphate of uranium.

Composition

A hydrated phosphate of calcium and uranyl uranium, Ca $\left(\mathrm{UO}_{2}\right)_{4}\left(\mathrm{PO}_{4}\right)_{2}(\mathrm{OH})_{4} \cdot 7 \mathrm{H}_{2} \mathrm{O}=\mathrm{CaO} \cdot 4 \mathrm{UO}_{3} \cdot \mathrm{P}_{2} \mathrm{O}_{5} \cdot 9 \mathrm{H}_{2} \mathrm{O}$. This formula was suggested by Frondel and Cuttitta (1954) on the basis of the isostructural relation to renardite, and is indicated by the analysis of Guillemin in Bignand and others (1954). The water content of phosphuranylite is uncertain; it may be $2 \mathrm{H}_{2} \mathrm{O}$ if the water lost up to about $110^{\circ} \mathrm{C}$ is taken as nonessential. The report analyses are cited below; none of them can be regarded as wholly satisfactory.

Genth deducted the $\mathrm{Pb}$ found in his analysis, no. 5, as due to admixed cerussite, although the actual presence of cerussite appar- 
Chemical analyses of phosphuranylite, in weight percent

\begin{tabular}{|c|c|c|c|c|c|c|}
\hline & 1 & 2 & 3 & 4 & 5 & 6 \\
\hline $\mathrm{CaO}$ & 4.60 & 2.3 & 2.6 & $\begin{array}{l}3.40 \\
\mathrm{Tr}\end{array}$ & $\overline{40}$ & 3.5 \\
\hline & $70 . \overline{45}$ & 76.4 & & 72.25 & $\begin{array}{r}41.70 \\
\end{array}$ & 79.1 \\
\hline $\mathrm{P}_{2} \mathrm{O}_{5}$ & 11.65 & 11.1 & 10.0 & 10.55 & 11.30 & 10.9 \\
\hline $\begin{array}{l}\mathrm{H}_{2} \mathrm{O} \\
\text { Insoluble }\end{array}$ & 13.30 & $\begin{array}{c}{[8.4]} \\
1.8\end{array}$ & 三 & $\left.\begin{array}{c}{[12.85} \\
.95\end{array}\right]$ & 10.48 & 6.5 \\
\hline Total & 100.00 & {$[100.0]$} & - & {$[\overline{100.00]}$} & 97.91 & $\overline{100.0}$ \\
\hline
\end{tabular}

1. Theoretical weight percentages, $\mathrm{CaO} \cdot 4 \mathrm{UO}_{3} \cdot \mathrm{P}_{2} \mathrm{O}_{5} \cdot 9 \mathrm{H}_{2} \mathrm{O}$.

2. Phosphuranylite. Rosmaneira, Portugal. Hallowell, analyst, in C. Frondel (1950a) on $200 \mathrm{mg}$.

3. Phosphuranylite. Ruggles mine, New Hampshire. Hallowell, analyst, in C. Frondel (1950a) on $35 \mathrm{mg}$.

4. Phosphuranylite. Carrasca, Portugal. Hallowell, analyst, in C. Frondel (1950a). Made on material containing about 10 percent of meta-autunite.

5. Phosphuranylite. Flat Rock mine, North Carolina. Genth (1879).

6. Phosphuranylite. Vatovory, Madagascar. Recalculated to 100 percent after deducting $\mathrm{Fe}_{2} \mathrm{O}_{3} 1.8, \mathrm{Al}_{2} \mathrm{O}_{3} \quad 0.4, \mathrm{SiO}_{2} 8.7$, insoluble 2.8 and $\mathrm{H}_{2} \mathrm{O}-2.9$ from original total of 99.7. Guillemin, analyst, in Bignand and others (1954).

ently was not determined, and derived the formula of the mineral as $\left(\mathrm{UO}_{2}\right)_{3}\left(\mathrm{PO}_{4}\right)_{2} \cdot 6 \mathrm{H}_{2} \mathrm{O}$. A later re-examination of type material by $\mathrm{C}$. Frondel (1950a) showed that $\mathrm{Pb}$ was absent but that $\mathrm{Ca}$ was present. Analyses 2, 3, 4, and 6 were made on material from other localities shown by X-ray and optical study to be identical with the type material.

A further complication exists in that X-ray powder study indicates that phosphuranylite is isostructural with both dewindtite and renardite (Hogarth and Nuffield, 1954). The composition of renardite and dewindtite cannot be reconciled on this basis.

The large variation observed in the optical properties of phosphuranylite indicates a variation in the chemical composition of the mineral. There seems to be a substitution of $\mathrm{Pb}$ for $\mathrm{Ca}$, and a series may extend between phosphuranylite and renardite. $V$. Ross (written communication, 1955) found in synthetic material that cation exchange can take place between $\mathrm{Ca}$ and Na. Spectrographic analyses are lacking. Soluble in acids.

\section{Crystallography and crystal habit:}

Orthorhombic. Crystal class not known. Found as thin coatings or aggregates that appear dense, earthy, or minutely scaly to the eye. Under the microscope, the mineral appears as tiny scales, plates, or laths with a rectangular outline. Morphological measurements are lacking. A single-crystal X-ray study by Hogarth and Nuffield (1954) on material from the Urgeiriça mine, Portugal, gave the following data: $a_{0} 15.85 \mathrm{~A}, b_{0} 17.42, c_{0} 13.76, a_{0}: b_{0}: c_{0}=$ 0.9098:1:0.7899. Space group $B m b$ or $B m m b$. Cell contents $6\left[\mathrm{Ca}\left(\mathrm{UO}_{2}\right)_{4}\left(\mathrm{PO}_{4}\right)_{2}(\mathrm{OH})_{4} \cdot 7 \mathrm{H}_{2} \mathrm{O}\right]$. 
In the orientation of Hogarth and Nuffield (1954), the laths are elongated on the $c$-axis and are flattened on $\{100\}$ or $\{110\}$. The optical properties conform to orthorhombic symmetry; although $2 V$ is variable and sometimes is $0^{\circ}$.

Physical properties

There is a perfect cleavage parallel to the flattening of the plates, $\{100\}$, and a second cleavage on $\{010\}$. Not brittle. Hardness about $2 \frac{1}{2}$. Specific gravity about 4.1. Color deep golden yellow to rich yellow. The color is more intense and more golden than that of the yellow members of the torbernite and metatorbernite groups. Not fluorescent in ultraviolet light.

Optical properties

\begin{tabular}{|c|c|c|c|c|c|}
\hline ORIENTATION & 1 & 2 & 3 & 4 & $\mathbf{5}$ \\
\hline $\begin{array}{l}E \text { or } \underset{Y}{Y} \\
O \text { or } Z=c\end{array}$ & $\begin{array}{l}1.658 \\
1.699 \\
1.699\end{array}$ & $\begin{array}{l}1.668 \\
1.710 \\
1.710\end{array}$ & $\begin{array}{l}1.690 \\
1.718 \\
1.718\end{array}$ & $\begin{array}{l}1.660 \\
1.700 \\
1.701 \\
\end{array}$ & $\overline{\overline{-}}$ \\
\hline $\begin{array}{l}2 V \\
\text { Optical } \\
\text { character. }\end{array}$ & $\begin{array}{c}0^{\circ}-5^{\circ} \\
\text { Biax. } \\
(-) ; \\
\text { in part } \\
\text { uniax. }\end{array}$ & $\begin{array}{c}10^{\circ}-25^{\circ} \\
\text { Biax. } \\
(-)\end{array}$ & $\begin{array}{c}5^{\circ}-20^{\circ} \\
\text { Biax. } \\
(-)\end{array}$ & $\begin{array}{c}5^{\circ}-20^{\circ} \\
\text { Biax. } \\
(-)\end{array}$ & $\underset{(-)}{12^{\circ}-22^{\circ}}$ \\
\hline
\end{tabular}

\begin{tabular}{|c|c|c|c|c|}
\hline \multirow{2}{*}{ ORIENTATION } & \multicolumn{4}{|c|}{$n$} \\
\hline & 6 & 7 & 8 & 9 \\
\hline $\begin{array}{l}E \text { or } \underset{Y}{X} \\
O \text { or } Z=c\end{array}$ & $\begin{array}{l}1.669 \\
1.710 \\
1.710\end{array}$ & $\begin{array}{r}1.674 \\
\approx 1.724 \\
1.724\end{array}$ & $\frac{\bar{Z}}{1.73 \overline{-1.768}}$ & $\begin{array}{l}1.682 \\
1.706 \\
1.708\end{array}$ \\
\hline $\begin{array}{l}2 V \\
\text { Optical } \\
\text { character. }\end{array}$ & $\underset{(-)}{\text { Small }}$ & $\begin{array}{l}5^{\circ}-10^{\circ} \\
\text { Biax. } \\
(-)\end{array}$ & $\begin{array}{l}5^{\circ}-20^{\circ} \\
\text { Biax. } \\
(-)\end{array}$ & $\underset{(-)}{51^{\circ}}$ \\
\hline $\begin{array}{l}\text { 1. Newry, } \\
\text { 2. Ruggles } \\
\text { 3. Flat Roc } \\
\text { 4. Rosmane } \\
\text { 5. Urgeiric } \\
\text { 6. Urgeiric } \\
\text { 7. Pamplon } \\
\text { 8. Wölsend } \\
\text { 9. La Crou }\end{array}$ & $\begin{array}{l}\text { C. Fror } \\
\text { New Ha } \\
\text {, North } \\
\text { rtugal. } \\
\text { ugal. Id } \\
\text { ugal. H } \\
\text { lombia. } \\
\text { varia. I } \\
\text { rance. B }\end{array}$ & $\begin{array}{l}\text { Idem. } \\
\text { Idem. } \\
\text { nd Nuffie } \\
\text { del (1950 } \\
\text { and other }\end{array}$ & 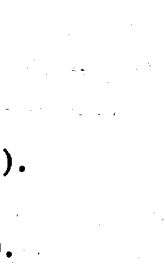 & \\
\hline
\end{tabular}

In transmitted light, deep yellow to golden yellow and distinctly pleochroic: $X$ colorless to pale yellow, $Y$ golden yellow, $Z$ golden yellow. Absorption generally $X<Y=Z$, sometimes $X<Y$ $<Z$. Sometimes sensibly uniaxial negative, but usually biaxial negative with $Z$ perpendicular to the flattening. $2 \mathrm{~V}$ is variable and ranges up to about $35^{\circ}$ but commonly is $5^{\circ}-20^{\circ}$. In biaxial material, $r>v$ strong. The indices of refraction vary over a wide range. This variation may be due in part to variation in water 
content, but probably is due largely to a substitution of $\mathrm{Pb}$ or $\mathrm{Na}$ for Ca. The material from Urgeiriça and Wölsendorf probably represents a mixture of plumboan phosphuranylite and renardite or dewindtite. C. Frondel (1950a) cites additional optical measurements.

\section{Thermal behavior}

About half of the water is lost at $110^{\circ} \mathrm{C}$.

\section{Synthesis}

Obtained by Ross (written communication, 1955) as a finegrained golden-yellow precipitate by addition of dilute solutions of trisodium phosphate and sodium hydroxide to a mixed solution of uranyl nitrate and calcium nitrate, the $\mathrm{pH}$ being maintained at about 5. The barium analogue of phosphuranylite was obtained by using barium nitrate instead of calcium nitrate. Also synthesized by Bignand, Goñi, and Guillemin (1954) by reaction of monocalcium phosphate and uranyl acetate in water at $180^{\circ} \mathrm{C}$, and by heating powdered autunite with calcium acetate and uranyl acetate in water at $180^{\circ} \mathrm{C}$; phosphuranylite can be converted to renardite by heating it with a lead salt in water at $160^{\circ} \mathrm{C}$.

\section{Identification}

Distinguished from autunite and meta-autunite, which are qualitatively of the same chemical composition, by its higher indices of refraction, lack of fluorescence, and its X-ray powder pattern. The X-ray powder-spacing data are given in the table on the following page. Renardite and dewindtite, which have similar diffraction patterns, contain lead and have higher indices of refraction. The golden-yellow color of phosphuranylite is a useful guide to identification.

\section{Natural formation}

Phosphuranylite is a secondary mineral, found associated with meta-autunite and, less commonly, with uranophane, beta-uranophane, hydrated uranium oxides, and opal. The mineral is found typically in the weathered zone of pegmatites that carry uraninite, and often occurs as films in cracks and crevices in the immediate neighborhood of altered uraninite crystals. At several localities phosphuranylite is an alteration product of meta-autunite. It also occurs sparingly in the sandstone-type uranium deposits on the Colorado Plateau. Although the mineral is widespread it has been found in only very small amounts.

Occurrence

Originally found in the Flat Rock pegmatite and the Buchanan pegmatite in Mitchell County, N. C. The specimens consist of 
$X$-ray powder-spacing data for phosphuranylite ${ }^{1}$

[Copper radiation, nickel filter]

\begin{tabular}{|c|c|c|c|c|c|c|}
\hline \multicolumn{4}{|c|}{1} & \multicolumn{3}{|c|}{2} \\
\hline$d(\mathrm{~A})$ & $I$ & $d(\mathrm{~A})$ & $I$ & $d(\mathrm{~A})$ & $I$ & $h k l$ \\
\hline $\begin{array}{r}10.16 \\
7.83 \\
7.20 \\
6.33 \\
5.83 \\
5.37 \\
4.96 \\
4.72 \\
4.33 \\
3.97 \\
3.83 \\
3.44 \\
3.36 \\
3.12 \\
3.07 \\
2.94 \\
2.86 \\
2.71 \\
2.59 \\
2.46 \\
2.43 \\
2.24 \\
2.21 \\
2.16\end{array}$ & $\begin{array}{r}1 \\
10 \\
1 / 2 \\
1 \\
8 \\
1 / 2 \\
1 \\
2 \\
3 \\
9 \\
1 \\
1 \\
2 \\
6 \\
4 \\
2 \\
6 \\
1 \\
1 \\
1 \\
2 \\
1 / 2 \\
1 \\
1\end{array}$ & $\begin{array}{l}2.10 \\
2.08 \\
2.04 \\
2.00 \\
1.895 \\
1.852 \\
1.828 \\
1.771 \\
1.719 \\
1.672 \\
1.656 \\
1.585 \\
1.537 \\
1.506 \\
1.433 \\
1.375 \\
1.358 \\
1.304 \\
1.282 \\
1.252 \\
1.236 \\
1.209 \\
1.197 \\
1.179\end{array}$ & $\begin{array}{r}1 / 2 \\
2 \\
1 \\
1 \\
5 \\
1 \\
1 \\
1 \\
3 \\
1 / 2 \\
1 \\
1 \\
2 \\
1 / 2 \\
1 \\
1 \\
1 / 2 \\
1 \\
1 \\
1 \\
1 / 2 \\
1 / 2 \\
1 / 2 \\
1\end{array}$ & $\begin{array}{r}10.34 \\
7.91 \\
5.83 \\
4.92 \\
4.73 \\
4.42 \\
4.30 \\
3.96 \\
3.88 \\
3.81 \\
3.44 \\
3.37 \\
3.15 \\
\\
3.10 \\
\\
2.93 \\
2.88\end{array}$ & $\begin{array}{r}3 \\
10 \\
5 \\
1 / 2 \\
2 \\
3 \\
1 \\
6 \\
3 \\
3 \\
2 \\
1 \\
6 \\
6 \\
\\
1 \\
6\end{array}$ & 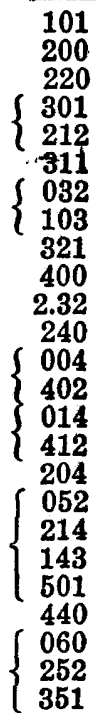 \\
\hline
\end{tabular}

${ }^{1}$ See also Bignand, Goñi, and Guillemin (1954).

1. Data from C. Frondel (1950a) on material from the Flat Rock mine, Mitchell County, N. C.

2. Data from Hogarth and Nuffield (1954) on material from Urgeiriça, Portugal.

smoky or milky quartz, feldspar, mica, and garnet coated by films of phosphuranylite and meta-autunite; one showed cubic molds of uraninite crystals partly filled by phosphuranylite. Later identified (C. Frondel, 1950a) from additional localities. These include Newry, Oxford County, Maine; the Ruggles and Palermo pegmatites in Grafton County, N. H.; Bedford Hills, Westchester County, N. Y.; Branchville, Fairfield County, Conn.; Pamplonita, Santander do Norte, Colombia; Carrasca and Urgeiriça, Portugal; Wölsendorf, Bavaria; Memões near Equador; Rio Grande do Norte, Brazil; Neudeck, Silesia. Reported by Bignand and others (1954) from La Crouzille and Margnac, Haute-Vienne, France, and Vatovory, Vinaninkarena, Madagascar. A mineral ascribed to phosphuranylite has been noted in eastern Kuangsi, China (Nan and Wu, 1943).

In the Western United States phosphuranylite has been found in Utah in the Posey mine and the North Point-Gonway claim, White Canyon district; the Cobalt No, 2 and Cactus Rat mines, 
Yellow Cat district, near Thompsons; the Grey Dawn mine, Paradox district; the Mineral Ten mine, Green River district (Weeks and Thompson, 1954). At the Wild Horse claims, Dripping Springs, near Temple Mountain, Emery County, Utah (Gruner and others, 1954a). Reported from uranium deposits in sandstone in the Wind River Basin, Wyo. (Gruner and Smith, 1955). At Marysvale, Utah, with alunite (Hamilton and Kerr, 1954a).

\section{Synonymy}

\section{RENARDITE}

Renardite Schoep (1928, 1930). Named after A. F. Renard (1842-1903), Belgian mineralogist, of the University of Ghent.

Composition

A hydrated phosphate of lead and hexavalent uranium, $\mathrm{Pb}$ $\left(\mathrm{UO}_{2}\right)_{4}\left(\mathrm{PO}_{4}\right)_{2}(\mathrm{OH})_{4} \cdot 7 \mathrm{H}_{2} \mathrm{O}=\mathrm{PbO} \cdot 4 \mathrm{UO}_{3} \cdot \mathrm{P}_{2} \mathrm{O}_{5} \cdot 9 \mathrm{H}_{2} \mathrm{O}$. The water content may be somewhat less than that given; analysis 6 gives $7 \mathrm{H}_{2} \mathrm{O}$ in the molar ratio. The four reported analyses, all made on rather impure material, are cited in the table below.

Chemical analyses of renardite, in weight percent

\begin{tabular}{|c|c|c|c|c|c|c|c|}
\hline & 1 & 2 & 3 & 4 & 5 & 6 & 7 \\
\hline \multirow{3}{*}{$\left.\begin{array}{l}\mathrm{PbO} \\
\mathrm{UO}_{3} \\
\mathrm{P}_{2} \mathrm{O}_{5} \\
\mathrm{H}_{2} \mathrm{O}+ \\
\mathrm{H}_{2} \mathrm{O}- \\
\text { Rem. }\end{array}\right\}$} & $\begin{array}{r}13.16 \\
68.92 \\
8.37\end{array}$ & \multirow{3}{*}{$\begin{array}{c}\left.\begin{array}{r}12.26 \\
64.82 \\
8.15 \\
3.77 \\
4.97 \\
6.53\end{array}\right\}\end{array}$} & $\begin{array}{r}13.05 \\
68.98 \\
8.67\end{array}$ & $\begin{array}{r}12.3 \\
67.6 \\
8.0\end{array}$ & $\begin{array}{r}12.73 \\
69.97 \\
8.31\end{array}$ & \multirow{3}{*}{$\begin{array}{r}12.65 \\
67.53 \\
8.96 \\
3.04 \\
4.67 \\
3.36\end{array}$} & $\begin{array}{r}12.8 \\
73.3 \\
8.5\end{array}$ \\
\hline & 9.55 & & 9.30 & 8.7 & 8.99 & & 4.5 \\
\hline & - & & - & 3.2 & - & & .9 \\
\hline a] & 100.00 & 100.50 & 100.00 & 99.8 & 100.00 & 100.21 & 100.0 \\
\hline
\end{tabular}

1. Theoretical weight percentages, $\mathrm{PbO} \cdot 4 \mathrm{UO}_{3} \cdot \mathrm{P}_{2} \mathrm{O}_{5} \cdot 9 \mathrm{H}_{2} \mathrm{O}$.

2. Renardite. Katanga. Schoep (1928). Remainder includes $(\mathrm{Fe}, \mathrm{Al})_{2} \mathrm{O}_{3}$ 3.68, $\mathrm{MoO}_{3}$ 0.74, quartz 2.11.

3. Analysis 2 recalculated to 100 percent after deduction of remainder.

4. Renardite. Grury, France. Branche, Chervet, and Guillemin (1951). Remainder is $\mathrm{CaO} 0.9, \mathrm{Al}_{2} \mathrm{O}_{3}$ 0.7, $\mathrm{Fe}_{2} \mathrm{O}_{3} 0.9, \mathrm{SiO}_{2}$ 0.7.

5. Analysis 4 recalculated to 100 percent after deduction of remainder.

6. Renardite. Katanga. Cuttitta, analyst, in C. Frondel and Cuttitta (1954). Remainder is $\mathrm{BaO} 0.89, \mathrm{Al}_{2} \mathrm{O}_{3} 0.31, \mathrm{Fe}_{2} \mathrm{O}_{3} \quad 0.62, \mathrm{SiO}_{2}$ 1.54. Spectrographic analysis also showed the presence of $\mathrm{Ca}, \mathrm{Mg}, \mathrm{Cu}, \mathrm{Mn}, \mathrm{Ni}, \mathrm{Y}$, and $\mathrm{V}$.

7. Renardite. Shinkolobwe, Katanga. Bignand, Goñi, and Guillemin (1954). Recalculated to 100 percent after deducting insol. 1.8 , and $\mathrm{H}_{2} \mathrm{O}-\left(110^{\circ}\right) 3.6$ percent. Remainder is $\mathrm{BaO}$.

The observed variation in the optical properties, associated with a zoning in the crystals, indicates that there is a variation in the chemical composition of the mineral. This may be a substitution of $\mathrm{Ba}$ or $\mathrm{Ca}$ for $\mathrm{Pb}$. Renardite probably is isostructural with phosphuranylite according to C. Frondel and Cuttitta (1954), and the optical data of C. Frondel (1950a) on phosphuranylite suggest that at least a partial series extends between these minerals by mutual substitution of $\mathrm{Ca}$ and $\mathrm{Pb}$. This view also is taken by 
Bignand, Goñi, and Guillemin (1954). Renardite is soluble in acids. In the closed tube it yields water and turns brown. Fuses to a black scoriaceous mass. Spectrographic analysis of Katanga material cited by C. Frondel and Cuttitta (1954) showed the presence of the following trace elements: $\mathrm{Na}, \mathrm{Ca}, \mathrm{Cu}, \mathrm{Mn}, \mathrm{Ni}, \mathrm{Y}, \mathrm{V}$.

crystallography and crystal habit

Orthorhombic, crystal class not known. The crystals, minute in size, generally are rectangular plates flattened on $\{100\}$ with $\{010\}$ and $\{101\}$ as shown in figure 14. Also lathlike by elongation along the $c$-axis; rarely elongated along the $a$-axis, or as rectangular prisms bounded by the three pinacoids; sometimes found as radial fibrous or lamellar aggregates. X-ray single-crystal study by C. Frondel and Cuttitta (1954) of the material of analysis 6 gave the orthorhombic cell dimensions: $a_{0} 16.01 \mathrm{~A}, b_{0}$ 17.5, $c_{0}$ 13.7, $a_{0}: b_{0}: c_{0}=0.9148: 1: 0.7828$. Cell contents $6\left[\mathrm{PbO} \cdot 4 \mathrm{UO}_{3} \cdot \mathrm{P}_{2} \mathrm{O}_{5} \cdot 9 \mathrm{H}_{2} \mathrm{O}\right]$. Space group probably $B m m b$, by analogy to phosphuranylite.

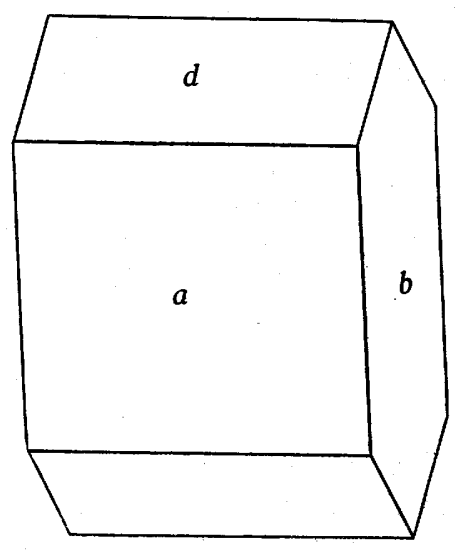

Frgure 14.-Renardite. Belgian Congo. Forms: $a\{100\}, b\{010\}, d\{101\}$. From

The only inclined form observed on the crystals, $\{101\}$, has a calculated angle of $4012^{\circ}$. The average measured angles reported by Schoep (1928) and C. Frondel and Cuttitta (1954) for this form are $39^{\circ} 47^{\prime}$ and $40^{\circ} 07^{\prime}$; the measurements are poor because of the small size and low quality of the crystals.

\section{Physical properties}

Cleavage $\{100\}$ perfect. Brittle. Hardness 31/2. Specific gravity given as a little over 4 by Schoep (1928) and as 4.35 by Branche and others (1951); 4.34 (calculated). Color yellow to brownish yellow, sometimes with a greenish cast; also golden yellow. Translucent. Luster subadamantine. Not fluorescent. 
Optical properties

\begin{tabular}{|c|c|c|c|c|c|}
\hline \multirow{2}{*}{$\begin{array}{l}\text { ORIENTA- } \\
\text { TION }\end{array}$} & \multicolumn{3}{|c|}{$n$} & \multirow[b]{2}{*}{ Pleochroism } & \multirow{4}{*}{$\begin{array}{l}\text { Biaxial } \\
\text { negative; } \\
\text { dispersion } \\
r>v\end{array}$} \\
\hline & 1 & 2 & 3 & & \\
\hline $\begin{array}{l}X=a \\
Y=c \\
Z=b\end{array}$ & $\begin{array}{l}1.715 \\
1.736 \\
1.739\end{array}$ & $\begin{array}{l}1.721 \\
1.741 \\
1.745\end{array}$ & $\begin{array}{l}1.716 \\
1.736 \\
1.740\end{array}$ & $\begin{array}{l}\text { Colorless. } \\
\text { Yellow. } \\
\text { Yellow. }\end{array}$ & \\
\hline $2 V$ & $\approx 40^{\circ}$ & $\approx 45^{\circ}$ & & & \\
\hline
\end{tabular}

1. Katanga. Schoep (1928).

2. Katanga. C. Frondel and Cuttitta (1954).

3. France. Branche and others (1951).

Some of the Katanga material has lower indices, ranging down to about $n_{x} 1.704$, and shows zones with the outer zones having the higher indices.

Thermal behavior

The water is expelled at $400^{\circ} \mathrm{C}$ (Bignand, 1955).

Synthesis

Obtained by Bignand (19.55) by heating powdered phosphuranylite with a strong water solution of lead acetate at $160^{\circ} \mathrm{C}$ and by heating powdered autunite with a solution of lead chloride or a solution of lead acetate and uranyl acetate in water at $160^{\circ} \mathrm{C}$. Also synthesized by V. Ross (written communication, 1955) by reaction of trisodium phosphate and potassium hydroxide solutions with a mixed solution of lead nitrate and uranyl nitrate in the molar ratio $2: 4: 1: 4$.

\section{Identification}

The powder-spacing data are given in the following table.

\section{$X$-ray powder-spacing data for renardite ${ }^{x}$}

[Symbol: b, broad. Copper radiation, nickel filter]

\begin{tabular}{|c|c|c|c|c|c|c|c|}
\hline$d(\mathrm{~A})$ & $I$ & $d(\mathrm{~A})$ & $I$ & $d(\mathrm{~A})$ & $I$ & $d(\mathrm{~A})$ & $I$ \\
\hline $\begin{array}{c}10.5 \\
7.97 \\
6.37 \\
5.83 \\
4.98 \\
4.80 \\
4.37 \\
3.99 \\
3.82 \\
3.38 \\
3.13\end{array}$ & $\begin{array}{r}4 \\
10 \\
3 \\
8 \\
4 \\
4 \\
7 \\
9 \\
5 \\
7 \\
8\end{array}$ & $\begin{array}{l}2.70 \\
3.09 \\
2.59 \\
2.54 \\
2.45 \\
2.27 \\
2.22 \\
2.17 \\
2.11 \\
2.09 \\
2.05\end{array}$ & $\begin{array}{l}1(b) \\
8 \\
2 \\
2 \\
3 \\
3 \\
3 \\
3 \\
1(b) \\
4(b) \\
4\end{array}$ & $\begin{array}{l}2.01 \\
1.95 \\
1.90 \\
1.85 \\
1.82 \\
1.78 \\
1.72 \\
1.70 \\
1.68 \\
1.66 \\
1.60\end{array}$ & $\begin{array}{l}4 \\
1(b) \\
6(b) \\
3 \\
2 \\
3 \\
4 \\
2 \\
2 \\
4 \\
4\end{array}$ & $\begin{array}{l}1.55 \\
1.514 \\
1.497 \\
1.471 \\
1.439 \\
1.377 \\
1.356 \\
1.302 \\
1.290 \\
1.266\end{array}$ & $\begin{array}{l}5(\mathrm{~b}) \\
3(\mathrm{~b}) \\
3(\mathrm{~b}) \\
2(\mathrm{~b}) \\
3(\mathrm{~b}) \\
4(\mathrm{~b}) \\
4(\mathrm{~b}) \\
3 \text { (b) } \\
3 \text { (b) } \\
4(\mathrm{~b})\end{array}$ \\
\hline
\end{tabular}

1 Material from the Katanga district, Belgian Congo.

Renardite has qualitatively the same chemical composition as dumontite, dewindtite, and parsonsite. It superficially resembles all of these minerals, especially dewindtite, but differs in its relatively low indices of refraction. The X-ray powder pattern closely 
resembles those of phosphuranylite and dewindtite. Phosphuranylite, rather similar in appearance to renardite, has lower indices of refraction and dewindtite has higher indices.

Natural formation and occurrence

Renardite is a secondary mineral, originally found at Kasolo in the Katanga district, Belgian Congo, where it occurs associated with torbernite, dewindtite, and dumontite. Later described by Branche and others (1951) from a number of localities in France: La Faye, Grury, Saône-et-Loire with torbernite, autunite, and kasolite; from Bauzot with autunite and uranophane; La Crouzille, Haute-Vienne; Bigay, Reliez, and Saint-Remy-sur-Durolles, Lachaux, Puy-de-Dôme. A mineral from Urgeiriça, Portugal, described by C. Frondel (1950a), probably is an intergrowth of renardite and phosphuranylite.

\section{Synonymy}

\section{DEWINDTITE}

Dewindtite Schoep (1922b, 1925a, b, 1930). Stasite Schoep (1922c, 1923b). Named after Jean Dewindt, Belgian geologist. The identity of stasite with dewindtite was recognized by Schoep $(1923 b)$. The status of dewindtite is very doubtful. The species has been made identical with renardite by Bignand, Goñi, and Guillemin (1954) on the basis of its virtual identity in X-ray powder-diffraction pattern with renardite and phosphuranylite, also remarked by C. Frondel $(1950,1954)$, and on the identity in optical properties of renardite with those of the unanalyzed so-called dewindtite from Wölsendorf described by Schoep and Scholz (1931). The chemical analyses and optical properties of the original dewindtite from the Katanga district, however, cannot be reconciled with those of renardite, although the two minerals otherwise are very similar, and further work is needed.

Composition

A hydrated phosphate of lead and hexavalent uranium. The formula is uncertain, and may be $\mathrm{Pb}_{3}\left(\mathrm{UO}_{2}\right)_{6}\left(\mathrm{PO}_{4}\right)_{4}(\mathrm{OH})_{6} \cdot 10 \mathrm{H}_{2} \mathrm{O}$ or $\mathrm{Pb}_{2}\left(\mathrm{UO}_{2}\right)_{4}\left(\mathrm{PO}_{4}\right)_{3}(\mathrm{OH})_{3} \cdot 7 \mathrm{H}_{2} \mathrm{O}$ according to the X-ray study of Hogarth and Nuffield (1954). Four rather unsatisfactory analyses have been reported. These are cited in the table below.

Analysis 2 was used by Schoep to derive the formula $\mathrm{Pb}_{3}\left(\mathrm{UO}_{2}\right)_{5}$ $\left(\mathrm{PO}_{4}\right)_{4}(\mathrm{OH})_{4} \cdot 10 \mathrm{H}_{2} \mathrm{O}$. Spectrographic analyses are lacking. Soluble in acids. Easily fusible. In the closed tube loses water and turns orange; becomes colorless when cold. 
Chemical analyses of dewindtite, in weight percent

\begin{tabular}{|c|c|c|c|c|c|}
\hline & 1 & 2 & 3 & 4 & 5 \\
\hline $\begin{array}{l}\mathrm{PbO} \\
\mathrm{UO}_{3} \\
\mathrm{P}_{2} \mathrm{O}_{5} \\
\mathrm{H}_{2} \mathrm{O} \\
\text { Rem. }\end{array}$ & $\begin{array}{r}25.75 \\
55.02 \\
10.93 \\
8.30 \\
\end{array}$ & $\begin{array}{r}24.85 \\
54.80 \\
10.14 \\
7.93 \\
-\end{array}$ & $\begin{array}{r}26.20 \\
55.77 \\
10.62 \\
6.71 \\
.40\end{array}$ & $\begin{array}{r}21.74 \\
55.50 \\
10.01 \\
5.82 \\
6.53\end{array}$ & $\begin{array}{r}26.20 \\
56.20 \\
10.60 \\
6.24 \\
.50\end{array}$ \\
\hline Total & 100.00 & 97.72 & 99.70 & 99.60 & 99.74 \\
\hline
\end{tabular}

1. Theoretical weight percentages, $3 \mathrm{PbO} \cdot 5 \mathrm{UO}_{3} \cdot 2 \mathrm{P}_{2} \mathrm{O}_{5} \cdot 12 \mathrm{H}_{2} \mathrm{O}$.

2. Dewindtite. Kasolo. Schoep $(1925 a, b)$. Crystals.

3. Dewindtite ("stasite"). Kasolo. Schoep (1922c, 1923b) $\mathrm{H}_{2} \mathrm{O}$ is ignition loss, remainder is insoluble. Duplicate determinations are cited.

4. Dewindtite. Kasolo. Schoep (1923b). Pulverulent. Remainder is $\mathrm{CaO}$ 1.32, $\mathrm{MgO} 2.75,(\mathrm{Al}, \mathrm{Fe})_{2} \mathrm{O}_{3} 2.06$, insoluble 0.40 . Impure sample, probably containing talc, etc.

5. Dewindtite. Kasolo. Steinkuhler, analyst, in Schoep (1923b). Remainder is insoluble. $\mathrm{H}_{2} \mathrm{O}$ is ignition loss.

\section{Crystallography}

Orthorhombic, crystal class not known. Found as microscopic rectangular tablets flattened on $\{100\}$ and terminated by $\{001\}$; $\{100\}$ is striated parallel to the $c$-axis. Also pulverulent to fine grained and compact. Morphological measurements are lacking. The unit cell is orthorhombic, and the dimensions are cited below. These data were obtained by Hogarth and Nuffield (1954) by the X-ray powder method, and by C. Frondel and Cuttitta (1954) by the single-crystal Weissenberg method; both studies on material from Katanga. Space group $B m b$ or $B m m b$, by analogy to phosphuranylite.

\begin{tabular}{ccc} 
& Unit-cell dimensions of dewindtite & \\
& 1 & 2 \\
$a_{0}$ & $16.00 \mathrm{~A}$ & $16.07 \mathrm{~A}$ \\
$b_{0}$ & 17.62 & 17.50 \\
$c_{0}$ & 13.66 & 13.62 \\
\hline
\end{tabular}

$a_{0}: b_{0}: c_{0}$

$0.9080: 1: 0.7752$

$0.9183: 1: 0.7783$

1. Hogarth and Nuffield (1954). 2. C. Frondel and Cuttitta (1954).

The unit-cell contents may be $4\left[\mathrm{~Pb}_{3}\left(\mathrm{UO}_{2}\right)_{6}\left(\mathrm{PO}_{4}\right)_{4}(\mathrm{OH})_{0^{\circ}}\right.$ $\left.10 \mathrm{H}_{2} \mathrm{O}\right]$ with a calculated specific gravity of 5.01 , or $6\left[\mathrm{~Pb}_{2}\left(\mathrm{UO}_{2}\right)_{4}\right.$ $\left.\left(\mathrm{PO}_{4}\right)_{3}(\mathrm{OH})_{3} \cdot 7 \mathrm{H}_{2} \mathrm{O}\right]$ with a calculated specific gravity of 5.06 .

\section{Physical properties}

Cleavage $\{100\}$ perfect. Brittle. Hardness not known. Specific gravity 5.03. Color canary yellow. Powder pale yellow. Translucent. Fluoresces green in ultraviolet light. 
Optical properties

\begin{tabular}{|c|c|c|c|c|}
\hline \multirow{2}{*}{$\begin{array}{l}\text { ORIENTA- } \\
\text { TION }\end{array}$} & \multicolumn{2}{|c|}{$n$} & \multirow[b]{2}{*}{ PLEOCHROISM } & \\
\hline & 1 & 2 & & \\
\hline $\begin{array}{l}X=a(?) \\
Y=c \\
Z=b(?)\end{array}$ & $\begin{array}{l}\overrightarrow{1.760} \\
1.768 \\
1.770\end{array}$ & $\begin{array}{l}\overline{1.762} \\
1.767 \\
1.768\end{array}$ & $\begin{array}{l}\text { Colorless. } \\
\text { Golden yellow. } \\
\text { Golden yellow. }\end{array}$ & $\begin{array}{l}\text { Biaxial negative; } \\
2 V \text { moderate; } \\
\text { dispersion } \\
r>v .\end{array}$ \\
\hline
\end{tabular}

Somewhat discordant measurements are given by Schoep (1925a) : $n_{X}$ 1.762, $n_{Y} 1.763,2 V$ large, $r<v$; optically positive. Schoep did not observe pleochroism, suggesting that his measurements were made on plates flattened on $\{100\}$ and that $X$ and $Y$ were confused with $Y$ and $Z$, respectively.

\section{Thermal behavior}

Schoep (1925a) gives dehydration data on both pulverulent and coarsely crystallized material; about 3 percent of the water is lost at $100^{\circ} \mathrm{C}$, and the rest is largely or entirely lost by $300^{\circ} \mathrm{C}$; oxygen begins to be lost toward $400^{\circ} \mathrm{C}$.

\section{Synthesis}

A yellow tetragonal compound with the composition $3 \mathrm{CaO} \cdot 5 \mathrm{UO}_{3}$. $2 \mathrm{P}_{2} \mathrm{O}_{5} \cdot 16 \mathrm{H}_{2} \mathrm{O}$ has been prepared by Blinkoff (1906). This is the calcium analogue of the formula for dewindtite proposed by Schoep. Efforts by Ross (written communication, 1955) to synthesize a phase with the composition attributed to dewindtite by Schoep were unsuccessful.

\section{Identification}

Dewindtite has the same qualitative chemical composition as renardite, dumontite, and parsonsite. It has lower indices of refraction than dumontite and parsonsite, and differs from renardite in having slightly higher indices. The X-ray powder pattern closely resembles those of renardite and phosphuranylite. Further study is needed of dewindtite, especially of its relation to renardite and to synthetic $\mathrm{Pb}\left(\mathrm{UO}_{2}\right)_{2}\left(\mathrm{PO}_{4}\right)_{2} \cdot 8 \mathrm{H}_{2} \mathrm{O}$ (lead-autunite). $\mathrm{X}$-ray powder-spacing data are not given here because the identity of the available specimens and the status of the mineral in general is in doubt.

\section{Natural formation and occurrence}

Dewindtite is a secondary mineral, found abundantly with torbernite, parsonsite, and dumontite at Shinkolobwe in the Katanga district, Belgian Congo, Africa. Reported from Wölsendorf, Bavaria (Schoep and Scholz, 1931). 
PA.RSONSITE

Synonymy

Parsonsite Schoep (1923b). Named after Arthur L. Parsons (1873- ), Professor of Mineralogy at the University of Toronto.

Composition

$\mathrm{A}$ hydrated phosphate of lead and hexavalent uranium, $\mathrm{Pb}_{2}$ $\left(\mathrm{UO}_{2}\right)\left(\mathrm{PO}_{4}\right)_{2} \cdot \mathrm{H}_{2} \mathrm{O}$. The water content is uncertain and may be $2 \mathrm{H}_{2} \mathrm{O}$. The mineral is considered by Bignand (1955) to be anhydrous with the formula $\mathrm{Pb}_{2}\left(\mathrm{UO}_{2}\right)\left(\mathrm{PO}_{4}\right)_{2}$. The three analyses so far reported are cited in the table below.

Chemical analyses of parsonsite, in weight percent

\begin{tabular}{|c|c|c|c|c|c|}
\hline & 1 & 2 & 3 & 4 & 5 \\
\hline $\begin{array}{l}\mathrm{PbO} \\
\mathrm{UO}_{3} \\
\mathrm{P}_{2} \mathrm{O}_{5} \\
\mathrm{H}_{2} \mathrm{O} \\
\text { Rem. }\end{array}$ & $\begin{array}{r}50.01 \\
32.06 \\
15.91 \\
2.02 \\
\end{array}$ & $\begin{array}{r}49.03 \\
31.42 \\
15.59 \\
3.96 \\
\end{array}$ & $\begin{array}{r}44.71 \\
29.67 \\
15.08 \\
1.56 \\
8.25\end{array}$ & $\begin{array}{r}47.43 \\
34.68 \\
14.46 \\
3.43 \\
\end{array}$ & $\begin{array}{r}48.92 \\
31.75 \\
15.92 \\
2.10 \\
1.21\end{array}$ \\
\hline Total & 100.00 & 100.00 & 99.27 & 100.00 & 99.90 \\
\hline $\mathrm{Sp} g r$ & - & - & 6.23 & 5.37 & 5.72 \\
\hline
\end{tabular}

1. Theoretical weight percentages, $\mathrm{Pb}_{2}\left(\mathrm{UO}_{2}\right)\left(\mathrm{PO}_{4}\right)_{2} \cdot \mathrm{H}_{2} \mathrm{O}$.

2. Theoretical weight percentages, $\mathrm{Pb}_{2}\left(\mathrm{UO}_{2}\right)\left(\mathrm{PO}_{4}\right)_{2} \cdot 2 \mathrm{H}_{2} \mathrm{O}$.

3. Parsonsite. Kasolo. Schoep (1923b). Remainder is $\mathrm{CaO} 0.63, \mathrm{CuO} 0.25$, $\mathrm{Al}_{2} \mathrm{O}_{3} 1.23, \mathrm{TeO}_{3} 3.01, \mathrm{MoO}_{3} 0.43, \mathrm{CO}_{2} 1.19$, insoluble 1.51. Original total given as 99.47. The analysis was made on impure material.

4. Parsonsite. Ruggles pegmatite, New Hampshire. Gonyer, analyst, in C. Frondel $(1950 \mathrm{~b})$. Recalculated to 100 percent after deduction of 5.64 percent quartz.

5. Parsonsite. Reliez, Puy-de-Dôme, France. Branche, Chervet, and Guillemin (1951). Remainder is $\mathrm{SiO}_{2} 0.47, \mathrm{Fe}_{2} \mathrm{O}_{3} 0.32, \mathrm{CaO} 0.42$.

The observed variation in the optical properties of parsonsite indicates that the composition of the mineral varies, but the mechanism of this is not known.

Spectrographic analyses have not been reported.

\section{Crystallography}

Parsonsite probably is monoclinic, but the possibility of triclinic symmetry cannot be ruled out. Goniometric morphological measurements are lacking. Visual examination under magnification, and measurements made under the microscope, show that the crystals from all of the known localities have a habit in general like those of figure 15, with the forms and angles as indicated thereon. Minute faces of $\{h k 0\}$ and $\{h k l\}$ forms also have been noted. X-ray measurements by the Weissenberg method (C. Frondel, 1950b) gave unsatisfactory results; the identity period along the $c$-axis is $6.8 \pm 0.1 \mathrm{~A}$, and the film symmetries, like the 
optical properties, indicate that the mineral probably is monoclinic. The morphology of the mineral has been described by Schoep (1923b), Buttgenbach (1947), C. Frondel (1950b), and Branche, Chervet, and Guillemin (1951).

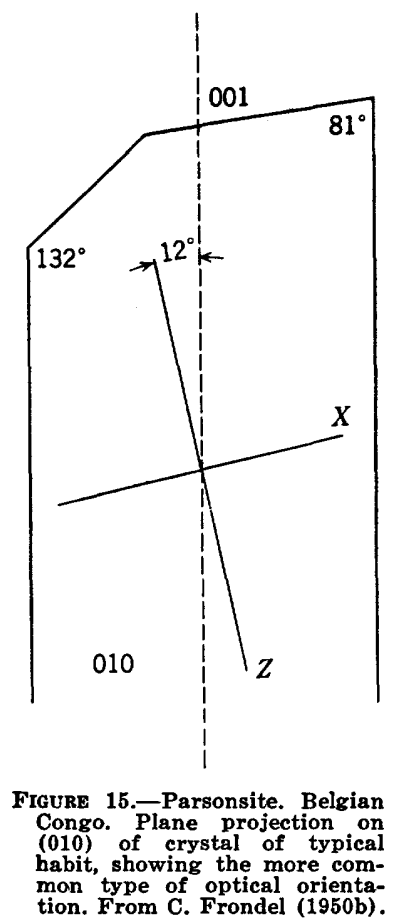

Crystal habit

The crystals usually are less than $1 \mathrm{~mm}$ in size. They are lathlike, with the elongation along the $c$-axis and the flattening on $\{010\}$ or, rarely, on $\{100\}$. There is a marked tendency for subparallel growth, and the crystals usually occur as rudely radial clusters or tufts; also as thin crusts, and as radial-fibrous aggregates. Some of the Belgian Congo material occurs as dull, earthy crusts with a chocolate-brown color, the color being due to admixture of foreign material. Microscopic inclusions may be present in the crystals, and some specimens, notably those from New Hampshire, show crystals with clear terminations that grade downward into translucent material with rough surfaces and diminished indices of refraction.

Physical properties

Cleavage $\{010\}$, but not readily observed. Fracture conchoidal. Hardness 21/2-3. Specific gravity of crystals from Reliez 5.72-5.75 (Branche, Chervet, and Guillemin, 1951); the values 6.23 of 
Schoep (1923b) and 5.37 of C. Frondel (1950b) probably are in error. Color usually pale citron yellow; also varying from pale yellow to honey brown, greenish brown; rarely pale rose. Luster subadamantine to somewhat greasy. Transparent when free of inclusions. Not fluorescent in ultraviolet light.

Optical properties

The indices of refraction and extinction angles in white light that are usually obtained are cited in the table below.

\begin{tabular}{|c|c|c|c|c|c|}
\hline \multirow[b]{2}{*}{$\begin{array}{l}\text { ORIENTA- } \\
\text { TION }\end{array}$} & \multicolumn{4}{|c|}{$n$} & \\
\hline & France & $\begin{array}{c}\text { BELGIAN } \\
\text { CoNG0 }\end{array}$ & $\begin{array}{c}\text { NEW } \\
\text { HAMPSHIRE }\end{array}$ & $\begin{array}{l}\text { WöLSEN- } \\
\text { DORF }\end{array}$ & \multirow{4}{*}{$\begin{array}{l}\text { Biaxial } \\
\text { negative. }\end{array}$} \\
\hline $\begin{array}{l}X \\
Y\end{array}$ & 1.85 & 1.85 & $\approx 1.870$ & $\approx 1.795$ & \\
\hline 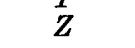 & $\overline{1.86}$ & $1 \overline{862}$ & $\approx \overline{1.890}$ & $\overline{1.815}$ & \\
\hline$Z \wedge c$ & $11^{\circ}-26^{\circ}$ & $12^{\circ}$ & $6^{\circ}-23^{\circ}$ & $8^{\circ}-20^{\circ}$ & \\
\hline
\end{tabular}

Not pleochroic. The dispersion is rather strong. Color yellow in transmitted light. The optical properties are described by Billiet (1926a), C. Frondel (1950b), and Branche, Chervet, and Guille$\min (1951)$.

The indices of refraction, extinction, extinction angle, and optical orientation show a large and unexplained variation. Part of the material from New Hampshire has $n_{X}$ more than $1.88\left(n_{z}\right.$ not known) ; part has $n_{Z}$ as low as 1.86 ( $n_{X}$ not known). Crystals from Wölsendorf have $n_{Z}$ ranging from 1.825 to less than $1.81\left(n_{X}\right.$ not known). The optical orientation generally has $Y=b$ and $Z$ inclined to the elongation, $c$, at angles of $2^{\circ}-36^{\circ}$ in the obtuse angle $\beta$, as shown in figure 15. Much of the New Hampshire material and some of the Wölsendorf material has $Y=b$ and $X$ inclined at small, varying angles to $c$ in the obtuse angle $\beta$.

Thermal behavior

The water is completely lost on heating to about $300^{\circ} \mathrm{C}$; the dehydration product and also the product of fusion at $1,000^{\circ} \mathrm{C}$ give an X-ray diffraction identical with that of unheated synthetic material (Bignand, 1955).

Synthesis

Obtained by Bignand (1955) as a fine powder by refluxing a boiling solution containing 1 millimole monocalcium phosphate, 1 millimole uranyl nitrate, and 2 millimoles lead chloride or acetate in $500 \mathrm{cc}_{2} \mathrm{O}$. Also obtained by Ross (written communication, 1955) by reaction of phosphoric acid with a mixed solution of lead nitrate and uranyl nitrate in the molar ratio $2: 2: 1$; lead autunite and finally hydrogen autunite are formed as the lead concentration is reduced to zero. 
Identification

Parsonsite superficially resembles renardite, dumontite, dewindtite phosphuranylite, and kasolite. It differs from these species in its nonrectangular crystal habit and inclined extinction. The relatively high indices of refraction are comparable only with those of dumontite. The X-ray powder-spacing data are given in the following table.

$X$-ray powder-spacing data for parsonsite ${ }^{1}$

[Copper radiation, nickel filter]

\begin{tabular}{|c|c|c|c|c|c|c|}
\hline$d(\mathrm{~A})$ & $I$ & $d(\mathrm{~A})$ & $I$ & $d(\mathrm{~A})$ & $I$ & $d(\mathrm{~A})$ \\
\hline $\begin{array}{r}10.16 \\
6.92 \\
6.03 \\
\mathbf{5 . 7 5} \\
\mathbf{5 . 1 6} \\
4.87 \\
4.25 \\
\mathbf{3 . 9 7} \\
3.44 \\
3.28\end{array}$ & $\begin{array}{r}2 \\
1 \\
2 \\
2 \\
2 \\
1 \\
10 \\
4 \\
4 \\
8\end{array}$ & $\begin{array}{l}\mathbf{3 . 1 5} \\
\mathbf{3 . 0 2} \\
2.95 \\
2.81 \\
2.73 \\
2.63 \\
2.55 \\
\mathbf{2 . 4 5} \\
2.37 \\
\end{array}$ & $\begin{array}{l}3 \\
3 \\
4 \\
4 \\
4 \\
1 \\
3 \\
2 \\
1 \\
1 \\
1\end{array}$ & $\begin{array}{l}2.27 \\
2.22 \\
2.13 \\
2.10 \\
1.990 \\
1.961 \\
1.921 \\
1.888 \\
1.852 \\
1.788\end{array}$ & $\begin{array}{r}2 \\
3 \\
6 \\
2 \\
1 \\
1 \\
1 / 2 \\
2 \\
5 \\
4\end{array}$ & $\begin{array}{l}1.728 \\
1.661 \\
1.629 \\
1.610 \\
1.578 \\
1.506 \\
1.433 \\
1.402 \\
1.370\end{array}$ \\
\hline
\end{tabular}

1 Data on material from the Ruggles pegmatite, Grafton Center, N. H. The original X-ray pattern of material from this locality (C. Frondel, 1950b) had a heavy background, and a number of the innermost lines were obscured.

Natural formation and occurrence

Parsonsite is a secondary mineral. It was originally described by Schoep (1923b) from Kasolo, Katanga district, Belgian Congo, where it occurs intimately associated with torbernite, dewindtite, and kasolite. Also found in the Ruggles pegmatite, near Grafton Center, N. H., with autunite and phosphuranylite as coatings on feldspar and quartz in the vicinity of altered uraninite crystals (C. Frondel, 1950b). Found very sparingly with meta-uranocircite in cavities in dark-purple fluorite at Wölsendorf, Bavaria (Schoep and Scholz, 1931). Found in France at La Faye, Grury, Saône-etLoire, and at Lachaux (Rophin, Reliez, Bencherelle, Gourniaud, Gagnols, Bigay and Les Peux) in Puy-de-Dôme (Branche, Chervet, and Guillemin, 1951).

Synonymy

\section{DUMONTITE}

Dumontite Schoep (1924d). Named after André Dumont (1809-57), Belgian geologist.

Composition

A hydrated basic phosphate of lead and hexavalent uranium. Formula probably $\mathrm{Pb}_{2}\left(\mathrm{UO}_{2}\right)_{3}\left(\mathrm{PO}_{4}\right)_{2}(\mathrm{OH})_{4} \cdot 3 \mathrm{H}_{2} \mathrm{O}=2 \mathrm{PbO} \cdot 3 \mathrm{UO}_{3} \cdot$ 
$\mathrm{P}_{2} \mathrm{O}_{5} \cdot 5 \mathrm{H}_{2} \mathrm{O}$. The only reported analysis, in weight percent, is cited below.

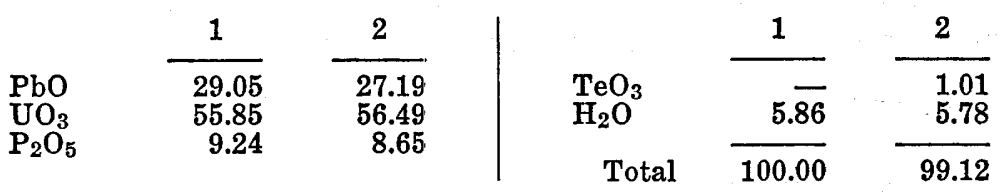

1. Theoretical weight percentages, $\mathrm{Pb}_{2}\left(\mathrm{UO}_{2}\right)_{3}\left(\mathrm{PO}_{4}\right)_{2}(\mathrm{OH})_{4} \cdot 3 \mathrm{H}_{2} \mathrm{O}$.

2. Dumontite. Shinkolobwe. Schoep (1924d).

Spectrographic analyses are lacking. Soluble in acids. Heated in the closed tube it loses water and turns orange. The water is largely or entirely lost below $300^{\circ} \mathrm{C}$. The $\mathrm{TeO}_{3}$ reported in the analyses may be due to admixture or it may be an essential constituent, presumably substituting as $\left(\mathrm{TeO}_{4}\right)$ for $\left(\mathrm{PO}_{4}\right)$.

\section{Crystallography}

Dumontite is orthorhombic, but the crystal class is not known. It occurs as small crystals elongated on the $c$-axis and flattened on $\{010\}$; striated parallel to the $c$-axis. The crystals show $\{100\}$ and $\{010\}$ and are generally terminated by $\{001\}$ and $\{013\}$ with or without $\{011\}$, or by $\{001\}$ alone. Measurements made on a

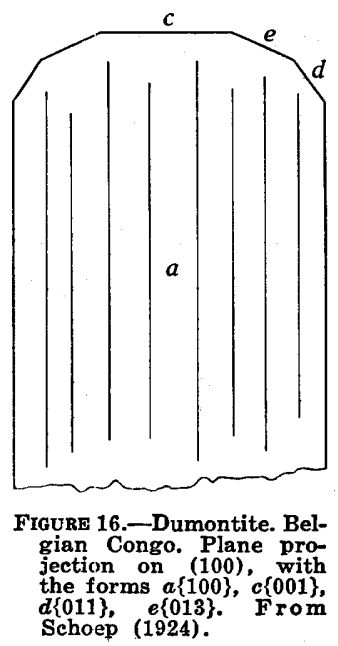

microscopic stage gave $(001) \wedge(011)=53^{\circ},(001) \wedge(013)=$ $23^{\circ} 30^{\prime}$, from which Schoep (1924d, 1930) obtained the partial ratio $b: c=1: 1.327$. X-ray single-crystal data are lacking. A crystal drawing is shown in figure 16, and photomicrographs are given by Schoep (1924d) and Buttgenbach (1947). 
Physical properties

Observations on the cleavage, hardness, and specific gravity are lacking. Color and streak yellow to ocher yellow. Translucent. Fluoresces weakly green in ultraviolet light.

Optical properties

\begin{tabular}{c} 
ORIENTATION \\
\hline$X=a$ \\
$Y=c$ \\
$Z=b$
\end{tabular}

\begin{tabular}{c}
$\frac{n}{\text { Billiet }(1926)}$ \\
\hline $\begin{array}{c}1.88 \\
1.89 \\
{[\approx 1.90]}\end{array}$
\end{tabular}

Biaxial positive; $r<v$ $2 V$ large.

Plates showing $X$ and $Y$ are not pleochroic according to Buttgenbach (1947); but Schoep (1924d, 1925b) gives $X$ pale yellow and $Y$ dark yellow, with the partial birefringence $n_{Y}-n_{X}$ as 0.010 .

Thermal behavior

A dehydration study by Schoep (1924d, 1925b) showed a loss at $100^{\circ} \mathrm{C}$ of 3.37 percent $\mathrm{H}_{2} \mathrm{O}$; at $200^{\circ}-250^{\circ} \mathrm{C}$ of 5.29 ; at $300^{\circ} \mathrm{C}$, 5.69 ; no further change at $400^{\circ} \mathrm{C}$ and $500^{\circ} \mathrm{C}$; and a further loss (of oxygen) to 6.27 at $600^{\circ} \mathrm{C}$ and 6.51 at $900^{\circ} \mathrm{C}$.

Synthesis

No data.

Identification

Distinguished from the other known phosphates of lead and uranium by its relatively high indices of refraction. The X-ray powder-spacing data for dumontite are given in the following table.

$X$-ray powder-spacing data for dumontite ${ }^{1}$

[Copper radiation, nickel filter]

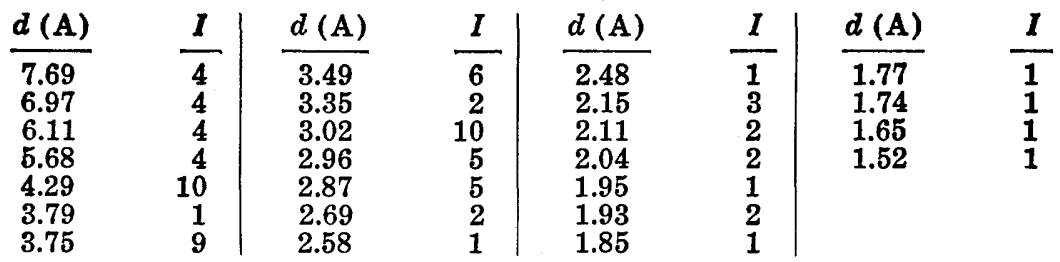

1 The specimen from the Katanga district, Belgian Congo, on which the present data were obtained, is believed to be authentic but is not wholly beyond question.

Natural formation and occurrence

Dumontite is a secondary mineral, found very sparingly with torbernite at Shinkolobwe, Katanga district, Belgian Congo. Said to occur with kasolite at Goodsprings, Nev., and with kasolite, uranophane, and autunite in the White Oak mine near Nogales, Ariz. 
WAIPURGITE

Synonymy

Walpurgin Weisbach $(1871,1877 \mathrm{c})$. Walpurgite Dana (1882b). Named from the occurrence in the Walpurgis vein at Schneeberg, Saxony.

Composition

A hydrated arsenate of bismuth and hexavalent uranium. The formula is uncertain, perhaps $\mathrm{Bi}_{4}\left(\mathrm{UO}_{2}\right)\left(\mathrm{AsO}_{4}\right)_{2} \mathrm{O}_{4} \cdot 3 \mathrm{H}_{2} \mathrm{O}$ or $(\mathrm{BiO})_{4}\left(\mathrm{UO}_{2}\right)\left(\mathrm{AsO}_{4}\right)_{2} \cdot 3 \mathrm{H}_{2} \mathrm{O}=2 \mathrm{Bi}_{2} \mathrm{O}_{3} \cdot \mathrm{UO}_{3} \cdot \mathrm{As}_{2} \mathrm{O}_{5} \cdot 3 \mathrm{H}_{2} \mathrm{O}$. The four reported analyses are cited in the table below. Analysis 2 was

Chemical analyses of walpurgite, in weight percent

\begin{tabular}{|c|c|c|c|c|c|}
\hline & 1 & 2 & 3 & 4 & 5 \\
\hline $\begin{array}{l}\mathrm{Bi}_{2} \mathrm{O}_{3} \\
\mathrm{UO}_{3} \\
\mathrm{P}_{3} \mathrm{O}_{5}\end{array}$ & $\begin{array}{l}62.05 \\
19.05\end{array}$ & $\begin{array}{l}61.8 \\
18.7 \\
.9\end{array}$ & $\begin{array}{r}61.87 \\
16.16 \\
5.88\end{array}$ & $\begin{array}{l}61.43 \\
20.29\end{array}$ & $\begin{array}{l}59.34 \\
20.54\end{array}$ \\
\hline $\begin{array}{l}\mathrm{As}_{2} \mathrm{O}_{6} \\
\mathrm{H}_{2} \mathrm{O}\end{array}$ & $\begin{array}{r}15 . \overline{30} \\
3.60\end{array}$ & $\begin{array}{r}14.1 \\
3.7\end{array}$ & $\begin{array}{r}12.45 \\
3.42\end{array}$ & $\begin{array}{r}11 . \overline{88} \\
4.32\end{array}$ & $\begin{array}{r}13 . \overline{03} \\
4.65\end{array}$ \\
\hline Total & 100.00 & 99.2 & 99.78 & 97.92 & 97.56 \\
\hline
\end{tabular}

Sp gr

5.95

1. Theoretical weight percentages for $\mathrm{Bi}_{4}\left(\mathrm{UO}_{2}\right)\left(\mathrm{AsO}_{4}\right)_{2} \mathrm{O}_{4} \cdot 3 \mathrm{H}_{2} \mathrm{O}$.

2. Schneeberg. E. Fischer (1948). Microchemical analysis on clear terminal parts of the crystals.

3. Schneeberg. Gonyer, analyst, in Evans (1950).

4, 5. Schneeberg. Winkler (1873).

made on clear material, and the others on cloudy crystals containing inclusions of bismutite (?). $\left(\mathrm{PO}_{4}\right)$ substitutes for $\left(\mathrm{AsO}_{4}\right)$ in the ratio of $1: 1.3$ in the material of analysis 3 , and $\left(\mathrm{PO}_{4}\right)$ probalbly was present in considerable amounts in the material of analyses 4 and 5 . This variation in the $\mathrm{PO}_{4}: \mathrm{AsO}_{4}$ ratio doubtless results in the observed zonal variation in the optical properties of the crystals.

Decomposed by nitric acid, leaving a white residue of bismuth arsenate, which goes into solution on the addition of hydrochloric acid.

Spectrographic analyses are lacking.

Crystallography and crystal habit

Walpurgite is triclinic, but the crystal class is not known. The mineral ordinarily occurs as distinct crystals about $2 \mathrm{~mm}$ in length. Also found as radial groupings and subparallel aggregates. The crystals are lathlike in shape by elongation along the $c$-axis and flattening on $\{010\}$. Twinning on $\{010\}$ is almost universal. The twinned crystals commonly are attached by one end of the $c$-axis, and have an oblique termination on the free end, giving a pseudo-monoclinic, gypsumlike appearance. A typical 
crystal is shown in figure 17 and additional drawings are given by Evans (1950), V. Goldschmidt (1913-23), and E. Fischer $(1945,1948)$.
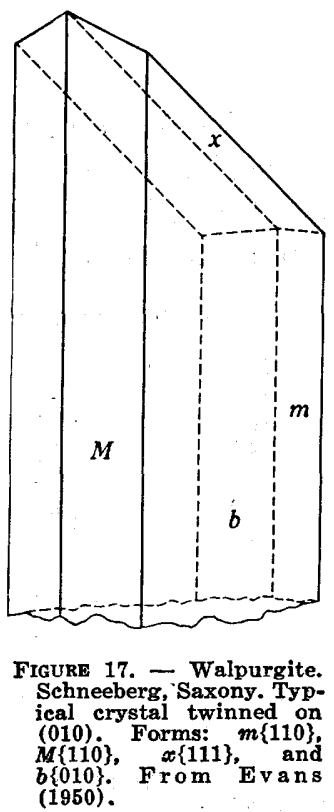

An angle table for the known forms is given below. The elements used to calculate the table are those of the X-ray unit cell obtained by Evans (1950) by the precession method on the material of analysis 3 . The relations of this cell to the morphological cells used earlier by E. Fischer $(1945,1948)$ and by Weisbach (1877) are ambiguous and have been discussed by Evans (1950). Unit-cell dimensions : $a_{0} 7.13 \mathrm{~A}, b_{0}$ 10.44, $c_{0} 5.49$, $a_{0}: b_{0}: c_{0}=0.638: 1: 0.525$. Space group probably $P \overline{1}$. Unit-cell contents uncertain. $\alpha 101^{\circ} 40^{\prime}, \beta 110^{\circ} 49^{\prime}, \gamma 88^{\circ} 17^{\prime}$.

\section{Angle table for walpurgite}

Triclinic

$a: b: c=0.638: 1: 0.525 ; \alpha 101^{\circ} 40^{\prime}, \beta 110^{\circ} 49^{\prime}, \gamma 88^{\circ} 17^{\prime}$

$p_{0}: q_{0}: r_{0}=0.748: 0.488: 1 ; \lambda 78^{\circ} 10^{\prime}, \mu 69^{\circ} 10^{\prime}, \nu 87^{\circ} 22^{\prime}$

$p_{0}^{\prime} 0.824, q_{0}^{\prime} 0.537 ; x^{\prime}{ }_{0} 0.380, y_{0}^{\prime} 0.224$

\begin{tabular}{lrrrrrr}
\hline FORMS & \multicolumn{1}{c}{$\phi$} & $\rho$ & $A$ & $B$ & \multicolumn{1}{c}{$C$} \\
\hline$b$ & 010 & $0^{\circ} 00^{\prime}$ & $90^{\circ} 00^{\prime}$ & $87^{\circ} 22^{\prime}$ & - & $78^{\circ} 10^{\prime}$ \\
$m \quad 110$ & 5504 & 9000 & 3218 & $55^{\circ} 04^{\prime}$ & 6616 \\
$M \quad \overline{1} 0$ & 12115 & 9000 & 3353 & 12115 & 7858 \\
$x$ & $\overline{1} \overline{11} 1$ & -12927 & 2929 & 11331 & 12927 & 5310 \\
\hline
\end{tabular}


Physical properties

Cleavage $\{010\}$ perfect. Rather brittle. Hardness 31/2. Specific gravity 6.69 (calculated from formula proposed by E. Fischer, 1948) ; measured values of 5.76 and 5.95 have been reported (Evans, 1950) but are probably low owing to inclusions and porosity in the samples. The specific gravity decreases with increasing substitution of $\mathrm{P}$ for As. Luster adamantine to greasy. Color wax yellow or straw yellow. Streak pale brownish yellow. Transparent to translucent. The crystals generally are turbid or cloudy owing to minute pores and inclusions; they commonly have a transparent zone at the free termination. Not fluorescent in ultraviolet light.

Optical properties

In transmitted light, colorless to pale yellow. Not pleochroic.

\begin{tabular}{|c|c|c|c|c|}
\hline \multirow{2}{*}{$\begin{array}{l}\text { ORIENTA- } \\
\text { TION }\end{array}$} & & \multirow[b]{2}{*}{ PleOChrorsm } \\
\hline & JOACHIMSTHAL & SCFINEEBERG & ScHNEAEBERG & \\
\hline $\begin{array}{l}X \\
Y\end{array}$ & $\begin{array}{l}1.90 \pm 0.03 \\
2.00 \pm .03\end{array}$ & $\begin{array}{l}1.871 \pm 0.005 \\
1.975 \pm .005\end{array}$ & $\begin{array}{l}1.91 \\
2.00\end{array}$ & $\begin{array}{l}\text { Colorless. } \\
\text { Very faint greenish } \\
\text { yellow. }\end{array}$ \\
\hline$Z$ & $2.05 \pm .03$ & $2.005 \pm .005$ & 2.06 & $\begin{array}{l}\text { Very faint greenish } \\
\text { yellow. }\end{array}$ \\
\hline
\end{tabular}

$2 V \quad$ Medium large $52^{\circ}$ (calc.) $50^{\circ}-60^{\circ}$

Biaxial negative; dispersion slight, $r<v$.

The rhomboidal laths have plane angles under the microscope of about $66^{\circ}$ and $114^{\circ} . X$ is nearly normal to the plates, and $Y^{\prime}$ makes an angle of about $12^{\circ}$ with the long edge in the obtuse angle. Plates turned on edge show twinning parallel to the flat face with an extinction angle of about $8^{\circ}$. The indices of refraction in zoned crystals vary by at least 0.03 , probably due to the variation in the ratio of $A s$ to $P$. The clear borders have slightly higher indices of refraction. The above optical description is from Larsen (1921) and George (1949).

Thermal behavior

Crystals become brown when heated and pass into orange yellow on cooling. Does not decrepitate. Yields water in the closed tube.

Synthesis

No data.

Identification

Walpurgite and the ill-defined oxide uranospherite are the only uranium minerals containing bismuth as an essential major constituent. Distinguished from the other uranium arsenates by its 
relatively high indices of refraction and specific gravity. The crystal form also is distinctive. The X-ray powder-spacing data are given in the following table.

$X$-ray powder-spacing data for walpurgite ${ }^{1}$

[Symbol: b, broad. Copper radiation, nickel filter]

\begin{tabular}{|c|c|c|c|c|c|c|c|}
\hline$d(\mathrm{~A})$ & $I$ & $d(\mathrm{~A})$ & $I$ & $d(\mathrm{~A})$ & $I$ & $d(\mathrm{~A})$ & $I$ \\
\hline $\begin{array}{c}10.65 \\
9.9 \\
6.56 \\
5.64 \\
5.44 \\
5.01 \\
4.87 \\
4.10\end{array}$ & $\begin{array}{r}1 \\
4 \\
1 \\
1 \\
1 \\
1 / 2 \\
1 \\
1 / 2\end{array}$ & $\begin{array}{l}3.97 \\
3.44 \\
3.38 \\
3.25 \\
3.11 \\
3.05 \\
2.72 \\
2.59\end{array}$ & $\begin{array}{r}1 \\
2 \\
2 \\
5 \\
10 \\
5 \\
4 \\
1 \text { (b) }\end{array}$ & $\begin{array}{l}2.50 \\
2.41 \\
2.33 \\
2.24 \\
2.19 \\
2.12 \\
2.07 \\
2.002\end{array}$ & $\begin{array}{l}1(b) \\
4(b) \\
1(b) \\
1(b) \\
3 \\
2(b) \\
2(b) \\
3(b)\end{array}$ & $\begin{array}{l}1.922 \\
1.895 \\
1.852 \\
1.807 \\
1.774 \\
1.695 \\
1.695\end{array}$ & $\begin{array}{l}2(b) \\
3(b) \\
3(b) \\
3(b) \\
3(b) \\
4 \\
4\end{array}$ \\
\hline
\end{tabular}

${ }^{1}$ Data on material from Schneeberg. Saxony.

Natural formation

Walpurgite is a secondary mineral, found in the oxidized zone of a vein carrying uraninite, cobalt and nickel arsenides, and native bismuth from which the $\mathrm{U}, \mathrm{Bi}$, and As content of the mineral has been derived.

occurrence

Originally found in the Walpurgis vein of the Weisser Hirsch mine at Neustädtel near Schneeberg, Saxony. It is here associated with troegerite, zeunerite, uranospherite, uranospinite, and torbernite. All but torbernite were first described as new species by Weisbach from this occurrence. Said also to occur at Joachimsthal, Bohemia (Larsen, 1921), from a specimen so labeled in the U. S. National Museum (no. 83971).

\section{VANADATES}

The seven known vanadates that contain uranium as an essential constituent include two important ore minerals, carnotite and tyuyamunite (with tyuyamunite's dehydration product, metatyuyamunite). The ill-defined mineral ferghanite and an unnamed mineral described by Chirvinsky (1925) may be related to or identical with metatyuyamunite. Carnotite, tyuyamunite, metatyuyamunite, and sengierite are layer structures containing zeolitic water and undergo cation exchange. The two remaining minerals uvanite and rauvite are fine-grained substances found impregnating sandstone and are not satisfactorily characterized in either their physical or chemical properties. 


\section{CARNOTITE}

Synonymy

Carnotite Friedel and Cumenge (1899). Named after MarieAdolphe Carnot (1839-1920), French mining engineer.

Composition

A hydrated vanadate of potassium and hexavalent uranium, $\mathrm{K}_{2}\left(\mathrm{UO}_{2}\right)_{2}\left(\mathrm{VO}_{4}\right)_{2} \cdot n \mathrm{H}_{2} \mathrm{O}$. The water is partly zeolitic and varies with the humidity at ordinary temperatures. Fully hydrated material contains about $3 \mathrm{H}_{2} \mathrm{O}$ and $n$ can range down at least to about $1 \mathrm{H}_{2} \mathrm{O}$. Two superior analyses are cited below; additional analyses are cited by Hintze (1931) and Doelter (1918).

Chemical analyses of carnotite, in weight percent

\begin{tabular}{|c|c|c|c|c|c|c|c|}
\hline & 1 & 2 & 3 & & 1 & 2 & 3 \\
\hline \multirow{4}{*}{$\begin{array}{l}\mathrm{Na}_{2} \mathrm{O} \\
\mathrm{K}_{2} \mathrm{O} \\
\mathrm{CaO} \\
\mathrm{MgO} \\
\mathrm{Fe}_{2} \mathrm{O}_{3}\end{array}$} & 10,44 & $\begin{array}{l}0.35 \\
9.58\end{array}$ & $\begin{array}{r}0.16 \\
10.00\end{array}$ & $\mathrm{UO}_{3}$ & $\begin{array}{l}63.42 \\
20.16\end{array}$ & $\begin{array}{l}65.62 \\
2112\end{array}$ & $\begin{array}{l}62.26 \\
20.57\end{array}$ \\
\hline & & .64 & .66 & $\mathrm{H}_{2} \mathrm{O}$ & 5.98 & 1.35 & 4.90 \\
\hline & - & .22 & .30 & Rem. & - & .48 & .37 \\
\hline & - & .04 & . b5 & Total & 100.00 & 99.40 & 99.77 \\
\hline
\end{tabular}

1. Theoretical weight percentages, $\mathrm{K}_{2}\left(\mathrm{UO}_{2}\right)_{2}\left(\mathrm{VO}_{4}\right)_{2} \cdot 3 \mathrm{H}_{2} \mathrm{O}$.

2. Carnotite. Cane Springs Pass, Utah. Hess and Foshag (1927). Remainder is $\mathrm{Al}_{2} \mathrm{O}_{3} 0.16$, insoluble 0.32 , with traces of $\mathrm{CuO}, \mathrm{PbO}, \mathrm{P}_{2} \mathrm{O}_{5}$. Air dried. Very pure sample.

3. Carnotite. Temple Mountain, Utah. Remainder is $\mathrm{CuO} 0.07, \mathrm{SO}_{3} \mathbf{0 . 2 6}$, insoluble 0.04. Dried at $16 \mathrm{~mm} \mathrm{H}_{2} \mathrm{O}$. Hillebrand (1924).

The small amounts of $\mathrm{Ca}, \mathrm{Ba}, \mathrm{Mg}$, and $\mathrm{Na}$ reported in most analyses of carnotite may be due to isomorphous substitution, especially as carnotite readily undergoes cation exchange. The $\mathrm{Ca}$ also may be due to admixture of tyuyamunite or metatyuyamunite. Spectrographic analyses of carnotite have not been reported. The mineral is easily soluble in dilute acids.

Crystallography and crystal habit

Carnotite is monoclinic, in the prismatic crystal class $(2 / m)$, according to the X-ray study of Donnay and Donnay (1955) on material from Cane Springs, Utah. Unit-cell dimensions are: $a_{0} 10.47 \mathrm{~A}, b_{0}$ 8.41, $c_{0} 6.91, a_{0}: b_{0}: c_{0}=1.245: 1: 0.822 . \beta 103^{\circ} 40^{\prime}$. Space group $P 2_{1} / a$. Cell contents $2\left[\mathrm{~K}_{2}\left(\mathrm{UO}_{2}\right)_{2}\left(\mathrm{VO}_{4}\right)_{2} \cdot n \mathrm{H}_{2} \mathrm{O}\right]$.

Carnotite occurs as a powder or as loosely coherent microcrystalline aggregates; sometimes as firm, compact masses; also disseminated or as coatings; rarely as crusts or aggregates of tiny platy crystals. Under the optical or electron microscopes, the crystals generally have a rhomboidal or diamond-shaped outline and 
are flattened on $\{001\}$; also elongated along the $b$-axis to lathlike forms, with $\{100\}$ and $\{110\}$ or $\{120\} ;(110) \wedge(1 \overline{10}) \approx 78^{\circ}$ (Crook and Blake, 1910). Typical crystal habits are shown in figure 18. The crystals simulate orthorhombic symmetry in both habit and optical properties. Carnotite crystals are sometimes twinned, with $\{001\}$ as twin plane and composition plane.

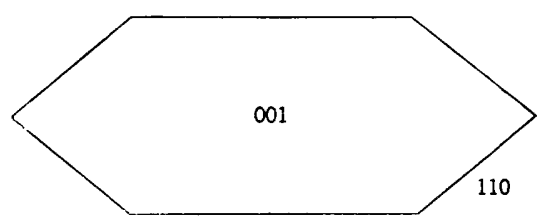

$A$

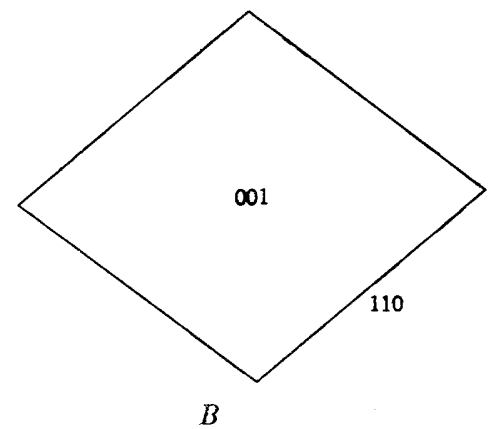

$B$

Frgure 18.-Carnotite. $A, B$. Typical habit as seen under the microscope.

Artificial anhydrous $\mathrm{K}\left(\mathrm{UO}_{2}\right)\left(\mathrm{VO}_{4}\right)$ is closely related in structure to carnotite. Sundberg and Sillén (1949) found it to be monoclinic with the space group $P 2_{1} c ; a_{0} 10.430 \mathrm{~A}, b_{0} 8.403, c_{0}$ $6.590 ; \beta 104^{\circ} 12^{\prime}$. Unit-cell contents $4\left[\mathrm{~K}\left(\mathrm{UO}_{2}\right)\left(\mathrm{VO}_{4}\right)\right]$; specific gravity 5.03 (calculated). The crystal structure is based on sheets of the composition $\left(\mathrm{UO}_{2} \mathrm{VO}_{4}\right)_{n}^{-n}$ interlaminated parallel to $\{001\}$ with sheets of $\mathrm{K}$ ions. The natural hydrated material (carnotite) apparently has a similar structure with $\mathrm{H}_{2} \mathrm{O}$ molecules between the vanadate layers; the $\{001\}$ spacings increase with increasing content of water (Murata and others, 1951).

Physical properties

Cleavage $\{001\}$ perfect, micaceous. Hardness not known, but soft. Not brittle. Specific gravity 4.70 (Cane Springs, Utah); lower values are usually obtained, due to porosity of the sample. Fine-grained masses dull or earthy; also pearly or showing a silky sheen when coarsely crystallized. Color bright yellow to lemon yellow, also greenish yellow. Not fluorescent. At liquid-air temperature, carnotite fluoresces greenish yellow (Haberlandt, Hernegger, and Scheminzky, 1950).

Optical properties

The indices of refraction increase as the content of water decreases. The indices of the material of analysis 2, cited below, were obtained on a sample dried over concentrated $\mathrm{H}_{2} \mathrm{SO}_{4}$ that contained 1.32 percent $\mathrm{H}_{2} \mathrm{O}$; when rehydrated to 1.72 percent $\mathrm{H}_{2} \mathrm{O}$ 
Optical properties of carnotite

\begin{tabular}{|c|c|c|c|c|c|}
\hline \multirow{2}{*}{$\begin{array}{l}\text { ORIENTA- } \\
\text { TION }\end{array}$} & \multicolumn{5}{|c|}{$n$} \\
\hline & 1 & 2 & 3 & 4 & 5 \\
\hline$X=c$ & 1.750 & - & - & $\overline{1.76}$ & 1.77 \\
\hline$Y=b$ & 1.925 & 1.895 & 2.06 & 1.90 & 1.92 \\
\hline$Z \wedge a \approx 14^{\circ}$ & 1.950 & 1.92 & 2.08 & 1.92 & 1.94 \\
\hline $2 V$ & $\approx 43^{\circ}$ & - & Small & $\approx 50^{\circ}$ & $50^{\circ}-60^{\circ}$ \\
\hline $\begin{array}{l}\text { ORIENTA- } \\
\text { TION }\end{array}$ & $\frac{n}{6}$ & \multicolumn{2}{|c|}{ PLEOChRoISM } & \multirow{3}{*}{\multicolumn{2}{|c|}{$\begin{array}{l}\text { Biaxial negative; } \\
\text { dispersion } r<v\end{array}$}} \\
\hline $\begin{array}{l}X=c \\
Y=b\end{array}$ & $\begin{array}{l}1.78 \\
-\end{array}$ & \multirow{2}{*}{\multicolumn{2}{|c|}{$\begin{array}{l}\text { Colorless to pale grayish yellow, } \\
\text { or nearly colorless. } \\
\text { Canary yellow to lemon yellow, } \\
\text { or greenish yellow. } \\
\text { Canary yellow to lemon yellow, } \\
\text { or slightly darker greenish } \\
\text { yellow than } Y \text {. }\end{array}$}} & & \\
\hline$Z \wedge a \approx 14^{\circ}$ & 1.96 & & & & \\
\hline $\begin{array}{l}\text { 1. Long Pa } \\
\text { 2. Locality } \\
\text { 3. Moab, U } \\
\text { 4. San Mig } \\
\text { 5. Calamity } \\
\text { 6. Olary, A }\end{array}$ & $\begin{array}{l}\text { olo. L } \\
\text { cnown. } \\
\text { Analy } \\
\text { ounty, } \\
\text { a, Colc } \\
\text { lia. Id }\end{array}$ & $\begin{array}{l}\text { arsen (1921). } \\
\text { Idem. } \\
\text { ysis } 2 \text { (see tal } \\
\text { Colo. George } \\
\text { lo. Idem. } \\
\text { dem. }\end{array}$ & $\begin{array}{l}\text { 243). Hess } \\
9) .\end{array}$ & and & (1927). \\
\hline
\end{tabular}

the indices decreased to $n_{Y} 2.02, n_{z} 2.06$ (the indices were measured in melts, and may be high owing to dehydration). When the crystal form can be discerned, $X$ is perpendicular to the plates and $Y$ bisects the acute termination of the laths or rhombs. The material generally is too fine grained for satisfactory optical study.

Thermal behavior

Observations on the dehydration of carnotite are given by Hillebrand (1924), Rohde (1925), and Murata and others (1951). The water content varies readily at ordinary conditions of temperature and humidity. The maximum content of water at room temperature in air saturated with moisture is near $3 \mathrm{H}_{2} \mathrm{O}$.

Synthesis

Microcrystalline carnotite has been obtained by Murata and others (1951) by dissolving potassium pyrovanadate in water, adjusting the solution to $\mathrm{pH} 6$, and adding the stoichiometric amount of uranyl nitrate. A gelatinous precipitate forms, which can be made coarse by adjusting the solution to $\mathrm{pH} 3$ and digesting on a steam bath for several weeks. An isostructural ammonium compound can be prepared analogously. The anhydrous compound $\mathrm{K}\left(\mathrm{UO}_{2}\right)\left(\mathrm{VO}_{4}\right)$, consisting of minute yellow scales, has been synthesized by fusion of potassium metavanadate and ammonium pyrouranate (Canneri and Pestelli, 1924). 
Cation exchange

Cation exchange in carnotite has been described by Hillebrand $(1913,1924)$ and Murata and others (1951). The $\mathrm{K}$ ions of carnotite can be exchanged very slowly by $\mathrm{Ba}, \mathrm{Sr}$, or $\mathrm{Ca}$ by treating the mineral in dilute solutions of these ions. The exchange is accompanied by an increase in the degree of hydration and an increase in the $\{001\}$ spacing, tyuyamunite being formed. The reverse change, from the alkaline earth compounds to carnotite, takes place very readily. $\left(\mathrm{NH}_{4}\right)$ apparently cannot be exchanged for $\mathrm{K}$ in carnotite. Cation exchange in carnotite and tyuyamunite was first recognized by Hillebrand, who found that $\mathrm{K}$ was exchanged for $\mathrm{Ca}$ when tyuyamunite was immersed for separation in Thoulet's solution (potassium mercuric iodide).

\section{Identification}

Carnotite very closely resembles tyuyamunite and metatyuyamunite, which have the same occurrence. The distinction from these species is best made by tests for $\mathrm{Ca}$ and $\mathrm{K}$ and by X-ray diffraction patterns. The optical properties of all of these species vary widely, overlap in part, and are not a reliable means of identification unless the water content has been closely controlled. The X-ray powder-spacing data are given in the following table.

$X$-ray powder-spacing data for carnotite ${ }^{1}$ [Copper radiation, nickel filter]

\begin{tabular}{|c|c|c|c|c|c|c|}
\hline$d(\mathrm{~A})$ & $I$ & $d(A)$ & $I$ & $d(\mathrm{~A})$ & $I$ & $d(\mathrm{~A})$ \\
\hline $\begin{array}{l}\mathbf{6 . 5 6} \\
\mathbf{5 . 1 2} \\
4.53 \\
4.25 \\
\mathbf{3 . 5 3} \\
\mathbf{3 . 2 5}\end{array}$ & $\begin{array}{r}10 \\
1 \\
1 / 2 \\
3 \\
5 \\
3\end{array}$ & $\begin{array}{l}3.12 \\
2.715 \\
2.594 \\
2.571 \\
2.475 \\
2.156\end{array}$ & $\begin{array}{r}7 \\
1 \\
1 / 2 \\
2 \\
1 \\
3\end{array}$ & $\begin{array}{l}2.032 \\
1.998 \\
1.942 \\
1.914 \\
1.831 \\
1.784\end{array}$ & $\begin{array}{l}1 \\
1 \\
2 \\
1 \\
1 \\
1\end{array}$ & $\begin{array}{l}1.678 \\
1.655 \\
1.613 \\
1.531 \\
1.508 \\
1.455\end{array}$ \\
\hline
\end{tabular}

${ }^{1}$ Data on material from Olary, South Australia. The measurements of Vaes and Kerr (1949), not cited above, probably were obtained on an impure samples.

\section{Natural formation and occurrence}

Carnotite is very widely distributed in the United States in the Colorado Plateau. The deposits have been known since 1898 . The mineral occurs chiefly in sandstones of Triassic or Jurassic age, either disseminated or locally as small relatively pure masses especially around petrified or carbonized tree trunks and other vegetal matter. The carnotite is of secondary origin and has formed by the action of meteoric waters on pre-existing relatively unoxidized uranium and vanadium minerals, including uraninite and montroseite. Associated minerals are tyuyamunite and metatyuyamunite chiefly, also volborthite, calciovolborthite, rossite, hewettite, rauvite, uvanite, gypsum, barite, zippeite, metatorbern- 
ite, hummerite, pascoite, navajoite, fervanite, steigerite, melanovanadite, and corvusite. The name carnotite is loosely used in some technologic and mining literature to refer to yellow uranyl vanadate ores, and then it includes tyuyamunite and metatyuyamunite.

Carnotite was originally described from Montrose County, Colo. There are many known occurrences in the Colorado Plateau and adjacent regions, and only a few of the older or more important districts are mentioned here. The Colorado localities include Paradox Valley and Roc and La Sal Creeks in Montrose County; along the Dolores River southwest of Gateway in Mesa County; near Placerville and Cedar in San Miguel County; near Meeker in Rio Blanco County; at Garo in Park County. In Utah notably on the San Rafael Swell west of Green River, Emery County; on the east side of the Henry Mountains in Garfield County; on the west and south of the La Sal Mountains and near Richardson and Thompsons in Grand County; north of Monticello in San Juan County. In Wyoming in the Pumpkin Buttes area of the Powder River Basin with tyuyamunite, uranophane, liebigite, and bayleyite. In sedimentary rocks of Cretaceous age near Edgemont, S. Dak., on the south side of the Black Hills, and near Carlisle, Wyo. (Bodine, 1954), on the east side of the Black Hills. With tyuyamunite and uranophane in a quartzite at Red Bluff, Gila County, Ariz. Carnotite apparently is rare outside of the Western United States. It occurs in the conglomerate of the Pottsville near Mauch Chunk (now Jim Thorpe), Carbon County, Pa., with uranophane, beta-uranophane, liebigite, and tyuyamunite. With tyuyamunite in silicified conglomerate in Duval County, Texas. As coatings on limestone in Ste. Genevieve County, Mo. (Muilenberg and Keller, 1950). At Radium Hill near Olary, South Australia, as an alteration of primary ores containing davidite (Crook and Blake, 1910) ; also in the Cowell district, South Australia (Whittle, 1954a). In red sandstone in the Katanga district, Belgian Congo (Schoep and Richet, 1922). With cinnabar and tyuyamunite(?) near San Carlos, Chihuahua, Mexico (George, 1949). Found as scattered deposits in the alluvial facies of Miocene sandstone over a large area in the extreme southwestern part of Siberia in the general region of the towns of Ferghana and Kokand. The carnotite here occurs with tyuyamunite and other vanadium and copper minerals. The uranium apparently was carried by sulfatic meteoric waters and was precipitated locally by organic matter (Popov, 1939). The deposits at Uigursai, northern Ferghana, have been described by Osipov (1941), who points out the resemblances to the uranium deposits of the Colorado Plateau. 
Synonymy

Tyuyamunite Nenadkevič (1912). Calciocarnotite Hillebrand (1913). Named from the original locality in Turkestan at Tyuya Muyun (the name of a hill traversed by the gorge of the Aravan River and resembling a camel's hump). There are many alternative spellings of the name.

\section{Composition}

A hydrated vanadate of calcium and hexavalent uranium, $\mathrm{Ca}\left(\mathrm{UO}_{2}\right)_{2}\left(\mathrm{VO}_{4}\right)_{2} \cdot 5-81 / 2 \mathrm{H}_{2} \mathrm{O}$. The water content varies zeolitically between the limits given. (See Thermal behavior.) The reported analyses of tyuyamunite are cited in the table below. The water

\section{Chemical analyses of tyuyamunite, in weight percent}

\begin{tabular}{|c|c|c|c|c|c|c|c|}
\hline & 1 & 2 & 3 & 4 & 5 & 6 & 7 \\
\hline $\begin{array}{l}\mathrm{Na}_{2} \mathrm{O} \\
\mathrm{K}_{2} \mathrm{O}\end{array}$ & 二 & 二 & 二 & $\begin{array}{r}0.21 \\
.18\end{array}$ & $\begin{array}{r}0.02 \\
.18\end{array}$ & $\overline{0.5}\}$ & 1.38 \\
\hline $\mathrm{CaO}$ & 5.88 & 5.99 & 6.75 & 5.01 & 5.63 & 5.9 & 5.79 \\
\hline $\begin{array}{l}\mathrm{BaO} \\
\mathrm{Mg}=0\end{array}$ & - & - & $\overline{10}$ & $\overline{-}$ & .54 & - & - \\
\hline $\begin{array}{l}\mathrm{MgO} \\
\mathrm{CuO}\end{array}$ & 一 & - & .08 & .09 & .09 & - & - \\
\hline $\mathrm{UO}_{3}$ & 59.97 & 63.09 & $57 . \overline{29}$ & 58.34 & 55.91 & 57.7 & 56.71 \\
\hline $\mathrm{V}_{2} \mathrm{O}_{5}$ & 19.06 & 21 & 18.49 & 18.72 & 18.76 & 19.5 & 19.28 \\
\hline $\mathrm{H}_{2} \mathrm{O}$ & 15.09 & 7.04 & 15.37 & 17.35 & 18.83 & 16.3 & 16.83 \\
\hline Rem. & - & - & 1.25 & & & 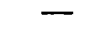 & \\
\hline Total & 100.00 & 97.12 & 99.23 & 100.00 & 100.00 & 99.9 & 99.98 \\
\hline
\end{tabular}

1. Theoretical weight percentages, $\mathrm{Ca}\left(\mathrm{UO}_{2}\right)_{2}\left(\mathrm{VO}_{4}\right)_{2} \cdot 8 \mathrm{H}_{2} \mathrm{O}$.

2. Tyuyamunite. Tyuya Muyun, Turkestan. Nenadkevič (1912). Dried over $\mathrm{P}_{2} \mathrm{O}_{5}$. Actually metatyuyamunite, due to desiccation, but included here because it is the original analysis of the mineral. Contains TI trace, and the $\mathrm{CaO}$ includes some SrO.

3. Tyuyamunite. Tyuya Muyun, Turkestan. Air dried. Remainder $\mathrm{PbO} 0.14$, $\mathrm{CO}_{2}$ 0.91, insoluble 0.20. Chlopin (1925).

4. Tyuyamunite. Tyuya Muyun, Turkestan. Recalculated to 100 percent after deducting 3.39 insoluble and $\mathrm{Fe}_{2} \mathrm{O}_{3}$. $\mathrm{Li}_{2} \mathrm{O}$ present in the $\mathrm{Na}_{2} \mathrm{O}$. Hillebrand (1924).

5. Tyuyamunite. Calamity Creek, Mesa County, Colo. Recalculated to 100 percent after deducting 1.78 insoluble and $\mathrm{Fe}_{2} \mathrm{O}_{3}$. Hillebrand (1924).

6. Tyuyamunite. Henry Mountains, Utah. Recalculated after deducting 8.51 insoluble, $0.26 \mathrm{BaO}$, and $1.10 \mathrm{Fe}_{2} \mathrm{O}_{3}$. Schaller, analyst, in Hess (1924).

7. Mixture of tyuyamunite and carnotite(?), Mailu-Su, Kirgezia, U.S.S.R., Melkov (1945).

content of the analyzed materials is within the established range for this hydrate, with the exception of analysis 2 . Small amounts of $\mathrm{Ba}, \mathrm{Mg}, \mathrm{Pb}, \mathrm{Cu}$, and $\mathrm{K}$ are reported in the analyses. The $\mathrm{Ba}$ and $\mathrm{K}$, at least, may be present in substitution for $\mathrm{Ca}$, especially as such substitutions are readily effected by cation exchange, but admixture of carnotite and other minerals is both likely and difficult to observe and eliminate. Tyuyamunite can be converted easily to carnotite by cation-exchange in solutions of potassium salts; the reverse exchange proceeds very slowly (Hillebrand, 
1913, 1914; Murata and others, 1951; Stern and others, 1956). The $\mathrm{K}: \mathrm{Ca}$ ratio at which the transition from the orthorhombic symmetry of tyuyamunite to the monoclinic symmetry of carnotite takes place is not known.

Spectrographic analyses are lacking. Soluble in dilute acids, except acetic. Tyuyamunite and metatyuyamunite fuse at a red heat to a dark-red liquid; carnotite does not (Hillebrand, 1924). Crystallography

Orthorhombic, crystal class not known. An angle table for the known forms based on the morphological elements of DolivoDobrovolsky (1925) obtained on tiny crystals from Tyuya Muyun is given below. A crystal drawing is shown in figure 19. Observations on the morphology also are given by Chirvinsky (1925) and by Merwin (cited in Hillebrand, 1924). X-ray singlecrystal measurements are lacking; the data reported in Palache, Berman, and Frondel (1951) for tyuyamunite actually refer to metatyuyamunite. An X-ray powder-diffraction pattern of tyuyamunite from the Small Spot mine, Mesa County, Colo., has been indexed in terms of an orthorhombic cell with $a_{0} 10.63 \mathrm{~A}, b_{0} 8.36$, $c_{0} 20.40$ (Stern and others, 1956); the (001) spacings decrease with decreasing water content.

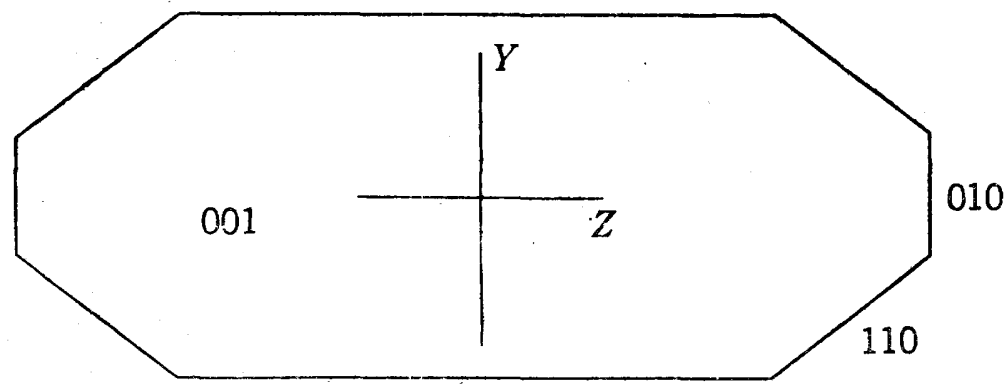

Figure 19.-Tyuyamunite. U. S. S. R. Plane projection on (001), showing optical orientation. From Dolivo-Dobrovolsky (1925).

Angle table for tyuyamunite

Orthorhombic

$a: b: c=1.303: 1: 2.337 ; \quad p_{0}: q_{0}: r_{0}=1.794: 2.337: 1$

$q_{1}: r_{1}: p_{1}=2.337: 0.558: 1 ; \quad r_{2}: p_{2}: q_{2}=0.428: 0.767: 1$

\begin{tabular}{|c|c|c|c|c|c|c|}
\hline FORMS & $\phi$ & $\rho=C$ & $\phi_{1}$ & $\rho_{1}=A$ & $\phi_{2}$ & $\rho_{2}=B$ \\
\hline $\begin{array}{ll}c & 001 \\
b & 010 \\
a & 100\end{array}$ & $\begin{array}{r}0^{\circ} \overline{00^{\prime}} \\
9000\end{array}$ & $\begin{array}{r}0^{\circ} 00^{\prime} \\
9000 \\
9000\end{array}$ & $\begin{array}{r}0^{\circ} 00^{\prime} \\
9000 \\
\end{array}$ & $\begin{array}{rl}90^{\circ} & 00^{\prime} \\
90 & 00 \\
0 & 00\end{array}$ & $\begin{array}{r}90^{\circ} 00^{\prime} \\
0 \overline{00}\end{array}$ & $\begin{array}{rl}90^{\circ} & 00^{\prime} \\
0 & 00 \\
90 & 00\end{array}$ \\
\hline $\begin{array}{ll}l & 120 \\
m & 110 \\
d & 101\end{array}$ & $\begin{array}{ll}21 & 00 \\
37 & 301 / 2 \\
90 & 00\end{array}$ & $\begin{array}{ll}90 & 00 \\
90 & 00 \\
60 & 52\end{array}$ & $\begin{array}{rr}90 & 00 \\
90 & 00 \\
0 & 00\end{array}$ & $\begin{array}{ll}69 & 00 \\
52 & 291 / 2 \\
29 & 08\end{array}$ & $\begin{array}{rr}0 & 00 \\
0 & 00 \\
29 & 08\end{array}$ & $\begin{array}{ll}21 & 00 \\
37 & 301 / 2 \\
90 & 00\end{array}$ \\
\hline $\begin{array}{ll}p & 111\end{array}$ & $37301 / 2$ & 7115 & 6650 & 5447 & 2908 & $41181 / 2$ \\
\hline
\end{tabular}


Crystal habit

Crystals are tiny scales and laths flattened on $\{001\}$ and elongated along the $b$-axis. Often in fanlike or radial aggregates. Crystal faces are dull and sometimes curved. Commonly massive, compact to microcrystalline; also pulverulent, and as thin films and coatings; as an impregnation of sandstone. Tyuyamunite is on the whole more coarsely crystallized than carnotite.

Physical properties

Cleavage $\{001\}$ perfect, micaceous; also $\{010\}$ and $\{100\}$ distinct. Not brittle; prone to cake on grinding. Hardness about 2. The specific gravity varies with the water content within the limits of stability of the phase; the range is not clearly established but seems to be within 3.3-3.6. On dehydration, the mineral passes reversibly to a lower hydrate, metatyuyamunite, with a specific gravity of 3.8-3.9. Luster of crystals adamantine to waxy, commonly pearly on $\{001\}$; massive material may be dull to waxy. Color yellow to canary yellow or lemon yellow; on direct comparison the color usually appears somewhat greenish as compared to carnotite. On exposure to direct sunlight the color of tyuyamunite changes to greenish yellow or dull green; the change is reversed by keeping the material in the dark or by treatment with solutions of dilute acids or of sodium peroxide (Murata and others, 1951). Translucent to opaque. Either not fluorescent or very weakly fluorescent in yellow green in ultraviolet light.

\section{Optical properties}

It is uncertain whether at least some of the optical data reported for tyuyamunite refer to this species or to metatyuyamunite. Dehydration of the sample during measurement may be a source of error, especially if melts are used. Some of the values reported on the following page are in the range of metatyuyamunite.

Dolivo-Dobrovolsky (1925) gives the optical orientation of Tyuya-Muyun material as $X=c, Y=a, Z=b ; 2 \mathrm{~V} 48^{\circ} ; n_{Z}-n_{Y}$ $0.028, n_{Z}-n_{X} 0.154, n_{Y}-n_{Z} 0.126$. On dehydration the indices increase, but the optical orientation, dispersion, pleochroism, and $2 \mathrm{~V}$ remain essentially the same. There are accompanying changes in the specific gravity and X-ray diffraction pattern. The birefringence decreases as the $\mathrm{Ca}$ is leached by acids (Chirvinsky, 1925). 
Optical properties of tyuyamunite

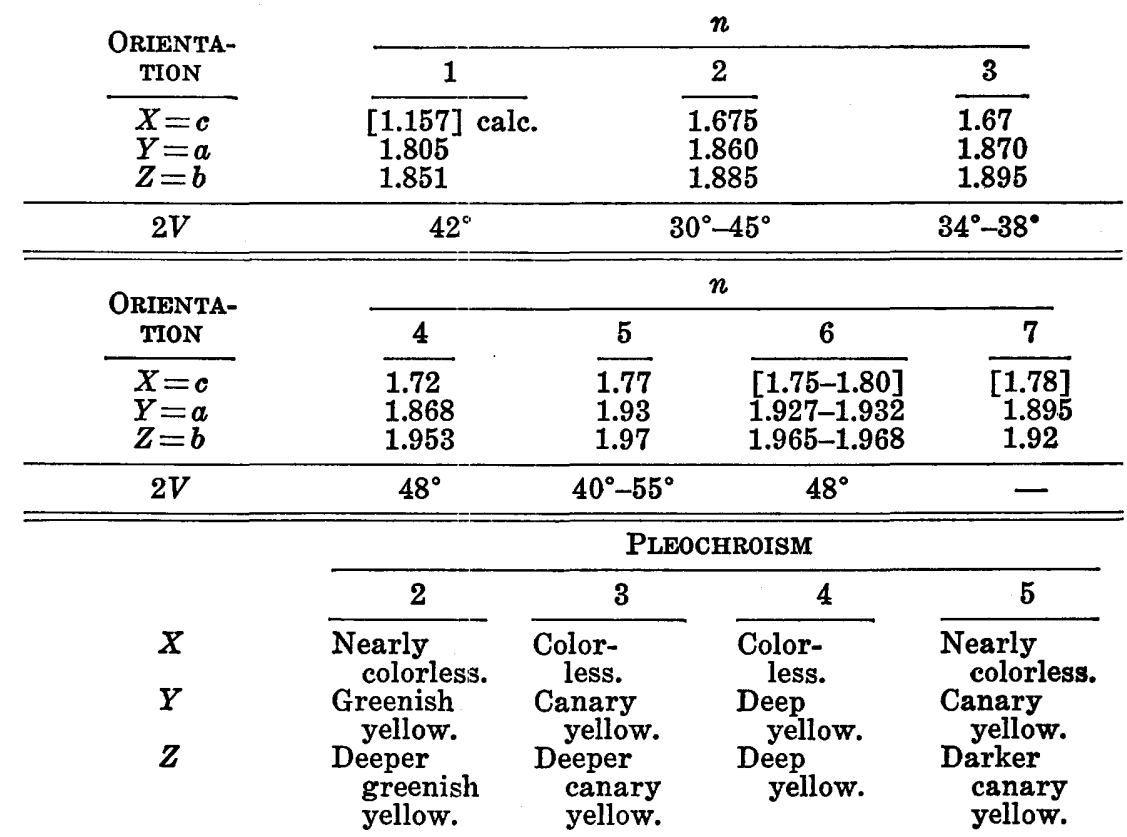

Biaxial negative, dispersion $r<v$ weak to rather strong.

1. Tyuyamunite, hydrated. Small Spot mine, Colorado. Stern and others (1956).

2. Tyuyamunite(?). Four localities. George (1949).

3. Tyuyamunite(?). Utah. Larsen (1921).

4. Metatyuyamunite (?). Utah. Hess (1924).

5. Metatyuyamunite (?). Turkestan. Larsen (1921).

6. Metatyuyamunite (?). Paradox Valley, Colo. Merwin, in Hillebrand (1924).

7. Metatyuyamunite (?). Merwin, in Hillebrand (1924).

\section{Thermal behavior}

The water content of tyuyamunite varies zeolitically between limits, with accompanying variation in the indices of refraction and specific gravity, as shown by Stern and coworkers (1956); Merwin, cited by Hillebrand (1924) ; Rohde (1925); and others. There also is a marked continuous decrease in the $d$-spacing of the low-angle basal reflections in the X-ray powder-diffraction pattern of both tyuyamunite and metatyuyamunite as the water content decreases (Murata and others, 1951). The limits of variation in water content within which tyuyamunite is stable seem to be $5 \mathrm{H}_{2} \mathrm{O}$ and $81 / 2 \mathrm{H}_{2} \mathrm{O}$. Hillebrand (1924) found that tyuyamunite from Turkestan and Colorado (analysis 5) contained $\approx 10 \mathrm{H}_{2} \mathrm{O}$ when kept at $20^{\circ} \mathrm{C}$ in air about saturated with moisture $\left(\mathrm{H}_{2} \mathrm{SO}_{4}\right.$ 
with sp gr 1.05). The air-dried material of analysis 3 has $\approx 8 \mathrm{H}_{2} \mathrm{O}$. On desiccation at room temperature or slight heating in air, tyuyamunite passes reversibly into a lower hydrate, metatyuyamunite, with a water content zeolitically between $3 \mathrm{H}_{2} \mathrm{O}$ and $5 \mathrm{H}_{2} \mathrm{O}$. The metatyuyamunite of analysis 3 , produced by drying over $\mathrm{P}_{2} \mathrm{O}_{5}$, has about $3 \mathrm{H}_{2} \mathrm{O}$. Rohde (1925) found that a sample kept over $\mathrm{H}_{2} \mathrm{SO}_{4}$ with specific gravity 1.05 , at $18^{\circ} \mathrm{C}$ contained 17.88 percent $\mathrm{H}_{2} \mathrm{O}$; kept 1 week over $\mathrm{P}_{2} \mathrm{O}_{5}$ it lost 10.21 percent $\mathrm{H}_{2} \mathrm{O}$, which was regained on exposure to air.

At the upper limit of hydration of tyuyamunite and of metatyuyamunite the water content apparently corresponds to double and single layers of water molecules intercalated between the $\{001\}$ sheets (Ashby, in Stern and others, 1956).

Synthesis

Obtained by dissolving calcium pyrovanadate in $\mathrm{HNO}_{3}$, adjusting to $\mathrm{pH} 3$, and then precipitating with the stoichiometric amount of uranyl nitrate. The $\mathrm{pH}$ is then adjusted to 3 , and the gelatinous precipitate digested on a steam bath for several weeks (Murata and others, 1951).

Identification

Tyuyamunite, metatyuyamunite, carnotite, and, to a less extent, zippeite resemble each other in the hand specimen. Zippeite can be distinguished easily by its low indices of refraction and content of sulfate. Tyuyamunite has lower indices of refraction than metatyuyamunite and carnotite. The X-ray powder-diffraction patterns of all of these minerals are distinctive. The spacing data for tyuyamunite are given in the table below. Mixtures of tyuyamunite and its dehydration product, metatyuyamunite, are very common, and care must be taken in the selection and preparation of samples for X-ray study.

\section{$X$-ray powder-spacing data for tyuyamunite ${ }^{1}$}

[Copper radiation, nickel filter]

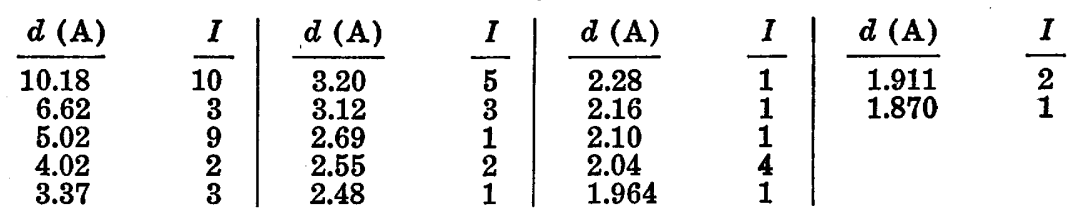

${ }^{1}$ Data on fully hydrated natural material from Hudspeth County, Texas. Spacing data for tyuyamunite of controlled water content also are given by Stern and others (1956).

Natural formation and occurrence

Tyuyamunite is widespread but less abundant than carnotite. It was originally described from Tyuya Muyun in the Alai Moun- 
tains, Ferghana district, Turkestan, U.S.S.R. The deposit at Tyuya Muyun was first worked in 1904, although there are traces of early Chinese mining activities for copper. Tyuya Muyun is situated in the southern part of the Ferghana basin in an area of hot and dry climate with desert topography. The ore and gangue minerals occur chiefly as crusts and cavity fillings in a series of sinuous solution caves and irregular openings following joints and rock-cleavage cracks in a fracture zone in limestone. The mineralization, which probably took place at relatively low temperatures and pressures, may have been effected by the leaching of uranium and vanadium by traversing meteoric waters from the country rocks, including low-grade uranium-bearing shales, followed by deposition in karst zones and fracture zones in the limestone. The chief gangue minerals are calcite and barite, with gypsum and celestite. The chief ore mineral is tyuyamunite; this is associated with vanadinite, malachite, and a number of vanadates, including many peculiar to the deposit containing $\mathrm{U}, \mathrm{Cu}$, $\mathrm{Ni}$, and Ca. Descriptions of the deposit are given by Hautpick (1911), Fersman (1927, 1930), Chirvinsky (1925), Alexandrov (1927), and Kurbatov (1926).

Tyuyamunite occurs widely in the oxidized zone of the sandstone-type uranium deposits of western and southwestern Colorado and the adjacent parts of Utah, New Mexico, and Arizona. It is associated with metatyuyamunite, carnotite, and, less commonly, hewettite, corvusite, becquerelite, meta-autunite, uranophane, and other secondary uranium and vanadium minerals. Tyuyamunite forms chiefly in limestones or limey sediments, or in places of strong calcite or gypsum mineralization, with the abundance of calcium leading to the formation of this species instead of carnotite. It is particularly abundant in the Grants area, N. Mex., and at the Monument No. 2 mine, Apache County, Ariz., and is found among other localities in mines in the Paradox Valley district, Montrose County, and the Egnar-Slick Rock district, San Miguel County, in Colorado; also the Henry Mountains district, Garfield County, the Big Indian Wash area, San Juan County, and the Yellow Cat area, Grand County, in Utah. It occurs coating caliche over a large area of valley fill south of Las Vegas, Clark County, Nev. (Lovering, 1954), in limestone near Pecos, Hudspeth County, and in silicified conglomerate with carnotite in Duval County, Texas, and in the Bisbee district, Arizona. Tyuyamunite also occurs at various deposits in Campbell, Carbon, Converse, Crook, Fremont, and Niobrara Counties, Wyo., and in Fall River County, S. Dak. 
Synonymy

Metatyuyamunite Stern, Stieff, Girhard, and Meyrowitz (1956). Named in reference to the fact that it is a lower hydrate of tyuyamunite.

Composition

A hydrated vanadate of calcium and hexavalent uranium, $\mathrm{Ca}\left(\mathrm{UO}_{2}\right)_{2}\left(\mathrm{VO}_{4}\right)_{2} \cdot 3-5 \mathrm{H}_{2} \mathrm{O}$. The water content varies zeolitically between 3 and $5 \mathrm{H}_{2} \mathrm{O}$, and on further hydration the mineral passes reversibly to tyuyamunite with $5-81 / 2 \mathrm{H}_{2} \mathrm{O}$. The two reported analyses of metatyuyamunite are cited below (see also analysis 2 of tyuyamunite).

Chemical analyses of metatyuyamunite, in weight percent

\begin{tabular}{|c|c|c|c|c|c|c|c|}
\hline \multirow{5}{*}{$\begin{array}{l}\mathrm{K}_{2} \mathrm{O} \\
\mathrm{CaO} \\
\mathrm{BaO} \\
\mathrm{SrO} \\
\mathrm{UO}_{3} \\
\mathrm{~V}_{2} \mathrm{O}_{4}\end{array}$} & 1 & 2 & 3 & & 1 & 2 & 3 \\
\hline & \multirow{4}{*}{$\begin{array}{r}6 . \overline{49} \\
66 . \overline{21}\end{array}$} & \multirow{4}{*}{$\begin{array}{r}6 . \overline{22} \\
\overline{-} \\
66 . \overline{80} \\
2.25\end{array}$} & \multirow{4}{*}{$\begin{array}{r}3.10 \\
5.83 \\
.30 \\
.09 \\
62.12 \\
1.33\end{array}$} & $\begin{array}{l}\mathrm{V}_{2} \mathrm{O}_{5} \\
\mathrm{H}_{2} \mathrm{O}\end{array}$ & $\begin{array}{r}21.05 \\
6.25\end{array}$ & $\begin{array}{r}18.27 \\
6.57\end{array}$ & $\begin{array}{r}19.79 \\
7.33\end{array}$ \\
\hline & & & & Insol. & - & - & .11 \\
\hline & & & & Total & 100.00 & 100.11 & 100.00 \\
\hline & & & & & - & 3.8 & 3.9 \\
\hline
\end{tabular}

1. Theoretical weight percentages, $\mathrm{Ca}\left(\mathrm{UO}_{2}\right)_{2}\left(\mathrm{VO}_{4}\right)_{2} \cdot 3 \mathrm{H}_{2} \mathrm{O}$.

2. Metatyuyamunite. Small Spot mine, Mesa County, Colo. Sherwood, anlyst, in Stern and others (1956).

3. Metatyuyamunite. May Day mine, Mesa County, Colo. Sherwood, anlyst, in Stern and others (1956).

Spectrographic analyses by Annell in Stern and others (1956) of the two analyzed samples showed the presence of $\mathrm{Al}, \mathrm{Sr}, \mathrm{Ba}, \mathrm{K}$, $\mathrm{Co}, \mathrm{Si}, \mathrm{Fe}$.

Crystallography and crystal habit

Orthorhombic. Crystals are tiny scales and laths flattened on $\{001\}$ and elongated along the $a$-axis and in all known specimens probably are dehydration pseudomorphs after tyuyamunite. Commonly found as compact to microcrystalline masses; also pulverulent, and as thin coatings and films; as an impregnation of sandstone. The X-ray single-crystal data given for tyuyamunite

Unit-cell dimensions for metatyuyamunite

\begin{tabular}{ccccc} 
& \multicolumn{1}{c}{$\frac{2}{1}$} & $\frac{3}{2}$ & 4 \\
$a_{0}$ & $10.40 \mathrm{~A}$ & $10.63 \mathrm{~A}$ & $10.54 \mathrm{~A}$ & $10.38 \mathrm{~A}$ \\
$b_{0}$ & 8.26 & 8.36 & 8.49 & 8.46 \\
$c_{0}$ & 19.41 & 16.96 & 17.34 & 17.02 \\
\hline$a_{0}: b_{0}: c_{0}$ & $1.26: 1: 2.35$ & $1.272 .1: 2.029$ & $1.241: 1: 2.042$ & $1.227: 1: 2.012$
\end{tabular}

Unit-cell contents $4\left[\mathrm{Ca}\left(\mathrm{UO}_{2}\right)_{2}\left(\mathrm{VO}_{4}\right) \cdot 3-5 \mathrm{H}_{2} \mathrm{O}\right]$; the space group is given by

Donnay and Donnay (1955) as Pnam or Pna2.

1. Tyuya Muyun. J. W. Frondel (written communication).

2. May Day mine, Colorado. Donnay and Donnay (1955).

3. Small Spot mine, Colorado. Idem.

4. Synthetic. Idem. 
in Palache, Berman, and Frondel (1951) actually refer to the present species (then unknown). These data, obtained by J. W. Frondel on crystals from Turkestan by the Weissenberg method, are given in the above table together with more recent data.

\section{Physical properties}

Cleavage $\{001\}$ perfect, $\{010\}$ and $\{100\}$ distinct. Hardness about 2. Specific gravity 3.8-3.9. Luster adamantine to waxy. Color canary yellow to greenish yellow. On exposure to sunlight the color changes to dark green or yellow green. The original color is restored when kept in the dark or by treatment with solutions of dilute acids or sodium peroxide, but not by dilute alkali solutions. Transparent in small grains. Not fluorescent. In contrast to carnotite, metatyuyamunite is easily fusible.

Optical properties

\begin{tabular}{|c|c|c|c|c|}
\hline \multirow[b]{2}{*}{ ORIENTATION } & \multicolumn{2}{|c|}{$n$} & \multirow[b]{2}{*}{ Pleochroism } & \multirow{4}{*}{$\begin{array}{l}\text { Biaxial } \\
\text { negative; } \\
\text { dispersion } \\
r<v \text { weak. }\end{array}$} \\
\hline & $\begin{array}{c}\text { SMALL SpOT } \\
\text { MINE, } \\
\text { COLORADO }\end{array}$ & $\begin{array}{l}\text { MAY DAY } \\
\text { MINE, } \\
\text { COLORADO }\end{array}$ & & \\
\hline $\begin{array}{l}X=c \\
Y=a\end{array}$ & $\begin{array}{r}{[1.68]} \\
1.835\end{array}$ & $\begin{array}{r}{[1.62]} \\
1.842\end{array}$ & \multirow{2}{*}{$\begin{array}{l}\overline{\text { Nearly colorless. }} \\
\text { Very pale canary } \\
\text { yellow. } \\
\text { Pale canary yellow. }\end{array}$} & \\
\hline$Z=b$ & 1.865 & 1.899 & & \\
\hline
\end{tabular}

$2 \mathrm{~V}$

$45^{\circ}$

$48^{\circ}$

The cited indices are for material that has been exposed to the air. The mineral hydrates or dehydrates rapidly in air, depending on the temperature and humidity, and the indices vary markedly. The following data from Stern and others (1956) illustrate the variation with the water content at room temperature in the indices of refraction of the crystals of analysis 2 (table, p. 254) :

Over $\mathrm{H}_{2} \mathrm{O} 16$ days Desiccated 16 days Heated to $100^{\circ} \mathrm{C}$

\begin{tabular}{cclc}
\multicolumn{4}{c}{$n$} \\
\hline$x$ & \multicolumn{1}{c}{$z$} & \multicolumn{1}{c}{$z$} & $2 V$ \\
\hline$[1.57]$ & 1.805 & 1.851 & $42^{\circ}$ \\
{$[1.88]$} & 1.959 & 1.976 & $47^{\circ}$ \\
{$[1.73]$} & 1.960 & 2.02 & $49^{\circ}$
\end{tabular}

\section{Phase}

Tyuyamunite. Metatyuyamunite. Metatyuyamunite.

See also under Tyuyamunite.

Thermal behavior

See under Tyuyamunite.

\section{Synthesis}

Obtained by gentle heating or desiccation of tyuyamunite. The $\mathrm{Ba}$ and $\mathrm{Sr}$ analogues of metatyuyamunite have been prepared directly by dissolving $\mathrm{Ba}$ or $\mathrm{Sr}$ pyrovanadate in $\mathrm{HNO}_{3}$, adjusting to $\mathrm{pH} 6$, and then precipitating with the stoichiometric amount of uranyl nitrate. A gelatinous precipitate forms immediately. 
The $\mathrm{pH}$ is then adjusted to 3 , and the precipitate digested on a steam bath for several weeks (Murata and others, 1950). Tyuyamunite can be prepared by an analogous procedure and metatyuyamunite presumably can be obtained by using sufficiently hot solutions. Metatyuyamunite readily exchanges $\mathrm{Ca}$ for $\mathrm{K}$ in solutions of potassium salts and is converted to carnotite. The reverse process takes place much less rapidly. The orthorhombic structure of metatyuyamunite can hold at least several percent of potassium in substitution for calcium before conversion to the monoclinic structure of carnotite.

\section{Identification}

Distinguished from tyuyamunite by its relatively high indices of refraction and specific gravity and its X-ray powder-diffraction pattern. The powder-spacing data are given in the table below;

\section{$X$-ray powder-spacing data for metatyuyamunite ${ }^{1}$}

[Symbols: b, broad; $f$, faint; $m$, medium; vf, very faint; vs, very strong; w, weak. Copper radiation, nickel filter]

\begin{tabular}{|c|c|c|c|c|c|}
\hline \multicolumn{2}{|c|}{1} & \multicolumn{2}{|c|}{2} & \multicolumn{2}{|c|}{3} \\
\hline$\overline{d(\mathrm{~A})}$ & $I$ & $d(\mathrm{~A})$ & $I$ & $d(\mathrm{~A})$ & $I$ \\
\hline $\begin{array}{l}9.94 \\
8.51 \\
6.51 \\
5.19 \\
4.48 \\
4.22 \\
3.77 \\
3.55 \\
3.24 \\
3.04 \\
2.85 \\
2.72 \\
2.59 \\
2.48 \\
2.19 \\
2.13 \\
2.05 \\
2.01 \\
1.96 \\
1.91 \\
1.85 \\
1.77 \\
1.74 \\
1.69 \\
1.66 \\
1.62 \\
1.57 \\
1.53 \\
1.49\end{array}$ & $\begin{array}{c}v f \\
v s \\
w \\
w \\
f \\
m \\
w \\
f \\
m \\
m \\
f \\
f \\
w \\
f \\
f, b \\
w, b \\
f \\
f \\
f \\
f \\
f \\
v f \\
f, b \\
v f, b \\
v f, b \\
v f, b \\
\text { vf } \\
\text { vf } \\
\text { vf } \\
\text { vf }\end{array}$ & $\begin{array}{l}8.51 \\
6.56 \\
5.19 \\
4.48 \\
4.22 \\
3.77 \\
3.58 \\
3.26 \\
3.05 \\
2.81 \\
2.58 \\
2.50 \\
2.35 \\
2.17 \\
2.12 \\
2.05 \\
1.99 \\
1.95 \\
1.91 \\
1.88 \\
1.85 \\
1.77 \\
1.73 \\
1.69 \\
1.66 \\
1.57 \\
1.53 \\
1.50\end{array}$ & $\begin{array}{c}v s \\
f \\
w \\
f \\
s \\
w \\
f \\
m, b \\
m, b \\
w \\
w \\
v f \\
v f \\
v f \\
w, b \\
f \\
f \\
f \\
f \\
f \\
f \\
f \\
f \\
f \\
f \\
v f \\
v f \\
v f\end{array}$ & $\begin{array}{l}8.43 \\
5.18 \\
4.46 \\
4.17 \\
3.74 \\
3.52 \\
3.28 \\
3.03 \\
2.805 \\
2.578 \\
2.113 \\
2.002 \\
1.949 \\
1.771\end{array}$ & $\begin{array}{r}10 \\
3 \\
1 \\
8 \\
2 \\
1 \\
6 \\
5 \\
2 \\
3 \\
4 \\
1 \\
1 \\
1\end{array}$ \\
\hline
\end{tabular}

${ }^{1}$ Natural metatyuyamunite is more or less admixed with the higher hydrate, tyuyamunite, and lines of this phase may be present in the patterns.

1. Synthetic material. Data from Stern and others (1956).

2. Natural material from the Small Spot mine, Mesa County, Colo. Idem.

3. Data from the Harvard file on natural material from Ferghana, U.S.S.R. 
the values vary appreciably with variation in water content, especially the spacing of the low-angle basal reflection (Murata and others, 1950).

Natural formation and occurrence

Metatyuyamunite is found with tyuyamunite and carnotite as coatings or disseminations in sandstone or limestone at many localities on the Colorado Plateau. The mineral is likely to be found at any tyuyamunite locality. Tyuyamunite and metatyuyamunite generally form in place of carnotite when the country rock of the deposit is limestone or sandstone containing calcite as cementing material. Metatyuyamunite is especially abundant in the Shiprock district and near Haystack Mountain and Laguna in the Grants district, New Mexico, and at the Monument No. 2 mine, Monument Valley, Apache County, N. Mex. Also found in Fall River County, S. Dak., and at Pumpkin Buttes in the Powder River Basin of Wyoming. At the May Day and Small Spot mines on Calamity Mesa, Mesa County, Colo., well crystallized with earlier formed gypsum in the Salt Wash sandstone member of the Morrison formation. Fine specimens have been found at the Mi Vida mine, Big Indian Wash, San Juan County, Utah. Identified on museum specimens of tyuyamunite from Tyuya Muyun, Ferghana, Turkestan, U.S.S.R.

\section{UNNAMED MINERAL OF CHIRVINSKY}

An unnamed mineral from the tyuyamunite deposit at Tyuya Muyun, Ferghana, Turkestan, U.S.S.R., has been briefly described by Chirvinsky (1925). Analyses are lacking, and the mineral is presumed to contain uranium only because of its physical properties and association. It may be only a variety of metatyuyamunite. Found as minute prismatic crystals with rectangular and sixsided cross sections. Drawings are given by Chirvinsky (1925). Cleavage prismatic and also across the prism, but not conspicuous. Color brown, with adamantine luster. In transmitted light, greenish yellow and darker in color than tyuyamunite. Parallel extinction; not pleochroic. The indices of refraction are very high, and the birefringence is not less than $0.02-0.025$. Soluble in acids without effervescence, leaving a gelatinous pseudomorph. 
Synonymy

Sengierite Vaes and Kerr (1949). Named after Edgar Sengier (1879- ), an official of the Union Minière du Haut Katanga.

\section{Composition}

A hydrated basic vanadate of copper and hexavalent uranium. The formula is suggested to be $\mathrm{Cu}\left(\mathrm{UO}_{2}\right)_{2}\left(\mathrm{VO}_{4}\right)_{2} \cdot 8-10 \mathrm{H}_{2} \mathrm{O}$ by Donnay and Donnay (1953) on the basis of structural and base-exchange relations to tyuyamunite. It was originally given as probably $\mathrm{Cu}\left(\mathrm{UO}_{2}\right)\left(\mathrm{VO}_{4}\right)(\mathrm{OH}) \cdot n \mathrm{H}_{2} \mathrm{O}$, with $n$ near 4 or 5 , by Vaes and Kerr (1949) on the basis of the approximate analysis cited below.

\begin{tabular}{|c|c|c|c|c|c|}
\hline & $\begin{array}{l}\text { Weight } \\
\text { percent }\end{array}$ & & $\begin{array}{l}\text { Weight } \\
\text { percent }\end{array}$ & & $\begin{array}{l}\text { Weight } \\
\text { percent }\end{array}$ \\
\hline \multirow{2}{*}{$\begin{array}{l}\mathrm{CuO} \\
\mathrm{UO}_{3}\end{array}$} & \multirow{2}{*}{$\begin{array}{l}\overline{14.82} \\
47.45\end{array}$} & \multirow{2}{*}{$\begin{array}{l}(\mathrm{Fe}, \mathrm{Al})_{2} \mathrm{O}_{3} \\
\mathrm{~V}_{2} \mathrm{O}_{5}\end{array}$} & \multirow{2}{*}{$\begin{array}{r}1.43 \\
15.96\end{array}$} & $\mathrm{H}_{2} \mathrm{O}$ & $\overline{15.77}$ \\
\hline & & & & Total & $\overline{95.43}$ \\
\hline
\end{tabular}

Analysis by Jadotville-Panda Laboratory, Union Minière du Haut Katanga, on 0.146 gram. The $(\mathrm{Fe}, \mathrm{Al})_{2} \mathrm{O}_{3}$ is believed due to admixture.

Spectrographic analysis showed $\mathrm{Cu}, \mathrm{V}$, and $\mathrm{U}$ to be the essential constituents (no data on trace elements); $\mathrm{K}, \mathrm{Ca}, \mathrm{Mg}$, and $\left(\mathrm{PO}_{4}\right)$ were shown to be lacking by qualitative chemical tests. Soluble in acids. In the closed tube sengierite loses water, assumes a bronze shade with metallic luster, and becomes opaque.

Crystallography and crystal habit

Sengierite is monoclinic according to the study of Donnay and Donnay (1953). Crystal class, prismatic $(2 / m)$. The mineral was earlier considered to be orthorhombic. Unit-cell dimensions :

$a_{0} 10.62 \mathrm{~A}, b_{0} 8.10, c_{0}$ 10.11, $a_{0}: b_{0}: c_{0}=1.311: 1: 1.284 . \beta 103^{\circ} 40^{\prime}$. Space group $P 2_{1} / a$. Unit-cell contents $2\left[\mathrm{Cu}\left(\mathrm{UO}_{2}\right)_{2}\left(\mathrm{VO}_{4}\right)_{2} \cdot 8\right.$ $\left.10 \mathrm{H}_{2} \mathrm{O}\right]$.

Crystals are thin plates with a six-sided outline and range in size up to a few millimeters in width. Found as flaky coatings in open fractures. The crystals are thin to very thin tabular on $\{001\}$ and are elongated $\{110\}$. Morphological measurements by Donnay and Donnay (1955) established the following forms: $c\{001\}, m\{110\}, a\{100\}, s\{201\}$ and $p\{111\}$. The following angular measurements were obtained: $c \wedge a 76^{\circ} 40^{\prime} ; c \wedge s 51^{\circ} 40^{\prime}$; and $(1 \overline{1} 0) \wedge(110) 105^{\circ} 30^{\prime}$ [with (001) polar]; these yield the axial elements $a: b: c=1.316: 1: 1.236, \beta 103^{\circ} 40^{\prime}$. A description of the orthorhombic interpretation together with a crystal drawing and photograph are given by Vaes and Kerr (1949). 
Physical properties

Cleavage $\{001\}$ perfect. Brittle. Hardness $21 / 2$. Specific gravity 4.41. Luster vitreous to adamantine. Color green. Streak light green. Data on fluorescence are lacking.

\section{Optical properties}

\begin{tabular}{l} 
ORIENTATION \\
\hline$X \wedge c 13^{\circ} 40^{\prime}$ \\
$Y=b$
\end{tabular}

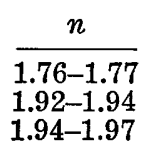

\section{PleochroisM}

Bluish green to colorless. Olive green. Yellowish green to colorless.
Biaxial negative; 2 V $37^{\circ}-39^{\circ}$; $r<v$ strong.

The indices of refraction were determined in melts and possibly may be high due to partial dehydration.

\section{Thermal behavior}

The water loss as a function of temperature, as measured on a 80 -mg sample, is : 3.94 percent at $100^{\circ} \mathrm{C}\left(=2.5\right.$ moles $\left.\mathrm{H}_{2} \mathrm{O}\right)$, 10.56 percent at $300^{\circ} \mathrm{C}\left(6.5\right.$ moles $\left.\mathrm{H}_{2} \mathrm{O}\right)$, calcination 15.77 percent $\left(\approx 10\right.$ moles $\left.\mathrm{H}_{2} \mathrm{O}\right)$, as calculated from the ratio $2 \mathrm{CuO} \cdot 2 \mathrm{UO}_{3} \cdot \mathrm{V}_{2} \mathrm{O}_{5} \cdot$ $10 \mathrm{H}_{2} \mathrm{O}$ of Vaes and Kerr (1949). When heated at $300^{\circ} \mathrm{C}$ and exposed to air for 2 days the sample regained water, the total loss then being 6.48 percent $\left(4 \mathrm{~mol} \mathrm{H}_{2} \mathrm{O}\right)$, indicating that 6 of the apparent $10 \mathrm{H}_{2} \mathrm{O}$ are relatively tightly held. Data on the variation in indices of refraction with water content are lacking.

\section{Synthesis}

Obtained by ion-exchange of tyuyamunite by Donnay and Donnay (1955).

\section{Identification}

Sengierite is the only well-defined uranium mineral that contains both copper and vanadium as major essential constituents. Distinguished from the platy green members of the torbernite and metatorbernite groups and from sincosite by its relatively high indices of refraction. Readily distinguished by its crystallography and other properties from other green uranium minerals such as liebigite, vandenbrandeite, johannite, and cuprosklodowskite. The $\mathrm{X}$-ray powder-spacing data are given in the table on the following page.

\section{Natural formation and occurrence}

Sengierite is a secondary mineral. Known only from the Elizabethville-Jadotville area of the Katanga district in the Belgian Congo. It occurs very sparingly along a fault, associated with black secondary oxides of $\mathrm{Fe}, \mathrm{Co}, \mathrm{Cu}$, and $\mathrm{Ni}$, and with volborthite (?), vandenbrandeite, malachite, garnierite, and chrysocolla. Uraninite occurs in pockets along the fault and is the ultimate source of the solutions that have deposited the sengierite, 
$X$-ray powder-spacing data for sengierite ${ }^{1}$

[Symbols: $\mathrm{m}$, moderate; s, strong; vs, very strong; vvs, very, very strong; vw, very weak; w, weak. Copper radiation, nickel filter]

\begin{tabular}{|c|c|c|c|c|c|}
\hline$d(\mathrm{~A})$ & $I$ & $h k l$ & $d(\mathrm{~A})$ & $I$ & $h k l$ \\
\hline 9.82 & vvs & 001 & 2.832 & $\mathbf{m}$ & 311 \\
\hline 5.75 & $\mathrm{~m}$ & $11 \overline{1}$ & 2.744 & $\mathrm{w}$ & 113 \\
\hline 5.02 & $w$ & 111 & 2.550 & $\mathrm{~m}$ & $13 \overline{1}, 023$ \\
\hline 4.91 & vs & 002 & 2.495 & $\nabla w$ & 322,131 \\
\hline 4.179 & $\mathrm{~m}$ & 201 & 2.398 & $\mathbf{w}$ & 213 \\
\hline 4.037 & $\mathrm{~m}$ & 020 & 2.345 & Vw & $21 \overrightarrow{4}$ \\
\hline 3.735 & $\mathbf{s}$ & 021 & 2.267 & $v w$ & 231 \\
\hline 3.262 & w & 003 & 2.163 & $w$ & 420,322 \\
\hline 3.197 & $\mathbf{s}$ & 202 & 2.124 & $\mathrm{~m}$ & 330 \\
\hline 3.179 & $\mathbf{s}$ & $220,22 \overline{1}$ & 2.087 & $\mathbf{m}$ & 402,033 \\
\hline 3.144 & $\mathbf{s}$ & 310,022 & 2.051 & $w$ & $51 \overline{1}$ \\
\hline 3.094 & $\mathbf{s}$ & $11 \overrightarrow{3}$ & 2.009 & $\mathbf{m}$ & 423 \\
\hline 2.970 & $\mathrm{~m}$ & $31 \overrightarrow{2}$ & 1.971 & vw & $41 \overline{4}, 14 \overline{1}$ \\
\hline 2.901 & $\mathrm{vw}$ & 221 & 1.951 & vw & $11 \overline{5}, 21 \overline{5}$ \\
\hline
\end{tabular}

1 Data of Donnay and Donnay (1955) on type material from the Katanga district, Belgian Congo.

\section{UNNAMED MINERAL OF CHERNIK}

An ill-defined hydrated vanadate of copper and uranium has been described, without a name, by Chernik (1922). An incomplete analysis gave, in weight percent, $\mathrm{K}_{2} \mathrm{O} 0.80, \mathrm{BaO} 0.84$, $\mathrm{CuO} 7.23$, $\mathrm{U}_{3} \mathrm{O}_{8}$ 38.27, $\mathrm{V}_{2} \mathrm{O}_{5} 38.28, \mathrm{H}_{2} \mathrm{O} 7.80$, total 93.22. Color dark green. Hardness 4. Specific gravity 4.46. Found associated with tyuyamunite at Tyuya Muyun, Ferghana, Turkestan, U.S.S.R. This substance has the same qualitative chemical composition as sengierite, and recalls the copper vanadates turanite, volborthite, and calciovolborthite, all of which lack uranium.

Synonymy

\section{FERGHANITE}

Ferghanite Antipov (1908). Named from the locality in the Ferghana district, Turkestan.

\section{Composition}

A hydrated vanadate of uranium, possibly containing lithium as an essential constituent. The only reported analysis, in weight percent, gives $\mathrm{Li}_{2} \mathrm{O}$ 1.22, $\mathrm{U}_{3} \mathrm{O}_{8}$ 77.00, $\mathrm{V}_{2} \mathrm{O}_{5}$ 17.60, $\mathrm{H}_{2} \mathrm{O}$ 10.75, total 106.57; it seems to be largely in error. (See Hess, 1924.) The yellow color and occurrence of the mineral as an oxidation product indicate that it is a uranyl compound. The formula is uncertain, possibly $\left(\mathrm{UO}_{2}\right)_{3}\left(\mathrm{VO}_{4}\right)_{2} \cdot 6 \mathrm{H}_{2} \mathrm{O}$. The mineral also might be a hydrated lithium uranyl vanadate. 


\section{Crystallography}

Probably orthorhombic. Found as scales flattened on $\{001\}$, with a 6-sided outline and plane interior angles of $106^{\circ}$ and $127^{\circ}$. $\mathrm{X}$-ray data are lacking.

Physical and optical properties

Cleavage $\{001\}$ perfect; also a second cleavage on $\{100\}(?)$ perpendicular to the optic plane. Hardness about 21/2. Specific gravity 3.31. Luster waxy. Color sulfur yellow. Translucent. Optically biaxial, with $2 V$ large and $X=c, Y=b, Z=a$. The indices of refraction and birefringence are low. Not pleochroic.

Thermal properties and synthesis

No data.

\section{Identification}

Ferghanite has the same qualitative chemical composition as uvanite, aside from the content of lithium. It resembles tyuyamunite, metatyuyamunite, and carnotite. The mineral is poorly defined and further study is needed. X-ray powder-spacing data are lacking.

\section{Natural formation and occurrence}

Ferghanite is found with other secondary uranium minerals at Tyuya Muyun in the Ferghana district, Turkestan, U.S.S.R. Ferghanite may represent a leached or base-exchanged product of tyuyamunite. (See Chirvinsky, 1925; Nenadkevič, 1912; Hillebrand, 1924.)

\section{Synonymy}

\section{UVANITE}

Uvanite Hess and Schaller (1914). Named in allusion to the presence of uranium and vanadium in the mineral.

\section{Composition}

A hydrated vanadate of uranium. The formula is uncertain, probably $\mathrm{U}_{2} \mathrm{~V}_{6} \mathrm{O}_{21} \cdot 15 \mathrm{H}_{2} \mathrm{O}$. The $\mathrm{Ca}$ in the only reported analysis, in weight percent, cited below, may be essential.

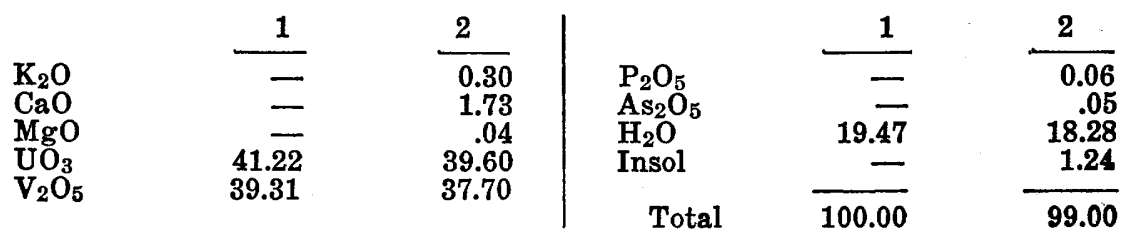

1. Theoretical weight percentages, $\mathrm{U}_{2} \mathrm{~V}_{6} \mathrm{O}_{21} \cdot \mathbf{1 5} \mathrm{H}_{2} \mathrm{O}$.

2. Uvanite. Temple Rock, Utah. Schaller, analyst, in Hess and Schaller (1914).

Uvanite is insoluble in water, but is soluble in ammonium carbonate solution. 
Crystallography and physical properties

Uvanite probably is orthorhombic. Morphological and singlecrystal X-ray data are lacking. The mineral occurs as minutely crystalline masses and coatings. Two pinacoidal cleavages. Color brownish yellow. Observations on the hardness and specific gravity are lacking. Not fluorescent in ultraviolet light.

Optical properties

\begin{tabular}{|c|c|c|c|}
\hline ORIENTATION & $n$ & PLEochroIsM & \\
\hline $\begin{array}{l}X \\
Y \\
Z\end{array}$ & $\begin{array}{l}1.817 \\
1.879 \\
2.057\end{array}$ & $\begin{array}{l}\text { Light brown. } \\
\text { Dark brown. } \\
\text { Greenish yellow. }\end{array}$ & $\begin{array}{l}\text { Biaxial positive; } \\
\quad 2 V 52^{\circ}\end{array}$ \\
\hline
\end{tabular}

Optical data from Larsen and Berman (1934) ; optical orientation not known.

Thermal behavior and synthesis

No data.

\section{Identification}

Uvanite resembles rauvite. The X-ray powder-spacing data are given in the table below. The status of uvanite is uncertain and the mineral needs further study.

\section{$X$-ray powder-spacing data for uvanite ${ }^{1}$}

[Symbols: b, broad; s, strong; vs, very strong; vw, very weak; w, weak. Copper radiation, nickel filter]

\begin{tabular}{|c|c|c|c|c|c|c|c|c|c|}
\hline \multicolumn{2}{|c|}{ HARVARD } & \multirow[b]{3}{*}{$d(\mathrm{~A})$} & \multirow[b]{3}{*}{$I$} & \multirow[b]{3}{*}{$d(\mathrm{~A})$} & \multirow[b]{3}{*}{$I$} & \multirow[b]{3}{*}{$d(\mathrm{~A})$} & \multirow[b]{3}{*}{$I$} & \multirow[b]{3}{*}{$d(\mathrm{~A})$} & \multirow[b]{3}{*}{$I$} \\
\hline STANDA & RD FILE & & & & & & & & \\
\hline$\overline{d(\mathrm{~A})}$ & $I$ & & & & & & & & \\
\hline 5.9 & 6 & 5.9 & $5(\mathrm{~b})$ & $\begin{array}{l}9.56 \\
5.72\end{array}$ & $\begin{array}{l}\mathrm{w} \\
\mathrm{w}\end{array}$ & 5.79 & 6 & & \\
\hline $\begin{array}{l}4.6 \\
3.3\end{array}$ & 4 & $\begin{array}{l}5.3 \\
3.39\end{array}$ & 4 (b) & 4.55 & vw & $\begin{array}{l}4.60 \\
3.34\end{array}$ & 7 & & \\
\hline $\begin{array}{l}2.0 \\
2.94\end{array}$ & 10 & $\begin{array}{l}0.09 \\
2.96\end{array}$ & $10^{2}$ & 2.93 & vs & $\begin{array}{l}3.34 \\
2.94\end{array}$ & 10 & $\begin{array}{l}5.50 \\
2.948\end{array}$ & $\begin{array}{l}\text { W } \\
\text { VS }\end{array}$ \\
\hline 2.24 & 8 & 2.24 & $5(b)$ & 2.202 & w & 2.21 & 4 & 2.217 & $\mathbf{s}$ \\
\hline $\begin{array}{l}1.71 \\
1.637\end{array}$ & $\begin{array}{l}9 \\
4\end{array}$ & $\begin{array}{l}1.71 \\
1.64\end{array}$ & $\begin{array}{l}8 \\
1(b)\end{array}$ & 1.695 & w & $\begin{array}{l}1.701 \\
1.626\end{array}$ & $\begin{array}{l}\mathbf{5} \\
\mathbf{1}\end{array}$ & 1.698 & $\mathbf{w}$ \\
\hline $\begin{array}{l}1.484 \\
1.356\end{array}$ & $\begin{array}{l}7 \\
2\end{array}$ & 1.4 & & & & 1.475 & 3 & 1.468 & $\mathbf{w}$ \\
\hline 1.288 & $\overline{3}$ & & & & & & & & \\
\hline $\begin{array}{l}1.180 \\
1119\end{array}$ & 1 & & & & & & & & \\
\hline & & & & & & & & & \\
\hline
\end{tabular}

${ }^{1}$ Data obtained from five different sources, all derived from type material from Temple Mountain, San Rafael Swell, Utah, are not wholly consistent, probably owing to the presence of impurities and to variation in film intensity and quality.

Natural formation and occurrence

Uvanite is found associated with carnotite, rauvite, hewettite, metatorbernite, hyalite, and gypsum in asphaltic sandstone of the 
Shinarump member of the Chinle formation at Temple Rock, 45 miles southwest of Green River, Emery County, Utah. Only a few authentic specimens are known.

\section{Synonymy}

\section{RAUVITE}

Rauvite Hess (1922, 1924). Named from the chemical symbols of the constituent elements, Ra, U, V.

Composition

A hydrated vanadate of calcium and uranium of uncertain formula, perhaps $\mathrm{CaO} \cdot 2 \mathrm{UO}_{3} \cdot 5 \mathrm{~V}_{2} \mathrm{O}_{5} \cdot 16 \mathrm{H}_{2} \mathrm{O}$. The two reported analyses, in weight percent, are cited below.

\begin{tabular}{|c|c|c|c|c|c|}
\hline & 1 & 2 & & 1 & 2 \\
\hline \multirow{2}{*}{$\begin{array}{l}\mathrm{CaO} \\
\mathrm{UO}_{3} \\
\mathrm{~V}_{2} \mathrm{O}_{4}\end{array}$} & \multirow{2}{*}{$\begin{array}{r}2.7 \\
28.1 \\
2.8\end{array}$} & \multirow{2}{*}{$\begin{array}{r}2.76 \\
31.49 \\
1.44\end{array}$} & $\begin{array}{l}\mathrm{V}_{2} \mathrm{O}_{5} \\
\mathrm{H}_{2} \mathrm{O}\end{array}$ & $\begin{array}{l}49.0 \\
17.5\end{array}$ & $\begin{array}{l}48.28 \\
15.49\end{array}$ \\
\hline & & & Total & $\overline{100.1}$ & $\overline{100.77}$ \\
\hline
\end{tabular}

1. Rauvite. Temple Rock, Utah. Schaller, analyst, in Hess (1924). Recalculated after deducting 27.06 percent impurities.

2. Rauvite. Monument No. 2 mine, Arizona. Sherwood, analyst, in Weeks and Thompson (1954). Analysis includes $\mathrm{Al}_{2} \mathrm{O}_{3}$ 0.70, acid insoluble 0.61.

Crystallography and physical properties

Crystal system not known. The mineral seems to have a layer structure with extensive disorder. It is very fine grained and extremely variable in physical and optical properties. Found as dense, slickensided masses, botryoidal crusts, and filmy coatings. Shrinkage cracks are generally present. Rauvite also occurs as an interstitial filling in sandstone. Color purplish or bluish black to brownish red; less commonly dirty orange yellow. Streak yellowish brown to olive. Under the microscope minutely crystalline, with a mean index of refraction of 1.88-1.89. Biaxial negative (?). Relatively coarsely crystallized material has $n$ 1.89-1.95 with high birefringence. Luster adamantine to waxy. In consistency ranges from waxy and sectile to brittle and glassy. Specific gravity 2.92 (material of analysis 2). Not fluorescent in ultraviolet light.

Thermal behavior and synthesis

No data.

Identification

Distinguished from corvusite and vanoxite in containing uranium. Uvanite has a brownish-yellow color different from that of rauvite, but the colors of these minerals may be variable depending on the state of oxidation of the $U$ and V. The X-ray powderspacing data for rauvite are given in the table below. The X-ray 
pattern shows faint, diffuse lines or bands, and the spacings vary considerably with water content.

$X$-ray powder-spacing data for rauvite ${ }^{1}$

[Copper radiation, nickel filter]

\begin{tabular}{cc|cc|cc|cc}
$\frac{d(\mathrm{~A})}{10.70}$ & $\frac{I}{10}$ & $\frac{d(\mathrm{~A})}{2.95}$ & $\frac{I}{5}$ & $\frac{d(\mathrm{~A})}{2.10}$ & $\frac{I}{1}$ & $\frac{d(\mathrm{~A})}{1.714}$ & $\frac{I}{1}$ \\
3.83 & 1 & 2.62 & 3 & 1.979 & 1 & 1.624 & 1 \\
3.49 & 2 & 2.22 & 1 & 1.832 & 1 & 1.543 & 1
\end{tabular}

${ }^{1}$ Material from Temple Mountain, San Rafael Swell, Utah.

Natural formation and occurrence

Rauvite occurs in small quantity in vanadiferous uranium ores at many localities on the Colorado Plateau and in the southern Black Hills. The mineral seems to be a hardened, gel-like precipitate, perhaps forming under more acid conditions than carnotite and tyuyamunite. It is probably derived by the alteration of uraninite and low-valence vanadium oxides, also possibly of tyuyamunite. In the oxidation of uraninite-montroseite ore, rauvite probably is the intermediate stage to carnotite and tyuyamunite, and it is generally associated with corvusite, vanadium hydromica, and some fully oxidized vanadium minerals.

Rauvite was found originally (Hess, 1922, 1924) at Temple Rock and nearby Flat Top, San Rafael Swell, Emery County, Utah, filling cracks and impregnating sandstone of the Shinarump member. It is associated with carnotite, uvanite, "hewettite," metatorbernite, and gypsum. Recently reported (Weeks and Thompson, 1954) from Colorado in the Small Spot and Arrowhead mines, Mesa County, and the Hummer mines, Montrose County; from Utah from the Cactus Rat and Corvusite mines, Grand County, and Temple Mountain, Emery County; from the Monument No. 2 mine, Apache County, Ariz., and the Road Hog No. 3A claim, Fall River County, S. Dak.

Concentrically zoned spheroidal concretionary impregnations of a material containing uranium and vanadium, possibly a uranium vanadate, have been found in sandstone and are described by Eichhoff and Reineck (1953).

\section{SIIICATES}

The natural silicates of uranium and thorium include two important groups of minerals, the thorite group and the uranophane group, together with huttonite, beta-uranophane, and five additional species. The thorite group comprises the tetragonal nesosilicates thorite, $\mathrm{ThSiO}_{4}$, and zircon, $\mathrm{ZrSiO}_{4}$, together with variants of these species, thorogummite and cyrtolite, that apparently 
contain variable amounts of $(\mathrm{OH})$ as $(\mathrm{OH})_{4}$ groups in substitution for $\left(\mathrm{SiO}_{4}\right)$. Coffinite, also a member of the thorite group, seems to be a hydroxyl-substituted variant of the as yet unknown anhydrous phase $\mathrm{USiO}_{4}$. Zircon and cyrtolite are not described in the present volume. Huttonite is a monoclinic polymorph of thorite that, with cheralite, is related structurally to monazite. The uranophane group includes the common mineral uranophane, $\mathrm{Ca}\left(\mathrm{UO}_{2}\right)_{2}\left(\mathrm{SiO}_{3}\right)_{2}$ $(\mathrm{OH})_{2} \cdot 5 \mathrm{H}_{2} \mathrm{O}$, together with the magnesium and copper analogues sklodowskite and cuprosklodowskite. Beta-uranophane is a polymorph of uranophane; the magnesium and copper analogues of beta-uranophane are not known. Of the five remaining silicates, cheralite, pilbarite, and gastunite are known only from single occurrences and the latter two are ill-defined. Soddyite also is rare, but kasolite is widespread in small amounts.

\section{Synonymy}

THORITE

Thorit Berzelius (1829). Orangit Bergemann (1851). Uranothorite Collier (1880). Wisaksonite Druif (1948). Torit. Orangeite. The name thorite and also the name of the element thorium are from Thor, the Scandinavian god of war. Orangeite in allusion to the orange-yellow color of the particular material.

A large number of minerals have been named as distinct species that seem from the available evidence to be identical with or closely allied to thorite. A recent study of a number of these minerals by C. Frondel (1953) has shown that two apparently different but closely related substances are represented. One, thorite proper, conforms to the traditional description of this species as a tetragonal, zircon-like phase with the ideal composition $\mathrm{ThSiO}_{4}$. It can vary in composition through the substitution of $\mathrm{U}$, rare earths, $\mathrm{Pb}, \mathrm{Zr}, \mathrm{Fe}$, and $\mathrm{Ca}$ chiefly, in variable and sometimes large amounts. Further, it very commonly alters to a noncrystalline metamict condition with accompanying hydration and in part at least oxidation of the $\mathrm{Fe}^{+2}$ and $\mathrm{U}^{+4}$ to $\mathrm{Fe}^{+3}$ and $\mathrm{U}^{+8}$. Such material occurs as more or less glassy pseudomorphs, is isotropic, and does not afford an X-ray powder-diffraction pattern. The second substance, for which the name thorogummite is used, seems to be an isostructural chemical variant of thorite in which there is a serial substitution of $(\mathrm{OH})_{4}$ for $\left(\mathrm{SiO}_{4}\right)$ as expressed in the formula $\mathrm{Th}\left(\mathrm{SiO}_{4}\right)_{1-\mathrm{x}}(\mathrm{OH})_{4 \mathrm{x}}$. It occurs as a crystalline but fine-grained alteration product of thorite, thorianite, and yttrialite, and seems to be a low-temperature weathering product. In addition, a number of minerals whose relations to thorite and thorogummite are not known are described following this section 
on thorite. A number of occurrences of material described directly under the name thorite also require reinvestigation.

\section{Composition}

The ideal limiting composition of thorite is $\mathrm{ThSiO}_{4}$. All of the analyzed natural material departs widely from this composition owing to solid solution and secondary alteration. The primary variation involves the substitution for $T h$ of $U$ and rare earths chiefly and of $\mathrm{Ca}, \mathrm{Fe}^{+2}, \mathrm{Fe}^{+3}, \mathrm{Mn}$, and $\mathrm{Al}$ to a usually minor extent. $\left(\mathrm{PO}_{4}\right)$ apparently substitutes for $\left(\mathrm{SiO}_{4}\right)$ in small amounts in some instances, and a highly phosphatian variety with $\mathrm{Si}: \mathrm{P}=1: 0.8$ has been reported but is of uncertain validity. (See Auerlite, p. 276.) A phosphatian variety containing about 4 weight percent $\mathrm{P}_{2} \mathrm{O}_{5}$ has been described by Hutton (1950). $\left(\mathrm{PO}_{4}\right)$ is known to substitute to a large extent for $\left(\mathrm{SiO}_{4}\right)$ in the isostructural mineral zircon, and $\left(\mathrm{SiO}_{4}\right)$ similarly enters the isostructural phosphate xenotime. Small amounts of As have been reported in some analyses of thorite. The $\mathrm{Pb}$ presumably is largely or entirely radiogenic. The mechanism of valence compensation for the entrance of other than quadrivalent elements has not been investigated. Synthetic $\mathrm{YAsO}_{4}$ and $\mathrm{YVO}_{4}$ also are isostructural with thorite.

Approximately 40 analyses have been reported of minerals referred to thorite. A small selection of these analyses is given in the table below. Many of the remaining analyses are summarized by Hintze (1915, v. 1, pt. 2A), E. S. Dana (1892), and by Doelter (1931, v. 4, pt. 3, p. 227), and others are cited by Hutton (1950) and Kalinin (1945).

Most of the analyses of thorite are of poor quality. The extent of compositional variation among the cations as indicated by the analyses can be summed up as follows, in terms of weight percent: $\mathrm{Ca}$ is commonly present in amounts ranging from 1 to 4 percent $\mathrm{CaO}$, with about 7 percent in calciothorite; $\mathrm{Fe}$, usually reported as $\mathrm{Fe}_{2} \mathrm{O}_{3}$ but probably originally present as $\mathrm{Fe}^{+2}$, is commonly present in amounts from 1 to 8 percent, with about 13 percent in ferrothorite; $\mathrm{Pb}$ generally is present in amounts less than 2 percent $\mathrm{PbO}$; $\mathrm{Mg}$ frequently is present, but in amounts less than 1 percent $\mathrm{MgO}$. The rare earths, chiefly Ce but with $\mathrm{Y}$ and others, are generally present in amounts of a few percent and in some material in larger amounts (freyalite and analysis 5). The kind and amount of the rare earths present are uncertain, especially in the older analyses, owing partly to faulty analytical procedures and to inaccurate knowledge of the atomic weights. The true valence state of the Ce also is uncertain. $\mathrm{Zr}$ is reported infrequently, and then in small amounts up to about 2 percent $\mathrm{ZrO}_{2}$; it may have been overlooked in many analyses. One of the analyses of the 
Selected chemical analyses of thorite, in weight percent

\begin{tabular}{|c|c|c|c|c|c|c|c|c|}
\hline & 1 & 2 & 3 & 4 & 5 & 6 & 7 & 8 \\
\hline $\mathrm{CaO}$ & & 0. & 4.38 & 0.3 & 0.35 & 1.39 & 2.34 & 1.62 \\
\hline $\mathrm{FeO}$ & 0.59 & .5 & & - & - & & .40 & 3.55 \\
\hline IgO & .0 & .0 & .01 & .3 & - & .05 & .04 & .12 \\
\hline $\mathrm{PbO}$ & .10 & .1 & 1.32 & $.47(\mathrm{~Pb})$ & - & 1.26 & 一 & - \\
\hline $\begin{array}{l}\mathrm{Ce}_{2} \mathrm{O}_{3} \text {, etc. } \\
\mathrm{Y}_{2} \mathrm{O}_{3} \text {. }\end{array}$ & .54 & .24 & .0 & $1.1\}$ & 7.18 & & - & 5.59 \\
\hline $\mathrm{Fe}_{2} \mathrm{O}_{3}$ & & & .7 & 2.3 & 1.71 & 6.59 & $4.01^{\prime}$ & 12.02 \\
\hline $\mathrm{l}_{2} \mathrm{O}$ & 1.29 & .32 & .13 & - & - & .12 & .33 & 4.10 \\
\hline $\mathrm{ThO}_{2}$ & 71.61 & 72.93 & 46.33 & 62.6 & 66.26 & 48.66 & 52.07 & 51.47 \\
\hline $\mathrm{UO}_{2}$ & 8.36 & 6.95 & 7.67 & 11.5 & .46 & 9.00 & & \\
\hline & & & 9.46 & 一 & - & 一 & 10.87 & .41 \\
\hline $\mathrm{TiO}_{2}$ & .10 & .04 & $\overline{-a}$ & $10-$ & $\overline{10}$ & - & $10 \overline{00}$ & .13 \\
\hline $\mathrm{SiO}_{2}$ & 16.47 & 17.96 & 19.56 & 19.5 & 14.10 & 17.47 & 19.38 & 10.22 \\
\hline $\mathrm{H}_{2} \mathrm{O}+$ & 86 & None & 5.67 & $1.68\}$ & 1.20 & .00 & & .00 \\
\hline $\mathrm{H}_{2} \mathrm{O}-$ & .86 & .22 & 3.57 & $.25\}$ & 6.40 & 10.88 & .31 & 0.64 \\
\hline Rem. & .07 & .12 & .22 & - & 2.23 & .73 & .11 & 3.13 \\
\hline Total & 100.00 & 99.95 & 99.94 & 100.0 & 99.89 & 100.20 & 100.86 & 98.88 \\
\hline p gr & 6.36 & - & 4.414 & 6.25 & 4.98 & 一 & 4.126 & 4.96 \\
\hline
\end{tabular}

1. Thorite. Tuolumne River, California. George (1951). Remainder is $\mathrm{ZrO}_{2}$. Dredge concentrate. Recalculated to 100 from original sum of 97.24. Valence state of $\mathrm{Fe}$ and $\mathrm{U}$ not known.

2. Thorite. Año Nuevo Creek, San Mateo County, Calif. Hutton (1952). Remainder is $\mathrm{CuO} 0.11$, MnO $<0.01$. Rare earths chiefly Y. From black sand.

3. Thorite ("uranothorite"). Hybla, Ontario. Ellsworth (1927). Remainder is $\mathrm{MnO} 0.07$, insoluble 0.15 .

4. Thorite ("uranothorite"). Southern Westland, New Zealand. Seelye, analyst, in Hutton (1950).

5. Thorite. Ceylon. Dunstan (1904). Remainder is $\mathrm{ZrO}_{2}$.

6. Thorite. Hitterö, Norway. Remainder is $\mathrm{MnO} 0.43, \mathrm{~K}_{2} \mathrm{O} 0.18, \mathrm{Na}_{2} \mathrm{O} 0.12$. Lindström (1881).

7. Thorite (uranothorite type). From near Lake Champlain, N. Y. Remainder is $\mathrm{Na}_{2} \mathrm{O}$. Parsons, analyst, in Collier (1880). $\mathrm{UO}_{3}$ content calculated from original value $\mathrm{U}_{2} \mathrm{O}_{3} 9.96$. Ce, $\mathrm{La}$, and $\mathrm{Zr}$ absent.

8. Thorite ("ferrithorite"). Kuperlisai, northern Kirghizia, U.S.S.R. Starik, Kravchenko, and Melikova (1941). Remainder is $\mathrm{MnO} 1.93,(\mathrm{Na}, \mathrm{K})_{2} \mathrm{O}$ $0.26, \mathrm{As}_{2} \mathrm{O}_{5}$ 0.51, CuO 0.23, $\mathrm{Cl} \mathrm{0.2,} \mathrm{Pb}$ and Ge trace; $\mathrm{V}, \mathrm{Sn}, \mathrm{Sb}$, and $\mathrm{Bi}$ nil.

related mineral thorogummite shows 4.78 percent $\mathrm{ZrO}_{2}$. There is evidence in natural material of only a very limited series extending between zircon and thorite. Uranium is very often present, sometimes in large amounts. The uranium is present as either or both $\mathrm{U}^{+4}$ and $\mathrm{U}^{+8}$ in the mineral, probably originally only as $\mathrm{U}^{+4}$ with the $\mathrm{U}^{+6}$ formed by later oxidation. Highly uranoan thorite (also called uranothorite, as a varietal designation) carries up to about 12 percent $U$ calculated as $\mathrm{UO}_{2}$. The limit of substitution of $\mathrm{U}$ into thorite is very much greater than in zircon. The tetragonal anhydrous compound $\mathrm{USiO}_{4}$ is not known in nature but an apparently hydrated variant of this compound is known as the mineral coffinite. One of the analyses of the related mineral thorogummite shows $\mathrm{U}>\mathrm{Th}$.

Some analyses reputedly of thorite apparently represent gross admixtures with silicates or other minerals, such as the analyses 
of Gleditsch and Qviller (1932), and in others, such as the material from Batum described by Chernik (1903), there is considerable doubt as to the true identity of the mineral at hand. The intimate admixture of zones or parts of material of different degrees of alteration and the common presence of microscopic inclusions of foreign material further complicate the crystallochemical interpretation of the analyses.

Thorite almost always has undergone extensive secondary alteration of both a structural and chemical nature. Structurally the mineral may lose its crystallinity and assume a glasslike state (metamict state) ; it then does not give an X-ray diffraction pattern and is optically isotropic. The change is primarily due to alpha-particle bombardment by radioactive decay of the Th and $\mathrm{U}$ present. The mechanism has been discussed by Pellas (1951, 1952, 1954), Hutton (1950), Pabst (1952), Hurley and Fairbairn (1953), Morehead and Daniels (1952), Gottardi (1951), and others. This structural alteration is accompanied by hydration and probably also by the oxidation in part or entirety of $\mathrm{Fe}^{+2}$ and $\mathrm{U}^{+4}$ to $\mathrm{Fe}^{+3}$ and $\mathrm{U}^{+6}$. Quantitative dehydration studies have not been made, but differential thermal analysis indicates that the water is lost continuously below about $250^{\circ} \mathrm{C}$. With very few exceptions the analyses of thorite show a stoichiometric deficiency of Si relative to the cations. This deficiency may be due to the leaching of silica during alteration, but the possibility also exists that thorite forms a continuous series with thorogummite.

Thorite is infusible. When fresh it is practically insoluble in hot concentrated acids other than HF, but highly altered types and those containing much rare earths are more or less completely attacked with gelatinization, especially if the material has first been ignited. Fragments of thorite when boiled briefly in strong oxalic acid solution and then dried, show a white film of thorium oxalate.

\section{Crystallography}

Thorite is tetragonal, in the ditetragonal dipyramidal class $(4 / m 2 / m 2 / m)$. This symmetry has long been accepted on the basis of the isostructural relation to zircon indicated by the crystal form and angles and the chemical composition (Brögger, 1890). The symmetry and the relation to zircon were first conclusively established by Pabst (1951a) by X-ray study of nonmetamict uranoan thorite from New Zealand (above table, analysis 4). Unit-cell dimensions follow.

Crystals of thorite closely resemble those of zircon but are rough and altered and do not afford accurate optical goniometric 
Unit-cell dimensions of thorite

\begin{tabular}{|c|c|c|c|}
\hline & SYNTHETIC & ANALYSIS 4 & \\
\hline $\begin{array}{l}a_{0} \\
c_{0}\end{array}$ & $\begin{array}{l}7.117 \mathrm{~A} \\
6.295\end{array}$ & $\begin{array}{l}7.12 \pm 0.03 \mathrm{~A} \\
6.32 \pm .03\end{array}$ & \multirow{2}{*}{$\begin{array}{l}\alpha_{0}: c_{0}=1: 0.888 ; \\
\text { space group } I 4 / a m d ; \\
\text { unit-cell contents } \\
4\left[\mathrm{Th}, \mathrm{U}\left(\mathrm{SiO}_{4}\right)\right] .\end{array}$} \\
\hline Reference & Frondel (1953) & Pabst (1951a) & \\
\hline
\end{tabular}

measurements. Approximate angular measurements have been reported by Zschau (1858), Nordenskiöld (1876), Breithaupt (1866), and others. Crystals of typical habit are shown in figure 20. The morphological unit and orientation of these descriptions,

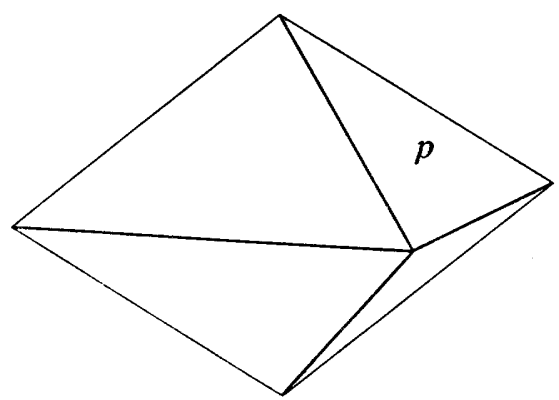

$A$

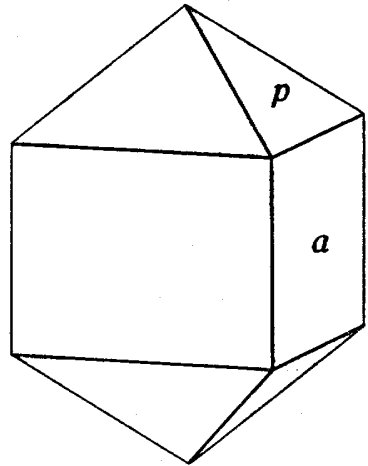

$B$

FIgURe 20.-Thorite. A. Pyramidal habit with $p\{111\} . B$. Prismatic habit with $p\{011\}$ and $a\{010\}$.

as originally given and later used by E. S. Dana (1892), V. Goldschmidt (1913-23), and others, correspond to the doubled, facecentered cell in the structural lattice and is here turned $45^{\circ}$ to conform to the body-centered unit. An angle table for the known forms (V. Goldschmidt, 1913-23) calculated from the dimensions of the $\mathrm{X}$-ray cell is given below.

Angle table for thorite

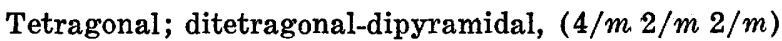

$a: c=1: 0.888 ; \quad p_{0}: r_{0}=0.888: 1$

\begin{tabular}{|c|c|c|c|c|}
\hline FORMS & $\phi$ & $\rho$ & $A$ & $\overline{\bar{M}}$ \\
\hline $\begin{array}{ll}c & 001 \\
a & 010 \\
m & 110\end{array}$ & $\begin{array}{r}0^{\circ} \overline{00} \\
4500\end{array}$ & $\begin{array}{r}0^{\circ} 00^{\prime} \\
9000 \\
9000\end{array}$ & $\begin{array}{l}90^{\circ} 00^{\prime} \\
9000 \\
4500\end{array}$ & $\begin{array}{l}90^{\circ} 00 \\
4500 \\
9000\end{array}$ \\
\hline $\begin{array}{ll}l & 130 \\
p & 011 \\
u & 031\end{array}$ & $\begin{array}{rr}18 & 26 \\
0 & 00 \\
0 & 00\end{array}$ & $\begin{array}{ll}90 & 00 \\
41 & 36 \\
69 & 251 / 2\end{array}$ & $\begin{array}{ll}71 & 34 \\
90 & 00 \\
90 & 00\end{array}$ & $\begin{array}{l}6326 \\
6200 \\
4833\end{array}$ \\
\hline $\begin{array}{ll}x & 121\end{array}$ & 2634 & 6316 & $66271 / 2$ & 7336 \\
\hline
\end{tabular}


In crystal habit, thorite usually is short prismatic with $\{100\}$ and the pyramid $\{101\}$; also pyramidal $\{101\}$ with prism faces small or absent. The other reported forms are small in size and are rare. The crystals occasionally are as large as 3 or $4 \mathrm{~cm}$. Also found massive; the substance calciothorite, perhaps identical with thorite, occurs as small reniform masses. As anhedral embedded grains and masses.

Oriented growths of zircon upon thorite, the crystal axes of the two minerals parallel, have been observed by Brögger (1890).

\section{Physical properties}

Cleavage $\{100\}$; said to be distinct in fresh material, but not usually observed in metamict crystals. Fracture conchoidal to subconchoidal and splintery. Brittle. Hardness about $4 \frac{1}{2}$, variable owing to alteration. The specific gravity varies widely, owing to compositional variation and alteration. The range of reported values is 6.7-4.1, decreasing with increase in content of water; usually about 4.3-5.4. The specific gravity of metamict crystals increases on heating. Luster of fresh fracture surfaces vitreous to resinous, sometimes greasy. Color brownish yellow, yellow to orange yellow; also brownish black to dark brown and reddish brown; less commonly greenish black to green. The color often is variable within a single crystal, as an irregular mottling or veining, or the crystals are outwardly brownish and inwardly orange yellow with an irregular demarcation between. Translucent to virtually opaque in large masses, transparent in thin section or small grains. Streak yellow to brown. Not fluorescent. Data are lacking on the systematic variation in properties as a function of composition. Paramagnetic, with a susceptibility considerably less than that of monazite.

\section{Optical properties}

Anisotropic nonmetamict thorite is extremely rare. The nonmetamict uranoan thorite from New Zealand described by Hutton (1950) and Pabst (1951a) (analysis 4) is uniaxial positive with $n_{o}$ 1.818-1.825, $n_{E}$ 1.839-1.840. Another specimen, from Langesund Fiord, Norway, was in part isotropic and in part uniaxial with $n_{o}$ $1.84 \pm 0.01$ and birefringence about 0.01 (Larsen, 1921). A phosphatian variety from New Zealand described by Hutton (1950) was pale yellow, uniaxial positive, with $n_{0} 1.78, n_{E} 1.79$. Nonmetamict crystals may be dichroic in shades of green, with absorption $O<E$. The color of metamict detrital grains commonly is drab brown to olive yellow and green.

Metamict material is isotropic and the index of refraction varies widely accompanying variation in composition and the degree of 
hydration. The index of refraction may differ considerably in parts of the same crystal, usually with an accompanying variation in color. When thorite is heated, the index increases markedly, up to a maximum when crystallization ensues. The recrystallized material, which may be either thorite, huttonite, or mixtures of these with $\mathrm{ThO}_{2}$ (see Thermal behavior), is too fine grained to permit measurement of other than the mean index of refraction of the aggregate. The index presumably increases with increasing substitution of $U$ for $T h$, but the value varies chiefly with the water content and this obscures any systematic relation. A summary of the observations on natural and heated thorite is given in the following table.

Index of refraction of metamict thorite

\begin{tabular}{|c|c|c|c|}
\hline LOCALITY & $\begin{array}{c}\text { BEFORE } \\
\text { HEATING }\end{array}$ & $\begin{array}{c}\text { AFTER } \\
\text { HEATING }\end{array}$ & $\begin{array}{l}\text { REFERENCE } \\
\text { AND REMARKS }\end{array}$ \\
\hline Brevig, Norway & $\overline{1.705}$ & $\overline{1.80-1.81+\left(850^{\circ} \mathrm{C}\right)}$ & Pabst (1952). \\
\hline Arö, Norway & 1.664 & $1.725\left(640^{\circ} \mathrm{C}\right)$ & Do. \\
\hline $\begin{array}{l}\text { Do } \\
\text { Arendal (?) }\end{array}$ & $1.71-1.78$ & $1.80\left(850^{\circ} \mathrm{C}\right)$ & Do. \\
\hline $\begin{array}{l}\text { Arendal (?), } \\
\text { Norway. }\end{array}$ & $1.72-1.78$ & $1.77-1.82+\left(850^{\circ} \mathrm{C}\right)$ & Do. \\
\hline Madagascar & 1.695 & $1.739\left(640^{\circ} \mathrm{C}\right)$ & Do. \\
\hline $\begin{array}{l}\text { Landbö, Norway } \\
\text { Brevig, Norway }\end{array}$ & $\begin{array}{l}1.683 \\
1.693\end{array}$ & $1.78 \pm 0.01$ (ign.) & Larsen (1921). \\
\hline $\begin{array}{l}\text { Langesund Fiord, } \\
\text { Norway. }\end{array}$ & $1.68-1.72+$ & - & Do. \\
\hline Do............ & 1.686 & 1.85 (ign.) & Do. \\
\hline Madagascar & $1.82 \pm 0.02$ & & $\begin{array}{l}\text { Uranoan. George } \\
(1949) .\end{array}$ \\
\hline California & $1.845 \pm 0.02$ & - & Do. \\
\hline $\begin{array}{c}\text { New Zealand } \\
\text { Do................ }\end{array}$ & $\begin{array}{l}1.87 \pm 0.01 \\
1.85 \pm 0.05\end{array}$ & 二 & $\begin{array}{l}\text { Do. } \\
\text { Do. }\end{array}$ \\
\hline Madagascar & $1.66-1.69$ & 一 & Do. \\
\hline California & $1.76-1.87$ & 一 & George (1951). \\
\hline Ontario & 1.710 & 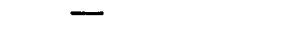 & $\begin{array}{l}\text { Uranoan. Ellsworth } \\
\text { (1927). }\end{array}$ \\
\hline Colorado & $1.86 \pm 0.01$ & 一 & Phair and \\
\hline Alaska & $1.86 \pm 0.01$ & - & Do. \\
\hline
\end{tabular}

In transmitted light, thorite commonly shows microscopic inclusions of various sorts, including magnetite and oriented uniaxial positive prisms of a highly birefringent mineral that may be zircon (Brögger, 1890). Sectoral and biaxial optical anomalies such as have been described for zircon have not been mentioned for thorite. Detrital grains of thorite may show anastomosing systems of cracks (Hutton, 1950).

Thermal behavior

When heated, metamict thorite crystallizes at elevated temperatures to fine-grained random aggregates of tetragonal 
$\mathrm{ThSiO}_{4}$ (thorite), monoclinic $\mathrm{ThSiO}_{4}$ (huttonite), or mixtures of these with $\mathrm{ThO}_{2}$ (thorianite) and amorphous $\mathrm{SiO}_{2}$. The behavior of different specimens varies considerably, in part presumably attending differences in composition. The nature of the products also is influenced by the temperature, by the length of time the sample is held at a given temperature, and probably also by the structural condition or degree of metamictization of the original sample. The nature of the atmosphere in which the material is held seems to be an added factor. In general, the crystallization progresses rapidly at $800^{\circ}-900^{\circ} \mathrm{C}$, but it may be effected by prolonged heating at somewhat lower temperatures. The differential thermal analysis curves show a sharp exothermic peak at about $880^{\circ} \mathrm{C}$. At $800^{\circ}-900^{\circ} \mathrm{C}$ the crystallization products as detected by X-ray diffraction patterns generally consist of $\mathrm{ThO}_{2}$ with thorite or with mixtures of thorite and huttonite, although some amorphous material still may persist. At higher temperatures, to $1,400^{\circ} \mathrm{C}$, huttonite is formed directly or by conversion of earlier formed thorite, and some $\mathrm{ThO}_{2}$ also may be present. In one sample investigated, huttonite was the only phase formed over the range, and a nonmetamict thorite (analysis 4) afforded only thorite up to $1,400^{\circ} \mathrm{C}$. It also has been reported that crystalline thorite when heated at $1,300^{\circ} \mathrm{C}$ in an inert water-free atmosphere does not form huttonite, and that a sample of the latter heated similarly at about $1,200^{\circ} \mathrm{C}$ reverted to the tetragonal phase. A 1:1 mixture of $\mathrm{ThO}_{2}$ and $\mathrm{SiO}_{2}$ formed huttonite directly at $1,400^{\circ} \mathrm{C}$. A summary of the thermal behavior of thorite has been given by Pabst (1952) and C. Frondel (1953). The closely related but nonmetamict mineral thorogummite exhibits a somewhat different thermal behavior.

\section{Synthesis}

Obtained in microcrystalline form by heating compressed tablets of powdered $\mathrm{SiO}_{2}$ and $\mathrm{ThO}_{2}$ in 1:1 molar proportions to nearly $1,000^{\circ} \mathrm{C}$ (Pabst, 1952); also by heating coprecipitated gels of $\mathrm{ThO}_{2}$ and $\mathrm{SiO}_{2}$ with a small amount of $\mathrm{NaCl}$ in air at $1,000^{\circ}-1,200^{\circ}$ C (Collette, written communication, 1953). Obtained as microscopic crystals by heating coprecipitated $\mathrm{ThO}_{2}$ and $\mathrm{SiO}_{2}$ with water and small amount of $\mathrm{ThF}_{4}$ in a steel bomb at $240^{\circ} \mathrm{C}$ or higher (C. Frondel and Collette, written communication, 1953).

\section{Alteration}

The alteration of thorite to the metamict state has already beer discussed. Thorite also may alter to thorogummite. This alteratior involves the development of dull microcrystalline turbid or opaque. rims, veinings, or complete pseudomorphs. Thorite also has beer 
observed to alter to soft, earthy, orange-red unidentified minerals. Thorite and orangeite were considered to be distinct species, but Scheerer (1860) and others showed that they were chemically and crystallographically identical. The resinous yellow to orangeyellow orangeite often forms the core of crystals and passes outwardly into dark-brown or black material (the original thorite) ; both are altered metamict phases of thorite proper.

\section{Identification}

Thorite very closely resembles huttonite, thorogummite, and zircon. Crystalline zircon can be distinguished by its relatively high indices of refraction, superior hardness, and its X-ray diffraction pattern; the crystal habit is identical with that of thorite. Metamict zircon closely resembles metamict thorite; aside from qualitative chemical tests, the relatively low specific gravity (which may overlap that of metamict thorite in part) and the X-ray powder pattern after heating (usually $\mathrm{ZrO}_{2}$ and $\mathrm{SiO}_{2}$ ) are useful criteria. Huttonite can be distinguished optically, and the X-ray pattern or evidence of tetragonal or monoclinic crystal form are conclusive. The distinction of thorite from thorogummite primarily

\section{$X$-ray powder-spacing data for thorite ${ }^{1}$}

[Symbols: b, diffuse line, possibly a doublet; c, broad band, centering as listed; $d$, diffuse line. Copper radiation, nickel filter]

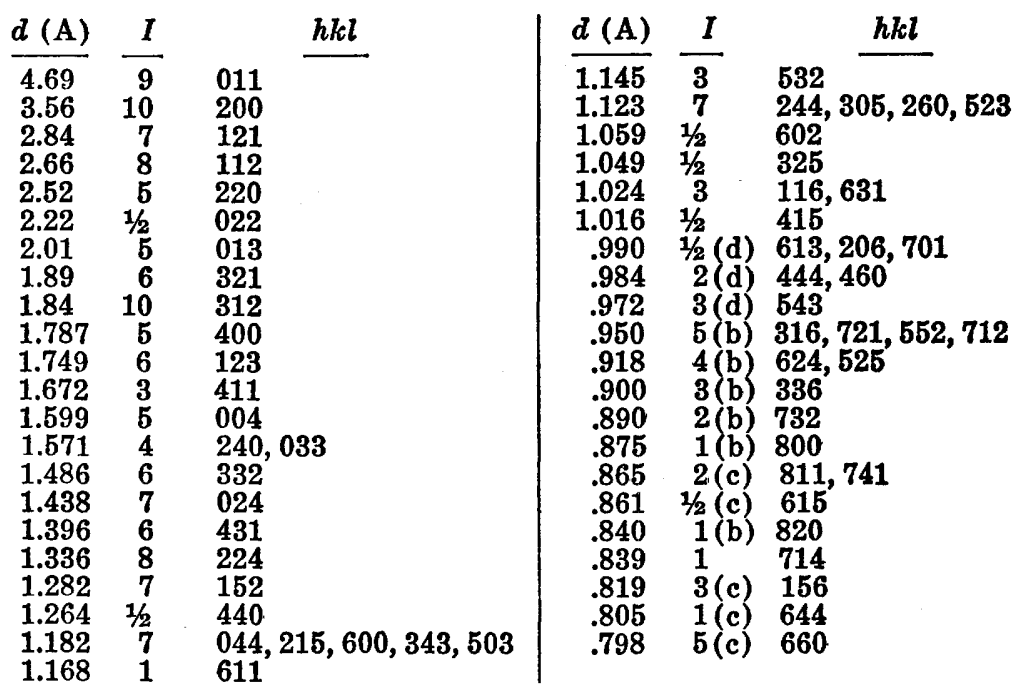

${ }^{1}$ Data on pure anhydrous synthetic tetragonal $\mathrm{ThSiO}_{4}$. Natural thorite is nearly or completely metamict. The spacings of such material when recrystallized by heating may differ slightly from those of pure synthetic material owing to a variable and sometimes large content of U, rare earths, or other elements in substitution for Th. 
rests on the presence or absence of essential water in compensation for a silica deficiency; thorogummite occurs as light-colored fine-grained dull to earthy microcrystalline aggregates and is a secondary product. The X-ray powder-spacing data for thorite are given in the above table. Thorogummite has an identical pattern. The $d$-spacings of both minerals vary as a function of compositional changes, such as a substitution of $U$ for Th or of $(\mathrm{OH})_{4}$ for $\left(\mathrm{SiO}_{4}\right)$.

Natural formation

Thorite occurs in nature as a primary mineral chiefly in pegmatites. It also occurs as an accessory mineral in black sands and other detrital deposits derived from gneissic or granitic terranes, in which it presumably has been originally contained in pegmatitic veins or stringers. Descriptions of detrital thorite are given by Hutton $(1950,1952,1953)$. In the pegmatite occurrences the thorite is in general an early formed mineral and occurs associated with zircon (cyrtolite), sphene, monazite, xenotime, allanite, and various niobate-tantalates such as fergusonite, betafite, and euxenite. Detrital thorite is associated chiefly with zircon, monazite, rutile, ilmenite, garnet, and magnetite. A uranoan thorite has been described by Phair and Shimamoto (1952) as a hydrothermal mineral in fluorite breccias in the Jamestown district, Boulder County, Colo. It is also found in close association with fluorite in the pegmatite occurrence at the Macdonald mine, Hybla, Ontario. Thorite is a minor constituent in calcite-fluorite-apatite veins transitional to pegmatites and in metasomatized zones in impure crystalline limestones in the Grenville series of Ontario and Quebec. A thorite-like mineral, eucrasite, occurs with fluorite in a mafic pyrochlore pegmatite, somewhat similar to the Macdonald pegmatite, near Barkevik, Norway, and another thorite-like mineral from this region, calciothorite, apparently is a relatively lateformed hydrothermal deposit.

\section{Occurrence}

Thorite was first found by Esmark in 1828 on the island of Lövö, opposite Brevik, in the Langesund Fiord, southern Norway (Esmark, 1836) ; this material was analyzed by Berzelius (1829) and resulted in the discovery of the element thorium. The mineral also occurs at Arö, Haö, and Sigtesö near Barkevik and at other places on the Langesund Fiord. Numerous additional localities are known in pegmatites associated with granites, augite syenites, and nepheline syenites in southern Norway, as at Garta, Sansvik, Bjellan, the island Landbö and other points near Arendal; at Svinör and Linland on the Lenes Fiord near Lindesnäs; at Kragerö 
and Hitterö. In Madagascar a uranoan variety occurs at Ambatofotsy and an iron-rich variety at Befaritra; the mineral occurs in pegmatites associated with euxenite, betafite, and fergusonite. As an accessory mineral in beach sands at South Westland, New Zealand (Hutton, 1950, Pabst, 1951b). The thorite-like minerals including hydrothorite and other supposed species described from the Pilbara gold field, Western Australia, are described elsewhere in this volume under Thorogummite. Found as a detrital mineral in sands of the Pekoeringan River, Central Celebes (originally described as a new species, wisaksonite, but later shown by Hutton (1954) to be metamict uranoan thorite). Thorite also has been described from pegmatite in hornblende granite at Beinn Laoghal, Sutherland, Scotland; Königshain, Saxony; the Batum region, Caucasus, U.S.S.R. ; with thorianite as detrital grains at Kondragula and elsewhere in Ceylon; in Italy at Nettuno, Sicily. In the United States thorite occurs in Henderson County, N. C., in disintegrated gneiss or granite with zircon and monazite. As crystals in the rare-earth pegmatite at Baringer Hill, Llano County, Texas, associated with gadolinite, allanite, fergusonite, uraninite, yttrialite, and zircon. In pegmatite in the Pikes Peak region, Colorado. Vein-like deposits of thorite have been found in the Wet mountains, Custer County, and the Powderhorn district, Gunnison County, Colo., and the Lemhi Pass and Deer Creek districts, Idaho and Montana (Christman and others, 1955; Olson and Wallace, 1956; Trites and Tooker, 1953). Found sparingly with allanite in pegmatitic patches in gneiss at Blueberry Mountain, Woburn (near Boston), Mass. (Richmond, 1937). An unidentified tetragonal thorium mineral, probably thorite, has been reported from the Harding pegmatite, New Mexico (Hirschi, 1928). The first highly uranoan variety of thorite was described by Collier (1880) under the name uranothorite from an unstated locality, perhaps a magnetite deposit, in the Lake Champlain region of New York; it had a dark red-brown color and high water content (analysis 7) and may have been thorogummite. Thorite occurs as a minor constituent of black sands in the gold placers of California, particularly along the Tuolumne River near La Grange. It occurs as a hydrothermal mineral in fluorite deposits in the Jamestown district, Boulder County, Colo.; also reported from the hydrothermal sulfide veins of Llallagua, Bolivia. In Canada, uranoan thorite occurs abundantly in large crystals in pegmatite at the Macdonald mine, Hybla, Haliburton County, Ontario, and it has been reported from pegmatites, calcite-fluorite-apatite veins, and metasomatized zones in crystalline limestone at various localities in the Grenville rocks of Quebec and Ontario (A. H, Lang, 1952; Robinson and 
Sabina, 1955). Found in gold placers in the Ruby district, Alaska, and in pegmatites in the Willow Creek district, Alaska (Moxham and Nelson, 1952). With pyrochlore in tin placers in Nigeria (Greenwood, 1948).

The thorite-like minerals auerlite, calciothorite, freyalite, eucrasite, ferrothorite, enalite, and parathorite need further study to establish their true status. Each is described in the following pages under its own heading. Auerlite seems to be a phosphate-containing variety of thorite or thorogummite. The position of calciothorite and especially of eucrasite and freyalite, both rich in rare earths, is less certain.

\section{AUERIITE}

Synonymy

Auerlite Hidden and Mackintosh (1888). Named after Carl Auer von Welsbach (1858-1929), German chemist, who developed incandescent mantles for a system of gas lighting.

\section{Description}

Found as prismatic tetragonal crystals with prism and pyramid, resembling zircon in habit and angles, but too rough on the surface to permit measurement. Hardness $21 / 2-3$. Specific gravity 4.42 to 4.76, greatest in dark orange-red material. On fracture surfaces the cluster is resinous and the color ranges from pale lemon yellow through orange to deep brown, red; externally dull and yellowish white. Subtranslucent to opaque. Analysis gave:

\begin{tabular}{|c|c|c|c|c|c|}
\hline & $\begin{array}{l}\text { Weight } \\
\text { percent }\end{array}$ & & $\underset{\text { percent }}{\text { Weight }}$ & & $\begin{array}{l}\text { Weight } \\
\text { percent }\end{array}$ \\
\hline $\begin{array}{l}\mathrm{ThO}_{2} \\
\mathrm{CaO} \\
\mathrm{MgO}\end{array}$ & $\begin{array}{r}70.13 \\
.49 \\
.29\end{array}$ & $\begin{array}{l}\mathrm{Fe}_{2} \mathrm{O}_{3} \\
\mathrm{Al}_{2} \mathrm{O}_{3} \\
\mathrm{SiO}_{2}\end{array}$ & $\begin{array}{l}1.38 \\
1.10 \\
7.64\end{array}$ & $\begin{array}{l}\mathrm{P}_{2} \mathrm{O}_{5} \\
\mathrm{H}_{2} \mathrm{O}, \mathrm{CO}_{2}\end{array}$ & $\begin{array}{r}7.46 \\
11.21 \\
0970\end{array}$ \\
\hline
\end{tabular}

Other partial analyses: $\mathrm{CO}_{2} 1.00$ and $\mathrm{H}_{2} \mathrm{O} 9.88$; $\mathrm{SiO}_{2} 9.25$ and 8.25; $\mathrm{P}_{2} \mathrm{O}_{5}$ 7.59; $\mathrm{ThO}_{2}$ 69.23. Soluble with gelatinization in $\mathrm{HCl}$. Infusible; on strong ignition turns dull brown and on cooling becomes orange again.

Auerlite was found associated with abundant zircon in disintegrated gneiss and granite at the Freeman mine and on the nearby Price property, on Green River, Henderson County, N. C. The auerlite occurs in part as parallel growths on zircon; parallel growths of xenotime on zircon occur in the same district.

The composition of auerlite was interpreted by Hidden and Mackintosh as a hydrated thorium silicate related to zircon and thorite in which, in modern terms, $\left(\mathrm{PO}_{4}\right)$ substituted for $\left(\mathrm{SiO}_{4}\right)$ 
in part. This view has been questioned (E. S. Dana, 1892) on the grounds that the substance may have been a mixture of a phosphate and a silicate. The parallel growths of zircon and xenotime, and the occurrence of phosphate in zircon and of silica in monazite and xenotime-then ascribed to admixture-were recalled in this regard. Hidden and Mackintosh (1888), however, were aware of the parallel growths formed with zircon, and stated that the mineral appeared to the eye to be homogeneous. It is now known that coupled series involving the substitution of $\left(\mathrm{PO}_{4}\right)$ and $\left(\mathrm{SiO}_{4}\right)$ occur in zircon, xenotime, and monazite, and it is very probable that the same mechanism can operate in thorite. Auerlite can be tentatively considered to be a highly phosphatian variety of thorite or thorogummite, with $\left(\mathrm{PO}_{4}\right):\left(\mathrm{SiO}_{4}\right) \approx 0.8: 1$.

\section{Synonjmy}

\section{CALCIOTHORITE}

Calciothorite Brögger (1887, 1890).

Description

Found as grains and as reniform masses as large as a walnut embedded in analcime (derived from nepheline) or feldspar in pegmatite on the islands Arö and Låven in the Langesund Fiord, Norway. The mineral seems to be of hydrothermal formation (Brögger, 1890). Fracture conchoidal. Brittle. Hardness 41/2. Specific gravity 4.11. Luster vitreous. Color deep red resembling almandite garnet. Translucent. Optically isotropic and presumably metamict.

Analysis by Cleve in Brögger :

\begin{tabular}{|c|c|c|c|c|c|c|c|}
\hline & $\begin{array}{l}\text { Weight } \\
\text { percent }\end{array}$ & & $\underset{\text { percent }}{\text { Weight }}$ & & $\begin{array}{l}\text { Weight } \\
\text { percent }\end{array}$ & & $\begin{array}{l}\text { Weight } \\
\text { percent }\end{array}$ \\
\hline $\begin{array}{l}\mathrm{a}_{2} \mathrm{O} \\
\mathrm{aO} \\
\mathrm{g} \mathrm{O} O\end{array}$ & $\begin{array}{r}0.67 \\
6.93 \\
.04\end{array}$ & $\begin{array}{l}\mathrm{Ce}_{2} \mathrm{O}_{2} \\
\mathrm{Y}_{2} \mathrm{O}_{3} \\
\mathrm{Al}_{2} \mathrm{O}_{3}\end{array}$ & $\begin{array}{r}0.39 \\
.23 \\
1.02\end{array}$ & $\begin{array}{l}\mathrm{Mn}_{2} \mathrm{O}_{3} \\
\mathrm{ThO}_{2} \\
\mathrm{SiO}_{2}\end{array}$ & $\begin{array}{r}0.73 \\
59.35 \\
21.09\end{array}$ & $\begin{array}{l}\text { Ign. } \\
\text { Total }\end{array}$ & $\frac{9.39}{99.84}$ \\
\hline
\end{tabular}

The analysis was made on material dried at $100^{\circ} \mathrm{C}$, at which temperature it had lost 2.3 percent weight $\left(\mathrm{H}_{2} \mathrm{O}\right) . \mathrm{P}_{2} \mathrm{O}_{5}$ was found in traces, no $\mathrm{B}$ was found, and no statement is made concerning U. Soluble with gelatinization in acids. Before the blowpipe turns white but does not fuse. In the closed tube yields much water.

Calciothorite may be a calcian variety of thorite or thorogummite, with $\mathrm{Th}: \mathrm{Ca} \approx 1.8: 1$. The mechanism of valence compensation is not apparent, but a substitution of $4\left(\mathrm{H}_{2} \mathrm{O}\right)$ for $\left(\mathrm{SiO}_{4}\right)$ could be invoked. 


\section{FREYAITTE}

Synonymy

Freyalith Damour (1878). Named for the Scandinavian goddess, Freya.

\section{Description}

Stated to resemble brown thorite. Scratches glass slightly. Specific gravity 4.06-4.17. Color brown. Streak yellowish gray. Luster resinous. Translucent in thin splinters. An approximate analysis gave:

\begin{tabular}{|c|c|c|c|c|c|c|}
\hline & $\begin{array}{l}\text { Weight } \\
\text { percent }\end{array}$ & $\begin{array}{l}\text { Weight } \\
\text { percent }\end{array}$ & & $\begin{array}{l}\text { Weight } \\
\text { percent }\end{array}$ & & $\underset{\text { wercent }}{\text { Weight }}$ \\
\hline $\begin{array}{l}\text { Alk. } \\
\mathrm{Fe}_{2} \mathrm{O}_{3}\end{array}$ & $\begin{array}{l}2.33 \\
2.47\end{array}$ & $\begin{array}{lr}\mathrm{Ce}_{3} \mathrm{O}_{4} & \overline{28.80} \\
\text { (La,etc.) } & \mathrm{O}_{3} \\
2.47\end{array}$ & $\begin{array}{l}\mathrm{ThO}_{2} \\
\mathrm{SiO}_{2}\end{array}$ & $\begin{array}{l}28.39 \\
20.02\end{array}$ & & 0.82 \\
\hline $\begin{array}{l}\mathrm{Al}_{2} \mathrm{O}_{3} \\
\quad\left(\mathrm{ZrO}_{2} ?\right)\end{array}$ & 6.31 & $\mathrm{Mn}_{3} \mathrm{O}_{4} \quad 1.78$ & $\mathrm{H}_{2} \mathrm{O}$ & 7.40 & Total & 100.79 \\
\hline
\end{tabular}

Soluble in acid with gelatinization; with $\mathrm{HCl}$ chlorine is given off. Before the blowpipe swells but does not fuse. In closed tube loses water and turns white. Found near Barkevik in the Langesund Fiord, Norway. Freyalite resembles eucrasite and the thorogummite from Iisaka, Japan, (analysis 3, table on page 281, under Thorogummite) in its very high content of rare earths. The mineral may be an intermediate member of a series to the hypothetical compound, $\mathrm{CeSiO}_{4}$.

\section{EUCRASITE}

Synonymy

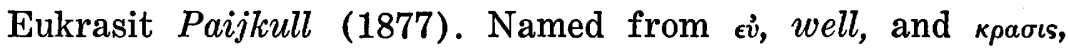
mixed, because so complex in composition.

Description

Massive; not in crystals as originally suggested (Brögger, 1890). Fracture uneven. Brittle. Hardness $4 \frac{1}{2}-5$. Specific gravity 4.39. Luster greasy. Color blackish brown to deep brown. Streak brown. Transparent in small grains. Optically isotropic and presumably metamict. Outwardly altered to a yellowishbrown ocherous material. Analysis gave:

\begin{tabular}{|c|c|c|c|c|c|}
\hline & $\begin{array}{l}\text { Weight } \\
\text { percent }\end{array}$ & & $\begin{array}{l}\text { Weight } \\
\text { percent }\end{array}$ & & $\begin{array}{l}\text { Weight } \\
\text { percent }\end{array}$ \\
\hline $\begin{array}{l}\mathrm{Na}_{2} \mathrm{O} \\
\mathrm{K}_{2} \mathrm{O} \\
\mathrm{MgO} \\
\mathrm{CaO} \\
\mathrm{Al}_{2} \mathrm{O}_{3} \\
\mathrm{Fe} \mathrm{O}_{2}\end{array}$ & $\begin{array}{r}2.48 \\
.11 \\
.95 \\
4.00 \\
1.77 \\
4.25\end{array}$ & $\begin{array}{l}\mathrm{Y}_{2} \mathrm{O}_{3} \\
(\mathrm{La}, \text { etc. })_{2} \mathrm{O}_{3} \\
\mathrm{CeO}_{3} \\
\mathrm{CeO}_{2} \\
\mathrm{ThO}_{2} \\
\mathrm{MnO}_{3}\end{array}$ & $\begin{array}{r}4.33 \\
2.42 \\
6.13 \\
5.48 \\
35.96 \\
2.34\end{array}$ & $\begin{array}{l}\mathrm{ZrO}_{2} \\
\mathrm{SnO}_{2}(?) \\
\mathrm{TiO}_{2} \\
\mathrm{SiO}_{2} \\
\mathrm{Ign} .\end{array}$ & $\begin{array}{r}0.60 \\
1.15 \\
1.27 \\
16.20 \\
9.15\end{array}$ \\
\hline $\mathrm{Er}_{2} \mathrm{O}_{3}$ & $\begin{array}{l}4.20 \\
1.62\end{array}$ & & & Total & 100.21 \\
\hline
\end{tabular}


Completely soluble in $\mathrm{H}_{2} \mathrm{SO}_{4}$ (apparently without gelatinization, in distinction from thorite) ; partly soluble in $\mathrm{HCl}$ with evolution of chlorine. Before blowpipe fusible on thin edges. Found at Borsrö near Barkevik on the Langesund Fiord, Norway, where it occurs with violet fluorite and altered biotite in a pyrochlorebearing pegmatite (Brögger, 1890). Eucrasite, like freyalite, may be a variety of thorite or thorogummite relatively high in rare earths.

\section{FERROTHORITE}

Ferrothorite Lacroix (1923). Apparently an altered variety of thorite containing much iron. Color red. Analysis: $\mathrm{Fe}_{2} \mathrm{O}_{3}$ 13.1, $\mathrm{U}_{3} \mathrm{O}_{8}$ 2.8, $\mathrm{ThO}_{2}$ 61.5, $\mathrm{SiO}_{2} 12.6, \mathrm{H}_{2} \mathrm{O}+5.50, \mathrm{H}_{2} \mathrm{O}-4.0$, total 99.5. Found with betafite in pegmatite at Befaritra, $2.5 \mathrm{~km}$ northeast of Lake Pilina, Madagascar. Thorites from the Sludianka and North Kirghizia regions, U.S.S.R., that have a high iron content have been described by Kalinin (1945) and by Starik, Kravchenko, and Melikova (1941).

\section{ENALITE}

Enalite Kimura and Miyake (1932). Tetragonal. Color orange yellow. Specific gravity 4.87. Index of refraction 1.68. Weakly birefringent. Chemical analysis of a mixture with monazite and cassiterite indicates that this mineral is a uranoan variety of thorite or thorogummite. Found in sands derived from pegmatite at Kotzugusawa, Fukuoka village, Ena prefecture, Gifu district, Japan. Analysis gave:

\begin{tabular}{|c|c|c|c|c|c|c|c|}
\hline & $\begin{array}{l}\text { Weight } \\
\text { percent }\end{array}$ & & $\begin{array}{l}\text { Weight } \\
\text { percent }\end{array}$ & & $\begin{array}{l}\text { Weight } \\
\text { percent }\end{array}$ & \multirow[b]{2}{*}{ Ign. loss } & $\begin{array}{l}\text { Weight } \\
\text { percent }\end{array}$ \\
\hline $\mathrm{CaO}$ & $\begin{array}{r}0.73 \\
95\end{array}$ & $\mathrm{Ce}_{2} \mathrm{O}_{3}$ & 11.59 & $\mathrm{SnO}_{2}$ & 4.81 & & 5.59 \\
\hline $\mathrm{Al}_{2} \mathrm{O}_{3}$ & 3.01 & $\begin{array}{l}\mathrm{Nd}_{2} \mathrm{U}_{3} \\
\mathrm{ThO}_{2}\end{array}$ & $\begin{array}{l}12.07 \\
28.96\end{array}$ & $\begin{array}{l}\mathrm{TiO}_{2} \\
\mathrm{SiO}_{2}\end{array}$ & $\begin{array}{l}1.37 \\
5.82\end{array}$ & Total & 99.43 \\
\hline $\mathrm{Fe}_{2} \mathrm{O}_{3}$ & .88 & $\mathrm{UO}_{2}$ & 10.63 & $\mathrm{P}_{2} \mathrm{O}_{5}$ & 12.52 & & \\
\hline
\end{tabular}

\section{PARATHORITE}

Thorite Shepard (1851). Parathorite Shepard (1857). Dana and Brush (1857). A mineral named from its supposed geometrical resemblance to thorite. The mineral was later shown by Dana and Brush (1857) to be orthorhombic rather than tetragonal. Composition unknown, aside from blowpipe tests that indicate the presence of iron and possibly of titanium. Found at Danbury, Conn., associated with danburite and feldspar. This name can be given significance only if the original material of Shepard is redescribed. 


\section{THOROGUMMITE}

Synonymy

Thorogummite Hidden and Mackintosh (1889). Mackintoshite Hidden and Mackintosh (1893). Hydrothorite Simpson (1927). Hyblite Ellsworth (1927) (includes alpha- and beta-hyblite). Maitlandite Simpson (1930). Nicolayite Simpson $(1912,1930)$. Hydroxyl-thorite.

The minerals here tentatively grouped together seem to be minor chemical variants of a single phase, for which the name thorogummite has priority, that is isostructural if not identical with thorite. Thorogummite differs from thorite in being secondary in origin and formed by the alteration of primary thorium minerals including thorite itself, in occurring as fine-grained aggregates that are not metamict but crystalline, and in containing essential water. Chemically, thorogummite is a hydroxylsubstituted variant of thorite, $\mathrm{ThSiO}_{4}$, in which there is a serial substitution of $(\mathrm{OH})_{4}$ for $\left(\mathrm{SiO}_{4}\right)$ with the general formula $\mathrm{Th}\left(\mathrm{SiO}_{4}\right)_{1-\mathrm{x}}(\mathrm{OH})_{4 \mathrm{x}}$. It is not known whether the series extends to anhydrous $\mathrm{ThSiO}_{4}$, or whether it may occur in primary (pegmatitic) thorite or is restricted to secondary low-temperature material.

A number of other ill-defined, thorite-like minerals have been given specific names. Although their relation to thorogummite and thorite is uncertain, they are grouped here under thorite. Further investigation is needed also to establish the true status of many substances described as thorite.

Composition

Essentially a hydrated thorium silicate, containing $\mathrm{U}, \mathrm{Pb}$, and rare earths in variable and sometimes large amounts in substitution for thorium. The material of analyses 2 and 6 of the table below has $\mathrm{U}>\mathrm{Th}$ in atomic percent. Small amounts of $\mathrm{Zr}, \mathrm{Ca}, \mathrm{Al}$, and $\mathrm{Fe}$ usually are also present in substitution for Th. $\mathrm{P}_{2} \mathrm{O}_{5}$ is reported in amounts up to a few percent and doubtless substitutes as $\left(\mathrm{PO}_{4}\right)$ for $\left(\mathrm{SiO}_{4}\right)$; this substitution is well established in both thorite and zircon. The unanalyzed mineral called hyblite apparently contains $\left(\mathrm{SO}_{4}\right)$ in substitution for $\left(\mathrm{SiO}_{4}\right)$ on the basis of qualitative tests.

$\mathrm{X}$-ray study indicates that thorogummite is isostructural with thorite, which has the ideal composition $\mathrm{ThSiO}_{4}$. The analyses of thorogummite, however, show a ratio of Si to total cations of less than the 1:1 ratio required by the formula $\mathrm{ThSiO}_{4}$. This fact, and the presence of essential water in the mineral (see Thermal behavior) has led to an interpretation of the composition in which there is a serial substitution of $(\mathrm{OH})_{4}$, for $\left(\mathrm{SiO}_{4}\right)$, as expressed by 
the general formula $\mathrm{Th}\left(\mathrm{SiO}_{4}\right)_{1-\mathrm{x}}(\mathrm{OH})_{4 \mathrm{x}}$ (C. Frondel, 1953). Infrared absorption measurements on both natural and synthetic thorogummite show the presence of bonded $\mathrm{OH}$. Thorogummite also is isostructural with coffinite, $\mathrm{U}\left(\mathrm{SiO}_{4}\right)_{1-\mathrm{x}}(\mathrm{OH})_{4 \mathbf{x}}$, and cyrtolite, $\mathrm{Zr}\left(\mathrm{SiO}_{4}\right)_{1-\mathbf{x}}(\mathrm{OH})_{4 \mathbf{x}}$.

Chemical analyses of thorogummite and related substances, in weight percent

\begin{tabular}{|c|c|c|c|c|c|c|c|c|c|}
\hline & 1 & 2 & 3 & 4 & 5 & 6 & 7 & 8 & 9 \\
\hline $\begin{array}{l}\mathrm{ThO}_{2} \\
\mathrm{ZrO}_{2}\end{array}$ & 41.44 & 24.46 & $\begin{array}{r}25.05 \\
4.78\end{array}$ & 57.79 & $\begin{array}{r}45.30 \\
88\end{array}$ & 24.72 & $\begin{array}{r}21.20 \\
.05\end{array}$ & $47 \overline{82}$ & 48.84 \\
\hline $\mathrm{JO}_{3}$ & $22 . \overline{43}$ & $37 . \overline{33}$ & 7.91 & $2 . \overline{98}$ & & & 18.63 & $=1.02$ & $13 . \overline{55}$ \\
\hline $\mathrm{UO}_{2}$ & & $\frac{1}{10}$ & & & 22.40 & 35.60 & & . & \\
\hline $\begin{array}{l}(\mathrm{Ce}, \mathrm{La})_{2} \mathrm{O}_{3} \\
(\mathrm{Y}, \mathrm{Er})_{2} \mathrm{O}_{3}\end{array}$ & 6.69 & $\begin{array}{l}.12 \\
.32\end{array}$ & $\begin{array}{r}.57 \\
12.19\end{array}$ & $\begin{array}{l}.24 \\
.73\end{array}$ & $\begin{array}{r}\mathrm{Tr} \\
1.86\end{array}$ & $\begin{array}{l}.10 \\
.25\end{array}$ & $\begin{array}{r}.08 \\
9.47\end{array}$ & 1.42 & \\
\hline $\begin{array}{l}\mathrm{CaO} \\
\mathrm{MgO}\end{array}$ & .41 & $\begin{array}{r}1.62 \\
.16\end{array}$ & .95 & $\begin{array}{r}1.65 \\
.60\end{array}$ & .59 & 1.28 & 二 & $\begin{array}{r}4.72 \\
17\end{array}$ & 1.32 \\
\hline 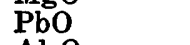 & 2.16 & 7.78 & $\overline{\operatorname{Tr}}$ & 1.25 & 3.74 & 7.90 & .17 & & $3 . \overline{55}$ \\
\hline $\begin{array}{l}\mathrm{Al}_{2} \mathrm{O}_{3} \\
\mathrm{Fe}_{2} \mathrm{O}_{3}\end{array}$ & $\begin{array}{l}.965 \\
.845\end{array}$ & 二 & $\begin{array}{l}2.22 \\
8.67\end{array}$ & 88 & - & - & $\begin{array}{l}8.84 \\
2.84\end{array}$ & $\begin{array}{r}.71 \\
1.56\end{array}$ & 1.48 \\
\hline $\mathrm{SiC}$ & 13.085 & $15 . \overline{30}$ & 21.10 & $15 . \overline{77}$ & 13.90 & 16.19 & 14.43 & 28.84 & 22.03 \\
\hline & 1.19 & & 1.77 & 1.33 & .67 & & 2.65 & & 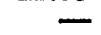 \\
\hline $\mathrm{H}_{2} \mathrm{O}+$ & 7.88 & $\begin{array}{l}8.37 \\
.19\end{array}$ & 10.80 & $\left\{\begin{array}{l}6.06 \\
0.12\end{array}\right.$ & 4.31 & $\begin{array}{r}12.04 \\
88\end{array}$ & 7.82 & $1.56\}$ & 9.66 \\
\hline $\begin{array}{l}\mathrm{H}_{2} \mathrm{O}- \\
\mathrm{Rem} .\end{array}$ & 1.23 & $\begin{array}{r}4.19 \\
.40\end{array}$ & 4.48 & $\begin{array}{c}9.12 \\
1.50\end{array}$ & $\begin{array}{r}.50 \\
2.25\end{array}$ & $\begin{array}{l}.88 \\
.94\end{array}$ & $\begin{array}{l}5.61 \\
8.28\end{array}$ & $\begin{array}{l}8.525 \\
4.69\end{array}$ & \\
\hline Total & 98.325 & 100.05 & 100.49 & 99.90 & 96.50 & $\overline{100.05}$ & $\overline{100.05}$ & 100.01 & 100.43 \\
\hline $5 n$ & $\begin{array}{l}4.43- \\
4.54\end{array}$ & 4.13 & $\begin{array}{l}3.26- \\
3.31\end{array}$ & & $\begin{array}{l}5.361- \\
5.438\end{array}$ & $\begin{array}{l}4.31 \\
4.45\end{array}$ & - & - & 4.222 \\
\hline
\end{tabular}

1. Thorogummite. Baringer Hill, Texas. Hidden and Mackintosh (1889). Atomic weight of rare earths given as 135 .

2. Thorogummite (nicolayite). Wodgina, Western Australia. E. S. Simpson (1930). Remainder is $(\mathrm{Nb}, \mathrm{Ta})_{2} \mathrm{O}_{5} 0.40$.

3. Thorogummite. Iisaka, Japan. Iimori and Hata (1938). Remainder is $(\mathrm{Nb}, \mathrm{Ta})_{2} \mathrm{O}_{5} 0.40, \mathrm{BeO} 0.40, \mathrm{MnO} 0.35,(\mathrm{AsSb})_{2} \mathrm{O}_{5} \quad 0.32, \mathrm{CO}_{2} 3.01$.

4. Hydrothorite. Wodgina, Western Australia. E. S. Simpson (1927). Remainder is $\mathrm{CO}_{2} 1.50$.

5. Mackintoshite. Baringer Hill, Texas. Hidden and Mackintosh (1893). Remainder is $\mathrm{K}_{2} \mathrm{O} 0.42$, $(\mathrm{Na}, \mathrm{Li})_{2} \mathrm{O} 0.68$, $\mathrm{FeO} 1.15$.

6. Maitlandite. Wodgina, Western Australia. E. S. Simpson (1930). Remainder is $(\mathrm{Nb}, \mathrm{Ta})_{2} \mathrm{O}_{5} 0.67, \mathrm{MnO} 0.07, \mathrm{FeO} 0.20$. Another partial analysis is given by Simpson.

7. Thorogummite. Haicheng prefecture, South Manchuria. Yosimura and Yamada, analysts, in Henmi (1951). Remainder is $\mathrm{BeO} 0.16, \mathrm{SnO}_{2} 0.31$, $\mathrm{Nb}_{2} \mathrm{O}_{5} 7.81$.

8. Zircon (cyrtolite). Karelia, U.S.S.R. Kostyleva (1946). Remainder is $\mathrm{TiO}_{2} 0.02, \mathrm{HfO}_{2} 1.70, \mathrm{U}_{3} \mathrm{O}_{8} 1.27, \mathrm{MnO} 0.11, \mathrm{Na}_{2} \mathrm{O} \quad 0.59, \mathrm{~K}_{2} \mathrm{O} 0.28, \mathrm{SO}_{3} 0.72$.

9. Thorogummite(?). Gordonia, South Africa. Mountain (1931).

Analysis 1 probably is the best of those available. It affords the formula given below, in which $(\mathrm{OH})_{4}$ has been calculated in the amount needed to establish valence compensation for the cations: $\left[\mathrm{Th}_{0.49} \mathrm{U}_{0.24}^{+6} \mathrm{Ce}_{0.13} \mathrm{Al}_{0.06} \mathrm{Fe}_{0.03}^{+3} \mathrm{Ca}_{0.02} \mathrm{~Pb}_{0.03}\right]_{1}$

$\left[\left(\mathrm{SiO}_{4}\right)_{0.67}\left(\mathrm{PO}_{4}\right)_{0.05}\left((\mathrm{OH})_{4}\right)_{0.33}\right]_{1.08}$. Several of the available analyses, cited in the table of analyses, are known to have been made on impure material. The material of analysis 1 has $\mathrm{x}=0.33$ and analysis 2 has $\mathrm{x}=0.25$, in terms of the general formula. 
Thorogummite is soluble with difficulty in acids, with separation of silica. Infusible; turns grayish green or brown on ignition.

Crystallography

Thorogummite is known only as microcrystalline aggregates. X-ray powder study by C. Frondel (1953) has shown that it is tetragonal and isostructural with thorite. Cell dimensions are:

Unit-cell dimensions of thorogummite

\begin{tabular}{|c|c|c|c|}
\hline & 1 & 2 & \\
\hline $\begin{array}{l}a_{0} \\
c_{0}\end{array}$ & $\begin{array}{l}\overline{7.068 \mathrm{~A}} \\
6.260\end{array}$ & $\begin{array}{l}7.08 \mathrm{~A} \\
6.28\end{array}$ & \multirow{2}{*}{$\begin{array}{l}\text { The idealized unit-cell } \\
\text { contents are } \\
4\left[\mathrm{Th}\left(\mathrm{SiO}_{4}\right)_{1-\mathbf{x}}\right. \\
\left.(\mathrm{OH})_{4 \mathbf{x}}\right]\end{array}$} \\
\hline$a_{0}: c_{0}$ & 0.8857 & 0.887 & \\
\hline
\end{tabular}

1. Baringer Hill, Texas. C. Frondel (1953).

2. South Manchuria. Henmi (1951).

The cell dimensions are very close to those of natural, nonmetamict thorite and of synthetic tetragonal $\mathrm{ThSiO}_{4}$. Thorogummite is not metamict and does not have to be heated to give an $\mathrm{X}$-ray diffraction pattern.

\section{Crystal habit}

Thorogummite occurs as dense fine-grained aggregates that are pseudomorphous after thorite or other thorium minerals. Such pseudomorphs, as at Baringer Hill, Texas, may enclose glassy residuals of metamict thorite. The mineral also occurs as opaline to microcrystalline crusts on altering thorite crystals, as at Hybla, Ontario, and as firm to earthy nodular masses.

\section{Physical properties}

Data on the cleavage and hardness are lacking. The reported values of the specific gravity range from 3.2-5.4; the variation doubtless is due to the fine-grained character of the material and to the large and variable content of nonessential water. Color yellowish brown; also greenish gray, or pale cream to nearly white. Varieties containing quadrivalent uranium are black, with a subvitreous luster, and are relatively hard $(\approx 51 / 2)$; these usually are alteration pseudomorphs after thorite. The luster of the light-colored types varies from dull to subvitreous. Not fluorescent.

\section{Optical properties}

Thorogummite is optically isotropic under low to moderate magnification due to aggregate polarization. The reported values for the mean index of refraction are variable, mostly between 1.54 and 1.64 ; the index increases on heating. The white partly opaline material (hyblite) from Hybla, Ontario, shows weak birefringence presumably due to strain or to parallel aggregation 
of submicroscopic crystallites. Under oil immersion at high magnification some samples of thorogummite are resolved into formless birefringent specks, and a few minute rods with parallel extinction can be distinguished.

\section{Thermal behavior}

All of the analyzed materials contain $\mathrm{H}_{2} \mathrm{O}$ in amounts varying from about 5 to 15 percent. Much of this water is nonessential, of an adsorbed or capillary nature in the fine-grained aggregates, and is lost below $110^{\circ} \mathrm{C}$. Most of the remainder is lost below about $200^{\circ}-250^{\circ} \mathrm{C}$ and this probably also is nonessential. A small part of the water, however, is retained to high temperatures and must be regarded as essential. Simpson (1930) found that the material of analysis 4 lost 9.12 percent $\mathrm{H}_{2} \mathrm{O}$ at $100^{\circ} \mathrm{C}$, about 5 percent at $600^{\circ} \mathrm{C}$, and the remaining $\mathrm{H}_{2} \mathrm{O}, 1.06$ percent, at about $800^{\circ} \mathrm{C}$. Differential thermal analysis of the Baringer Hill thorogummite showed a gradual loss of $\mathrm{H}_{2} \mathrm{O}$ around $150^{\circ} \mathrm{C}$ and an exothermic peak at $750^{\circ} \mathrm{C}$, with no further change to $1,050^{\circ} \mathrm{C}$. The break at $750^{\circ} \mathrm{C}$ is interpreted (C. Frondel, 1953) as loss of $(\mathrm{OH})$ with accompanying recrystallization to a mixture of $\mathrm{ThSiO}_{4}$ and $\mathrm{ThO}_{2}$, as follows:

$\mathrm{Th}\left(\mathrm{SiO}_{4}\right)_{1-\mathrm{x}}(\mathrm{OH})_{4 \mathrm{x}} \rightarrow(1-\mathrm{x}) \mathrm{ThSiO}_{4}+\mathrm{xThO}_{2}+2 \mathrm{xH}_{2} \mathrm{O}$ Another sample, of finer grain size, gave the exothermic break at about $575^{\circ}$ C. X-ray powder study of thorogummite showed that unheated samples and also samples heated to $110^{\circ} \mathrm{C}, 470^{\circ} \mathrm{C}$, and $610^{\circ} \mathrm{C}$ gave a thorite powder pattern, whereas samples heated to $1,000^{\circ} \mathrm{C}$ gave mixed patterns of thorite and $\mathrm{ThO}_{2}$. Crystalline anhydrous tetragonal $\mathrm{ThSiO}_{4}$ and $\mathrm{ZrSiO}_{4}$ give thermal-analysis graphs without thermal breaks up to $1,050^{\circ} \mathrm{C}$.

\section{Synthesis}

Thorogummite together with hydroxyl-containing variants of huttonite and zircon have been synthesized by reaction of $\mathrm{SiO}_{2}$ gel with $\mathrm{ThO}_{2}$ or $\mathrm{ZrO}_{2}$ gel in water at $150^{\circ}-700^{\circ} \mathrm{C}$ and at 15,000 psi pressure (C. Frondel and Collette, written communication, 1954). Both the content of ( $\mathrm{OH})$ and the unit-cell dimensions increase as the temperature of synthesis decreases. Infrared absorption measurements show the presence of bonded $(\mathrm{OH})$.

\section{Identification}

The separation of thorite and thorogummite is based on the presence in the latter of essential water, as $(\mathrm{OH})$, in substitution for $\left(\mathrm{SiO}_{4}\right)$. The demonstration of this substitution requires primarily a dehydration study and chemical evidence of a deficiency of $\left(\mathrm{SiO}_{4}\right)$ equivalent to the $(\mathrm{OH})$ present, together with infrared absorption measurements to establish bonded $(\mathrm{OH})$. 
Thorogummite cannot be distinguished by qualitative chemical tests from metamict thorite at least, as the latter has a similar range of chemical composition and contains large amounts of nonessential water. The X-ray powder patterns of the two minerals also are virtually identical.

Thorogummite seems to be a secondary mineral, microcrystalline and not metamict, and usually is yellowish brown or greenish gray, opaque, and dull in luster. Thorite is coarsely crystallized (although almost always metamict), black to brown, commonly glassy in appearance in large pieces and translucent when not black, and it occurs as a primary deposit principally in pegmatites.

Indexed X-ray powder-spacing data for thorogummite from Baringer Hill, Texas, are given in the following table.

\section{$X$-ray powder-spacing data for thorogummite}

[Symbo] : d, diffuse. Copper radiation, nickel filter]

\begin{tabular}{|c|c|c|c|c|c|}
\hline$d(\mathrm{~A})$ & $I$ & $h k l$ & $d(\mathrm{~A})$ & $I$ & $h k l$ \\
\hline $\begin{array}{l}4.695 \\
3.537 \\
2.821 \\
2.653 \\
2.499 \\
2.336 \\
2.203 \\
2.000 \\
1.869 \\
1.818 \\
1.767 \\
1.740 \\
1.653 \\
1.582 \\
1.565 \\
1.469 \\
1.431\end{array}$ & $\begin{array}{r}9 \\
10 \\
4 \\
6 \\
3 \\
1 / 2 \\
4 \\
4 \\
3 \\
6 \\
1 \\
1 \\
1 \\
1 \\
1 \\
2 \\
3\end{array}$ & $\begin{array}{l}011 \\
200 \\
121 \\
112 \\
220 \\
022 \\
031 \\
013 \\
321 \\
312 \\
400 \\
123 \\
411 \\
420 \\
004 \\
332 \\
024\end{array}$ & $\begin{array}{c}1.379 \\
1.326 \\
1.267 \\
1.172 \\
1.130 \\
1.112 \\
1.088 \\
1.055 \\
1.039 \\
1.021-1.013 \\
.976 \\
.953-.951 \\
.908 \\
.888 \\
.833 \\
.807 \\
.791\end{array}$ & $\begin{array}{l}2 \\
3 \\
2 \\
4(d) \\
1 \text { (d) } \\
2 \text { (d) } \\
1 / 2 \text { (d) } \\
1 / 2 \text { (d) } \\
1 / 2 \text { (d) } \\
1 \text { (d) } \\
3 \text { (d) } \\
2 \text { (d) } \\
3 \text { (d) } \\
\text { (d) } \\
\text { (d) } \\
\text { (d) } \\
\text { (d) }\end{array}$ & $\begin{array}{c}431 \\
224 \\
431 \\
044 \\
532 \\
244 \\
541 \\
622 \\
631 \\
415,116 \\
444 \\
552 \\
624 \\
800 \\
644 \\
662 \\
840\end{array}$ \\
\hline
\end{tabular}

1 Data from C. Frondel (1953) on material from Baringer Hill, Texas. The pattern, virtually identical with that of thorite, often is rather diffuse owing to small particle size. Natural material contains variable amounts of uranium, rare earths, and other cations in substitution for $\mathrm{Th}$ and the content of $(\mathrm{OH})$ is variable, but nothing is known of the attendant variation in spacings. Tetragonal.

\section{Natural formation}

Thorogummite, so far as is known, is a secondary mineral formed by the alteration of thorite, thorianite, or yttrialite. In some material, as in that from Hybla, Ontario, and Wodgina, Western Australia, the thorogummite clearly is a weathering product. The question whether primary thorite may contain essential $(\mathrm{OH})$, however, remains open.

\section{Occurrence}

Thorogummite was originally described by Hidden and Mackintosh (1889) from the rare-earth pegmatite at Baringer Hill, Llano County, Texas. A description of the pegmatite, now inac- 
cessible, is given by Landes (1932). The mineral occurs as dense, dull, grayish-green pseudomorphs after tetragonal crystals of thorite. The parent thorite is closely associated with fergusonite, uraninite, zircon (altered to cyrtolite), and gadolinite. A black mineral in tetragonal crystals (the mackintoshite of Hidden and Mackintosh, 1893) that also occurs here apparently is an intermediate stage of alteration of the original thorite to thorogummite; it is analogous to the so-called maitlandite from Wodgina, Western Australia. The essential identity of the Baringer Hill thorogummite with material later described under the same name from other localities, and with several chemically similar minerals that had been described under other names in the belief that they were distinct species, was established by C. Frondel (1953). The localities of these minerals follow. Thorogummite was described as such from Iisaka, Fukushima-Ken, Japan, (Iimori and Hata, 1938b) as a yellowish, gumlike alteration product of yttrialite in a pegmatite; from Haicheng Prefecture, South Manchuria, (Henmi, 1951) as an alteration of thorite; and from Wodgina, Western Australia, (E. S. Simpson, 1912, 1930) as yellow earthy nodules in the weathered outcrop of pegmatites. The thorogummite from the latter locality was later renamed nicolayite. A mineral from Easton, Pa., referred to as thorogummite by mineral collectors also is found to belong here; it occurs as yellow-brown masses formed by the alteration of thorianite, and is associated with uranophane and several unidentified minerals. Minerals identical with thorogummite that have been described under other names include the following: Hyblite from Hybla, Ontario, (Ellsworth, 1927) where it occurs as thin, white crusts in cracks between uranoan thorite crystals and the weathered feldspathic and pyritic matrix in which they are embedded, and grades into the glassy, black thorite from which it has been derived; hydrothorite from Wodgina, Western Australia, (E. S. Simpson, 1927) is found as a weathering product in a pegmatite; maitlandite, earlier called mackintoshite, occurs at Wodgina, Western Australia, (E. S. Simpson, 1930) and seems to be an intermediate alteration product of thorite that on further oxidation passes into thorogummite. A pale-yellow earthy mineral from a pegmatite at Gordonia, South Africa, may be identical with thorogummite (Mountain, 1931).

\section{Synonymy}

COFFINITE

Coffinite Stieff, Stern, and Sherwood (1955). Named after R. Clare Coffin (1886- ), American geologist, who studied the uranium-vanadium deposits in southwestern Colorado. 


\section{Composition}

Coffinite is a silicate of quadrivalent uranium that contains a variable amount of hydroxyl, $(\mathrm{OH})$, in substitution for $\left(\mathrm{SiO}_{4}\right)$. The formula can be written $\mathrm{U}\left(\mathrm{SiO}_{4}\right)_{1-\mathrm{x}}(\mathrm{OH})_{4 \mathrm{x}}$. The limits of substitution of $(\mathrm{OH})$ are not known; material from the La Sal No. 2 mine, Colorado, apparently has $\mathrm{x} \approx 0.5$ and this value may be near the maximum. The anhydrous end member $\mathrm{U}\left(\mathrm{SiO}_{4}\right)$, is not known either as a mineral or as a synthetic compound.

The above interpretation of the chemical composition of coffinite is based on X-ray powder-diffraction studies that indicate an isostructural relation to zircon, thorite, and thorogummite, and on infrared absorption measurements that prove the existence of both a hydroxyl bond and a $\mathrm{SiO}_{4}$ bond in the crystal structure. Coffinite is the uranium analogue of thorogummite and cyrtolite, which are hydroxyl-substituted variants of thorite, $\mathrm{ThSiO}_{4}$, and zircon, $\mathrm{ZrSiO}_{4}$, respectively. Thorium has not been observed in solid solution in coffinite, but uranium substitutes for thorium in thorogummite up to at least $1: 1$, and a complete series may exist between the two species.

Chemical analyses of pure coffinite are lacking. The analyses reported in the table below were made on very fine-grained material admixed with black organic matter, clay, and uranium and vanadium minerals. The As, $P$, and $V$ reported in the analyses is not regarded as essential, on the basis of acid-leaching and heating experiments. It is possible, however, that $\left(\mathrm{PO}_{4}\right)$ at least can substitute for $\mathrm{SiO}_{4}$ in the zircon-type structure, provided that valence compensation is effected. The $\mathrm{Al}$ reported in the analyses is due to admixed clay.

Coffinite is decomposed by dilute $\mathrm{HNO}_{3}$ and $\mathrm{H}_{2} \mathrm{SO}_{4}$, apparently more readily as the content of $(\mathrm{OH})$ increases.

Chemical analyses of coffinite-bearing samples, in weight percent

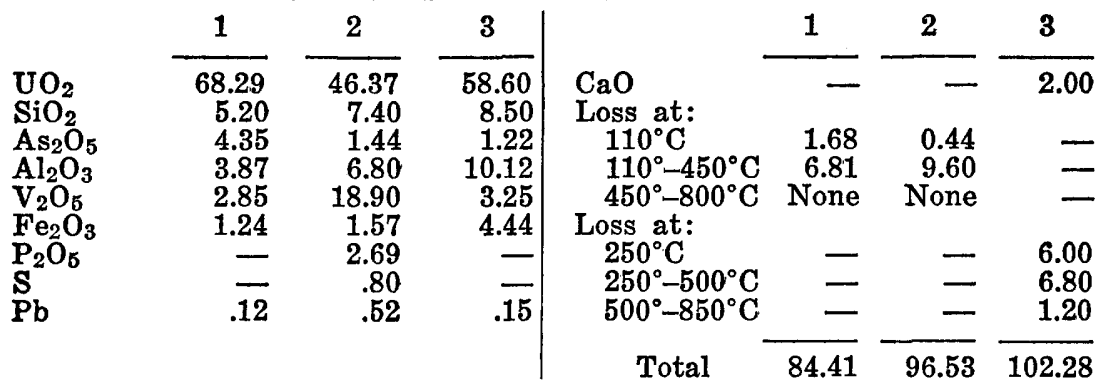

1. La Sal No. 2 mine, Mesa County, Colo. Analysis of heavy-liquid concentrate containing admixed clay, vanadates, etc. Sherwood, analyst, in Stieff, Stern, and Sherwood (1956).

2,3. Arrowhead mine, Mesa County, Colo. Analyses of heavy-liquid concentrates containing admixed clay, vanadates, etc. Sherwood, analyst, in Stieff, Stern, and Sherwood (1956). 


\section{Crystallography}

Found as aggregates or disseminations of extremely small particles, approximately $10^{-5}$ to $10^{-6} \mathrm{~cm}$ in size as indicated by line broadening on X-ray powder patterns. X-ray powder data, given in the table below, indicate that coffinite is tetragonal and isostructural with zircon. The unit-cell dimensions of material from the Arrowhead mine, Mesa County, Colo., are $a_{0} 6.94 \mathrm{~A}, c_{0} 6.31 \mathrm{~A}$; $a_{0}: c_{0}=1: 0.908$. The cell dimensions and ratio vary slightly for samples from different localities. Gruner and Smith (1955) obtained $a_{0} 6.92 \mathrm{~A}, c_{0} 6.22 ; a_{0}: c_{0}=1: 0.899$, on coffinite from the Jack Pile mine, New Mexico; on heating to $500^{\circ} \mathrm{C}$ in air the cell dimensions decreased to $a_{0} 6.85 \mathrm{~A}, c_{0} 6.15$. When heated at $600^{\circ} \mathrm{C}$ for 24 hours the structure was almost completely destroyed, but when heated in $\mathrm{CO}_{2}$ at $680^{\circ} \mathrm{C}$ for 22 hours the structure was not destroyed. Hoekstra and Fuchs (1956) obtained the following cell dimensions on synthetic coffinite: $a_{0}=6.977 \mathrm{kX}, c_{0}=6.307$.

Physical and optical properties

Color black in the hand specimen. Luster dull or inclining to adamantine and then resembling a high-rank coal. Pulverulent to friable or brittle. Fracture of the aggregates earthy or irregular to subconchoidal. Relatively dense brittle aggregates have a hardness of 5-6. The specific gravity of the most highly purified specimen so far examined is 5.1; ordinarily lower due to porosity and admixture, varying down to about 2.2 .

Coffinite is opaque under the microscope except on the thinnest edges, which are pale to dark brown in color and generally show minute opaque inclusions. Isotropic, owing to aggregate polarization. The index of refraction of synthetic coffinite as determined by Hoekstra and Fuchs (1956) is 1.83-1.85. In polished section, the mineral appears as grayish-black to black aggregates of very fine particles; isotropic, with low reflectance.

Thermal behavior

Complete dehydration and thermal curves for coffinite are lacking. The partial data reported in the table of analyses were obtained on impure samples.

synthesis

Coffinite has been synthesized by Hoekstra and Fuchs (1956) by a hydrothermal technique.

\section{Identification}

In the hand specimen coffinite very closely resembles the microcrystalline varieties of uraninite, with which it often is associated or admixed in the uranium-vanadium deposits of the Colorado Plateau. Coffinite also is easily confused with a number of black, 
low-valence vanadium compounds, including corvusite, uvanite, vanoxite, rauvite, and montroseite, and may go unrecognized when admixed in small amount with black carbonaceous material. The mineral can be identified with certainty by X-ray powder photographs in connection with chemical tests to establish the presence of uranium and silica. The X-ray powder pattern is very similar to that of thorite. The spacing data are given in the following table.

\section{$X$-ray powder-spacing data for coffinite ${ }^{1}$}

[Symbols : f, faint; $m$, medium; s, strong; w, weak. Copper radiation, nickel filter]

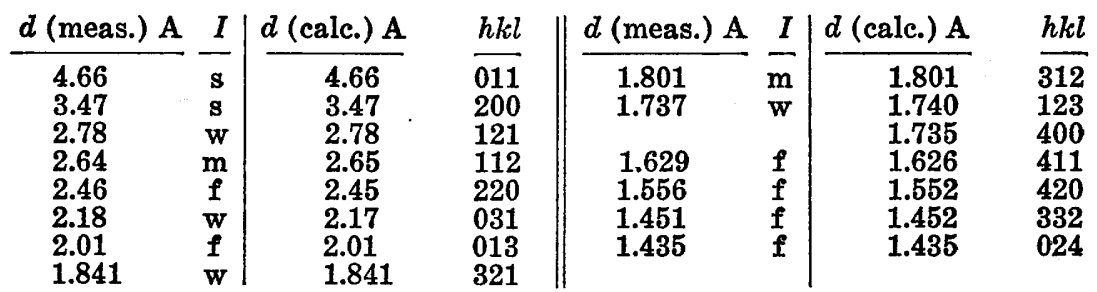

${ }^{1}$ Data from Stieff, Stern, and Sherwood (1956) on material from the Arrowhead mine, Gateway district, Mesa County, Colo. Nothing is known of the variation in spacings attending variation in content of $(\mathrm{OH})$ or of other substitutions in the cation or anion positions. The pattern of coffinite often is rather diffuse owing to small particle size. Coffinite ordinarily is found virtually inextricably admixed with fine-grained uraninite. The indexing given below is for a tetragonal cell with $a_{0}=6.94, c_{0}=6.31 \mathrm{~A}$.

Natural formation

The environmental conditions under which coffinite formed in the uranium-vanadium deposits in the sedimentary rocks of the Colorado Plateau province are not clearly understood. The mineral occurs with uraninite in the unoxidized deeper part of the deposits, and probably was formed from solutions at relatively low temperature and pressure. The presence of low-valence vanadium minerals in the unoxidized ores suggests that the deposition took place under strongly reducing conditions. Coffinite is commonly associated with uraninite, montroseite, an unidentified black low-valence vanadium mineral, and carbonaceous substances. It has been observed replacing fragments of vegetal material in the sandstone. Coffinite also has been found with uraninite and sulfides in a hydrothermal vein deposit at the Copper King mine, Larimer County, Colo.

\section{Occurrence}

Most of the known localities for coffinite are in the black vanadium-rich ores in the Uravan mineral belt in southwestern Colorado and southeastern Utah. In many of the mines it is the main uranium mineral in the black unoxidized ore. The deposits 
here are in the Salt Wash sandstone member of the Morrison formation (Jurassic). Localities in this area include the Arrowhead, La Sal No. 2, Matchless, and Black Mama mines in the Gateway district, Mesa County, Colo.; Corvusite mine, Gateway district, Grand County, Utah; Grey Dawn mine, Paradox district, San Juan County, Utah; Virgin No. 2 mine, Uravan district; and the Wild Steer mine, Bull Canyon district, in Montrose County, Colo.; and the Little Muriel mine, Slick Rock district, San Miguel County, Colo. Coffinite also is found in the Morrison formation in the Laguna area, Grants district, Valencia County, N. Mex. It occurs in the Shinarump member of the Chinle formation of Triassic age in the Denise No. 1 mine, Green River district, Emery County, Utah, and in other parts of the Chinle formation, in the Mi Vida mine, Monticello district, San Juan County, Utah. It is found in rocks of Permian age at the Robinson and Weatherly properties near Placerville, San Miguel County, Colo., the J. B. Smith farm, Section unit 1, Saddle Mountain Creek area, Kiowa County, Okla., and in Section 63, Block 47, H and T C Survey, Potter County, Tex. Coffinite occurs in the Laramie formation of Cretaceous age at the Old Leyden mine, Jefferson County, Colo., and in hydrothermal veins of Tertiary age in the Copper King mine, Prairie Divide, Larimer County, Colo. At the Ruth Group of claims, in the Chinle formation near Holbrook, Ariz. Found in Wyoming in the Poison Basin claims, Carbon County, the Busfield property, Crook County, the Little Mo and the Vitro Uranium Co. mines in Fremont County, and the Kell Boy No. 3 mine in Johnson County (Gruner and Smith, 1955), also at the Lucky Mc mine, Fremont County (R. G. Coleman, written communication, 1955).

\section{Synonymy}

\section{HUTTONITE}

Huttonite Pabst (1951b). Named after C. Osborne Hutton (1910 - ), mineralogist and petrographer.

\section{Composition}

Thorium silicate, $\mathrm{ThSiO}_{4}$. Huttonite is dimorphous with thorite and is isostructural with monazite, (Ce,La) $\mathrm{PO}_{4}$. The only reported analysis, given below, in weight percent, made on a con-

\begin{tabular}{|c|c|c|c|c|c|}
\hline & 1 & 2 & & 1 & 2 \\
\hline $\mathrm{ThO}_{2}$ & $\overline{81.47}$ & $\overline{76.6}$ & $\mathrm{SiO}_{2}$ & 18.53 & 19.7 \\
\hline $\begin{array}{l}\mathrm{Fe}_{2} \mathrm{O}_{3} \\
\mathrm{Ce}_{2} \mathrm{O}_{3} \text {, etc. }\end{array}$ & 二 & 2.6 & Total & 100.00 & 100.1 \\
\hline
\end{tabular}

1. Theoretical weight percentages, $\mathrm{ThSiO}_{4}$.

2. Huttonite. New Zealand. Hutton, analyst, in Pabst (1951b). U, Ca, Mg, $\mathrm{H}_{2} \mathrm{O}$ lacking; traces of $\mathrm{Mn}$ and $\mathrm{P}_{2} \mathrm{O}_{5}$. 
centrate of grains from a beach sand, shows a small amount of cerium earths and no uranium in substitution for thorium.

Unaffected by $\mathrm{HF}$, but finely powdered material is slowly dissolved by repeated evaporation in concentrated $\mathrm{H}_{2} \mathrm{SO}_{4}$. Infusible. Decomposed by fusion in $\mathrm{Na}_{2} \mathrm{CO}_{3}$.

\section{Crystallography}

Monoclinic, in the prismatic crystal class $(2 / m)$. The mineral is known only as minute anhedral grains in beach sands.

The unit-cell dimensions of huttonite and of some isostructural substances are given below.

\section{Unit-cell dimensions of huttonite}

\begin{tabular}{|c|c|c|c|c|c|}
\hline & $a_{0}$ & $b_{0}$ & $c_{0}$ & $\boldsymbol{\beta}$ & REFERENCE \\
\hline $\begin{array}{l}\mathrm{ThSiO}_{4} \\
\mathrm{CePO}_{4} \\
\mathrm{LaPO}_{4} \\
\mathrm{BiPO}_{4}\end{array}$ & $\begin{array}{l}6.80 \mathrm{~A} \\
6.77 \\
6.84 \\
6.75\end{array}$ & $\begin{array}{l}6.96 \mathrm{~A} \\
7.01 \\
7.06 \\
6.96\end{array}$ & $\begin{array}{l}6.54 \mathrm{~A} \\
6.45 \\
6.49 \\
6.42\end{array}$ & $\begin{array}{l}104^{\circ} 55^{\prime} \\
10338 \\
10334 \\
104\end{array}$ & $\begin{array}{l}\text { Pabst (1951b). } \\
\text { Mooney (1948). } \\
\text { Do. } \\
\text { Zemann (1950). }\end{array}$ \\
\hline
\end{tabular}

Space group $P 2_{1} / n$; unit-cell contents $Z=4$. Data for huttonite on natural material; other data on synthetic material.

Physical properties

Distinct cleavage $\{001\}$; also an indistinct cleavage on $\{100\}(?)$. Fracture conchoidal. Hardness not known. Specific gravity 7.1 (measured) ; 7.18 (calculated). Colorless to very pale cream. Luster adamantine. Fluoresces a faint dull white with a pink tinge in short-wave ultraviolet light (2540 A).

Optical properties

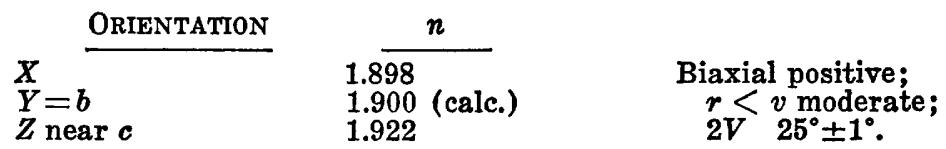

The above data are from Hutton, in Pabst (1951b).

Thermal behavior

No data.

\section{Synthesis}

Obtained in microcrystalline form by heating metamict thorite or a mixture of $\mathrm{ThO}_{2}$ and $\mathrm{SiO}_{2}$ to temperatures over roughly $900^{\circ}-1,000^{\circ} \mathrm{C}$. Tetragonal $\mathrm{ThSiO}_{4}$ or $\mathrm{ThO}_{2}$ may form at lower temperatures, and the furnace atmosphere and other factors may influence the temperature stability and nature of the products formed (Pabst, 1952). In some experiments, huttonite was obtained by sintering of $\mathrm{ThO}_{2}$ and $\mathrm{SiO}_{2}$ in the range of $1,300^{\circ}-1,500^{\circ}$ $\mathrm{C}$ and thorite at lower temperatures, $1,000^{\circ}-1,250^{\circ} \mathrm{C}$, (Frondel 
and Collette, written communication, 1954). Huttonite also has been synthesized hydrothermally, by reaction of coprecipitated hydrous $\mathrm{ThO}_{2}$ and $\mathrm{SiO}_{2}$ in alkaline solutions between $300^{\circ}$ and $700^{\circ} \mathrm{C}$ (Frondel and Collette, written communication, 1954); there is evidence that the product contains $(\mathrm{OH})_{4}$ in substitution for $\left(\mathrm{SiO}_{4}\right)$, analogous to thorogummite.

\section{Identification}

Distinguished from crystalline thorite by its X-ray powder and single-crystal diffraction patterns and by other symmetry-dependent properties. Almost all natural thorite is metamict and isotropic, with an index of refraction below that of huttonite. Huttonite doubtless can take up uranium in solid solution (as it presumably does when formed by heating metamict uranoan thorite) and might also become metamict. In the absence of outward crystal form it would then be indistinguishable from thorite. The monazite structure type to which huttonite belongs, however, may be in herently more stable than that of thorite and may not be as prone to metamictization (Pabst, 1951b). Thorogummite, which has essentially the same chemical composition as thorite and huttonite, is an earthy secondary mineral and gives an X-ray powder pattern different from that of huttonite and identical with that of thorite. The rare-earth phosphate, monazite, has lower indices of refraction and gravity than huttonite, and the X-ray powcler patterns of the two minerals, although similar, can be distingu: shed. The X-ray powder-spacing data for huttonite are given in the following table.

\section{X-ray powder-spacing data for huttonite ${ }^{1}$}

[Symbol: b, broad. Copper radiation, nickel filter]

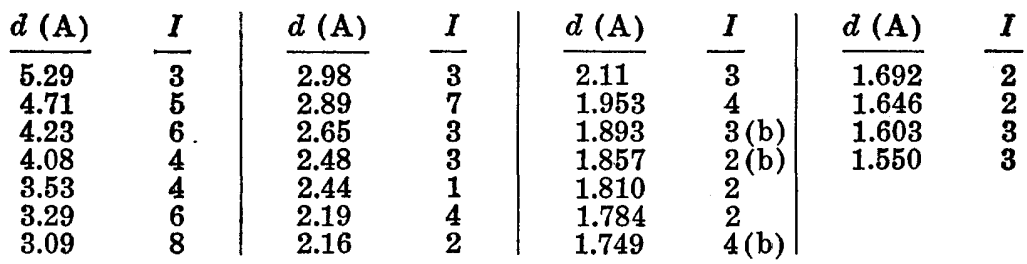

${ }^{1}$ Data from Pabst (1951b) on natural material from South Westland, New Zealand.

Natural formation and occurrence

Huttonite is a primary mineral. It has been found in detrital sands at Harirari, Saltwater Creek, Okarito, Five Mile Beach, Bruce Bay, the mouth of the Waikukupa River, and Gillespie's Beach, in South Westland, New Zealand. The mineral probably has been derived from nearby schists. 


\section{CHERAIITE}

Synonymy

Cheralite Bowie and Horne (1953). Named from Chera, the ancient Dravidian kingdom corresponding to the modern territory of Travancore, where the mineral was found.

\section{Composition}

A phosphate-silicate of thorium, calcium, and rare earths chiefly. Cheralite is isostructural with monazite and conforms to the monazite formula type, $\mathrm{AXO}_{4}$. The material of analysis 1 has the formula ( $\mathrm{Th}, \mathrm{Ca}, \mathrm{Ce}, \mathrm{La}, \mathrm{U}, \mathrm{Pb})\left(\mathrm{PO}_{4}, \mathrm{SiO}_{4}\right)$, with $\mathrm{Th}: \mathrm{Ca}: \mathrm{Ce}$ : $\mathrm{La}: \mathrm{U}=1.15: 1.08: 0.84: 0.78: 0.14$ and $\mathrm{P}: \mathrm{Si}=3.6: 0.4$. Cheralite is essentially an intermediate member of a solid solution series apparently extending between monazite, $\mathrm{CePO}_{4}$, and the compound CaTh $\left(\mathrm{PO}_{4}\right)_{2}$, known only artificially. Substitutions of this general type are well known in monazite proper, in which the entrance of $\mathrm{Th}^{+4}$ in place of $\mathrm{Ce}^{+3}$ ordinarily is compensated by a concomitant substitution of $\mathrm{Si}$ for $\mathrm{P}$ (giving a series toward huttonite, monoclinic $\mathrm{ThSiO}_{4}$ ). In the present mineral, valence compensation for the entrance of $\mathrm{Th}^{+4}$ is largely effected by the concomitant substitution of $\mathrm{Ca}^{+2}$, and only a small substitution of $\mathrm{Si}$ for $\mathrm{P}$ is required. (On the suggested nomenclature for solid solutions in the ternary system $\mathrm{CePO}_{4}-\mathrm{CaTh}\left(\mathrm{PO}_{4}\right)_{2}-\mathrm{ThSiO}_{4}$, see Bowie and Horne, 1953, fig. 1.)

The two reported analyses of cheralite, in weight percent, are as follows:

\begin{tabular}{|c|c|c|c|c|c|}
\hline & 1 & 2 & & 1 & 2 \\
\hline $\begin{array}{l}\mathrm{PbO} \\
\mathrm{CaO} \\
\text { ( } \mathrm{La}, \text { etc. })_{2} \mathrm{O}_{3}\end{array}$ & $\begin{array}{r}0.92 \\
6.30 \\
13.35 \\
14.21\end{array}$ & $\begin{array}{r}0.07 \\
5.73 \\
13.45 \\
13.98\end{array}$ & $\begin{array}{l}\mathrm{SiO}_{2} \\
\mathrm{P}_{2} \mathrm{O}_{5} \\
\mathrm{H}_{2} \mathrm{O}_{+}\end{array}$ & $\begin{array}{r}2.10 \\
26.80 \\
.06\end{array}$ & $\begin{array}{r}1.15 \\
25.90 \\
.30\end{array}$ \\
\hline $\begin{array}{l}\mathrm{U}_{3} \mathrm{O}_{8} \\
\mathrm{ThO}_{2}\end{array}$ & $\begin{array}{r}4.05 \\
31.50\end{array}$ & $\begin{array}{r}6.56 \\
29.45\end{array}$ & Total & 99.29 & 99.59 \\
\hline
\end{tabular}

1. Cheralite. Travancore. Analysis by Radiochemical Division, in Bowie and Horne (1953). $\mathrm{Al}_{2} \mathrm{O}_{3}$ and $\mathrm{Fe}_{2} \mathrm{O}_{3}$ trace. $\mathrm{La}$ earths are chiefly $\mathrm{La}, \mathrm{Pr}$, and $\mathrm{Nd}$, with minor $\mathrm{Y}, \mathrm{Sm}$, and Gd.

2. Cheralite. Travancore. Johnstone, analyst, in Bowie and Horne (1953). Total includes $\mathrm{Fe}_{2} \mathrm{O}_{3} 2.50, \mathrm{MnO} 0.18, \mathrm{TiO}_{2} 0.32$, and the (La, etc.) ${ }_{2} \mathrm{O}_{3}$ includes $\mathrm{Y}_{2} \mathrm{O}_{3} 0.19$.

\section{Crystallography}

Presumed to be monoclinic from the isostructural relation to monazite indicated by X-ray powder-diffraction study. Morphological data are lacking. Found as masses up to 2 inches across, occasionally showing unidentified crystal faces. The unit-cell dimensions for cheralite and synthetic $\mathrm{CaTh}\left(\mathrm{PO}_{4}\right)_{2}$, obtained from powder photographs, are as follows: 
Unit-cell dimensions of cheralite

\begin{tabular}{|c|c|c|c|}
\hline & Cheralite & $\operatorname{CaTh}\left(\mathrm{PO}_{4}\right)_{2}$ & \\
\hline $\begin{array}{l}a_{0} \\
b_{0} \\
c_{0}\end{array}$ & $\begin{array}{l}6 . " 14 \mathrm{~A} \\
7.100 \\
6.43\end{array}$ & $\begin{array}{l}6.69 \mathrm{~A} \\
6.93 \\
6.38\end{array}$ & $\begin{array}{l}\text { Space group presumably } \mathrm{P2}_{1} / n ; \\
\text { unit-cell contents } \\
4\left[(\mathrm{Th}, \mathrm{Ca}, \mathrm{Ce}, \text { etc. })\left(\mathrm{PO}_{4}, \mathrm{SiO}_{4}\right)\right] \text {. }\end{array}$ \\
\hline
\end{tabular}

$a_{0}: b_{0}: c_{0} \quad 0.9629: 1: 0.9186 \quad 0.9654: 1: 0.9206$

$\begin{array}{lll}\beta & 104.6^{\circ} & 104.4^{\circ}\end{array}$

Physical properties.

Cleavage $\{010\}$ distinct, $\{100\}$ difficult, parting on $\{001\}$ poor. Brittle. Hardne:ss 5. Specific gravity $5.3 \pm 0.1$ (measured) ; 5.41 (calculated). Liuster vitreous to resinous. Color pale to dark green. Streak white. 'Transparent. No data on fluorescence.

Optical properties

ORIENTA-

\begin{tabular}{l} 
TION \\
\hline$X=b$ \\
$Y=7^{\circ}$
\end{tabular}

$\begin{array}{ll}\frac{n}{1.779} & \text { PLEOCHROISM } \\ 1.780 & \text { Green. } \\ 1.816 & \text { Yreen. } \\ & \text { Yellowish green. }\end{array}$

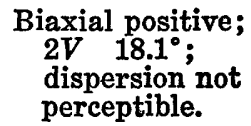

Biaxial positive;

dispersion not perceptible.

Thermal behavior

No data.

Synthesis

The isostructural compound $\mathrm{CaTh}\left(\mathrm{PO}_{4}\right)_{2}$, which cheralite approaches in composition, was synthesized by Bowie and Horne (1953) by heating an equimolar mixture of $\mathrm{Ca}_{3}\left(\mathrm{PO}_{4}\right)_{2}$ and $\mathrm{Th}_{3}\left(\mathrm{PO}_{4}\right)_{4} \cdot 4 \mathrm{H}_{2} \mathrm{O}$ at $1,400^{\circ} \mathrm{C}$.

\section{Identification}

Cheralite ha:s lower indices of refraction than monazite and huttonite. Xencitime and zircon, both sometimes green, are uniaxial with different indices. Almost all thorite is metamict and ordinarily contiains less than a few percent of $\mathrm{P}_{2} \mathrm{O}_{5}$. The X-ray powder-spacing data for cheralite are given in the table below.

\section{X-ray powder-spacing data for cheralite ${ }^{1}$}

[Symbols: ms, miderately strong; mw, moderately weak; mwb, moderately weak, broad; s, strong; vs, very strong; vvw, very, very weak; vw, very weak; w, weak. Copper radiation, nickel filter]

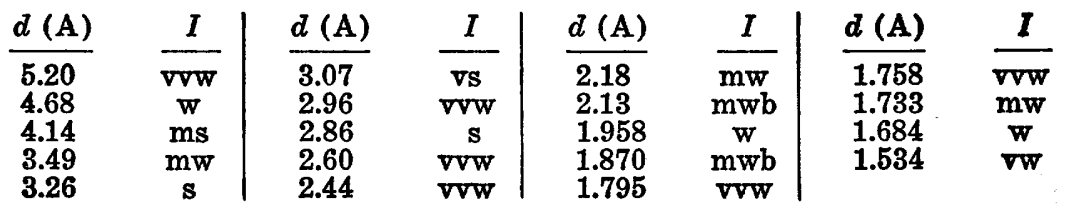

1 Data from Bowie and Horne (1953) on material from Travancore, India. 
Natural formation and occurrence

Found as a primary mineral in a pegmatite at Kuttakuzhi in Kalkulam Taluk (Parish) about 23 miles east southeast of Trivandrum, Travancore, southern India. Associated with partly metamict dark zircon with a radioactivity equivalent to 0.1 percent $\mathrm{U}_{3} \mathrm{O}_{8}$ and minor amounts of black tourmaline and chrysoberyl. Also found sparingly in the kaolinized granitic wall rock and in the gravels of adjacent streams. An ounce or two of the mineral is said to occur per cubic yard of pegmatite.

Synonymy

\section{PILBARITE}

Pilbarite Simpson (1910). Named from the locality at Pilbara, Western Australia.

Description

Found as nodular or earthy masses. Color canary yellow. Hardness of the aggregate $21 / 2-3$. Specific gravity not known. Under the microscope, pilbarite is isotropic (presumably owing to aggregate polarization) with $n$ from less than 1.73-1.76, average 1.74, and shows birefringent inclusions (Larsen, 1921). Apparently a hydrated silicate of lead, thorium, and hexavalent uranium. The only reported analysis, made on material of questionable purity, approximates, in ratios, the formula $\mathrm{PbO} \cdot \mathrm{ThO}_{2} \cdot \mathrm{UO}_{3} \cdot 2 \mathrm{SiO}_{2} \cdot$ $4 \mathrm{H}_{2} \mathrm{O}$. Simpson (1910) gives the following analysis of pilbarite.

\begin{tabular}{|c|c|c|c|c|c|c|c|}
\hline & $\begin{array}{l}\text { Weight } \\
\text { percent }\end{array}$ & & $\underset{\text { percent }}{\text { Weight }}$ & & $\begin{array}{l}\text { Weight } \\
\text { percent }\end{array}$ & & $\underset{\text { percent }}{\text { Weight }}$ \\
\hline $\mathrm{Na}_{2} \mathrm{O}$ & 0.04 & $\mathrm{MnO}$ & $\mathrm{Tr}$ & $\mathrm{ThO}_{2}$ & 31.34 & $\mathrm{H}_{2} \mathrm{O}$ & 7.66 \\
\hline $\mathrm{K}_{2} \mathrm{U}$ & .09 & $\begin{array}{l}\mathrm{Al}_{2} \mathrm{O}_{3} \\
\mathrm{Ce}_{2} \mathrm{O}_{3}\end{array}$ & $\begin{array}{r}0.15 \\
.19\end{array}$ & $\mathrm{Ta}_{3} \mathrm{O}_{5}$ & $\begin{array}{r}27.09 \\
.47\end{array}$ & Total & 99.56 \\
\hline $\mathrm{MgO}$ & .21 & $\mathrm{Fe}_{2} \mathrm{O}_{3}$ & .20 & $\mathrm{SiO}_{2}$ & 12.72 & & \\
\hline $\mathrm{PbO}$ & 17.26 & $\mathrm{Y}_{2} \mathrm{O}_{3}$ & .49 & $\mathrm{P}_{2} \mathrm{O}_{5}$ & 1.08 & & \\
\hline
\end{tabular}

$\mathrm{H}_{2} \mathrm{O}$ includes $\mathrm{H}_{2} \mathrm{O}+4.16, \mathrm{H}_{2} \mathrm{O}-3.50$. Contains about 0.39 cc $\mathrm{He}$ per gram.

Soluble in acids. Pilbarite is a fine-grained weathering product, said to be in part pseudomorphous after a lead silicate. Known only from the Pilbara gold field, Western Australia. Two reputed specimens of pilbarite examined by C. Frondel in 1953 gave unlike $\mathrm{X}$-ray patterns, neither of which could be identified with any known uranium or thorium mineral.

Synonymy

URANOPHANE

Uranophane Websky (1853, 1859). Uranotil Bořický (1870, 1878). Lambertite Lind and Davis (1919). Uranotyle. Uranophane was named from Uran, uranium, and $\psi a \iota v \in \sigma a l$, to appear. Uranotile similarly from $\tau_{\iota} \lambda o s, a$ fiber, alluding to its composition and characteristic habit. The identity of uranophane and uranotil, long 
accepted by some authors, including E. S. Dana (1892), was confirmed by C. Frondel (1956b), to the extent of showing that nontype specimens from the two original localities were identical. The identity of lambertite with uranophane was established by Larsen, Hess, and Schaller (1926). Lambertite was named after Ross Lambert of Casper, Wyo., who discovered the deposit near Lusk, Wyo.

\section{Composition}

A hydrated silicate of calcium and hexavalent uranium, $\mathrm{CaO}$. $2 \mathrm{UO}_{3} \cdot 2 \mathrm{SiO}_{2} \cdot 6 \mathrm{H}_{2} \mathrm{O}=\mathrm{Ca}\left(\mathrm{UO}_{2}\right)_{2}\left(\mathrm{SiO}_{3}\right)_{2}(\mathrm{OH})_{2} \cdot 5 \mathrm{H}_{2} \mathrm{O}$. Uranophane is dimorphous with beta-uranophane. The structural formula of uranophane is here written as of an inosilicate, as is suggested by the acicular crystal habit. Another possible interpretation is $\mathrm{Ca}\left(\mathrm{UO}_{2}\right)_{2}\left(\mathrm{Si}_{2} \mathrm{O}_{7}\right) \cdot 6 \mathrm{H}_{2} \mathrm{O}$, and Strunz (1949) writes it as a nesosilicate $\mathrm{Ca}\left(\mathrm{UO}_{2}\right)_{2}\left(\mathrm{SiO}_{3} \mathrm{OH}\right)_{2} \cdot 5 \mathrm{H}_{2} \mathrm{O}$. A selection of the reported analyses of uranophane is given in the table below.

\section{Chemical anaylses of uranophane, in weight percent}

\begin{tabular}{|c|c|c|c|c|c|c|}
\hline & 1 & 2 & $\mathbf{3}$ & 4 & 5 & 6 \\
\hline $\mathrm{CaO}$ & 6.55 & 5.27 & $\begin{array}{l}6.67 \\
\operatorname{Tr}\end{array}$ & 7.05 & 5.77 & 8.53 \\
\hline $\begin{array}{l}\mathrm{Al}_{2} \mathrm{U}_{3} \\
\mathrm{~F}_{2}\end{array}$ & E\} & .51 & $\begin{array}{l}\operatorname{Tr} \\
\operatorname{Tr}\end{array}$ & .14 & - & Z \\
\hline $\mathrm{UO}_{3}$ & $66.80^{\prime}$ & 66.75 & 66.67 & 65.87 & 66.40 & 65.24 \\
\hline $\mathrm{SiO}_{2}$ & 14.03 & 13.78 & 13.72 & 13.24 & 13.40 & 12.66 \\
\hline $\mathrm{H}_{2} \mathrm{O}$ & 12.62 & 12.67 & 12.02 & 13.11 & 11.71 & 13.02 \\
\hline Rem. & & .45 & 1.30 & & 2.60 & \\
\hline Total & 100.00 & 99.43 & 100.38 & 99.41 & 99.88 & 99.45 \\
\hline Sp gr & - & 3.96 & 3.834 & - & - & - \\
\hline
\end{tabular}

1. Theoretical weight percentages, $\mathrm{Ca}\left(\mathrm{UO}_{2}\right)_{2}\left(\mathrm{SiO}_{3}\right)_{2}(\mathrm{OH})_{2} \cdot 5 \mathrm{H}_{2} \mathrm{O}$.

2. "Uranotil". Wölsendorf, Bavaria. Bořický (1870). Remainder is $\mathrm{P}_{2} \mathrm{O}_{5}$.

3. Uranophane (?). Mitchell County, N. C. Genth (1879). Remainder is $\mathrm{PbO} 0.60, \mathrm{BaO} 0.28, \mathrm{SrO} 0.13, \mathrm{P}_{2} \mathrm{O}_{5} 0.29$. Average of two.

4. Uranophane(?). Mitchell County, N. C. Foullon (1883). Average of two.

5. Uranophane. Mitchell County, N. C. Gonyer, analyst, in C. Frondel (1956b). Remainder is chiefly $\mathrm{ThO}_{2}$ with $\mathrm{Y}_{2} \mathrm{O}_{3}$.

6. Uranophane. Lusk, Wyo. Sherwood, analyst, in Wilmarth and Johnson (1954).

Additional analyses are cited by E. S. Dana (1892), Doelter (1919, v. 2, pt. 3, p. 421), Nováček (1935b), and Gorman and Nuffield (1955). An approximate analysis of an impure substance probably containing uranophane or beta-uranophane is given by Nordenskiöld (1884). An analysis of impure material approximating the ratios $\mathrm{CaO} \cdot 2 \mathrm{UO}_{3} \cdot \mathrm{SiO}_{2} \cdot 6 \mathrm{H}_{2} \mathrm{O}$ is given by Thoreau (1930).

The slight variation in optical properties indicates that there is a compositional variation in the mineral, possibly a substitution of $\mathrm{Pb}$ or $\mathrm{Ba}$ for $\mathrm{Ca}$. Th and $\mathrm{Y}$ apparently substitute for $\mathrm{Ca}$ in the material of analysis 5. Spectrographic analyses are lacking. 
Soluble in warm $\mathrm{HCl}$ with separation of flocculent silica. Before the blowpipe turns dark and yields water.

\section{Crystallography}

Uranophane is monoclinic; the crystal class is not known. The crystals are minute needles, with poorly developed faces, and do not afford good morphological measurements. Bořický (1870) quotes V. R. Zepharovich (written communication) as considering his (Bořický's) Wölsendorf material to be orthorhombic on the basis of partial and poor goniometric measurements and this interpretation, supported by the parallel optical extinction of the fibers, was accepted by Dana (1892) and most modern authors. The direction of elongation of the needles was taken as the $c$-axis. Pjatnitzky (1892) summarized the morphological data of Schrauf (1873) and of Zepharovich, and from new measurements on crystals from Schneeberg and Joachimsthal he concluded that the mineral was triclinic. His elements are: $a: b: c=0.6257: 1: 0.5943$; a $87^{\circ} 41^{\prime}, \beta 85^{\circ} 18^{\prime}, \gamma 96^{\circ} 31^{\prime}$. The material of Pjatnitzky probably was uranophane and not the later described dimorph beta-uranophane. (See Nováček, 1935b.) According to Pjatnitzky the mineral has inclined extinction against the elongation of about $2^{\circ}$; in most modern optical descriptions the extinction is stated or inferred to be parallel. The needles often are a slightly divergent composite of smaller fibers, or are warped or bent, and the significance of such a small extinction angle is doubtful.

$X$-ray single-crystal studies of uranophane have been made by Billiet $(1936 \mathrm{a}, \mathrm{b})$, who interpreted the crystallography in terms of orthorhombic symmetry, and by Gorman and Nuffield (1955) who proved the symmetry to be monoclinic with the elongation of the crystals along the $b$-axis. The cell dimensions obtained by these authors are cited below. In neither case is there a close correlation with the earlier morphological measurements, but the latter are only approximate at best.

\begin{tabular}{|c|c|c|c|}
\hline \multicolumn{4}{|c|}{ Unit-cell dimensions of uranophane } \\
\hline & 1 & 2 & \multirow{3}{*}{$\begin{array}{l}\text { Unit-cell contents } \\
2\left[\mathrm{Ca}\left(\mathrm{UO}_{2}\right)_{2}\left(\mathrm{SiO}_{3}\right)_{2}\right. \\
\left.(\mathrm{OH})_{2} 5 \mathrm{H}_{2} \mathrm{O}\right] ; \text { space group } \\
P 2_{1} / a \text { or } P 2 / a \text { (Gorman } \\
\text { and Nuffield, } 1955) .\end{array}$} \\
\hline $\begin{array}{l}a_{0} \\
b_{0} \\
c_{0}\end{array}$ & $\begin{array}{c}6.69 \mathrm{~A} \\
15.31 \\
7.32\end{array}$ & $\begin{array}{c}15.87 \mathrm{~A} \\
7.05 \\
6.66\end{array}$ & \\
\hline$\underset{\beta}{a_{0}: b_{0}: c_{0}}$ & $0.437: 1: 0.478$ & $\begin{array}{c}2.252: 1: 1.067 \\
97^{\circ} 15^{\prime}\end{array}$ & \\
\hline
\end{tabular}

Crystal habit

Crystals of uranophane are acicular to hairlike, and occur as stellate or tufted aggregates or as crusts. Also massive, microcrystalline, with a fibrous or felted structure and appearing dense to the unaided eye; as soft, shredded, or felted coatings. 
The morphology of the crystals is known only from the examination of minute crystals under magnification. The needles usually have a nearly square cross section (interfacial angle $\approx 97^{\circ}$ ) with a good cleavage in the [010] zone parallel to one pair of faces, probably $\{100\}$, with a high luster, and traces of cleavage parallel to the other pair, probably $\{001\}$, with poor luster. The needles are terminated commonly by a single large oblique face with an angle to $\{100\}$ of $\approx 95^{\circ}$ and to $\{001\}$ of $\approx 93^{\circ}$; occasionally with small modifying faces in the [010] zone with four narrow $\{h 0 l\}$ faces, and terminated by a pair of inclined faces. Drawings of the crystals are given by Pjatnitzky (1892) and Thoreau (1930). Buttgenbach (1926) mentions crystals from Katanga bounded by four faces in the [010] zone and terminated by faces inclined at $25^{\circ}$ and $54^{\circ}$ to the direction of elongation. A summary description of the morphology is given by Billiet $(1936 \mathrm{a}, \mathrm{b})$ in an orthorhombic interpretation.

\section{Physical properties}

One perfect cleavage and traces of another parallel to the elongation of the needles; the perfect cleavage probably is on $\{100\}$. Brittle. Hardness about 21/2. Specific gravity 3.7-3.9 in massive material, the variation due to porosity and to admixture; 3.809 on crystals (Billiet, 1936a, b) ; 3.83 (measured), 3.85 (calculated) on Wölsendorf crystals used in the X-ray study of Gorman and Nuffield (1955). Luster vitreous, pearly on the good cleavage; massive material may appear dull or earthy to waxy. Color lemon yellow to pale straw yellow and honey brown; also greenish yellow to yellowish green (especially in dense massive material) ; orange yellow. Crystals are weakly fluorescent in green in ultraviolet light; massive material usually is not fluorescent (Gorman and Nuffield, 1955).

Optical properties

The optical data given below are representative.

\begin{tabular}{|c|c|c|c|c|c|c|c|}
\hline \multirow{2}{*}{$\begin{array}{l}\text { ORIENTA- } \\
\text { TION }\end{array}$} & \multicolumn{7}{|c|}{$n$} \\
\hline & 1 & 2 & 3 & 4 & 5 & 6 & 7 \\
\hline $\begin{array}{l}X \\
Y \\
Z=b\end{array}$ & $\begin{array}{l}1.642 \\
1.665 \\
1.672\end{array}$ & $\begin{array}{l}1.643 \\
1.667 \\
1.670\end{array}$ & $\begin{array}{l}1.645 \\
1.665 \\
1.667\end{array}$ & $\begin{array}{l}1.647 \\
1.661 \\
1.668\end{array}$ & $\begin{array}{l}1.648 \\
1.666 \\
1.675\end{array}$ & $\frac{1.642}{1.668}$ & $\begin{array}{l}1.642 \\
1.666 \\
1.668\end{array}$ \\
\hline $2 \mathrm{~V}$ & $-45^{\circ}(\mathrm{N}$ & Small & $32^{\circ}(\mathrm{Na})$ & - & - & - & Small \\
\hline
\end{tabular}

Weakly pleochroic, with $X$ colorless, $Y$ pale canary yellow, $Z$ canary yellow; dispersion $r<v$, strong; optically negative.

1. Wyoming. Larsen, Hess, and Schaller (1926).

2. Silesia. Larsen (1921).

3. Schneeberg. Idem.

4,5. Joachimsthal. Nováček (1935b).

6. Mitchell County, N. C. C. Frondel (1956b), analysis 5.

7. Nabburg, Bavaria. Gorman and Nuffield (1955). 
In some orientations abnormal blue interference colors are shown in white light. $X$ is perpendicular to a flat face or cleavage. Under the microscope, dense material appears as a matted intergrowth of shreds and minute fibers. Hamilton and Kerr (1954b) found that unanalyzed uranophane from Marysvale, Utah, had the relatively low indices $n_{X} 1.634, n_{Z} 1.667$.

Larsen and Berman (1934), following Pjatnitzky (1892), state that uranophane is probably triclinic and give the following optical data for a specimen from an unstated locality : $Z \wedge c 2^{\circ}, 2 \mathrm{~V}$ $32^{\circ}, r<v$ marked; $n_{X} 1.642, n_{Y} 1.667, n_{Z}$ 1.669. Branche, Chervet, and Guillemin (1951) state that the extinction angle is $\approx 3^{\circ}$.

\section{Thermal behavior}

The differential thermal analysis curve of uranophane shows minor endothermic peaks at $150^{\circ} \mathrm{C}, 330^{\circ} \mathrm{C}$, and $570^{\circ} \mathrm{C}$, a major endothermic peak at $230^{\circ} \mathrm{C}$, and an exothermic peak at $730^{\circ} \mathrm{C}$; between $300^{\circ} \mathrm{C}$ and $600^{\circ} \mathrm{C}$ the structure is broken down and an $\mathrm{X}$-ray pattern is not afforded, but at $800^{\circ} \mathrm{C}$ recrystallization takes place to an unidentified substance (Hamilton and Kerr, 1954b).

\section{Synthesis}

No data.

Identification

Both the crystallized and dense types of uranophane are indistinguishable by the unaided eye from the corresponding types of beta-uranophane. There also is a very close resemblance to sklodowskite and to the earthy microcrystalline varieties of soddyite and kasolite. A distinction from these minerals can be made by optical and X-ray means. Beta-uranophane has higher indices and inclined extinction. The X-ray powder-spacing data are given. in the following table.

$X$-ray powder-spacing data for uranophane ${ }^{1}$

[Copper radiation, nickel filter]

\begin{tabular}{|c|c|c|c|c|c|c|}
\hline$d(\mathrm{~A})$ & $I$ & $d(\mathrm{~A})$ & $I$ & $d(\mathrm{~A})$ & $I$ & $d(\mathrm{~A})$ \\
\hline $\begin{array}{l}7.88 \\
6.61 \\
5.42 \\
4.76 \\
4.29 \\
3.94 \\
3.60 \\
3.51 \\
3.41 \\
3.35 \\
3.20\end{array}$ & $\begin{array}{r}10 \\
4 \\
4 \\
5 \\
2 \\
9 \\
4 \\
4 \\
1 \\
1 \\
5\end{array}$ & $\begin{array}{l}3.09 \\
2.99 \\
2.91 \\
2.69 \\
2.63 \\
2.57 \\
2.52 \\
2.40 \\
2.26 \\
2.20 \\
2.10\end{array}$ & $\begin{array}{l}1 \\
8 \\
8 \\
4 \\
5 \\
2 \\
2 \\
1 \\
2 \\
4 \\
5\end{array}$ & $\begin{array}{l}2.06 \\
1.969 \\
1.906 \\
1.889 \\
1.867 \\
1.827 \\
1.769 \\
1.747 \\
1.717 \\
1.659 \\
1.601\end{array}$ & $\begin{array}{l}2 \\
7 \\
2 \\
1 \\
3 \\
1 \\
\mathbf{1} \\
3 \\
\mathbf{1} \\
\mathbf{2} \\
1\end{array}$ & $\begin{array}{l}1.579 \\
1.537 \\
1.496 \\
1.461 \\
1.442 \\
1.382 \\
1.372 \\
1.345 \\
1.325 \\
1.262 \\
1.239\end{array}$ \\
\hline
\end{tabular}

1 Material from the Ruggles pegmatite, Grafton Center, N. H. Direct comparison of films taken of material from numerous localities shows little or no significant variations in spacing. 
Natural formation

Uranophane is of supergene origin. It may occur as more or less complete pseudomorphs after crystals of uraninite, and if the alteration is zonal it constitutes the outermost parts. It also occurs as coatings along cracks in the matrix adjacent to such pseudomorphs. More generally uranophane occurs as coatings along joint planes or crevices in igneous or other rocks without close association with primary uranium minerals and it seems to have been deposited by meteoric waters. Uranophane is a common mineral in the oxidized zone of vein deposits of uraninite, as in the Belgian Congo, and then is among the last formed of the secondary minerals derived by alteration of the uraninite; in large part it seems to have formed by the action of meteoric waters carrying silica on earlier formed secondary uranium minerals. It is a much more typical alteration product of uraninite in pegmatites than in the vein occurrences of that species. Associated minerals include beta-uranophane, kasolite, meta-autunite, phosphuranylite, and hydrated uranium oxides.

\section{Occurrence}

Uranophane is one of the commonest of the secondary uranium minerals and only a partial list of the known localities is given here. It was found originally at Kupferberg, Silesia, both as dense masses pseudomorphous after uraninite and as tufted aggregates of crystals in the oxidized part of the copper veins. This is the material originally described under the name uranophane by Websky (1853). The analysis of this mineral unfortunately was very poor and prevented the recognition of its identity with the mineral later described under the name uranotil by Bořický (1870) from Wölsendorf, Bavaria. The latter material occurs rather abundantly at Wölsendorf as crusts of acicular crystals and as fibrous nodular aggregates in cavities in massive purple fluorite as an alteration of uraninite; a summary description of this fluorite deposit is given by Strunz (1953). Uranophane also has been identified from Joachimsthal, Bohemia (Nováček, $1935 \mathrm{~b}$ ) ; the Weisser Hirsch mine near Neustädtel, Saxony (Weisbach, 1873b) ; Schneeberg, Saxony (Nováček, 1935b) ; Kasolo, Katanga district, Belgian Congo (Nováček, 1935b; Thoreau, 1930). The first specimen sent to Belgium following the discovery of uranium in the Katanga district in 1913 was described as consisting of pitchblende altering to gummite and uranophane; a photograph of the specimen is given by Buttgenbach (1925, fig. 30). It has been identified by X-ray and optical study by C. Frondel (1956b) as composing the outer rind on gummite pseudomorphs after uraninite from numerous localities, includ- 
ing various pegmatites in the Spruce Pine district, Mitchell County, N. C. ; pegmatites at North Wilton, Palermo, Beryl Mountain and Ruggles, in New Hampshire; the Uruguru Mountains, Tanganyika, Africa; Rajputana, India; Karelia, U.S.S.R.; Wolfe Creek, Jackson County, N. C.; Calamuchita, Cordoba, Argentina. Further study of such pseudomorphs doubtless would greatly extend the list of occurrences. Found in Canada (Hogarth, 1951) at Great Bear Lake, Northwest Territory; in the Lake Athabaska district, Saskatchewan; Villeneuve, Quebec; Henvey Township, Parry Sound district, Ontario; Theano Point, Lake Superior. At numerous localities in Puy-de-Dôme, France (Branche and others, 1951). The mineral also has been reported from Stone Mountain, Ga. (Watson, 1902) ; Mount Painter in the Flinders Range, South Australia; the Urgeiriça mine, Portugal; Johanngeorgenstadt, Saxony; Namaqualand, Africa. With autunite and torbernite in deeply oxidized veins in the Cuneo-Lurisia district, Italy. On the Bergell Alp, Switzerland (Hirschi, 1925).

In the Western United States, uranophane has been found in Utah in the Grey Dawn mine, Paradox district, the Henry Mountains district, the Marysvale district (Hamilton and Kerr, 1954), and the Happy Jack mine, San Juan County; in New Mexico in the Grants district in beautiful crystals in vugs in Todilto limestone at the Hanosh mine; in Wyoming at Pumpkin Buttes, and at the Silver Cliff mine near Lusk, where the mineral occurs as fracture fillings and small replacement pockets in calcareous sandstone and has been worked as an ore (Wilmarth and Johnson, 1954) ; in Arizona in the Cato Sells mine, Monument Valley district. Found in fluorite deposits on the west side of the Thomas Range about 100 miles southwest of Salt Lake City, in Juab County, Utah. Uranophane doubtless occurs at many other localities in this general region. An unidentified mineral closely related to uranophane but with higher indices of refraction and small differences in the X-ray powder pattern occurs at the Desanti mine, Gallup, N. Mex., and at Marysvale and other localities in Utah (Gruner, written communication, 1954, $n_{X}$ 1.675-1.680, $n_{Y}$ 1.72-1.73, $n_{Z}$ 1.76-1.77).

\section{SKLODOWSKITE}

Synonymy

Chinkolobwite Schoep (1923a, c). Sklodowskite Schoep (1924e), Sklodovskite. Shinkolobwite. The name sklodowskite is after Madame Marie Curie (1867-1934), whose maiden name was Sklodowska. She was one of the pioneers in the study of radioactivity, and her work in that field was historic. Madame Curie, 
jointly with her husband Pierre Curie and A. H. Becquerel, was awarded a Nobel Prize in physics in 1904, and, after becoming professor of physics at the Sorbonne, Paris, she was awarded a Nobel Prize in chemistry in 1911.

The name chinkolobwite, from the supposed locality at Shinkolobwe, Katanga district, Belgian Congo, has priority over sklodowskite; chinkolobwite was later shown by Schoep (1925b) to be identical with sklodowskite, but as the original locality was given erroneously the name sklodowskite has been retained for the species.

\section{Composition}

A hydrated silicate of magnesium and hexavalent uranium, $\mathrm{Mg}\left(\mathrm{UO}_{2}\right)_{2}\left(\mathrm{SiO}_{3}\right)_{2}(\mathrm{OH})_{2} \cdot 5 \mathrm{H}_{2} \mathrm{O}=\mathrm{MgO} \cdot 2 \mathrm{UO}_{3} \cdot 2 \mathrm{SiO}_{2} \cdot 6 \mathrm{H}_{2} \mathrm{O}$. The three reported analyses, cited in the table below, are unsatisfactory, but the composition of the mineral is substantiated by X-ray and other evidence. Analysis 2, reported as of sklodowskite by Schoep (1924e), apparently has $\mathrm{Ca}$ in substitution for $\mathrm{Mg}$, with $\mathrm{Ca}>\mathrm{Mg}$ in atomic percent. This would class the material as magnesian uranophane, but the optical orientation is that of sklodowskite.

Chemical analyses of sklodowskite, in weight percent

\begin{tabular}{|c|c|c|c|c|}
\hline & 1 & 2 & 3 & 4 \\
\hline $\mathrm{MgO}$ & 4.80 & 3.74 & 1.91 & $\overline{3.96}$ \\
\hline Pbo & 三 & $\bar{Z}$ & - & 1.17 \\
\hline NiO & - & .20 & - & $\pi$ \\
\hline $\mathrm{CoO}$ & - & $1 \overline{00}$ & 1.27 & \\
\hline $\mathrm{TeO}_{3}$ & 6805 & $\begin{array}{r}1.08 \\
64.72\end{array}$ & 67.25 & $\begin{array}{r}2.64 \\
66.33\end{array}$ \\
\hline $\begin{array}{r}U_{3} \\
\mathrm{SiO}_{2}\end{array}$ & $\begin{array}{l}68.00 \\
14.29\end{array}$ & $\begin{array}{l}64.72 \\
14.28\end{array}$ & $\begin{array}{l}13.49 \\
\end{array}$ & $\begin{array}{l}00.00 \\
12.53\end{array}$ \\
\hline $\mathrm{H}_{2} \mathrm{O}$ & 12.86 & 13.41 & $\mathbf{1 3 . 3 3}$ & 14.27 \\
\hline Rèm. & - & 1.97 & & \\
\hline Total & 100.00 & 99.40 & 99.82 & 100.90 \\
\hline
\end{tabular}

1. Theoretical weight percentages, $\mathrm{MgO} \cdot 2 \mathrm{UO}_{3} \cdot 2 \mathrm{SiO}_{2} \cdot 6 \mathrm{H}_{2} \mathrm{O}$.

2. Sklodowskite (chinkolobwite). Schoep (1924e).

3. Sklodowskite (chinkolobwite). Schoep (1924e). Remainder is $(\mathrm{Na}, \mathrm{K})_{2} \mathrm{O}$. Analysis made on radially fibrous spherulites.

4. Sklodowskite (chinkolobwite). Schoep (1924e). Analysis on compact granular material.

As the analyzed material apparently was impure and somewhat altered, the occurrence of $\mathrm{Ca}$ in substitution for $\mathrm{Mg}$ in this species requires confirmation. Uranophane that possibly contains $\mathrm{Mg}$ in substitution for $\mathrm{Ca}$ is described by Hamilton and Kerr (1954b). The $\mathrm{Co}, \mathrm{Ni}, \mathrm{Te}$, and probably the $\mathrm{Pb}$ reported in the analyses are believed to be due to admixture. An analysis of very impure material from Kasolo, Katanga district, Belgian Congo, is given by Schoep (1926b). 
Sklodowskite is soluble in acids with gelatinization. Spectrographic analyses are lacking.

Crystallography

Presumed to be monoclinic from the isostructural relation to uranophane indicated by X-ray powder-diffraction photographs and the chemical composition. Found as velvety coatings of tiny acicular crystals or as radially fibrous spherulites; also compact granular; very rarely as coarse needles with discernible faces. Schoep (1927c, 1930) and Billiet (1936b) have described crystals in an orthorhombic setting with the elongation taken as the $c$-axis; in a monoclinic setting with the elongation taken as the $b$-axis, the crystals show $\{001\},\{100\}$, and a number of $\{h 0 l\}$ and $\{\bar{h} 0 l\}$ forms together with terminal $\{0 k l\}$ (?) faces.

Billiet $(1936 \mathrm{~b})$ in an X-ray single-crystal study by the rotation method reported a cell with $a_{0} 6.68 \mathrm{~A}, b_{0} 15.53, c_{0} 7.13$ in the orthorhombic interpretation, but rigorous evidence of the symmetry is lacking. An isostructural relation to uranophane was first suggested by Schoep (1927) on chemical and morphological grounds, and later was accepted by Billiet (1936a). Billiet's interpretation of uranophane as orthorhombic (with cell dimensions comparable to those of cuprosklodowskite) was shown to be incorrect by Gorman and Nuffield (1955).

\section{Physical properties}

There is a cleavage in the zone [010], probably on $\{100\}$. Brittle. Hardness not known. Specific gravity $3.776 \pm 0.005$ (Billiet, 1936b) ; lower values are reported by Schoep (1924e) ; 3.77 (calculated). Color pale citron yellow. Luster of fibrous aggregates, silky ; of crystals or of dense masses, subvitreous. Not fluorescent in ultraviolet light.

Optical properties

$\begin{array}{cc}\text { ORIENTATION } & \begin{array}{c}n \\ \text { KATANGA }\end{array} \\ \begin{array}{l}X \\ Z\end{array}=b & 1.613 \\ 1.635 \\ 1.657\end{array}$
Biaxial negative;
$2 V$ very large;
not pleochroic.

The optical orientation of sklodowskite differs from that of uranophane, the axial plane in the latter being parallel to the $b$-axis. The data cited are from Billiet (1926) and Schoep (1924e). Somewhat discordant optical data are given on the original chinkolobwite by Schoep (1925).

Thermal behavior

The study of Schoep (1924b) indicates that the mineral loses about half of its water at about $110^{\circ} \mathrm{C}$ and most of the rest in the 
range $250^{\circ}-350^{\circ} \mathrm{C}$; at $500^{\circ} \mathrm{C}$ it is anhydrous and deep greenish yellow in color. Samples heated to $150^{\circ} \mathrm{C}$ reabsorb 1.8 percent $\mathrm{H}_{2} \mathrm{O}$ on standing 12 hours in air, and at $250^{\circ}-260^{\circ} \mathrm{C}$ reabsorb 4.1 percent under the same conditions.

Synthesis

No data.

Identification

Sklodowskite is very similar in appearance to uranophane and beta-uranophane and cannot be distinguished from them with certainty at sight. It differs from uranophane in its optical orientation, and beta-uranophane has inclined extinction and higher indices of refraction. A qualitative test for $\mathrm{Mg}$ and $\mathrm{X}$-ray verification are desirable. The X-ray powder-spacing data are given in the following table.

$X$-ray powder-spacing data for sklodowskite ${ }^{1}$

[Symbol: b, broad. Copper radiation, nickel filter]

\begin{tabular}{|c|c|c|c|c|c|c|c|}
\hline (A) & $I$ & $d(\mathrm{~A})$ & $I$ & $d(\mathrm{~A})$ & $I$ & $d(\mathrm{~A})$ & $I$ \\
\hline $\begin{array}{l}8.42 \\
6.37 \\
5.91 \\
4.82 \\
4.51 \\
4.33 \\
4.19 \\
4.00 \\
3.52 \\
3.27 \\
3.00\end{array}$ & $\begin{array}{r}10 \\
2 \\
5 \\
4 \\
1 \\
4 \\
8 \\
5 \\
6 \\
7 \\
6\end{array}$ & $\begin{array}{l}2.87 \\
2.80 \\
2.74 \\
2.70 \\
2.66 \\
2.52 \\
2.34 \\
2.27 \\
2.22 \\
2.19 \\
2.17\end{array}$ & $\begin{array}{r}5 \\
2 \\
2 \\
1 \\
1 \\
1 \\
2 \\
1 / 2 \\
2 \\
2 \\
2\end{array}$ & $\begin{array}{l}2.13 \\
2.09 \\
1.985 \\
1.961 \\
1.918 \\
1.884 \\
1.848 \\
1.821 \\
1.801 \\
1.768 \\
1.740\end{array}$ & $\begin{array}{c}3 \\
3 \\
2 \\
2 \\
2 \\
1 \\
2 \\
1 / 2 \\
1 \\
1(b) \\
1(b)\end{array}$ & $\begin{array}{l}1.707 \\
1.672 \\
1.647 \\
1.623 \\
1.593 \\
1.563 \\
1.540 \\
1.512 \\
1.490\end{array}$ & $\begin{array}{l}1(\mathrm{~b}) \\
1 / 2 \\
1(b) \\
2 \\
1(b) \\
1 \\
1 \\
1 \\
1\end{array}$ \\
\hline
\end{tabular}

1 Material from the Katanga district, Belgian Congo.

Natural formation

A secondary mineral formed by the action of meteoric waters carrying silica on uraninite or earlier formed secondary uranium minerals. With uranophane and beta-uranophane it is among the last formed of the secondary uranium minerals in a given paragenesis.

Occurrence

Originally found in the Katanga district, Belgian Congo, where it occurs rarely in the oxidized zone of the ore bodies or filling cracks in a siliceous breccia. Also found, at Kasolo, with curite and cerussite as pseudomorphs after uraninite (Hacquaert, 1927). Typical associated minerals include kasolite, soddyite, uranophane, curite, and torbernite. From the Grants area, New Mexico (Rapaport, 1952). At the Oyler Tunnel claim, near Fruita, Wayne County, Utah (Gruner and others, 1954b). Reported from the 
Honeycomb Hills, Utah (Wilmarth and others, 1952). At the New Haven mine, Crook County, Wyo. (Gruner and Smith, written communication, 1955).

\section{CUPROSKIODOWSKITE}

Synonymy

Kieselkupfer-Uranoxyd John (1845), Cuprosklodovskite Vaes (1933). Jáchymovite Nováček (1935a). Cuprosklodowskite. Cuprosklovskite. Cuprosklowskite.

Named by Buttgenbach (in presenting the note by Vaes, 1933) in allusion to the belief that it is the copper analogue of sklodowskite. Jachymovite from the locality at Jachymov (=Joachimsthal), Bohemia. The identity of jachymovite with cuprosklodowskite was established by Nováček (1935b) and Billiet (1936b). It is not known with certainty if the copper uranium silicate described by John in $\mathbf{1 8 4 5}$ is identical with cuprosklodowskite. (See Nováček, 1935b.) Cuprosklodowskite is found to be the chief component of most museum specimens of the supposed uranium sulfates called uranochalcite, voglianite, and urangrün. (See Nováček, 1935b, and C. Frondel, 1952.)

Composition

A hydrated silicate of hexavalent uranium and copper, $\mathrm{Cu}\left(\mathrm{UO}_{2}\right)_{2}\left(\mathrm{SiO}_{3}\right)_{2}(\mathrm{OH})_{2} \cdot 5 \mathrm{H}_{2} \mathrm{O}=\mathrm{CuO} \cdot 2 \mathrm{UO}_{3} \cdot 2 \mathrm{SiO}_{2} \cdot 6 \mathrm{H}_{2} \mathrm{O}$. The three reported analyses (cited below) made on extremely small samples are in reasonably close agreement with the formula given. The formula above is parallel to those of uranophane and sklodowskite, with which minerals cuprosklodowskite probably is isostructural. Spectrographic analyses and thermal dehydration data are lacking.

Chemical analyses of cuprosklodowskite, in weight percent

\begin{tabular}{|c|c|c|c|c|}
\hline & 1 & 2 & 3 & 4 \\
\hline $\mathrm{CuO}$ & 9.04 & 8.99 & $\begin{array}{r}9.07 \\
18\end{array}$ & 9.0 \\
\hline $\begin{array}{l}\mathrm{UO}_{3} \\
\mathrm{SiO}_{2} \\
\mathrm{H}_{2} \mathrm{O}\end{array}$ & $\begin{array}{l}65 . \overline{02} \\
13.65 \\
12.29\end{array}$ & $\begin{array}{l}64 . \overline{96} \\
13.40 \\
11.72\end{array}$ & $\begin{array}{r}64.65 \\
13.90 \\
11.88\end{array}$ & $\begin{array}{l}64.7 \\
14.4 \\
12.1\end{array}$ \\
\hline Total & 100.00 & 99.07 & 99.68 & 100.2 \\
\hline
\end{tabular}

1. Theoretical weight percentages, $\mathrm{CuO} \cdot 2 \mathrm{UO}_{3} \cdot 2 \mathrm{SiO}_{2} \cdot 6 \mathrm{H}_{2} \mathrm{O}$.

2. Joachimsthal. Nováček (1935a) on $4.5 \mathrm{mg}$. Specimen labeled uranochalcite. With $\mathrm{CaO}, \mathrm{PbO}$, and $\mathrm{Fe}_{2} \mathrm{O}_{3}$ in traces.

3. Joachimsthal. Nováček (1935a) on $8.5 \mathrm{mg}$. Specimen labeled voglianite.

4. Katanga. Nováček (1935b) on $2 \mathrm{mg}$. With $\mathrm{Fe}_{2} \mathrm{O}_{3}$ trace.

Crystallography

The symmetry of cuprosklodowskite is not known with certainty. The mineral may be monoclinic, from the isostructural relation to uranophane suggested by X-ray powder-diffraction 
patterns and the chemical composition. Commonly found as thin crusts and films with a small-botyroidal surface and a radialfibrous or matted-fibrous structure. Also as silky coatings or tufts of minute acicular crystals, often radiating from a center. Rarely in coarse acicular crystals of sufficient size to discern crystal faces. Material of this kind from Kalongwe, Belgian Congo, described by Vaes (1933) in an orthorhombic setting with the elongation as the $c$-axis, and here redescribed as monoclinic with the elongation as the $b$-axis, showed under the microscope eight faces in the zone [010], presumably $\{001\},\{00 \overline{1}\},\{h 0 l\}$ and $\{\bar{h} 0 l\}$, together with a terminal $\{0 \mathrm{kl}\}$ (?) form. Billiet (1936b) found by the X-ray rotation method that the identity period along the needle axis was $7.24 \mathrm{~A}$ on Kalongwe crystals.

Physical properties

Cleavage $\{100\}$ (reported by Nováček, 1935a, from observations made under the microscope). Hardness not known. Specific gravity about 3.5 (George, 1949). Color yellowish green to grass green and greenish yellow. Luster of aggregates dull to silky. Transparent under the microscope. Not fluorescent in ultraviolet light.

Optical properties

\begin{tabular}{|c|c|c|c|c|}
\hline \multirow{2}{*}{$\begin{array}{l}\text { ORIFNTA- } \\
\text { TION }\end{array}$} & \multicolumn{2}{|c|}{$n(\mathrm{Na})$} & \multirow[b]{2}{*}{ Pléchroism } & \\
\hline & 1 & 2 & & \\
\hline $\begin{array}{l}X=a \\
Y=c \\
Z=b\end{array}$ & $\begin{array}{l}1.654 \\
1.664 \\
1.664\end{array}$ & $\begin{array}{l}1.655 \\
1.667 \\
1.667\end{array}$ & $\begin{array}{l}\text { Nearly colorless (?). } \\
\text { Yellowish green. } \\
\text { Yellowish green(?). }\end{array}$ & \multirow{2}{*}{$\begin{array}{l}\text { Biaxial negative; } 2 V \\
\text { very small to } 0^{\circ} \\
\text { (from indices); dis- } \\
\text { persion } r>v \\
\text { (Vaes 1933). }\end{array}$} \\
\hline Anal. no. 1 & 2 & 3 & & \\
\hline
\end{tabular}

1 See table, p. 304.

1,2. Joachimsthal. Nováček (1935a).

Under the microscope cuprosklodowskite appears as matted fibers or as tiny needles, which may be somewhat flattened on $\{100\}$. The terminations are oblique and unsymmetrical, presumably due to distortion of the end faces. Crystals resting on the plane of flattening and cleavage, $\{100\}$, have positive elongation and show pleochroism and abnormal interference colors; crystals viewed on edge, through $\{010\}$, have negative elongation, do not show pleochroism and are nearly isotropic (Nováček, 1935a). The pleochroism has been variously described: the elongation, $Y$, is yellowish green; perpendicular thereto the crystals are colorless in thin crystals and blue in thick ones (Schoep, 1936a), or colorless (Vaes, 1933), or yellowish to nearly colorless 
(Nováček, 1935a), the absorption of $X$ and $Z$ not being separately known. The indices of refraction reported by Vaes (1933) on Kalongwe material (1.68-1.70) were found to be high by Schoep (1936a).

Larsen (1921) and Larsen and Berman (1934) give the following data for matted fibers of "uranochalcite" from Johanngeorgenstadt: biaxial positive, $2 V$ small, $Z=c$ (elongation); $n_{X}$ 1.655 (very pale yellowish green), $n_{Y} 1.655$ (very pale yellowish green), $n_{z} 1.662$ (pale greenish yellow). These data if they refer to cuprosklodowskite (as is likely) must be partly in error.

Thermal behavior and synthesis

No data.

Identification

Cuprosklodowskite differs from the other known uranium silicates in its green color and its content of copper. The indices of refraction are close to those of uranophane in part, but the optical orientation is different. It also bears a superficial resemblance to chrysocolla and malachite. X-ray powder-spacing data are given in the following table.

$X$-ray powder-spacing data for cuprosklodowskite ${ }^{1}$

[Symbols: b, broad; vb, very broad; vd, very diffuse. Copper radiation, nickel filter]

\begin{tabular}{|c|c|c|c|c|c|c|}
\hline$d(\mathrm{~A})$ & $I$ & $d(\mathrm{~A})$ & $I$ & $d(\mathrm{~A})$ & $I$ & $d(\mathrm{~A})$ \\
\hline $\begin{array}{l}8.18 \\
6.10 \\
4.82 \\
4.29 \\
4.09 \\
3.52 \\
3.30 \\
3.20 \\
3.10 \\
2.97\end{array}$ & $\begin{array}{r}10 \\
6 \\
7 \\
\mathbf{2} \\
9 \\
6 \\
\mathbf{6} \\
\mathbf{2} \\
\mathbf{1} \\
\mathbf{8}\end{array}$ & $\begin{array}{l}2.87 \\
2.72 \\
2.64 \\
2.36 \\
2.29 \\
2.21 \\
2.17 \\
2.12 \\
2.07 \\
2.04\end{array}$ & $\begin{array}{l}\mathbf{1} \\
\mathbf{5} \\
\mathbf{5} \\
1 \\
\mathbf{2} \\
\mathbf{6} \\
\mathbf{3} \\
\mathbf{2} \\
\mathbf{2} \\
4\end{array}$ & $\begin{array}{l}1.906 \\
1.860 \\
1.805 \\
1.766 \\
1.736 \\
1.703 \\
1.643 \\
1.614 \\
1.587 \\
1.564\end{array}$ & $\begin{array}{l}5(\mathrm{~b}) \\
4(\mathrm{~b}) \\
3 \\
3 \\
2 \\
1 \\
3 \\
1 \\
1 \\
1\end{array}$ & $\begin{array}{l}1.503 \\
1.472 \\
1.436 \\
1.397 \\
1.362 \\
1.332 \\
1.301 \\
1.279 \\
1.227\end{array}$ \\
\hline
\end{tabular}

1 Material from Joachimsthal, Bohemia. Some cuprosklodowskite is extremely fine grained and gives faint and diffuse patterns.

Natural formation

A secondary mineral, formed by the alteration, essentially in place, of earlier formed uranium minerals or deposited from solutions in the oxidized zone of uranium deposits. Relatively common at Joachimsthal and Lake Athabaska, Canada, where copper minerals occur with uraninite in the primary vein material.

Occurrence

Found originally at Kalongwe, Katanga district, Belgian Congo, in a fissure carrying uranium minerals in a talcose argillaceous rock. Here it has been formed by the action of copper-bearing solutions on kasolite, and it is associated with vandenbrandeite, 
chrysocolla, malachite, and gummite (Schoep, 1936b; Vandendriessche, 1936). Also found at Kambove in Katanga. At Joachimsthal, Bohemia, where it occurs closely associated with liebigite, uranophane, and beta-uranophane; at Johanngeorgenstadt, Saxony. Recently observed (Hogarth, 1951) at the Nicholson mine on the north shore of Lake Athabaska, Saskatchewan, Canada, where it occurs with uranophane, kasolite, and other secondary minerals in the outcroppings of the uraninite veins. Found at the Posey mine in Red Canyon, San Juan County, Utah, associated with becquerelite and brochanthite in the oxidized zone of a copperuranium deposit (Weeks and Thompson, 1954); also at the Frey No. 4 mine in Frey Canyon, San Juan County, Utah (Gruner and others, 1954b); in the Todilto limestone in the Sanastee area, N. Mex. (Gruner and Smith, 1955).

Synonymy

\section{BETA-URANOPHANE}

$\beta$-Uranotile Nováček (1935a, b). Beta-Uranotile. Beta-Uranophane. Named in allusion to the dimorphous relation to uranophane.

\section{Composition}

A hydrated silicate of hexavalent uranium and calcium, $\mathrm{Ca}$ $\left(\mathrm{UO}_{2}\right)_{2}\left(\mathrm{SiO}_{3}\right)_{2}(\mathrm{OH})_{2} \cdot 5 \mathrm{H}_{2} \mathrm{O}=\mathrm{CaO} \cdot 2 \mathrm{UO}_{3} \cdot 2 \mathrm{SiO}_{2} \cdot 6 \mathrm{H}_{2} \mathrm{O}$. Dimorphous with uranophane. The five reported microanalyses of the mineral, cited in the table below, are in reasonably good agreement with the formula given. The small but significant variation observed in the optical properties indicates a variation in the chemical composition, possibly a small substitution of $\mathrm{Mg}$ or $\mathrm{Pb}$ for $\mathrm{Ca}$ or a variation in water content. Spectrographic and thermal analyses are lacking.

Chemical analyses of beta-uranophane, in weight percent

\begin{tabular}{|c|c|c|c|c|c|c|}
\hline & 1 & 2 & 3 & 4 & 5 & 6 \\
\hline $\begin{array}{l}\mathrm{CaO} \\
\mathrm{UO}_{3} \\
\mathrm{SiO}_{2} \\
\mathrm{H}_{2} \mathrm{O}\end{array}$ & $\begin{array}{r}6.55 \\
66.80 \\
14.03 \\
12.62\end{array}$ & $\begin{array}{r}7.32 \\
66.29 \\
13.11 \\
12.87\end{array}$ & $\begin{array}{r}4.8 \\
53.5 \\
31.9 \\
9.9\end{array}$ & $\begin{array}{r}5.0 \\
56.4 \\
29.3 \\
10.2\end{array}$ & $\begin{array}{r}7.1 \\
66.9 \\
12.9 \\
12.6\end{array}$ & $\begin{array}{r}6.1 \\
66.5 \\
13.1 \\
14.3\end{array}$ \\
\hline Total & 100.00 & 99.59 & 100.1 & 100.9 & 99.5 & 100.0 \\
\hline Sp gr & - & 3.95 & 3.8 & 3.8 & 3.85 & - \\
\hline
\end{tabular}

1. Theoretical weight percentages, $\mathrm{CaO} \cdot 2 \mathrm{UO}_{3} \cdot 2 \mathrm{SiO}_{2} \cdot 6 \mathrm{H}_{2} \mathrm{O}$.

2. Joachimsthal. Nováček (1935a), on $7.5 \mathrm{mg} \cdot \mathrm{CO}_{2}$ present in small amount, owing to admixture, but not determined.

3,4. Near Spruce Pine, N. C. Nováček, analyst, in Steinocher and Nováček (1939). Made on samples containing admixed quartz and weighing 4.5 and 1.7 mg.

5. Wölsendorf, Bavaria. Nováček, analyst, in Steinocher and Nováček (1939) on $2 \mathrm{mg}$.

6. Bigay, Puy-de-Dôme, France. Branche and others (1951). 
Crystallography and crystal habit

Monoclinic, crystal class not known. Found as velvety to bristly coatings or subradial to fanlike aggregates of needlelike crystals that may be as much as $1 \mathrm{~mm}$ in length. Also as dense aggregates with a confused fibrous or felted structure as seen under the microscope (usually pseudomorphous after uraninite). The needles usually are somewhat thicker than those of uranophane and sklodowskite, but still too small for satisfactory goniometric measurements. The crystals are prismatic on the $c$-axis with a square or rectangular cross section due to the development of $\{010\}$ and $\{100\}$; sometimes somewhat flattened on $\{010\}$. The needles are ordinarily terminated with a relatively large face of $\{001\}$, with a $\rho$ angle of about $4^{\circ}\left(\beta=94^{\circ}\right)$, with small unequally developed faces of $\{h 0 l\}$ and $\{\bar{h} 0 l\}$ forms with $\rho$ angles of $44^{\circ}$, $48^{\circ} 36^{\prime}, 58^{\circ}$, and about $70^{\circ}$. In the structure cell $\{102\}$ and $\{\overline{102}\}$ have $\rho$ angles of $47^{\circ} 1^{\prime}$ and $46^{\circ} 5^{\prime}$, respectively. The crystals commonly show zonal growth, best observed through $\{010\}$, with which is associated a variation in the optical properties.

Twins on $\{100\}$ are common and show re-entrant angles at the termination and opposed extinction angles on $\{010\}$. Usually contact twins but occasionally overlapping as in Carlsbad twins of feldspar. The twinning and crystal habit have been described and figured by Steinocher and Nováček (1939), and Branche and others (1951). (See also figure 21.)

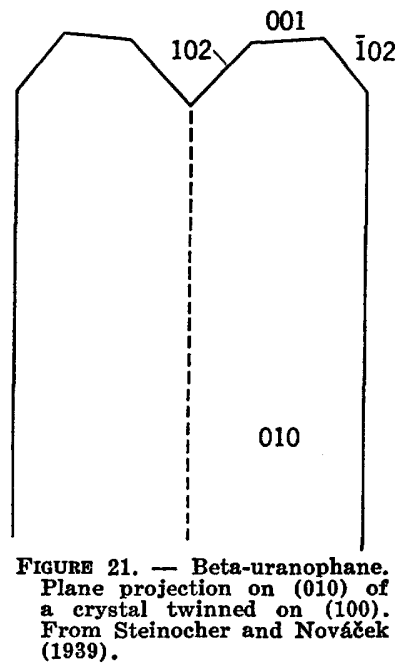

X-ray single-crystal data obtained by Gorman and Nuffield (1955) by the Weissenberg method on crystals from Faraday township, Ontario, are as follows: $a_{0} 6.64 \mathrm{~A}, b_{0} 15.55, c_{0} 14.01$, $a_{0}: b_{0}: c_{0}=0.427: 1: 0.901$. $\beta 91^{\circ}$. Space group $P 2_{1} / c$. Unit-cell contents $4\left[\mathrm{Ca}\left(\mathrm{UO}_{2}\right)_{2}\left(\mathrm{SiO}_{3}\right)_{2}(\mathrm{OH})_{2} \cdot 5 \mathrm{H}_{2} \mathrm{O}\right]$. 
Physical properties

Cleavage $\{010\}$ perfect; also a cleavage reported on $\{100\}$. Fracture conchoidal. Brittle. Hardness probably about $21 / 2-3$. Specific gravity about $3.9 ; 3.90$ (measured), 3.93 (calculated), on the material of the X-ray study of Gorman and Nuffield (1955). Color usually yellowish green; also greenish yellow, citron yellow, or pure yellow. Luster of crystals inclining to vitreous; also silky in fine-fibrous aggregates and tending toward greasy or waxy in dense massive aggregates. Fluoresces faint green in ultraviolet light (Haberlandt, Hernegger, and Scheminzky, 1950; Gorman and Nuffield, 1955).

Optical properties

$n(\mathrm{Na})$

\begin{tabular}{|c|c|c|c|c|}
\hline \multirow[b]{2}{*}{ ORIENTATION } & & & & \\
\hline & 1 & 2 & 3 & 4 \\
\hline $\begin{array}{l}X=b \\
Y \\
Z\end{array}$ & $\begin{array}{l}1.661-1.671 \\
1.682-1.694 \\
1.689-1.702\end{array}$ & $\begin{array}{l}1.663 \\
1.688 \\
1.697\end{array}$ & $\begin{array}{l}1.660 \\
1.683 \\
1.688\end{array}$ & $\begin{array}{l}1.670-1.678 \\
1.698-1.723 \\
1.715-1.730\end{array}$ \\
\hline$Z \hat{2 V} c$ & $\begin{array}{l}+44^{\circ}-57^{\circ} \\
711^{\circ}\end{array}$ & $\begin{array}{l}+3212^{\circ} \\
62^{\circ}\end{array}$ & $\begin{array}{c}+24^{\circ}-36^{\circ} \\
50^{\circ}\end{array}$ & $\begin{array}{r}+18^{\circ}-30^{\circ} \\
\text { Small to } 40^{\circ}\end{array}$ \\
\hline
\end{tabular}

$n$

\begin{tabular}{|c|c|c|c|c|}
\hline & & & & \\
\hline ORIENTATION & 5 & 6 & PleochroIsM & \\
\hline $\begin{array}{l}X=b \\
Y \\
Z\end{array}$ & $\begin{array}{l}1.665 \\
1.687 \\
1.695\end{array}$ & $\begin{array}{l}1.665 \\
1.684 \\
1.695\end{array}$ & $\begin{array}{l}\text { Colorless. } \\
\text { Lemon yellow. } \\
\text { Lemon yellow. }\end{array}$ & $\begin{array}{l}\text { Biaxial negative; strong } \\
\quad \text { crossed dispersion, } r>v\end{array}$ \\
\hline${ }_{2 \hat{2}} c$ & $\approx 40^{\circ}$ & $\begin{array}{r}\approx 30^{\circ} \\
35^{\circ}\end{array}$ & & \\
\hline
\end{tabular}

1. Joachimsthal. Steinocher and Nováček (1939).

2. Mitchell County, N. C. Idem.

3. Argentina. George (1949).

4. Portugal. Idem.

5. France. Branche and others (1951).

6. Utah. Hamilton and Kerr (1954b).

Crystals resting on $\{100\}$ show parallel extinction and no dispersion; crystals resting on $\{010\}$, the plane of perfect cleavage and flattening, show inclined extinction and strong dispersion so that in white light in no position is the extinction complete. The extinction direction $Z$ is in the obtuse angle. Absorption generally $X<Y=Z$, but in some material the absorption of $Z$ is slightly stronger than $Y$. Measurements of the extinction angle $Z \wedge c$ for different wavelengths on material from Joachimsthal; Bedford, N. Y.; and Mitchell County, N. C., are given by Steinocher and Nováček (1939); the angle decreases with decreasing wavelength.

The crystals often show zonal growth, due to compositional variation of an unknown nature, with accompanying variation in 
the optical properties. In the Joachimsthal material described by Steinocher and Nováček (1939) the inner zones have lower refractive indices, lower birefringence, and larger extinction angles than the outer zone.

Additional data on the optical properties are given by Nováček (1935b), Armstrong (1935), Steinocher and Nováček (1939), Meixner (1940b), and Larsen (1921). The data of Larsen (1921), later used by Armstrong (1935), Larsen and Berman (1934), and Winchell (1933) - but not Winchell (1951)-are erroneously identified as referring to schroeckingerite and the mistake was not rectified until the work of Nováček (1935b).

Thermal behavior and synthesis

No data.

Identification

Beta-uranophane has the same chemical composition as uranophane, and very closely resembles both this species and sklodowskite in general appearance. It can be distinguished optically by its inclined extinction and relatively high indices from both species. The X-ray powder-spacing data differ widely from those of uranophane; they are given in the following table.

$X$-ray powder-spacing data for beta-uranophane 1

[Symbol: b, broad. Copper radiation, nickel filter]

\begin{tabular}{|c|c|c|c|c|c|c|c|}
\hline$d(\mathrm{~A})$ & $I$ & $d(\mathrm{~A})$ & $I$ & $d(\mathrm{~A})$ & $I$ & $d(\mathrm{~A})$ & $I$ \\
\hline $\begin{array}{l}7.83 \\
\mathbf{6 . 6 6} \\
\mathbf{6 . 1 5} \\
\mathbf{5 . 0 7} \\
\mathbf{4 . 8 5} \\
\mathbf{4 . 5 5} \\
\mathbf{4 . 1 1} \\
\mathbf{3 . 9 0} \\
\mathbf{3 . 7 5} \\
\mathbf{3 . 5 1} \\
\mathbf{3 . 4 1} \\
\mathbf{3 . 3 5} \\
\mathbf{3 . 1 9} \\
\mathbf{3 . 0 4}\end{array}$ & $\begin{array}{r}10 \\
4 \\
4 \\
4 \\
4 \\
4 \\
3 \\
9 \\
1 \\
6 \\
1 \\
2 \\
5 \\
4\end{array}$ & $\begin{array}{l}2.99 \\
2.91 \\
2.83 \\
2.78 \\
2.59 \\
2.41 \\
2.36 \\
2.29 \\
2.21 \\
2.20 \\
2.17 \\
2.13 \\
2.11 \\
2.08\end{array}$ & $\begin{array}{l}3 \\
2 \\
4 \\
3 \\
5 \\
2(b) \\
2(b) \\
1 \\
2(b) \\
2(b) \\
1 \\
1 \\
1 \\
2\end{array}$ & $\begin{array}{l}2.04 \\
2.01 \\
1.98 \\
1.93 \\
1.877 \\
1.841 \\
1.807 \\
1.778 \\
1.734 \\
1.701 \\
1.658 \\
1.623 \\
1.590 \\
1.551\end{array}$ & $\begin{array}{l}1(b) \\
1 \\
3(b) \\
3(b) \\
3 \\
3 \\
3 \\
2 \\
3 \\
2(b) \\
1(b) \\
3(b) \\
1 / 2 \\
1\end{array}$ & $\begin{array}{l}1.528 \\
1.506 \\
1.484 \\
1.461 \\
1.441 \\
1.417 \\
1.388 \\
1.358 \\
1.310 \\
1.293 \\
1.274 \\
1.264 \\
1.186 \\
1.161\end{array}$ & $\begin{array}{l}1 \\
1 \\
1 \\
1 \\
1 \\
1 \\
1(b) \\
2(b) \\
1(b) \\
1(b) \\
2 \\
2 \\
1(b) \\
2(b)\end{array}$ \\
\hline
\end{tabular}

1 Material from Joachimsthal, Bohemia. Direct comparison of films of material from numerous localities shows no significant variations in spacing.

Natural formation

Beta-uranophane is a secondary mineral with the same occurrence and association as its dimorph, uranophane. The latter phase apparently is the stable one at ordinary temperatures and pressures, as Steinocher and Nováček (1939) note that beta-uranophane may convert to uranophane when finely crushed. This implies that care must be taken in preparing powdered samples for X-ray or optical examination. Beta-uranophane is less common than uranophane. 
Occurrence

Originally described from Joachimsthal, Bohemia, where it occurs as crusts of tiny needles on altered uraninite; it is here commonly associated with liebigite and calcite. Later described by Steinocher and Nováček (1939) from Wölsendorf, Bavaria, and from pegmatites at Bedford, Westchester County, N. Y., and near Spruce Pine, Mitchell County, N. C. George (1949) records the mineral from the Urgeiriça mine, Portugal; the La Chiquita mine, San Javia, Cordoba, Argentina; and the Deer Park pegmatite, Mitchell County, N. C. Identified from carnotite localities at Mauch Chunk (now Jim Thorpe), Pa., and the Henry Mountains, Utah. The mineral also has been reported by $\mathrm{C}$. Frondel (1956b) from the following localities: Easton, Pa., as yellow needles derived by the alteration of uranoan thorianite in serpentine; at Newry, Maine, with altered uraninite in pegmatite; and the Ruggles and Palermo mines in New Hampshire; at Theano Point, Lake Superior, Canada, as dense golden-yellow crusts on uraninite; from Rajputana, India, on "gummite" pseudomorphs after uraninite; various pegmatites in the Spruce Pine district, Mitchell County, N. C.; also from Frankford, near Philadelphia, $\mathrm{Pa}$, as films on gneiss and constituting part of the mixture earlier described as the mineral randite (C. Frondel, 1950b). Found at Bigay, La Crouzille, and other places in the Puy-de-Dôme district, France (Branche and others, 1951). In the Freedom No. 2 mine, Marysvale, Utah (Hamilton and Kerr, 1954b), and the W. Wilson mine in the Boulder batholith, Montana (H. D. Wright and others, 1954). From the Grants area, New Mexico (Rapaport, 1952). At Sankara, Nellore, India (Meixner, 1940a). Found in Canada in Faraday Township, Hastings County, Ontario, and in Huddersfield Township, Pontiac County, Quebec (Gorman and Nuffield, $1955)$; also from the Kenora district, Ontario (Satterly, 1955). Published identifications of uranophane based on chemical evidence alone, especially before 1935 when the dimorphism was first recognized, are ambiguous.

\section{GASTUNITE}

Gastunite Haberlandt and Schiener (1951). A name given tentatively to an apparently new uranium mineral found as radialfibrous wartlike aggregates on the Radhausberg near Bad Gastein in the Hohe Tauern, Salzburg, Austria. A secondary mineral, found associated with uranophane, beta-uranophane, schroeckingerite, calcite, fluorite, and stilbite in crevices in gneiss. Spectrographic analysis indicates that it is a calcium uranyl silicate containing a minor amount of lead. Color yellowish green. Under 
the microscope it shows parallel extinction with anomalous steelblue interference colors; weakly pleochroic, colorless to lemon yellow; $n_{z} \approx 1$ 1.597. In ultraviolet light gastunite fluoresces light yellow green (Haberlandt, Hernegger, and Scheminzky, 1950). Named from the Roman designation, Gastuna, for the place Gastein.

Synonymy

\section{SODDYITE}

Soddite Schoep (1922d, 1923d). Soddyite Billiet (1926) ; Schoep (1927d). Named after Frederick Soddy (1877-1956), English radiochemist.

Composition

A hydrated silicate of hexavalent uranium, $\left(\mathrm{UO}_{2}\right)_{5}\left(\mathrm{SiO}_{4}\right)_{2}$ $(\mathrm{OH})_{2} \cdot 5 \mathrm{H}_{2} \mathrm{O}=5 \mathrm{UO}_{3} \cdot 2 \mathrm{SiO}_{2} \cdot 6 \mathrm{H}_{2} \mathrm{O}$. The ratio here given, first suggested by Wherry (1922), was established by the X-ray study of Gorman (1952). The ratio $12 \mathrm{UO}_{3} \cdot 5 \mathrm{SiO}_{2} \cdot 14 \mathrm{H}_{2} \mathrm{O}$ was earlier suggested by Schoep (1930). The only reported analysis, in weight percent, follows.

\begin{tabular}{|c|c|c|c|c|c|}
\hline & 1 & 2 & & 1 & 2 \\
\hline \multirow{2}{*}{$\begin{array}{c}\mathrm{UO}_{3} \\
\mathrm{SiO}_{2}\end{array}$} & \multirow{2}{*}{$\begin{array}{r}86.24 \\
7.24\end{array}$} & \multirow{2}{*}{$\begin{array}{r}85.27 \\
7.87\end{array}$} & $\mathrm{H}_{2} \mathrm{O}$ & 6.52 & 6.26 \\
\hline & & & Total & $\overline{100.00}$ & 100.00 \\
\hline
\end{tabular}

1. Theoretical weight percentages, $5 \mathrm{UO}_{3} \cdot 2 \mathrm{SiO}_{2} \cdot 6 \mathrm{H}_{2} \mathrm{O}$.

2. Soddyite, Kasolo. Average of three partial analyses. Schoep (1930).

Spectrographic analyses and thermal dehydration data are lacking. Soddyite is infusible before the blowpipe. In the closed tube it blackens and loses water and oxygen. Soluble in $\mathrm{HCl}$ with gelatinization.

Crystallography

Soddyite is orthorhombic, in the dipyramidal class $(2 / m 2 / m 2 / m)$. An angle table for the known forms, calculated from the elements of the structure cell, is given below. A single-

$$
\text { Angle table for soddyite }
$$

Orthorhombic; dipyramidal, $(2 / \mathrm{m} 2 / \mathrm{m} 2 / \mathrm{m})$

$a: b: c=0.742: 1: 1.669 ; \quad p_{0}: q_{0}: r_{0}=2.249: 1.669: 1$

$q_{1}: r_{1}: p_{1}=0.742: 0.445: 1 ; \quad r_{2}: p_{2}: q_{2}=0.599: 1.348: 1$

\begin{tabular}{|c|c|c|c|c|c|c|}
\hline FORMS & $\phi$ & $\rho=C$ & $\phi_{1}$ & $\rho_{1}=A$ & $\phi_{2}$ & $\rho_{2}=B$ \\
\hline $\begin{array}{ll}c & 001 \\
\text { s } & 114 \\
r & 113\end{array}$ & $\begin{array}{l}53^{\circ} 25^{\prime} \\
5325\end{array}$ & $\begin{array}{r}0^{\circ} 00^{\prime} \\
3500 \\
4302\end{array}$ & $\begin{array}{l}0^{\circ} 00^{\prime} \\
2239 \\
29051 / 2\end{array}$ & $\begin{array}{l}90^{\circ} 00^{\prime} \\
62341 / 2 \\
5646\end{array}$ & 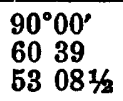 & $\begin{array}{l}90^{\circ} 00^{\prime} \\
7001 \\
66001 / 2\end{array}$ \\
\hline$p 111$ & 5325 & 7021 & $59041 / 2$ & $40511 / 2$ & $23581 / 2$ & $55511 / 2$ \\
\hline
\end{tabular}


crystal Weissenberg X-ray study by Gorman (1952) of crystals from Kasolo gave the following data: $a_{0} 8.32 \mathrm{~A}, b_{0} 11.21, c_{0}$ 18.71, $a_{0}: b_{0}: c_{0}=0.742: 1: 1.669$. Space group $F d d d$. Cell contents $3\left[5 \mathrm{UO}_{3} \cdot 2 \mathrm{SiO}_{2} \cdot 6 \mathrm{H}_{2} \mathrm{O}\right]$. There is a strongly marked pseudocell with $c_{d} / 3$.

\section{Crystal habit}

Soddyite occurs as distinct crystals, often with a subparallel arrangement or as divergent clusters; also massive to earthy and composed of microscopic fibers, and as cross-fiber veinlets. Crystals are pyramidal in habit with $\{111\}$ or a vicinal pyramid close tu this in index as the dominant form. Typical crystal habits are shown in figure 22. The crystals often are distorted by elongation parallel to [110], giving a platy or prismatic appearance

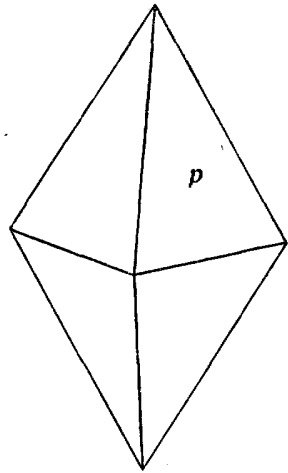

A

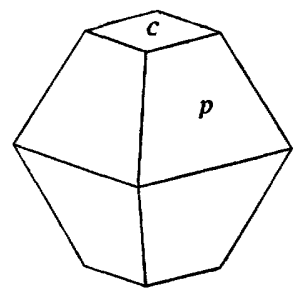

$B$

Figurg 22.-Soddyite, $A$. Belgian Congo. Form: $p\{111\}$. From Gorman (1952). B. Forms: $p\{111\}$. $c\{001\}$. From Gorman (1952).

(Gorman, 1952). In some descriptions the direction of elongation has been erroneously taken as the $c$-axis, giving rise to differences in the description of the cleavages and the optical orientation from that given here. $\{111\}$ usually is striated parallel to the horizontal edges, in part owing to oscillatory combination with vicinal pyramids of the type $\{h h l\}$, and elongated crystals may be rounded to barrel-like shapes. $\{001\}$ when present is ordinarily small, but some crystals are thick tabular on this form.

Physical properties

Cleavage $\{001\}$ perfect, $\{111\}$ good. Hardness 31/2. Specific gravity 4.70 (measured), 4.75 (calculated). Color dull yellow to canary yellow in opaque crystals, amber yellow in transparent crystals; also greenish yellow to dull straw yellow in fibrous or massive material. Streak pale yellow to straw yellow. Luster of clear crystals vitreous to subadamantine, of cloudy crystals or 
massive aggregates subvitreous to dull and earthy. Transparent to opaque, the crystals sometimes with a transparent outer zone and a turbid interior. Either weakly fluorescent in orange yellow in ultraviolet light (Buttgenbach, 1947) or not perceptibly fluorescent (Gorman, 1952).

Optical properties

\begin{tabular}{|c|c|c|c|c|c|}
\hline \multirow{2}{*}{$\begin{array}{l}\text { ORIENTA- } \\
\text { TION }\end{array}$} & \multicolumn{3}{|c|}{$\boldsymbol{n}$} & \multirow[b]{2}{*}{ PLEOCHROISM } & \multirow{4}{*}{$\begin{array}{l}\text { Biaxial negative; } \\
\text { dispersion } r>v, \\
\text { usually reported } \\
\text { strong. }\end{array}$} \\
\hline & 1 & 2 & 3 & & \\
\hline $\begin{array}{l}X=c \\
Y=b \\
Z=a\end{array}$ & $\begin{array}{l}1.650 \\
1.685 \\
1.715\end{array}$ & $\begin{array}{l}1.650 \\
1.685 \\
1.712\end{array}$ & $\begin{array}{l}1.654 \\
1.685 \\
1.699\end{array}$ & $\begin{array}{l}\text { Colorless. } \\
\text { Very pale yellow. } \\
\text { Pale green yellow. }\end{array}$ & \\
\hline $2 V$ & Large & $84^{\circ}$ calc & $\approx 70^{\circ}$ & & \\
\hline
\end{tabular}

1. Kasolo. George (1949).

2. Kasolo. Gorman (1952).

3. Namaqualand. Gevers and others (1937).

Under the microscope the crystals generally have a murky or cloudy appearance, especially toward the center, and may show concentric zones of transparent and cloudy material (Gorman, 1952). Schoep (1923d) stated that the mineral was optically positive, with $n_{X} 1.645, n_{Y} 1.662$, and $2 V$ large.

Thermal behavior

No data.

Synthesis

Obtained by Gruner (1952) by heating uranyl nitrate solution in glass containers at temperatures of $200^{\circ}-278^{\circ} \mathrm{C}$; it does not form in alkaline solutions, and is stable at a pH as low as 2.6.

\section{Identification}

Soddyite is the only uranyl silicate that does not contain lead or some other cation in addition to uranium. It most closely resembles kasolite in general appearance but differs from that species in crystallography, optical properties, and in lacking lead. The X-ray powder-spacing data for soddyite are given in the table on the following page.

\section{Natural formation and occurrence}

Soddyite is a secondary mineral. It was originally described from Kasolo in the Katanga district, Belgian Congo, where it occurs in massive form admixed with curite and as dusty crusts or fibrous veinlets. Kasolite, sklodowskite, uranophane, and torbernite are associated minerals. The curite is earlier formed and the sklodowskite, uranophane, and torbernite later formed, ac- 
cording to Schoep (1930). Soddyite also occurs as dense strawyellow pseudomorphs after uraninite in the Ruggles pegmatite, Grafton Center, N. H., where it is closely associated with uranophane and kasolite (C. Frondel, 1956b). It has been found sparingly as crusts in the Norrabees pegmatite area south of the Orange River, Namaqualand, Africa (Gevers, Partridge, and Joubert, 1937). Reported from the Honeycomb Hills area, Utah (Wilmarth and others, 1952); also from the Steel City mine, Yavapai County, Ariz., where it occurs with kasolite and uranothorite (M. E. Thompson, written communication, 1954), and from the Jack Pile mine, Laguna, N. Mex. (Gruner and Smith, 1955). From the Lucky Mc mine, Fremont County, Wyo. (Gruner and Smith, written communication, 1955).

\section{$X$-ray powder-spacing data for soddyite 1}

[Copper radiation, nickel filter]

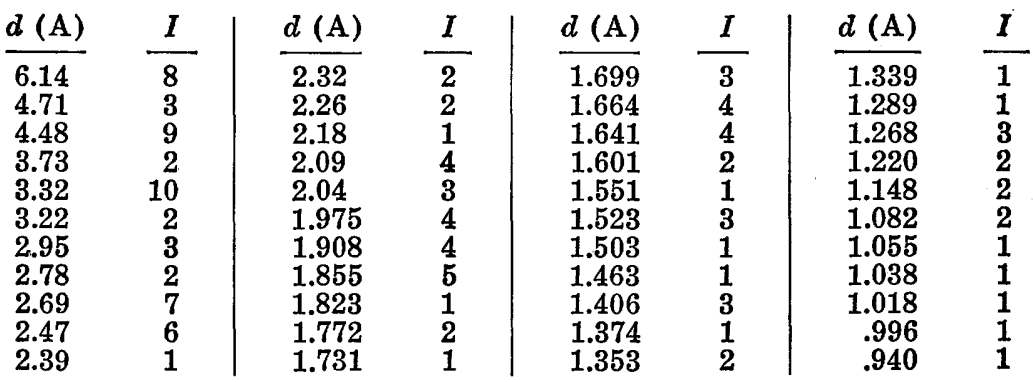

1 Material from the Ruggles pegmatite, Grafton Center, N. H.

Synonymy

KASOLITE

Kasolite Schoep (1921b). Named after the locality at Kasolo, Katanga district, Belgian Congo.

Composition

A hydrated silicate of lead and hexavalent uranium. Formula probably $\mathrm{PbO}_{3} \mathrm{UO}_{3} \cdot \mathrm{SiO}_{2} \cdot \mathrm{H}_{2} \mathrm{O}=\mathrm{Pb}\left(\mathrm{UO}_{2}\right)\left(\mathrm{SiO}_{3}\right)(\mathrm{OH})_{2}$. The four reported analyses are cited below. Analysis 3 seems to be the best of these.

Schoep $(1921 b, 1930)$ gave the formula of the mineral as $3 \mathrm{PbO} \cdot 3 \mathrm{UO}_{3} \cdot 3 \mathrm{SiO}_{2} \cdot 4 \mathrm{H}_{2} \mathrm{O}$, and Buttgenbach (1947) gave $5 \mathrm{PbO} \cdot$ $3 \mathrm{UO}_{3} \cdot 3 \mathrm{SiO}_{2} \cdot 4 \mathrm{H}_{2} \mathrm{O}$. The formula $\mathrm{PbO} \cdot \mathrm{UO}_{3} \cdot \mathrm{SiO}_{2} \cdot \mathrm{H}_{2} \mathrm{O}$ was suggested by Billiet and de Jong (1936) and by Brasseur (1939) from the calculated unit-cell contents.

The $\mathrm{Ba}$ and $\mathrm{Cu}$ reported in analysis 5 may be in substitution for $\mathrm{Pb}$, but the large content of $\mathrm{Na}_{2} \mathrm{O}$ and $\mathrm{Fe}_{2} \mathrm{O}_{3}$ indicates that 
Chemical analyses of kasolite, in weight percent

\begin{tabular}{|c|c|c|c|c|c|}
\hline & 1 & 2 & 3 & 4 & 5 \\
\hline $\begin{array}{l}\mathrm{PbO} \\
\mathrm{Fe}_{2} \mathrm{O}_{3} \\
\mathrm{UO}_{3} \\
\mathrm{SiO}_{2} \\
\mathrm{H}_{2} \mathrm{O} \\
\mathrm{Rem} .\end{array}$ & $\begin{array}{r}37.54 \\
49 . \overline{26} \\
10.17 \\
3.03 \\
-\end{array}$ & $\begin{array}{r}32.16 \\
.40 \\
48.26 \\
9.00 \\
3.28 \\
\end{array}$ & $\begin{array}{r}36.20 \\
.41 \\
49.28 \\
9.42 \\
3.59 \\
.94\end{array}$ & $\begin{array}{r}34.44 \\
.58 \\
49.00 \\
9.14 \\
3.77 \\
.53\end{array}$ & $\begin{array}{r}32.6 \\
2.0 \\
46.8 \\
8.6 \\
4.3 \\
5.0\end{array}$ \\
\hline Total & 100.00 & 93.10 & 99.84 & .97 .46 & 99.3 \\
\hline
\end{tabular}

1. Theoretical weight percentages, $\mathrm{Pb}\left(\mathrm{UO}_{2}\right)\left(\mathrm{SiO}_{3}\right)(\mathrm{OH})_{2}$.

2. Kasolite. Kasolo. Schoep (1921b). Clear crystals.

3. Kasolite. Kasolo. Schoep (1921b). Massive, unaltered. Remainder is $\mathrm{CaO} 0.16, \mathrm{MgO} 0.03, \mathrm{CO}_{2} 0.85$. $\mathrm{CO}_{2}$.

4. Kasolite. Katanga. Schoep (1921b). Massive, altered(?). Remainder is

5. Kasolite. Grury, France. Branche and others (1951). Remainder is $\mathrm{BaO}$ 1.7, $\mathrm{CuO} 0.9, \mathrm{Na}_{2} \mathrm{O} 2.4$.

the material was impure. Spectrographic analyses are lacking. Kasolite is easily soluble in acids with gelatinization. Fusible to a dark vitreous mass.

Crystallography

Monoclinic, in the prismatic crystal class $(2 / m)$. An angle table for the known forms calculated from the morphological angles of Brasseur (1939) is given below. The unit and orientation corresponds to that of the X-ray unit cell. Widely divergent morphological measurements, owing to the poor surface quality

Angle table for kasolite

Monoclinic; prismatic, $(2 / \mathrm{m})$

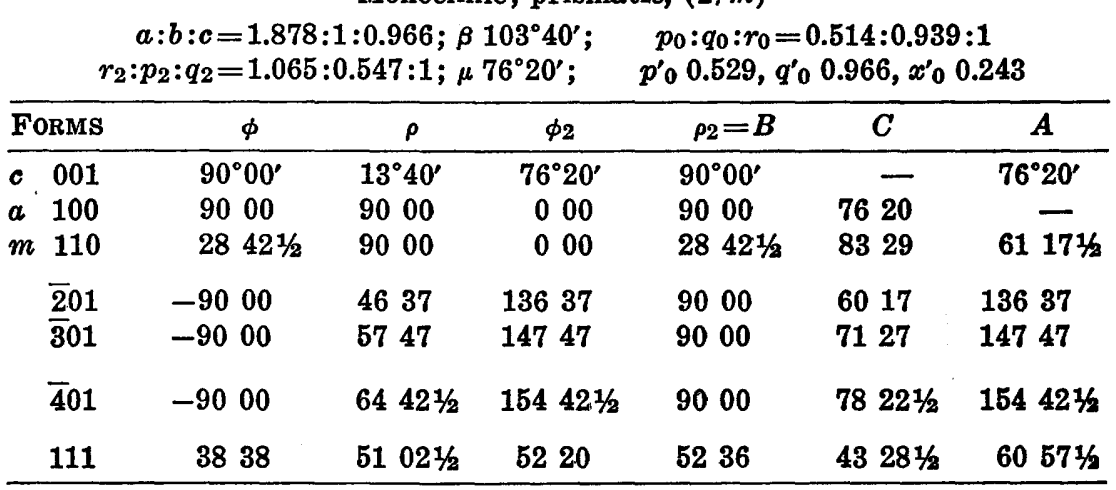

of the crystals of this mineral, were reported by Buttgenbach (1922) and others. Three X-ray single-crystal studies have been reported as follows: 
Unit-cell dimensions of kasolite

\begin{tabular}{|c|c|c|c|c|}
\hline & 1 & 2 & $\mathbf{3}$ & \multirow{3}{*}{$\begin{array}{l}\text { Space group } \\
P 2_{1} / a \text { (Gorman, } \\
\text { written commu- } \\
\text { nication, 1951); } \\
\text { unit-cell contents } \\
4\left[\mathrm{PbO} \cdot \mathrm{UO}_{3^{*}}\right. \\
\mathrm{SiO}_{2} \cdot \mathrm{H}_{2} \mathrm{O}^{\circ} \text {. }\end{array}$} \\
\hline $\begin{array}{l}a_{0} \\
b_{0} \\
c_{0}\end{array}$ & $\begin{array}{c}13.31 \mathrm{~A} \\
7.02 \\
6.72\end{array}$ & $\begin{array}{c}13.25 \mathrm{~A} \\
7.05 \\
6.82\end{array}$ & $\begin{array}{c}13.24 \mathrm{~A} \\
6.94 \\
6.70\end{array}$ & \\
\hline$\beta$ & $\begin{array}{c}1.896: 1: 0.9573 \\
105^{\circ}\end{array}$ & $\begin{array}{c}1.879: 1: 0.967 \\
102^{\circ} 40^{\circ}\end{array}$ & $\begin{array}{c}1.909: 1: 0.966 \\
104^{\circ} 20^{?}\end{array}$ & \\
\hline
\end{tabular}

1. Billiet and de Jong (1936).

2. Brasseur (1939).

3. Milne (written communication, 1951).

\section{Crystal habit}

The morphology of kasolite has been described by Brasseur (1939), Billiet and de Jong (1936), Mélon (1934), Schoep (1923a, 1927d, 1930), Buttgenbach (1922), and Branche and others (1951). The crystals rarely are more than a few millimeters in size. They have a stout prismatic habit with the elongation along the $b$-axis, and show $\{001\},\{100\}$, and $\{110\}$ as the common forms; small faces of $\{111\}$ are often present, and the other reported forms are rare and small in size. Occasionally flattened on $\{001\}$ and lathlike by extension along the $b$-axis. $\{100\}$ commonly is striated or serrated parallel to the edge with $\{001\}$. The crystals usually are attached to the matrix by one end of the $c$-axis, and subparallel growths radiating from the point of attachment are common; also as divergent groups of rough crystals, as rosettes of lathlike crystals, and as radial fibrous aggregates. Kasolite also occurs as compact granular masses, and as dense gumlike crusts.

\section{Physical properties}

Cleavage $\{001\}$ perfect; also indistinct cleavages on $\{100\}$ and $\{010\}$. Brittle. Hardness about 41/2. Specific gravity 5.96, Katanga material (Schoep, 1930) ; 5.83, material from France (Branche and others, 1951) ; 6.5, Katanga material (Billiet and de Jong, 1936) ; 6.256, calculated from the cell data of Brasseur (1939). Luster subadamantine to greasy. Color ocher yellow to brownish yellow in the ordinary translucent to opaque material; amber brown in transparent crystals; rarely lemon yellow to green, or reddish orange. Powder pale brownish yellow. Not fluorescent in ultraviolet light. The luster of massive material usually is dull to earthy.

Either not pleochroic, or very weakly pleochroic with $X$ and $Y$ very pale yellow and $Z$ almost colorless or slightly grayish (George, 1949). The optic plane is very nearly parallel $\{100\}$. 
Optical properties

\begin{tabular}{|c|c|c|c|c|c|}
\hline \multirow{2}{*}{$\begin{array}{l}\text { ORIENTA- } \\
\text { TION }\end{array}$} & \multicolumn{4}{|c|}{$n$} & \\
\hline & 1 & 2 & 3 & 4 & \\
\hline $\begin{array}{l}X=b \\
Y \\
Z \wedge c+0.5^{\circ}\end{array}$ & $\begin{array}{l}1.877 \\
1.880 \\
1.935\end{array}$ & $\begin{array}{l}1.895 \\
1.910 \\
1.950\end{array}$ & $\begin{array}{l}1.89 \\
1.90 \\
1.97\end{array}$ & $\begin{array}{l}1.90 \\
1.91 \\
1.95\end{array}$ & Biaxial positive \\
\hline
\end{tabular}

1. Katanga. George (1949).

2. Katanga. Larsen and Berman (1934).

3. Katanga. Mélon (1954).

4. France. Branche and others (1951).

Both Mélon (1934) and Buttgenbach (1922) give $X=b$ and $Z$ $\approx c$, but George (1949) and Larsen and Berman (1934) give $X$ $=b$ and $Y \wedge c \approx 11^{\circ}$ [probably owing to confusion of $\{100\}$ and $\{001\}] .2 V 43^{\circ} 18^{\prime}$ (yellow), $42^{\circ} 18^{\prime}$ (red) (Mélon, 1934).

Thermal behavior

Schoep (1921b) states that kasolite loses about 0.59 percent $\mathrm{H}_{2} \mathrm{O}$ at $110^{\circ} \mathrm{C}$ and that all of the water is lost near $450^{\circ} \mathrm{C}$. Fusion begins at about $1,100^{\circ}$.

Synthesis

Obtained by Gruner (1952) by heating uranyl nitrate solution with boro-silicate glass and lead in an atmosphere of $\mathrm{H}_{2} \mathrm{~S}$ in a steel bomb at $200^{\circ} \mathrm{C}$.

\section{Identification}

Kasolite is distinguished from the other uranium silicates by its very high indices of refraction and its crystal habit. The X-ray powder-spacing data are given in the following table.

\section{$X$-ray powder-spacing data for kasolite ${ }^{1}$}

[Symbol: b, broad. Copper radiation, nickel filter]

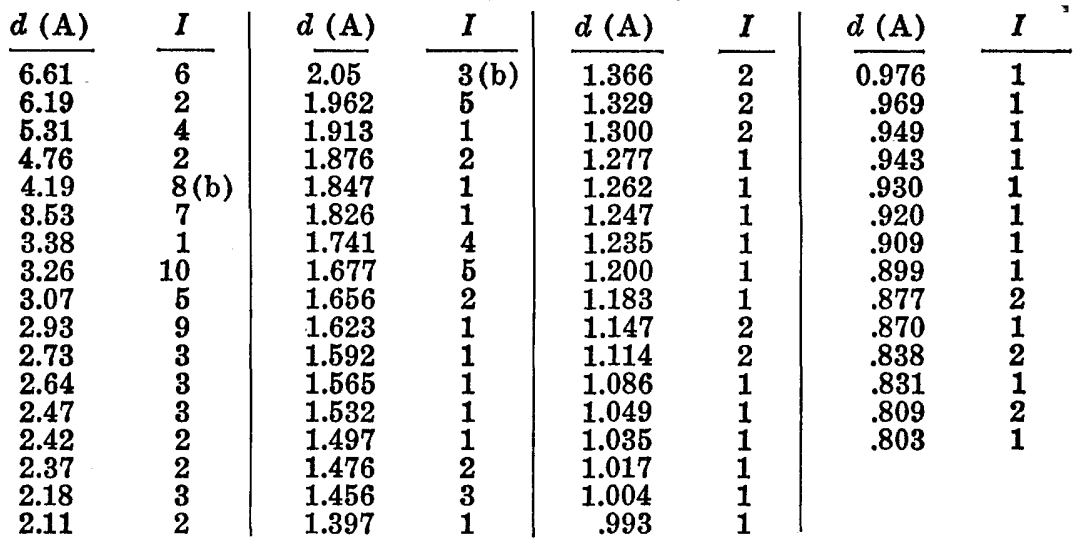

${ }^{1}$ Material from Shinkolobwe, Katanga district. Belgian Congo. Specimens with the same optical properties from other localities give an identical pattern. Material from a few localities shows diminished indices of refraction and contains more or less $\mathrm{Ca}$ in substitution for $\mathrm{Pb}$ (Mineral $\mathrm{B}$ of $\mathrm{C}$. Frondel, $1956 \mathrm{~b})$; the $\mathrm{X}$-ray pattern is virtually identical with that of ordinary kasolite. 
Massive material closely resembles at sight a number of other uranium minerals, including soddyite and various phosphates. The high specific gravity is a useful means of identification and separation.

\section{Natural formation}

Kasolite is a secondary mineral. It occurs in the Katanga district apparently largely as a product of the reaction of meteoric waters carrying silica with earlier formed secondary uranium minerals. Kasolite also is a relatively common constituent of the outer silicate zone of alteration of gummite pseudomorphs after uraninite, and has been derived by the alteration of the intermediate zone of lead-uranium oxides. (See C. Frondel, 1956b.)

\section{Occurrence}

Kasolite was originally found at Kasolo in the Katanga district, Belgian Congo, where it occurred abundantly in the early workings of the oxidized veins of uraninite. It was associated with torbernite, curite, dewindtite, and other phosphates. Reported from Wölsendorf, Bavaria. Found as orange-yellow gumlike crusts at the Nicholson mines, Lake Athabaska, Saskatchewan, Canada (Hogarth, 1951). Identified by Branche and others (1951) from various localities in France: Grury, Saône-et-Loire; at Reliez and Bigay, Lachaux, Puy-de-Dôme; at Boko Songo. Kasolite also has been identified in pseudomorphs after uraninite in pegmatite at the following localities (C. Frondel, 1956b): Kakanas, South Africa; Bisundi, Rajputana, India; the Ruggles pegmatite near Grafton Center, N. H. In these pseudomorphs the kasolite occurs in the outer, silicate zone of alteration as earthy to firm microcrystalline aggregates of minute shreds and fibers, often more or less admixed with uranophane. A mineral that seems to be the calcium analogue of kasolite, with the same X-ray pattern but lower indices of refraction, also occurs in gummite pseudomorphs (Mineral B of C. Frondel, 1956b). Kasolite occurs as crusts on altered uraninite at Great Bear Lake, Canada. Reported from near Mauch Chunk (now Jim Thorpe), Pa. (Klemic and Baker, 1954), and from the Goodsprings district, Clarke County, and the East Walker River area, Lyon County, in Nevada (Staatz and Bauer, 1953 ; Lovering, 1954). 


\section{MULTIPIF OXIDES}

The multiple oxides, more familiarly known as niobate-tantalate-titanates, comprise a large group of minerals of complex composition. A few of these minerals that contain uranium as an essential constituent or in relatively large amounts are described here. These include brannerite, davidite, and the pyrochloremicrolite series-all minerals presently or potentially of economic interest_-together with the fairly common but unimportant mineral betafite and two minerals that are known only from single occurrences, pisekite and delorenzite. Other multiple oxides of interest because of their occasional content of uranium, but not described here, include fergusonite, samarskite, euxenitepolycrase, polymignite, and eschynite-priorite.

Synonymy

\section{BETAFITE}

Betafite Lacroix (1912a, b, 1914). Samiresite Lacroix (1912a, b). Blomstrandite Lindstrom (1874) [not the blomstrandine, blomstrandinite of Brögger (1906)]. Mendelejevite Vernadsky (1914, 1923). Unnamed mineral Bjorlykke (1931). Betafite is named after the locality at Betafo, Madagascar.

Considerable uncertainty exists about the composition and systematic relations of betafite. The name as here used includes several supposedly independent species that have been united with betafite on the basis of X-ray and crystallochemical study. Samiresite, apparently a lead-rich variety of betafite, and the titaniumrich material of Bjørlykke (1931) from Norway may be distinct although related minerals.

\section{Composition}

An oxide (or niobate-tantalate) of $\mathrm{U}, \mathrm{Ca}, \mathrm{Nb}, \mathrm{Ta}$, and $\mathrm{Ti}$. The formula is uncertain, perhaps (U,Ca) $(\mathrm{Nb}, \mathrm{Ta}, \mathrm{Ti})_{3} \mathrm{O}_{9} \cdot \mathrm{nH}_{2} \mathrm{O}$ or $\mathrm{AB}_{3}(\mathrm{O}, \mathrm{OH})_{9}$. The agreement among the analyses reported as of this species is not good, and the crystal chemistry of the mineral requires further investigation. The composition has been discussed by Machatschki (1932a) and Reuning (1933). Water is present in varying amounts, and may be, in part or entirely, nonessential and due to alteration. $\mathrm{Pb}, \mathrm{Th}$, and rare earths are present in small and variable amounts, presumably in substitution for (U,Ca). The reported analyses of betafite are cited in the table 
below. The material of analysis 1 (samiresite) has $\mathrm{Pb}: \mathrm{U} \approx 3: 8$ and the amount of lead present is too large to be radiogenic; the $\mathrm{X}$-ray pattern of this material shows small differences from the normal pattern of betafite and the mineral may be a distinct species. The uranium reported as $\mathrm{U}^{+6}$ in the analyses probably is due to the oxidation of $U^{+4}$ originally present. George (1949) reports that analyses of relatively fresh betafite from Madagascar showed 21-23 percent $\mathrm{U}_{3} \mathrm{O}_{8}$ and that highly altered material showed about 12 percent $\mathrm{U}_{3} \mathrm{O}_{8}$.

Spectrographic analyses have been reported only of the material of analysis 9. Betafite is more or less completely decomposed by treatment with acids, depending on the extent of alteration. Fusible with difficulty to a black slag.

Chemical analyses of betafite, in weight percent

\begin{tabular}{|c|c|c|c|c|c|}
\hline & 1 & 2 & 3 & 4 & 5 \\
\hline $\begin{array}{l}\mathrm{CaO} \\
\mathrm{MnO}\end{array}$ & - & $\begin{array}{r}3.93 \\
.15\end{array}$ & 3.45 & 3.12 & $\begin{array}{r}4.00 \\
50\end{array}$ \\
\hline $\mathrm{PbO}$ & $7 . \overline{35}$ & .10 & $\overline{\operatorname{Tr}}$ & $\overline{\mathbf{T r}}$ & \\
\hline $\mathrm{MgO}$ & & .13 & .40 & $\mathbf{T r}$ & .20 \\
\hline $\mathrm{FeO}$ & 1.06 & 1.20 & - & - & 1.35 \\
\hline$(\mathrm{Y}, \mathrm{Er})_{2} \mathrm{O}_{3}$ & $\overline{20}$ & 3.11 & $\begin{array}{l}.90 \\
60\end{array}$ & $1 \overline{00}$ & .30 \\
\hline $\mathrm{UO}_{2}$ & 21.20 & & & & \\
\hline $\mathrm{UO}_{3}$ & - & 26.37 & 26.60 & 27.15 & 18.10 \\
\hline $\mathrm{SnO}_{2}$ & .10 & .37 & .30 & .37 & .30 \\
\hline $\mathrm{ThO}_{2}$ & 一 & 1.30 & 1.30 & 1.12 & - \\
\hline $\mathrm{SiO}_{2}$ & $\overline{71}$ & .59 & $\overline{10}$ & $\overline{50}$ & - \\
\hline $\begin{array}{l}\mathrm{Al}_{2} \mathrm{O}_{3} \\
\mathrm{Fe}_{2} \mathrm{O}_{3}\end{array}$ & .74 & .24 & $\begin{array}{l}2.10 \\
2.87\end{array}$ & $\begin{array}{r}1.50 \\
50\end{array}$ & 二 \\
\hline $\mathrm{TiO}_{2}$ & 6.70 & 16.51 & 18.30 & 16.20 & 10.80 \\
\hline $\mathrm{Nb}_{2} \mathrm{O}_{5}$ & 45.80 & $\mathbf{3 7 . 3 6}$ & $\mathbf{3 4 . 8 0}$ & $\mathbf{3 4 . 8 0}$ & 23.30 \\
\hline $\mathrm{Ta}_{2} \mathrm{O}_{5}$ & 3.70 & 1.46 & $\mathbf{T r}$ & 1.00 & 28.50 \\
\hline $\mathrm{H}_{2} \mathrm{O}$ & 12.45 & 2.47 & 7.60 & 12.50 & 9.60 \\
\hline Rem. & .30 & & & .38 & .40 \\
\hline Total & 99.60 & 99.15 & 99.22 & 99.64 & 99.85 \\
\hline Sp gr & - & $.83-4.93$ & 4.17 & 3.75 & 4.74 \\
\hline
\end{tabular}

1. Samiresite. Samiresy. Pisani, analyst, in Lacroix (1912b). Remainder is $\mathrm{K}_{2} \mathrm{O} 0.30$, ign. 12.45 .

2. Betafite. Sludianka. Chernik (1927).

3. Betafite. Ambolatara. Pisani, analyst, in Lacroix (1922).

4. Betafite. Ambalahazo. Pisani, analyst, in Lacroix (1922). Remainder is $\mathrm{K}_{2} \mathrm{O} 0.38$.

5. Blomstrandite (?). Tongafeno. Pisani, analyst, in Lacroix (1922). Remainder is $\mathrm{Bi}_{2} \mathrm{O}_{3}$. 
Chemical analyses of betafite, in weight percent-Continued

\begin{tabular}{|c|c|c|c|c|c|}
\hline & 6 & 7 & 8 & 9 & 10 \\
\hline $\mathrm{CaO}$ & 8.96 & 7.02 & 6.62 & 二 & 4.17 \\
\hline $\mathrm{PbO}$ & $1 . \overline{70}$ & $1 . \overline{42}$ &.$\overline{33}$ & .63 & 1.77 \\
\hline $\mathrm{MgO}$ & $\mathrm{Tr}$ & $\operatorname{Tr}$ & $\mathbf{T r}$ & $=$ & .22 \\
\hline (Y.Er & $\bar{z}$ & - & - & 二 & 220 \\
\hline$(\mathrm{Ce}, \mathrm{La})_{2} \mathrm{O}_{3}$ & 二\} & 3.30 & 5.96 & & 2.15 \\
\hline $\mathrm{UO}_{2}$ & & & 9.64 & & 18.68 \\
\hline $\begin{array}{l}\mathrm{UO}_{3} \\
\mathrm{SnO}_{2}\end{array}$ & 15.52 & 20.20 & 二 & 12.83 & $\overline{00}$ \\
\hline 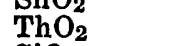 & $=$ &.$\overline{04}$ &.$\overline{12}$ & $4 . \overline{22}$ & .06 \\
\hline $\mathrm{SiO}_{2}$ & .62 & .64 & .42 & - & 5.38 \\
\hline $\mathrm{Al}_{2} \mathrm{O}_{3}$ & .98 & .36 & 1.20 & 二 & .39 \\
\hline $\begin{array}{l}\mathrm{Fe}_{2} \mathrm{O}_{3} \\
\mathrm{TiO}_{2}\end{array}$ & $\begin{array}{r}5.52 \\
35.05\end{array}$ & $\begin{array}{r}6.96 \\
34.22\end{array}$ & $\begin{array}{r}6.24 \\
32.27\end{array}$ & 二 & $\begin{array}{l}5.27 \\
20.81\end{array}$ \\
\hline $\mathrm{Nb}_{2} \mathrm{O}_{5}$ & 8.51 & 10.11 & 11.95 & - & 30.03 \\
\hline $\mathrm{Ta}_{2} \mathrm{O}_{5}$ & 12.85 & 7.61 & 11.75 & 一 & .77 \\
\hline $\mathrm{H}_{2} \mathrm{O}$ & 9.63 & 7.45 & 13.59 & - & 6.63 \\
\hline Rem. & - & - & E & 一 & 一 \\
\hline Total & 99.34 & 99.33 & 100.09 & & 100.09 \\
\hline $\mathrm{Sp}$ gr & $3.93-3.98$ & $4.31-4.34$ & - & & 一 \\
\hline
\end{tabular}

6. Titanian betafite. Tangen, Norway. Black, with vitreous luster. Bjørlykke (1931).

7. Tangen, Norway. Black with dull luster. Bjørlykke (1931).

8. Tangen, Norway. Yellow brown, with vitreous luster. Bjørlykke (1931).

9. Cady Mountains, Calif. Pale yellowish brown to greenish. Hewett and Glass (1953). Spectrographic analysis by K. J. Murata shows the presence of $\mathrm{Nb}, \mathrm{U}$, and $\mathrm{Ti}$ ( $>5$ percent); $\mathrm{Ca}(1-5$ percent) ; La, Fe, Si, Ba, Sr, Ta (0.X percent); Pb, Mn, Zr, Y, Sn, B, As(?) (0.0X percent); Be, Al (0.00X percent).

10. Chin-chou region, south Manchuria. Takubo, Ueda, and Nishimura (1951).

\section{Crystallography and crystal habit}

Isometric, in the hexoctahedral crystal class $(4 / m \overline{3} 2 / m)$. Known only as crystals. These commonly are an inch or so in size, but may be as much as 6 inches or more. The crystal habit usually is octahedral, often with modifying faces of $\{011\}$; also with more complex modifying faces. A typical crystal is shown in figure 23. Some crystals are distorted by flattening parallel to a pair of faces of $\{011\}$ or are elongated parallel to an $a$-axis or [111]. The observed forms (from Palache, Berman, and Frondel, 1944) are as follows. 
Betafite

Titanian variety

Blomstrandite

Samiresite

Mendeleyevite

$\begin{array}{ccccccc}a\{100\} & \frac{d\{011\}}{\mathrm{x}} & \frac{0\{111\}}{\mathrm{x}} & \frac{g\{023\}}{\mathrm{x}} & \frac{m\{113\}}{\mathrm{x}} & \frac{r\{233\}}{\mathrm{x}} & \frac{\mathrm{x}}{\mathrm{x}} \\ - & \mathrm{x} & \mathrm{x} & - & - & - \\ - & \mathrm{x} & \mathrm{x} & - & \mathrm{x} & - \\ - & \mathrm{x} & \mathrm{x} & - & \mathrm{x} & -\end{array}$

Single-crystal X-ray data are lacking. The mineral apparently is invariably metamict. X-ray powder-diffraction studies of heated betafite from Madagascar by Reuning (1933) gave an isometric cell with $a_{0} 11.06 \mathrm{~A}$. Bjørlykke (1931) obtained $a_{0} 5.158$ or 10.317 A on titanian material from Norway (analyses $6,7,8$ ); the pattern differed somewhat from that of the Madagascar material. The diffraction lines obtained on heating may not refer to betafite but to microlite-pyrochlore or some other product.

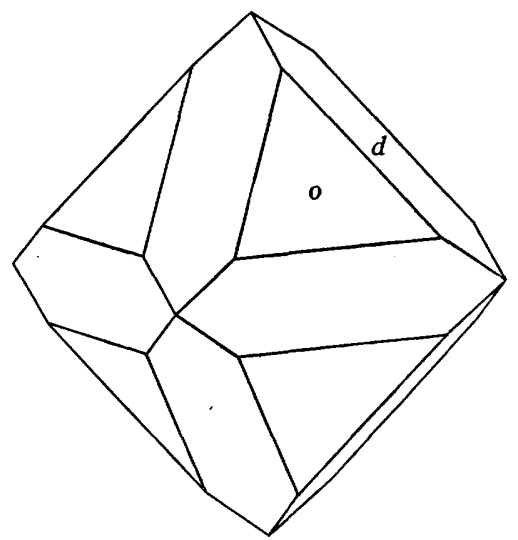

Frgure 23.-Betafite. Madagascar. Typical habit, showing the forms $d\{011\}$ and o\{111\}.

Physical properties

Fracture conchoidal to uneven. Brittle. Hardness variable, 3-51/2. Specific gravity 3.7-4.9. Samiresite, containing $\mathrm{Pb}$, has a specific gravity of about 5 . The reported specific gravities probably all are much lower than that proper to unaltered nonmeta- 
mict material. Luster waxy or greasy to vitreous. The crystals commonly are filmed or are surficially altered to a brownishyellow material with dull luster that passes inwardly into relatively unaltered metamict betafite. The outer, more altered parts are relatively high in water and low in uranium. The inner parts are brown, greenish brown, yellowish brown, or yellow; also black, with a semimetallic luster. Translucent to opaque. Not fluorescent.

Optical properties

In crushed grains pale yellow to nearly colorless in transmitted light. Isotropic. Indices of refraction are:

\begin{tabular}{|c|c|c|}
\hline$n$ & NAME & LOCALITY \\
\hline $\begin{array}{l}1.925 \pm 0.01 \\
1.915 \pm .02 \\
1.92-1.96 \\
1.95 \pm .03 \\
2.02 \pm .02\end{array}$ & $\begin{array}{l}\text { Betafite } \\
\text { Samiresite } \\
\text { Betafite } \\
\text { Betafite }\end{array}$ & $\begin{array}{l}\text { Betafo, Madagascar } \\
\text { Antaifasy, Madagascar } \\
\text { Samiresy, Madagascar } \\
\text { Madagascar }\end{array}$ \\
\hline 1.910 & $\begin{array}{l}\text { (black } \\
\text { Betafite }\end{array}$ & California \\
\hline
\end{tabular}

\begin{tabular}{l} 
REFBRENCE \\
\hline Larsen (1921). \\
Do. \\
Do. \\
George (1949). \\
Do. \\
Hewett and Glass \\
(1953).
\end{tabular}

Thermal behavior

Differential thermal analysis curves of betafite are given by Orcel and Lévy (1953), Kerr and Holland (1951), and Takubo, Ueda, and Nishimura (1951).

Synthesis

No data.

Identification

Betafite can be distinguished from niobate-tantalates and other minerals that it resembles, with the exception of isometric species such as thorianite, uraninite, and microlite-pyrochlore, by its outward form. The color, specific gravity, and index of refraction are useful criteria but are not wholly reliable because of their variation with the degree of alteration and with composition. Betafite most closely resembles the metamict highly uranoan varieties of pyrochlore-microlite and the two species in some of the reported localities may have been confused. The X-ray powder-spacing data for heated betafite and samiresite are given in the table on the following page.

\section{Natural formation and occurrence}

Found as a primary mineral in pegmatites, associated with fergusonite, thorite, cyrtolite, rutile, euxenite, allanite, beryl, sphene, and magnetite. The mineral is relatively abundant in the potassium-rich pegmatites of Madagascar where crystals up to 
6 inches in size have been found (Lacroix, 1922, v. 1, p. 378). Found as large crystals and groups at Ambatolampikely, Sama, and Andibakely; at Ambolotara, west of Betafo; at Antanifotsy, $2 \mathrm{~km}$ east of Ampangabe; at numerous localities in the region between Antanifotsy and Marafeno. Also at Samiresy (samiresite) with native bismuth. At Tongafeno as large crystals (blomstrandite) with beryl, columbite, and zircon; this material was presumed by Lacroix (1922, v. 1, p. 383) to be identical with the unanalyzed material from Norway earlier described by Lindstrom under this name. Found in Siberia at Sludianka, on Lake Baikal (mendeleyevite) in a pegmatite with sphene, garnet, zircon, magnetite, and pyroxene. A variety of betafite(?) from Yelisseyevka, Ukraine, has been described by Barsanov (1945a). A titanian variety occurs in Norway in pegmatite at Hogsjaaen, near Tangen; also at Evje, Landsnerk, and Ljosland in Satersdalen. Reported from the Brown Derby pegmatite in Gunnison County, Colo., and the Pidlite pegmatite, Mora County, N. Mex. (Page, 1950). Described by Hewett and Glass (1953) from a pegmatite in the Cady Mountains, San Bernardino County, Calif. Betafite occurs in Spain in the La Coma mine, Cordoba (Leal Luna, 1943), and in pegmatite in the Chin-chou region, south Manchuria (Takubo, Ueda, and Nishimura, 1951). (See also Takubo, Ueda, Nishimura, and Masutomi, 1953.) Also identified in a specimen from an unstated locality in Peru (C. Frondel, written communication, 1953), probably the pegmatite at Pampacolca, Castilla Province, Arequipa, described by Freyre (1948). Found in pegmatite in the Sui-chung district, south Manchuria (Kuno, 1950).

$X$-ray powder-spacing data for betafite

[Copper radiation, nickel filter]

\begin{tabular}{|c|c|c|c|c|c|c|c|}
\hline \multicolumn{4}{|c|}{$\begin{array}{l}\text { BETAFITE, ANTANIFOTSY, } \\
\text { MADAGASCAR }\end{array}$} & \multicolumn{4}{|c|}{ SAMIRESITE, MADAGASCAR } \\
\hline$d(\mathrm{~A})$ & $I$ & $d(\mathrm{~A})$ & $I$ & $d(\mathrm{~A})$ & $\boldsymbol{I}$ & $d(\mathrm{~A})$ & $I$ \\
\hline $\begin{array}{l}3.99 \\
\mathbf{3 . 5 5} \\
\mathbf{3 . 2 8} \\
\mathbf{3 . 1 9} \\
\mathbf{2 . 9 8} \\
\mathbf{2 . 5 7} \\
\mathbf{2 . 4 9} \\
\mathbf{2 . 2 0} \\
\mathbf{2 . 0 0} \\
\mathbf{1 . 8 2} \\
\mathbf{1 . 7 0}\end{array}$ & $\begin{array}{r}3 \\
1 \\
1 \\
2 \\
10 \\
2 \\
3 \\
1 \\
1 \\
8 \\
2\end{array}$ & $\begin{array}{l}1.63 \\
1.59 \\
1.55 \\
1.485 \\
1.355 \\
1.290 \\
1.181 \\
1.154 \\
1.050 \\
1.025 \\
.990\end{array}$ & $\begin{array}{l}1 \\
1 \\
6 \\
1 \\
1 \\
1 \\
2 \\
3 \\
1 \\
1 \\
2\end{array}$ & $\begin{array}{l}4.05 \\
3.55 \\
3.20 \\
2.99 \\
2.81 \\
2.61 \\
2.50 \\
2.02 \\
1.83\end{array}$ & $\begin{array}{r}6 \\
2 \\
10 \\
2 \\
1 \\
1 \\
8 \\
2 \\
5\end{array}$ & $\begin{array}{l}1.71 \\
1.67 \\
1.59 \\
1.48 \\
1.36 \\
1.25 \\
1.20 \\
1.153\end{array}$ & $\begin{array}{l}\mathbf{3} \\
\mathbf{3} \\
\mathbf{1} \\
\mathbf{2} \\
\mathbf{2}\end{array}$ \\
\hline
\end{tabular}




\section{PYROCHIORE-MICROIITE}

\section{Synonymy}

Pyrochlore Wöhler (1826). Hydrochlore, Fluochlore Hermann (1850). Niobpyrochlor Machatschki (1932a). Pyrrhit Rose (1840, 1842). Koppite Knop (1875). Hatchettolite Smith (1877), Allen (1877). Azor-pyrrhit Hubbard (1886). Uranpyrochlor Holmquist (1896). Chalcolamprite Flink (1898, 1901). Endeiolite Flink (1901. Marignacite Weidman and Lenher (1907). Ellsworthite Walker and Parsons (1923).

Microlite Shepard (1835, 1837c, 1842). Pyrochlore Hayes (1842, 1844). Haddamite Shepard (1870). Tantal pyrochlore Machatschki (1932a). Neotantalite Termier (1902). Niobtantal pyrochlore Machatschki (1932a). Metasimpsonite Simpson (1938). Djalmaite Guimarães $(1939,1941)$.

Uranium is often present in variable amounts in solid solution in the pyrochlore-microlite series. It is not an essential constituent, however, as in the other minerals with which this work is concerned. Nevertheless, the widespread occurrence and abundance at some localities of pyrochlore-microlite and uraniumcontaining varieties thereof has made it desirable to include a summary description of these minerals. A more detailed account is given in Palache, Berman, and Frondel (1944).

A large number of supposedly independent species have been described, chiefly in the older literature, that were later united with pyrochlore-microlite when a fuller understanding of the complex crystal chemistry of these minerals was reached through $\mathrm{X}$-ray study. These include the uranium-rich minerals hatchettolite, ellsworthite, and djalmaite, all of which are properly classed as uranoan varieties of pyrochlore or microlite.

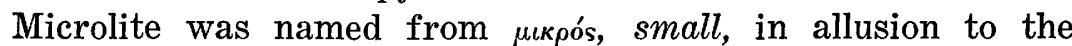
minute size of the crystals from the original locality at Chesterfield, Mass. Pyrochlore from $\pi v \rho$, fire, and $\chi^{\lambda \omega \rho o ́ s, ~ g r e e n, ~ b e c a u s e ~}$ the mineral turns green on ignition.

\section{Composition}

Pyrochlore and microlite are multiple oxides containing essentially $\mathrm{Ca}, \mathrm{Na}, \mathrm{Nb}$, Ta with $(\mathrm{OH})$ and $\mathrm{F}$. The general formula can be written $\mathrm{A}_{2} \mathrm{~B}_{2} \mathrm{O}_{6}(\mathrm{O}, \mathrm{OH}, \mathrm{F})$, where $\mathrm{A}=\mathrm{Na}, \mathrm{Ca}, \mathrm{Fe}^{+2}, \mathrm{U}^{+4}$ chiefly, also $\mathrm{K}, \mathrm{Mg}, \mathrm{Mn}^{+2}, \mathrm{Sb}^{+3}, \mathrm{~Pb}$, rare earths, $\mathrm{Th}, \mathrm{Zr}$, and $\mathrm{B}=\mathrm{Nb}$ and $\mathrm{Ta}$ chiefly, also $\mathrm{Ti}, \mathrm{Sn}, \mathrm{Fe}^{+3}, \mathrm{~W}$. $\mathrm{Nb}$ and $\mathrm{Ta}$ substitute mutually to give a complete series, the names microlite and pyrochlore being applied to the halves of the series with $\mathrm{Ta}>\mathrm{Nb}$ and $\mathrm{Nb}$ $>\mathrm{Ta}$, respectively. Microlite is essentially $(\mathrm{Na}, \mathrm{Ca})_{2} \mathrm{Ta}_{2} \mathrm{O}_{0}$ $(\mathrm{O}, \mathrm{OH}, \mathrm{F})$ and pyrochlore $\mathrm{NaCaNb}_{2} \mathrm{O}_{6} \mathrm{~F}$. 
The composition of pyrochlore-microlite varies widely accompanying simple and coupled substitutions in the $A$ and $B$ positions; also with coupling to the substitution of $O$ for $(\mathrm{OH})$ and $F$. A summary of the observed substitutions is given in Palache, Berman, and Frondel (1944), and the crystal chemistry involved has been discussed by Machatschki (1932a, b) and Rosén and Westgren (1938). Uranium is often present in amounts up to at least 15 weight percent $\mathrm{UO}_{3}$. The uranium probably was originally present entirely as $\mathrm{U}^{+4}$, the $\mathrm{U}^{+6}$ reported being due to oxidation. Some selected analyses of material high in uranium are cited in the table below. Additional partial analyses of microlite, cited by

Chemical analyses of pyrochlore-microlite, in weight percent

\begin{tabular}{|c|c|c|c|c|c|c|c|}
\hline & 1 & 2 & 3 & 4 & 5 & 6 & 7 \\
\hline $\mathrm{Na}_{2} \mathrm{O}$ & & & 1.37 & 3.37 & 3.15 & 3.40 & \\
\hline $\begin{array}{l}\mathrm{CaO} \\
\mathrm{MnO}\end{array}$ & $\begin{array}{r}13.62 \\
.22\end{array}$ & $\begin{array}{r}13.25 \\
.51\end{array}$ & 8.87 & 15.03 & $\underset{\mathrm{Tr}}{6.00}$ & 二 & $\begin{array}{r}12.38 \\
.24\end{array}$ \\
\hline $\mathrm{FeO}$ & - & & $2 . \overline{19}$ & - & 6.32 & .56 & .89 \\
\hline MgO & $\overline{11}$ & .36 & .15 & .07 & $\operatorname{Tr}$ & .24 & .13 \\
\hline $\mathrm{PbO}$ & .41 & .54 & 一 & & - & 1.10 & .194 \\
\hline $\mathrm{Y}_{2} \mathrm{O}_{3}$, etc. & - & .62 & - & .35 & 1368 & - & - \\
\hline $\mathrm{UO}_{2}$ & $8 . \overline{42}$ & 11.40 & $15 . \overline{50}$ & .77 & 8.33 & 2.17 & 1.92 \\
\hline $\mathrm{UO}_{3}^{-}$ & 10.68 & 4.41 & 一 & - & - & 9.38 & 2.45 \\
\hline $\mathrm{ZrO}_{2}$ & & 4.12 & $\overline{30}$ & $\overline{c 1}$ & - & .80 & Tr \\
\hline & .25 & 1.44 & .30 & 1.61 & $\overline{T r}$ & $\operatorname{Tr}$ & .22 \\
\hline $\begin{array}{l}\mathrm{ThO}_{2} \\
\mathrm{SiO}_{2}\end{array}$ & $2 . \overline{68}$ & 1.57 & 二 & - & 11 & 二 &.$\overline{22}$ \\
\hline $\mathrm{Fe}_{2} \mathrm{O}_{3}$ & 3.80 & 3.46 & 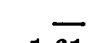 & - & .26 & $=$ & \\
\hline & 9.79 & 11.37 & 1.61 & & 4.20 & 2.54 & .032 \\
\hline & 34.27 & 31.33 & 34.24 & 3.56 & 26.22 & 1.41 & 4.10 \\
\hline $2_{5}$ & 4.27 & 10.29 & 29.83 & 74.27 & 27.39 & 72.27 & 74.40 \\
\hline $\mathrm{H}_{2} \mathrm{O}$ & 11.42 & 4.29 & 4.49 & .27 & 1.45 & 4.62 & 1.266 \\
\hline Total & 100.32 & 99.60 & 98.55 & 100.14 & 98.90 & 99.65 & 98.66 \\
\hline & & & & & & & \\
\hline Total & 100.11 & 99.60 & 98.55 & 100.14 & 98.10 & 99.65 & 98.66 \\
\hline
\end{tabular}

\begin{tabular}{llllllll}
\hline $\mathrm{Sp} \mathrm{gr}$ & 3.758 & 4.509 & $4.77-4.90$ & 6.42 & 4.21 & $5.75-5.88$ & -
\end{tabular}

1. Uranoan pyrochlore (ellsworthite). Hybla, Ontario. Chocolate-brown type. Todd, analyst, in Walker and Parsons (1923).

2. Uranoan pyrochlore (hatchettolite). Hybla, Ontario. Black type. Todd, analyst, in Walker and Parsons (1923).

3. Uranoan pyrochlore (hatchettolite). North Carolina. Allen (1877); see also Smith (1877). The $\mathrm{SnO}_{2}$ contains $\mathrm{WO}_{3}$.

4. Microlite. Topsham, Maine. Gonyer, analyst, in Palache and Gonyer (1940). Total includes $\mathrm{WO}_{3} 0.17, \mathrm{~K}_{2} \mathrm{O} 0.41$.

5. Uranoan pyrochlore. Tschoroch, Caucasus. Chernik (1902).

6. Uranoan microlite (djalmaite). C. P. Guimarães (1939). Total includes $\mathrm{Bi}_{2} \mathrm{O}_{3} 0.98$, $\mathrm{WO}_{3}$ 0.18. Posse farm, Minas Gerais, Brazil.

7. Uranoan microlite (djalmaite). Germinal, Minas Gerais, Brazil. Peixoto, analyst, in $\mathrm{D}$. Guimarães (1950). Total includes $\mathrm{Al}_{2} \mathrm{O}_{3} 0.22, \mathrm{Bi}_{2} \mathrm{O}_{3}$ trace. Original total given as $\mathbf{9 9 . 6 6 2}$. 
George (1949), are given below. Small amounts of $\mathrm{Pb}$ are reported in uranium-containing varieties and presumably the $\mathrm{Pb}$ is radiogenic.

\begin{tabular}{ll}
$\begin{array}{c}\mathrm{U}_{3} \mathrm{O}_{8} \\
\text { (WEMGHT } \\
\text { PERCENT) }\end{array}$ & \multicolumn{1}{c}{ CoLOR } \\
$\begin{array}{l}\mathbf{0 . 4 0}(\text { estimated). } \\
.37\end{array}$ & Pale yellow \\
$\begin{array}{l}\text { 1.5-2.0 } \\
\text { (estimated). }\end{array}$ & Pale yellow \\
6.04 & Amber to dark brown \\
& Light to dark brown
\end{tabular}

$\frac{\text { LocaliTY }}{\text { Rociadar, Maestar Canyon, }}$
N. Mex.
Harding mine, New Mexico
Amelia Court House, Va.
Brown Derby mine, Gunnison
County, Colo.

Pyrochlore and microlite are infusible or fusible with diffculty. The fine powder is insoluble or soluble with difficulty in $\mathrm{HCl}$; slowly decomposed by concentrated $\mathrm{H}_{2} \mathrm{SO}_{4}$ and readily decomposed by fusion with $\mathrm{KHSO}_{4}$.

Crystallography and crystal habit

Isometric, in the hexoctahedral crystal class $(4 / m \overline{3} 2 / m)$. The crystals usually are octahedral, often with modifying faces of $d\{011\}, m\{113\}$ or $a\{001\}$ and, less commonly, $n\{112\}$ and $p\{122\}$. Typical crystals are shown in figure 24. The crystals commonly are only a few millimeters in size or less, but have been observed as large as $6 \mathrm{~cm}$. Also found as embedded grains

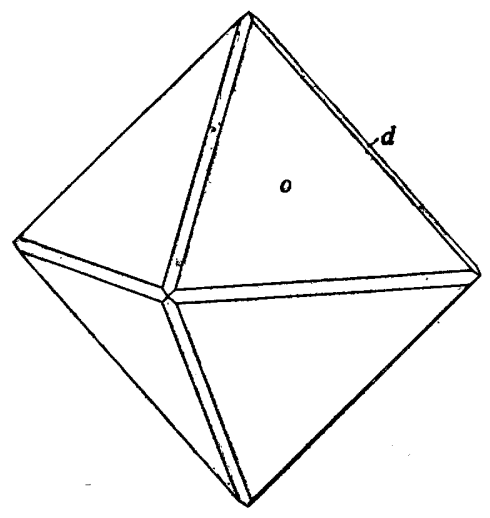

$A$

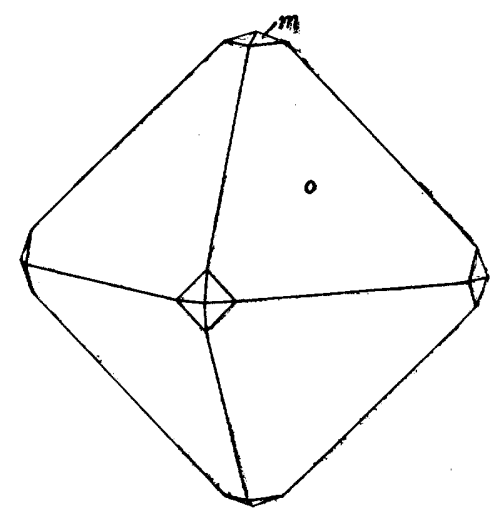

$B$

Figurw 24.-Microlite. A. Forms: $d\{011\}, o\{111\}$. B. Forms: $o\{011\}, m\{118\}$. 
or irregular masses, or as thin crusts or veins formed by the alteration of other minerals. Twins on $\{111\}$ are rare.

Numerous X-ray unit-cell measurements have been reported, mostly in the range $a_{0}=10.3-10.4 \mathrm{~A}$, but usually on unanalyzed material. Some selected values are given in the table below.

Selected unit-cell measurements of pyrochlore-microlite

\begin{tabular}{|c|c|c|c|c|}
\hline$a_{0}(\mathrm{~A})$ & MINERAL & LOCALITY & $\begin{array}{c}\text { ANALYSIS } \\
\text { NO. }\end{array}$ & REFERENCE \\
\hline$\overline{10.397}$ & Djalmaite & Germinal, Minas & 17 & Tavora (1949). \\
\hline 10.41 & Microlite & $\begin{array}{l}\text { Gerais. } \\
\text { Topsham, Maine }\end{array}$ & ${ }^{14}$ & $\begin{array}{l}\text { Shaub, in Palache } \\
\text { and Gonyer } \\
\text { (1940) }\end{array}$ \\
\hline 10.39 & Pyrochlore & $\begin{array}{c}\text { Kaiserstuhl, } \\
\text { Baden. }\end{array}$ & ${ }^{2} 6$ & $\begin{array}{l}\text { Brandenberger } \\
\text { (1931). }\end{array}$ \\
\hline 10.399 & $\begin{array}{l}\text { Synthetic } \\
\text { pyrochlore. }\end{array}$ & & - & Gaertner (1950). \\
\hline 10.441 & $\begin{array}{l}\text { Microlite (before } \\
\text { ignition). }\end{array}$ & $\begin{array}{c}\text { Amelia Court } \\
\text { House, Va. }\end{array}$ & 一 & Arnott (1950) \\
\hline 10.424 & $\begin{array}{l}\text { Microlite (after } \\
\text { ignition). }\end{array}$ & 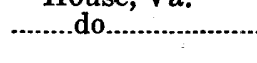 & 一 & Do. \\
\hline $\begin{array}{l}10.404 \\
10.318 \\
10.296\end{array}$ & $\begin{array}{l}\text { Pyrochlore } \\
\text { Ellsworthite }\end{array}$ & $\begin{array}{l}\text { Brevik, Norway } \\
\text { Hybla, Ontario } \\
\text { Cardiff Town- } \\
\text { ship, Ontario. }\end{array}$ & 二 & $\begin{array}{l}\text { Do. } \\
\text { Do. } \\
\text { Do. }\end{array}$ \\
\hline
\end{tabular}

1 See table, p. 327.

${ }^{2}$ In Palache, Berman, and Frondel (1944).

Space group $F d 3 m$. Unit-cell contents $8\left[\mathrm{NaCa}(\mathrm{Nb}, \mathrm{Ta})_{2} \mathrm{O}_{6}\right.$ $(\mathrm{O}, \mathrm{OH}, \mathrm{F})]$. Metamict natural material recrystallizes to the original phase on heating.

Physical properties

Cleavage or parting on $\{111\}$ sometimes distinct but usually not distinguishable. Brittle. Fracture subconchoidal to uneven or splintery. Hardness 5-51/2, lower in metamict material. Specific gravity varies widely, $3.6-6.4$, usually $4.3-5.7$; the values increase with increasing content of $\mathrm{Ta}$, and decrease markedly on alteration. The specific gravity of metamict material increases on heating. Calculated specific gravities: 4.31 (pyrochlore), 6.31 (microlite). Luster vitreous to resinous. Color of pyrochlore brown to black, often brown in yellowish, reddish, or blackish shades; color of microlite pale yellow to brown, sometimes hyacinth red, olive buff, or green. Material high in uranium usually is dark brown to black. Translucent to opaque. Not fluorescent. 
Optical properties

Isotropic, but may show weak anomalous birefringence in nonmetamict material. The index of refraction ranges from about 1.9 to 2.2 depending on the composition and degree of alteration, but correlated data are lacking. The index increases with increasing content of Ta. The index of refraction of metamict material increases on heating. Some reported values are given in the table below.

Index of refraction of pyrochlore-microlite

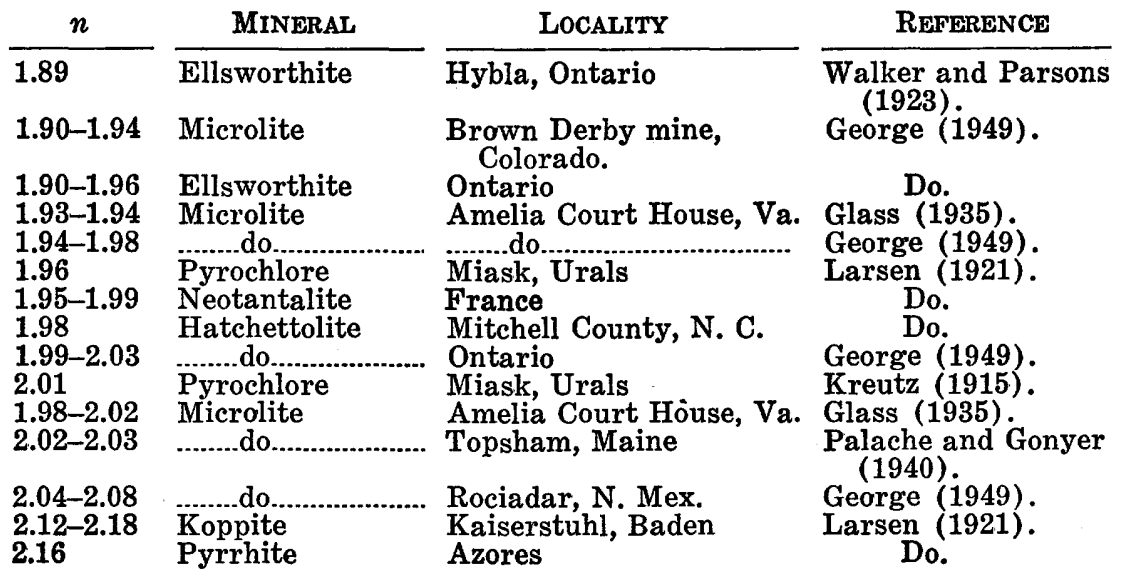

Thermal behavior

No data.

Synthesis

Obtained by fusion of $\mathrm{CaO}, \mathrm{NaF}$, and $(\mathrm{Ta}, \mathrm{Nb})_{2} \mathrm{O}_{5}$; varieties containing rare earths and uranium also have been prepared (Holmquist, 1896).

\section{Alteration}

The uranoan varieties of pyrochlore-microlite tend to become metamict. The change is accompanied by a decrease in the specific gravity and index of refraction, by increasing hydration, and probably also by oxidation of $\mathrm{U}^{+4}$ to $\mathrm{U}^{+6}$. A description of altered pyrochlore is given by Barsanov (1945b).

\section{Identification}

The specific gravity, crystal form, optical properties, and to some extent the colors are useful diagnostic criteria. The X-ray powder pattern is very characteristic (table below). X-ray powderspacing data also are given by Gaertner (1930) and Rosén and Westgren (1938). Among uranium and thorium minerals there is 
possibility of confusion with thorianite and cerianite particularly and to a less extent with uraninite, betafite, ampangabeite, and thorite. Perovskite also is similar. Anhedral grains and masses, especially when dark brown or black in color, more or less closely resemble fergusonite and some other niobate-tantalates. Differentiation of the members of the microlite-pyrochlore series itself is best done by analytical determination of $\mathrm{Nb}$ and $\mathrm{Ta}$, and the specific gravity of heated material is a useful guide.

$X$-ray powder-spacing data for microlite ${ }^{1}$

[Copper radiation, nickel filter]

\begin{tabular}{|c|c|c|}
\hline$d(\mathrm{~A})$ & $I$ & $h k l$ \\
\hline $\begin{array}{l}\mathbf{5 . 9 8} \\
\mathbf{3 . 6 9} \\
\mathbf{3 . 1 1} \\
\mathbf{2 . 9 8} \\
\mathbf{2 . 5 8} \\
\mathbf{2 . 3 8} \\
\mathbf{2 . 1 1}\end{array}$ & $\begin{array}{r}6 \\
1 / 4 \\
4 \\
10 \\
3 \\
1 \\
1 / 4\end{array}$ & $\begin{array}{r}111 \\
022 \\
113 \\
222 \\
004 \\
133 \\
224\end{array}$ \\
\hline 1.999 & 2 & $\left\{\begin{array}{l}333 \\
115\end{array}\right.$ \\
\hline $\begin{array}{l}1.836 \\
1.757 \\
1.705 \\
1.585 \\
1.563 \\
1.500\end{array}$ & $\begin{array}{r}8 \\
2 \\
1 / 2 \\
1 / 4 \\
8 \\
2\end{array}$ & $\begin{array}{l}044 \\
135 \\
244 \\
335 \\
226 \\
444\end{array}$ \\
\hline 1.455 & 2 & $\left\{\begin{array}{l}117 \\
155\end{array}\right.$ \\
\hline 1.352 & 2 & $\left\{\begin{array}{l}137 \\
355\end{array}\right.$ \\
\hline $\begin{array}{l}1.302 \\
1.272\end{array}$ & $\underset{1 / 2}{2}$ & $\begin{array}{r}008 \\
337\end{array}$ \\
\hline 1.225 & $1 / 4$ & $\left\{\begin{array}{l}066 \\
000\end{array}\right.$ \\
\hline $\begin{array}{l}1.202 \\
1.194 \\
1.165\end{array}$ & $\begin{array}{r}1 / 4 \\
\mathbf{3} \\
\mathbf{3}\end{array}$ & $\begin{array}{r}228 \\
555 \\
266 \\
048\end{array}$ \\
\hline 1.141 & 1 & $\left\{\begin{array}{l}119 \\
357\end{array}\right.$ \\
\hline $\begin{array}{l}1.130 \\
1.112 \\
1.093 \\
1.064\end{array}$ & $\begin{array}{r}1 / 4 \\
1 / 2 \\
1 \\
3\end{array}$ & $\begin{array}{l}\text { J07 } \\
248 \\
466 \\
139 \\
448\end{array}$ \\
\hline 1.047 & 1 & $\left\{\begin{array}{l}177 \\
339 \\
557\end{array}\right.$ \\
\hline
\end{tabular}

\begin{tabular}{|c|c|c|}
\hline$d(\mathrm{~A})$ & $I$ & $h k l$ \\
\hline 1.018 & $1 / 2$ & $\begin{array}{l}0.2 .10 \\
268\end{array}$ \\
\hline 1.009 & $1 / 2$ & $\begin{array}{l}377 \\
159\end{array}$ \\
\hline $\begin{array}{r}1.003 \\
.972\end{array}$ & $\begin{array}{r}3 \\
1 / 2\end{array}$ & $\begin{array}{l}666 \\
359\end{array}$ \\
\hline .939 & 1 & $1.1,11$ \\
\hline .921 & 2 & 088 \\
\hline .911 & 2 & $\begin{array}{l}179 \\
\mathbf{5 5 9}\end{array}$ \\
\hline .881 & 4 & $\begin{array}{l}2.6 .10 \\
668\end{array}$ \\
\hline .869 & 3 & $\begin{array}{l}0.0 .12 \\
488\end{array}$ \\
\hline .859 & 1 & $\begin{array}{l}\mathbf{1 . 5 . 1 1} \\
\mathbf{7 7 7}\end{array}$ \\
\hline .848 & $1 / 4$ & $\begin{array}{l}2.2 .12 \\
4.6 .10\end{array}$ \\
\hline .837 & 2 & 3.5.11 \\
\hline $\begin{array}{l}.824 \\
.822\end{array}$ & $\begin{array}{l}3 \\
1\end{array}$ & $\begin{array}{l}0.4 .12 \\
199 \\
1.1 .13\end{array}$ \\
\hline .797 & 1 & $\begin{array}{l}1.7 .11 \\
5.5 .11 \\
399\end{array}$ \\
\hline $\begin{array}{l}.795 \\
.785\end{array}$ & $\begin{array}{l}3 \\
2\end{array}$ & $\begin{array}{l}6.6 .10 \\
4.4 .12\end{array}$ \\
\hline .778 & 1 & $\begin{array}{l}3.7 .11 \\
779\end{array}$ \\
\hline .777 & $1 / 2$ & $\begin{array}{l}6.6 .12 \\
4.8 .10\end{array}$ \\
\hline
\end{tabular}

1 Data of Arnott (1950), obtained on heated microlite from Amelia Court House, Va. The spacings vary slightly attending the substitution of $\mathrm{U}, \mathrm{Nb}$, and other elements in the pyrochlore-microlite series.

Natural formation and occurrence

Pyrochlore occurs typically as a primary mineral in pegmatites derived from alkalic igneous rocks, and is associated with zircon, sphene, apatite, aegirine, perovskite, and a number of uncommon minerals containing $\mathrm{Zr}, \mathrm{Ti}, \mathrm{Nb}, \mathrm{Ta}$, and rare earths. It also occurs 
as an accessory mineral in nepheline syenites and various alkalic dike rocks and in limestones metamorphosed at the contact with alkalic intrusives. The Ta-rich member of the series, microlite, and also pyrochlore, occur chiefly in granite pegmatites, especially those with marked lithium and albite phases. It is then typically associated with lepidolite, spodumene, albite, columbite-tantalite, cassiterite, zircon, tourmaline, garnet, and various niobate-tantalates. Pyrochlore-microlite also occurs as detrital minerals, as in Western Australia.

Long lists of localities are given by Palache, Berman, and Frondel (1944) and Hintze (1933, v. 1, pt. 4A). Highly uranoan varieties are known chiefly from the following localities: The so-called ellsworthite (analysis 1) occurs at the Macdonald mine, Hybla, Monteagle Township, Hastings County, Ontario, Canada. The mineral was found as amber-yellow or dark-brown anhedral grains and nodular masses in a large calcite-quartz pod in a microcline pegmatite; it was closely associated with abundant cyrtolite, sphene, pyrrhotite, and other sulfides. At least a ton of pure ellsworthite has been obtained at the locality (Ellsworth, 1932b). Also found in pegmatite in Cardiff Township, Haliburton County, Ontario. Uranoan varieties of pyrochlore-microlite also have been reported from other localities in the Grenville region of Ontario (A. H. Lang, 1952). The hatchettolite variety was originally found with samarskite in granite pegmatites in Mitchell County, N. C. (analysis 3). More or less similar material described under the name hatchettolite has been reported from the Woodcox mine, Monteagle Township, Hastings County, Ontario (analysis 2) where it occurs with cyrtolite, columbite, and a samarskite-like mineral in granite pegmatite; also from near Mount Bity, Madagascar (Lacroix, 1922, v. 1), and Pala, San Diego County, Calif., in pegmatite. A uranoan variety of microlite (analysis 6) occurs in granite pegmatite on Posse farm, Conçeicão County, and at Germinal, Nazareno district, in Minas Gerais, Brazil; this mineral was originally described under the name djalmaite and was later shown by Tavora (1950) to be a uranoan variety of microlite. A uranoan pyrochlore occurs as an accessory mineral in granite in the southeastern corner of Kano province, northern Nigeria. Uranoan varieties of pyrochloremicrolite have been found in pegmatites in New Mexico and Colorado (Page, 1950), especially in the Harding mine, Dixon County, N. Mex., and in the Brown Derby pegmatite, Gunnison County, Colo. Pyrochlore containing up to several percent $\mathrm{ThO}_{2}$ 
occurs with magnetite, apatite, and columbite as an accessory mineral in a carbonatite intrusion near Mbeya, southern Tanganyika (Fawley and James, 1955).

Synonymy

\section{PISEKITE}

Pisekite Krejči (1923). Named from the occurrence at Pisek, Bohemia.

\section{Description}

An ill-defined mineral, found from qualitative tests to be essentially a niobate-tantalate-titanate of uranium and rare earths, with thorium and tin. Quantitative analyses are lacking. Found both as fibro-lamellar aggregates and as supposedly monoclinic crystals with a habit similar to that of monazite. The crystals are described by Krejči (1923) as elongated on the $b$-axis and flattened on $\{100\}$, with $\{100\},\{110\},\{101\},\{10 \overline{1}\}$ and angles close to those of monazite. These crystals were originally considered to be pseudomorphs after monazite. Nováček (1936) later stated, however, that they were not pseudomorphs, and that the mineral was related to ampangabeite. X-ray data are lacking.

Fracture conchoidal. Hardness 51/2-6. Specific gravity 4.032. Luster vitreous to resinous. Color yellowish brown to black. Streak gray. Isotropic. Metamict according to Ježek (1923). Found with monazite, tantalian rutile (strueverite), garnet, tourmaline, and beryl as a primary mineral in pegmatite at Pisek, Bohemia.

\section{Synonymy}

\section{BRAMNERITE}

Brannerite Hess and Wells (1920). Cordobaite (mentioned by George, 1949). Absite Whittle (1954c). Brannerite is named after J. C. Branner (1850-1922), American geologist. Absite is a superfluous name for a thorian variety of brannerite.

\section{Composition}

Essentially an oxide of uranium and titanium, containing minor amounts of Th, rare earths, $\mathrm{Ca}$, and $\mathrm{Fe}$. The formula is uncertain, perhaps $\mathrm{AB}_{2} \mathrm{O}_{6}$ with $\mathrm{A}=\mathrm{U}, \mathrm{Ca}, \mathrm{Fe}, \mathrm{Th}, \mathrm{Y}$, and $\mathrm{B}=\mathrm{Ti}$ and $\mathrm{Fe}$ in part. The water reported in the analyses is probably nonessential and due to alteration. The five reported analyses are cited in the table below. The $\mathrm{U}^{+\infty}$ and $\mathrm{Fe}^{+3}$ reported probably was originally present as $\mathrm{U}^{+4}$ and $\mathrm{Fe}^{+2}$. The mineral is decomposed by hot concentrated $\mathrm{H}_{2} \mathrm{SO}_{4}$ or by fusion with $\mathrm{KHSO}_{4}$. The Idaho material contains helium (Hess and Wells, 1920). 
Chemical analyses of brannerite, in weight percent

\begin{tabular}{|c|c|c|c|c|c|}
\hline & 1 & 2 & 3 & 4 & 5 \\
\hline $\begin{array}{l}\mathrm{CaO} \\
\mathrm{BaO}\end{array}$ & $\begin{array}{r}2.9 \\
.3\end{array}$ & $\begin{array}{r}2.74 \\
<.01\end{array}$ & $=$ & 2.7 & 2.8 \\
\hline $\begin{array}{l}\text { SrO } \\
\mathrm{PbO}\end{array}$ & .1 & $<.01$ & $2 \overline{79}$ & $3 \overline{2}$ & 二 \\
\hline $\mathrm{FeO}$ & 2.9 & 3.11 & 2.100 & 5.4 & $2 . \overline{4}$ \\
\hline $\mathrm{UO}_{2}$ & 10.3 & - & $\overline{00}$ & - & 8.2 \\
\hline $\mathrm{U}_{3} \mathrm{O}_{8}$ & 33.5 & 51.76 & 31.83 & $43 . \overline{3}$ & \\
\hline $\mathrm{ThO}_{2}$ & 4.1 & 1.20 & 12.81 & .3 & 5.0 \\
\hline $\mathrm{Ce}_{2} \mathrm{O}_{3}$ & $\because$ & - & $(1 \overline{43}$ & .4 & \\
\hline$(\mathrm{Y}, \mathrm{Er})_{2} \mathrm{O}_{3}$ & 3.9 & 1.10 & $\{3.71$ & 1.8 & 6.5 \\
\hline $\mathrm{TiO}_{2}$ & 39.0 & 32.45 & 35.13 & 35.2 & 32.9 \\
\hline $\begin{array}{l}\mathrm{SiO}_{2} \\
\mathrm{Rem}\end{array}$ & .6 & .16 & & 3.3 & \\
\hline $\mathrm{H}_{2} \mathrm{O}$ & 2.0 & $2 . \overline{35}$ & 9.95 & 3.7 & 2.6 \\
\hline Total & 100.2 & 97.21 & 99.34 & 100.6 & 98.2 \\
\hline Sp gr & 5.42 & 5.17 & 4.2 & 4.82 & 5.43 \\
\hline
\end{tabular}

1. Brannerite. Kelly Gulch, Idaho. Rem. is $\mathrm{CO}_{2} \mathbf{0 . 2 0}$. Wells, analyst, in Hess and Wells (1920). Contains a small amount of admixed euxenite.

2. Brannerite (cordobaite). Cordoba, Spain. Bureau of Standards analysis, in George (1949).

3. Brannerite. Crocker's Well, South Australia. Remainder is $\mathrm{Sc}_{2} \mathrm{O}_{3} \mathbf{0 . 1 9}$, $\mathrm{Fe}_{2} \mathrm{O}_{3}$ 1.37, $\mathrm{P}_{2} \mathrm{O}_{5}$ 0.13. Dalwood, analyst, in Whittle (1954d).

4. Brannerite. Vosges, France. Branche and others (1951). Remainder is $\mathrm{SnO}_{2}$.

5. Brannerite. Mono County, Calif. May, analyst, in Pabst (1954). Remainder is $\mathrm{Pb}, \mathrm{Ni}, \mathrm{Nb}, \mathrm{Ta}, \mathrm{Zr}, \mathrm{Mn}, \mathrm{Mg}$. The rare earths are mostly $\mathrm{Y}$ and $\mathrm{Er}$.

Crystallography and crystal habit

The crystal system of brannerite is not known. It probably is either orthorhombic or monoclinic. The mineral occurs as rounded detrital grains and pebbles; also as irregular embedded grains and masses, and as indistinct crystals. Imperfect crystals from California were reported by Pabst (1954) to have an orthogonal prism zone with the partial ratio $a: b=0.528$. This value is near the $a: b$ ratio of samarskite and yttrotantalite. The observed forms and measurements for the California crystals are given in the table below. The Idaho material had earlier been considered by Hess and Wells (1920) to be an isometric paramorph after a tetragonal or orthorhombic species, and George (1949) considered the mineral to be monoclinic from visual inspection of large rough crystals from Fuenteovejuna, Spain.

Goniometric measurements on brannerite from California

\begin{tabular}{|c|c|c|c|c|c|}
\hline Form & $\phi$ & RANGE OF $\phi$ & FORM & $\phi$ & RANGE OF $\phi$ \\
\hline $\begin{array}{l}010 \\
160 \\
130\end{array}$ & $\begin{array}{rr}0^{\circ} 00^{\prime} \\
18 & 12 \\
31 & 42\end{array}$ & $\begin{array}{l}16^{\circ} 04^{\prime}-19^{\circ} 39^{\prime} \\
3022-3235\end{array}$ & \multirow{2}{*}{$\begin{array}{l}110 \\
210 \\
310 \\
610\end{array}$} & \multirow{2}{*}{$\begin{array}{ll}61^{\circ} 34^{\prime} \\
75 & 05 \\
79 & 37 \\
84 & 58\end{array}$} & \multirow{2}{*}{ 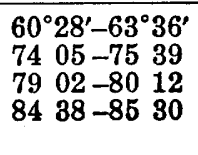 } \\
\hline $\left.\begin{array}{l}120 \\
590\end{array}\right\}(?)$ & 4535 & $4329-4725$ & & & \\
\hline
\end{tabular}


Brannerite is metamict, and X-ray single-crystal data are lacking. Unheated brannerite sometimes yields a few faint powderdiffraction lines corresponding to an isometric face-centered substance with $a_{0} 5.39$ or $10.78 \mathrm{~A}$ and relative intensities similar to those of pyrochlore (Pabst, 1954). The metamict material recrystallizes in random orientation on heating over about $800^{\circ} \mathrm{C}$ and then gives a distinctive X-ray powder pattern (see table below).

$X$-ray powder-spacing data for brannerite ${ }^{1}$

[Symbol: $d$, diffuse. Copper radiation, nickel filter]

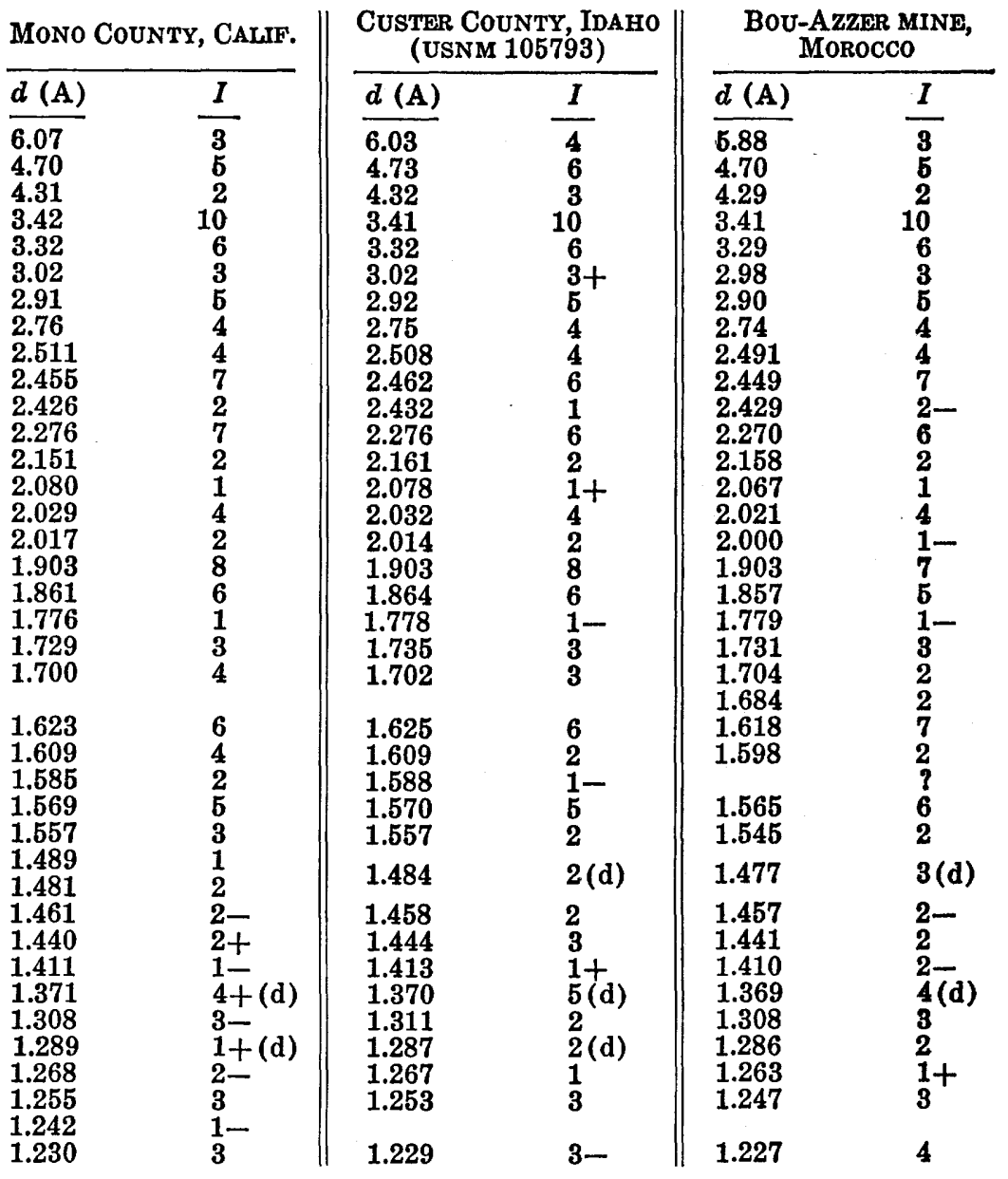

1 The data given here, from Pabst (1954), were obtained on material crystallized by heating in air to about $1,000^{\circ} \mathrm{C}$. Minor variations in the spacings may be expected in material from other localities owing to variation in composition. 
Physical properties

Fracture (of metamict material) conchoidal. Hardness 41/2 (Idaho), 51/2 (Western Australia), varying with the degree of alteration. The reported specific gravity ranges from 4.2 to 5.4, depending on the degree of hydration and alteration. Luster vitreous when fresh, becoming resinous when altered; on weathering turns dull and may become incrusted with white to brown earthy alteration products. Color black, changing to brownish olive green, yellow brown, or yellow on alteration. Streak dark greenish brown to yellowish brown. Transparent in very thin splinters. Not fluorescent.

Optical properties

In transmitted light, yellowish green. Isotropic (metamict). Material from Idaho has $n 2.26 \pm 0.02$ in Li light, $n 2.30 \pm 0.02$ in Na light; material from France has $n 2.23 \pm 0.01$ in $\mathrm{Na}$ light.

Thermal behavior and synthesis

No data.

Alteration

The metamict brannerite from Idaho is surficially altered to an earthy brownish-yellow material that gives a weak X-ray diffraction pattern of anatase; after strong heating in air the material gives the $X$-ray pattern of rutile (Pabst, 1954).

\section{Identification}

Brannerite very closely resembles a number of metamict niobate-tantalates, from which it is best distinguished by X-ray powder patterns of heated, recrystallized material and by chemical evidence. The X-ray powder-spacing data are given in the table on the following page.

Natural formation and occurrence

Originally found as rounded crystals and grains in a gold placer near the head of Kelly Gulch in western Custer County, Idaho. The mineral presumably has been derived from pegmatite veins and stringers in the country rock. Also found in a pegmatite near Fuenteovejuna, Cordoba, Spain (George, 1949). A variety of brannerite relatively high in thorium occurs at Crocker's Well about 20 miles north of Manna Hill, South Australia, in quartz veins and brecciated zones in granitoid rock associated with rutile, xenotime, apatite, and zircon (Whittle, 1954d) ; the geology of the deposit has been described by Whittle (1954d) and King (1954). Brannerite or a mineral closely related to it found with uraninite in calcite veins in the Nichols Nob copper mine in the northern Flinders Range, South Australia, is mentioned by 
Whittle (1954a), who gives a partial analysis of impure material. With molybdenite at Chateâu-Lambert in the Vosges, France (Branche and others, 1951). From Dean's mine on the West Walker River, near Coleville, Mono County, Calif., as a trace constituent in mesothermal quartz veins traversing quartz-monzonite (Pabst, 1954). Brannerite occurs as a detrital constituent of a Precambrian quartz-pebble conglomerate at or near the base of the Huronian series over an extensive area in the Blind River district, Ontario, on the north shore of Lake Huron about 80 miles east of Sault Sainte Marie (Nuffield, 1954; Traill, 1954) ; descriptions of the deposit also are given by Joubin (1954), Hart and others (1955) and Bateman (1955). Also found at Bou-Azzer, Morocco (Pabst, 1954).

\section{DAVIDITE}

Synonymy

Davidite Mawson (1906). Mavudzite Pinto Coelho (1954). Ferutite Kazitsyn (1954). Named after T. W. E. David (18581934), Australian geologist. Davidite was discredited as a species by Crook and Blake (1910), but Mawson (1916) later pointed out that these workers did not examine authentic material. The species validity of davidite has been fully confirmed by the work of Bannister and Horne (1950) and of Kerr and Holland (1951). Mavudzite and ferutite from Mozambique are davidite.

\section{Composition}

An oxide chiefly of $\mathrm{Ti}, \mathrm{Fe}$, and $\mathrm{U}$, together with variable amounts of rare earths, $\mathrm{Cr}, \mathrm{V}$, and Th. The formula of the mineral is uncertain. Bannister and Horne (1950) derive the formula $\mathrm{AB}_{3}(\mathrm{O}, \mathrm{OH})_{7}$, or $\mathrm{AB}_{3} \mathrm{O}_{7}$ if the water is regarded as nonessential with $\mathrm{A}=\mathrm{Fe}^{+2}$, rare earths, $\mathrm{U}^{+6}, \mathrm{Ca}, \mathrm{Zr}, \mathrm{Th}$, and $\mathrm{B}=\mathrm{Ti}, \mathrm{Fe}^{+3}, \mathrm{~V}$, Cr. In this interpretation, the ideal end member is $\mathrm{FeTi}_{3} \mathrm{O}_{7}$ in which substitution of $\mathrm{Fe}^{+2}$ by $\mathrm{U}^{+6}$ and rare earths is balanced by the substitution of $\mathrm{Ti}$ by $\mathrm{Fe}^{+3}$ and $\mathrm{V}$. The reported analyses of the essentially pure mineral are given in the table below. Additional analyses of material containing admixed gangue are cited by Bannister and Horne (1950). George (1949) states that fairly pure samples of davidite from South Australia contained $\mathrm{U}_{3} \mathrm{O}_{8} 3.63, \mathrm{~V}_{2} \mathrm{O}_{5} 2.30$, and $\mathrm{Th}$ trace, and that three samples of davidite concentrates from Mozambique contained $\mathrm{U}_{3} \mathrm{O}_{8} 7.79,9.63$, 8.19; $\mathrm{ThO}_{2} 0.05,0.19,0.08$. The $\mathrm{U}$ presumably is present in the original mineral as $\mathrm{U}^{+4}$. A partial spectrographic analysis of Mozambique material reported by Kerr and Holland (1951) showed the presence of $\mathrm{Nb}, \mathrm{Bi}, \mathrm{Pb}$, and $\mathrm{Al}$. 
Chemical analyses of davidite, in weight percent

\begin{tabular}{|c|c|c|c|c|c|c|}
\hline & 1 & 2 & 3 & 4 & $\mathbf{5}$ & 6 \\
\hline $\mathrm{Na}_{2} \mathrm{O}$ & 0.15 & 1.72 & - & - & - & - \\
\hline $\mathrm{CaO}$ & .3 & 1.00 & 1.5 & - & - & None \\
\hline $\mathrm{PbO}$ & .72 & - & 1.1 & 一 & - & .9 \\
\hline $\mathrm{FeO}$ & 16.5 & 12.37 & 16.0 & 17.96 & 10.36 & - \\
\hline $\mathrm{Fe}_{2} \mathrm{O}_{3}$ & 10.2 & 13.57 & 13.0 & 8.58 & 15.73 & 31.6 \\
\hline $\mathrm{Cr}_{2} \mathrm{O}_{3}$ & .17 & 3.23 & & 2.97 & 一 & .6 \\
\hline $\mathrm{V}_{2} \mathrm{O}_{5}$ & 1.4 & & 4.6 & .91 & - & 1.5 \\
\hline $\mathrm{U}_{3} \mathrm{O}_{8}$ & 9.8 & 7.10 & & 9.19 & 5.26 & $\overline{7}$ \\
\hline$(\mathrm{Ce}, \mathrm{L} a)_{2} \mathrm{O}_{3}$ & 5.6 & 5100 & 8.3 & & 7.15 & 7.1 \\
\hline $\mathrm{TiO}_{2}$ & 54.5 & 51.00 & 54.3 & 49.22 & 47.91 & 47.4 \\
\hline $\mathrm{ZrO}_{2}$ & .4 & 3.30 & - & 一 & 一 & 一 \\
\hline $\mathrm{ThO}_{2}$ & .07 & & $\overline{15}$ & 一 & 二 & $\overline{12}$ \\
\hline $\begin{array}{l}\mathrm{H}_{2} \mathrm{O}+ \\
\text { Rem. }\end{array}$ & $\begin{array}{l}.05 \\
.06\end{array}$ & $\begin{array}{l}1.09 \\
5.57\end{array}$ & $\begin{array}{r}1.5 \\
.6\end{array}$ & 二 & - & $\begin{array}{l}1.2 \\
8.9\end{array}$ \\
\hline Total & 99.92 & 99.95 & 100.9 & 一 & - & 99.2 \\
\hline Sp gr & 4.46 & 4.48 & - & - & - & - \\
\hline
\end{tabular}

1. Davidite. Mozambique. Ryan and Maple, analysts, in Bannister and Horne (1950). Remainder is $\mathrm{SiO}_{2}$. $\mathrm{Nb}, \mathrm{Mg}$, and $\mathrm{Ta}$ not found.

2. Davidite. Mozambique. Golding, analyst, in Bannister and Horne (1950). Remainder is $\mathrm{SiO}_{2} 0.68, \mathrm{Al}_{2} \mathrm{O}_{3} 4.24, \mathrm{~K}_{2} \mathrm{O} 0.32$, Ba trace, $\mathrm{MnO}$ trace, NiO 0.05, $\mathrm{S} 0.09, \mathrm{H}_{2} \mathrm{O}-0.19$.

3. Davidite. Radium Hill, South Australia. Cooke (1916). Remainder is $\mathrm{MgO}$ 0.6, CuO trace, Sc present, Th trace; $\mathrm{Zr}$ absent.

4,5. Davidite. Mozambique. Ledoux and Co. analysis, in Kerr and Holland (1951).

6. Davidite. Radium Hill, South Australia. T. W. Dalwood, analyst, in Whittle $(1954 \mathrm{~b})$. Total $\mathrm{Fe}$ as $\mathrm{Fe}_{2} \mathrm{O}_{3}$. Remainder is $\mathrm{UO}_{2}$.

Davidite is infusible, and is slowly attacked by $\mathrm{HF}$ and strong $\mathrm{H}_{2} \mathrm{SO}_{4}$ or $\mathrm{HNO}_{3}$.

Crystallography and crystal habit

Hexagonal, in the ditrigonal pyramidal crystal class $(3 m)$. The mineral occurs massive, as rough cuboidal crystals (South Australia), and as distinct crystals either tabular on $\{0001\}$ or pyramidal with ditrigonal pyramids dominant (Mozambique). The crystals from Mozambique sometimes occur in irregular clusters and are large; one crystal fragment, part of a much larger individual, was 12 inches long and weighed 22 pounds. The crystals occasionally are twinned by rotation around the axis [11 $\overline{2} 0]$. The hemimorphic character is evident in single individuals and in interpenetrant twins, but well-developed aggregate twins simulate holohedral symmetry. Crystal drawings and photographs are given by Bannister and Horne (1950).

A partial angle table for the forms observed on Mozambique crystals, based on measurements with a contact goniometer (Bannister and Horne, 1950), is given below. The crystals from South Australia are too rough to permit measurement. X-ray single-crystal measurements are lacking, due to the metamict 
Angle table for davidite

Hexagonal-R; ditrigonal pyramidal, $(3 \mathrm{~m})$

$a: c=1: 1.37 ; \alpha 84^{\circ} 97^{\prime} ; p_{0}: r_{0}=1.58: 1 ; \lambda 94^{\circ} 04^{\prime}$

\begin{tabular}{crrrrr}
\hline LOWER & \multicolumn{2}{c}{ UPPER } & $\phi$ & $\rho$ \\
\hline $\bar{c}$ & $c$ & 0001 & 111 & - & $0^{\circ}$ \\
& $h$ & $21 \overline{3} 0$ & $5 \overline{14}$ & $11^{\circ}$ & 90 \\
& $-h$ & 1230 & $41 \overline{5}$ & -11 & 90 \\
& $-l$ & $25 \overline{7} 0$ & $31 \overline{4}$ & -14 & 90 \\
$-\bar{n}$ & & $03 \overline{3} 4$ & $77 \overline{2}$ & -30 & 50 \\
& $o$ & $11 \overline{2} \overline{1}$ & $41 \overline{2}$ & 0 & 70 \\
$\bar{p}$ & & $22 \overline{4} 1$ & $71 \overline{5}$ & 0 & 80 \\
& $s$ & $52 \overline{7} 8$ & $20.5 . \overline{1}$ & 14 & 51 \\
& $t$ & $41 \overline{5} \overline{6}$ & 510 & 19 & 50 \\
$-\bar{v}$ & $-u$ & $34 \overline{7} 3$ & $13.4 \overline{8}$ & -5 & 73 \\
$-\bar{w}$ & & $34 \overline{7} 2$ & $41 \overline{3}$ & -5 & 78 \\
$-\bar{x}$ & & $12 \overline{3} 3$ & $74 \overline{2}$ & -11 & 54 \\
$-\bar{y}$ & & $26 \overline{8} 9$ & $19.13 . \overline{5}$ & -16 & 52 \\
$-\bar{z}$ & & $13 \overline{4} 4$ & $32 \overline{1}$ & -16 & 55 \\
& & $16 \overline{7} 8$ & $16.13 . \overline{5}$ & -22 & 52 \\
\hline
\end{tabular}

character of the mineral, and it has not been possible to index the X-ray powder-spacing data obtained from material recrystallized by heat.

\section{Physical properties}

Fracture (of metamict material) subconchoidal to uneven. Brittle. Hardness about 6 . Specific gravity 4.5, doubtless varying with the degree of alteration and the composition, but correlated data are lacking; the specific gravity of crystalline davidite is not known. Luster vitreous to submetallic and shining. Fresh surfaces black or grayish black; slightly oxidized or altered surfaces are brownish black, dark brown, or reddish. Streak grayish black to dark brown. Material containing large amounts of inclusions (South Australia) has a metallic luster and a hackly fracture. Opaque; very thin splinters are translucent and clove brown or reddish brown. Not fluorescent.

\section{Optical properties}

Crushed grains are isotropic (metamict). Color in transmitted light, brown or reddish brown. Index of refraction about 2.3. Light gray and isotropic in polished section. The davidite from Radium Hill contains numerous inclusions, chiefly hematite, rutile, and ilmenite as remnants after replacement. 
Thermal behavior

The materials from South Australia and Mozambique are metamict, but recrystallize after powdering and heating to high temperature. Bannister and Horne (1950) find that both minerals apparently recrystallize as single-phase systems when heated in a nonoxidizing nitrogen atmosphere at $1,000^{\circ} \mathrm{C}$. A different product results when the metamict material is heated in air. Kerr and Holland (1951) reported that the differential thermal analysis curves of the South Australia and Mozambique material are similar, with major exothermic peaks at about $680^{\circ} \mathrm{C}$ (possibly due to oxidation) and at about $800^{\circ} \mathrm{C}$. X-ray powder study of heated material indicates that the material from the two localities is essentially the same, although the X-ray patterns of the two minerals show some differences in detail.

Synthesis

No data.

Identification

Davidite closely resembles ilmenite, from which it differs in being metamict and in containing considerable amounts of uranium. X-ray powder-spacing data for heated davidite from the two known localities are given in the table on the following page.

Natural formation and occurrence

Davidite is a primary mineral. It was originally described from Radium Hill, 20 miles east southeast of Olary, South Australia. It occurs there as rough crystals and irregular masses and grains in high-temperature hydrothermal lodes containing quartz, biotite, hematite, ilmenite, magnetite, rutile, and iron and copper sulfides. Details of the occurrence have been given by Mawson (1916, 1944), Whittle (1954b), Sprigg (1954), and Parkin and Glasson (1954). Carnotite occurs as films and fracture fillings as a weathering product of the davidite. Davidite also has been reported in South Australia at Crockers Well and Beinbowrie in the Olary district and a mineral somewhat analogous to davidite has been described (with an analysis of an impure sample) from Houghton, near Adelaide (Whittle, 1954a; Webb and Whittle, 1954). Davidite or a mineral closely related to it occurs at Mavusi in the Tete district of Mozambique, Portuguese East Africa. It occurs both massive and as large crystals in a scapolite-calcitedolomite rock and in epidiorite formed along shear zones in norite and anorthosites. (See Bannister and Horne, 1950, and Luna and Freitas, 1954.) Associated minerals include rutile, sphene, magnetite, ilmenite, apatite, tourmaline, and molybdenite. 
$X$-ray powder-spacing data for davidite ${ }^{1}$

\begin{tabular}{|c|c|c|c|c|c|c|c|}
\hline \multicolumn{4}{|c|}{ KERR AND HOLLAND (1951) } & \multicolumn{4}{|c|}{ BANNISTER AND HORNE (1950) } \\
\hline \multicolumn{2}{|c|}{$\begin{array}{l}\text { COPPER RADIATION } \\
\text { MOZAMBIQUE }\end{array}$} & \multicolumn{2}{|c|}{$\begin{array}{c}\text { COPPER RADIATION } \\
\text { SOUTH } \\
\text { AUSTRALIA }\end{array}$} & \multicolumn{2}{|c|}{$\begin{array}{l}\text { COBALT RADIATION } \\
\text { MOZAMBIQUE }\end{array}$} & \multicolumn{2}{|c|}{$\begin{array}{c}\text { COBALT RADIATION } \\
\text { SOUTH } \\
\text { AUSTRALIA }\end{array}$} \\
\hline$d(\mathrm{~A})$ & $I$ & $d(\mathrm{~A})$ & $I$ & $d(\mathrm{~A})$ & $I$ & $d(\mathrm{~A})$ & $I$ \\
\hline $\begin{array}{r}6.71 \\
5.16 \\
4.47 \\
4.15 \\
3.40 \\
3.23 \\
3.05 \\
2.87 \\
2.62 \\
2.48 \\
2.42 \\
2.25 \\
2.19 \\
2.10 \\
2.03 \\
1.96 \\
1.91 \\
1.84 \\
1.80 \\
1.78 \\
1.70 \\
1.60 \\
1.57 \\
1.55 \\
1.51 \\
1.44 \\
1.38 \\
1.12 \\
1.07 \\
.90 \\
.89 \\
.86 \\
.83 \\
.82\end{array}$ & $\begin{array}{r}2 \\
1 \\
2 \\
6 \\
9 \\
8 \\
8 \\
10 \\
3 \\
8 \\
3 \\
8 \\
3 \\
2 \\
1 \\
2 \\
4 \\
2 \\
6 \\
1 \\
9 \\
5 \\
1 \\
1 \\
3 \\
7 \\
4 \\
1 \\
2 \\
3 \\
2 \\
3 \\
3 \\
1\end{array}$ & $\begin{array}{l}3.42 \\
3.25 \\
3.08 \\
2.86 \\
2.65 \\
2.49 \\
2.44 \\
2.26 \\
2.20 \\
2.15 \\
2.09 \\
2.04 \\
1.97 \\
1.92 \\
1.85 \\
1.81 \\
1.78 \\
1.71 \\
1.69 \\
1.65 \\
1.60 \\
1.58 \\
1.55 \\
1.51 \\
1.44\end{array}$ & $\begin{array}{r}6 \\
6 \\
3 \\
10 \\
2 \\
7 \\
3 \\
7 \\
4 \\
1 \\
1 \\
4 \\
1 \\
2 \\
2 \\
8 \\
2 \\
8 \\
8 \\
1 \\
9 \\
2 \\
2 \\
1 \\
9\end{array}$ & $\begin{array}{l}4.1 \\
3.64 \\
3.37 \\
3.21 \\
3.03 \\
2.96 \\
2.86 \\
2.82 \\
2.74 \\
2.62 \\
2.58 \\
2.49 \\
2.46 \\
2.41 \\
2.23 \\
2.18 \\
2.12 \\
1.91 \\
1.89 \\
1.80 \\
1.70 \\
1.69 \\
1.59 \\
1.54 \\
1.51 \\
1.435 \\
1.373 \\
1.364 \\
1.213 \\
1.153 \\
1.123\end{array}$ & $\begin{array}{r}5 \\
3 \\
7 \\
7 \\
6 \\
6 \\
8 \\
7 \\
4 \\
4 \\
4 \\
5 \\
5 \\
4 \\
8 \\
4 \\
7 \\
4 \\
4 \\
7 \\
10 \\
10 \\
8 \\
4 \\
4 \\
9 \\
7 \\
7 \\
6 \\
5 \\
6\end{array}$ & $\begin{array}{l}3.45 \\
3.41 \\
3.32 \\
3.22 \\
3.03 \\
2.97 \\
2.48 \\
2.46 \\
2.42 \\
2.24 \\
2.19 \\
2.13 \\
1.97 \\
1.90 \\
1.86 \\
1.80 \\
1.70 \\
1.68 \\
1.62 \\
1.60 \\
1.54 \\
1.436 \\
1.370 \\
1.357 \\
1.349 \\
1.096 \\
1.042\end{array}$ & $\begin{array}{r}5 \\
5 \\
5 \\
8 \\
2 \\
2 \\
6 \\
5 \\
4 \\
5 \\
5 \\
5 \\
2 \\
2 \\
5 \\
5 \\
3 \\
10 \\
4 \\
5 \\
4 \\
5 \\
3 \\
4 \\
4 \\
3 \\
6\end{array}$ \\
\hline
\end{tabular}

1 The data here cited, obtained by Bannister and Horne (1950) and Kerr and Holland (1951) on recrystallized metamict material from two localities, are not in close agreement owing presumably to differences in chemical composition and the manner of heat treatment.

\section{DELORENZITE}

Synonymy

Delorenzite Zambonini (1908). Named after Giuseppe de Lorenzo (1871- ), Italian geologist.

Composition

An oxide of $\mathrm{Y}, \mathrm{U}, \mathrm{Fe}$, and $\mathrm{Ti}$. The formula is uncertain. The mineral was originally interpreted by Zambonini as a metatitanate with the approximate ratios $\mathrm{UO}_{2} \cdot \mathrm{Y}_{2} \mathrm{O}_{3} \cdot 2 \mathrm{FeO} \cdot 24 \mathrm{TiO}_{2}$. The suggestion was made by Palache, Berman, and Frondel (1944) that it was a multiple oxide in the formula type $\mathrm{AB}_{3} \mathrm{O}_{8}$ with $\mathrm{A}=$ $\mathrm{U}, \mathrm{Fe}, \mathrm{Y}$, and $\mathrm{B}=\mathrm{Ti}$ and $\mathrm{Sn}($ ?). The matter is speculative, how- 
ever, because the state of oxidation of the $\mathrm{Fe}$ and $\mathrm{U}$ is not known. The only reported analysis, in weight percent, gave $\mathrm{FeO} 4.25, \mathrm{UO}_{2}$ 9.87, $\mathrm{Y}_{2} \mathrm{O}_{3} 14.63, \mathrm{SnO}_{2} 4.33, \mathrm{TiO}_{2} 66.03$, total 99.11 with doubtful traces of $\mathrm{Nb}$ (from Italy, šterrba-Böhm, analyst, in Zambonini, 1908).

Delorenzite is infusible before the blowpipe. The powder is decomposed by fusion in $\mathrm{KHSO}_{\mathbf{4}}$. Spectrographic analyses are lacking.

Crystallography and crystal habit

Orthorhombic, in the dipyramidal crystal class $(2 / m 2 / m 2 / m)$. Found only as crystals. These are elongated along the $c$-axis and are tabular to lath-shaped by flattening on $\{010\}$. The faces $\{110\}$ and $\{100\}$ are striated vertically, and the crystals usually are arranged in subparallel groups. The crystals closely resemble those of polycrase in habit and angles. X-ray single-crystal measurements are lacking (the crystals are metamict).

An angle table in the original unit and orientation of Zambonini (1908) is given below. Crystal drawings are given by Zambonini (1908) and Palache, Berman, and Frondel (1944).

Angle table for delorenzite

Orthorhombic; dipyramidal, $(2 / \mathrm{m} 2 / \mathrm{m} 2 / \mathrm{m})$

$a: b: c=0.3375: 1: 0.3412 ; \quad p_{0}: q_{0}: r_{0}=1.0109: 0.3412: 1$

$q_{1}: r_{1}: p_{1}=0.3375: 0.9892: 1 ; \quad r_{2}: p_{2}: q_{2}=2.9308: 2.9628: 1$

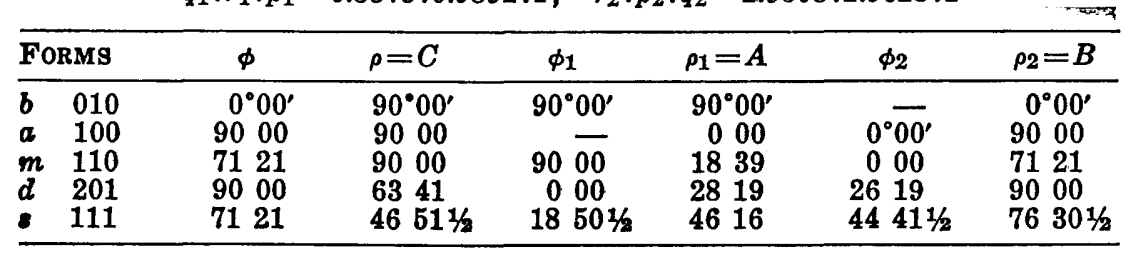

Physical properties

Fracture subconchoidal. Brittle. Hardness 51/2-6. Specific gravity about 4.7; 5.87 (Pabst, 1953a). Luster slightly resinous. Color black. Opaque in large pieces.

Optical properties

Crushed grains are chestnut brown in transmitted light. Isotropic (metamict).

Synthesis and thermal behavior

No data.

\section{Identification}

Delorenzite closely resembles several other multiple oxides containing $\mathrm{Nb}$, $\mathrm{Ta}$, or $\mathrm{Ti}$, including polycrase-euxenite, eschynitepriorite, yttrotantalite, and polymignite. It is distinguished from these in lacking $\mathrm{Nb}$ and $\mathrm{Ta}$, although these elements might well 
be expected to occur in solid solution in other occurrences of delorenzite that might be found. The X-ray powder pattern obtained on material that had been crystallized by heating at $1,000^{\circ}$ $\mathrm{C}$ for 3 hours (see table below) is very similar to that of euxenite (Pabst, written communication, 1953).

\section{$X$-ray powder-spacing data for delorenzite ${ }^{1}$}

[Copper radiation, nickel filter]

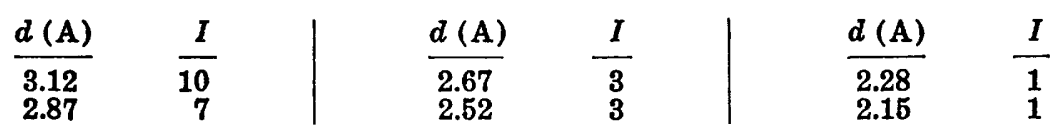

${ }^{1}$ Data obtained on metamict delorenzite from the type locality, Craveggia, Piedmont, Italy, reerystallized by heating in air at $1,000^{\circ} \mathrm{C}$.

Natural formation and occurrence

Delorenzite is a primary mineral found as crystals embedded in feldspar or granular quartz in pegmatite at Craveggia, Val Vigesso, Piedmont, Italy. It occurs associated with columbite, ilmenite, tantalian rutile (strueverite), spessartite, and beryl. 


\section{DETERMINATIVE TABLES}

The following tables are intended as an aid in the identification of uranium and thorium minerals. They list the known species that contain these elements as essential constituents on the basis of their X-ray powder interplanar $d$-spacings, chemical composition, optical properties, specific gravity, and fluorescence. Before using the tables, it is desirable first to establish the presence of uranium or thorium by chemical, radiometric, or other tests.

\section{URANIUM AND THORIUM MINERALS ARRANGED ACCORDING TO X-RAY POWDER-DIFFRACTION INTERPIANAR SPACINGS}

Table 1 lists all uranium and thorium minerals for which X-ray powder-diffraction data are available in order of decreasing spacing of the darkest line of the pattern. Minerals that show two or more darkest lines of nearly the same intensity are entered at two or more places in the table. In addition, the next three darkest lines are given for each mineral. Reference should be made to the text descriptions for a complete listing of the $d$-spacings and of the relative line intensities.

The $d$-spacings of many of the species listed in the table vary considerably because of variation in chemical composition or in content of zeolitic water. A tentative identification based on X-ray measurements should always be verified by chemical, optical, or other tests. X-ray powder-spacing data are lacking for sharpite, richetite, voglite, fritzscheite, studtite, pilbarite, kahlerite, and ferghanite, and the data given for dumontite are not considered wholly reliable.

The $d$-spacings obtained by X-ray powder photography are subject to both random and systematic sources of error. Chief among the systematic errors are those due to absorption of radiation in the sample, eccentricity in the position of the powder mount in the camera, and uncertainty as to the effective diameter of the camera. Both random and systematic sources of error in general are greater at the smaller angles of reflection (larger interplanar spacings) and hence strongly effect the darkest lines, as these in general are at relatively small angles. The random error or error in line measurement is estimated at $\pm 0.1^{\circ} 2 \theta$ or an upper limit of error of $0.35 \mathrm{~A}$ for $d$-spacings in the range $5^{\circ}-10^{\circ} 2 \theta$, $0.1 \mathrm{~A}$ in the range $10^{\circ}-30^{\circ}, 0.01 \mathrm{~A}$ in the range $30^{\circ}-90^{\circ}$, and less than $0.002 \mathrm{~A}$ for spacings with $2 \theta$ greater than $90^{\circ}$. 
TABLE 1.-Uranium and thorium minerals arranged according to $X$-ray powder-diffraction interplanar spacings

\begin{tabular}{|c|c|c|c|c|}
\hline $\begin{array}{l}\text { Darkest line } \\
\text { (angstrom) }\end{array}$ & Mineral & \multicolumn{3}{|c|}{$\begin{array}{l}\text { Three next darkest } \\
\text { lines (angstrom) }\end{array}$} \\
\hline $\begin{array}{l}13.0 \\
10.7 \\
10.33 \\
10.33 \\
10.3\end{array}$ & 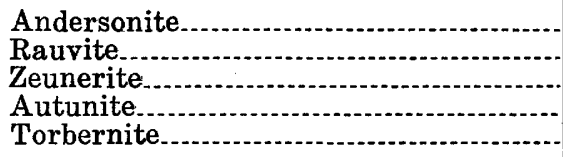 & $\begin{array}{l}7.97 \\
2.95 \\
3.60 \\
4.96 \\
4.94\end{array}$ & $\begin{array}{l}\mathbf{5 . 6 8} \\
\mathbf{3 . 4 9} \\
\mathbf{5 . 0 7} \\
\mathbf{3 . 5 9} \\
\mathbf{3 . 5 8}\end{array}$ & $\begin{array}{l}5.22 \\
2.62 \\
3.40 \\
3.49 \\
3.51\end{array}$ \\
\hline $\begin{array}{r}10.27 \\
10.18 \\
10.16 \\
10.15 \\
9.85\end{array}$ & 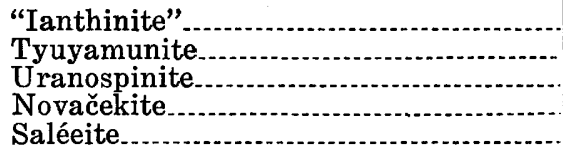 & $\begin{array}{l}5.18 \\
5.02 \\
3.56 \\
3.58 \\
3.49\end{array}$ & $\begin{array}{l}3.27 \\
3.20 \\
\mathbf{3 . 3 9} \\
\mathbf{5 . 0 6} \\
\mathbf{4 . 9 5}\end{array}$ & $\begin{array}{l}4.06 \\
2.04 \\
5.13 \\
3.35 \\
2.19\end{array}$ \\
\hline $\begin{array}{l}9.82 \\
9.69 \\
9.14 \\
9.03 \\
8.93\end{array}$ & $\begin{array}{l}\text { Sengierite } \\
\text { Sabugalite } \\
\text { Abernathyite... } \\
\text { Hydrogen autunite } \\
\text { Metazeunerite. }\end{array}$ & $\begin{array}{l}4.91 \\
4.86 \\
3.84 \\
3.80 \\
3.72\end{array}$ & $\begin{array}{l}3.735 \\
\mathbf{3 . 4 7} \\
\mathbf{3 . 3 4} \\
3.27 \\
3.30\end{array}$ & $\begin{array}{l}3.197 \\
2.19 \\
3.59 \\
3.51 \\
3.56\end{array}$ \\
\hline $\begin{array}{l}8.85 \\
8.76 \\
8.76 \\
8.68 \\
8.66\end{array}$ & $\begin{array}{l}\text { Uranospinite. } \\
\text { Metazeunerite } \\
\text { Swartzite.... } \\
\text { Liebigite.... } \\
\text { Metatorbernite. }\end{array}$ & $\begin{array}{l}3.59 \\
3.71 \\
5.50 \\
6.81 \\
3.69\end{array}$ & $\begin{array}{l}3.34 \\
3.28 \\
7.31 \\
\mathbf{5 . 4 0} \\
\mathbf{3 . 2 4}\end{array}$ & $\begin{array}{l}5.10 \\
3.55 \\
4.82 \\
4.55 \\
3.51\end{array}$ \\
\hline $\begin{array}{l}8.59 \\
8.51 \\
8.51 \\
8.43 \\
8.42\end{array}$ & $\begin{array}{l}\text { Troegerite } \\
\text { Metatyuyamunite } \\
\text { Meta-autunite } \\
\text { Metatyuyamunite. } \\
\text { Sklodowskite.... }\end{array}$ & $\begin{array}{l}3.79 \\
4.22 \\
3.50 \\
4.17 \\
4.19\end{array}$ & $\begin{array}{l}3.30 \\
3.25 \\
3.63 \\
3.28 \\
3.27\end{array}$ & $\begin{array}{l}4.35 \\
3.04 \\
3.24 \\
3.03 \\
3.52\end{array}$ \\
\hline $\begin{array}{l}8.24 \\
8.19 \\
8.18 \\
7.97 \\
7.95\end{array}$ & $\begin{array}{l}\text { Rabbittite } \\
\text { Meta-uranocircite. } \\
\text { Cuprosklodowskite } \\
\text { Andersonite. } \\
\text { Renardite. }\end{array}$ & $\begin{array}{c}11.28 \\
3.58 \\
4.09 \\
13.0 \\
3.11\end{array}$ & $\begin{array}{l}4.37 \\
5.37 \\
2.97 \\
5.68 \\
2.88\end{array}$ & $\begin{array}{r}4.71 \\
2.08 \\
4.82 \\
5.22 \\
10.25\end{array}$ \\
\hline $\begin{array}{l}7.88 \\
7.83 \\
7.83 \\
7.73 \\
7.66 \\
7.63 \\
7.58 \\
7.53 \\
7.50 \\
7.49\end{array}$ & $\begin{array}{l}\text { Uranophane } \\
\text { Phosphuranylite } \\
\text { Beta-uranophane. } \\
\text { Johannite... } \\
\text { Bayleyite. } \\
\text { Epi-ianthinite } \\
\text { Ianthinite } \\
\text { Billietite } \\
\text { Becquerelite } \\
\text { Schoepite. }\end{array}$ & \begin{tabular}{|c|}
3.94 \\
3.97 \\
3.90 \\
6.16 \\
13.1 \\
3.78 \\
3.78 \\
3.77 \\
3.22 \\
3.26
\end{tabular} & $\begin{array}{l}2.99 \\
\mathbf{5 . 8 3} \\
\mathbf{3 . 5 1} \\
\mathbf{3 . 4 1} \\
\mathbf{3 . 8 3} \\
\mathbf{3 . 2 0} \\
\mathbf{3 . 5 8} \\
\mathbf{3 . 1 7} \\
\mathbf{3 . 7 5} \\
\mathbf{3 . 6 4}\end{array}$ & $\begin{array}{l}2.91 \\
2.86 \\
3.19 \\
3.87 \\
2.69 \\
3.36 \\
3.34 \\
2.03 \\
3.56 \\
2.60\end{array}$ \\
\hline $\begin{array}{l}7.31 \\
7.31 \\
7.26 \\
7.19 \\
7.12\end{array}$ & 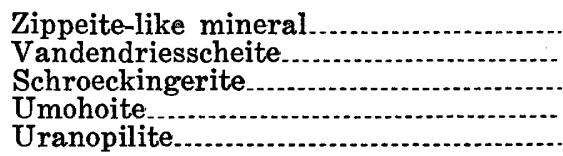 & $\begin{array}{l}3.66 \\
3.19 \\
4.796 \\
4.80 \\
9.18\end{array}$ & $\begin{array}{l}3.15 \\
3.58 \\
8.48 \\
3.60 \\
4.28\end{array}$ & $\begin{array}{c}3.51 \\
1.989 \\
2.876 \\
14.3 \\
3.65\end{array}$ \\
\hline $\begin{array}{l}7.10 \\
7.06 \\
6.81 \\
6.56 \\
6.28\end{array}$ & 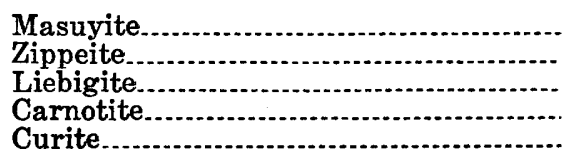 & $\begin{array}{l}3.15 \\
3.12 \\
8.68 \\
3.12 \\
3.97\end{array}$ & $\begin{array}{l}3.54 \\
3.51 \\
\mathbf{5 . 4 0} \\
\mathbf{3 . 5 3} \\
\mathbf{3 . 1 4}\end{array}$ & $\begin{array}{l}1.984 \\
2.86 \\
4.55 \\
4.25 \\
\mathbf{3 . 5 3}\end{array}$ \\
\hline
\end{tabular}


TABLE 1.-Uranium and thorium minerals arranged according to $X$-ray powder-diffraction interplanar spacings-Continued

\begin{tabular}{|c|c|c|c|c|}
\hline \multirow{2}{*}{$\begin{array}{c}\text { (angstrom) } \\
\\
6.16 \\
\text { Darkest line } \\
5.68 \\
5.50 \\
5.22 \\
5.02\end{array}$} & Mineral & \multicolumn{3}{|c|}{$\begin{array}{l}\text { Three next darkest } \\
\text { lines (angstrom) }\end{array}$} \\
\hline & $\begin{array}{l}\text { Johannite. } \\
\text { Andersonite. } \\
\text { Swartzite } \\
\text { Andersonite... } \\
\text { Tyuyamunite. }\end{array}$ & $\begin{array}{l}7.73 \\
13.0 \\
8.76 \\
13.0 \\
10.18\end{array}$ & $\begin{array}{l}3.41 \\
7.97 \\
7.31 \\
7.97 \\
3.20\end{array}$ & $\begin{array}{l}3.87 \\
5.22 \\
4.82 \\
5.68 \\
2.04\end{array}$ \\
\hline $\begin{array}{l}4.94 \\
4.89 \\
4.86 \\
4.695 \\
4.69\end{array}$ & 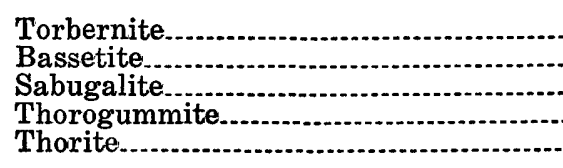 & \begin{tabular}{|l}
10.3 \\
3.46 \\
9.69 \\
3.537 \\
3.56
\end{tabular} & $\begin{array}{l}3.58 \\
8.59 \\
3.47 \\
2.653 \\
1.84\end{array}$ & $\begin{array}{l}3.51 \\
2.20 \\
2.19 \\
1.818 \\
2.66\end{array}$ \\
\hline $\begin{array}{l}4.66 \\
4.60 \\
4.48 \\
4.44 \\
4.29\end{array}$ & 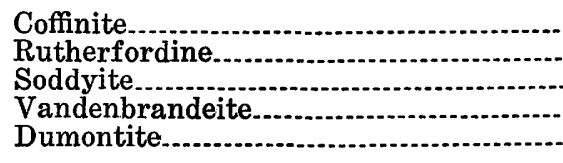 & $\begin{array}{l}3.47 \\
3.21 \\
3.32 \\
5.26 \\
3.02\end{array}$ & $\begin{array}{l}2.64 \\
4.29 \\
6.14 \\
2.97 \\
3.75\end{array}$ & $\begin{array}{l}1.801 \\
3.90 \\
2.69 \\
2.59 \\
3.49\end{array}$ \\
\hline $\begin{array}{l}4.28 \\
4.25 \\
4.09 \\
3.97 \\
3.94\end{array}$ & 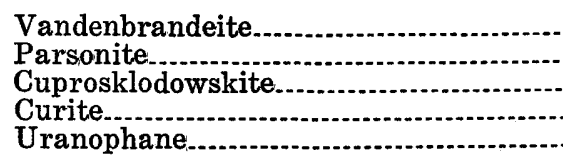 & $\begin{array}{l}2.91 \\
3.28 \\
8.18 \\
6.28 \\
7.88\end{array}$ & $\begin{array}{l}5.05 \\
2.132 \\
2.97 \\
3.14 \\
2.99\end{array}$ & $\begin{array}{l}2.55 \\
1.661 \\
4.82 \\
3.53 \\
2.91\end{array}$ \\
\hline $\begin{array}{l}3.90 \\
3.78 \\
3.77 \\
3.71 \\
\mathbf{3 . 6 9}\end{array}$ & $\begin{array}{l}\text { Beta-uranophane. } \\
\text { Epi-ianthinite..... } \\
\text { Billietite............. } \\
\text { Metazeunerite.... } \\
\text { Metatorbernite... }\end{array}$ & $\begin{array}{l}7.83 \\
7.63 \\
7.53 \\
8.76 \\
8.66\end{array}$ & $\begin{array}{l}3.51 \\
3.20 \\
3.17 \\
3.28 \\
3.24\end{array}$ & $\begin{array}{l}3.19 \\
3.36 \\
2.03 \\
3.55 \\
3.51\end{array}$ \\
\hline $\begin{array}{l}3.60 \\
3.59 \\
3.58 \\
3.56 \\
3.56\end{array}$ & $\begin{array}{l}\text { Zeunerite } \\
\text { Uranospinite. } \\
\text { Meta-uranocircite } \\
\text { Uranospinite. } \\
\text { Thorite }\end{array}$ & $\begin{array}{r}10.33 \\
8.85 \\
8.19 \\
10.16 \\
1.84\end{array}$ & $\begin{array}{l}5.07 \\
3.34 \\
2.08 \\
3.39 \\
4.69\end{array}$ & $\begin{array}{l}\mathbf{3 . 4 0} \\
\mathbf{5 . 1 0} \\
\mathbf{5 . 3 7} \\
\mathbf{4 . 9 0} \\
\mathbf{2 . 6 6}\end{array}$ \\
\hline $\begin{array}{l}3.537 \\
3.50 \\
3.49 \\
3.47 \\
3.46 \\
3.45 \\
3.43 \\
3.42 \\
\mathbf{3 . 4 1}\end{array}$ & $\begin{array}{l}\text { Thorogummite } \\
\text { Meta-autunite. } \\
\text { Saléeite } \\
\text { Coffinite } \\
\text { Bassetite } \\
\text { Fourmarierite } \\
\text { Fourmarierite. } \\
\text { Brannerite. } \\
\text { Brannerite. }\end{array}$ & $\begin{array}{l}4.695 \\
8.51 \\
9.85 \\
4.66 \\
4.89 \\
3.09 \\
3.08 \\
1.903 \\
1.903\end{array}$ & $\begin{array}{l}2.653 \\
3.63 \\
4.95 \\
2.64 \\
8.59 \\
1.907 \\
1.903 \\
2.455 \\
2.462\end{array}$ & $\begin{array}{l}1.818 \\
3.24 \\
2.19 \\
1.801 \\
2.20 \\
1.729 \\
1.990 \\
2.276 \\
2.276\end{array}$ \\
\hline $\begin{array}{l}3.41 \\
3.34 \\
3.32 \\
3.26 \\
\mathbf{3 . 2 6}\end{array}$ & $\begin{array}{l}\text { Brannerite } \\
\text { Clarkeite- } \\
\text { Soddyite-} \\
\text { Schoepite- } \\
\text { Kasolite- }\end{array}$ & $\begin{array}{l}1.903 \\
3.17 \\
4.48 \\
7.49 \\
2.93\end{array}$ & $\begin{array}{l}2.449 \\
5.77 \\
6.14 \\
3.64 \\
4.19\end{array}$ & $\begin{array}{l}2.270 \\
1.968 \\
2.69 \\
2.60 \\
\mathbf{3 . 5 3}\end{array}$ \\
\hline $\begin{array}{l}3.22 \\
3.21 \\
3.21 \\
3.20 \\
3.17\end{array}$ & $\begin{array}{l}\text { Vandendriesscheite } \\
\text { Rutherfordine... } \\
\text { Thorianite } \\
\text { Samiresite } \\
\text { Clarkeite }\end{array}$ & $\begin{array}{l}3.61 \\
4.60 \\
1.68 \\
2.50 \\
3.34\end{array}$ & $\begin{array}{l}7.41 \\
4.29 \\
1.97 \\
4.05 \\
\mathbf{5 . 7 7}\end{array}$ & $\begin{array}{l}2.55 \\
3.90 \\
2.78 \\
1.83 \\
1.968\end{array}$ \\
\hline
\end{tabular}


TABLE 1.-Uranium and thorium minerals arranged according to $X$-ray powder-diffraction interplanar spacings-Continued

\begin{tabular}{|c|c|c|c|c|}
\hline $\begin{array}{l}\text { Darkest line } \\
\text { (angstrom) }\end{array}$ & Mineral & \multicolumn{3}{|c|}{$\begin{array}{l}\text { Three next darkest } \\
\text { lines (angstrom) }\end{array}$} \\
\hline $\begin{array}{l}3.16 \\
3.14 \\
3.12 \\
\mathbf{3 . 1 1} \\
\mathbf{3 . 1 1}\end{array}$ & $\begin{array}{l}\text { Uranospherite } \\
\text { Uraninite } \\
\text { Delorenzite } \\
\text { Walpurgite- } \\
\text { Cerianite }\end{array}$ & $\begin{array}{l}3.87 \\
1.645 \\
2.87 \\
3.05 \\
1.90\end{array}$ & $\begin{array}{l}3.47 \\
1.926 \\
2.67 \\
3.25 \\
1.62\end{array}$ & $\begin{array}{l}5.25 \\
1.051 \\
2.52 \\
9.9 \\
2.69\end{array}$ \\
\hline $\begin{array}{l}3.09 \\
3.09 \\
3.08 \\
3.07 \\
3.02\end{array}$ & $\begin{array}{l}\text { Fourmarierite } \\
\text { Monazite } \\
\text { Fourmarierite- } \\
\text { Cheralite } \\
\text { Dumontite }\end{array}$ & $\begin{array}{l}3.45 \\
2.86 \\
3.43 \\
3.26 \\
4.29\end{array}$ & $\begin{array}{l}1.907 \\
3.28 \\
1.903 \\
2.86 \\
3.75\end{array}$ & $\begin{array}{l}1.720 \\
2.14 \\
1.990 \\
4.14 \\
3.49\end{array}$ \\
\hline $\begin{array}{l}2.98 \\
2.98 \\
2.96 \\
2.95 \\
2.94\end{array}$ & 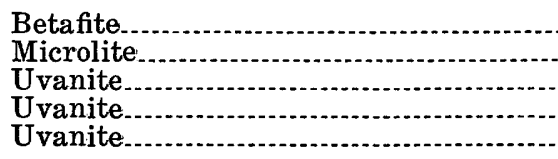 & $\begin{array}{l}1.82 \\
1.836 \\
1.71 \\
2.22 \\
1.71\end{array}$ & $\begin{array}{l}1.55 \\
1.563 \\
\mathbf{5 . 9} \\
1.70 \\
2.24\end{array}$ & $\begin{array}{l}3.99 \\
5.98 \\
2.24 \\
1.47 \\
1.48\end{array}$ \\
\hline $\begin{array}{l}2.94 \\
2.93 \\
2.93 \\
2.89 \\
2.87 \\
2.86\end{array}$ & 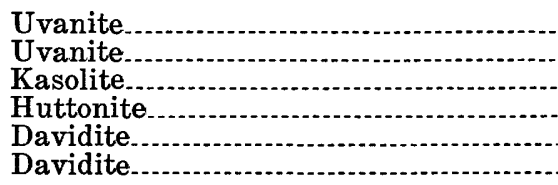 & $\begin{array}{l}4.60 \\
2.20 \\
3.26 \\
3.09 \\
1.70 \\
1.60\end{array}$ & $\begin{array}{l}5.79 \\
9.56 \\
4.19 \\
4.23 \\
\mathbf{3 . 4 0} \\
1.44\end{array}$ & $\begin{array}{l}1.71 \\
1.70 \\
3.53 \\
3.29 \\
3.23 \\
1.81\end{array}$ \\
\hline $\begin{array}{l}1.84 \\
1.70 \\
1.69 \\
1.68 \\
1.645\end{array}$ & 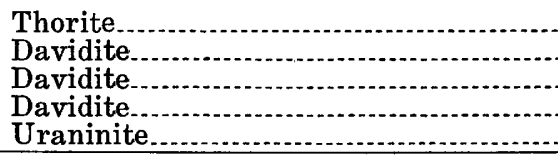 & $\begin{array}{l}3.56 \\
1.69 \\
1.70 \\
3.22 \\
3.14 \\
\end{array}$ & $\begin{array}{l}4.69 \\
1.435 \\
1.435 \\
2.48 \\
1.926\end{array}$ & $\begin{array}{l}2.66 \\
1.59 \\
1.59 \\
1.04 \\
1.05\end{array}$ \\
\hline
\end{tabular}

\section{URANIUM AND THORIUM MINERALS ARRANGED ACCORDING TO CHFMICAL COMPOSITION}

In tables 2 and 3 the known minerals that contain uranium and thorium as essential constituents are arranged according to the principal cation or cations present in addition to uranium (table 2), and according to the principal anion or anions present (table 3). The lists include only those cations or anions that occur as essential constituents in these minerals, with some exceptions, and do not include vicarious constituents that occur in small and variable amounts in solid solution. 
TABLE 2.-Known uranium and thorium minerals listed by principal cation or cations (in addition to uranium)

[The minerals that contain only uranium as the essential cation include the oxides ianthinite, epi-ianthinite, becquerelite, schoepite, masuyite, richetite(?), and uraninite; the carbonates rutherfordine, sharpite, and studtite (?); the sulfates uranopilite and zippeite; the molybdate umohoite; the phosphate troegerite; the vanadates ferghanite(?), rauvite, and uvanite; and the silicates coffinite and soddyite. These minerals are not included in the following list, but are included in table 3]

\begin{tabular}{|c|c|c|}
\hline ALUMINUM, Al & Sengierite & Pilbarite \\
\hline Sabugalite & Torbernite & Renardite \\
\hline BARIUM, Ba & Uranospathite & Richetite \\
\hline Billietite & Vandenbrandeite & Thorianite \\
\hline Meta-uranocircite & Voglite & Thorite \\
\hline BISMUTH, Bi & Zeunerite & Uraninite \\
\hline $\begin{array}{l}\text { Uranospherite } \\
\text { Walpurgite }\end{array}$ & $\begin{array}{l}\text { IRON, Fe } \\
\text { Bassetite }\end{array}$ & $\begin{array}{l}\text { Vandendriesscheite } \\
\text { RARE EARTHS, }\end{array}$ \\
\hline CALCIUM, $\mathbf{C a}$ & Brannerite & Ce, Y, La, etc. \\
\hline Andersonite & Davidite & Brannerite \\
\hline Autunite & Delorenzite & Cerianite \\
\hline Betafite & Kahlerite & Cheralite \\
\hline Beta-uranophane & Thorite & Davidite \\
\hline Brannerite & MAGNESIUM, Mg & Delorenzite \\
\hline Cheralite & Bayleyite & Monazite \\
\hline Clarkeite & Novačekite & Pisekite \\
\hline Davidite & Rabbittite & Thorite \\
\hline Gastunite & Saléeite & Thorianite \\
\hline Liebigite & Sklodowskite & Thorogummite \\
\hline Meta-autunite & Swartzite & TIN, Sn \\
\hline Metatyuyamunite & MANGANESE, Mn & Pisekite \\
\hline Microlite & Fritzscheite & Delorenzite \\
\hline Phosphuranylite & POTASSIUM, $\mathbf{K}$ & THORIUM, Th \\
\hline Pyrochlore & Abernathyite & Brannerite \\
\hline Rabbittite & Carnotite & Cerianite \\
\hline Rauvite & Clarkeite & Cheralite \\
\hline Schroeckingerite & SODIUM, Na & Davidite \\
\hline Swartzite & Andersonite & Huttonite \\
\hline Tyuyamunite & Clarkeite & Monazite \\
\hline Unnamed mineral of & Microlite & Pilbarite \\
\hline Bignand (1954) & Pyrochlore & Pisekite \\
\hline Uranophane & Schroeckingerite & Thorianite \\
\hline Uranospinite & LEAD, $\mathrm{Pb}^{1}$ & Thorite \\
\hline Voglite & Cheralite & Thorogummite \\
\hline CHROMIUM, Cr & Clarkeite & Uraninite \\
\hline Davidite & Curite & TITANIUM, Ti \\
\hline COPPER, $\mathrm{Cu}$ & Dewindtite & Betafite \\
\hline Cuprosklodowskite & Dumontite & Brannerite \\
\hline Johannite & Fourmarierite & Davidite \\
\hline Metatorbernite & Gastunite & Delorenzite \\
\hline Metazeunerite & Kasolite & ZIRCONIUM, Zr \\
\hline Peligotite & Parsonsite & Davidite \\
\hline
\end{tabular}

1 All uranium and thorium minerals contain some lead owing to radioactive decay. 
TABLE 3.-Known uranium and thorium minerals listed by principal anion or anions present

Becquerelite, $7 \mathrm{UO}_{3} \cdot 11 \mathrm{H}_{2} \mathrm{O}$

\section{OXIDES}

Billietite, $\mathrm{BaO} \cdot 6 \mathrm{UO}_{3} \cdot 11 \mathrm{H}_{2} \mathrm{O}$

Cerianite. $\mathrm{CeO}_{2}$

Clarkeite, $(\mathrm{Na}, \mathrm{K}, \mathrm{Ca}, \mathrm{Pb}) \mathrm{U}_{2} \mathrm{O}_{7} \cdot n \mathrm{H}_{2} \mathrm{O}$

Curite, $\mathrm{PbO} \cdot 8 \mathrm{UO}_{3} \cdot 4 \mathrm{H}_{2} \mathrm{O}$

Epi-ianthinite, hydrated uranyl oxide

Fourmarierite, $\mathrm{PbO} \cdot 4 \mathrm{UO}_{3} \cdot 5 \mathrm{H}_{2} \mathrm{O}$

Ianthinite, $2 \mathrm{UO}_{2} \cdot 7 \mathrm{H}_{2} \mathrm{O}$ (?)

Masuyite, $\mathrm{UO}_{3} \cdot 2 \mathrm{H}_{2} \mathrm{O}$

Richetite, hydrated oxide of $\mathrm{U}$ and $\mathrm{Pb}$ (?)

Schoepite, $2 \mathrm{UO}_{3} \cdot 5 \mathrm{H}_{2} \mathrm{O}$

Thorianite, $\mathrm{ThO}_{2}$

Uraninite, $\mathrm{UO}_{2}$

Uranospherite, $(\mathrm{BiO})\left(\mathrm{UO}_{2}\right)(\mathrm{OH})_{3}($ ?)

Vandenbrandeite, $\mathrm{Cu}\left(\mathrm{UO}_{2}\right) \mathrm{O}_{2} \cdot 2 \mathrm{H}_{2} \mathrm{O}$

- Vandendriesscheite, $\mathrm{PbO} \cdot 7 \mathrm{UO}_{3} \cdot 12 \mathrm{H}_{2} \mathrm{O}$

\section{FLUORIDES}

Schroeckingerite, $\mathrm{NaCa}\left(\mathrm{UO}_{2}\right)\left(\mathrm{CO}_{3}\right)_{3}\left(\mathrm{SO}_{4}\right) \mathrm{F} \cdot 10 \mathrm{H}_{2} \mathrm{O}$

\section{CARBONATES}

Andersonite, $\mathrm{Na}_{2} \mathrm{Ca}\left(\mathrm{UO}_{2}\right)\left(\mathrm{CO}_{3}\right)_{3} \cdot 6 \mathrm{H}_{2} \mathrm{O}$

Bayleyite, $\mathrm{Mg}_{2}\left(\mathrm{UO}_{2}\right)\left(\mathrm{CO}_{3}\right)_{3} \cdot 18 \mathrm{H}_{2} \mathrm{O}$

Liebigite, $\mathrm{Ca}_{2}\left(\mathrm{UO}_{2}\right)\left(\mathrm{CO}_{3}\right)_{3} \cdot 10 \mathrm{H}_{2} \mathrm{O}$

Rabbittite, $\mathrm{Ca}_{3} \mathrm{Mg}_{3}\left(\mathrm{UO}_{2}\right)_{2}\left(\mathrm{CO}_{3}\right)_{6}(\mathrm{OH})_{4} \cdot 18 \mathrm{H}_{2} \mathrm{O}$

Rutherfordine, $\left(\mathrm{UO}_{2}\right)\left(\mathrm{CO}_{3}\right)$

Schroeckingerite, $\mathrm{NaCa}_{3}\left(\mathrm{UO}_{2}\right)\left(\mathrm{CO}_{3}\right)_{3}\left(\mathrm{SO}_{4}\right) \mathrm{F} \cdot 10 \mathrm{H}_{2} \mathrm{O}$

Sharpite, $\left(\mathrm{UO}_{2}\right)\left(\mathrm{CO}_{3}\right) \cdot \mathrm{H}_{2} \mathrm{O}($ ?)

Studtite, hydrated carbonate of $\mathrm{U}($ ?)

Swartzite, $\mathrm{CaMg}\left(\mathrm{UO}_{2}\right)\left(\mathrm{CO}_{3}\right)_{3} \cdot 12 \mathrm{H}_{2} \mathrm{O}$

Unnamed mineral of Bignand (1954), Ca, U, hydrated carbonate

Voglite, $\mathrm{Ca}_{2} \mathrm{Cu}\left(\mathrm{UO}_{2}\right)\left(\mathrm{CO}_{3}\right)_{4} \cdot 6 \mathrm{H}_{2} \mathrm{O}$ (?)

\section{SULFATES}

Johannite, $\mathrm{Cu}\left(\mathrm{UO}_{2}\right)_{2}\left(\mathrm{SO}_{4}\right)_{2}(\mathrm{OH})_{2} \cdot 6 \mathrm{H}_{2} \mathrm{O}$

Uranopilite, $\left(\mathrm{UO}_{2}\right)_{6}\left(\mathrm{SO}_{4}\right)(\mathrm{OH})_{10} \cdot 12 \mathrm{H}_{2} \mathrm{O}$

Zippeite, $2 \mathrm{UO}_{3} \cdot \mathrm{SO}_{3} \cdot 5 \mathrm{H}_{2} \mathrm{O}$

Peligotite (=johannite?)

Umohoite, $\left(\mathrm{UO}_{2}\right)\left(\mathrm{MoO}_{4}\right) \cdot 4 \mathrm{H}_{2} \mathrm{O}$

\section{MOLYBDATES}

ARSENATES

Abernathyite, $\mathrm{K}_{2}\left(\mathrm{UO}_{2}\right)\left(\mathrm{AsO}_{4}\right)_{2} \cdot 8 \mathrm{H}_{2} \mathrm{O}$

Kahlerite, $\mathrm{Fe}\left(\mathrm{UO}_{2}\right)_{2}\left(\mathrm{AsO}_{4}\right)_{2} \cdot 8 \mathrm{H}_{2} \mathrm{O}$

Metazeunerite, $\mathrm{Cu}\left(\mathrm{UO}_{2}\right)_{2}\left(\mathrm{AsO}_{4}\right)_{2} \cdot 8 \mathrm{H}_{2} \mathrm{O}$

Novacekite, $\mathrm{Mg}\left(\mathrm{UO}_{2}\right)_{2}\left(\mathrm{AsO}_{4}\right)_{2} \cdot 8-10 \mathrm{H}_{2} \mathrm{O}$

Troegerite, $\mathrm{H}_{2}\left(\mathrm{UO}_{2}\right)_{2}\left(\mathrm{AsO}_{4}\right)_{2} \cdot 8 \mathrm{H}_{2} \mathrm{O}$

Uranospathite, $\mathrm{Cu}\left(\mathrm{UO}_{2}\right)_{2}\left(\mathrm{AsO}_{4}, \mathrm{PO}_{4}\right)_{2} \cdot 16 \mathrm{H}_{2} \mathrm{O}$ (?)

Uranospinite, $\mathrm{Ca}\left(\mathrm{UO}_{2}\right)_{2}\left(\mathrm{AsO}_{4}\right)_{2} \cdot 10_{2} \mathrm{HO}$

Walpurgite, $\mathrm{Bi}_{4}\left(\mathrm{UO}_{2}\right)\left(\mathrm{AsO}_{4}\right)_{2} \mathrm{O}_{4} \cdot 3 \mathrm{H}_{2} \mathrm{O}$

Zeunerite, $\mathrm{Cu}\left(\mathrm{UO}_{2}\right)_{2}\left(\mathrm{AsO}_{4}\right)_{2} \cdot 10-16 \mathrm{H}_{2} \mathrm{O}$ 
TABLE 3.-Known uranium and thorium minerals listed by principal anion or anions-Continued

\section{PHOSPHATES}

Autunite, $\mathrm{Ca}\left(\mathrm{UO}_{2}\right)_{2}\left(\mathrm{PO}_{4}\right)_{2} \cdot 10-12 \mathrm{H}_{2} \mathrm{O}$

Bassetite, $\mathrm{Fe}\left(\mathrm{UO}_{2}\right)_{2}\left(\mathrm{PO}_{4}\right)_{2} \cdot 8 \mathrm{H}_{2} \mathrm{O}$

Cheralite, ( $\mathrm{Th}, \mathrm{Ca}, \mathrm{Ce}, \mathrm{U}, \mathrm{Pb}),\left(\mathrm{PO}_{4}, \mathrm{SiO}_{4}\right)$

Dewindtite, $\mathrm{Pb}_{3}\left(\mathrm{UO}_{2}\right)_{6}\left(\mathrm{PO}_{4}\right)_{4}(\mathrm{OH})_{6} \cdot 10 \mathrm{H}_{2} \mathrm{O}($ ?)

Dumontite, $\mathrm{Pb}_{2}\left(\mathrm{UO}_{2}\right)_{3}\left(\mathrm{PO}_{4}\right)_{2}(\mathrm{OH})_{4} \cdot 3 \mathrm{H}_{2} \mathrm{O}$

Fritzscheite, $\mathrm{Mn}\left(\mathrm{UO}_{2}\right)_{2}\left(\mathrm{PO}_{4}, \mathrm{VO}_{4}\right)_{2} \cdot 8 \mathrm{H}_{2} \mathrm{O}$ (?)

Meta-autunite, $\mathrm{Ca}\left(\mathrm{UO}_{2}\right)_{2}\left(\mathrm{PO}_{4}\right)_{2} \cdot 8 \mathrm{H}_{2} \mathrm{O}$

Metatorbernite, $\mathrm{Cu}\left(\mathrm{UO}_{2}\right)_{2}\left(\mathrm{PO}_{4}\right)_{2} \cdot 8 \mathrm{H}_{2} \mathrm{O}$

Meta-uranocircite, $\mathrm{Ba}\left(\mathrm{UO}_{2}\right)_{2}\left(\mathrm{PO}_{4}\right)_{2} \cdot 8 \mathrm{H}_{2} \mathrm{O}$

Monazite, (Ce,La, Th) $\left(\mathrm{PO}_{4}\right)$

Parsonsite, $\mathrm{Pb}_{2}\left(\mathrm{UO}_{2}\right)\left(\mathrm{PO}_{4}\right)_{2} \cdot \mathrm{H}_{2} \mathrm{O}$

Phosphuranylite, $\mathrm{Ca}\left(\mathrm{UO}_{2}\right)_{4}\left(\mathrm{PO}_{4}\right)_{2}(\mathrm{OH})_{4} \cdot 7 \mathrm{H}_{2} \mathrm{O}$

Renardite, $\mathrm{Pb}\left(\mathrm{UO}_{2}\right)_{4}\left(\mathrm{PO}_{4}\right)_{2}(\mathrm{OH})_{4} \cdot 7 \mathrm{H}_{2} \mathrm{O}$

Sabugalite, $\mathrm{HAl}\left(\mathrm{UO}_{2}\right)_{4}\left(\mathrm{PO}_{4}\right) \cdot 16 \mathrm{H}_{2} \mathrm{O}$

Saléeite, $\mathrm{Mg}\left(\mathrm{UO}_{2}\right)_{2}\left(\mathrm{PO}_{4}\right)_{2} \cdot 8-10 \mathrm{H}_{2} \mathrm{O}$

Torbernite, $\mathrm{Cu}\left(\mathrm{UO}_{2}\right)_{2}\left(\mathrm{PO}_{4}\right)_{2} \cdot 10-\mathrm{H}_{2} \mathrm{O}$

Uranospathite, $\mathrm{Cu}\left(\mathrm{UO}_{2}\right)_{2}\left(\mathrm{PO}_{4}, \mathrm{AsO}_{4}\right)_{2} \cdot 16 \mathrm{H}_{2} \mathrm{O}$ (?)

VANADATES

Carnotite, $\mathrm{K}_{2}\left(\mathrm{UO}_{2}\right)_{2}\left(\mathrm{VO}_{4}\right)_{2} \cdot 1-3 \mathrm{H}_{2} \mathrm{O}$

Ferghanite, $\left(\mathrm{UO}_{2}\right)_{3}\left(\mathrm{VO}_{4}\right)_{2} \cdot 6 \mathrm{H}_{2} \mathrm{O}($ ?)

Metatyuyamunite, $\mathrm{Ca}\left(\mathrm{UO}_{2}\right)_{2}\left(\mathrm{VO}_{4}\right)_{2} \cdot 3-5 \mathrm{H}_{2} \mathrm{O}$

Rauvite, $\mathrm{CaO} \cdot 2 \mathrm{UO}_{3} \cdot 5 \mathrm{~V}_{2} \mathrm{O}_{5} \cdot 16 \mathrm{H}_{2} \mathrm{O}$

Sengierite, $\mathrm{Cu}\left(\mathrm{UO}_{2}\right)_{2}\left(\mathrm{VO}_{4}\right)_{2} \cdot 8-10 \mathrm{H}_{2} \mathrm{O}$ (?)

Tyuyamunite, $\mathrm{Ca}\left(\mathrm{UO}_{2}\right)_{2}\left(\mathrm{VO}_{4}\right)_{2} \cdot 5-8 \mathrm{H}_{2} \mathrm{O}$

Uvanite, $\mathrm{U}_{2} \mathrm{~V}_{6} \mathrm{O}_{21} \cdot 15 \mathrm{H}_{2} \mathrm{O}$

\section{SILICATES}

Beta-uranophane, $\mathrm{Ca}\left(\mathrm{UO}_{2}\right)_{2}\left(\mathrm{SiO}_{3}\right)_{2}(\mathrm{OH})_{2} \cdot 5 \mathrm{H}_{2} \mathrm{O}$

Cheralite, (Th,Ca,Ce,U,Pb) $\left(\mathrm{PO}_{4}, \mathrm{SiO}_{4}\right)$

Coffinite, $\mathrm{U}\left(\mathrm{SiO}_{4}\right)_{1-\mathrm{x}}(\mathrm{OH})_{4 \mathrm{x}}$

Cuprosklodowskite, $\mathrm{Cu}\left(\mathrm{UO}_{2}\right)_{2}\left(\mathrm{SiO}_{3}\right)_{2}(\mathrm{OH})_{2} \cdot 5 \mathrm{H}_{2} \mathrm{O}$

Gastunite, $\mathrm{Ca}, \mathrm{Pb}$ uranyl silicate

Huttonite, $\mathrm{ThSiO}_{4}$

Kasolite, $\mathrm{Pb}\left(\mathrm{UO}_{2}\right)\left(\mathrm{SiO}_{3}\right)(\mathrm{OH})_{2}$

Pilbarite, $\mathrm{PbO} \cdot \mathrm{ThO}_{2} \cdot \mathrm{UO}_{3} \cdot 2 \mathrm{SiO}_{2} \cdot 4 \mathrm{H}_{2} \mathrm{O}$

Sklodowskite, $\mathrm{Mg}\left(\mathrm{UO}_{2}\right)_{2}\left(\mathrm{SiO}_{3}\right)_{2}(\mathrm{OH})_{2} \cdot 6 \mathrm{H}_{2} \mathrm{O}$

Soddyite, $\left(\mathrm{UO}_{2}\right)_{5}\left(\mathrm{SiO}_{4}\right)_{2}(\mathrm{OH})_{2} \cdot 5 \mathrm{H}_{2} \mathrm{O}$

Thorite, ( $\mathrm{Th}, \mathrm{U}, \mathrm{Ce}, \mathrm{Fe}, \mathrm{etc}).\left(\mathrm{SiO}_{4}\right)$

Thorogummite, (Th,U,Ce,etc.) $\left(\mathrm{SiO}_{4}\right)_{1-\mathrm{x}}(\mathrm{OH})_{4 \times}$

Uranophane, $\mathrm{Ca}\left(\mathrm{UO}_{2}\right)_{2}\left(\mathrm{SiO}_{3}\right)(\mathrm{OH})_{2} \cdot 5 \mathrm{H}_{2} \mathrm{O}$

NIOBATES-TANTALATES-TITANATES (MULTIPLE OXIDES)

Betafite, (U,Ca) $(\mathrm{Nb}, \mathrm{Ta}, \mathrm{Ti})_{3} \mathrm{O}_{9} \cdot \mathrm{H}_{2} \mathrm{O}$

Brannerite, (U,Ca,Fe, Th, Y) ${ }_{3} \mathrm{Ti}_{5} \mathrm{O}_{16}$

Davidite, (Fe,Ce,La, Y,U,Ca,Zr,Th) $(\mathrm{Ti}, \mathrm{Fe}, \mathrm{V}, \mathrm{Cr})_{3}(\mathrm{O}, \mathrm{OH})_{7}$

Delorenzite, $\mathrm{UO}_{2} \cdot \mathrm{Y}_{2} \mathrm{O}_{3} \cdot 2 \mathrm{FeO} \cdot 24 \mathrm{TiO}_{2}$ (?)

Microlite, ideally $(\mathrm{Na}, \mathrm{Ca})_{2} \mathrm{Ta}_{2} \mathrm{O}_{6}(\mathrm{O}, \mathrm{OH}, \mathrm{F})$

Pisekite, contains Th,Sn,rare earths, U,Nb,Ta,Ti

Pyrochlore, ideally $\mathrm{NaCaNb}_{2} \mathrm{O}_{6} \mathrm{~F}$ 

OPIICAI PROPERTIES

Table 4 lists all uranium and thorium minerals for which data are available on the basis of their index or indices of refraction. The isotropic minerals include metamict and fine-grained anisotropic minerals for which only a mean index of refraction can be measured. The uniaxial minerals are listed in order of increasing value of $n_{o}$, and the biaxial minerals are listed in order of increasing value of $n_{Y}$. The optical properties of many uranium and thorium minerals may vary widely, owing to solid solution, variation in the content of zeolitic water, or to chemical alteration, and the observed range of variation is given in the table. Reference should be made to the text for full optical descriptions.

TABLE 4.-Indices of refraction of uranium and thorium minerals

I. ISOTROPIC MINERALS

Thorogummite

Thorite

Pilbarite

Pyrochlore-microlite

Betafite

Clarkeite

Cerianite

Thorianite

Brannerite

Davidite $n$

\begin{aligned} \hline $1.54-1.64 \\ 1.68-1.87 \\ 1.73-1.76 \\ 1.9-2.2 \\ 1.915-2.02 \\ 1.94-1.97 \\ >2.0(?) \\ \\ 2.2-2.35 \\ \\ \approx 2.26-2.30 \\ \approx 2.3\end{aligned}$

II. UNIAXIAL NEGATIVE MINERALS

Abernathyite

Autunite

Torbernite

Meta-autunite

Zeunerite

Metazeunerite

Andersonite Metatorbernite Thorite

\begin{aligned} & \multicolumn{1}{c}{$n_{0}$} \\ & 1.597 \\ & 1.55 \\ & 1.592 \\ & $1.595-1.613 \\ & 1.610 \\ & 1.643-1.651\end{aligned}$

$\frac{1}{c} n_{E}$
1.570
$1.577-1.60$
1.581
$1.585-1.600$
1.582
$1.623-1.635$

III. UNIAXIAL POSITIVE MINERALS

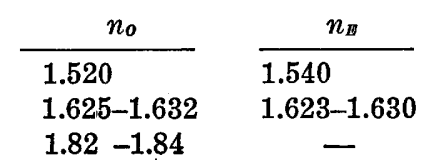


TABLE 4.-Indices of refraction of uranium and thorium minerals-Continued

IV. BIAXIAL NEGATIVE MINERALS

[Many members of the torbernite and metatorbernite groups may be either biaxial or uniaxial depending on the content of zeolitic water; most are biaxial under ordinary conditions]

Bayleyite

Swartzite

Uranospathite

Schroeckingerite

Studtite

Uranospinite

Saléeite

Autunite

Sabugalite

Johannite

Meta-autunite

Troegerite

Meta-uranocircite

Kahlerite

Sklodowskite

Novacekite

Uranophane

Cuprosklodowskite

Beta-uranophane

Soddyite

Phosphuranylite

Zippeite (proper)

Schoepite

Altered ianthinite

Renardite

Vandenbrandeite

Billietite

Epi-ianthinite

Rutherfordine

Becquerelite

Tyuyamunite

Vandendriesscheite

Parsonsite

Metatyuyamunite

Kasolite

Carnotite

Ianthinite

Masuyite

Fourmarierite

Sengierite

Walpurgite

Richetite

Curite

Clarkeite

\begin{tabular}{|c|c|c|}
\hline$n_{Y}$ & $n_{x}$ & $n_{z}$ \\
\hline 1.490 & 1.455 & 1.500 \\
\hline 1.51 & 1.465 & 1.540 \\
\hline $1.51-1.52$ & $1.48-1.49$ & $1.52-1.53$ \\
\hline $1.537-1.545$ & $1.489-1.496$ & $1.538-1.545$ \\
\hline 1.555 & 1.545 & 1.568 \\
\hline $1.567-1.584$ & $1.55-1.56$ & $1.57-1.59$ \\
\hline $1.570-1.582$ & $1.554-1.565$ & $1.571-1.585$ \\
\hline $1.575-1.59$ & 1.533 & $1.577-1.60$ \\
\hline $1.581-1.583$ & 1.564 & $1.583-1.585$ \\
\hline $1.592-1.597$ & $1.572-1.577$ & $1.612-1.616$ \\
\hline $1.595-1.610$ & $1.585-1.600$ & $1.595-1.613$ \\
\hline $1.620-1.630$ & $1.584-1.600$ & $1: 623-1.630$ \\
\hline $1.621-1.623$ & 1.610 & 1.623 \\
\hline 1.632 & - & 1.634 \\
\hline 1.635 & 1.613 & 1.657 \\
\hline $1.637-1.641$ & $1.620-1.625$ & $1.637-1.641$ \\
\hline $1.661-1.667$ & $1.642-1.648$ & $1.667-1.675$ \\
\hline $1.664-1.667$ & 1.655 & $1.664-1.667$ \\
\hline $1.682-1.723$ & $1.661-1.678$ & $1.688-1.730$ \\
\hline 1.685 & $1.650-1.654$ & $1.699-1.715$ \\
\hline $1.699-1.73$ & $1.65-1.69$ & $1.70-1.73$ \\
\hline $1.71-1.72$ & $1.64-1.66$ & $1.76-1.77$ \\
\hline $1.714-1.730$ & $1.685-1.705$ & $1.730-1.740$ \\
\hline 1.730 & 1.695 & 1.790 \\
\hline $1.736-1.741$ & $1.715-1.721$ & $1.716-1.740$ \\
\hline $1.78-1.792$ & $1.76-1.77$ & 1.80 \\
\hline $1.780-1.832$ & $1.725-1.733$ & $1.790-1.839$ \\
\hline 1.79 & 1.70 & 1.793 \\
\hline $1.728-1.730$ & $1.720-1.723$ & $1.755-1.760$ \\
\hline $1.805-1.825$ & $1.725-1.75$ & $1.82-1.835$ \\
\hline $1.805-1.87$ & $1.57-1.67$ & $1.85-1.89$ \\
\hline $1.81-1.88$ & $1.76-1.79$ & $1.82-1.89$ \\
\hline 1.86 & $1.85-1.87$ & $1.86-1.89$ \\
\hline 1.835-1.842 & $1.62-1.68$ & $1.865-1.899$ \\
\hline $1.880-1.91$ & $1.877-1.90$ & $1.935-1.97$ \\
\hline $1.90-2.06$ & $1.75-1.78$ & $1.92-2.08$ \\
\hline 1.90 & 1.674 & 1.92 \\
\hline 1.906 & 1.785 & 1.917 \\
\hline $1.90-1.92$ & $1.85-1.86$ & $1.90-1.94$ \\
\hline $1.92-1.94$ & $1.76-1.77$ & $1.94-1.97$ \\
\hline $1.975-2.00$ & $1.87-1.90$ & $2.00-2.05$ \\
\hline $2.00-2.07$ & $=1.8$ & - \\
\hline $2.07-2.11$ & 2.06 & $2.12-2.15$ \\
\hline 2.098 & 1.997 & 2.108 \\
\hline
\end{tabular}


TABLE 4.-Indices of refraction of uranium and thorium minerals-Continued V. BIAXIAL POSITIVE MINERALS

Liebigite

Rabbittite

Voglite

Johannite

Bassetite

Uranopilite

Sharpite

Dewindtite

Cheralite

Monazite

Uvanite

Dumontite

Huttonite

Uranospherite

\begin{tabular}{llll}
\multicolumn{1}{c}{$n_{Y}$} & \multicolumn{2}{c}{$n_{X}$} & \multicolumn{1}{c}{$n_{Z}$} \\
1.502 & & 1.497 & 1.539 \\
1.508 & 1.502 & & 1.525 \\
$1.525-1.547$ & $1.513-1.541$ & & $1.542-1.564$ \\
$1.592-1.597$ & $1.572-1.577$ & $1.612-1.616$ \\
1.610 & 1.605 & 1.617 \\
$1.623-1.625$ & $1.621-1.623$ & $1.632-1.634$ \\
$\approx 1.67-1.72$ & 1.633 & 1.72 \\
1.768 & 1.760 & 1.770 \\
1.780 & 1.779 & 1.816 \\
$1.787-1.791$ & $1.785-1.800$ & $1.840-1.849$ \\
1.879 & 1.817 & 2.057 \\
1.89 & 1.88 & 1.90 \\
1.90 & 1.898 & 1.922 \\
1.985 & 1.955 & 2.05
\end{tabular}

\section{URANIUM AND THORIUM MINERALS ARRANGED ACCORDING TO} COLOR

The listing of table 5 on the basis of color is only a rough guide to the identification of uranium and thorium minerals and must be used with caution. The color of many uranium and thorium minerals varies widely in different specimens, attending variation in chemical composition, particle size, and other factors and the difference in color among many species although characteristic is slight and difficult to describe. The perception and description of color by different observers also varies. A number of minerals have been listed in more than one category in an effort to include at least the commonly observed variations in color.

TABLE 5.-Uranium and thorium minerals arranged by color VIOLET, VIOLET BLACK

Ianthinite

Rauvite

Rauvite (bluish black) Uranospathite

Andersonite
Cheralite
Cuprosklodowskite
Johannite
Kahlerite
Liebigite

Andersonite

Cheralite

Johannite

Liebigite
Unnamed mineral of Bignand (1954) (greenish blue)

\section{Umohoite}

BLUE, VARIOUS, SHADES

GREEN, VARIOUS SHADES

Metatorbernite
Metazeunerite
Microlite
Rabbittite
Schroeckingerite
Sengierite

Swartzite

Torbernite

Uranospathite

Vandenbrandeite

Voglite

Zeunerite 
TABLE 5.-Uranium and thorium minerals arranged by color-Continued GREENISH YELLOW TO YELLOWISH GREEN

Autunite
Andersonite
Bassetite
Beta-uranophane
Cuprosklodowskite

Bassetite

Betafite

Abernathyite
Autunite
Bassetite
Bayleyite
Beta-uranophane
Billietite
Carnotite
Dewindtite
Epi-ianthinite
Ferghanite
Masuyite
Meta-autunite

Gastunite

Kahlerite

Liebigite

Meta-autunite

Meta-uranocircite

OLIVE, VARIOUS SHADES

Brannerite

Cerianite

\section{YELLOW}

Metatyuyamunite

Novacekite

Parsonsite

Phosphuranylite

(golden yellow)

Pilbarite

Renardite

Rutherfordine

Sabugalite

Saléeite

Schoepite

Sklodowskite
Metatyuyamunite

Schroeckingerite

Sharpite

Uranophane

Uranospathite

Microlite

Uraninite

Soddyite

Studtite

Thorogummite

Troegerite

Tyuyamunite

Uranophane

Uranopilite

Uranospherite

Uranospinite

Zippeite (golden yellow)

OCHER YELLOW TO STRAW YELLOW

Betafite (outwardly)
Beta-uranophane
Kasolite
Monazite (outwardly)
Novacekite

Parsonsite

Pilbarite

Rutherfordine

Saléeite

Sklodowskite

Soddyite

Thorogummite

Uranophane

Walpurgite

\begin{tabular}{lcc}
\multicolumn{4}{c}{ BROWNISH } & YELLOW TO YELLOWISH BROWN \\
Bassetite & Monazite & Thorite \\
Becquerelite & Parsonsite & Thorogummite \\
Betafite & Pyrochlore & Uvanite \\
Billietite & Schoepite & Vandendriesscheite \\
Kasolite & Soddyite & \\
& BROWN AND REDDISH BROWN \\
Clarkeite & Monazite & Thorianite \\
Huttonite & Pyrochlore & Thorite \\
Kasolite & Rauvite & Thorogummite \\
& ORANGE, VARIOUS SHADES \\
Kasolite & Thorite & Vandendriesscheite \\
Masuyite & Uranospherite & Zippeite \\
& ORANGE RED TO RED \\
Curite & Pyrochlore & \\
Fourmarierite & Vandendriesscheite
\end{tabular}


TABLE 5.-Uranium and thorium minerals arranged by color-Continued

\section{BLACK AND BROWNISH BLACK}

$\begin{array}{lll}\text { Betafite } & \text { Pisekite } & \text { Thorianite } \\ \text { Brannerite } & \text { Pyrochlore } & \text { Thorite } \\ \text { Davidite } & \text { Rauvite } & \text { Umohoite } \\ \text { Delorenzite } & \text { Richetite } & \text { Uraninite }\end{array}$

\section{Davidite}

Thorianite

GRAY, GREENISH GRAY, BLACKISH GRAY
Thorogummite

Uraninite

Thorogummite

\section{Bayleyite}

WHITE TO CREAM
Huttonite

\section{URANIOM AND THORIOM MINERALS ARRANGED ACCORDING TO SPECIFIC GRAVITY}

The listing in table 6 is in order of increasing value of the measured specific gravity. For many of the minerals a range of values is given. The range may express lack of precision in the reported experimental values, especially in powdery or fibrous minerals, or it may reflect variation in the chemical composition of the mineral such as the mutual substitution of different cations or anions or variation in the content of zeolitic water. For some minerals only a single determination of the specific gravity is available, although a variation may be expected from the known nature of the mineral. Reference should be made to the text for a further discussion of these matters in specific instances. The table in general is useful only as a rough guide for determinative purposes. Data on the specific gravity are lacking for a number of uranium minerals.

TABLE 6.-Specific gravity of uranium and thorium minerals

\begin{tabular}{ll|ll}
2.05 & Bayleyite & 3.32 & Johannite \\
$\mathbf{2 . 3}$ & Swartzite & $>3.3$ & Sharpite \\
$\mathbf{2 . 4 1}$ & Liebigite & $\approx 3.4$ & Bassetite \\
$\mathbf{2 . 5 0}$ & Uranospathite & 3.45 & Uranospinite \\
$\mathbf{2 . 5 5}$ & Schroeckingerite & 3.47 & Zeunerite \\
$\mathbf{2 . 5 7}$ & Rabbittite & $3.5 ;$ variable & Meta-autunite \\
$\mathbf{2 . 8}$ & Andersonite & 3.5 & Fritzscheite \\
$\mathbf{3 . 0 5 - 3 . 2}$ & Autunite & $\approx 3.6$ & Zippeite \\
3.2; variable, & Saléeite & 3.64 & Metazeunerite \\
larger & & $3.7 ;$ variable & Novacekite \\
3.2 & Sabugalite & lower & \\
3.2-5.4 & Thorogummite & 3.7 & Abernathyite \\
$\mathbf{3 . 2}$ & Torbernite & $3.7-3.8$ & Metatorbernite \\
$\mathbf{3 . 3 - 3 . 5}$ & Troegerite & $3.7-3.9$ & Uranophane \\
$\mathbf{3 . 3 - 3 . 6}$ & Tyuyamunite & $3.7-4.9$ & Betafite \\
$\mathbf{3 . 3 1}$ & Ferghanite & 3.77 & Sklodowskite
\end{tabular}


TABLE 6.-Specific gravity of uranium and thorium minerals-Continued

\begin{tabular}{|c|c|c|c|}
\hline $3.8-3.9$ & Metatyuyamunite & 5.1 ; variable, & Coffinite \\
\hline 3.9 & Beta-uranophane & lower & \\
\hline 3.96 & Uranopilite & 5.1-5.2; & Becquerelite \\
\hline 4.03 & Pisekite & also 5.6 & \\
\hline 4.08 & Meta-uranocircite & $5.3-5.4$ & Billietite \\
\hline 4.1 & Phosphuranylite & 5.35 & Cuprosklodowskite \\
\hline $\begin{array}{l}4.1-6.7 ; 4.3-5.4 \\
\text { usually }\end{array}$ & Thorite & $\begin{array}{l}5.3 \\
5.7\end{array}$ & Cheralite \\
\hline $4.2-5.4$ & Brannerite & 5.7 , and lower & Rutherfordine \\
\hline 4.3 ; variable & Pyrochlore & 5.74 & Fourmarierite \\
\hline 4.3 & Renardite & $5.7-5.9$ & Walpurgite \\
\hline 4.4 & Sengierite & $5.8-6.0$ & Kasolite \\
\hline 4.5; variable & Davidite & 6.36 & Uranospherite \\
\hline $4.5-4.7$ & Umohoite & 6.3; variable & Microlite \\
\hline $4.6-5.4$ & Monazite & $6.3-6.4$ & Clarkeite \\
\hline $4.6-5.6$ & Vandendriesscheite & 7.1 & Huttonite \\
\hline $4.7 ; 5.9$ & Delorenzite & 7.2 (calc.) & Cerianite \\
\hline 4.70 & Soddyite & $7.2-7.4$ & Curite \\
\hline 4.7 ; often lower & Carnotite & $7.5-9.7 ; 10.9$ & Uraninite \\
\hline $4.8-5.0$ & Schoepite & (calc.) pure & \\
\hline 5.0 & Vandenbrandeite & $9.7-9.8 ; 10.0$ & Thorianite \\
\hline 5.03 & Dewindtite & (calc.) pure & \\
\hline 5.08 & Masuyite & & \\
\hline
\end{tabular}

URANIUM AND THORIUM MINERALS ARRANGFD ACCORDING TO FUUORESCENCE

The color and relative intensity of the visible fluorescence produced by ultraviolet radiation in uranium and thorium minerals are listed in tables 7 and 8 alphabetically by species (table 7 ) and by color and intensity of fluorescence (table 8). The data are for short-wave radiation ( $2537 \mathrm{~A})$ at room temperature. In longwave radiation the color of the fluorescence is in general the same but the intensity is diminished. At liquid-air or liquid-oxygen temperatures the fluorescence is either the same or more intense than that at room temperature. The data of the tables have been derived from text references and the following additional primary sources: Meixner (1940b), Przibram (1946), Haberlandt, Hernegger, and Scheminsky (1950), Horne (1951), and Bultemann (1954). In a number of instances where conflicting data have been reported or where information has been lacking new observations were made on identified specimens in the Harvard collection. Many descriptions of the fluorescence of uranium minerals that have appeared in popular literature and in technical works on ultraviolet radiation are of questionable value for lack of positive identification of the minerals examined.

The description of the fluorescent color and intensity is given here in broad terms because in detail these characteristics vary considerably as seen by different observers and also vary between 
different specimens of the same species. The latter variation is due to surface films or alteration, admixture, variations in particle size and degree of hydration, solid solution, and other factors.

The fluorescence of uranium minerals is an intrinsic fluorescence due to the uranyl ion, in distinction to the more common type of impurity-activated fluorescence, such as zinc orthosilicate activated by manganese. The following generalizations can be made about the fluorescence of uranium minerals:

(a) Fluorescence is not shown by minerals containing quadrivalent uranium, such as uraninite, coffinite, and uranoan varieties of the niobate-tantalates. These minerals generally are black in color and primary in origin. All of the fluorescent uranium minerals contain uranyl ion and are secondary in origin.

(b) The characteristic emission color of the strongly and moderately fluorescent uranium minerals is greenish yellow to yellowish green (except andersonite and liebigite, which are green). These minerals comprise chiefly the hydrated uranyl phosphates and arsenates containing alkaline earths, alkalies, or hydrogen (members of these groups containing copper or iron fluoresce weakly if at all) together with certain uranyl sulfates and carbonates.

(c) The uranyl silicates, uranyl vanadates, and hydrated oxides fluoresce weakly or not at all.

(d) The uranyl minerals containing lead fluoresce either weakly in yellow-brown or brown rather than yellow-green colors, or do not fluoresce at all.

(e) Dehydration in general reduces the intensity of fluorescence.

TABLE 7.-Fluorescence of uranium and thorium minerals listed alphabetically

Abernathyite

Andersonite

Autunite

Bassetite

Bayleyite

Becquerelite

Betafite

Beta-uranophane

Billietite

Brannerite

Carnotite

Cerianite

Cheralite

Clarkeite
Strong greenish yellow.

Strong green to greenish yellow.

Strong greenish yellow.

Not fluorescent.

Weak yellow green.

Weak yellow brown to brown; also dull green to not fluorescent.

Not fluorescent.

Weak greenish yellow to dull green: also not fluorescent.

Weak yellow green to dull green.

Not fluorescent.

Not fluorescent; also reported as sometimes faint yellow green. At liquid-air temperatures moderate brown fluorescence.

No data.

No data.

Not fluorescent. Synthetic $\mathrm{Na}_{2} \mathrm{U}_{2} \mathrm{O}_{7}$ fluoresces weak olive brown. 
TABLE 7.-Fluorescence of uranium and thorium minerals listed alphabetically

Coffinite

Cuprosklodowskite

Curite

Davidite

Delorenzite

Dewindtite

Dumontite

Epi-ianthinite

Ferghanite

Fourmarierite

Fritzscheite

Gastunite

Huttonite

Ianthinite

Johannite

Kahlerite

Kasolite

Liebigite

Masuyite

Meta-autunite

Metanovacekite

Metatorbernite

Metatyuyamunite

Meta-uranocircite

Metazeunerite

Microlite

Monazite

Novacekite

Parsonsite

Phosphuranylite

Pilbarite

Pisekite

Pyrochlore

Rabbittite

Renardite

Richetite

Rutherfordine

Sabugalite

Saléeite

Schoepite

Schroeckingerite

Sharpite

Sklodowskite

Soddyite

Studtite

Swartzite

\section{-Continued}

Not fluorescent.

Not fluorescent.

Not fluorescent.

Not fluorescent.

Not fluorescent.

Very weak brown or greenish to not fluorescent.

Weak greenish or not fluorescent.

Dull green to weak yellow green.

No data.

Not fluorescent.

No data.

Moderate yellow green.

Weak dull white.

Not fluorescent.

Not fluorescent.

Not fluorescent.

Not fluorescent. At liquid-air temperature weak brown.

Strong to moderate green to bluish green.

Faint green to not fluorescent.

Moderate greenish yellow (less strong than autunite).

No data; presumably yellow green.

Generally not fluorescent; sometimes weak yellow green (surface alteration or film ?).

Not fluorescent.

Moderate yellow green.

Weak yellowish green.

Not fluorescent.

Not fluorescent.

Weak green to yellowish green.

Not fluorescent.

Not fluorescent; also reported as faint yellowish brown or brown. Often brightly fluorescent in yellow green due to admixed meta-autunite.

No data.

No data.

Not fluorescent.

Weak yellow green.

Faint brown to not fluorescent.

No data.

Not fluorescent or faint green or greenish white. Strong to moderate greenish yellow.

Strong to moderate greenish yellow to yellow green.

Moderate to weak green to yellow green.

Strong yellow green to light bluish greeen.

Very weak greenish (requires verification).

Not fluorescent.

Dull orange brown to not fluorescent.

Yellow green (requires verification).

Strong yellow green. 
TABLE 7.-Fluorescence of uranium and thorium minerals listed alphabetically

Thorianite

Thorite

Thorogummite

Torbernite

Troegerite

Tyuyamunite

Umohoite

Uraninite

Uranocircite

Uranophane

Uranopilite

Uranospathite

Uranospherite

Uranospinite

Uvanite

Vandenbrandeite

Vandendriesscheite

Voglite

Walpurgite

Zeunerite

Zippeite

Zippeite-like minerals

TABLE 8. - Fluorescence of uranium and thorium minerals listed by color and intensity of fuorescence

[Note that some minerals are listed in several places]

YELLOWISH-GREEN TO GREENISH-YELLOW FLUORESCENCE

Strong to moderate intensity:

Abernathyite

Autunite

Gastunite

Meta-autunite

Metanovacekite(?)

Meta-uranocircite

Sabugalite

Saléeite

Schroeckingerite

Swartzite

Troegerito

Not fluorescent.

Faint white fluorescence when pure; black highly uranoan material does not fluoresce.

Yellow to brown thorogummite fluoresces yellowish white; black thorogummite does not fluoresce.

Generally not fluorescent; sometimes faint yellow green (surface film or alteration ?).

Strong to moderate yellow green (synthetic hydrogen uranyl arsenate).

Not fluorescent; reported as sometimes faint yellow green.

Not fluorescent.

Not fluorescent (but often coated or veined by fluorescent alteration products).

Strong to moderate yellow green.

Weak yellow green to not fluorescent; dense aggregates usually not fluorescent. At liquid-air tèmperatures brilliant yellow.

Strong yellow green to greenish yellow.

No data on authentic fully hydrated material; the dehydration product (phosphatian metazeunerite) fluoresces yellow green.

Not fluorescent.

Strong to moderate yellow green.

Not fluorescent.

Not fluorescent.

Not fluorescent or faint dull brown. At liquid-air temperatures brilliant orange.

Not fluorescent.

Not fluorescent.

Not fluorescent.

Strong to moderate yellow green.

Variable, moderate yellow green to not fluorescent.

Uranospathite (dehydrated)

Uranopilite

Uranocircite

Uranospinite

Zippeite

Weak intensity:

Bayleyite

Beta-uranophane

Billietite

Epi-ianthinite

Metatorbernite

Metazeunerite 
TABLE 8.-Fluorescence of uranium and thorium minerals listed by color and intensity of fluorescence-Continued

YELLOWISH-GREEN TO GREENISH-YELLOW FLUORESCENCE-

Weak intensity-Continued

Continued

Novacekite

Studtite

Rabbittite

Torbernite

Schoepite

Uranophane

GREEN FLUORESCENCE

Strong to moderate intensity :

Billietite

Andersonite

Liebigite

Dewindtite

Schoepite

Dumontite

Schroeckingerite

Epi-ianthinite

Weak intensity:

Beta-uranophane

Masuyite

Novacekite

Becquerelite

Sharpite

Becquerelite

Renardite

Phosphuranylite

Soddyite

Vandendriesscheite

Huttonite

WHITE OR NEARLY WHITE FLUORESCENCE

Thorite

Betafite

Bassetite

Becquerelite

Brannerite

Carnotite

Clarkeite

Coffinite

Cuprosklodowskite

Thorogummite

Curite

Davidite

Delorenzite

Dewindtite

Dumontite

Fourmarierite

Ianthinite

NOT FLUORESCENT

Kahlerite

Phosphuranylite

Pyrochlore

Rauvite

Renardite

Rutherfordine

Sengierite

Sklodowskite

Soddyite

Thorianite

Thorite

Thorogummite

Torbernite

Tyuyamunite

Umohoite

Uraninite

Uranophane

Uranospherite

Kasolite

Johannite

Uvanite

Masuyite

Vandenbrandeite

Metatorbernite

Vandendriesscheite

Metatyuyamunite

Voglite

Microlite

Walpurgite

Monazite

Zeunerite

Parsonsite

Cerianite

Cheralite

Ferghanite

Fritzscheite

NO DATA

Pilbarite

Pisekite

Richetite

Uranospathite 


\section{REFERENCES}

Abbott, A. T., 1954, Monazite deposits in calcareous rocks, northern Lemhi County, Idaho: Idaho Bur. Mines and Geology Pamph. 99.

Adam G. J., 1869, Tableau minéralogique, Paris.

Ahlfeld, F., and Angelelli, V., 1948, Las especies minerales de la Republica Argentina: Univ. Nac. de Tucuman, Inst. Geol. y Min., Pub. 458, 304 p. Aikin, A., 1814, Manual of mineralogy, 1st ed.; London.

Alberman, K. B., and Anderson, J. S., 1949, The oxides of uranium: Chem. Soc. London Jour. 1949, Suppl. Issue no. 2, p. S303-S311.

Alberman, K. B., Blakey, R. C., and Anderson, J. S., 1951, The oxides of uranium-part II, Binary system $\mathrm{UO}_{2}-\mathrm{CaO}: \mathrm{Chem}$. Soc. London Jour. 1951, p. 1352-1356.

Alexandrov, S. P. 1927, Radiographien Tüjamujunscher Erze: Zeitschr. Kristallographie, Band 65, p. 141.

Allen, O. D., 1877, Chemical constitution of hatchettolite and samarskite from Mitchell County, North Carolina: Am. Jour. Sci., 3d ser., v. 14, p. 128-131.

Allen, R. E., 1953, Uranium and its compounds, a bibliography of unclassified literature: U. S. Atomic Energy Comm. TID-3041, 126 p., issued by U. S. Atomic Energy Comm. Tech. Inf. Service Extension, Oak Ridge, Tenn. - 1955, Thorium, a bibliography of published literature: U. S. Atomic Energy Comm. TID-3044, Supp. 1, 298 p., issued by U. S. Atomic Energy Comm. Tech. Inf. Service Extension, Oak Ridge, Tenn.

Altschuler, Z. S., Clarke, R. S., and Young, E. J., 1955, Uranium in apatite [abs.]: Am. Mineralogist, v. 40, p. 308.

Anderson, J. S., 1953, Travaux récents sur la chimie des oxydes d'uranium: Soc. chim. France Bull. 1953, p. 781-788.

Anderson, J. S., Edington, D. N., Roberts, L. E. J., and Wait, E., 1954, The oxides of uranium-part IV, The system $\mathrm{UO}_{2}-\mathrm{ThO}_{2}-\mathrm{O}: \mathrm{Chem}$. Soc. London Jour. 1954, p. 3324-3331.

Anfosso, A., 1943, La presenza della torbernite nella pegmatiti di Delianova in Calabria: Soc. naturalisti Napoli Boll. 53, p. 99.

Antipov, J., 1900, On a new deposit of uranium-mica and on natural zinc oxide from Olkusch [in Russian]: Verh. Russisch-Kaiserlich. Mineralogisches Gesellschaft St. Petersburg, ser. 2, Band 38, p. 38.

1908, Über einiger Mineralien aus russischen Lagerstätten: Gornyi Zhur. St. Petersburg, v. 4, p. 259 (Abs. in Jahrb. Min. II, p. 38, 1909).

Arendt, R., and Knop, W., 1857, Ueber Eigenschaften einiger Uransalze: Chem. Centralbl., Neue Folge, Jahrg. 2, no. 10, p. 162-166.

Armstrong, E. J., 1935, Schroeckingerite from Bedford, N. Y.: Am. Mineralogist, v. 20, p. 62-63.

Arnott, R. J., 1950, X-ray diffraction data on some radioactive oxide minerals: Am. Mineralogist, v. 35, p. 386-400.

Athanasesco, [N.], 1886, Recherches sur quelquess sulfates basiques cristallisés: Acad. Sci. Paris Comptes rendus, tome 103, p. 271-272.

Aubel, R. van, 1927, Sur la présence d'uraninite cristallisée dans les gîtes uranifères de Kasolo, Katanga: Acad. Sci. Paris Comptes rendus, tome 185, p. 586.

Axelrod, J. M., Grimaldi, F. S., Milton, C., and Murata, K. J., 1951, The uranium minerals from the Hillside Mine, Yavapai County, Arizona: Am. Mineralogist, v. 36, p. 1-22.

Bachelet, M., Cheylan, E., Douis, M., and Goulette, J. C., 1952, Préparation et propriétés des uranylcarbonates: Soc. chim. France Bull. 1952, p. 565-569. 
Bain, G. W., 1950, Geology of the fissionable materials: Econ. Geology, v. 45, p. 273-323.

Baldanza, B., 1953, Uranocircite: Periodico di Mineralogia (Rome), v. 22, p. 249.

Bannister, F. A., and Horne, J. E. T., 1950, A radioactive mineral from Mozambique related to davidite: Mineralog. Mag., v. 29, p. 101-112.

Barsanov, G. P., 1945a, Ampangabeite from the Yelisseyevka deposit, Ukraine: Acad. Sci. U. R. S. S. Comptes rendus, v. 48, p. 128-131.

- 1945b, On the secondary alteration of pyrochlore: Acad. Sci. U. R. S. S., Comptes rendus, v. 49, p. 136-139.

Bastin, E. S., 1950, Interpretation of ore textures: Geol. Soc. America Mem. $45,101 \mathrm{p}$.

Bateman, J. D., 1955, Recent uranium developments in Ontario: Econ. Geology, v. 50, p. 361-372.

Bauer, Anton, 1939, Untersuchungen zur Kenntnis der spezifisch leichten Zirkone: Neues Jahrb. Mineralogie, Beilage-Band 75, Abt. A, p. 159-204.

Bearth, P. 1934, Röntgenspektroskopische Analyse eines Turnerites aus dem Tavetsch: Schweizer. mineralog. petrog. Mitt., Band 14, p. 442-446.

Beck, C. W., 1950, Differential thermal analysis curves of carbonate minerals: Am. Mineralogist, v. 35, p. 985-1013.

Becker, A., and Jannasch, P., 1915: Jahrb, Radioaktivität und Elektronik, Band 12, p. 1.

Becquerel, Henri, 1888, Recherches sur les variations des spectres d'absorption dan les cristaux: Annales Chimie et Physique 6e sér. tome 14, p. 170-279.

1896, Sur les radiations émises par phosphorescence: Acad. Sci. Paris Comptes rendus, tome 122 , p. $420-421$.

Behrendsen, O., 1902, Über die radioactive im Uranpecherz vorkommende "fluchtige Substanz": Zeitschr. Physik, Band 3, p. 572.

Beintema, J., 1938, On the composition and the crystallography of autunite and the meta-autunites: Rec. travaux chim. Pays-Bas et Belgique, tome 57, p. 155-175.

Beiser, A., 1952, Nuclear emulsion technique: Rev. Modern Physics, v. 24, p. 273.

Benier, J., 1949, Note sur l'uranocircite de Vinaninkarena, Madagascar: Madagascar Bull. Geol. 1, p. 3.

Bergemann, C., 1851, Beiträge zur Kenntnis eines neuen metallischen Körpers: Annalen Physik, Band 82, p. 561.

Bergman, A. G., 1925, Hydration water of crystalline compounds [in Russian] : Russkogo Fiz.-Khim. Obshch. Zhur., v. 56, p. 561.

Berman, E., 1955, Unit-cell dimensions of uraninite: Am. Mineralogist, v. 40, p. 925-927.

Berman, R., in press, Studies of uranium minerals (XXI): Fully hydrated torbernite and zeunerite: Am. Mineralogist.

Bernardo Ferreira, A., and Cotelo Neiva, J. M., 1945, Jazigos uraníferos de Souto de Aguiar-da-Beira: Portugal, Serviço de Fomento Mineiro Estudos, Notas e Trabalhos, v. 1, fasc. 1-2, p. 177-189.

Bernhardi, J. J., 1809, Ueber die Grenzen der Mineralogie: Erfurt, Germany. Berzelius, J. J., 1819, Nouveau système de minéralogie: Paris, $295 \mathrm{p}$.

$1823,1824,1826$, Några försök med uranoxid och dess forening: Akad. Stockholm Handl. 152, 1823; Annalen Physik I, p. 359, 1824; Karsten's Archiv, v. 11, p. 124, 1826.

1824, Analyse de l'uranite d'Autun: Annales sci. nat., tome 1, p. 446. 
Berzelius, J. J., 1829, Undersökning af ett nytt mineral (Thorit) : Akad. Stockholm Handl. 1.

Bespalov, M. M., 1941, On the discovery of a new mineral of the thorianite group [in Russian]: Sovietskaya Geologiya, [v. 11], no. 6, p. 105-107.

Beudant, F. S., 1832, Traité élémentaire de minéralogie, 2d ed.: Paris, tome 2, p. 672 .

Bignand, C., 1955, Sur les propriétés et les synthèses de quelques minéraux uranifères: Soc. française Minéralogie et Cristallographie Bull., tome 78, p. 1-26.

Bignand, C., Goñi, J., and Guillemin, C., 1954, La phosphuranylite, ses relations avec la dewindtite et la renardite: Soc. française Minéralogie et Cristallographie Bull., tome 77, p. 1299-1306.

Billiet, V., 1926, Détermination des indices de réfraction de la becquerélite, de la curite, de la kasolite, de la fourmariéreite, de la parsonsite, de la dumontite, et de l'ianthinite: Soc. française Minéralogie Bull., tome 49, p. 136.

1936a, Het uranotielvraagstuk: Natuurk. Tijdschr. Ned.-Indië, v. 18, p. 79.

- 1936b, Uranotiel en sklodowskiet: Natuurk. Tijdschr. Ned.-Indië, v. 18, p. 284.

Billiett, V., and de Jong, W. F., 1935, Schoepiet en becquereliet: Natuurk. Tijdschr. Ned-Indië, v. 17, p. 157.

- 1936, Over kasoliet: Natuurk. Tijdschr. Ned-Indië, v. 18, p. 261.

Billington, D., and Crawford, J. H., 1956, Radiation damage: Princeton Univ. Press.

Biltz, W., and Muller, H., 1927, Systematic-affinity principle; XLI, Uranium oxides: Zeitschr. anorg. u. allgemeine Chemie, Band 163, p. 257-296.

Bjørlykke, H., 1931, Ein Betafitmineral von Tangen bei Kragero: Norsk geol. Tidsskr. Bind 12, p. 73.

Blake, C. A., Lowrie, R. S., Hill, D. G., and Brown, K. B., 1950, Studies in the carbonate-uranium system; Part 1, Investigations in the Four Component System $\mathrm{UO}_{3}-\mathrm{Na}_{2} \mathrm{O}-\mathrm{CO}_{2}-\mathrm{H}_{2} \mathrm{O}:$ U. S. Atomic Energy Comm. AECD-3280, 39 p., issued by U. S. Atomic Energy Comm. Tech. Inf. Service Extension, Oak Ridge, Tenn.

Blinkoff, C., 1906, Thesis, Berne. [Cited in Mellor, 1932.]

Blomstrand, C. W., 1884, Om ett uranmineral från trakten af Moss samt om de nativa uranaterna i allmänket: Geol. Fören. Stockholm Förh., Band 7, p. 59-101.

- 1890, Om monazitem från ural: Jour. prakt. Chemie, Band 41, p. 266.

Bodine, M. W., Jr., 1954, Mineralogy of the Carlisle deposit, Crook County, Wyoming, in Annual Report for June 30, 1953, to April 1, 1954, Part 1: U. S. Atomic Energy Comm. RME-3096 (Part 1), p. 16-37, issued by U. S. Atomic Energy Comm. Tech. Inf. Service Extension, Oak Ridge, Tenn.

Bořický, E., 1870, Uranotil, ein neues Mineral von Wölsendorf in Bayern: K. böhm. Gesell. Wiss. Sitzungsber. 35.

1878, Erklärung über Dr. C. O. Cech's "Notizen zur Kenntnis des uranotil": K.-K. Geol. Reichsanstalt [Austria] Verh., Jahrg. 1878, p. 353-354.

Born, I. von, 1772, Lythophylacium Bornianum, pt. 1, p. 42, Prague.

Boullé, A., and Dominé-Bergès, M., 1948, Nouvelle préparation de l'oxyde d'uranium $\mathrm{UO}_{2}$ et etude de sa décomposition: Acad. Sci. Paris Comptes rendus, tome 227 , p. 1365-1367. 
Boullé, A., Jary, R, and Dominé-Bergès, M., 1950, Sur les oxydes d'uranium résultant de la décomposition de l'oxylate dit d'uranyle: Acad. Sci. Paris Comptes rendus, tome 230, p. 300-302.

— 1951, Sur les oxydes d'uranium à composition variables: Acad. Sci. Paris Comptes rendus, tome 233, p. 1281.

Bourgeois, L., 1898, Sur un phosphate d'urane cristallisé: Soc. française Minéralogie Bull., tome 21, p. 32-39.

Bowen, N. L., 1919, Abnormal birefringence of torbernite: Am. Jour. Sci., 4th ser., v. 48, p. 195-198.

Bowie, S. H. U., 1951, Autoradiographic techniques in geological research: Great Britain Geol. Survey Bull. 3, p. 58-70.

Bowie, S. H. U., and Horne, J. E. T., 1953, Cheralite, a new mineral of the monazite group: Mineralog. Mag., v. 30, p. 93-99.

Branche, G., Chervet, J., and Guillemin, C., 1951, Nouvelles espèces uranifères françaises: Soc. française Minéralogie et Cristallographie Bull., tome 74, p. 457-488.

Brandenberger, E., 1931, Die Kristallstruktur von Koppit: Zeitschr. Kristallographie, Band 76, p. 322.

Brasseur, H., 1939, Sur la kasolite: Acad. royale Belgique Bull., Cl. Sci., 5e sér., tome 25, p. 654-659.

1941, Contribution à la connaissance de la fourmariérite: Soc. royale sci. Liége Bull. 6, p. 369.

- 1946, Contribution à la connaissance de la fourmariérite: Soc. royale sci. Liége Bull. 12, p. 523.

1948, Properties and chemical formula of fourmarierite: Am. Mineralogist, v. 33, p. 619-621.

-1949, Étude de la billietite: Acad. royale Belgique Bull., Cl. Sci., 5e sér., tome 35, p. 793-804.

1950, Étude roentgenographique de la masuyite: Soc. royale sci. Liége Bull. 19, p. 239.

Brauer, G., and Grandinger, H., 1951, über anomale Mischkristalle im Bereiche des Fluoritgittertyps: Natur., Jahrg. 38, Heft 24, p. 559-560.

Breger, I. A., and Deul, M., 1956, The organic geochemistry of uranium, in Page, L. R., Stocking, H. E., Smith, H. B., compilers, Contributions to the geology of uranium and thorium by the U. S. Geological Survey and Atomic Energy Commission for the United Nations International Conference on Peaceful Uses of Atomic Energy, Geneva, Switzerland, 1955: U. S. Geol. Survey Prof. Paper 300, p. 505-510.

Breithaupt, A., 1820, Kurze Charakteristik des Mineral-Systems: Freiberg. 1829, Neue kristallographische Bestimmung und mineralogische Charakteristek verschiedner Mineralspecien: Jour. Chemie und Physik, Band 56, p. 301.

—_ 1841, 1847, Handbuch der Mineralogie, Band 2, Band 3: Dresden and Leipzig.

1865, Mineralogische Studien: Berg.-u. hüttenm. Zeitung, Band 24, p. 302.

1866, Mineralogische Studien, no. 38, Orangit und Thorit: Berg.-u. hüttenm. Zeitung, Band 25, p. 114.

Brezina, A., 1879, Ueber den Autunit: Zeitschr. Kristallographie, Band 3, p. 273.

1890, Ueber die Kristallform des Uranothallit: K.-K. Naturh. Hofmuseum [Wien] Annalen, Band 5, p. 495. 
Brögger, W. C., 1887, Forelöbig meddelelse om mineralerner på de sydnorske augit-og nefelin-syeniters grovkornige gange: Geol. Fören. Stockholm Förh., Band 9, p. 258.

- 1890, Die Mineralien der Syenitpegmatitgänge der südnorwegischen Augit-und Nephelinsyenit: Zeitschr. Kristallographie, Band 16, p. 116.

— 1906, Die Mineralien des südnorwegischen Granitpegmatitgänge: Norske vidensk. Mat.-naturvidensk. Kl., no. 6, p. 1-162.

Brooke, H. J., 1831, On mengite, a new species of mineral: Philos. Mag., v. 10, p. 187.

Brooke, H. J., and Miller, W. H., 1852, Introduction to mineralogy: London, $517 \mathrm{p}$.

Brooker, E. J., and Nuffield, E. W., 1952, Studies of radioactive compounds; IV, Pitchblende from Lake Athabaska, Canada: Am. Mineralogist, v. 37, p. $363-385$.

Brophy, G. P., and Kerr, P. F., 1953, Hydrous uranium molybdate in Marysvale [Utah] ore, a preliminary report, in Annual Report for June 30, 1952, to April 1, 1953: U. S. Atomic Energy Comm. RME-3046, p. 45-51, issued by U. S. Atomic Energy Comm. Tech. Inf. Service Extension, Oak Ridge, Tenn.

Brückmann, F. E., 1727, Magnelia dei in locis subterraneis, oder unterirdische Schatz-kammer aller Konigreich und Lander in ausfürlicher Beschreibung: Braunschweig, pt. 1, 204 p.

Bruet, E., 1952, Minéraux radioactifs et terres rares: Paris, $250 \mathrm{p}$.

Bruno, M., 1950, Soluzioni solide anormale di sesquiossido in biossido di cerio: Ricerca sci., v. 20, p. 645-647.

Buchholz, Y., 1903, Der Wassergehalt des Kupferuranits : Zentralbl. Mineralogie 1903, p. 362.

Büchner, E. H., 1906, The composition of thorianite, and the relative radioactivity of its constituents: Royal Soc. London Proc., v. 78A, p. 385.

Bueno, V., A.M., 1951, Estudio comparativo de uranio por difraccion de rayos $\mathrm{X}$ y seleccion de lineas caracteristicas para la determinacion de su presencia en los minerales: Revista Cienc. Peru, v. 51, no. 475-476, p. 13-30.

Bultemann, H. W., 1954, Fluorezenzanalytische Untersuchungen an sekundaren Uranmineralien: Neues Jahrb. Mineralogie, Abh. 86, p. 155.

Burgers, W. G., and Liempt, J. A. M. van, 1930, Zum Verhalten des Thoroxyds in Wolframglühdrähten: Zeitschr. anorg. Chemie, Band 193, p. 144.

Busz, K., 1914, Ueber den Monazit von Dattas, Diamantina, Provinz Minas Geraes in Brasilien: Neues Jahrb. Mineralogie, Beilage-Band 39, p. 482499.

Butler, B. S., and others, 1920, The ore deposits of Utah: U. S. Geol. Survey Prof. Paper 111, p. 115.

Buttgenbach, H., 1922, Note sur la kasolite: Acad. royale sci. Belgique Bull., Cl. Sci., 5e sér., tome 8, p. 573-576.

1924, La fourmariérite, nouvelle espèce minérale: Soc. géol. Belgique Annales, tome 47, p. c41.

1925, Minéralogie du Congo Belge: Bruxelles, p. 66.

1926, Minéralogie du Congo Belge: Soc. royale sci. Liége, tome 13, no. 5, p. 3 .

1935, Sur un sulfate d'urane du Katanga: Inst. royal colonial belge Mém., tome 6, p. 449.

- 1947, Les minéraux de Belgique et du Congo Belge: Paris and Liége. Cahen, L., 1954, Géologie du Congo Belge: Liége, 577 p. 
Canneri, G., and Pestelli, V., 1924, La sintesi della carnotite: Gazz. chim. italiana, v. 54, p. 641.

Cerveira, A., 1951, Sobre a metalogenia do urânio em Portugal: Soc. geol. Portugal Bol., v. 8, p. 142-182.

Champeaux, C., 1801, Exact story of the discovery of uranium oxide in France, and the position of that substance: Jour. Mines, v. 10, p. 529.

Chapman, E. J., 1853, Mineralogy: London, p. 148.

Chernik, G., 1902, Einige Worte über die Zusammensetzung zweier seltener Mineralien: Annales géol. min. Russie, v. 5, p. 196.

- 1903, Über die Natur und die chemische Zusammensetzung [etc.] Monazitsandes: Russ. K. min. Gesell. Verh., v. 41, p. 43.

1922, Analyses of the urano-vanadic ores from the Tyuya-Muyum deposit [in Russian]: Acad. sci. U.R.S.S. Bull., sér. 6, tome 16, p. 505-514.

1927, Sur la composition chimique d'une bétafite de Sludianka: Soc. française Mineralogie Bull., tome 50, p. 485-489.

Chervet, J., and Branche, G., 1955, Contribution à l'étude des minéraux secondaires d'uranium françaises: Sciences de la Terre, tome 3, no. 1, $186 \mathrm{p}$.

Chirvinsky, P. N., 1925, Tyuyamunite from the Tyuya-Muyun radium mine in Fergana: Mineralog. Mag., v. 20, p. 287-295.

Chrétien, A., and Kraft, J., 1938, Recherches sur les orthophosphates d'uranyle: Soc. chim. France Bull., $5^{\circ}$ sér., tome 5, p. 372.

Christ, C. L., Clark, J. R., and Evans, H. T., Jr., 1955, Crystal structure of rutherfordine, $\mathrm{UO}_{2} \mathrm{CO}_{3}$ : Science, v. $121, \mathrm{p} .472$.

Christman, R. A., Brock, M. R., Pearson, R. C., and Singewald, Q. D., 1955, Wet Mountains, Colorado, thorium investigations, 1952-1954: U. S. Geol. Survey open-file report, $50 \mathrm{p}$.

Chudoba, K., and Stackelberg, M. von, 1936, Dichte und struktur des Zirkons: Zeitschr. Kristallographie, Band 95, p. 230-246.

Church, A. H., 1865, Revision of the mineral phosphates: uranite: Chem. News, v. 12, p. 183.

1875, On the composition of autunite: Chem. Soc. London Jour., v. 28, p. 109.

1877, Note on uranocircite: Mineralog. Mag. v. 1, p. 234.

Collier, P., 1880, Analysis of a mineral resembling thorite: Am. Chem. Soc. Jour., v. 2, p. 73.

Comstock, W. J., 1880, On the chemical composition of the uraninite from Branchville, Conn.: Am. Jour. Sci., 3d ser., v. 19, p. 220.

Coninck, F. W. de, 1903, Etude de quelques sels d'uranium: Annales Chimie et Physique, $7^{\bullet}$ sér., tome 28, p. 5.

Connah, T. H., 1953, Uranium occurrence, Pine Log mine, Bakerville: Queensland Govt. Mining Jour., v. 54, p. 655.

Conybeare, C. E. B., and Ferguson, R. B., 1950, Metamict pitchblende from Goldfields, Saskatchewan, and observations on some ignited pitchblendes: Am. Mineralogist, v. 35, p. 401-406.

Cooke, W. T., 1916, Chemical notes on davidite: Royal Soc. South Australia Trans. and Proc., v. 40, p. 267.

Coomaraswamy, A. K., 1904, Uraninite: Spolia Zeylanica, 1, pt. IV, 1 p. [Abstract in Neues Jahrb. Mineralogie I, p. 165, 1906.]

Cooper, M., 1953, 1954, 1955, Bibliography and index of literature on uranium and thorium and radioactive occurrences in the United States, pt. 1, Arizona, Nevada, and New Mexico: Geol. Soc. America Bull., v. 64, p. 197-234, 1953. 
pt. 2, California, Idaho, Montana, Oregon, Washington, and Wyoming, op. cit., p. 1103-1172, 1953.

pt. 3, Colorado and Utah: Geol. Soc. America Bull., v. 65, p. 467-590, 1954. pt. 4, Arkansas, Iowa, Kansas, Louisiana, Minnesota, Missouri, Nebraska, North Dakota, Oklahoma, South Dakota, and Texas: Geol. Soc. America Bull., v. 66, p. 257-326.

Courtel, R., and Loriers, J., 1950, Sur la formation de $\mathrm{Ce}_{2} \mathrm{O}_{3}$ cubique dans l'oxydation du cerium: Acad. Sci. Paris Comptes rendus, tome 230, p. 735. Croft, W. J., 1954, An X-ray line study of uraninite, in Annual Report for June 30, 1953, to April 1, 1954, Part 2: U. S. Atomic Energy Comm. RME3096 (Part 2), p. 7-71, issued by U. S. Atomic Energy Comm. Tech. Inf. Service Extension, Oak Ridge, Tenn.; also New York Acad. Sci. Annals, 1956 , v. 62 , art. 20 , p. $449-502$.

Crohn, P. W., 1950, Uranium mineral discovery: Mining and Geol. Jour. (Victoria Dept. Mines) v. 4, no. 2, p. 22.

Cronstedt, A., 1758, Mineralogie; eller Mineral-Rikets Upstallning: Stockholm, $198 \mathrm{p}$.

Crook, T., and Blake, G. S., 1910, On carnotite and an associated mineral complex from South Australia: Mineralog. Mag., v. 15, p. 271-284.

Crookes, W., 1900, Radioactivity of uranium: Royal Soc. London Proc., v. 66, p. 409.

Croxton, F. E., 1951, Uranium and its compounds, a bibliography of unclassified literature: Carbide and Carbon Chemicals Co., K-25 Plant, Oak Ridge, Tenn., Rept. K-295, Pt. 2, 1951, 708 p.

Curie, [Marie] S., 1898, Rayons émis par les composés de l'uranium et du thorium: Acad. Sci. Paris Comptes rendus, tome 126, p. 1101.

Curie, P., Curie, M., and Bémont, G., 1898, Sur une nouvelle substance fortement radio-active, contenue dans la pechblende: Acad. Sci. Paris Comptes rendus, tome, 127, p. 1215.

Dahl, H. M., and Kerr., P. F., 1953, Radioactive features of vein minerals, Prospector Mine, Marysvale, Utah, in Annual Report for June 30, 1952 to April 1, 1953: U. S. Atomic Energy Comm. RME-3046, p. 64-72, issued by U. S. Atomic Energy Comm. Tech. Inf. Service Extension, Oak Ridge, Tenn.

Damour, A. A., 1878, Sur la freyalite: Soc. française. minéralogie Bull., tome, 1 , p. 33-35.

Dana, E. S., 1882a, On crystals of monazite from Alexander County, North Carolina: Am. Jour. Sci., 3d ser., v. 24, p. 247.

1882b, System of mineralogy, 5th ed., App. III: New York, John Wiley and Sons, p. 16.

1892, System of mineralogy, 6th ed.: New York, John Wiley and Sons.

Dana, J. D., 1866, Note on the possible identity of turnerite with monazite: Am. Jour. Sci., 2d ser., v. 42, p. 420.

1868, System of mineralogy, 5th ed.; New York, John Wiley and Sons, p. 154.

Dana, J. D., and Brush, G. J., 1857, Parathorite; Am. Jour. Sci., 2d ser., v. 24, p. 124.

Dauber, H., 1854, Untersuchungen an Mineralien der Sammlung des Hrn. Dr. Krantz in Bonn: Annalen der Physik, Band 92, p. 237.

David, L. R., 1953, Thorium, a bibliography of unclassified literature: U. S. Atomic Energy Comm. TID-3044, 124 p., issued by U. S. Atomic Energy Comm. Tech. Inf. Service Extension, Oak Ridge, Tenn. 
Davidson, C. F., 1949, A prospector's handbook to radioactive mineral deposits, London, Great Britain Geol. Survey, 28 p.

- 1953, The origin of the gold-uranium ores of the Witwatersrand: Mining Mag., v. 88, p. 73-85.

- 1955, The mineralization of the Witwatersrand: Mining Mag., $\nabla .92$, p. 152.

Davidson, C. F, and Atkin, O., 1952, The occurrence of uranium in phosphate rock: Great Britain Geol. Survey and Museum, Atomic Energy Div., Rept. 124.

Davidson, C. F., and Bowie, S. H. U., 1951, On thucholite and related hydrocarbon-uraninite complexes, with a note on the origin of the Witwatersrand gold ores: Great Britain Geol. Survey Bull. 3, p. 1-19.

Davidson, C. F., and Ponsford, D. R. A., 1954, On the occurrence of uranium in coals: Mining Mag., v. 91, p. 265.

Davis, C. W., 1926, The composition and age of uranium minerals from Katanga, South Dakota, and Utah: Am. Jour. Sci., 5th ser., v. 11, p. 201-217.

Debray, H., 1861, Mémoire sur la production d'un certain nombre de phosphates et d'arséniates cristallisés: Annales Chimie et Physique, 3e sér., tome 61, p. 419.

De Lury, J. S., and Ellsworth, H. V., 1931, Uraninite from the Huron Claim, Winnipeg River area, S. E. Manitoba: Am. Mineralogist, v. 16, p. 569-575.

Derriks, J. J., and Vaes, J. F., 1956, The Shinkolobwe uranium deposit: Current status of our geological and metallogenic knowledge; in Proceedings of the International Conference on the Peaceful Uses of Atomic Energy, v. 6, New York, United Nations, p. 94-128.

Des Cloizeaux, A., 1854, De l'emploi des propriétés optiques biréfringentes en minéralogie: Annales des Mines, tome 11, p. 261.

— 1858, Sur l'emploi des propriétés optiques biréfringentes pour la détermination des espèces cristalliseés: Annales des Mines, tome 14, p. 339.

1873, Briefliche Mitteilungen: Deutsche geol. Gesell. Zeitschr., Band 25, p. 568.

Dickinson, S. B., Wade, M. L., and Webb, B. P., 1954, Geology of the East Painter uranium deposits: South Australia Geol. Survey Bull. 30, p. 84.

Doelter, C., and others, 1911-1931, Handbuch der Mineralchemie: 4 v. divided into parts, Dresden and Leipzig.

Dolivo-Dobrovolsky, V. V., 1925, Crystals of tyuyamunite [in Russian]: Zapiski Rossiysk. Mineralog. Obshch., v. 54, p. 359-376.

Dominé-Bergès, M., 1953, Conditions de formation et caractérisation de phosphates d'uranium hexavalent: Acad. Sci. Paris Comptes rendus, tome 236, p. 242-244.

Donnay, G., and Donnay, J. D. H., 1953, Tyuyamunite, carnotite, and sengierite [abs.]: Geol. Soc. America Bull. v. 64, no. 12, pt. 2, p. 1412.

1955, Contribution to the crystallography of uranium minerals: U. S. Geol. Survey TEI-507, 42 p., issued by U. S. Atomic Energy Comm. Tech. Inf. Service Extension, Oak Ridge, Tenn.

Druif, J. H., 1948, On the occurrence of a new mineral species in the deposits of the River Pekoeringan, district Masamba, Celebes: Med. Algemeen Proefstation voor de Landbouw, Buitenzorg, Java, no. 69, p. 8.

Dunstan, W. R., 1904, The occurrence of thorium in Ceylon: Nature, v. 69, p. $510,553,559$. 
Dunstan, W. R., and Blake, G. S., 1905, Thorianite, a new mineral from Ceylon: Royal Soc. London Proc., v. 76, p. 253.

Dunstan, W. R., and Jones, B. M., 1906, A variety of thorianite from Galle, Ceylon: Royal Soc. London Proc., v. 77, p. 385.

Duwez, P., and Odell, F., 1950, Phase relationships in the system zirconiaceria: Am. Ceramic Soc. Jour., v. 33, p. 274.

Ebelman, J. J., 1843, Note on the chemical composition of pitchblende: Jour. prakt. Chemie, Band 30, p. 414.

Eichhoff, H. J., and Reineck, H. E., 1953, Uran-Vanadinkerne mit Verfarbungshofen in Gesteinen: Neues Jahrb. Mineralogie, Monatsh. 11-12, p. 294-314.

Ellsworth, H. V., 1921, Geol. Survey Canada Summary Report 1921 D, p. 60.

- 1925, Radioactive minerals as geological age indicators: Am. Jour. Sci., 5th ser., v. 9, p. 127.

1927, Uranothorite from the Macdonald mine, Hybla, Ontario: Am. Mineralogist, v. 12, p. 368.

1929, 1930, in National Research Council Division of Geology and Geography, Annual Report, 1929, 1930, Appendix H, Exhibit A.

1932a, Monazite colored by carbon from Dickens Township, Ontario: Am. Mineralogist, v. 17, p. 19-28.

1932b, Rare element minerals of Canada: Canada Geol. Survey Econ. Geology ser., no. 11, 272 p.

Ellsworth, H. V., and Osborne, F. F., 1934, Uraninite from Lac Pied des Monts, Saguenay district, Quebec: Am. Mineralogist, v. 19, p. 421-425.

Erichsen, L. von, 1951, Über die Heliumabgabe von Monazit in Abhängigkeit von Gasphase, Druck und Temperatur: Neues Jahrb. Mineralogie, Monatsh., 2, p. 25-33.

Esmark, M. T., 1836, Thoriten, opdagen og beskreven: Nyt mag. naturvidensk., Oslo, Bind 2, p. 277.

Evans, H. T., Jr., 1950, Studies of uranium minerals (VI) ; Walpurgite: Am. Mineralogist, v. 35, p. 1021-1027.

Evans, H. T., Jr., and Frondel, C., 1950, Studies of uranium minerals (II) ; Liebigite and uranothallite: Am. Mineralogist, v. 35, p. 251-254.

Everhart, D. L., and Wright, R., 1953, The geologic character of typical pitchblende veins: Econ. Geology, v. 48, p. 77.

Faessler, A., 1942, Untersuchungen zum Problem des metamikten Zustandes: Zeitschr. Kristallographie, Band 104, p. 81.

Fairchild, J. G., 1929, Base exchange in artificial autunites: Am. Mineralogist, v. 14, p. $265-275$.

Faul, H., editor, 1954, Nuclear geology: New York, John Wiley and Sons, $414 \mathrm{p}$.

Fawley, A. P., and James, T. C., 1955, A pyrochlore (columbium) carbonatite, southern Tanganyika: Econ. Geology, v. 50, p. 571-585.

Ferber, J. J., 1774, Mineral-Geschichte von Böhmen: Berlin, p. 83.

Fersman, A. E., 1927, Morphology and geochemistry of Tyuya Muyun [in Russian]: Verh. für Radium-Kentnis, Band 3, p. 1-93.

1930, Geochemische Migration der Elemente, Pt. 2, Die Uran-Vanadium Grube Tuja Muyun in Turkestan: Abhandl. prakt. Geologie, Halle, v. 19, p. 1-52.

Fischer, E., 1945, Kristallform und Kristallelemente des Walpurgins: Zeitschr.

Kristallographie, Band 106, p. 25-33.

1948, Chemische Zusammensetzung des Walpurgins: Neues Jahrb.

Mineralogie, Monatsh., Abt. A, 1945-1948, p. 44-46. 
Fischer, R. P., 1942, Vanadium deposits of Colorado and Utah: U. S. Geol. Survey Bull. 936-P, p. 363-394.

1950, Uranium-bearing sandstone deposits of the Colorado Plateau: Econ. Geology, v. 45, p. 1-11.

Fischer, R. P., and Hilpert, L. S., 1952, Geology of the Uravan Mineral Belt: U. S. Geol. Survey Bull. 988-A, p. 1-13.

Fisher, N. H., and Sullivan, C. J., 1954, Uranium exploration by the Bureau of Mineral Resources, Geology and Geophysics, in the Rum Jungle Province, Northern Territory, Australia: Econ. Geology, v. 49, p. 826.

Fleischer, Michael, and Rabbitt, J. C., 1952, Geochemistry, in Annual Review of Nuclear Science, v. I, 1952: Stanford, California, Annual Reviews, Inc., p. $465-478$.

Flink, G., 1898, Berättelse om en mineralogisk Resa i syd-Grønland sommaren 1897: Meddelelser om Grønland, v. 14, p. 221-262.

- 1901, Undersögelser af minerales frå Julianehaab: Meddelelser om Grønland, v. 24, p. 160, 166.

Florencio, W., and Castro, C. de, 1943, Uraninita em Minas: Acad. Brasileira de Ciencias Anais, año 15, p. 19-29.

Forbes, D., and Dahill, T., 1855, Mineralogiske iagttagelser omkring arendan og Kragero: Nyt. mag. naturvidensk., Oslo, Bind 8, p. 227.

Ford, R. B., 1955, Mineralogy of a uraninite-bearing pegmatite, Lac la Ronge, Saskatchewan: Econ. Geology, v. 50, p. 196-205.

Forjaz, A. Pereira, 1917, Etudes spectrographiques des minéraux portugais d'uranium et de zirconium: Acad. Sci. Paris Comptes rendus, tome 164, p. 102.

Foullon, H. von, 1883, Ueber Verwitterungsprodukte des Uranpecherzes: K.-K. Geol. Reichsanstalt [Austria] Jahrb., Band 33, p. 1-29.

Foye, W. G., and Lane, A. C., 1934, Correlations by radioactive minerals in the metamorphic rocks of southern New England: Am. Jour. Sci., 5th ser., v. 28, p. 127-138.

Frenzel, A., 1874, Mineralogisches Lexicon für das Königreich Sächsen: Leipzig, $380 \mathrm{p}$.

Freyre, A., 1948, Los minerales radio-activos en la pegmatita de Pampacolca: Soc. Quim. Peru Bol, v. 14, p. 1.

Friedel, C., and Cumenge, E., 1899, Sur un nouveau mineral d'urane, la carnotite: Soc. française Minéralogie Bull., tome 22, p. 26-29; also Acad. Sci. Paris Comptes rendus, tome 128, p. 532.

Frohberg, M. H., 1950, Uranium in Russian-occupied Saxony: Canada Geol. Assoc. Proc., v. 2, p. 43.

Frondel, Clifford, 1950a, Studies of uranium minerals (I); Parsonsite and randite: Am. Mineralogist, v. 35, p. 245-250.

$1950 \mathrm{~b}$, Studies of uranium minerals (V) ; Phosphuranylite: Am. Mineralogist, v. 35 , p. $756-763$.

1951a, Studies of uranium minerals (VIII) ; Sabugalite, an aluminumautunite: Am. Mineralogist v. 36, p. 671-680.

1951b, Studies of uranium minerals (IX); Saléeite and novacekite: Am. Mineralogist, v. 36, p. 680-686.

- 1952, Studies of uranium minerals (X) ; Uranopilite: Am. Mineralogist, v. 37, p. $950-959$.

1953, Hydroxyl substitution in thorite and zircon: Am. Mineralogist, v. 38 , p. 1007-1018.

1954, Bassetite and uranospathite: Mineralog. Mag., v. 30, p. 343-353. 
Frondel, Clifford, 1955, A precision X-ray powder camera: Am. Mineralogist, v. 40, p. $876-884$.

- 1956a, Mineral composition of gummite: Am. Mineralogist, v. 41, p. 539-568.

1956b, The mineralogy of thorium, in Page, L. R., Stocking, H. E., Smith, H. B., compilers, Contributions to the geology of uranium and thorium by the U. S. Geological Survey and Atomic Energy Commission for the United Nations International Conference on Peaceful Uses of Atomic Energy, Geneva, Switzerland, 1955: U. S. Geol. Survey Prof. Paper 300, p. 567-580.

Frondel, Clifford, Collette, R. L., Ross, Virginia, and Berman, Eleanor, 1954, Synthesis of uranium minerals, in Annual Report for July 1, 1953, to June 30, 1954 : U. S. Atomic Energy Comm. RME-3101, 18 p., issued by U. S. Atomic Energy Comm. Tech. Inf. Service Extension, Oak Ridge, Tenn. Frondel, Clifford, and Cuttitta, F., 1954, Studies of uranium minerals (XIV); Renardite: Am. Mineralogist, v. 39, p. 448-451.

Frondel, Clifford, and Meyrowitz, R., 1956, Studies of uranium minerals (XIX) ; Rutherfordine, diderichite, and clarkeite: Am. Mineralogist, v. 41, p. 127-133.

Frondel, Clifford, Riska, D. D., and Frondel, J. W., 1956, X-ray powder data for uranium and thorium minerals: U. S. Geol. Survey Bull. 1036-G, p. 91-153.

Frondel, J. W., 1951, Studies of uranium minerals (VII); Zeunerite: Am. Mineralogist, v. 36, p. 249-255.

Frondel, J. W., and Cuttitta, F., 1953, Studies of uranium minerals (XII) ; The status of billietite and becquerelite: Am. Mineralogist, v. 38, p. 1019-1024.

1954, Studies of uranium minerals (XVI) ; An alteration product of ianthinite: Am. Mineralogist, v. 39, p. 1018-1020.

Frondel, J. W., and Fleischer, M., 1955, Glossary of uranium- and thoriumbearing minerals, 3d. ed.: U. S. Geol. Survey Bull. 1009-F, p. 169-209; also 2d ed.: U. S. Geol. Survey Circ. 74, 1950, and Circ. 194, 1952.

Gaertner, H. R. von, 1930, Die Kristallstrukturen von Loparit und Pyrochlor: Neues Jahrb. Mineralogie, Beilage-Band 61, p. 1.

Garrels, R. M., 1955, Some thermodynamic relations among the uranium oxides and their relations to the oxidation states of the uranium ores of the Colorado Plateaus: Am. Mineralogist, v. 40, p. 1004-1021.

Gaubert, P., 1904, Produits de déhydration de quelques phosphates et orientation du chlorure de baryum sur les minéraus du groupe de l'autunite: Soc. française Minéralogie Bull., tome 27, p. 222-223.

Geffroy, J., and Scarcia, J. A., 1954, Contribution à l'étude des pechblendes françaises: Sciences de la Terre, tome 2, no. 1-2, $157 \mathrm{p}$.

1955, Contributions à l'étude des. pechblendes françaises: Comm. Énergie Atomique, Centre d'Études Nucléaires de Saclay, CEA-380, 185 p.

Genth, F. A., 1879, Examination of the North Carolina uranium minerals: Am. Chem. Soc. Jour., v. 1, p. 89.

George, D'Arcy, 1949, Mineralogy of uranium and thorium bearing minerals: U. S. Atomic Energy Comm. RMO-563, 198 p., issued by U. S. Atomic Energy Comm. Tech. Inf. Service Extension, Oak Ridge, Tenn.

- 1951, Thorite in California: Am. Mineralogist, v. 36, p. 129-132.

Gevers, T., Partridge, F., and Joubert, G., 1937, The pegmatite area south of Orange River, Namaqualand: South Africa Geol. Survey Mem., v. 31, p. 172 . 
Giolitte, F., and Liberi, G., 1906, Sui fenomeni di equilibrio fra gli idrati del sulfato uranoso III Esaidrato, pentaidrato e sulfati basici: Gazz. chim. italiana, v. 36, II, p. 443.

Glass, J. J., 1935, The pegmatite minerals from near Amelia, Virginia: Am. Mineralogist, v. 20, p. 741-768.

Gleditsch, E., and Qviller, B., 1932, Investigation of uranothorites from the Arendal district, Norway: Philos. Mag., ser. 7, v. 14, p. 233.

Gliszczynski, S. von, 1939, Beitrag zur "Isomorphie" von Monazit und Crocoit: Zeitschr. Kristallographie, Band 101, p. 1.

Gmelin, L., 1928, 1936, Handbuch der anorganischen Chemie, 8th ed.: [Thorium], Band 6, Abt. 1, p. 68-191, 1928; [Uranium], Band 55, p. 1-279, 1936.

Goldschmidt, V., 1899, Ueber Trögerit und künstlichen Uranospinit: Zeitschr. Kristallographie, Band 31, p. 468.

- 1913-1923, Atlas der Kristallformen, [9 volumes, atlas and text]: Heidelberg, v. 1, 1913; v. 2, 1913; v. 3, 1916; v. 4, 1918; v. 5, 1918; v. 6, 1920 ; v. 7, 1922; v. 8, 1922; v. 9, 1923.

Goldschmidt, V. M., and Thomassen, L., 1923, Die Kristallstruktur natürlicher und synthetischer Oxyde von Uran, Thorium und Cerium: Norske vidensk. Kristiana Skr. Mat.-naturvidensk. Kl., no. 2, p. 1-48.

Goldschmidt-Clermont, Y., 1953, Photographic emulsions, in Beckerley, J. G., Annual review of nuclear science, v. 3: Stanford, California, Annual Reviews, Inc., p. 141-170.

Goldsztaub, S., 1932, Communication sur la chalcolite: Soc. française Minéralogie. Bull., tome 55, p. 7.

Goodman, C., and Picton, D. C., 1941, Autoradiography of ores: Phys. Rev., v. 60, p. 688 .

Goodman, C., and Thompson, G. A., 1943, Autoradiography of minerals: Am. Mineralogist, v. 28, p. 456-467.

Gordon, S. G., 1939, Thorium-free monazite from Llallagua, Bolivia: Acad. Nat. Sci. Philadelphia, Notulae Naturae, no. 2, 7 p.

Gorman, D. H., 1952, Studies of radioactive compounds; V-Soddyite: Am. Mineralogist, v. 37, p. 386-393.

Gorman, D. H., and Nuffield, E. W., 1955, Studies of radioactive compounds; VIII-Uranophane and beta-uranophane: Am. Mineralogist, v. 40, p. 634-645.

Gottardi, G., 1951, Sullo stato metamittico della Torite: Soc. toscana sci. nat. Atti., v. 58, Series A, p. 86.

Graham, A. R., 1955, Cerianite, $\mathrm{CeO}_{2}-$ a new rare-earth oxide mineral: Am. Mineralogist, v. 40 , p. 560-564.

Graton, L. C., 1930, Hydrothermal origin of the Rand gold deposits: Econ. Geology, v. 25, Supp. to no. 3, p. 1-185.

Grawe, O. R., 1943, Metatorbernite in Missouri flint fire clay: Missouri Geol. Survey and Water Res., v. 28, 2d ser., p. 153.

Greenwood, R., 1948, The geology of the plateau tinfields: Nigeria Geol. Survey Bull. 19, p. 79.

Gregory, M., 1950, Production of radium in Cornwall: Royal Geol. Soc. Cornwall Trans., v. 17, p. 306-312.

Grimaldi, F. S., May, I., Fletcher, M. H., and Titcomb, J., compilers, 1954, Collected papers on methods of analysis for uranium and thorium: U. S. Geol. Survey Bull. 1006, 184 p.

Grönvold, F., and Haraldsen, H., 1948, Oxidation of uranium dioxide: Nature, v. 162 , p. 69 . 
Gross, E. B., 1956, Mineralogy and paragenesis of the uranium ore, Mi Vida mine, San Juan County, Utah: Econ. Geology, v. 51, p. 632-648.

Gruen, D. M., 1954, Absorption spectra and electrical conductivities of $\mathrm{UO}_{2}-\mathrm{ThO}_{2}$ solid solutions: Am. Chem. Soc. Jour., v. 76, p. 2117-2120.

Gruner, J. W., 1952, New data of syntheses of uranium minerals, in Annual report for July 1, 1951, to June 30, 1952, Part I: U. S. Atomic Energy Comm. RMO-983, 26 p., issued by U. S. Atomic Energy Comm. Tech. Inf. Service Extension, Oak Ridge, Tenn.

— 1953, Syntheses of uranium minerals at room and elevated temperatures: Am. Mineralogist, v. 38, p. 342.

- 1954, The chemical formula of clarkeite: Am. Mineralogist, v. 39, p. 836-838.

Gruner, J. W., Gardiner, Lynn, and Smith, D. K., Jr., 1953, Annual Report for July 1, 1952 to March 31, 1953: U. S. Atomic Energy Comm. RME3044, 58 p., issued by U. S. Atomic Energy Comm. Tech. Inf. Service Extension, Oak Ridge, Tenn.

- 1954, Mineral associations in the uranium deposits of the Colorado Plateau and adjacent regions: U. S. Atomic Energy Comm. RME-3092, 49 p., issued by U. S. Atomic Energy Comm. Tech. Inf. Service Extension, Oak Ridge, Tenn.

Gruner, J. W., Rosenzweig, Abraham, and Smith, D. K., Jr., 1954, The mineralogy of the "Mi Vida" uranium ore deposit of the Utex Exploration Company in the Indian Wash area, Utah, in Annual Report for April 1, 1953, to March 31, 1954: U. S. Atomic Energy Comm. RME-3094, p. 15-27, issued by U. S. Atomic Energy Comm. Tech. Inf. Service Extension, Oak Ridge, Tenn.

Gruner, J. W., and Smith, D. K., Jr., 1955, Annual Report for April 1, 1954 to March 31, 1955: U. S. Atomic Energy Comm. RME-3020, 37 p., issued by U. S. Atomic Energy Comm. Tech. Inf. Service Extension, Oak Ridge, Tenn.

Guillemin, C., and Pierrot, H., 1956a, La schoepite du gîte Marignac II, HauteVienne: Soc. française Minéralogie et Cristallographie Bull., tome 79, p. 182-183.

$1956 \mathrm{~b}$, Nouvelle méthode synthèse de la johannite $\mathrm{Cu}\left(\mathrm{UO}_{2}\right)_{2}\left(\mathrm{SO}_{4}\right)_{2-}$ $(\mathrm{OH})_{2} \cdot 6 \mathrm{H}_{2} \mathrm{O}$ : Soc. française Minéralogie et Cristallographie Bull., tome 79 , p. 170-172.

—_ 1956c, La sabugalite du gîte de Marignac II, Haute-Vienne: Soc. française Minéralogie et Cristallographie Bull., tome 79, p. 179-181.

Guimarães [Guimarens], C. P., 1939, Djalmaita, un novo minéral radioativo: Acad. Brasileira de Ciencias Anais, año 9, p. 347-350, 1939; Am. Mineralogist, v. 26, p. 343-346, 1941 [in English.]

Guimarães, Djalma, 1950, A jazida de djalmaita, de Volta Grande, Rio das Mortes, Minas Gerais: Acad. Brasileira de Ciencias Anais, año 22, p. 51-71.

Haberlandt, H., 1949, Neue Lumineszenzuntersuchungen an Fluoriten und anderen Mineralien IV: Akad. Wiss. Wien, Math.-naturwiss. Kl., Sitzungsber., Abt. 1, Band 158, p. 609-646.

Haberlandt, H., Hernegger, F., and Scheminsky, F., 1950, The fluorescence spectra of uranium minerals in filtered ultraviolet light: Spectrochimica Acta, v. 4, p. 21.

Haberlandt, H., and Schiener, A., 1951, Die Mineral und Elementvergesellschaftung des Zentralgneisgebietes von Badgastein (Hohe Tauern): Tschermaks Mineralog. Petrog. Mitt., Band 2, Heft 3, p. 292-354. 
Hacquaert, A. L., 1927, Some pseudomorphs of uranium-minerals from Katanga: Natuurk. Tijdschr. Ned.-Indië, v. 9, p. 34.

Haidinger, W., 1830, Über den Johannit, eine neue Spezies des Mineralreiches: Annalen Physik, Band 20, p. 472; K. böhm. Gesell. Wiss. Abh. 1830; Edinburgh Jour. Sci., v. 4, p. 306.

1845, Handbuch der bestimmenden Mineralogie: Vienna, 510 p.

1853, in Vogl, J. F., Drei neue Mineral-Vorkommen von Joachimsthal:

K.-K. Reichsanstalt [Austria] Jahrb., Jahrg. 4, p. 221-223.

Hallimond, A. F., 1915, On bassetite and uranospathite, new species hitherto classed as autunite: Mineralog. Mag., v. 17, p. 221.

1916, The crystallography and dehydration of torbernite: Mineralog. Mag., v. 17, p. 326.

- 1920, Meta-torbernite; I-its physical properties and relation to torbernite: Mineralog. Mag., v. 19, p. 43.

Hamilton, P. K., and Kerr, P. F., 1954a, Phosphuranylite at Marysvale, Utah, in Annual Report for June 30, 1953, to April 1, 1954, Part 1: U. S. Atomic Energy Comm. RME-3096 (Part 1), p. 49-51, issued by U. S. Atomic Energy Comm. Tech. Inf. Service Extension, Oak Ridge, Tenn.

- 1954b, Uranophane and beta-uranotile, Marysvale, Utah, in Annual Report for June 30, 1953, to April 1, 1954, Part 1: U. S. Atomic Energy Comm. RME-3096 (Part 1), p. 38-48, issued by U. S. Atomic Energy Comm. Tech. Inf. Service Extension, Oak Ridge, Tenn.

Harada, Z., 1948, Chemical analyses of Japanese Minerals. (II): Hokkaido Univ. Faculty Sci. Jour. ser. 4, v. 8, p. 203.

Harris, W. W., and Scott, R. H., 1949, Optical properties of three uranium phosphates: U. S. Atomic Energy Comm. AECD-2746, 13 p. [Microcard copy on file in U. S. Atomic Energy Comm. depository libraries.]

Hart, R. C., Harper, H. G., and Algoman Field Staffs, 1955, Uranium deposits of the Quirke Lake trough, Algoman district, Ontario: Canadian Min. Metall. Bull. 517, v. 48, p. 260-265.

Harvey, C. O., 1951, The chemical determination of uranium, with special reference to its occurrence as a minor constituent of minerals and rocks: Great Britain Geol. Survey Bull. 3, p. 43.

Hata, S., and Iimori, T., 1938, New localities of torbernite, autunite, and uraninite: Tokyo Inst. Phys. Chem. Research Bull., v. 17, p. 355-358.

Hautpick, E. de, 1911, Radioactive minerals of Russia: Mining Jour. [London], v. 92, p. 185.

Haüy, R. J., 1801, Traité de minéralogie, v. 4: Paris, p. 319.

Hayes, A. O., 1842, On the identity of pyrochlore with the microlite of Prof. Shepard: Am. Jour. Sci., 1st ser., v. 43, p. 33-35.

- 1844, Re-examination of microlite and pyrochlore: Am. Jour. Sci., 1st ser., v. 46 , p. 158-166.

Hecht, Friedrick, 1933, Quantitative Mikro-Gesamtanalysen von CeylonThorianiten: Mikrochemie, v. 12, p. 193.

Hecht, Friedrick, and Körner, E., 1928, Beitrage zur Methodik der chemischen Analyse der Uranpechblenden: Monatsh. Chemie, Band 49, p. 438.

Hecht, Friedrick, and Kroupa, E., 1936, Die Bedeutung der quantitativen Mikroanalyse radioaktiven Mineralien für die geologische Zeitmessung: Zeitschr. anal. Chemie, Band 106, p. 82-103.

Hedvall, J. A., 1925, Beitrage zur Kenntnis der komplexen uranyl Carbonate: Zeitschr. anorg. u. allgemeine Chemie, Band 146, p. 225. 
Heintz, W., 1869, Notiz über Widerherstellung des salpetersäuren Uranoxyds aus dem phosphersäuren Salz und über saltpeterphosporsäures Uranoxyd: Annalen der Chemie, Band 151, p. 216-222.

Henmi, K., 1951, Rare element minerals produced in Hai-cheng hsien, southern Manchuria: Geol. Soc. Japan Jour., v. 57, p. 345.

Henrich, F., 1922, Beiträge zur Kenntnis der Kalkuran-glimmer (Autunite) : Deutsche chem. Gesell. Ber., Jahrg. 55, p. 1212-1215.

Hering, H., and Perio, P., 1952, The equilibrium of uranium oxides between $\mathrm{UO}_{2}$ and $\mathrm{U}_{3} \mathrm{O}_{8}$ : Soc. chim. France Bull. 1952, p. 351-357.

Hermann, R., 1847, Ueber die geognostische Beschaffenbeit des Mineralbruchs aus der Schischimskaja Gora: Jour. prakt. Chemie, Band 40, p. 21.

- 1850, Untersuchungen über die Zusammensetzung der Tantalerze: Jour. prakt. Chemie, v. 50, p. 186.

1859, Ưber die Zusammensetzung der Gruppe der Uransilicate gehörenden Mineralien: Jour. prakt. Chemie, Band 76, p. 326.

- 1864, Über die Zusammensetzung des Monazits: Jour. prakt. Chemie, Band 93, p. 109.

Hernández-Pacheco, E., 1945, El mineral de uranio de Albalá (Cáceres): Acad. cien. Madrid Rev., tomo 39, p. 539-540.

Hess, F. L., 1922, Uranium-bearing asphaltic sediments of Utah: Eng. and Min. Jour.-Press, v. 114, p. 274.

1924, New and known minerals from the Utah-Colorado carnotite region: U. S. Geol. Survey Bull. 750-D, 30 p.

Hess, F. L., and Foshag, W. F., 1927, Crystalline carnotite from Utah: U. S. Natl. Mus. Proc., v. 72, Art. 12.

Hess, F. L., and Schaller, W. T., 1914, Pintadoite and uvanite, two new vanadium minerals from Utah: Washington Acad. Sci. Jour., v. 4, p. 576.

Hess, F. L., and Wells, R. C., 1920, Brannerite, a new uranium mineral: Franklin Institute Jour., v. 189, p. 225-237, 779-780.

Hewett, D. F., and Glass, J. J., 1953, Two uranium-bearing pegmatite bodies in San Bernardino County, California: Am. Mineralogist, v. 38, p. 1040-1050.

Hidden, W. E., 1886, Contributions to mineralogy: Am. Jour. Sci., 3d ser., v. 32, p. 204-211.

1889, [Yttrium minerals from Llano County, Texas]: New York Acad. Sci. Trans. 8, p. 185.

Hidden, W. E., and Mackintosh, J. B., 1888, On a new thorium mineral, auerlite: Am. Jour. Sci., 3d ser., v. 36, p. 461-463.

- 1889, A description of several yttria and thoria minerals from Llano County, Texas: Am. Jour. Sci., 3d ser., v. 38, p. 481.

1893, On mackintoshite, a new thorium and uranium mineral: Am. Jour. Sci., 3d ser., v. 46, p. 98.

Hiemstra, S. A., 1955, Baddeleyite from Phalabora, Eastern Transvaal: Am. Mineralogist, v. 40, p. 275-282.

Hillebrand, W. F., 1891, On the occurrence of nitrogen in uraninite, and on the composition of uraninite in general: U. S. Geol. Survey Bull. 78, p. 43-79.

- 1892, New analyses of uraninite: U. S. Geol. Survey Bull. 90, p. 22. 1893, A further example of the isomorphism of thoria and uranium dioxide: U. S. Geol. Survey Bull. 113, 41 p.

1903, Mineral analyses: U. S. Geol. Survey Bull. 220, 111 p.

1913, A danger to be guarded against in making mineral separations

by means of heavy solutions: Am. Jour. Sci., 4th ser., v. 35, p. 440. 
Hillebrand, W. F., 1924, Carnotite and tyuyamunite and their ores in Colorado and Utah: Am. Jour. Sci., 5th ser., v. 8, p. 201-216.

Hintze, C., 1898-1939, Handbuch der Mineralogie: 4 vols. divided into parts, and including a supplementary volume and a general index volume, Leipzig and Berlin.

Hirschi, H., 1925, Uranerz im tertiären Granit vom Bergell: Schweizer. mineralog. petrog. Mitt., Band 5, p. 249, 429.

1928, Thormineral aus Lithium-pegmatit von Camp Harding bei Embudo, New Mexico: Schweizer. mineralog. petrog. Mitt., Band 8, p. 260-261.

Hoekstra, H. R., and Fuchs, L. H., 1956, Synthesis of coffinite-USiO 4 : Science, v. 123 , p. 105.

Hoekstra, H. R., and Katz, J. J., 1955, Age of uraninite from crystallographic data: Nature, v. 175 , p. 605.

Hoekstra, H. R., Siegel, S., Fuchs, L. H., and Katz, J. J., 1955, The uraniumoxygen system; $\mathrm{UO}_{2.5}$ to $\mathrm{U}_{3} \mathrm{O}_{8}$ : Jour. Phys. Chemistry, v. 59, p. 136-138.

Hogarth, D. D., 1951, Studies of radioactive compounds; II, Meta-zeunerite, uranophane, kasolite, and cuprosklodowskite in Canada: Am. Mineralogist, v. 36, p. 411-414.

Hogarth, D. D., and Nuffield, E. W., 1954, Studies of radioactive compounds; VII, Phosphuranylite and dewindtite: Am. Mineralogist, v. 39, p. 444-447.

Holland, H. D., and Gottfried, D., 1955, The effect of nuclear radiation on the structure of zircon: Acta Crystallographica, v. 8, p. 291.

Holland, H. D., and Kulp, J. C., 1950, Geologic age from metamict minerals: Science, v. 111 , p. 312.

Holmes, A., 1948, Monazite from Bodmin Moor, Cornwall; a study in geochronology: Royal Soc. Edinburgh Proc., v. 63, p. 115.

Holmquist, P. J., 1896, Synthetische Studien über die Perowskit and Pyrochlor Mineralien: Uppsala Univ., Geol. Inst. Bull. 3, p. 180-268.

Hoppe, G., 1951, The accessory heavy minerals in eruptive rocks, with examples from the Ramberg granite and other Harz rocks: Geologica, no. $9,114 \mathrm{p}$.

Horne, J. E. T., 1951, The photoluminescence of minerals: Great Britain Geol. Survey Bull. 3, p. 20.

Howes, H. L., and Wilber, D. T., 1916, Fluorescing sodium uranyl phosphate: Phys. Rev., v. 7, p. 394.

Hubbard, L. L., 1886, Azor-Pyrrhit und Zirkon vom Laacher See, soweit Pyrrhit und Azorit von San Miguel: Naturh. Ver. preuss. Rheinlande, Westfalen Verh., Jahrg 43, p. 217.

Huber, E. J., Holley, C. E., and Meierkord, E. H., 1952, The heats of combustion of thorium and uranium: Am. Documentation Inst., Doc. 3576.

Hund, F., and Dürrwächter, W., 1951, Anomale Mischkristalle im System $\mathrm{ThO}_{2}-\mathrm{La}_{2} \mathrm{O}_{3}$ : Zeitschr. anorg. $u$. allgemeine Chemie, Band 265, p. 67-72.

Hund, F., and Niessen, G., 1952, Anomale Mischkristalle im System Thoriumoxyd-Uranoxyd: Zeitschr. Elektrochemie, Band 56, p. 972-979.

Hund, F., Wagner, R., and Peetz, U., 1952, Anomale Mischkristalle im System Cerdioxyd-Uranoxyd: Zeitschr. Elektrochemie, Band 56, p. 61-65.

Hurlburt, C. S., Jr., 1950, Studies of uranium minerals (IV) ; Johannite: Am. Mineralogist, v. 35, p. 531-535.

- 1954, Studies of uranium minerals (XV); Schroeckingerite: Am. Mineralogist, v. 39, p. 901-907.

Hurley, P. M., and Fairbairn, H. W., 1953, Radiation damage in zirconA possible age method: Geol. Soc. America Bull. 64, p. 659-673. 
Hussak, E., 1899, Mineralogische Notizen aus Brasilien: Tschermak's Mineralog. petrog. Mitt., Band 18, p. 346.

Hüttig, G. F., and Schroeder, E. von, 1922, Über die Hydrate des Urantetroxyds und Urantrioxyds: Zeitschr. anorg. u. allgemeine Chemie, Band 121, p. 243.

Hutton, C. O., 1947, The nuclei of pleochroic haloes: Am. Jour. Sci., v. 245, p. 154.

1950, Studies of heavy detrital minerals: Geol. Soc. America Bull., v. 61 , p. 635-716.

1952, Accessory mineral studies of some California beach sands: U. S. Atomic Energy Comm. RMO-981, 112 p., issued by Atomic Energy Comm. Tech. Inf. Service Extension, Oak Ridge, Tenn. [Summary available as RME-3045, p. 9, issued in 1953.]

1953, Studies of the minor constituents in some California beach sands, in Final technical report [for May 1, 1951-June 30, 1953], Part 1: U. S. Atomic Energy Comm. RME-3049, p. 6-36, issued by U. S. Atomic Energy Comm. Tech. Inf. Service Extension, Oak Ridge, Tenn.

- 1954, Wisaksonite is metamict uranoan thorite: Am. Mineralogist, v. 39, p. $825-829$.

limori, S., and Iwase, E., 1938, The fluorescence spectrum of autunite: Tokyo Inst. Phys. Chem. Research Sci. Paper, v. 34, p. 372.

Iimori, T., 1941, The microgranular uraninite from Iisaka and its absolute age: Am. Jour. Sci., v. 239, p. 819.

Iimori, T., and Hata, S., 1938, Japanese thorogummite and its parent mineral: Tokyo Inst. Phys. Chem. Research Sci. Paper, v. 34, p. 447-454.

Ingerson, E., 1938, Uraninite and associated minerals from Haddam Neck, Conn.: Am. Mineralogist, v. 23, p. 269-276.

Jaffe, H. W., 1955, Precambrian monazite and zircon from the Mountain Pass district, San Bernardino County, California: Geol. Soc. America Bull., v. 66, p. 1247-1256.

Jaffe, H. W., Sherwood, A. M., and Peterson, M. J., 1948, New data on schroeckingerite: Am. Mineralogist, v. 33, p. 152-157.

Jakób, W., and Tołłoczko, St., 1911, Chemische Analyse des Thorianits von Ceylon: Akad. Wiss. Krakau Anz., Math.-Naturw. Kl., Reihe A, no. 8A, p. 558-560.

James, C. C., 1947, Uranium ores in Cornish mines: Royal Geol. Soc. Cornwall Trans., v. 17 (pt. 5, for 1945), p. 256-268.

Jameson, R., 1820, A system of mineralogy, 3d ed.: Edinburgh.

Ježek, B., 1916, Über den Johannit von Joachimsthal: Acad. Sci. Empereur François Joseph Bull., internat., Cl. sci. math. nat., $20^{\circ}$ année, p. 358-376. - 1922, Morphological and physical properties of zeunerite: Ceská Akademia véd a Uměni u Praze, Rozpravy, v. 31, no. 15.

1923, Roentgenographic contribution to the knowledge of pisekite [in Czechoslovakian]: Casopis Min. Geol. Prague, v. 1, p. 69-70.

John, J. F., 1821, Chemische Untersuchung eines natürlichen Uranvitriols: Chemische Untersuchung, v. 5, p. 254; Jour. Chemie u. Physik, v. 32, p. 248.

—_ 1845, Uranvitriol: Jahrb. Mineralogie 1845, p. 299.

Johnstone, S. J., 1914, Monazites from some new localities: Soc. Chem. Industry Jour., v. 33, p. 55-59.

1954, Minerals for the chemical and allied industries: New York, John Wiley and Sons, $692 \mathrm{p}$. 
Joubin, F. R., 1954, Uranium deposits of the Algoma district, Ontario: Canadian Min. Metall. Bull., v. 47, no. 510, p. 673-679.

Kalinin, P. V., 1945, Thorite from pegmatite veins of Sludianka [in Russian]: Zapiski Rossiysk. Mineralog. Obshch., v. 74, pt. 3, p. 200.

Karkhanavala, M. D., and Shankar, J., 1954, An X-ray study of natural monazite: India Acad. Sci. Proc., v. 40A, p. 67.

Karsten, D. L. G., 1793, Werner's Verbesserungen in der Mineralogie: Berlin, p. 43.

1800, Mineralogische Tabellen, 1st ed.: Berlin, p. 56.

Kašpárek, A., and Němec, D., 1951, Wolframite and autunite from Dolní Bory [in Czechoslovakian]: Sborník Klubu Prírod. Brně, v. 29, p. 76-80.

Katz, J. J., and Rabinowitch, E., 1951, The chemistry of uranium; pt. 1, The element, its binary and related compounds, National Nuclear Energy Series, Div. VIII, v. 5: New York, Atomic Energy Comm. and McGrawHill Book Co., Inc., 609 p.

Kazitsyn, Y. V., 1954, Ferutite [in Russian]: Zapiski Rossiysk. mineralog. Obshch., v. 83 , no. 4 , p. 425.

Keller, W. D., 1952, Torbernite in Missouri fire clay: Am. Mineralogist, v. 37, p. $125-128$.

Kerr, P. F., 1950, Mineralogical studies of uraninite and uraninite-bearing deposits, July 1, 1949, to June 30, 1950: U. S. Atomic Energy Comm. RMO-715, 61 p. [Microcard copy on file in U. S. Atomic Energy Comm. depository libraries.]

- 1951, Natural black uranium powders: Science, v. 114, p. 91.

1956, The natural occurrence of uranium and thorium, in Proceedings of the International Conference on the Peaceful Uses of Atomic Energy, v. 6, New York, United Nations, p. 5-59.

Kerr, P. F., and Holland, H. D., 1951, Differential thermal analyses of davidite: Am. Mineralogist, v. 36, p. 563-573.

Kerr, P. F., and Kulp, J. L., 1952, Pre-Cambrian uraninite, Sunshine mine, Idaho: Science, v. 115, p. 86-88.

Kersten, C., 1839, Untersuchung des Monazits: Annalen Physik, Band 47, p. 389.

Khlopin, V. G., 1925, The chemical formula and age of tyuyamunite [in Russian]: Acad. sci. U.R.S.S., Comptes rendus, 1925, p. 73-76.

- 1938, Oxygen method of determination of geological age based on atomic disintegration and its application to the age determination of Karelian uraninites and uraninites from Wilberforce and South Dakota [in Russian with English summary]: Acad. sci. U.R.S.S. Bull., Cl. sci. math. nat., sér. chim., 1938, p. 489-497.

Kidd, D. F., and Haycock, M. H., 1935, Mineragraphy of the ores of Great Bear Lake: Geol. Soc. America Bull., v. 46, p. 879-960.

Kimura, K., and Iimori, T., 1936, Monazite, uraninite, and autunite from Japan [abstract, in Japanese]: Geol. Soc. Japan Jour., v. 43, p. 450-452.

Kimura, K., and Miyake, Y., 1932, On enalite, a new variety of urano-thorite, found in Naegi, Gifu prefecture [in Japanese]: Chem. Soc. Japan Jour., v. 53, p. 93-100.

King, D., 1954, Geology of the Crockers Well uranium deposit: South Australia Geol. Survey Bull. 30, p. 70.

King, R. U., Leonard, B. F., Moore, F. B., and Pierson, C. T., 1953, Uranium in the metal-mining districts of Colorado: U. S. Geol. Survey Circ. 215, $10 \mathrm{p}$. 
Kirchheimer, F., 1952, Die Uranerzvorkommen im mittleren Schwarzwald: Badische geol. Landesanstalt Mitt. 1951, p. 1-74.

_ 1953, Weitere Untersuchungen über das Vorkommen von Uran im Schwarzwald: Baden-Württemberg. geol. Landesamt Abh., Heft 1, 60 p. Kirsch, G., 1925, Über die Zusammensetzung des Pechblenden: Tschermak's Mineralog. petrog. Mitt., Band 38, p. 227.

Klaproth, M. H., 1789, The chemical investigation of uranite, a newly discovered metallic substance: Crell's Chem. Jour. London, v. 2, p. 387; also Akad. Wiss. Berlin Mem., 1789, p. 273; Gessell. naturf. Freunde Berlin Schr., Band 9, p. 273.

- 1792, 1797, Chemische und mineralogische Kenntnis des Uran: R. preuss. Akad. Wiss. Berlin Mem., Band 160 (1792) for 1786-87; v. 2, p. 197 (1797).

1797, Beiträge zur chemischen Kenntnis der Mineralkörpers, Band 2, p. 217. [English translation in Analytical essays towards promoting the chemical knowledge of mineral substances, London, 476 p., 1801.]

Klemic, H., and Baker, R. C., 1954, Occurrences of uranium in Carbon County, Pennsylvania: U. S. Geol. Survey Circ. 350, 8 p.

Knop, A., 1875, Ueber "Koppit" vom Kaiserstuhl: Neues Jahrb. Mineralogie 1875, p. 67.

Knop, W., 1856, Neue Methode die Phosphorsäure zu bestimmen: Chem. Centralbl., Neue Folge, Jahrg. 1, no. 49, 769-779.

Kobayashi, M., 1912, On the composition of thorianite: Tōhoku Imp. Univ. Sci. Repts., 1st ser., v. 1, p. 201-206.

Kobell, Fr. von, 1853, Die Mineral-Namen: Munich, p. 84.

Kohl, E., 1941, U̇ber des Uranpecherz nebst Abkömmlingen im Bereich des Mansfelder Kupferschiefers und seine Herkunst: Zeitschr. prakt. Geologie, Jahrg. 49, p. 99-107.

- 1954, Die metallischen Rohstoffe-ihre Lagerungsverhältnisse und ihre wirtschaftliche Bedeutung; Band 10, Uranium: Stuttgart, 234 p.

Kohman, T. P., and Saito, N., 1954, Radioactivity in geology and cosmology, in Beckerley, J. G., ed., Annual Review of Nuclear Science, v. 4: Stanford, California, Annual Reviews, Inc., p. 401-462.

Konjarov, G., 1938, Uranium ore on the Goten [in Bulgarian with German summary]: Trudy podzemnaya bogat. min. ind., Bulgarija, v. 8, p. 236-244. [Abstract in Neues Jahrb. Mineralogie, 1939, Referate II, p. 789-790.]

Kostyleva, E. E., 1946, On metamictic disintegration of the zircon group of minerals: Voprosy mineralogii geokhimii i petrografii, Akademii Nauk S.S.S.R., Fersman Memorial v., p. 27-35. [Translated by T. Stadnichenko, in U. S. Geol. Survey Trace Elements Inv. Rept. 369, U. S. Atomic Energy Comm., Tech. Inf. Service, Oak Ridge, Tenn.]

Kraft, J., 1938, Uranyl orthoarsenates: Acad. Sci. Paris Comptes rendus, tome 206, p. 57.

Kratochvíl, F., 1952, New occurrences of autunite and torbernite in Bohemia [in Czechoslovakian with English and Russian summaries]: Ceskoslovenské Státní Geol. Ústav Sborník, v. 19, p. 329-336.

Krejčí, A., 1923, Pisekite, a new radioactive mineral or pseudomorph [in Czechoslovakian]: Casopis Min. Geol. Prague, v. 1, p. 2-5.

Kreutz, St., 1915, Sur la réfringence du pyrochlore et de la béckélite: Akad. Wiss. Krakau Anz., Math.-Naturw. Kl., Reihe A, no. 8-10A, p. 236-240. [Cited in Jahrb. Mineralogie 1918, p. 134.] 
Krieger, P., 1932, An association of gold and uraninite from Chihuahua, Mexico: Econ. Geology, v. 27, p. 651-660.

Kuno, H., 1950, Pegmatites of Sui-chung district, south Manchuria: Geol. Soc. Japan Jour., v. 56, p. 79-83.

Kurbatov, I., 1926, Über Vanadium Verbindungen und das neue Mineral "Usbekite": Centralbl. Mineralogie 1926, Abt. A, p. 345.

Lacroix, A., 1893-1913, Minéralogie de la France et de ses colonies, v. 1, $1893-1895$; v. 2, 1897; v. 3, 1901; v. 4, 1910; v. 5, 1913: Paris.

— 1912a, Les niobotantalotitanates uranifères des pegmatites de Madagascar: Acad. Sci. Paris Comptes rendus, tome 154, p. 1040.

1912b, Sur un groupe de niobotantalates cubiques, radioactifs, des pegmatites du Vakinankaratra: Soc. française Minéralogie Bull., tome 35, p. 84-92.

1914, Sur quelques déformations des cristaux de bétafite et de béryl: Soc. française Minéralogie Bull., tome 37, p. 101-107.

- 1922, 1923, Minéralogie de Madagascar, [3 v.], tome 1, 2, 1922; tome 3, 1923: Paris.

Lambertson, W. A., and Mueller, M. H., 1953, Uranium oxide phase equilibrium studies III: Am. Ceramic Soc. Jour., v. 36, p. 365-368.

Lambertson, W. A., Mueller, M. H., and Gunzel, F. H., 1953, Uranium oxide phase equilibrium studies IV: Am. Ceramic Soc. Jour., v. 36, p. 397-399.

Landes, K., 1932, The Baringer Hill, Texas, pegmatite: Am. Mineralogist, v. 17, p. $381-390$.

Lang, A. H., 1952, Canadian deposits of uranium and thorium: Canada Geol. Survey Econ. Geology Ser., no. 16, 159 p.

Lang, S. M., 1953, An annotated bibliography of selected references on the solid-state reactions of the uranium oxides: Natl. Bur. Standards Circ. $535,95 \mathrm{p}$.

Lang, S. M., Maxwell, L. H., and Geller, R. R., 1949, Physical properties of porcelains in the systems $\mathrm{MgO}-\mathrm{BeO}-\mathrm{ZrO}_{2}$ and $\mathrm{MgO}-\mathrm{BeO}-\mathrm{ThO}_{2}$ and their phase relations: Natl. Bur. Standards Jour. Research, v. 43, p. 429.

Larsen, E. S., Jr., 1921, The microscopic determination of the nonopaque minerals: U. S. Geol. Survey Bull. 679, 294 p.

Larsen, E. S., Jr., and Berman, H., 1926, The identity of gilpinite and johannite: Am. Mineralogist, v. 11, p. 1.

1934, The microscopic determination of the nonopaque minerals, $2 d$ ed.: U. S. Geol. Survey Bull. 848, 266 p.

Larsen, E. S., Jr., and Brown, G. V., 1917, Gilpinite, a new uranium mineral from Colorado: Am. Mineralogist, v. 2, p. 75-79.

Larsen, E. S., Jr., and Gonyer, F. A., 1937, Dakeite, a new uranium mineral from Wyoming: Am. Mineralogist, v. 22, p. 561-563.

Larsen, E. S., Jr., Hess, F. L., and Schaller, W. T., 1926, Uranium minerals from Lusk, Wyoming: Am. Mineralogist, v. 11, p. 155-164.

Larsen, E. S., Jr., Keevil, N. B., and Harrison, H. C., 1952, Method for determining the age of igneous rocks using the accessory minerals: Geol. Soc. America Bull., v. 63, p. 1045-1052.

Leal Luna, J. de D., 1943, Algunas consideraciones sobre la edad del universo y edad de tres minerales españoles: Inst. Geol. y Minero España Notas y Comm., no. 11, p. 149-217.

Le Conte, J. L., 1847, On coracite, a new ore of uranium: Am. Jour. Sci., 2d ser., v. 3, p. 173-175.

Ledoux, A., 1913, Les roches cristallines du Kasai: Soc. géol. Belgique Annales, tome 40, p. C177. 
Lemmlein, G. G., 1945, Colored haloes surrounding inclusions of monazite in quartz: Nature, v. 155, p. 724.

Levine, C. A., and Seaborg, G. T., 1951, Occurrence of plutonium in nature: Am. Chem. Soc. Jour., v. 73, p. 3278-3283.

Lévy, A., 1823, Description of a new mineral (turnerite): Annals of Philosophy, v. 5, p. 241.

- 1837, Description d'une collection de minéraux [etc.], v. 3: London, p. 329.

Lind, S. C., and Davis, C. W., 1919, A new deposit of uranium ore: Science, v. 49, p. 443.

Lienau, H., 1898, Beiträge zur Kenntnis der Uranylsalze: Dissertation, Univ. of Berlin. [Cited in Croxton, 1951.]

Lietz, J., 1937, Beiträge zur Frage der Zirkone niedriger Dichte: Zeitschr. Kristallographie, Band 98, p. 201-210.

Lindstrom, G., 1874, Blomstrandit, ett nytt uranmineral från Nohl: Geol. Fören. Stockholm Förh., Band 2, p. 162.

1881, Analysis of thorite from Hitterö: Geol. Fören. Stockholm Förh., Band 5, p. 500 .

Louw, J. D., 1955, Geological ages of Witwatersrand uraninites: Nature, $\nabla$. 175, p. 349.

Lovering, T. G., 1954, Radioactive deposits of Nevada: U. S. Geol. Survey Bull. 1009-C, p. 63-106.

Ludwig, C. F., 1803, Ludwig's ed., Werner's Handbuch der Mineralogie, v. 1: Leipzig, p. 55.

Luna, I. R. de, and Freitas, F., 1954, Geology and metallogeny of the uranium deposits of the Mavudzi Valley, Tete (Portuguese East Africa) : Internat. Geol. Cong., 19th, Algiers 1952, Comptes rendus, fasc. 20, p. 293-307.

Machatschki, F., 1932a, Die Pyrochlor-Romeit Gruppe: Chemie der Erde, v. 7, p. 56,64 .

1932b, Die Kristallstruktur des Pyrrhit: Zentralbl. Mineralogie 1932, Abt. A, p. 33.

McKelvey, V. E., Everhart, D. L., and Garrels, R. M., 1956, Origin of uranium deposits: Econ. Geology 50th Anniversary v., pt. 1, p. 464-533.

McKelvey, V. E., and Nelson, J. M., 1950, Characteristics of marine uraniumbearing sedimentary rocks: Econ. Geology, v. 45, p. 35-53.

Magneli, A., and Kihlborg, L., 1951. On the cerium dioxide-uranium dioxide system: Acta Chem. Scandinavica, v. 5, p. 578.

Marckwald, W., 1906, Utber Uranerze aus Deutsch-Ostafrika : Zentralbl. Mineralogie 1906 , p. 761.

Marsh, J. K., 1929, The order of fractionation of rare-earth bromates, and a search for illinium: Chem. Soc. London Jour. 1929, p. 2387.

Matveyeff, C., 1932, Einige Data die Röntgenspektroskopie der Monazite von Bortschowotschny-kette, Transbaikalien: Neues Jahrb. Mineralogie, Beilage-Band 65, Abt. A, p. 223.

Mawson, D., 1906, On certain new mineral species associated with carnotite in the radioactive ore body near Olary: Royal Soc. South Australia Trans. and Proc., v. 30, p. 191.

- 1916, Mineral notes: Royal Soc. South Australia Trans. and Proc., v. 40, p. 262 .

1944, The nature and occurrence of uraniferous mineral deposits in South Australia: Royal Soc. South Australia Trans. and Proc., v. 68, p. 334. 
Meen, V. B., 1948, A uraninite crystal of unusual size: Toronto Univ. Studies, Geol. Ser., no. 52, p. 90.

Meixner, H., 1940a, Notizen über neue Vorkommen einiger Uranminerale: Zentralbl. Mineralogie-1940, Abt. A, p. 145-148.

1940b, Fluoreszenzanalytische, optische und chemische Beobachtungen an Uranmineralen: Chemie der Erde, Band 12, p. 433-450.

1953, Kahlerit, ein neues Mineral der Uranglimmergruppe, aus der Hüttenberger Erzlagerstätte: Der Karinthin, Folge 23, p. 277-280.

Melkov, V. G., 1942, Peligotite, a new mineral species [in Russian] : Zapiski vses. mineralog. Obshch., v. 71, p. 9-11.

1945, On the uranovanadate from the Mailu-Su deposit in Kirgizia [in Russian]: Zapiski Rossiysk. mineralog. Obshch., v. 74, p. 41.

Mellor, J. W., 1927, 1932, A comprehensive treatise on inorganic and theoretical chemistry, v. 7, 1927, v. 12, 1932: London, Longmans, Green and Co.

Mélon, J., 1924, Analyse et composition de la fourmariérite: Soc. géol. Belgique Annales, tome 47, p. B200-B202.

- 1934, Contribution à l'étude de la kasolite: Acad. royale Belgique Bull., Cl. Sci. 5e sér., tome 20, p. 178-182.

- 1938, La sharpite, nouveau carbonate d'uranyle du Congo belge: Inst. royal colonial belge Bull. 9, p. 333-336.

Mertie, J. B., Jr., 1953, Monazite deposits of the southeastern Atlantic States: U. S. Geol. Survey Circ. 237, 31 p.

Michel-Lévy, A., and Lacroix, A., 1888, Les minéraux des roches: Paris, p. 157.

Micke, K. E. von, 1950, Über ostafrikanische Glimmerpegmatitlagerstätten: Deutsche geol. Gesell. Zeitschr., Band 102, p. 101.

Miholić, S., 1954, Genesis of the Witwatersrand gold-uranium deposits: Econ. Geology, v. 49, p. 537-540.

Miller, L. J., 1955, Uranium ore controls of the Happy Jack deposit, White Canyon, San Juan County, Utah: Econ. Geology, v. 50, p. 156-169.

Miller, L. J., and Kerr, P. F., 1954, Progress report on the chemical environment of pitchblende, in Annual Report for June 30, 1953, to April 1, 1954, Part 2: U. S. Atomic Energy Comm. RME-3096 (Part 2), p. 72-92, issued by U. S. Atomic Energy Comm. Tech. Inf. Service Extension, Oak Ridge, Tenn.

Miller, P. D., Pray, H. A., and Munger, H. P., 1949, The preparation of uranyl carbonate and measurement of its solubility: U. S. Atomic Energy Comm. AECD-2740, 15 p. [Microcard copy on file in U. S. Atomic Energy Comm. depository libraries.]

Millosevich, F., 1912, Zeunerite e altri minerali dell' isola de Montecristo: R. accad. Lincei Atti, Rend. Cl. sci. fis. mat. e nat., v. 21, p. 594-597.

Milne, I. H., and Nuffield, E. W., 1951, Studies of radioactive compounds; I, Vandenbrandeite: Am. Mineralogist, v. 36, p. 394-410.

Montgomery, A., 1954, Uranium minerals of the Mauch Chunk area, Pennsylvania: Pennsylvania Acad. Sci. Proc., v. 208, p. 102.

Montignie, E., 1937, Etude de quelques sals d'uranyle: Soc. chim. France Bull., $5^{\mathrm{e}}$ sér., tome 4, p. 1142-1144.

Mooney, R. C. L., 1948, Crystal structures of some rare earth phosphates: Jour. Chem. Physics, v. 16, p. 1003.

Moore, F. B., and Butler, C. R., 1952, Pitchblende deposits at the Wood and Calhoun mines, Central City mining district, Gilpin County, Colorado: U. S. Geol. Survey Circ. 186, 8 p. 
Moore, G. W., and Levish, M., 1955, Uranium-bearing sandstone in the White River badlands, Pennington County, South Dakota: U. S. Geol. Survey Circ. $359,7 \mathrm{p}$.

Morehead, F. F., and Daniels, F., 1952, Storage of radiation energy in crystalline lithium fluoride and metamict minerals: Jour. Phys. Chemistry, v. 56, p. 546.

Mountain, E. D., 1931, Pegmatites of the Cape Province: Albany Museum Records, Grahamstown [Union of South Africa], v. 4, p. 122.

Moxham, R. M., and Nelson, A. E., 1952, Reconnaissance for radioactive deposits in south-central Alaska, 1947-49: U. S. Geol. Survey Circ. 184, $13 \mathrm{p}$.

Mrose, M. E., 1950, Studies of uranium minerals (III) ; Saléeite from Schneeberg, Saxony: Am. Mineralogist, v. 35, p. 525-530.

1953, Studies of uranium minerals (XIII); Synthetic uranospinites: Am. Mineralogist, v. 38, p. 1159-1168.

Mügge, O., 1884, Beiträge zur Kenntniss der Cohäsionverhältnisse einiger Mineralien: Neues Jahrb. Mineralogie, 1884, Band 1, Abh. 1, p. 59 (p. 50-62).

Muilenburg, G. A., and Keller, W. D., 1950, Carnotite and radioactive shale in Missouri: Am. Mineralogist, v. 35, p. 323-324.

Murata, K. J., Cisney, E. A., Stieff, L. R., and Zworykin, E. V., 1951, Hydration and base exchange properties of carnotite, tyuyamunite, and related compounds [abs.]: Am. Mineralogist, v. 36, p. 323.

Murata, K. J., Rose, H. J., and Carron, M. K., 1953, Systematic variation of rare earths in monazite: Geochim. et Cosmochim. Acta, v. 4, p. 292-300.

Nag-Chowdhury, B. D., and Mousuf, A. K., 1946, The estimation of uranium and thorium from the $\beta$-radioactivity of minerals: Natl. Inst. Sci. India Proc., v. 12, p. 341-349.

Nan, Y. T., and Wu, L. P., 1943, Note on some uranium minerals from eastern Kuangsi: Geol. Soc. China Bull., v. 23, p. 169-172.

National Research Council, 1924 et seq., Committee on measurement of geologic time; also Natl. Research Council Bull. 80, 1931.

Nenadkević, K. A., 1912, Tyuyamunite-a new mineral species [in Russian]: Acad. imp. sci. St. Pétersbourg Bull., sér. 6, tome 6, p. 945-946.

1926, On the chemical composition of uranite from Karelia [in Russian]: Acad. sci. U.R.S.S. Bull., tome 20, p. 767-774.

Neuerburg, G. J., 1956, Uranium in igneous rocks of the United States, in Page, L. R., Stocking, H. E., Smith, H. B., compilers, Contributions to the geology of uranium and thorium by the U. S. Geological Survey and Atomic Energy Commission for the United Nations International Conference on Peaceful Uses of Atomic Energy, Geneva, Switzerland, 1955: U. S. Geol. Survey Prof. Paper 300, p. 55-64.

Neuhaus, A., 1954, Utber Uraninit im Granit von Weissenstadt, Fichtelgebirge: Fortschr. Mineralogie, Band 32, p. 80.

Nininger, R. D., 1954, Minerals for atomic energy: New York, D. Van Nostrand, $367 \mathrm{p}$.

Nordenskiöld, A. E., 1876, Mineralogische Mitteilungen: Geol. Fören. Stockholm Förh., Band 3, p. 226.

1878, Cleveit, ett nytt yttro-uran mineral: Geol. Fören. Stockholm Förh., Band 4, p. 28.

1884, Uransilicat von Garte Feldspathbruch bei Arendal: Geol. Fören. Stockholm Förh., Band 7, p. 121. 
Nováček, R., 1935a, Revision of the secondary uranium minerals from Jachymov [in Czechoslovakian]: Národni Mus., Casopis, oddil př́rod, ročnik 19, p. 100-107.

$1935 \mathrm{~b}$, Study on some secondary uranium minerals: Cěské Spolěcnost Nauk, Věstnĭk Král, 1935, no. 7, Cl. 2, 36 p.

1936, Some remarks on the mineralogy of the Pisek district [in

Czechoslovakian]: Věda Př́rodní (Prague), v. 17, p. 228-230.

1939, The identity of dakeite and schroeckingerite: Am. Mineralogist, v. 24, p. $317-323$.

1941, On the question of the chemical formula of uranopilite and $\beta$-uranopilite [in Czechoslovakian with German and French summaries]: Cěské Spolěcnost Nauk, Veštnǐk Král. 1941, no. 17, 13 p.

Nuffield, E. W., 1954, Brannerite from Ontario, Canada: Am. Mineralogist, v. 39 , p. 520-522.

Nuffield, E. W., and Milne, I. H., 1953, Studies of radioactive compounds; VI, Meta-uranocircite: Am. Mineralogist, v. 38, p. 476-488.

Olson, J. C., and Wallace, S. R., 1956, Thorium and rare earth minerals in the Powderhorn district, Gunnison County, Colorado: U. S. Geol. Survey Bull. 1027-0, p. 693-723.

Orcel, J., and Lévy, C., 1953, Analyse thermique de la bétafite, minéral metamict: Acad. Sci. Paris Comptes rendus, tome 236, p. 1177-1179.

Osipov, L. A., 1941, Geological peculiarities of the Uigursaisk uranium deposits [in Russian]: Sovietskaya Geologiya, [v. 11], no. 3, p. 36.

Pabst, A., 1951a, X-ray examination of uranothorite: Am. Mineralogist, $\nabla$. 36 , p. 557-562.

1951b, Huttonite, a new monoclinic thorium silicate: Am. Mineralogist, v. 36, p. 60-69, including C. 0 . Hutton, With an account of its occurrence, analysis, and properties.

1952, The metamict state: Am. Mineralogist, v. 37, p. 137-157.

1954, Brannerite from California: Am. Mineralogist, v. 39, p. 109-117.

Padurow, N. N., and Schusterius, C., 1953, Roentgenographische Untersuchungen im system $\mathrm{In}_{2} \mathrm{O}_{3}-\mathrm{Y}_{2} \mathrm{O}_{3}-\mathrm{CeO}_{2}-\mathrm{ThO}_{2}$ : Deutsche keram. Gesell. Ber., Band 30, p, 251.

Page, L. R., 1950, Uranium in pegmatites: Econ. Geology, v. 45, p. 12-34.

Page, L. R., Stocking, H. E., and Smith, H. B., compilers, 1956, Contributions to the geology of uranium and thorium by the U. S. Geological Survey and Atomic Energy Commission for the United Nations International Conference on Peaceful Uses of Atomic Energy, Geneva, Switzerland, 1955: U. S. Geol. Survey Prof. Paper 300, 739 p.

Paijkull, S. R., 1877, Mineralogiska notiser; Eukrasit, ett nytt mineral från Brevig: Geol. Fören. Stockholm Förh., Band 3, p. 350.

Palache, C., 1934, Crystallography of the uranium oxides: Am. Mineralogist, v. 19 , p. $309-315$.

Palache, C., and Berman, H., 1933, Oxidation products of pitchblende from Great Bear Lake: Am. Mineralogist, v. 18, p. 20-24.

Palache, C., Berman, H., and Frondel, C., 1944, 1951, Dana's system of mineralogy, 7th ed., v. 1, 1944, 834 p.; v. 2, 1951, 1124 p.: New York, John Wiley and Sons.

Palache, C., and Gonyer, F. A., 1940, Microlite and stibiotantalite from Topsham, Maine: Am. Mineralogist, v. 25, p. 411-417.

Palmqvist, S., 1936, Preparation of crystalline uranyl ammonium phosphate: K. fysiog. Sällsk. Lund Förh., Band 6, p. 43-49. 
Parker, R. L., 1937, A note on the morphology of monazite: Am. Mineralogist, v. 22 , p. $572-580$.

1954, Die Mineralfunde der Schweizer Alpen: Basel, $311 \mathrm{p}$.

Parkin, L. W., and Glasson, K. R., 1954, The geology of the Radium Hill uranium mine, South Australia: Econ. Geology, v. 49, p. 815.

Parrish, W., 1939, Unit cell and space group of monazite: Am. Mineralogist, v. 24, p. 651-652.

Parsons, A. L., 1932, Crystal habit of uraninite from Cardiff Township, Ontario: Toronto Univ. Studies, Geol. Ser., no. 32, p. 17-18.

Passerini, L., 1930, Isomorfismo tra ossidi di metalli tetravalenti; I, Sistemi $\mathrm{CeO}_{2}-\mathrm{ThO}_{2} ; \mathrm{CeO}_{2}-\mathrm{ZrO}_{2} ; \mathrm{CeO}_{2}-\mathrm{HfO}_{2}$ : Gazz. chim. italiana, v. 60, p. 762-776.

Peacock, M. A., 1935, On johannite from Joachimsthal and Colorado: Zeitschr. Kristallographie, Band 90, p. 112.

Peixoto, F., and Guimaraẽs, D., 1953, Problemas de cronogeologia; Univ. Minas Gerais, Escola eng., Inst. pesquisas radioativas, Pub. no. 1, p. 1-34.

Péligot, E., 1841, Sur le poids atomique de l'urane: Acad. Sci. Paris Comptes rendus, tome 12, p. 735-737; Jour. prakt. Chemie, Band 24, p. 442.

Pellas, P., 1951, Sur la destruction spontanée des réseaux cristallins de minéraux radioactifs: Acad. Sci. Paris Comptes rendus, tome 233, p. 1369-1371.

— 1952, Sur la transition ordre-désordre dans les réseaux cristallins de minéraux radioactifs: Acad. Sci. Paris Comptes rendus, tome 234, p. 538-540.

1954, Sur la formation de l'état metamicte dans le zircon: Soc. française Minéralogie et Cristallographie Bull., tome 77, p. 447.

Pelloux, A., 1934, I minerali uraniferi e le sorgenti di acque radioattive della miniera di Lurisia presso Roccaforte di Mondovi: Soc. Linguistica Sci. Lett. (Geneva), v. 13, p. 137-170.

Penfield, S. L., 1882, On the occurrence and composition of some American varieties of monazite: Am. Jour. Sci., 3d ser., v. 24, p. 250-254.

Perio, P., 1953a, Variétés crystallines de $\mathrm{UO}_{3}$ : Soc. chim. France Bull. 1953, p. 776-777.

1953b, Considérations sur les oxydes d'uranium compris entre $\mathrm{UO}_{2}$ et $\mathrm{U}_{3} \mathrm{O}_{8}$ : Soc. chim. France Bull. 1953, p. 840 .

1953c, L'oxydation de $\mathrm{UO}_{2}$ à basse température: Soc. chim. France Bull. 1953, p. 256-263.

Permingeat, F., 1952, Présence de la pechblende dans la minéralisation du gîte d'Azegour, Maroc.: Acad. Sci. Paris Comptes Rendus, tome 234, p. 123, 232.

Phair, G., and Levine, H., 1953, Notes on the differential leaching of uranium, radium, and lead from pitchblende in $\mathrm{H}_{2} \mathrm{SO}_{4}$ solutions: Econ. Geology, v. 48, p. 358-369.

Phair, G., and Shimamoto, K. O., 1952, Hydrothermal uranothorite in fluorite breccias from the Blue Jay mine, Jamestown, Boulder County, Colorado: Am. Mineralogist, v. 37, p. 659-666.

Phillips, R., 1823, Analysis of uranite of Cornwall: Annals of Philosophy, v. 5, p. 57.

Phillips, W., 1816, Elementary introduction to mineralogy, 1st ed.: London.

Pinto Coelho, A. V., 1954, O minério de urânio de Mavudzi-Tete (Moçambique): Garcia de Orta, v. 2, no. 2, p. 209-219.

Pisani, F., 1861, Analyse de l'uranite d'Autun et de la chalkolite de Cornouailles: Acad. Sci. Paris Comptes rendus, tome 52, p. 817. 
Pisani, F., 1904, Examen de plusieurs minéraux au point de vue de leur radioactivité: Soc. française Minéralogie Bull., tome 27, p. 58-63.

Pjatnitzky, P., 1892, Ueber die Kristallform des Uranotil: Zeitschr. Kristallographie, Band 21, p. 74 .

Popov, V. I., 1939, On the occurrence in northern Fergana of deposits analogous to carnotite sandstones [in Russian]: Sovietskaya Geologia, v. 9, no. 4-5, p. 32-39.

Primak, W., Fuchs, L. H., and Day, P., 1953, Radiation damage in insulators: Phys. Rev., v. 92, p. 1064.

Protas, J., 1956, Synthèse de la billietite: Soc. française Minéralogie et Cristallographie Bull., tome 79, p. 350-351.

Przibram, K., 1946, Observations sur la fluorescence de quelques minéraux congolais et belges: Acad. royale Belgique Bull., Cl. sci., $5^{\mathrm{e}}$ sér., tome 32 , p. 363-369.

Puller, R. E. O., 1871, Ueber die wichtigsten Bestimmungsmethoden des Arsens in gewichtanalytischer Beziehung: Zeitschr. anal. Chemie, Band 10 , p. 72 .

Quensel, P., 1940, The uraninite minerals (ulrichite and pitchblende), Varuträsk: Geol. Fören. Stockholm Förh., Band 62, p. 391.

Radominsky, F. V. C., 1874, Sur un phosphate de cerium renfermant du fluor: Acad. Sci. Paris Comptes rendus, tome 78, p. 764.

1875, Reproduction artificielle de la monazite et de la xenotime: Acad. Sci. Paris Comptes rendus, tome 80, p. 304.

Ramdohr, P., 1936, Klockmann's Lehrbuch der Mineralogie, 11th ed.: Stuttgart, $625 \mathrm{p}$.

1950, Die Erzmineralien und ihre Verwachsungen: Berlin.

1955, Neue Beobachtungen an Erzen des Witwatersrand in Südafrika und ihre genetisches Bedeutung: Deutsch. Akad. Wiss. Berlin Abh., Math.naturwiss. Kl., no. $5,43 \mathrm{p}$.

Ramsay, W., Collie, J. N., and Travers, M., 1895, Helium, a constituent of certain minerals: Chem. Soc. London Jour., v. 67, p. 684.

Ramsay, W., and Zilliacus, A., 1897, Monazit von Impilaks: Finskaventensk.soc. Öfversigt Förh., v. 39, p. 1-9.

Rankama, K., and Sahama, Th. G., 1949, Geochemistry: Chicago, Univ. of Chicago Press, 912 p.

Rapaport, Irving, 1952, Interim report on the ore deposits of the Grants district, New Mexico: U. S. Atomic Energy Comm. RMO-1031, 19 p., issued by U. S. Atomic Energy Comm. Tech. Inf. Service Extension, Oak Ridge, Tenn.

Rath, W., 1951, Ceramic insulators for high frequency capacitors: Deutsche keram. Gesell. Ber., Band 28, p. 177.

Reuning, E., 1933, Mikrolith Varietåten von Donkerhuk, Südwestafrika: Chemie der Erde, v. 8, p. 186.

Richmond, W. E., 1937, Paragenesis of the minerals from Blueberry Mountain, Woburn, Mass.: Am. Mineralogist, v. 22, p. 290-300.

Rimbach, E., 1904, Ueber Löslichkeit und Zersetzlichkeit von Doppelsalzen in Wasser. (III. Mitteil.) Urandoppelsalzen: Deutsche chem. Gesell. Ber., Band 37, p. 461-487.

Rinne, F., 1901a, Kalkuranit und seine Entwässerrungsprodukte (Metakalkuranit) : Zentralbl. Mineralogie 1901, p. 709.

1901b, Kupferuranit und seine Entwässerungsprodukte (Metakupferuranit) : Zentralbl Mineralogie, 1901, p. 618. 
Roberts, L. E. J., 1954, The oxides of uranium. part 5: The chemisorption of oxygen on $\mathrm{UO}_{2}$ and on $\mathrm{UO}_{2}-\mathrm{ThO}_{2}$ solid solutions: Chem. Soc. London Jour. 1954, p. 3332.

Roberts, W. A., and Gude, A. J., 3d., 1953a, Geology of the area adjacent to the Free Enterprise Mine, Jefferson County, Montana: U. S. Geol. Survey Bull. 988-G, p. 143-155.

- 1953b, Uranium-bearing deposits west of Clancey, Jefferson County, Montana: U. S. Geol. Survey Bull. 988-F., p. 121-141.

Robinson, S. C., 1955, Mineralogy of uranium deposits, Goldfields, Saskatchewan: Canada Geol. Survey Bull. 31, 128 p.

Robinson, S. C., and Sabina, A. P., 1955, Uraninite and thorianite from Ontario and Quebec: Am. Mineralogist, v. 40, p 624-633.

Rodden, C. J., editor, 1950, Analytical chemistry of the Manhattan Project: National Nuclear Energy Series., Div. VIII, v. 1: New York, Atomic Energy Commission and McGraw-Hill Book Co.

Rodden, C. J., and Tregoning, J. J., 1950, Manual of analytical methods for the determination of uranium and thorium in their ores: U. S. Govt. Printing Office, Washington, D. C., 55. p.

Rogers, A. F., 1947, Uraninite crystals with a new form from Portland, Conn.: Am. Mineralogist, v. 32, p. 83-89.

Rohde, E. Ya., 1925, Upon tyuyamunite and some minerals of the uranite group [in Russian]: Zapiski Rossiysk Mineralog. Obshch., v. 54, p. 377-383.

Rose, G., 1840, Beschreibung einiger neuen Mineralien des Urals: Annalen Physik, Band 48, p. 562.

1842, Reise nach dem Ural, dem Altai, und dem kaspischen Meere, v. 2: Berlin.

Rosén, O., and Westgren, A., 1938, On the structure and composition of minerals belonging to the pyrochlore-atopite group and an X-ray analysis of disintegrated stibio-microlite: Geol. Fören. Stockholm Förh., Band 60 , p. 226-235.

Rosenqvist, I. T., 1947, Bidrag til diskusjonen om Haugesundshalrøyas Alder: Norsk geol. Tidsskr., Bind 26, p. 219-220.

Rosenzweig, A., Gruner, J. W., and Gardiner, L., 1954, Widespread occurrence and character of uraninite in the Triassic and Jurassic sediments of the Colorado Plateau: Econ. Geology, v. 49, p. 351-362.

Ross, C. S., Henderson, E. P., and Posnjak, E., 1931, Clarkeite, a new uranium mineral: Am. Mineralogist, v. 16, p. 213-220.

Ross, V., 1955a, Studies of uranium minerals (XVII) ; Synthetic schroeckingerite: Am. Mineralogist, v. 40, p. 515-519.

$1955 \mathrm{~b}$, Studies of uranium minerals (XXI) ; Synthetic hydrogen autunite: Am. Mineralogist, v. 40, p. 917-919.

Rowe, R. B., 1952, Petrology of the Richardson radioactive deposit, Wilberforce, Ontario: Canada Geol. Survey Bull. 23.

Rüdorff, W., and Valet, G., 1952, Über das Ceruranblau und die Halbleitereigenschaften der Mischkristallreihe $\mathrm{UO}_{2}-\mathrm{CeO}_{2}$ : Zeitschr. Naturforschung., Band $7 \mathrm{~b}$, p. 57.

Ruff, O., Ebert, F., and Woitinek, H., 1929, Das System $\mathrm{ZrO}_{2}-\mathrm{ThO}_{2}$ : Zeitschr. anorg. Chemie, Band 180, p. 252.

Rundle, R. E., Baenziger, N. C., Wilson, A. S., and McDonald, R. A., 1948, The structure of the carbides, nitrides, and oxides of uranium: Am. Chem. Soc. Jour., v. 70, p. 99-105. 
Sabot, R.-C., 1920, Etude cristallographique et optique d'un certain nombre de minéraux des pegmatites de Madagascar et minéraux de l'Oural: Dissertation, Geneva, 1914, 138p. [Abstract in Neues Jahrb. Mineralogie 1920, Referate, p. 138.]

Saito, S., 1927, Ammonium uranyl phosphate: Tōhoku Imp. Univ. Sci. Repts., 1st ser., v. 16, p. 739 .

Sandberger, F., 1877 [No title], Neues Jahrb. Mineralogie, Jahrg. 1877, p. 167.

Sarkar, T. C., 1941, The lead ratio of a crystal of monazite from the Gaya district, Bihar: Indian Acad. Sci. Proc., v. 13, sec. A., p. 245.

Satterly, J., 1955, Radioactive mineral occurrences in the vicinity of Hawk and Richard Lakes: Ontario Dept. Mines, Geol. Circ. 1, p. 1-6.

Schaller, W. T., 1933, A large crystal of monazite from North Carolina: Am. Mineralogist, v. 18, p. 435.

Scheerer, T., 1847, Untersuchung einiger Mineralien, welche tantalsäureähnliche Metallsäuren enthalten: Annalen Physik, Band 72, p. 570.

1860, [No title; paragraph of notes on scientific meeting held Jan. 3, 1860; Prof. Scheerer discussed a specimen containing thorite and orangeite] : Berg.-u. hüttenm. Zeitung, Band 19, p. 124.

Schetelig, J., 1913, Mineralogische Studien 1: Norsk geol. Tidsskr, Bind 2, no. $9,37 \mathrm{p}$.

Schneiderhöhn, H., 1952, Vergleich der Uranerzvorkommen des mittleren Schwarzwaldes mit anderen Lagerstätten: Badische geol. Landesanstalt Mitt. 1952, p. 84-105.

Schoep, A., 1921a, La curite, nouveau minéral radioactif: Acad. Sci. Paris Comptes rendus, tome 173, p. 1186.

1921b, Sur la kasolite, nouveau minéral radioactif: Acad. Sci. Paris Comptes rendus, tome 173, p. 1476.

- 1922a, Sur la becquerélite, nouveau minéral radioactif: Acad. Sci. Paris Comptes rendus, tome 174, p. 1240.

1922b, Sur la dewindtite, nouveau minéral radioactif: Acad. Sci. Paris Comptes rendus, tome 174, p. 623.

-1922c, Sur la stasite, un minéral nouveau, dimorphe de la dewindtite: Acad. Sci. Paris Comptes rendus, tome 174, p. 875.

1922d, La soddite, nouveau minéral radioactif: Acad. Sci. Paris Comptes rendus, tome 174, p. 1066.

- 1923a, Les minéraux uranifères (radioactifs) du Congo belge-becquerélite, curite, soddite, shinkolobwite, kasolite, dewindtite, parsonsite: Soc. belge géologie Bull., tome 33, p. 169-197.

$1923 b$, Sur la parsonsite, nouveau minéral radioactif: Acad. Sci. Paris Comptes rendus, tome 176, p. 171-173.

1923c, Sur la shinkolobwite, nouveau minéral uranifère de Katanga: Soc. belge géologie Bull., tome 33, p. 87-88.

1923d, Sur les formes cristeaux de soddite et sur leur propriétés optiques: Soc. belge géologie Bull., tome 33, p. 83-85.

- 1924a, Recherches sur la becquerélite et sur la schoepite, mesures de cristaux, analyse chimique, déhydration: Soc. chim. Belgique Bull., tome 33, p. 578-587.

1924b, Sur la forme cristalline de la becquerélite et de la schoepite, sur leur composition chimique et sur le polymorphisme de I'hydroxyde d'uranium $\mathrm{UO}_{3} \cdot 2 \mathrm{H}_{2} \mathrm{O}$ : Soc. chim. Belgique Bull., tome 33, p. 88-98.

1924c, Sur la composition chimique de la fourmariérite: Soc. francaise Minéralogie Bull., tome 47, p. 157. 
Schoep, A., 1924d, La dumontite, a nouveau minéral radioactif : Acad. Sci. Paris Comptes rendus, tome 179, p. 693.

1924e, Sur la sklodowskite, nouveau minéral uranifère; ses analogies avec l'uranotite: Soc. française Minéralogie Bull. 47, p. 162; Acad. Sci. Paris Comptes rendus, tome 179, p. 413.

- 1925a, Nouvelles recherches sur la dewindtite: Soc. chim. Belgique Bull., tome 34, p. 347.

1925b, Nouvelle recherches sur la dewindtite-biréfringence, composition chimique et déhydration de ce minéral; Comparaison avec la dumontite: Soc. française Minéralogie Bull., tome 48, p. 77-85.

1926a, Over janthiniet, een nieuw uranium mineraal uit Katanga: Natuurk. Tijdschr. Ned.-Indië, v. 7, p. 97.

- 1926b, Sur l'identité entre la shinkolobwite et la sklodowskite: Soc. belge Géologie Annales, tome 48, p. 303-306.

1927a, Sur l'ianthinite, nouveau minéral uranifère: Soc. belge Géologie Annales, v. 49, B188-B192, and Nouvelles observations sur l'ianthinite, p. B310-B312.

1927b, Over de vormen van curiet en van janthinietkristallen: Natuurk. Tijdschr. Ned.-Indië, v. 9, p. 1-3.

$1927 \mathrm{c}$, Isomorfie van sklodowskiet met uranofaan: Natuurk. Tijdschr. Ned.-Indië, v. 9, p. 30.

1927d, Kristallografische mededeelingen, kristallen van kasoliet, soddyiet, en brochantiet: Natuurk. Tijdschr. Ned.-Indië, v. 9, p. 25.

1928, La renardite, nouveau minéral uranifère: Soc. française Minéralogie Bull. tome 51, p. 247-252.

1930, Les minéraux du gîte uranifère du Katanga: Mus. Congo belge Annales, sér. 1, tome 1, fasc. 2, $43 \mathrm{p}$.

1932, La vandenbrandeite, un nouveau minéral uranifère: Mus. Congo belge Annales, sér. 1, tome 1, fasc. 3, p. 25.

1936a, Over cuprosklodowkiet: Natuurk. Tijdschr. Ned.-Indië, v. 18, p. 282.

1936b, Sur les associations à cuprosklodowskite du Katanga: Soc. belge Géologie Bull., tome 46, p. 298.

1939, Splijtingen, corrosiefiguren en monokliene synemetrie van saléeiet; epitaxie op metatorberniet: K. Vlaamsche Akad. Wetensch. Belgie, Verh. 1939, p. 65-70.

Schoep, A., and Billiet, V., 1935, Note sur le réseau de l'uraninite: Soc. belge Géologie Annales, tome 58, p. B198-B206.

Schoep, A., and Leenheer, L. de, 1937, Qu'est-ce que la gummite?: Soc. belge Géologie Bull., tome 46, p. 309-316.

Schoep, A., and Richet, E., 1922, Sur la présence de la carnotite au Congo: Soc. belge Géologie Bull., tome 32, p. 150-152.

Schoep, A., and Scholz, A., 1931, Sur les minéraux uranifères (pechblende, ianthinite, kasolite, etc.) decouverts a Wölsendorf (Bavière), et sur un nouveau minéral d'uranium: Soc. belge Géologie Bull., tome 41, p. 71-75.

Schoep, A., and Stradiot, S., 1947, Paraschoepite and epiianthinite, two new uranium minerals from Shinkolobwe (Belgian Congo): Am. Mineralogist, v. 32, p. 344-350.

1948, Additional data on the properties of becquerelite and billietite: Am. Mineralogist, v. 33, p. 503-507. 
Schrauf, A., 1872, Chalkolith und Zeunerit nebst Bemerkungen über Walpurgin und Trögerit: Tschermak's Mineralog. petrog. Mitt., Band 2, p. 181.

1873, Schröckingerit, ein neues Mineral von Joachimsthal: Tschermak's Mineralog. petrog. Mitt., Band 3, p. 137.

- 1882, Uranothallit, false Liebigit, von Joachimsthal: Zeitschr. Kristallographie, Band 6, p. 410-413.

Schroeckinger, J. von, 1875, Ueber neue Anbrüche von Silbererzen in Joachimsthal. K.-K. Geol. Reichsanstalt [Austria] Verh., Jahrg. 1875, p. 66.

Shannon, E. V., 1926, Some minerals from the Kensington Mica Mine, Montgomery County, Maryland: Am. Mineralogist, v. 11, p. 35-37.

Shaub, B. M., 1938, The occurrence, crystal habit, and composition of the uraninite from the Ruggles mine, near Grafton Center, New Hampshire: Am. Mineralogist, v. 23, p. 334-341.

1940, Age of the uraninite from the McLear pegmatite near Richville Station, St. Lawrence County, New York: Am. Mineralogist, v. 25, p. $480-487$.

Shepard, C. U., 1835, Microlite, a new mineral species: Am. Jour. Sci., v. 27, p. 361 .

1837a, Description of edwardsite, a new mineral: Am. Jour. Sci., v. 32, p. 162.

1837b, Notice of eremite, a new mineral species: Am. Jour. Sci., v. 32,

p. 341.

1837c, Chemical examination of microlite: Am. Jour. Sci., v. 32, p. 338. 1842, On the want of identity between microlite and pyrochlore: Am. Jour. Sci., 2 d ser., v. 43, p. 116.

1851, On new localities of American minerals: Am. Assoc. Adv. Sci. Proc., v. 4, p. 321.

- 1857, Treatise on mineralogy, 3d. ed., v. 2: Paris, p. 287. 1870, Unknown mineral (microlite?) in Haddam columbite: Am. Jour. Sci., v. 50, p. 93.

Shibata, Y., and Kimura, K., 1921, Chemical investigation of Japanese minerals containing rarer elements; II, Analyses of columbite and monazite from Ishikawa, Iwaki Province [in Japanese]: Chem. Soc. Japan Jour., v. 42 , p. $957-964$.

Silman, J. F. B., 1954, Native tin associated with pitchblende at Nesbitt LaBine Uranium Mines, Beaverlodge, Saskatchewan: Am. Mineralogist, v. 39, p. 529-531.

Simpson, E. S., 1910, Pilbarite, a new mineral from the Pilbara goldfields, Western Australia: Chem. News, v. 102, p. 283.

1912, Radium-uranium ores from Wodgina: Western Australia Geol. Survey Bull. 48, p. 9-21.

1927, Contributions to the mineralogy of Western Australia, Series II: Royal Soc. Western Australia Jour., v. 13, p. 27.

- 1930, Contributions to the mineralogy of Western Australia: Royal Soc. Western Australia Jour., v. 16, p. 25, 33.

1938, Metasimpsonite: Western Australia Dept. Mines, Rept. 1937, p. 88.

Slowinski, E., and Elliott, N., 1952, Lattice constants and magnetic susceptibilities of solid solutions of uranium and thorium dioxides: Acta Crystallographica, v. 5, p. 768 .

Smith, E. S. C., and Maslowski, E. O. E., 1937, New locality for autunite: Am. Mineralogist, v. 22, p. 1184. 
Smith, J. L., 1848, 1851, Two new minerals, medjidite and liebigite: Am. Jour. Sci., 3d ser., v. 5, p. 336; v. 11, p. 259.

1877, Examination of American minerals; No. 6: Am. Jour. Sci., v. 13, p. 365 .

Smith, T. H., 1926, Mineralogical notes; No. 2.: Australian Museum Rec., v. 15, p. 69.

Sousa, A. de, 1952, Note sur l'analyse d'une monazite du filon de Boa Esperança, Alto Ligonha-Mozambique: Soc. geol. Portugal Bol., v. 10, p. 189-192.

Spence, H. S., 1930a, Pegmatite minerals of Ontario and Quebec: Am. Mineralogist, v. 15, p. 488.

$1930 \mathrm{~b}, \mathrm{~A}$ remarkable occurrence of thucholite and oil in a pegmatite dyke, Parry Sound district, Ontario: Am. Mineralogist, v. 15, p. 499-520.

1940, Uraninite and thucholite from Pied des Monts, Charlevoix County, Quebec: Am. Mineralogist, v. 25, p. 711-718.

Spence, H. S., and Muench, O. B., 1935, Monazite from West Portland township, Quebec: Am. Mineralogist, v. 20, p. 724-732.

Spencer, L. J., 1898, Supplementary list of British minerals: British Assoc. Adv. Sci. Rept. 875.

1903, A third list of new mineral names: Mineralog. Mag., v. 13, p. 368. 1928, Mineralogical chemistry (1926-1927): Chem. Soc. London Ann. Repts., v. 24 (for 1927).

Sprigg, R. C., 1954, Geology of the Radium Hill mining field: South Australia Geol. Survey Bull. 30, p. 7.

Staatz, M. H., and Bauer, H. L., Jr., 1953, Uranium in the East Walker River area, Lyon County, Nevada: U. S. Geol. Survey Bull. 988-C, p. 29-43.

Stackelberg, M. von, and Chudoba, K., 1937, Dichte und Struktur des Zirkons; II : Zeitschr. Kristallographie, Band 97, p. 252-262.

Stackelberg, M. von, and Rottenbach, E., 1939, Dichte und Struktur des Zirkons; II, III : Zeitschr. Kristallographie, Band 102, p. 173, 207.

Starik, I. E., Kravchenko, L. L., and Melikova, O. S., 1941, A finding of ferrithorite in north Kirghizia: Acad. sci. U. R. S. S., Comptes rendus, v. 32, p. 254-255.

Starik, I. E., Samartzeva, A. G., and Yashchenko, M. L., 1941, Solubility of secondary uranium minerals: Acad. sci. U. R. S. S., Comptes rendus, v. 31 , p. $909-910$.

Starynkevič, I., 1922, The chemical formula of monazite and several analyses of Russian monazites [in Russian]: Acad, sci. U.R.S.S., Comptes rendus 1922, p. $28-30$.

Steacy, H. R., 1953, An occurrence of uraninite in a black sand: Am. Mineralogist, v. 38, p. 549.

Steinkuhler, W., 1923, Contribution à l'étude de la torbernite de Cornouailles $\left(\mathrm{CuO} \cdot 2 \mathrm{UO}_{3} \cdot \mathrm{P}_{2} \mathrm{O}_{5} \cdot 8 \mathrm{H}_{2} \mathrm{O}\right)$ : Soc. chim. Belgique Bull. 32, p. 253, 270.

Steinocher, V., and Nováček, R., 1939, On $\beta$-Uranotile: Am. Mineralogist, v. 24, p. $324-338$.

Stěp, J., and Becke, F., 1904, Das Vorkommen des Uranpecherzes zu St. Joachimsthal: Akad. Wiss. Wien, Math.-naturwiss. Kl., Sitzungsber., Band 113, p. 585.

Stern, T. W., and Annell, C. S., 1954, A second locality of novacekite: Am. Mineralogist, v. 39 , p. 675.

Stern, T. W., Stieff, L. R., Girhard, M. N., and Meyrowitz, R., 1956, The occurrence and properties of metatyuyamunite, $\mathrm{Ca}\left(\mathrm{UO}_{2}\right)_{2}\left(\mathrm{VO}_{4}\right)_{2} \cdot 3-5 \mathrm{H}_{2} \mathrm{O}$ : Am. Mineralogist, v. 41, p. 187-201. 
Stern, T. W., and Weeks, A. D., 1952, Second occurrence of bayleyite in the United States: Am. Mineralogist, v. 37, p. 1058-1060.

Stieff, L. R., Stern, T. W., and Sherwood, A. M., 1955, Preliminary description of coffinite-a new uranium mineral: Science, v. 121, p. 608.

1956, Coffinite, a uranous silicate with hydroxyl substitution-a new mineral: Am. Mineralogist, v. 41, p. 675-688.

Stillwell, F. L., 1952, Uraninite from Rum Jungle and Fergusson River, Northern Territory: Mawson Anniversary Volume, Univ. Adelaide, p. 161-166.

Stillwell, F. L., and Edwards, A. B., 1954, Uranium minerals from Mount Painter: Geol. Survey South Australia Bull. 30, p. 94.

Stočes, B., 1918, Contributions to the knowledge of uranium mica [in Czechoslovakian]: Ceská Akademia ved a umeni [Prague], Rozpravy, ročník 27, čislo $27,4 \mathrm{p}$.

Strunz, H., 1949, Mineralogische Tabellen: Leipzig, 192 p.

—_ 1953, Mineralien und Lagerstätten in Ostbayern: Regensburg.

Strutt, R. J., 1905, On the radioactive minerals: Royal Soc. London Proc., v. 76, p. 88.

Sullivan, C. J., and Matheson, R. S., 1952, Uranium-copper deposits, Rum Jungle, Australia: Econ. Geology, v. 47, p. 751.

Sundberg, I., and Sillén, L. G., 1949, On the crystal structure of $\mathrm{KUO}_{2} \mathrm{VO}_{4}$ (synthetic anhydrous carnotite): Arkiv Kemi, v. 1, p. 337-351.

Swanson, H. E., and Fuyat, R. K., 1953, Standard X-ray diffraction powder patterns, Natl. Bur. Standards Circ. 539, v. 2.

Takubo, J., Ueda, T., and Nishimura, S., 1951, Studies on minerals bearing rare elements; Pt. 13, Betafite found in Chin-chou region, Manchuria [in Japanese, with English summary]: Geol. Soc. Japan Jour., v. 57, p. $171-175$.

Takubo, J., Ueda, T., Nishimura, S., and Masutomi, J., 1953, New localities of the minerals containing rare elements [in Japanese, with English abstract]: Geol. Soc. Japan Jour., v. 59, p. 47-58.

Tavora, E., 1949, Cela unitária e grupo especial de djalmaita: Acad. Brasileira de Ciencias Anais, año 21, p. 337-352.

1950, Djalmaita e microlita: Acad. Brasileira de Ciencias Anais, año 22, p. 139-140.

- 1951, Dados estruturais sobre a uranita do Acarí, R. G. N.: Acad. Brasileira de Ciencias Anais, año 23, p. 155.

Termier, P., 1902, Sur la neotantalite, espèce minérale nouvelle: Soc. française Minéralogie Bull., tome 25, p. 34-38.

Thompson, M. E., Ingram, B., and Gross, E. B., 1956, Abernathyite, a new uranium mineral of the metatorbernite group: Am. Mineralogist, v. 41, p. 82-90.

Thompson, M. E., Weeks, A. D., and Sherwood, A. M., 1955, Rabbittite, a new uranium carbonate from Utah: Am. Mineralogist, v. 40, p. 201-206.

Thoreau, J., 1930, Sur une variété d'uranotile de Shinkolobwe (Katanga): Soc. géol. Belgique Annales, tome 53, p. B60-B64.

1933, L'uranolépidite, nouveau minéral uranifère de Shinkolobwe (Katanga): Soc. géol. Belgique Annales, tome 55, p. C3.

- 1948, Caractères cristallographiques de la billietite et de la vandendriescheite: Soc. géol. Belgique Bull., v. 71, B76-78.

Thoreau, J., and Vaes, J. F., 1932, La saléeite, nouveau minéral uranifère: Soc. belge géologie Bull., tome 42, p. 96-100. 
Thorpe, A., 1895, Monazite. A mineral containing helium: Chem. News, v. 72, p. 32.

Thurlow, E. E., and Wright, R. J., 1950, Uraninite in the Coeur d'Alene district, Idaho: Econ. Geology, v. 45, p. 395-404.

Tomkeieff, S. I., 1946, The geochemistry of uranium: Sci. Progress, v. 34, p. 696.

Traill, R. J., 1952, Synthesis and X-ray study of uranium sulphate minerals, Am. Mineralogist, v. 37, p. 394-406.

- 1954, A preliminary account of the mineralogy of radioactive conglomerates in the Blind River region, Ontario: Canadian Mining Jour., v. 75, p. $63-68$.

Traube, H., 1895, Ueber die Aetzfiguren einiger Minerale: Neues Jahrb. Mineralogie, Beilage-Band 10, p. 454.

Trites, A. F., Jr., and Chew, R. T. 3d, 1955, Geology of the Happy Jack mine, White Canyon area, San Juan County, Utah; U. S. Geol. Survey Bull. 1009-H, p. 235-248.

Trites, A. F., Jr., and Tooker, E. W., 1953, Uranium and thorium deposits in east-central Idaho, southwestern Montana: U. S. Geol. Survey Bull. 988-H, p. 157-209.

Trzebiatowski, W., and Selwood, P. W., 1950, Magnetic susceptibilities of urania-thoria solid solutions: Am. Chem. Soc. Jour., v. 72, p. 4504.

Ueda, T., 1953, The crystal structure of monazite $\left(\mathrm{CePO}_{4}\right)$ : Kyoto Univ. Coll. Sci. Mem., ser. B, v. 20, p. 225-249.

Ueda, T., and Korekawa, M., 1954, On the metamictization: Kyoto Univ., Coll. Sci. Mem., ser. B, v. 21, p. 151-162.

Ungemach, H., 1929, Précisions cristallographiques sur quelques minéraux du Congo Belge: Soc. géol. Belgique Annales, tome 52, Pub. Spec. relatives au Congo Belge, p. C75.

United Nations, 1956, Proceedings of the International Conference on the Peaceful Uses of Atomic Energy; V. 6, Geology of uranium and thorium: New York, United Nations, 825 p.

Vaes, J. F., 1933, Sur un minéral de Kalongwe (Katanga): Soc. géol. Belgique Annales, tome 56, p. B331-B332.

- 1947, Six nouveaux minéraux d'urane provenant de Shinkolobwe (Katanga): Soc. géol. Belgique Annales, tome 70, p. B212-B230.

1949, Becquerelite et billietite: Soc. géol. Belgique Annales, tome 72, p. B237-B248.

Vaes, J. F., and Kerr., P. F., 1949, Sengierite, a preliminary description: Am. Mineralogist, v. 34, p. 109-120.

Vandendriessche, A., 1936, La pechblende du nouveau gîte uranifère de Kalongwe: Comm. special Katanga, Service. Mines Annales, tome 6, p. 70-80.

Vernadsky, V., 1914 [Mendelejevite]: Acad. imp. sci. St. Pétersbourg Bull., sér. 2, tome 8, p. 1368.

Vernadsky, W. J., 1923, La mendelejevite, nouveau minéral radioactif: Acad. Sci. Paris Comptes rendus, tome 176, p. 993.

Vickers, R. C., 1953, An occurrence of autunite in Lawrence County, South Dakota: U. S. Geol. Survey Circ. 286, 5 p.

Vier, D. T., Schultz, M. L., and Bigeleisen, J., 1948, The fluorescence of uranium trioxide hydrates: Optical Soc. America Jour., v. 38, p. 811.

Vine, J. D., and Prichard, 'G. E., 1954, Uranium in the Poison Basin area, Carbon County, Wyoming: U. S. Geol. Survey Circ. 344, 8 p.

Viswanathan, P., 1953, Thorianite in Travancore: Mineralog. Mag., v. 88, p. 282. 
Vogl, J. F., 1853, Drei neue Mineral-Vorkommen von Joachimsthal: K.-K. Geol. Reichsanstalt [Austria] Jahrb., Jahrg. 4, p. 221-223.

- 1857, Gangverhält und Mineralreichtumnisse von Joachimsthal: Teplitz.

Walker, T. L., 1898, The crystalline symmetry of torbernite: Am. Jour. Sci., 4th ser., v. 6, p. 41.

1923, Schoepite, a new uranium mineral from Kasolo, Belgian Congo: Am. Mineralogist, v. 8, p. 67-69.

- 1924, Uraninite from Cardiff Township, Ontario: Toronto Univ. Studies, Geol. Ser., no. 17, p. 42-45.

Walker, T. L., and Parsons, A. L., 1923, Ellworthite and associated minerals from Hybla, Ontario: Toronto Univ. Studies, Geol. Ser., no. 6, p. 13-20.

Wallerius, J. G., 1747, Mineralogia, eller Mineralriket: Stockholm, 249 p.

Wamser, C. A., Belle, J., Bernsohn, E., and Williamson, B., 1952, The constitution of the uranates of sodium: Am. Chem. Soc. Jour., v. 74, p. 1020.

Wasserstein, B., 1951, Cube-edges of uraninite as a criterion of age: Nature, v. 166, p. 380 .

1954, Age of uraninites by a new method: Nature, v. 174, p. 1004.

Watson, T. L., 1902, On the occurrence of uranophane in Georgia: Am. Jour. Sci., 4th ser., v. 13, p. 464.

Watts, H., 1849, On phosphocerite, a new mineral containing phosphate of cerium: Chem. Soc. London Jour., v. 2, p. 131.

Webb, B. P., and Whittle, A. W. G., 1954, Uranium investigations in the Adelaide Hills: South Australia Geol. Survey Bull. 30, p. 115.

Websky, M., 1853, Ueber die geognostischen Verhältnisse der Erzlagerstätten von Kupferberg: Deutsche geol. Gesell. Zeitschr., Band 5, p. 427.

1859, Ueber Uranophan: Deutsche geol. Gesell. Zeitschr., Band 11, p. 384.

1870, Ueber die chemische Konstitution des Uranophans: Deutsche geol. Gesell. Zeitschr., Band 23, p. 92.

Weeks, A. D., and Thompson, M. E., 1954, Identification and occurrence of uranium and vanadium minerals from the Colorado Plateaus: U. S. Geol. Survey Bull. 1009-B, p. 13-62.

Weidman, S., and Lenher, V., 1907, Marignacite, a new variety of pyrochlore from Wausau, Wisconsin: Am. Jour. Sci., 4th ser., v. 23, p. 287.

Weisbach, A., 1871, Vorläufige Mitteilung-Trögerit, Walpurgin: Neues Jahrb. Mineralogie Jahrg. 1871, p. 869.

-1872, [Communication from Freiberg, Feb. 9, 1872, on uranium minerals from Neustädtel]: Neues Jahrb. Mineralogie, Jahrg. 1872, p. 206-208.

1873a, Neue Uranerze von Neustädtel bei Schneeberg: Neues Jahrb. Mineralogie, Jahrg. 1873, p. 315.

1873b, Neue Uranerze von Schneeberg: Neues Jahrb. Mineralogie, Jahrg. 1873, p. 296.

- 1875, Synopsis mineralogica, systematische Übersicht des Mineralreiches: Freiberg, p. 48.

1877a, Mineralogische Mitteilung: Berg- u. hüttenm. Jahrb., Band 42, p. 53 .

1877b, Ưber die Kristallform des Walpurgin: Neues Jahrb. Mineralogie, Jahrg. 1877, p. 1.

1877c, Über Uranocircit, ein neues Glied der Gruppe des sogennanten Uranglimmers: Neues Jahrb. Mineralogie, Jahrg. 1877, p. 185, 406. 
Weisbach, A., 1882, Mineralogische notizen II: Neues Jahrb. Mineralogie, Johrg. 1882, p. 258.

Wells, A. F., 1950, Structural inorganic chemistry, 2d ed.: Oxford, Clarendon Press, $727 \mathrm{p}$.

Wells, R. C., 1930, Uraninite from Placer de Guadalupe, Chihuahua: Am. Mineralogist, v. 15, p. 470-473.

Wells, R. C., Fairchild, J. G., and Ross, C. S., 1933, Thorianite from Easton, Pennsylvania: Am. Jour. Sci., 5th ser., v. 26, p. 45-54.

Wells, R. L., and Rambosek, A. J., 1954, Uranium occurrences in Wilson Creek area, Gila County, Arizona: U. S. Atomic Energy Comm. RME-2005 (rev.), 15 p., issued by U. S. Atomic Energy Comm. Tech. Inf. Service Extension, Oak Ridge, Tenn.

Werner, A. G., 1780, Cronstedt's Versuch einer Mineralogie, ubersetz und vermehrt: Leipzig, p. 217.

- 1789, [No title]: Bergmaennisches Jour., Band 2, p. 376.

Werther, G., 1948, Ueber die Verbindungen des Phosphinsäure und Arseniksäure mit Uran-oxyd: Jour. prakt. Chemie, Band 43, p. 321.

West, W. S., and White, M. G., 1952, The occurrence of zeunerite at Brooks Mountain, Seward Peninsula, Alaska: U. S. Geol. Survey Circ. 214, 7 p.

Wherry, E. T., 1908, Radioactive minerals found in Pennsylvania and their effect on the photographic plate: Franklin Inst. Jour., v. 165, p. 57.

1922, Soddite [abs.]: Am. Mineralogist, v. 7, p. 179.

1929, Mineral determination by absorption spectra I: Am. Mineralogist, v. 14, p. 308.

White, M. G., 1952, Radioactivity of selected rocks and placer concentrates from northeastern Alaska: U. S. Geol. Survey Circ. 195, 12 p.

White, M. G., and Stevens, J. M., 1953, Reconnaissance for radioactive deposits in the Ruby-Poorman and Nixon Fork districts, west-central Alaska: U. S. Geol. Survey Circ. 279, 19 p.

White, W. C., and Yagoda, H., 1950, Abundance of $\mathrm{N}^{15}$ in the nitrogen occluded in radioactive minerals: Science, v. 111, p. 307-308.

Whittle, A. W. G., 1954a, Radioactive minerals in South Australia: South Australia Geol. Survey Bull. 30, p. 126.

1954b, Mineragraphy and petrology of the Radium Hill mining field: South Australia Geol. Survey. Bull. 30, p. 51.

1954c, Absite, a new mineral related to brannerite: South Australia Dept. Mines Mining Review, no. 97, p. 99-106.

1954d, Petrology of Crockers Well uranium deposit: South Australia Geol. Survey Bull. 30, p. 79.

Williams, G. J., and Skerl, A. F., 1940, Mica in Tanganyika Territory: Tanganyika Geol. Div. Bull. 14, 47 p.

Wilmarth, V. R., Bauer, H. L., Staatz, M. H., and Wyant, D. G., 1952, Uranium in fluorite deposits: U. S. Geol. Survey Circ. 220, p. 13.

Wilmarth, V. R., and Johnson, D. H., 1954, Uranophane at Silver Cliff Mine, Lusk, Wyoming: U. S. Geol. Survey Bull. 1009-A, p. 1-12.

Wimmenauer, W., 1952, Mikroskopische Untersuchungen an Uranerzen aus dem mittleren Schwarzwald: Badische geol. Landesanstalt, Mitteilungsblatt 1951, p. 75-83.

Winchell, A. N., 1933, Elements of optical mineralogy; Pt. 2, Descriptions of minerals, 3d ed.: New York, John Wiley and Sons, 459 p.

- 1951, Elements of optical mineralogy; Pt. 2, Descriptions of minerals, 4th ed.: New York, John Wiley and Sons, 551 p. 
Winkler, C., 1873, Ueber die chemische Konstitution einiger neuer Uranmineralien: Jour. prakt. Chemie, Band 7, p. 3.

Wleugel, S., 1878, Ueber das Vorkommen von Indium im norwegischen Mineralien: Nyt. mag. naturvidensk. Oslo, Bind 24, p. 333-336; abstract in Zeischr. Kristallographie, 1880, Band 4, p. 520.

Wöhler, F., 1826, Ueber den Pyrochlor: Annalen Physik, Band 7, p. 417. 1846, Ueber den Kryptolith, eine neue Mineralspecies: Annalen Physik, Band 67, p. 424; Göttingen gelehrte Anz., p. 19.

Wright, H. D., 1954, Mineralogy of a uraninite deposit at Caribou, Colorado: Econ. Geology, v. 49, p. 129-174.

Wright, H. D., Bieler, B. H., Shulhof, W. P., and Emerson, D. O., 1954, Mineralogy of uranium-bearing deposits in the Boulder batholith, Montana, in Annual Report [for] April 1, 1953, to March 31, 1954: U. S. Atomic Energy Comm. RME-3095, 78 p., issued by U. S. Atomic Energy Comm. Tech. Inf. Service Extension, Oak Ridge, Tenn.

Wright, R. J., 1955, Ore controls in sandstone uranium deposits of the Colorado Plateau: Econ. Geology, v. 50, p. 135-155.

Wyant, D. G., 1952, Lost Creek (Wamsutter) schroeckingerite deposit, Sweetwater County, Wyoming: U. S. Geol. Survey Trace Elements Memo. Rept. 10B, 12 p., issued by U. S. Atomic Energy Comm. Tech. Inf. Service Extension, Oak Ridge, Tenn.

Wylie, A. W., 1948, Constitution of monazite: Nature, v. 161, p. 97. 1950, Composition of some Australian monazites: Australian Jour. Applied Sci., v. 1, p. 164.

Yagoda, H., 1946a, The localization of uranium and thorium minerals in polished section: Am. Mineralogist, v. 31, p. 87-124.

$1946 \mathrm{~b}$, Radiocolloid aggregates in uranium minerals : Am. Mineralogist, v. 31, p. $462-470$.

- 1948, Tracks of densely ionizing particles in nuclear emulsion: Nucleonics, v. 2, p. 2.

1949, Radioactive measurements with nuclear emulsions: New York, John Wiley and Sons, $356 \mathrm{p}$.

Zachariasen, W. H., 1948, Crystal radii of the heavy elements: Phys. Rev., v. 73, p. 1104.

Zambonini, F., 1908, Delorenzite, un nuovo minerale: R. Accad. Sci. Napoli Rend., v. 14, p. 113-118.

Zemann, J., 1950, Beiträge zur Kristallchemie des Wismuts: Tschermaks Mineralog. petrog. Mitt., Folge 3, Band 1, p. 361-377.

Zemel, V. K., 1936, Analyses on monazite from the gold placers of Aldan and the southern Yenissei [in Russian, with German summary] : Zhur. Prikladnoi Khimii, v. 9, p. 1969-1971.

Zippe, F. X. M., 1824, Beiträge zur Kenntniss des böhmischen Mineralreichs: Gesell. Mus. Böhmen, Verh. 1824, p. 81.

Zschau, E., 1858, Thorite: Am. Jour. Sci., 2d ser., v. 25, p. 359.

Zückert, R., 1925, Die Paragenesen von gediegen Silber und Wismut mit Kobalt-Nickel-Kiesen und der Uranpechblende zu St. Joachimsthal in Böhmen: Preuss. geol. Landesanstalt, Mitt. Abt. Gesteins-, Erz-, Kohle-, v. Salz-Gntersuchungen, Heft 1, p. 69-132. 


\section{INDEX}

[Species names and the pages on which the descriptions begin are in boldface type]

A

Abernathyite
Absite
Aldanite
Alpha-hyblite
Alpha-thorianite
Andersonite
Auerlite
Autunite
Azor-pyrrhit

B

Basisch-schwefelsaures

Basisches schwefelsaures.

\section{Uranoxidoxidul}

Uranoxyd

Basisches Uransulphat

Bassetite related minerals

.................141

.135

.200

204

Bayleyite

Beck-Blände

Becquerelite

Beta-hyblite

Beta-thorianite

Beta-uranophane

Beta-uranopilite

Beta-Uranotile

Betafite

Billietite

Bjørlykke, unnamed mineral of .

Blomstrandine

Blomstrandinite

Blomstrandite

Brannerite

Bröggerite

112

Calciocarnotite

Calciothorite

Calcouranit

Carnotite

Cerianite

Chalcolamprite

Chalcolite

Chalcolith

Chalkolith

-....

Cheralite

Chernik, unnamed mineral of . .260

Chinkolobwite
Page

Chirvinsky, unnamed mineral of....257

Chlorothorite ............................ 12

Clarkeite ................................. 95

Cleveite ..................................... 12

Coffinite .......................................

Copper-Uranite .......................171

Coracite ................................... 11

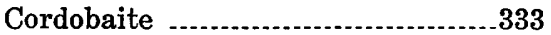

Cryptolite .....................................

Cuprosklodovskite _..................304

Cuprosklodowskite ......................304

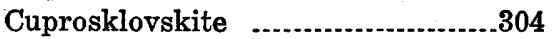

Cuprosklowskite ........................304

Cuprouranit ................................171

Curite ........................................ 92

D

Dakeite ..........................................

Dauberit ........................................

Davidite ............................................

Delorenzite ...................................

Dewindtite -...................................

Diderichite .....................................

Djalmaite ..........................................

Dumontite .....................................

\section{$\mathbf{E}$}

Edwardsite .......................................

Eisenpecherz ............................ 11

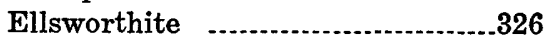

Enalite ............................................

Endeiolite ......................................

Epi-ianthinite ......................... 60

Eremite -........................................

Eucrasite ..............................278

Eukrasit ........................................

F

Ferghanite .................................

Ferrothorite ..........................279

Ferutite .........................................

Fluochlore ......................................

Flutherite .................................

Fourmarierite ............................ 87

Freyalite .....................................

Freyalith ......................................

Fritzscheite ...................................... 


\begin{tabular}{|c|c|}
\hline $\mathbf{G}$ & M \\
\hline Page & Page \\
\hline Gamma-thorianite & Mackintoshite \\
\hline Gastunite & Maitlandite \\
\hline Gilpinite & Marignacite .. \\
\hline Grüner Glimmer. & Masuyite ............ \\
\hline Gummite .............. & Mavudzite .......... \\
\hline & Medjidite $\ldots$ \\
\hline $\mathrm{H}$ & Mendelejevite \\
\hline Haddamite & Mengite \\
\hline Hatchettolite & Meta-autunite \\
\hline Hörnbergite . & Meta-autunite I . \\
\hline Huttonite. & Meta-autunite II \\
\hline Hyblite & alcolite \\
\hline Hydrochlore & Meta-torbernite I \\
\hline Hydrothorite & Meta-uranocircite \\
\hline Hydroxyl-thorite & anopilite $\quad \cdots$ \\
\hline I & $\begin{array}{l}\text { Metakupferuranit } \\
\text { Metasimpsonite }\end{array}$ \\
\hline anthinite ..... & rnite ........ \\
\hline unnamed related mineral ..... 62 & munite \\
\hline "Ianthinite" -........... & rite $\quad . .$. \\
\hline Ianthite & Mica viridis ..... \\
\hline $\mathbf{J}$ & $\begin{array}{l}\text { Microlite } \\
\text { "Mineral X" }\end{array}$ \\
\hline novite & te \\
\hline Johannit & Monazit ..................... \\
\hline Johannite & $\begin{array}{l}\text { Monazite } \\
\text { Monazitoid }\end{array}$ \\
\hline $\mathbf{K}$ & $\mathbf{N}$ \\
\hline .204 & $\mathrm{Nas}$ \\
\hline Kalk-uran-carbonate & Neogastunite \\
\hline Kalk Uranglimmer & Neotantalite \\
\hline Kalk-Uranit $\quad \ldots \ldots \ldots \ldots \ldots$ & ayite ....... \\
\hline Kararfveit & Niobpyrochlor \\
\hline Kasolite & Niobtantal pyrochlore \\
\hline Kieselkupfer-Uranoxyd & Nivenite \\
\hline Koppite & Novacekite \\
\hline eite & \\
\hline Kristallisirtes Uranpecherz _....... 12 & $\mathbf{0}$ \\
\hline Kryptolith & Orangeite \\
\hline Kupfer-Uranglimmer & Orangit ... \\
\hline $\begin{array}{l}\text { Kupfer-Uranit } \\
\text { Kupferuranglimmer }\end{array}$ & Ulatigle \\
\hline Kupferuranit ... & $\ldots 72$ \\
\hline $\mathbf{L}$ & $\ldots 279$ \\
\hline & ite ...... \\
\hline$\ldots . .294$ & Pechblende ...... \\
\hline 108 & Pecherz .......... \\
\hline ime-Uranite ... & Pechuran \\
\hline
\end{tabular}




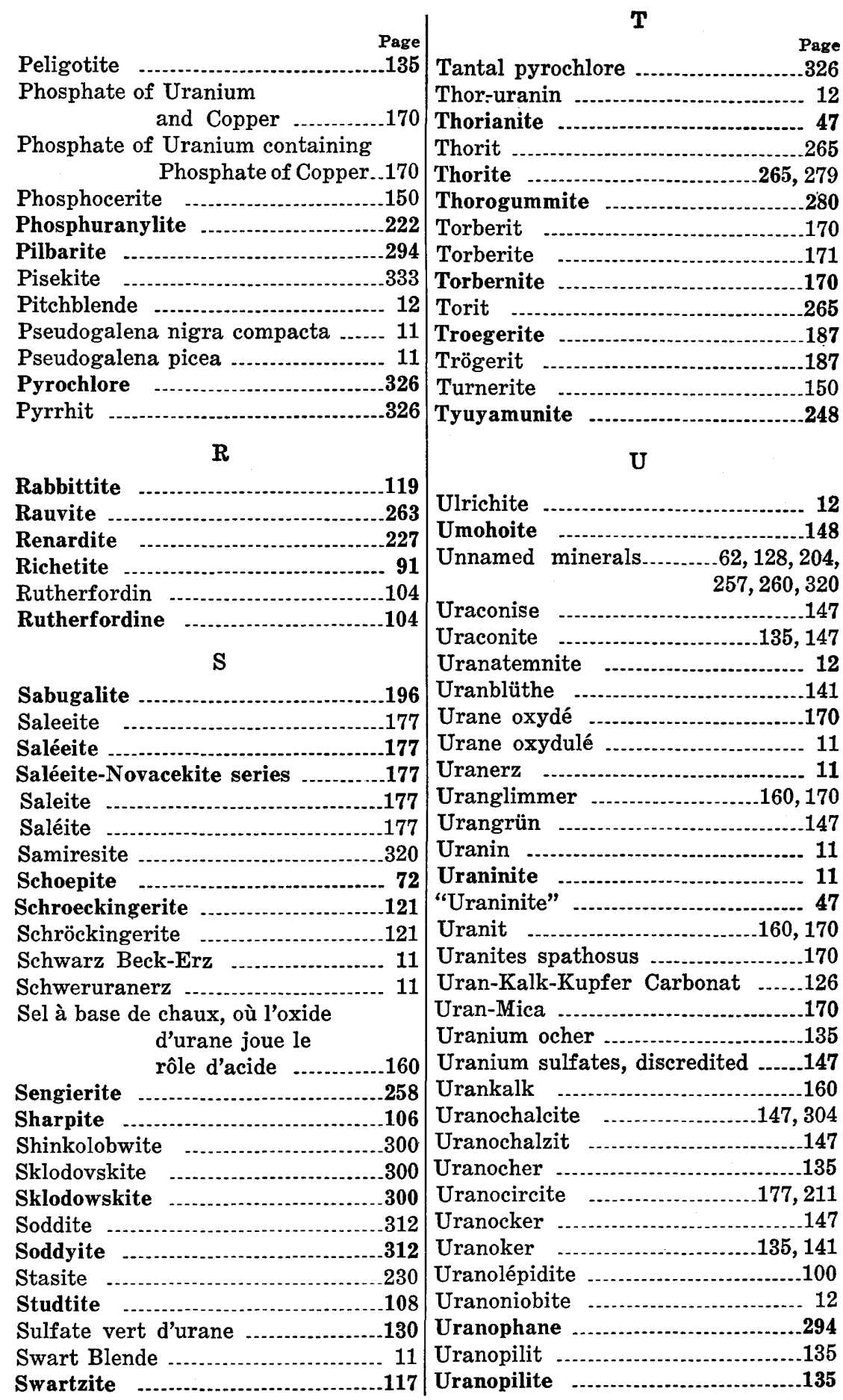




\begin{tabular}{|c|c|}
\hline & V \\
\hline Page & Page \\
\hline Uranospathite & Vandenbrandeite \\
\hline Uranosphärit ...... & Vandenbrandéite \\
\hline Uranospherite & Vandendriesscheite \\
\hline Uranospinite & Voglianite $\ldots \ldots \ldots \ldots \ldots \ldots \ldots . . . . . . . . . . . .147,304$ \\
\hline Uranothallite & Voglite \\
\hline Uranothorianite & \\
\hline Uranothorite & W \\
\hline Uranotil & Walpurgin ...... \\
\hline Uranotile & Walpurgite \\
\hline 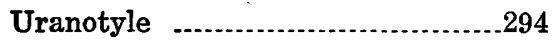 & Wisaksonite \\
\hline Uranpecherz & \\
\hline Uranphyllit & $\mathrm{Z}$ \\
\hline Uranpyrochlor & Zeunerite ...... \\
\hline Uranvitriol & Zippeit \\
\hline 150 & Zippeite \\
\hline Uvanite & Zippeite-like minerals ..............141 \\
\hline
\end{tabular}




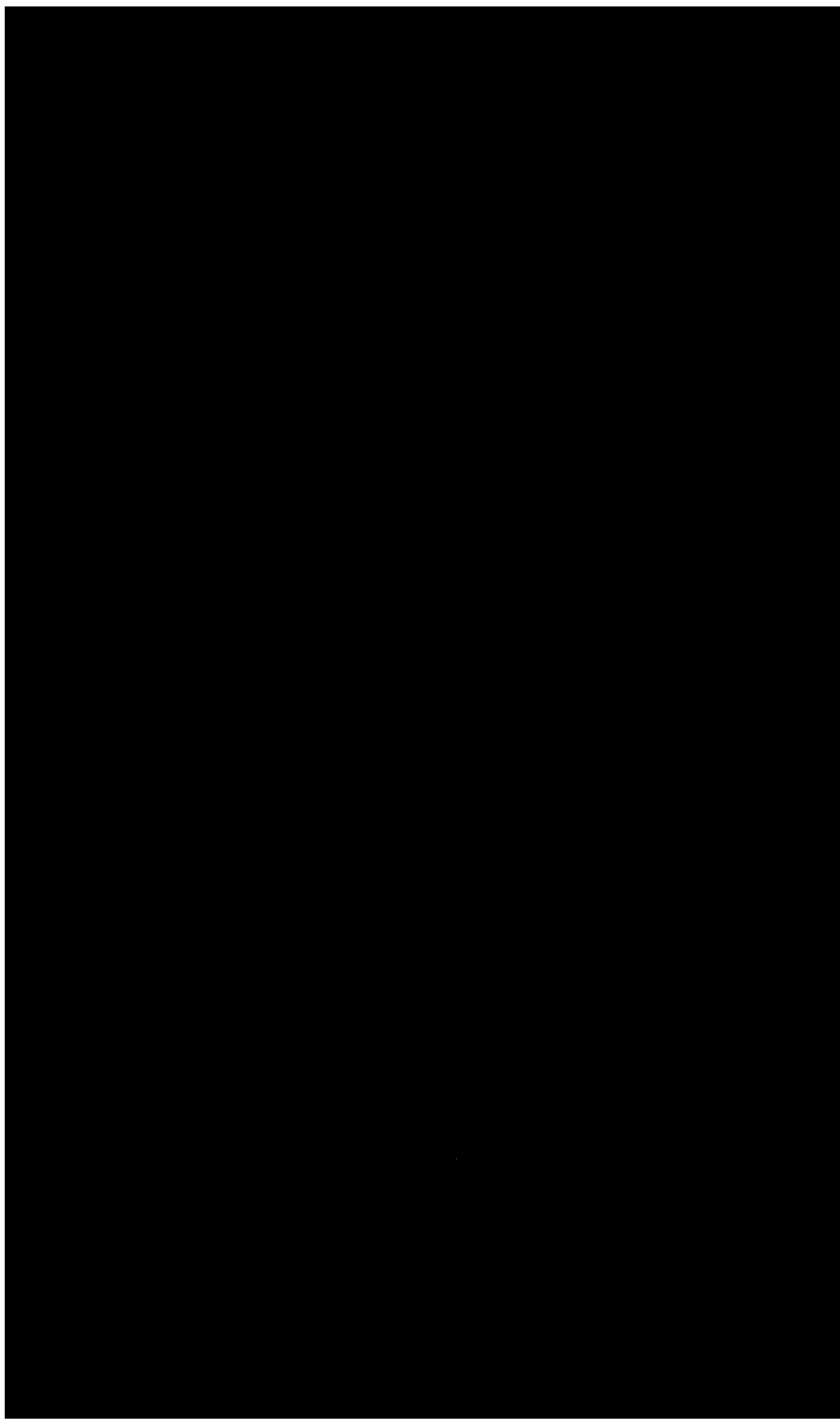




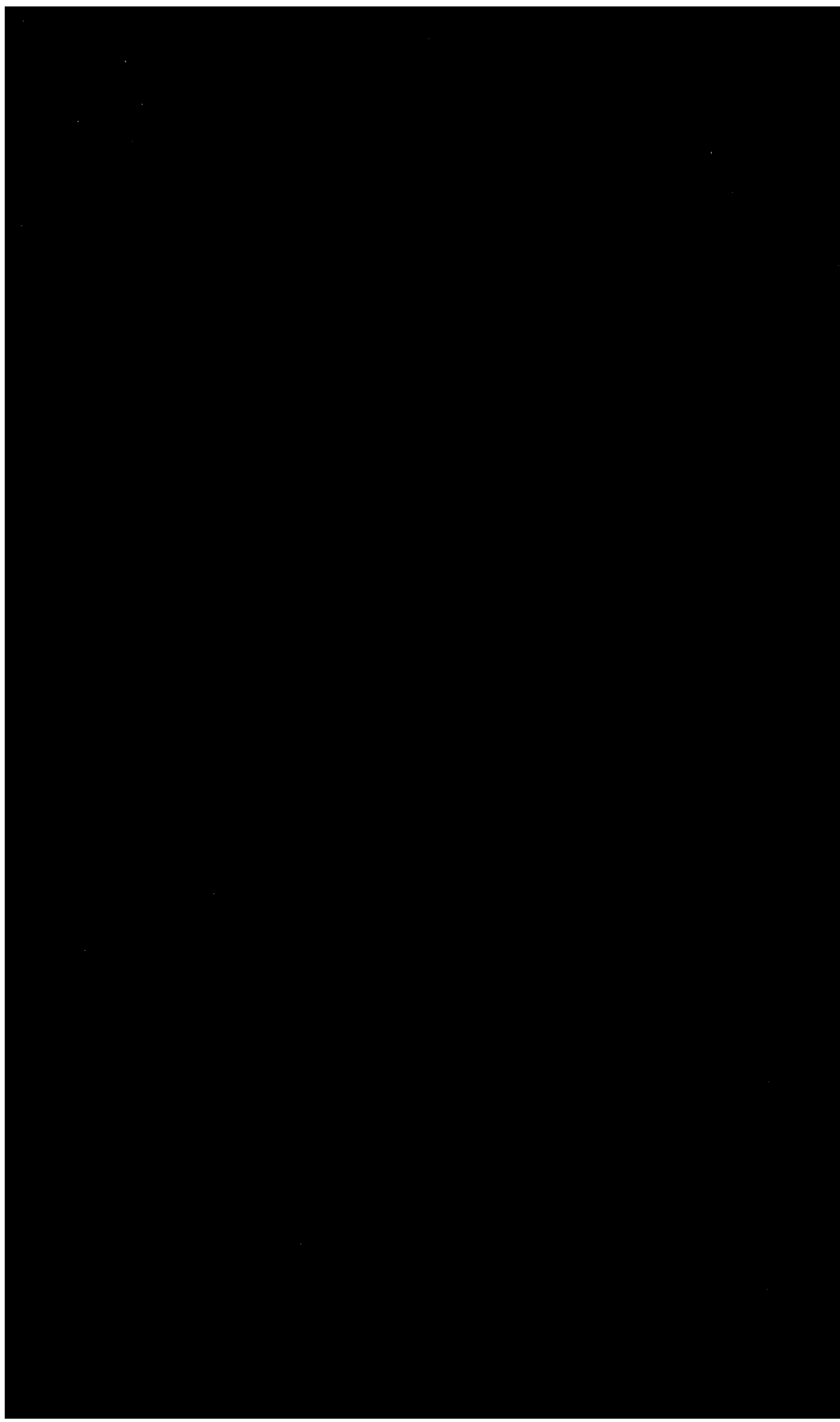

